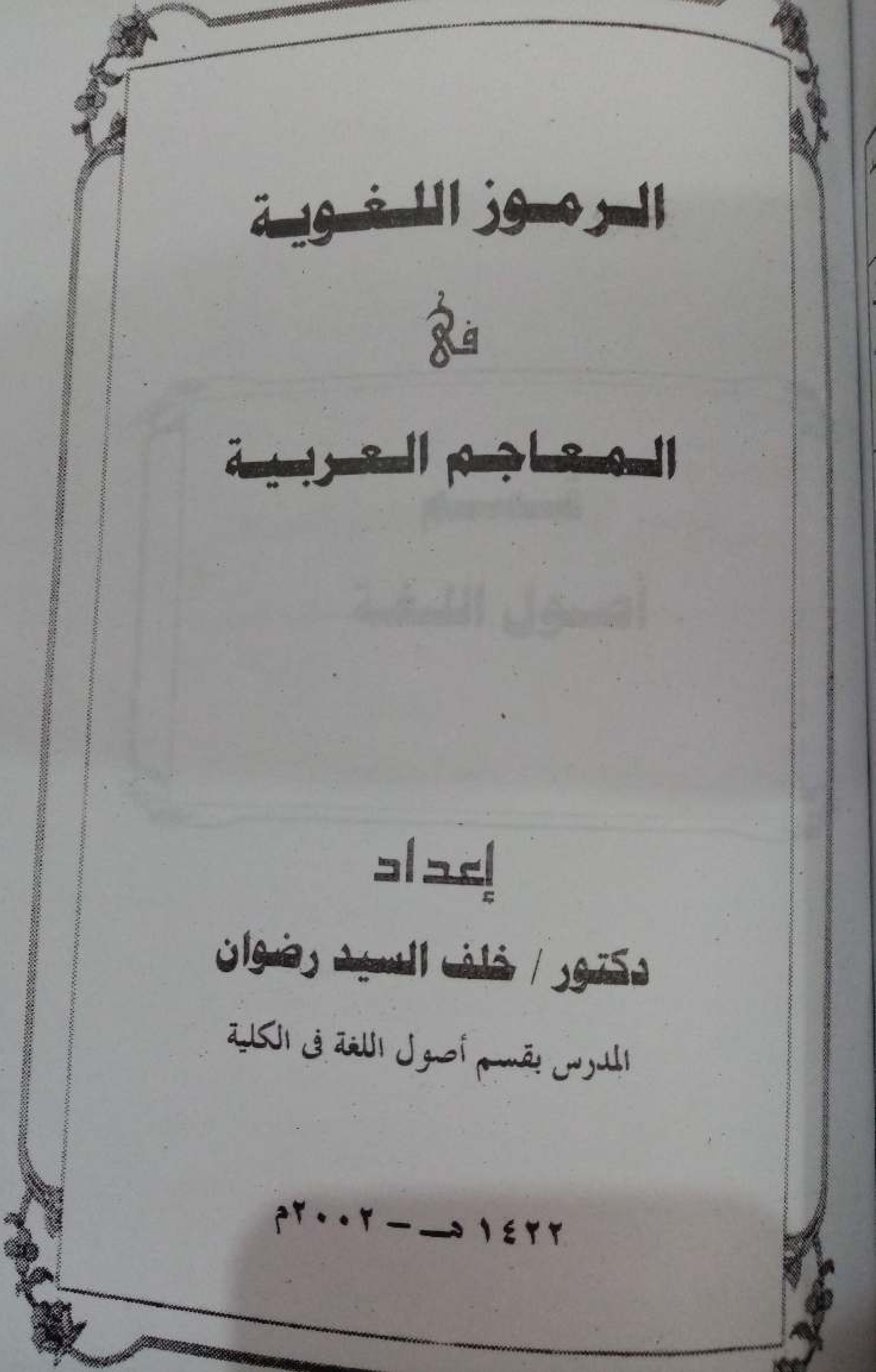


بسمم الله الرحمـن الرحيمه

الهيمستّد بـ

الحهمد لله اللذى شرف العربية بنزول القرآن بلسان الهرب.

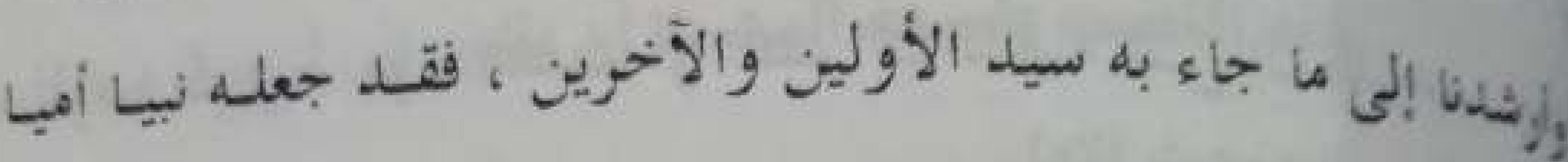

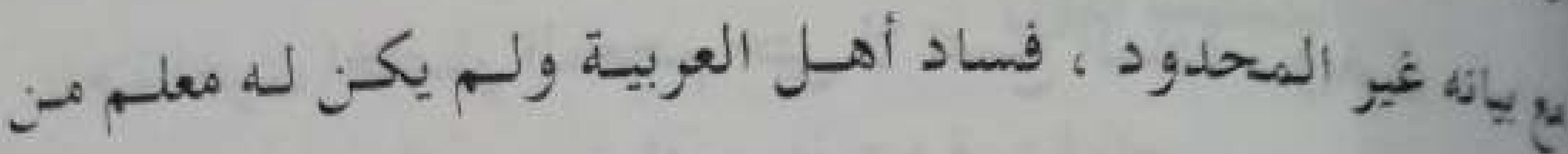

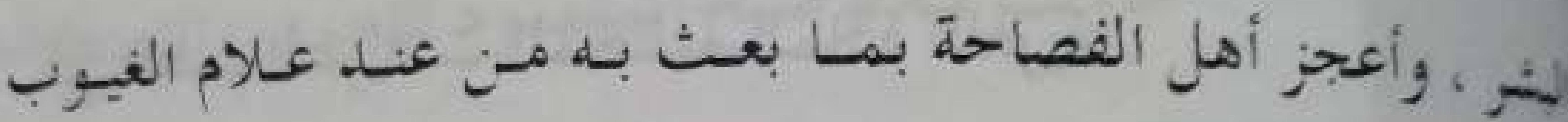

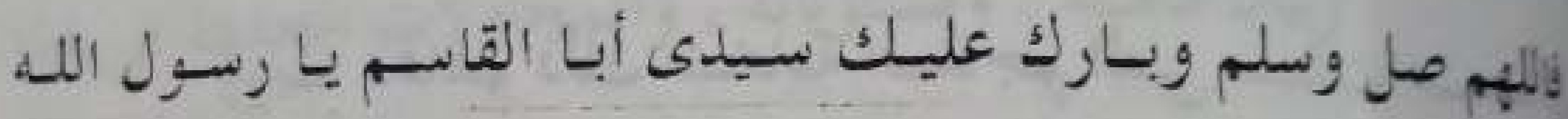

رئلى آلك وأصحابك الأنمة الهيداة إلى يوم اللين .

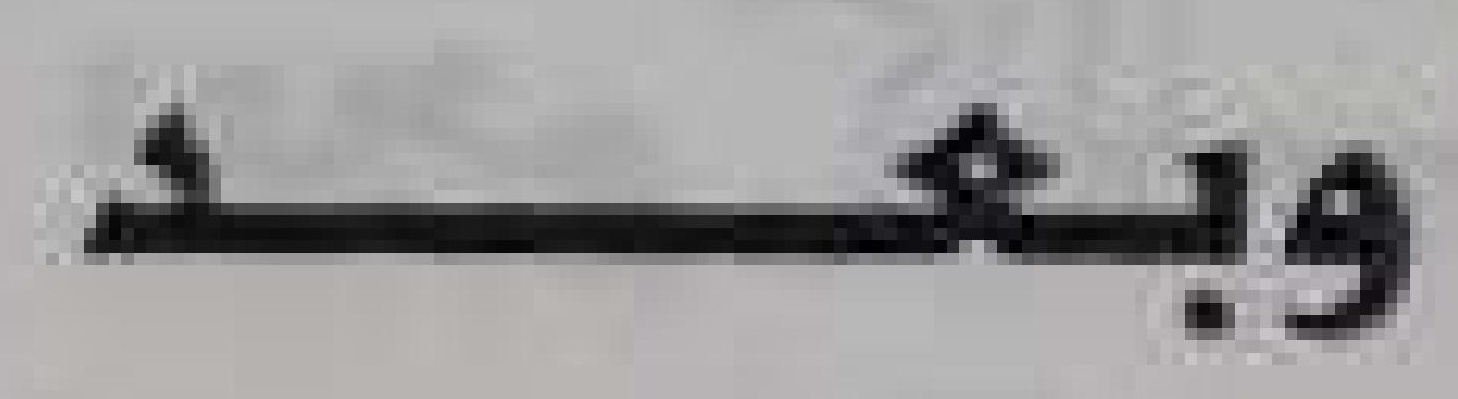

فإن معجماتنا اللغوية مليئة بالفر ائد والنفائس الجليلـة الأثر ،

بالغة النفع ، المتنوعة المعارف ، وقدل نهل من معينها العلماء قديما وحديثا ، ونسيظلون عاكفين عليها ، دارسين لها ، يستخرجون مـ رئ بطرنه العلوم النافعة ، والثروات اللفوية الزاخـرة ، رغبة في إحبـاء

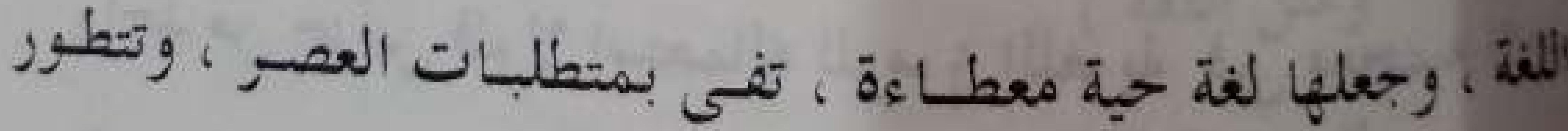

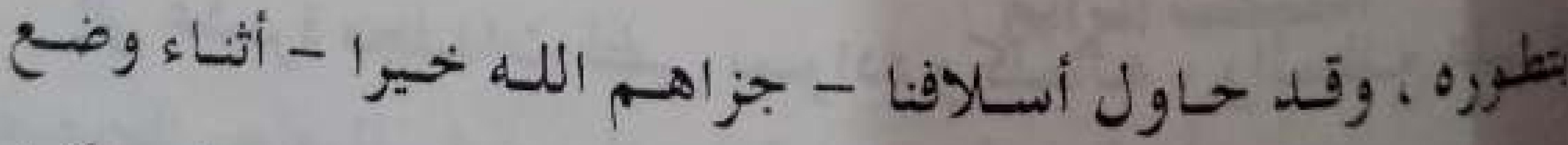

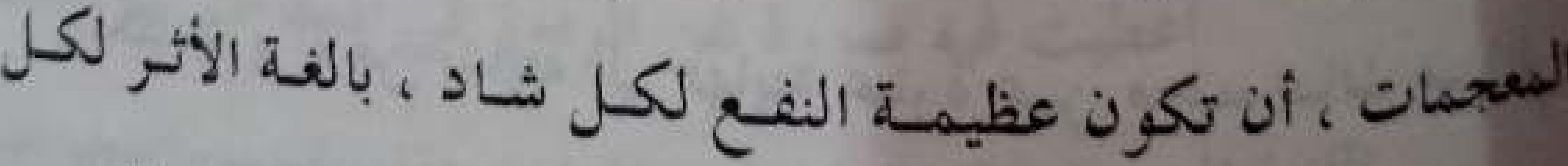

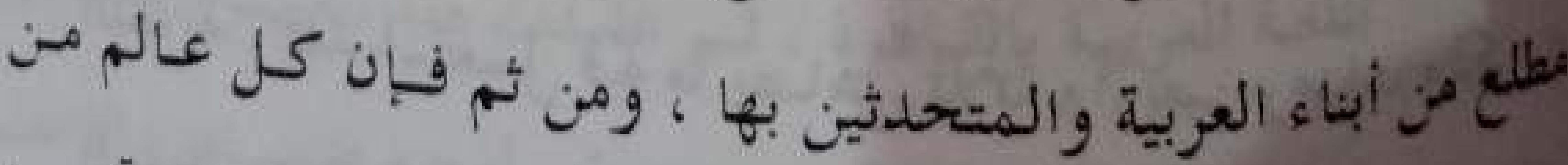

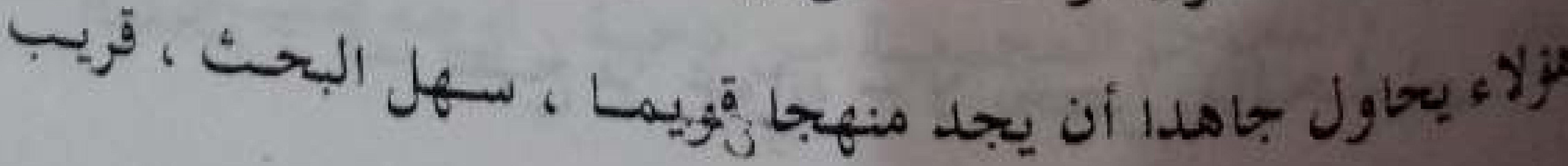




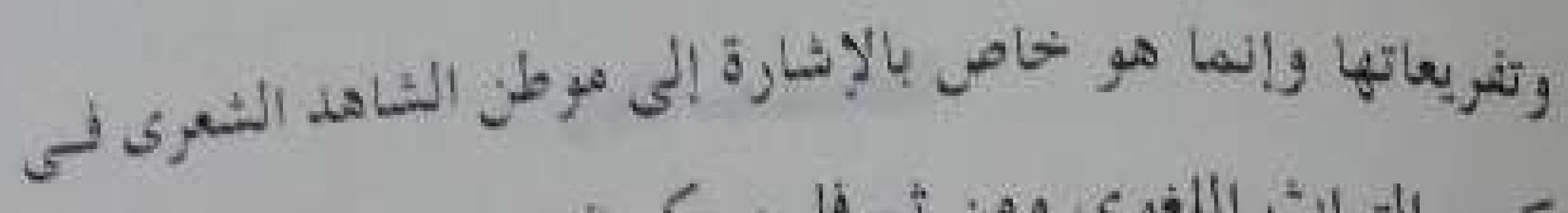

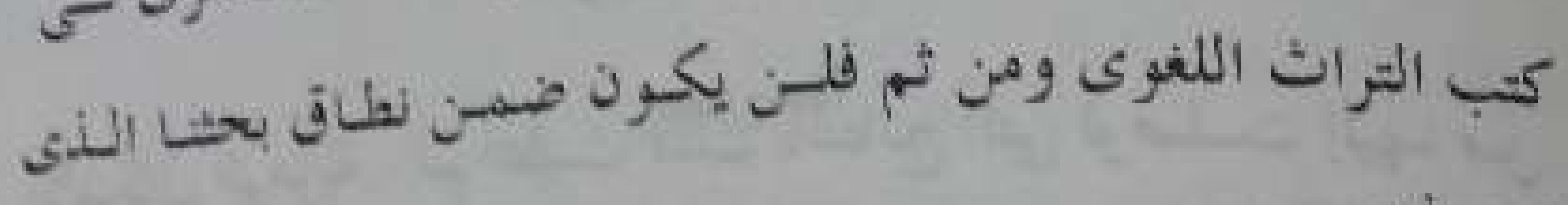
ف ن

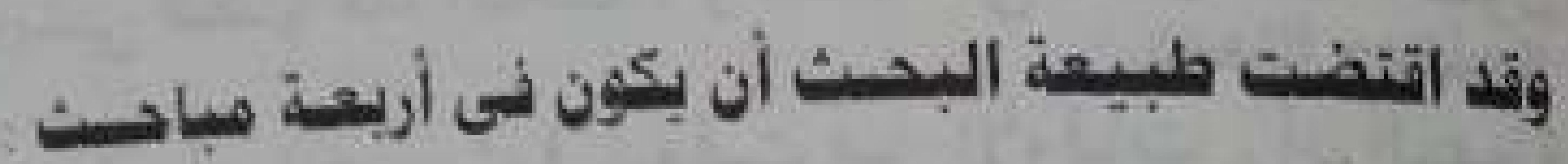
المبحث الأول

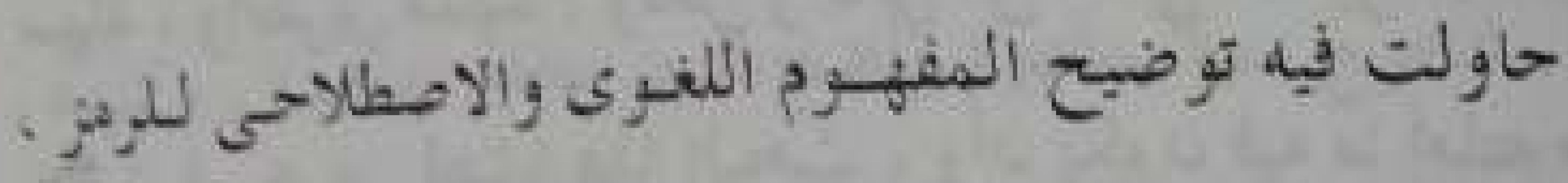

وبيان ماهيته ، و ومستوياته ، والمحاولات الحديثة في هنا الثنأن. المبحث الثدانى

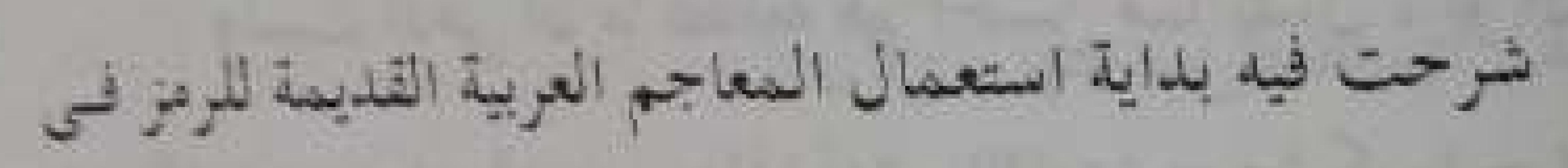

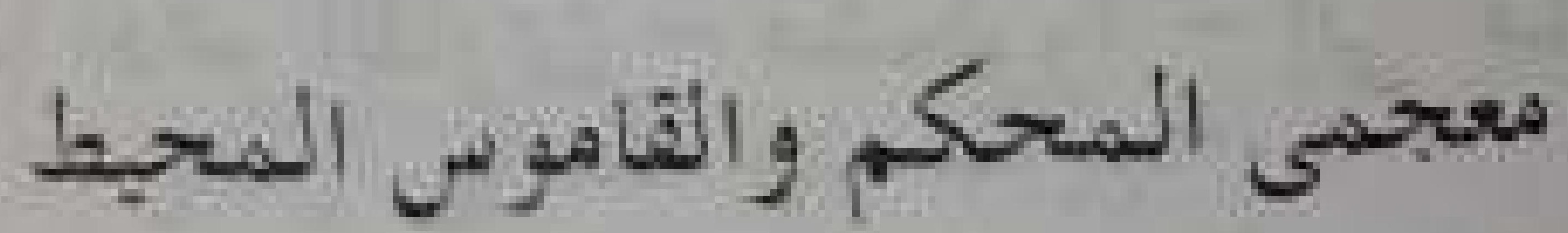

\section{المبحث الثنالت}

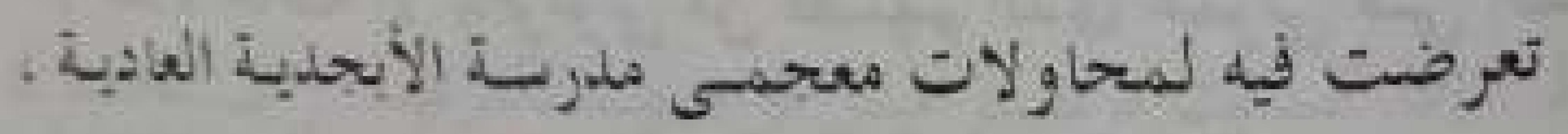

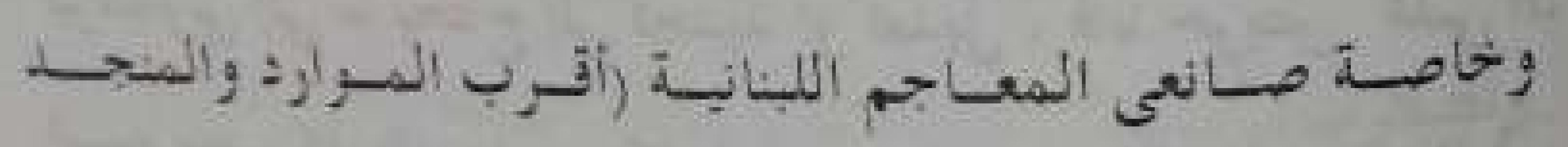

ومتز اللغة ).

\section{المبحت المرابع}

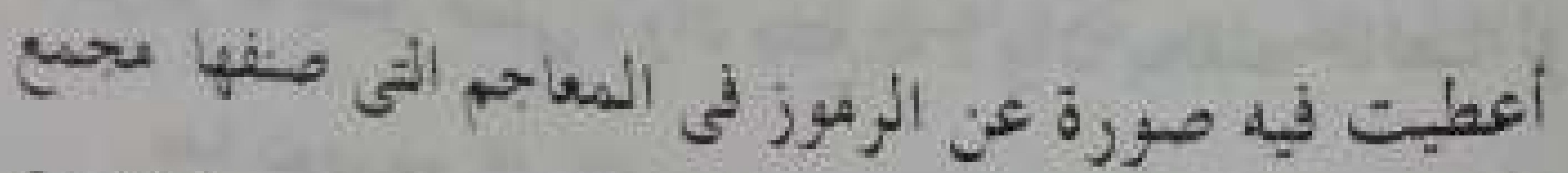

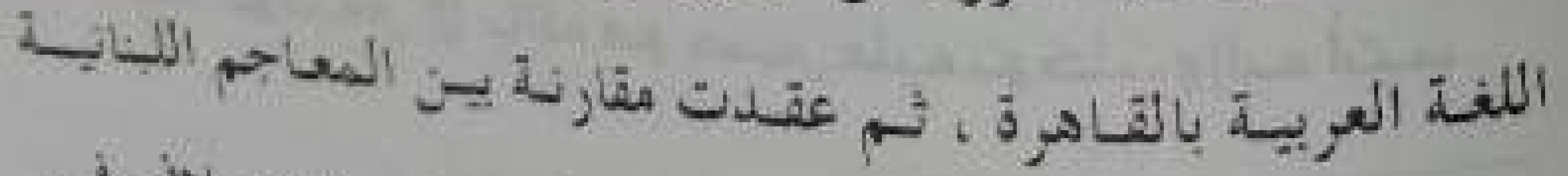

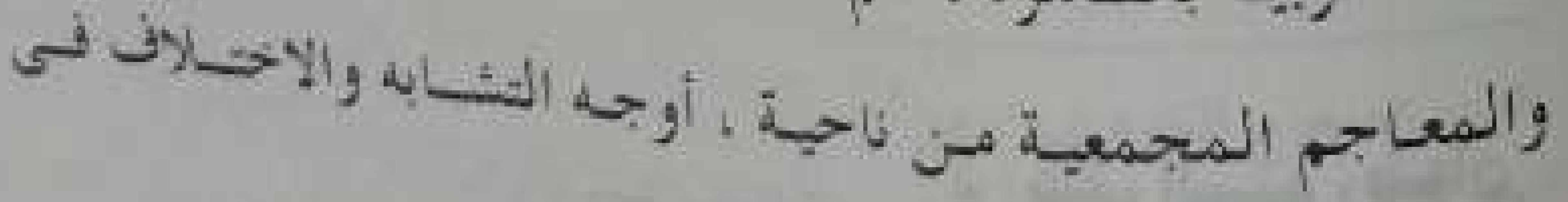

sin-

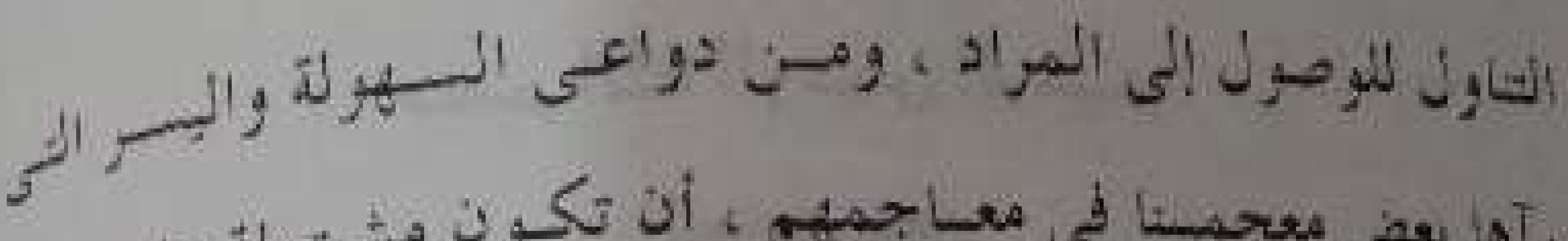

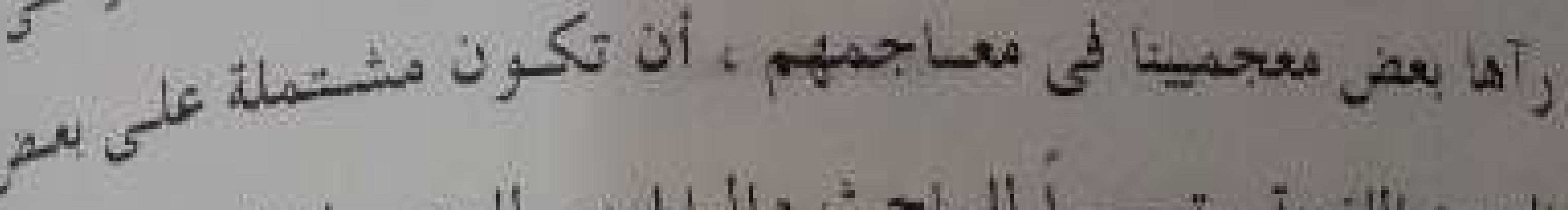

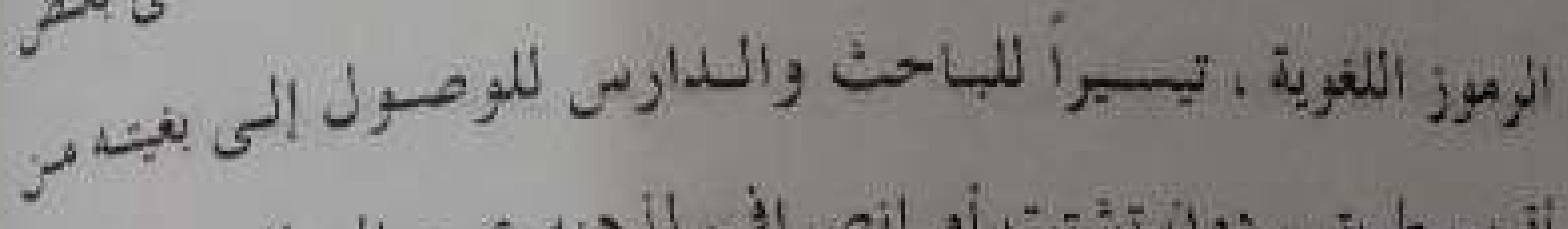

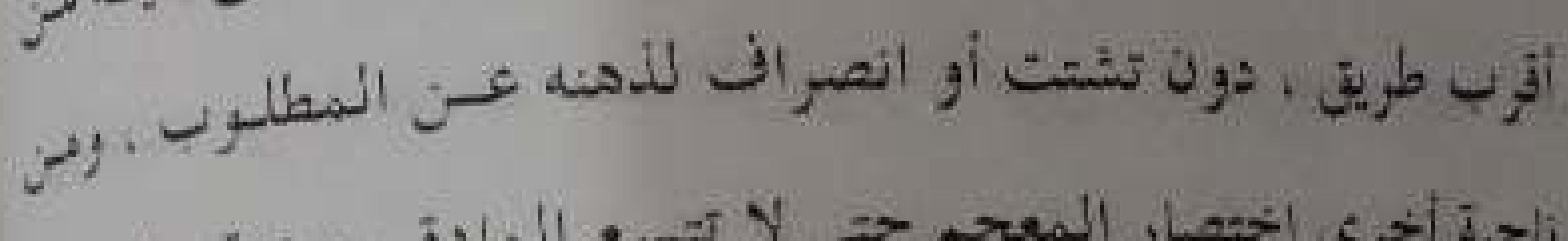

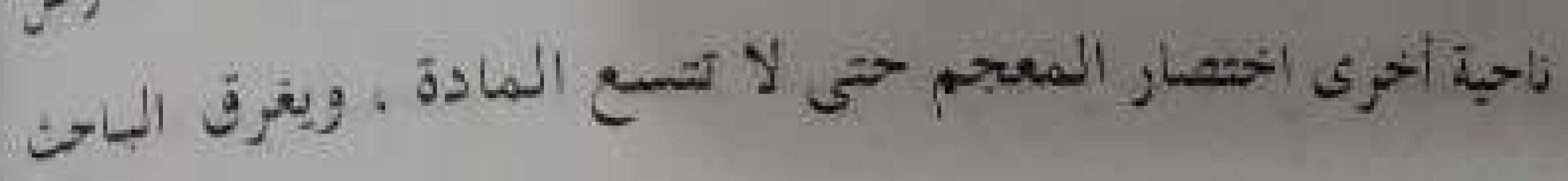
في نصم التخريعات النختلفة للمادة اللغوية

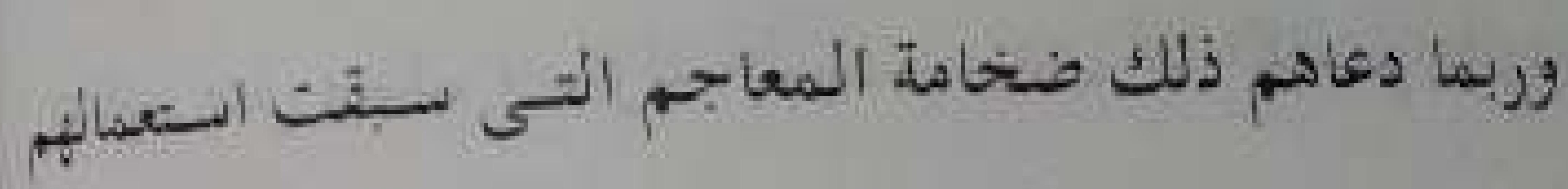

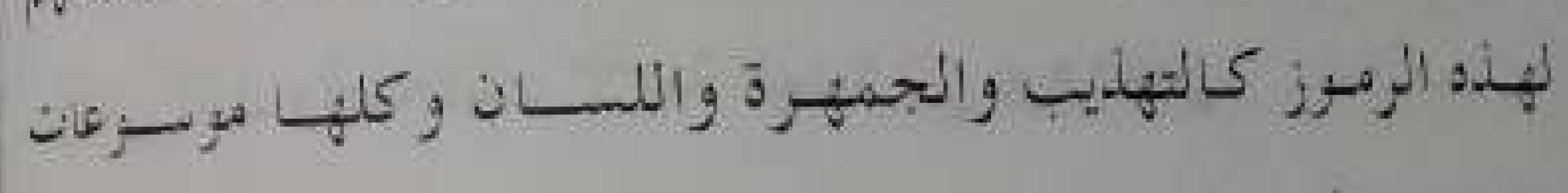

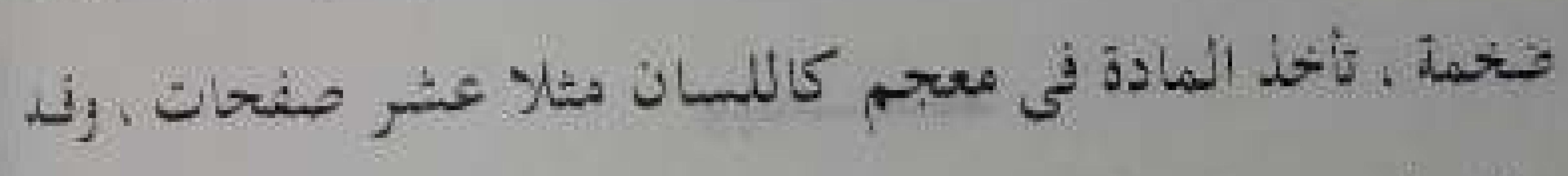

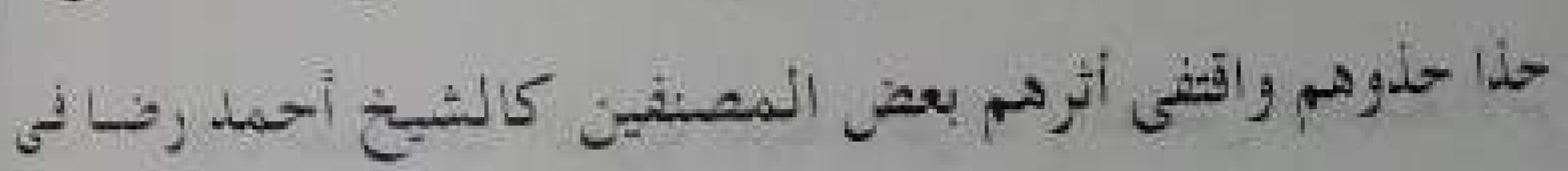

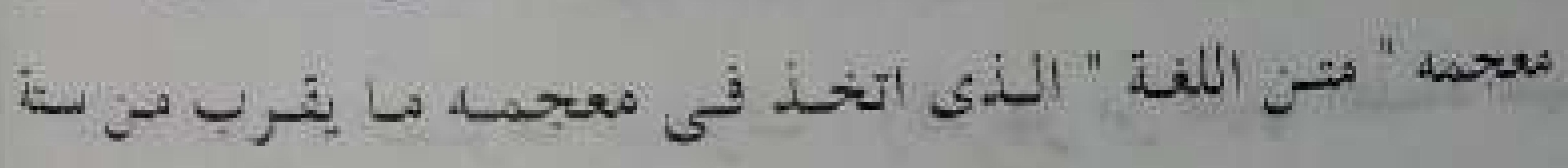

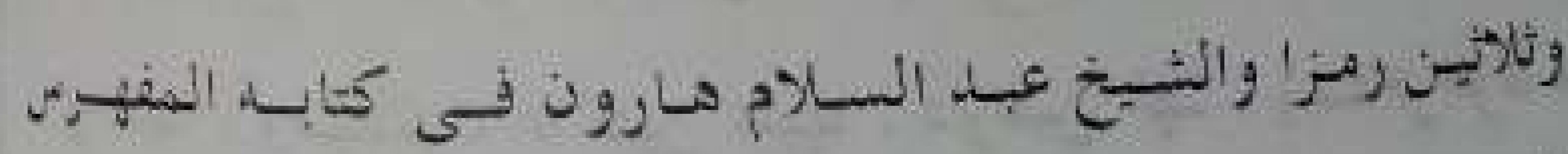

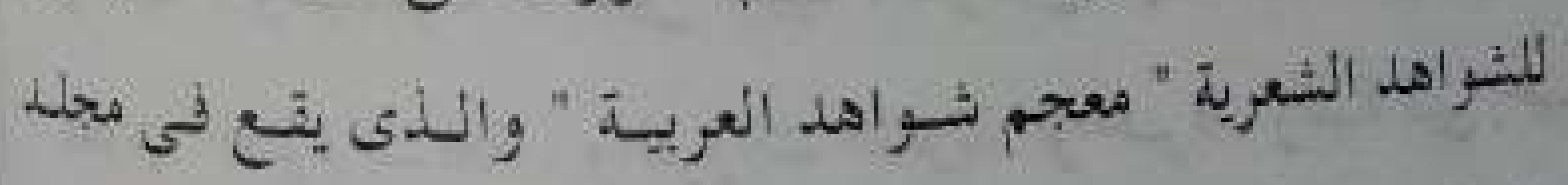

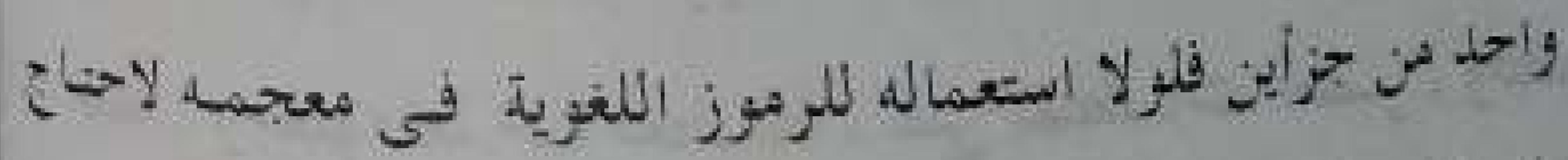

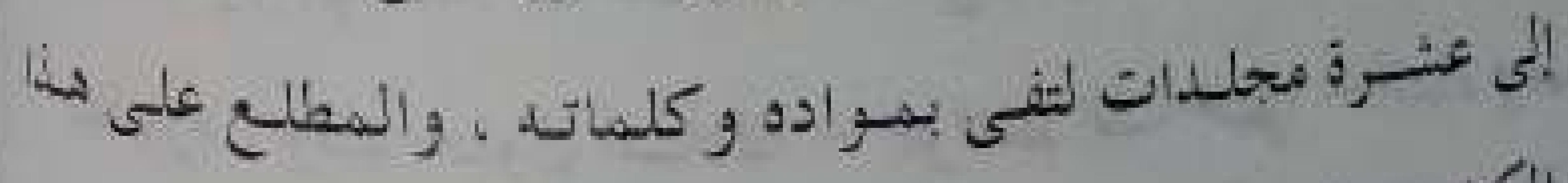

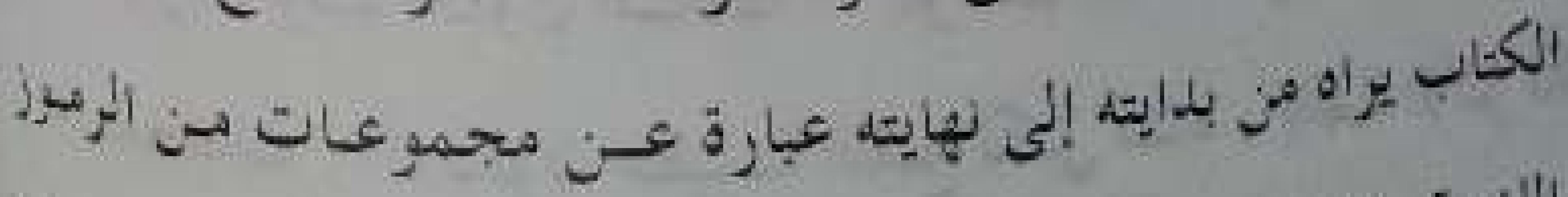

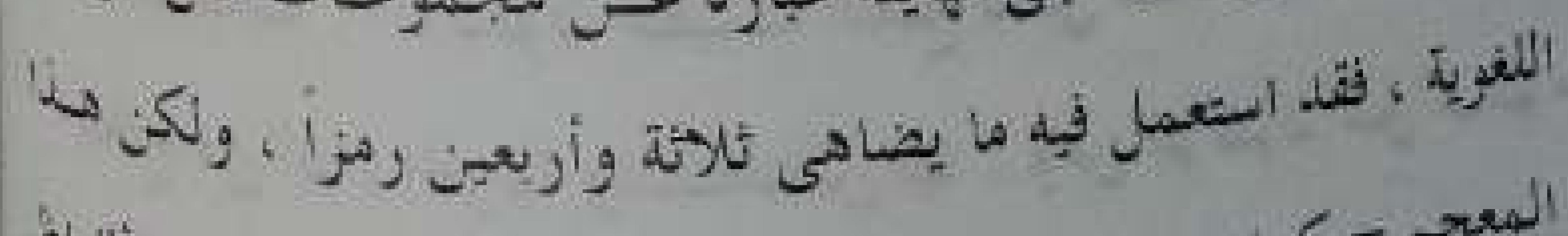

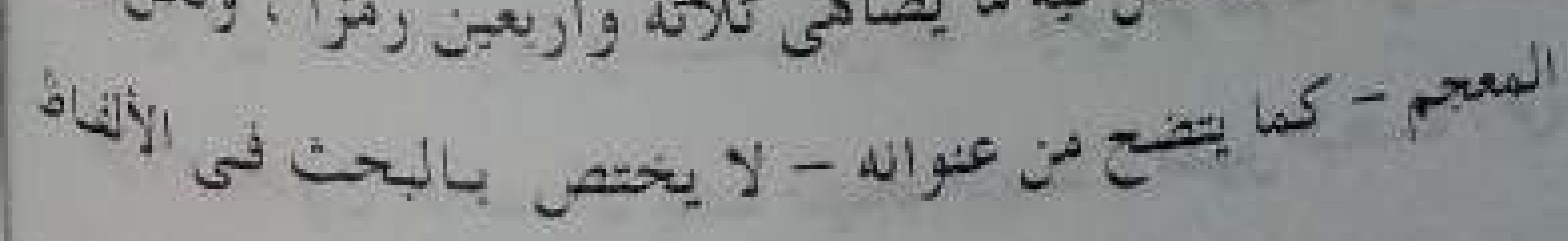




\section{$-191-$

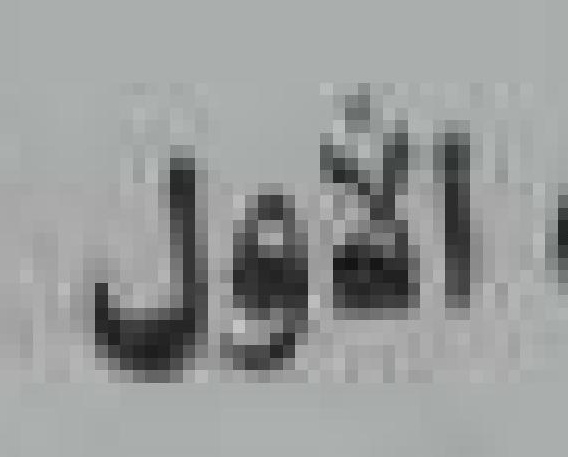

$\longrightarrow$ الم

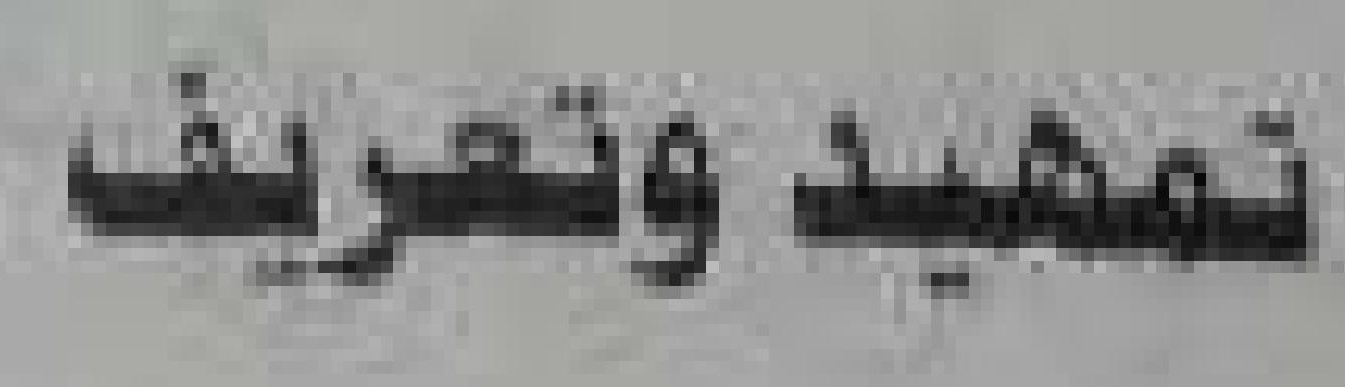

المفهوه اللفوىى

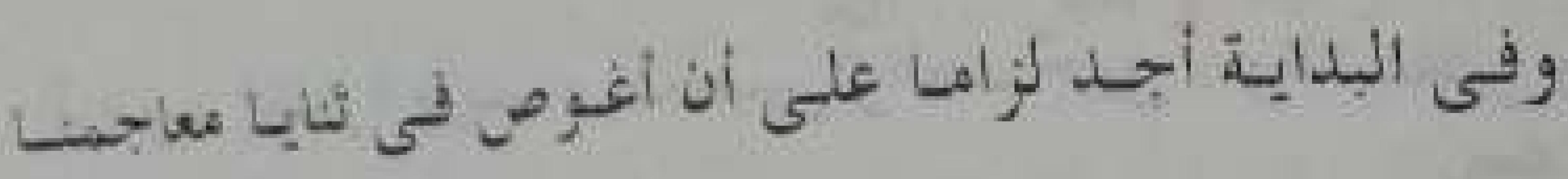

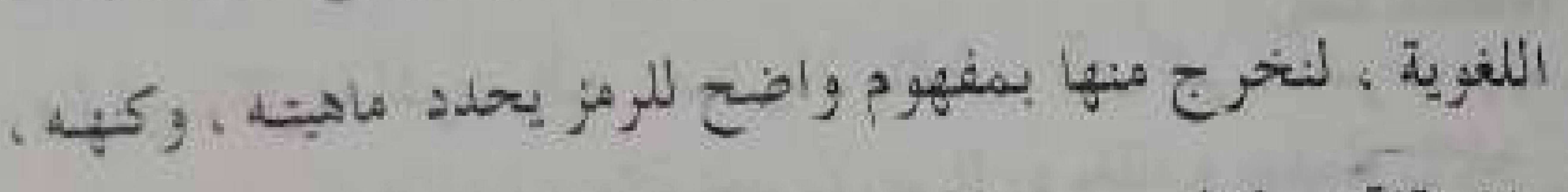

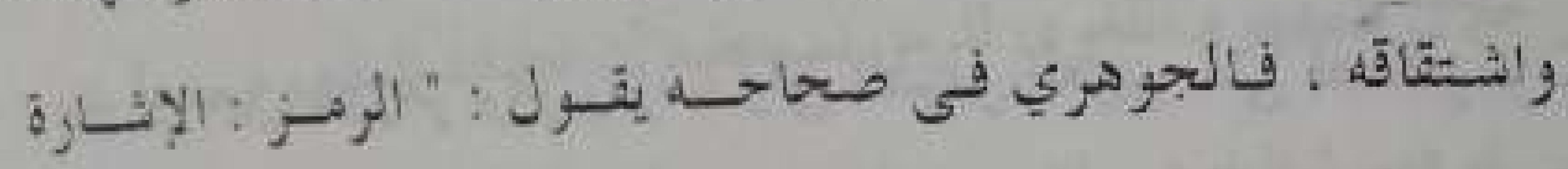

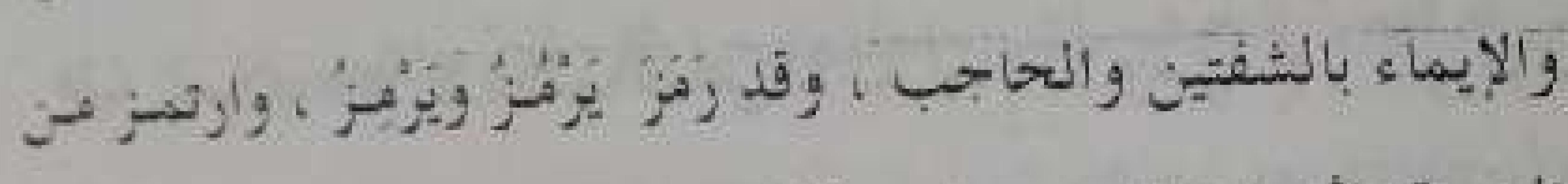

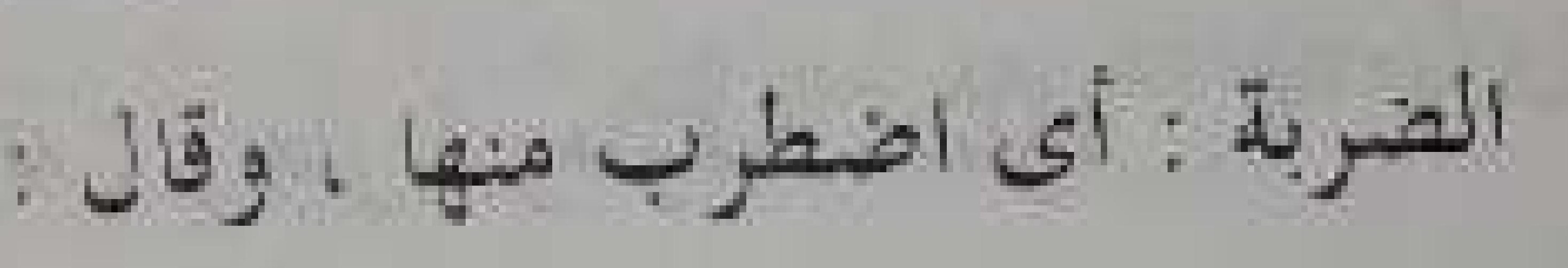

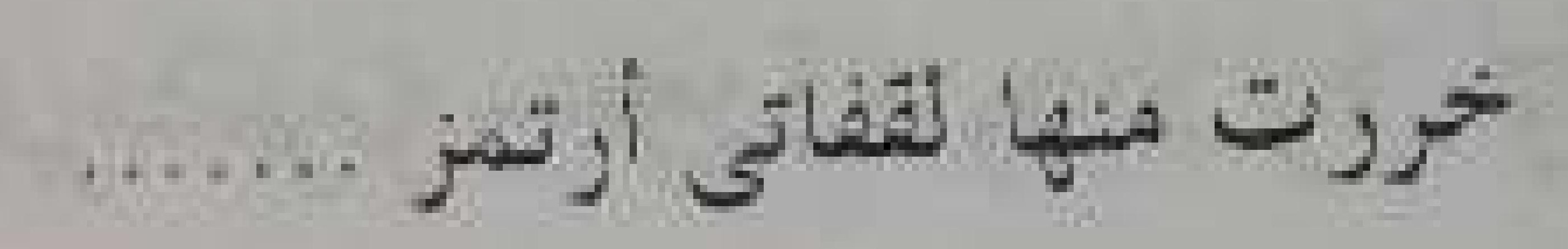

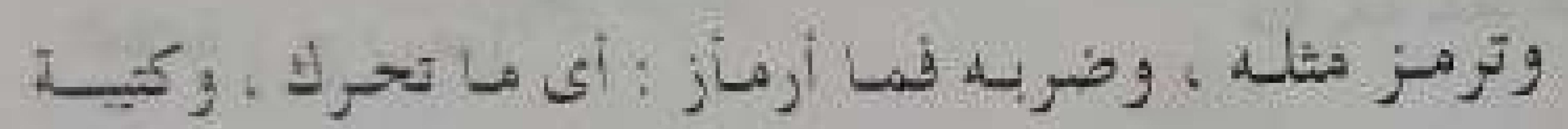

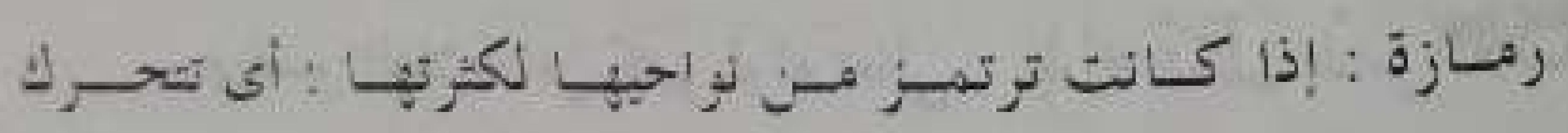

$$
\text { (1) "وتصن }
$$

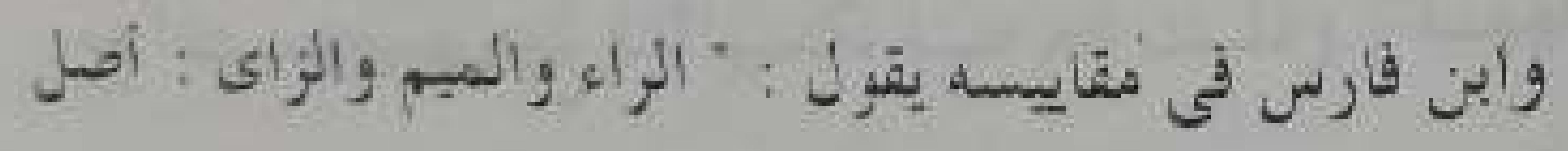

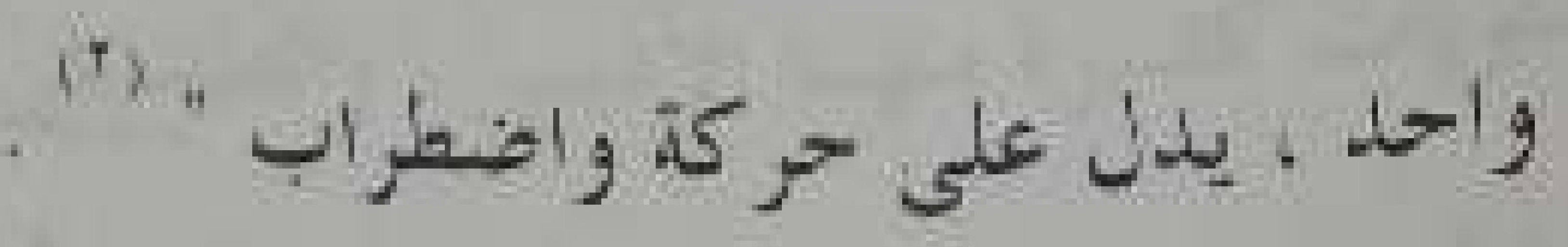

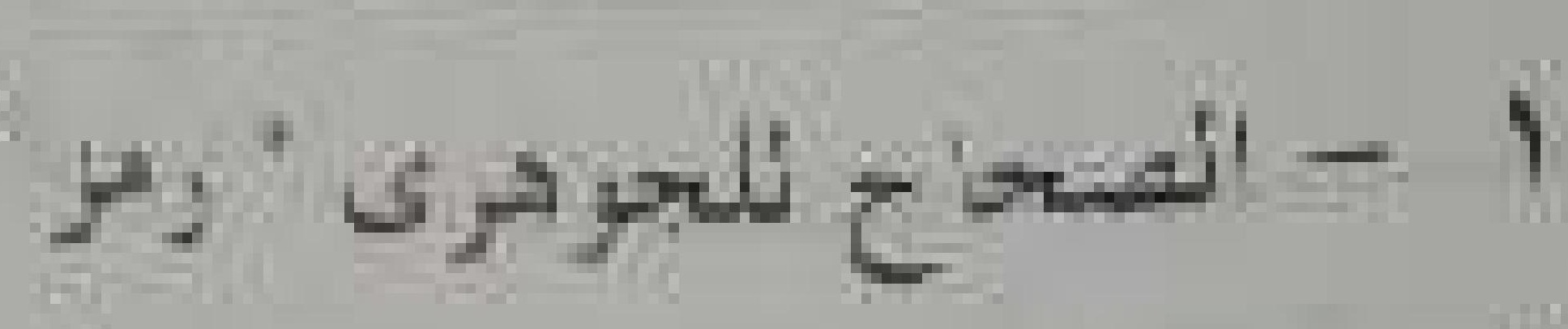

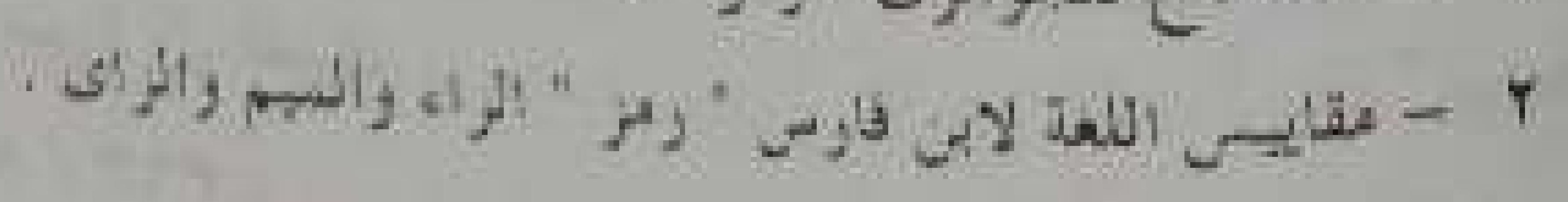

\section{$-19 .-$}

الأشكال الرمزية ، ثم أعقبت ذلك باليتائج التي توصلست إليها برو

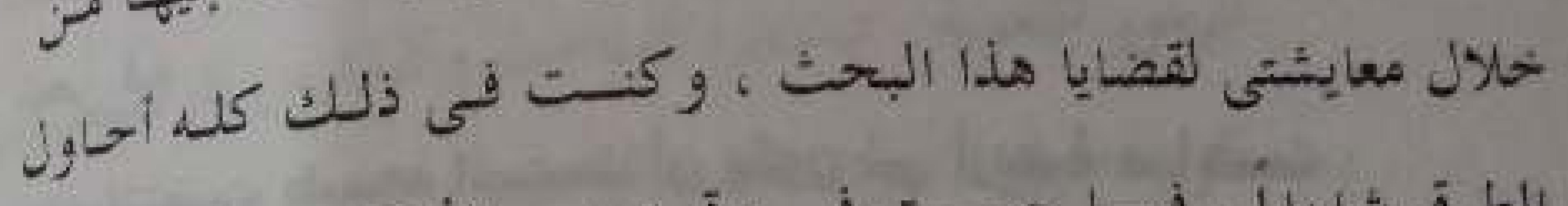

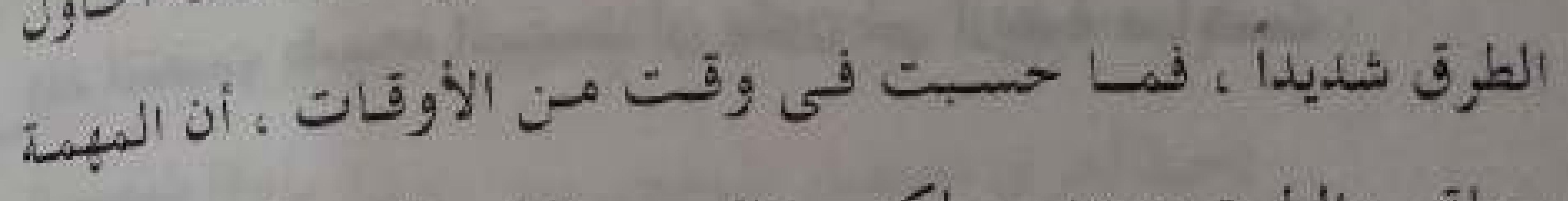

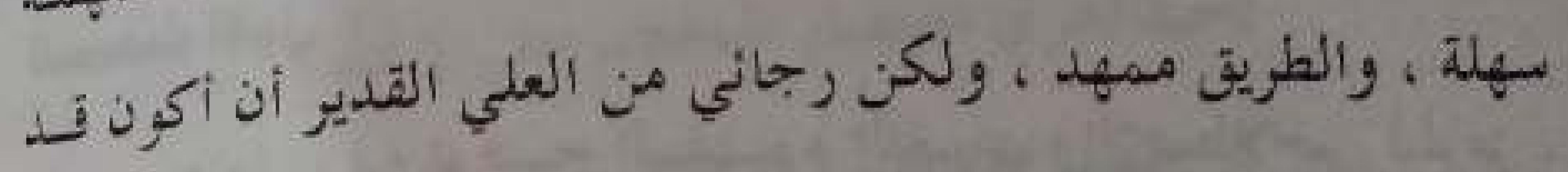

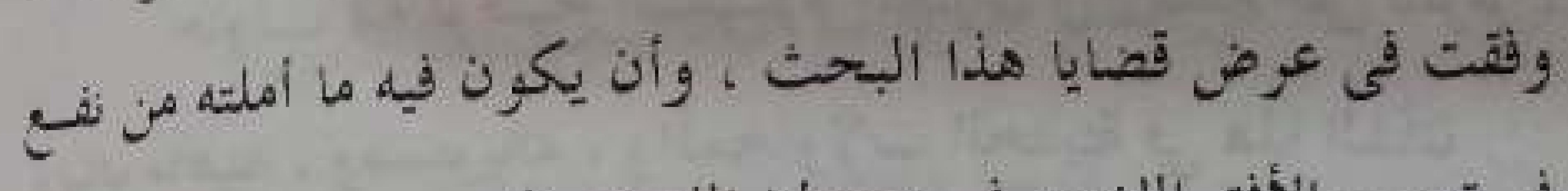
فى توسيع الأفت اللغوي فى محيطنا اللغوي العربى . ولبست أدعى أن ما تطالعه هو أحسن مـا يقـان ، أو أندا نمبرا

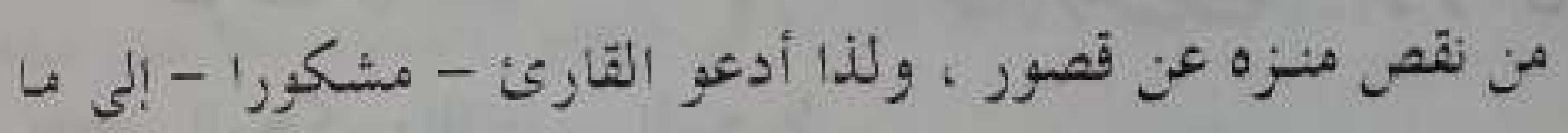

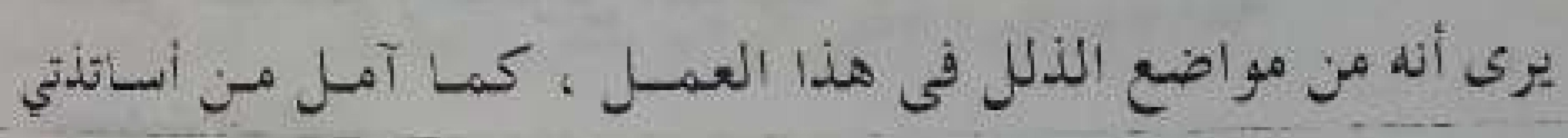
الأجلاء خاصة ألا يحرمونى مز فحلهمب الذى غمرنى في الهاضى،

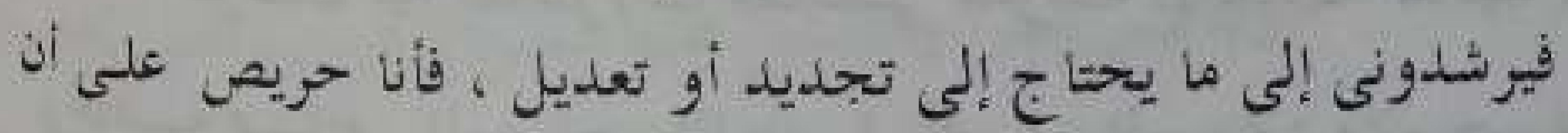

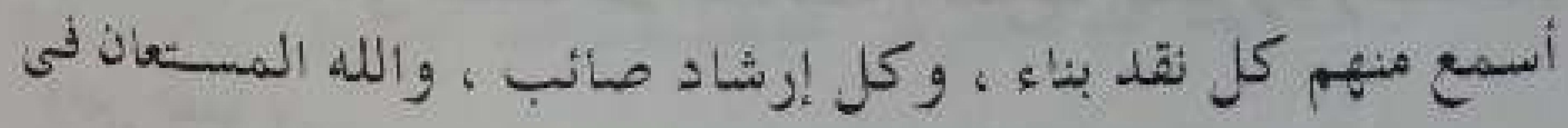

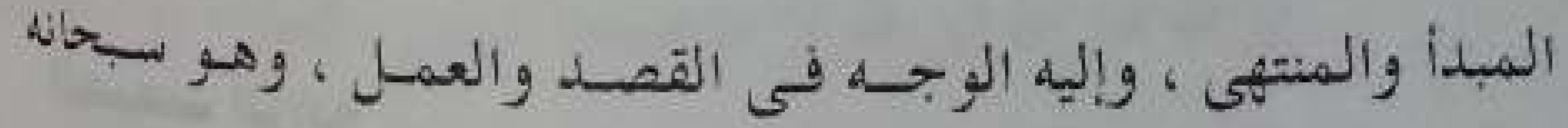

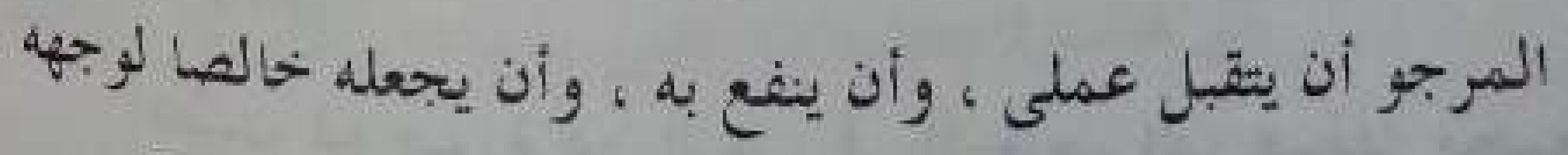

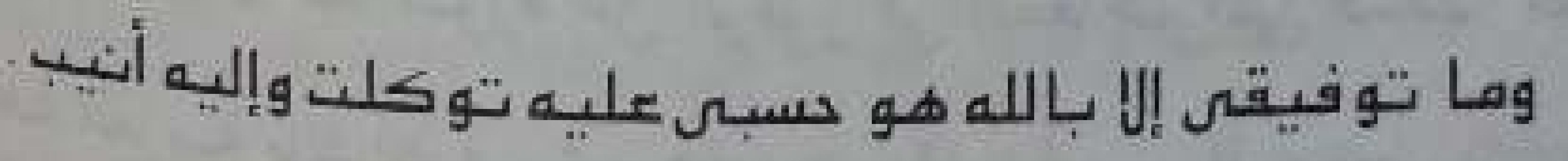

\footnotetext{
في

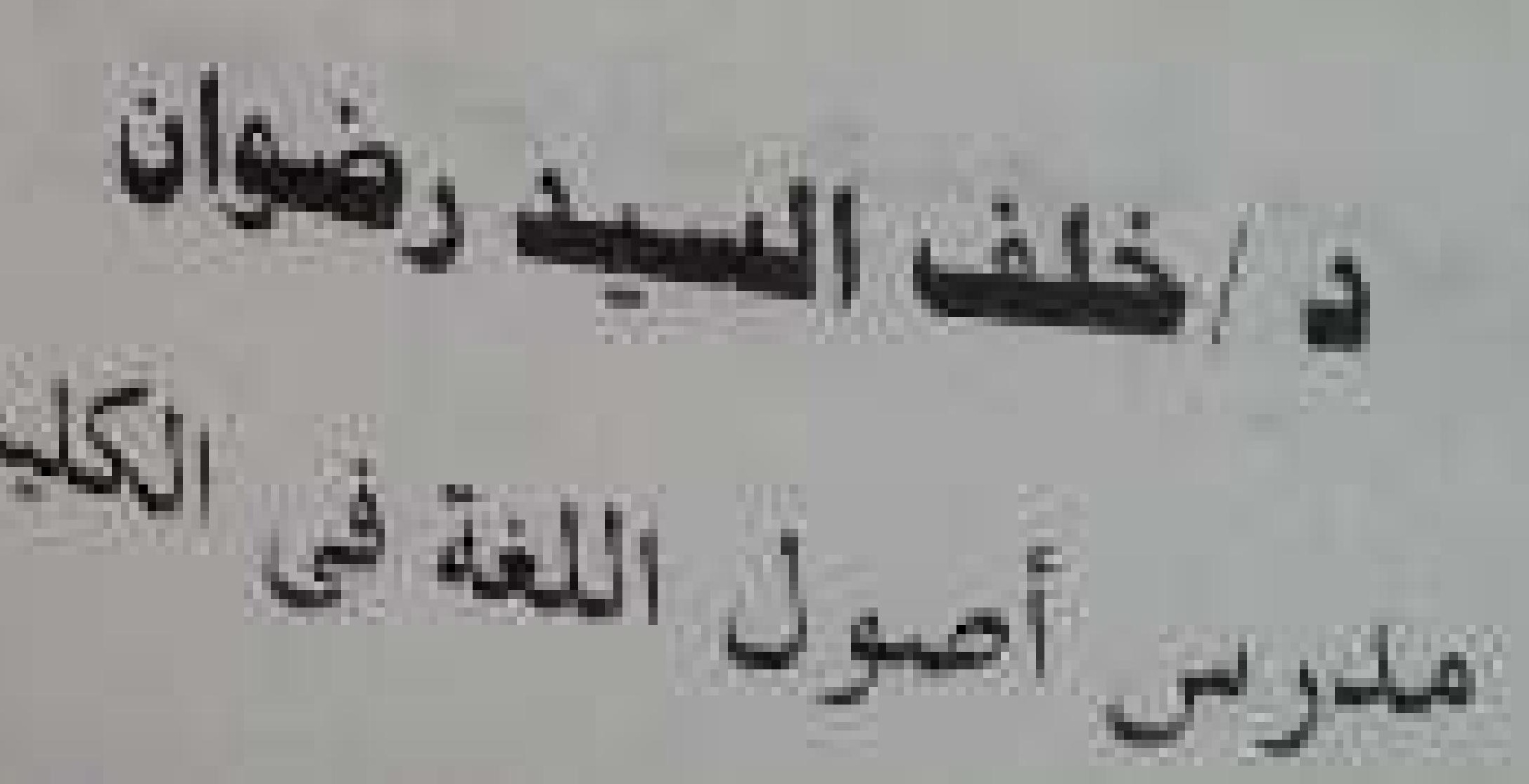




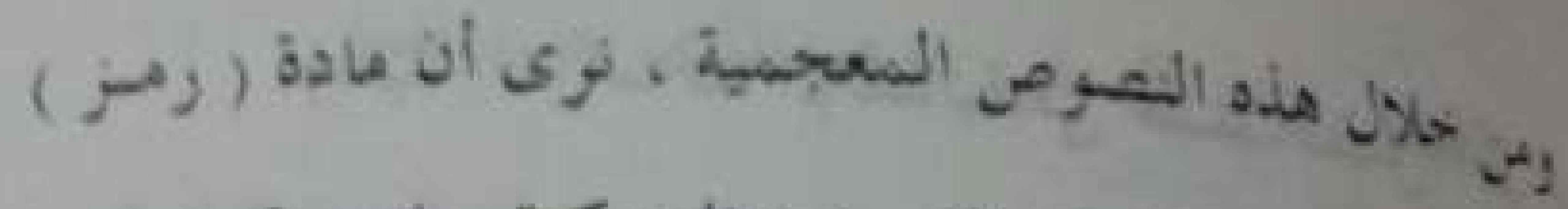

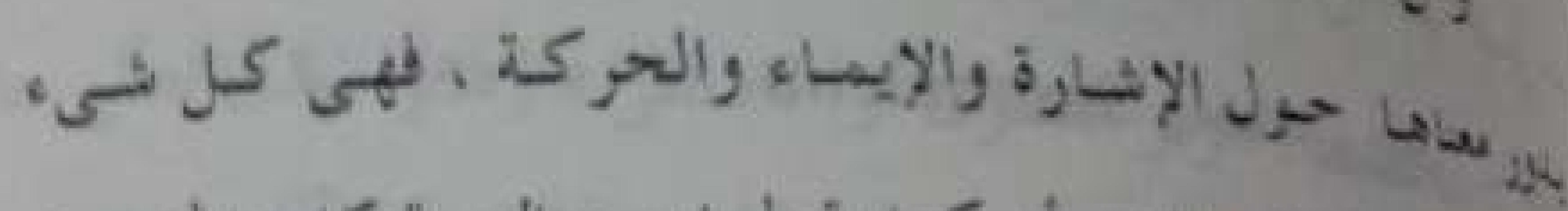

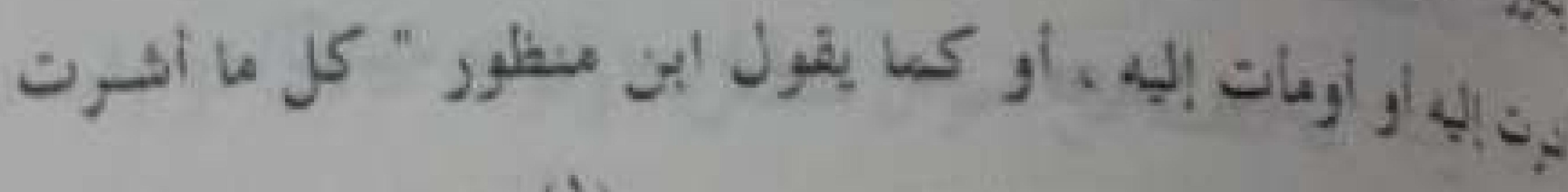

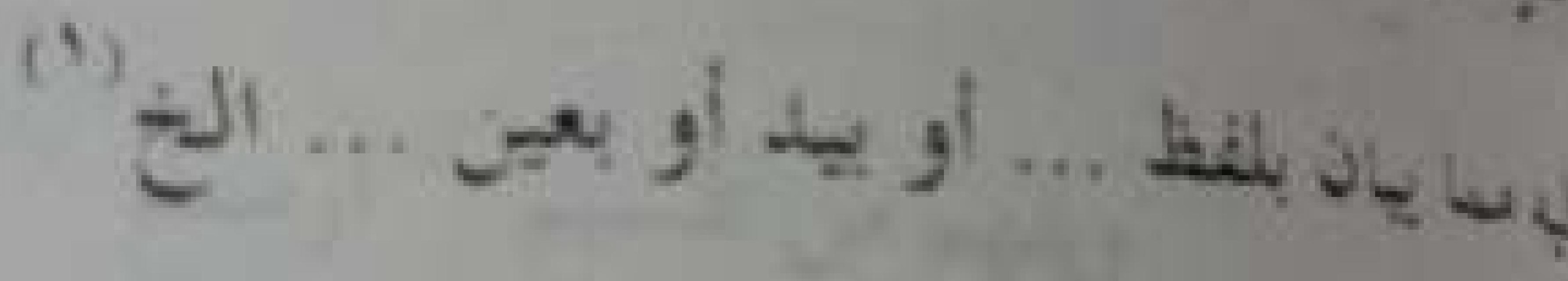

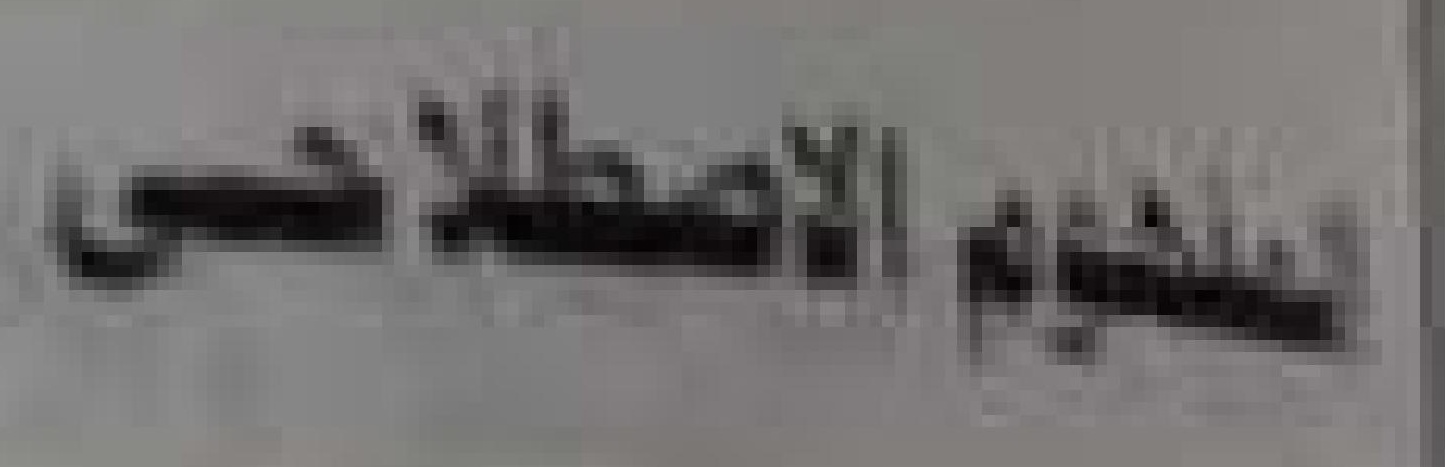

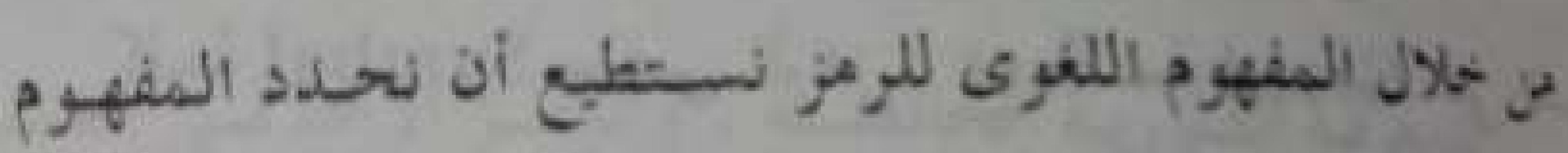

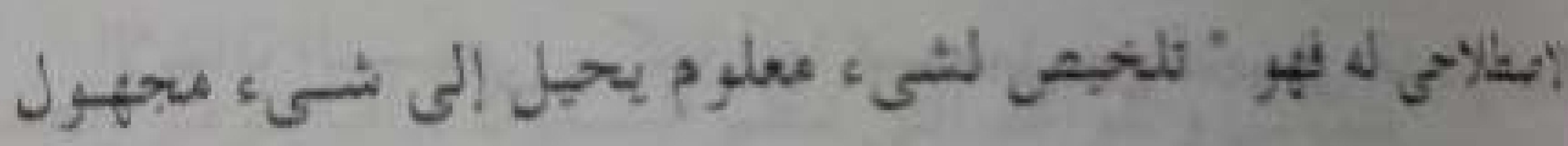

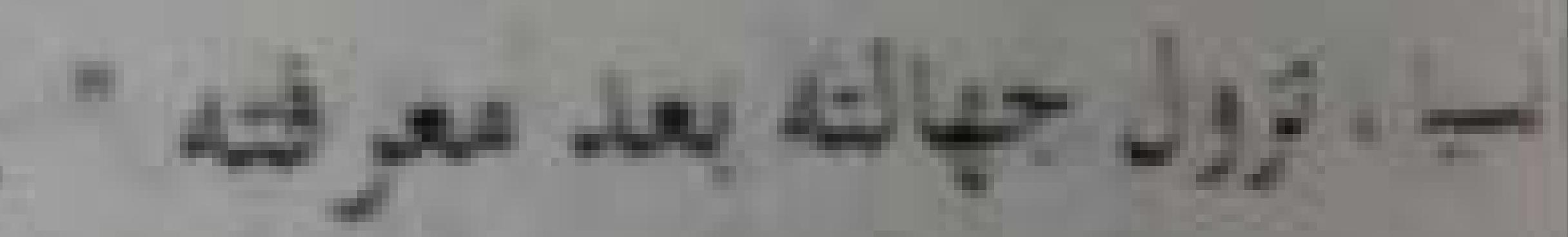

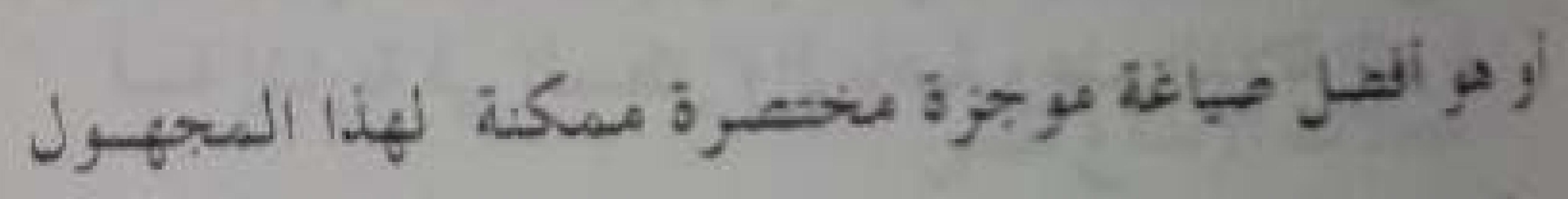
.

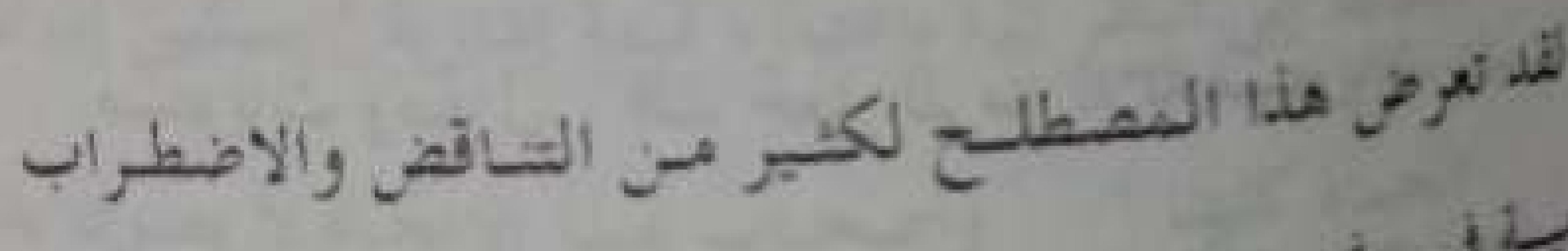

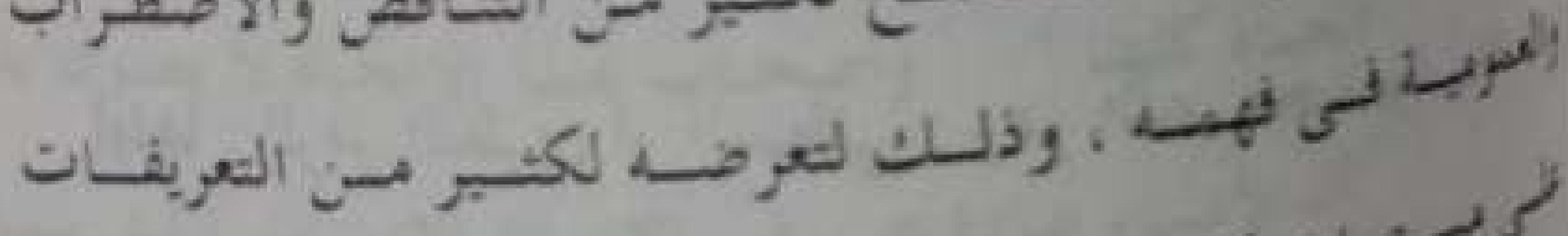

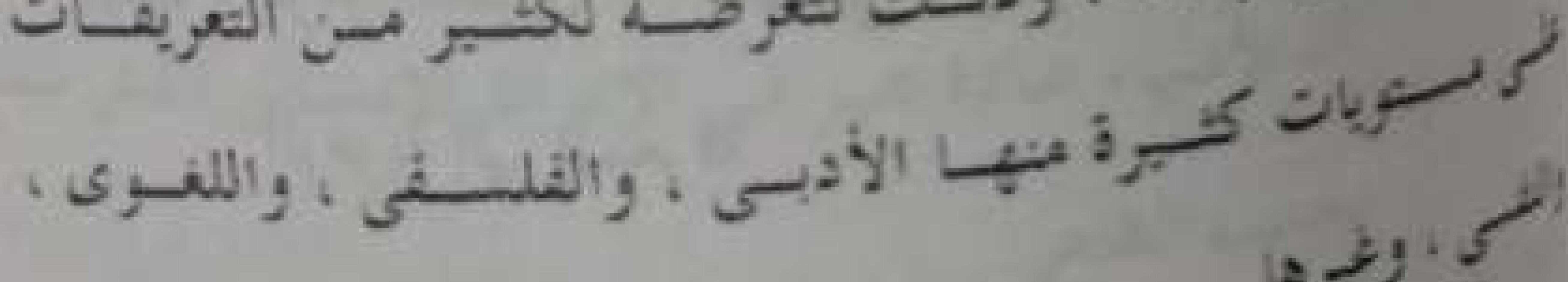
$2,+3,5$
$-18 r-$

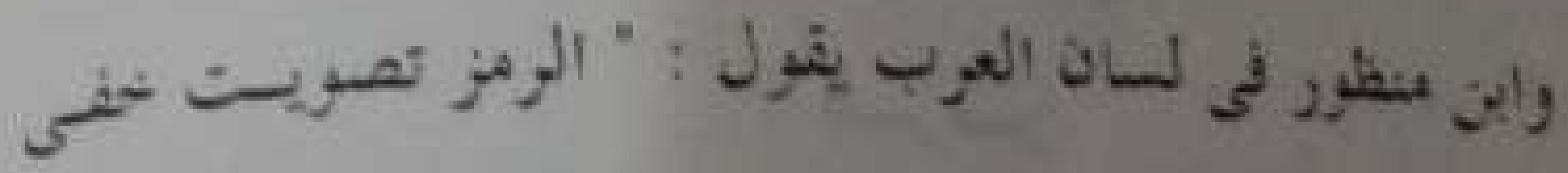

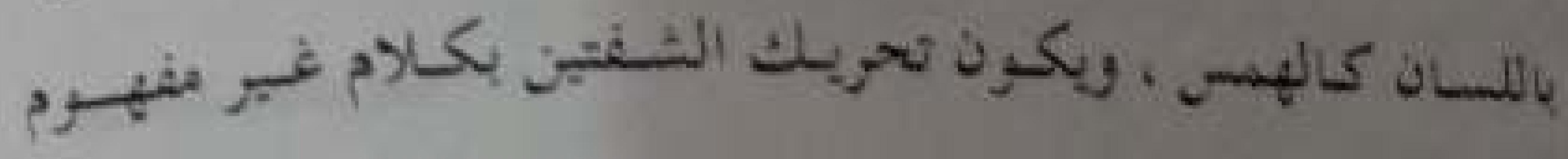

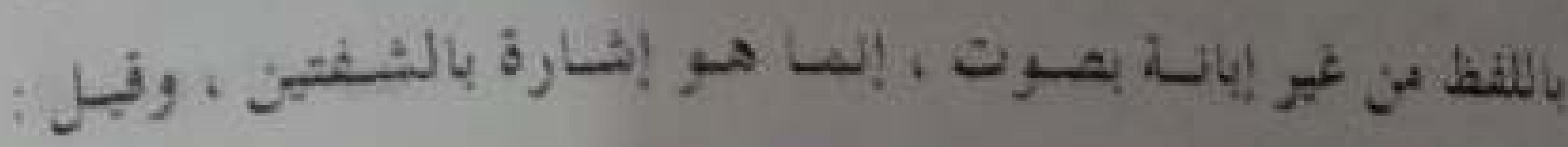

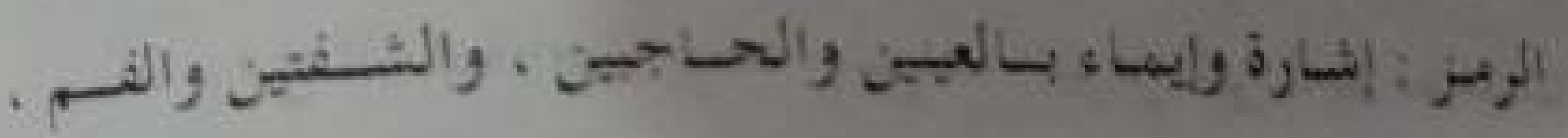

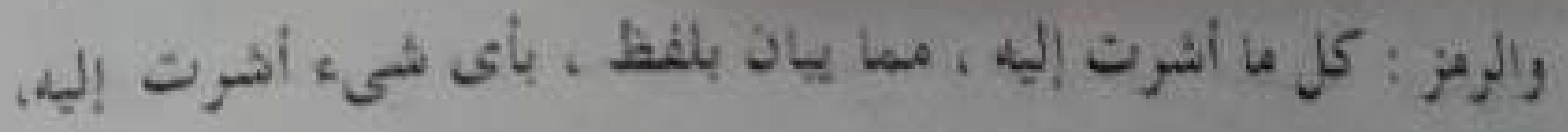

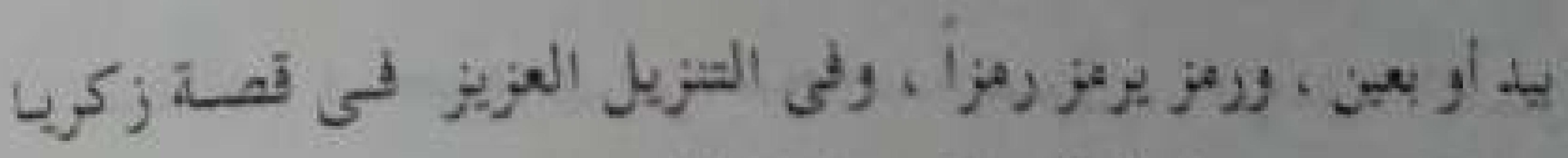

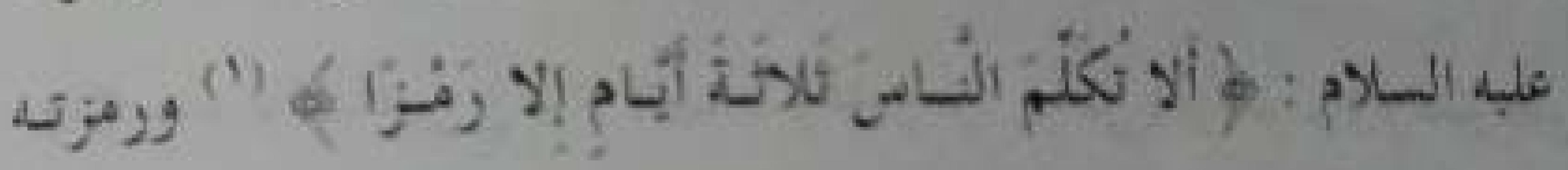

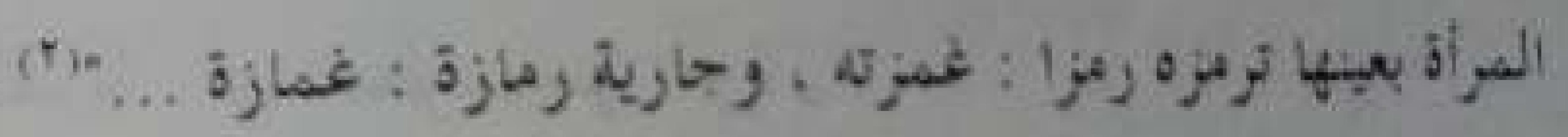

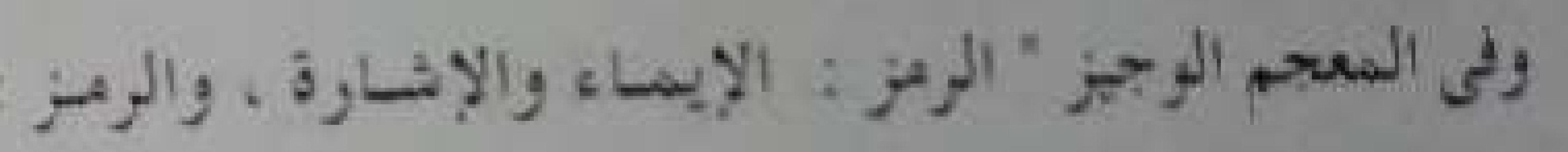
(i) jos (z) istal

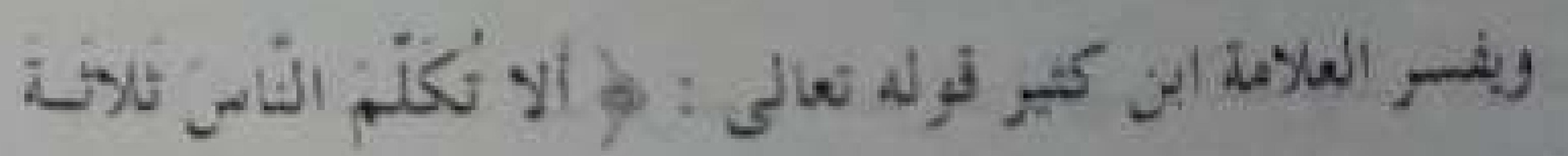

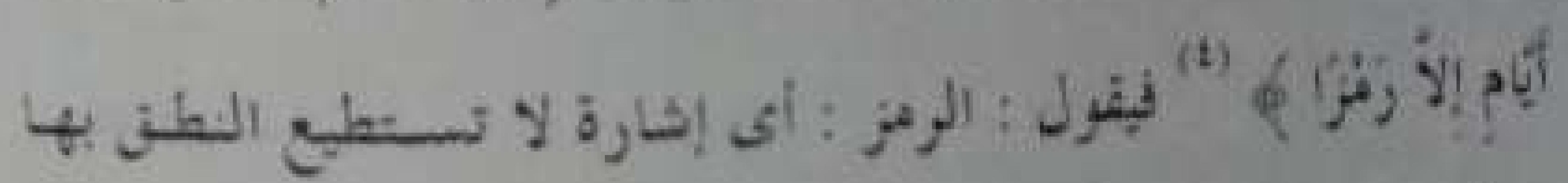

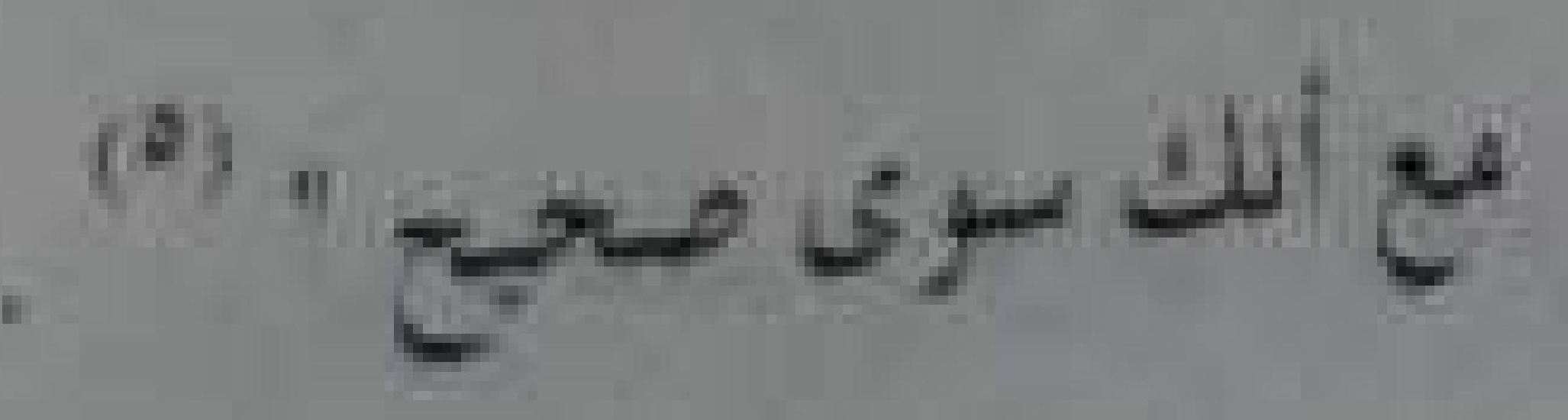

(1) 101,0 JT $3,2,-1$

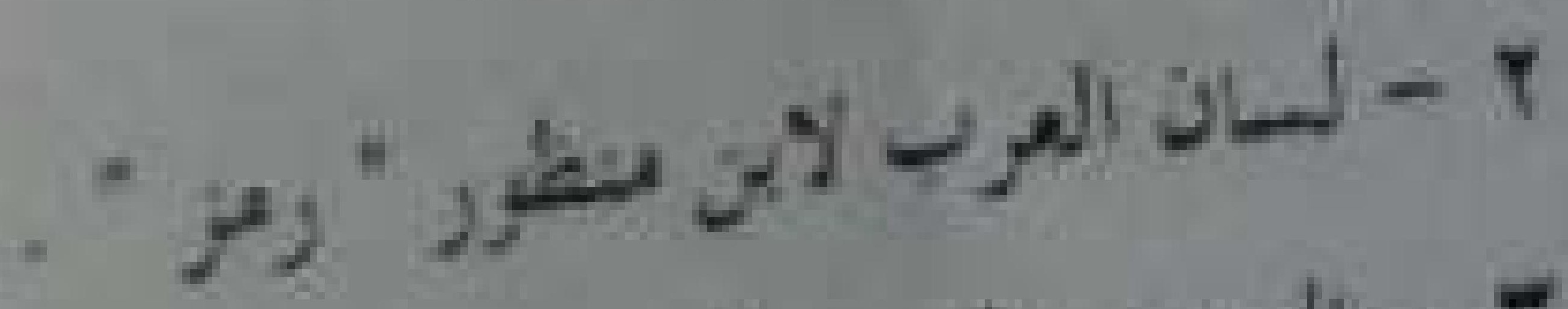

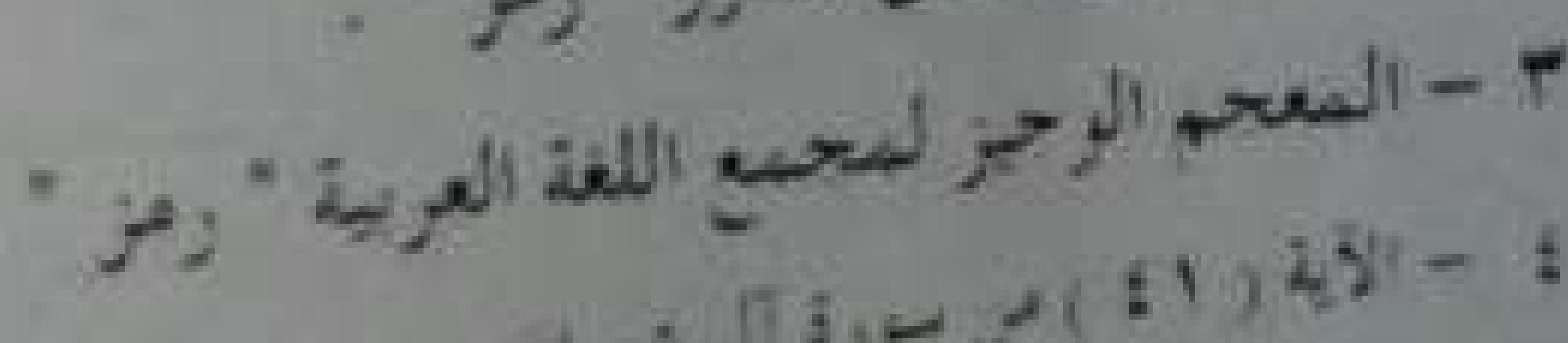

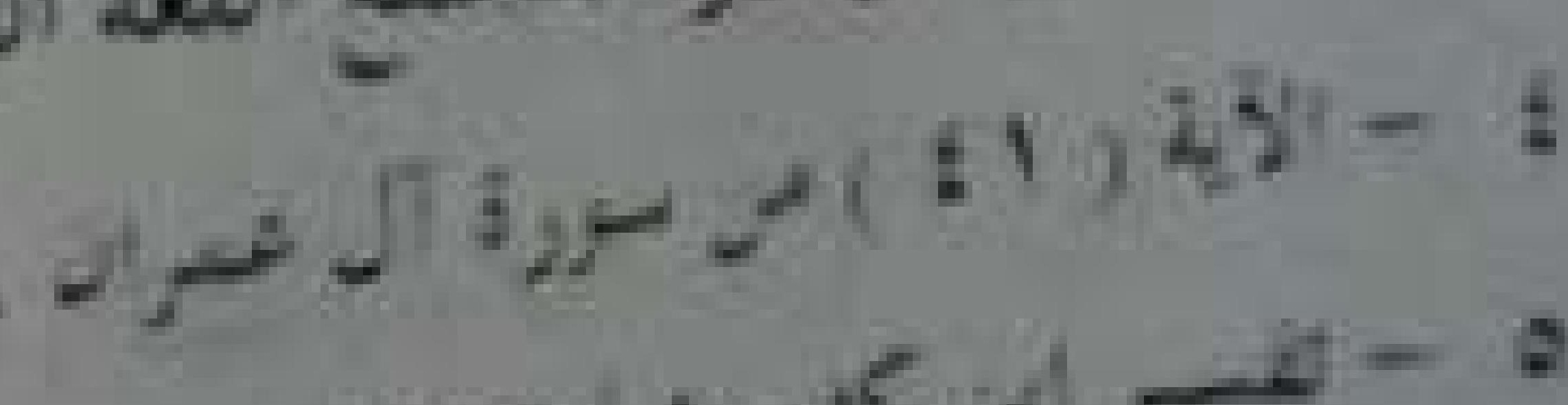
mil $1,5: A=0$ 


$$
-190=
$$

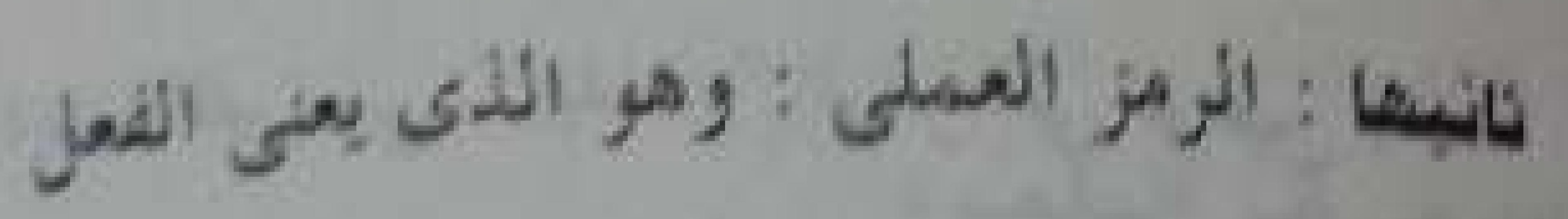

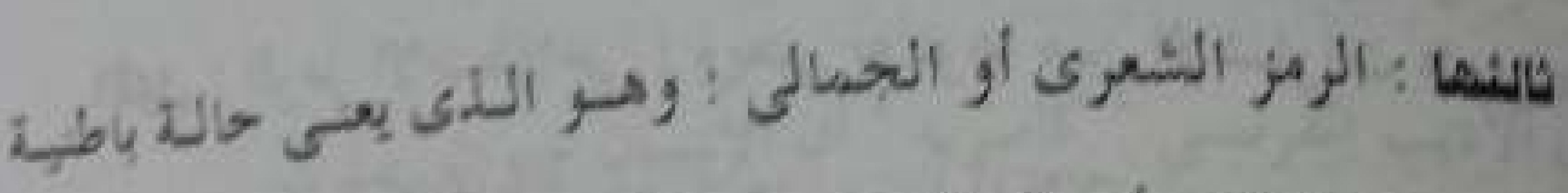

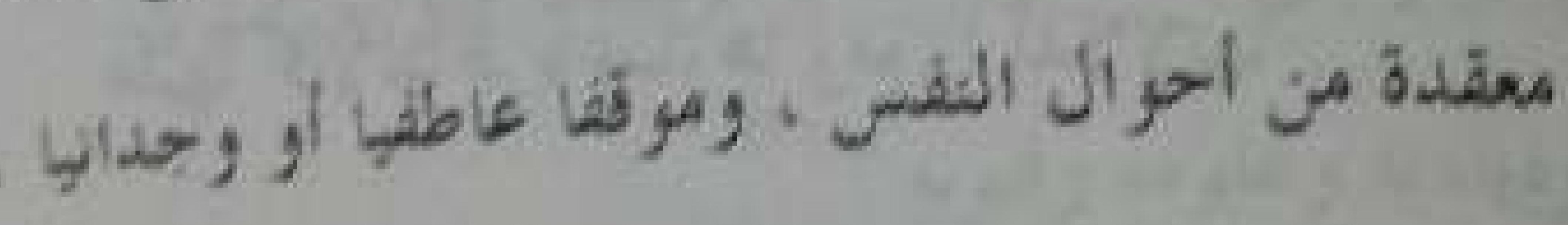

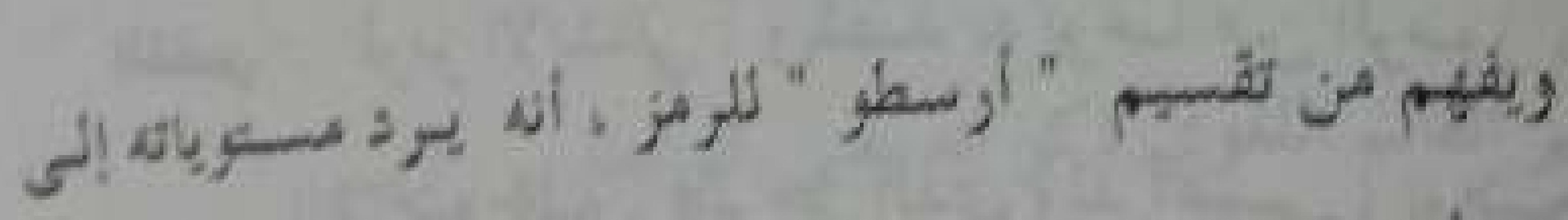

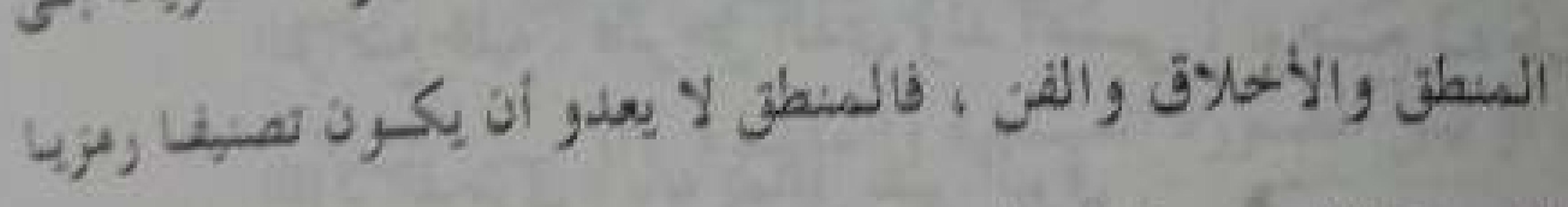

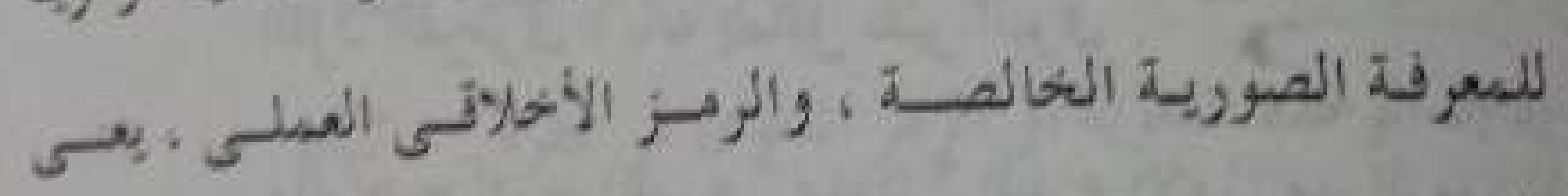

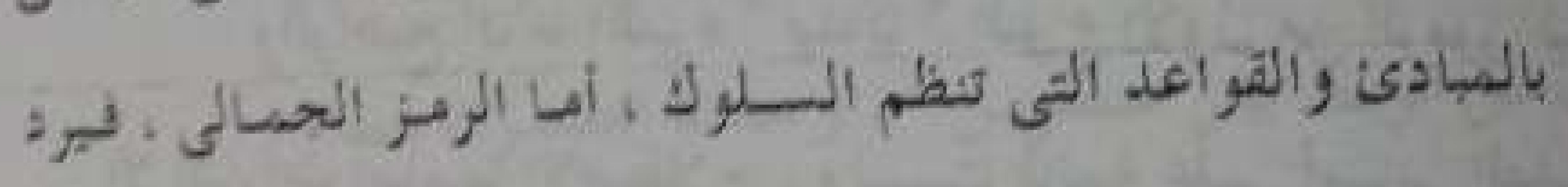

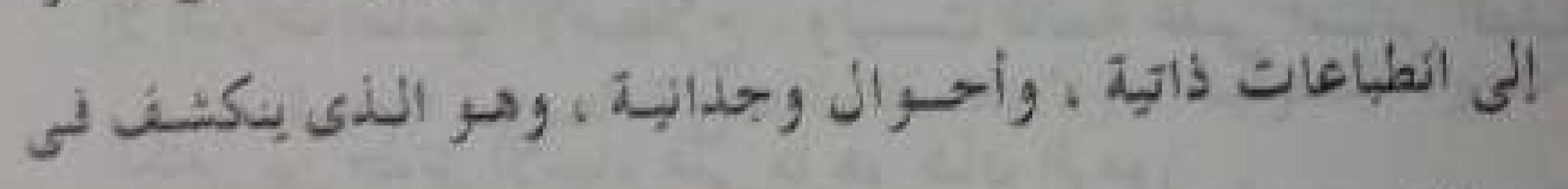

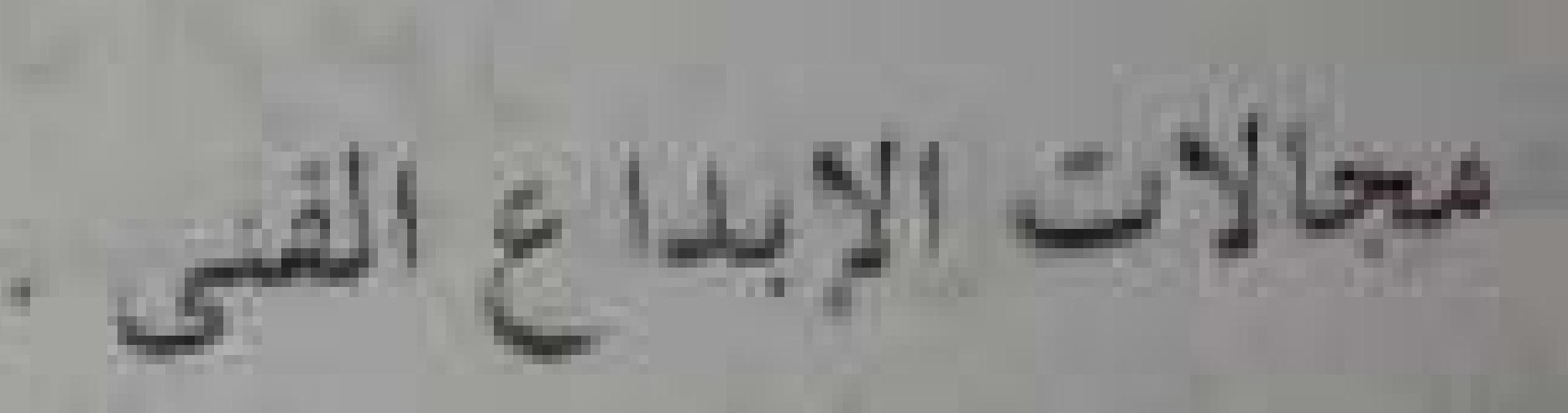

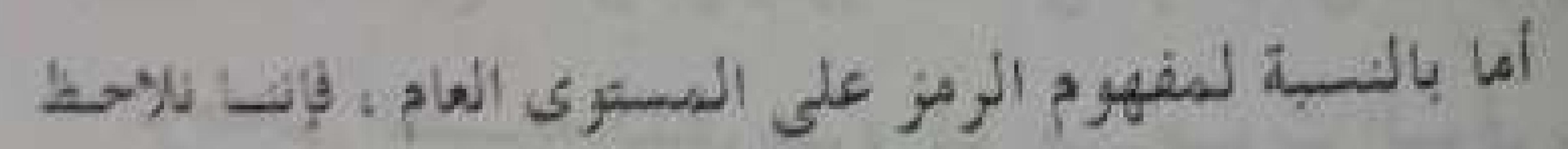

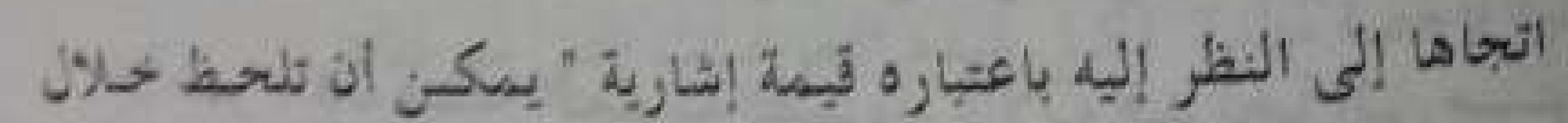

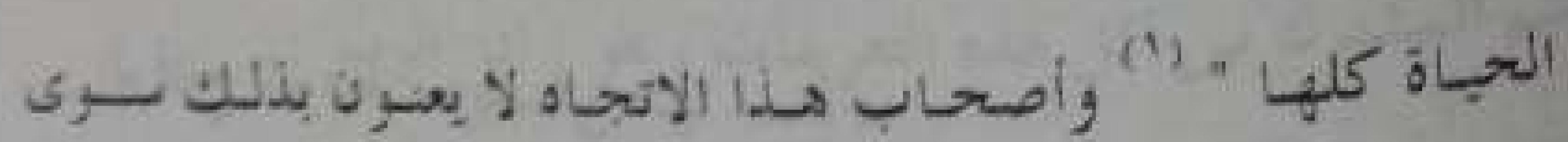

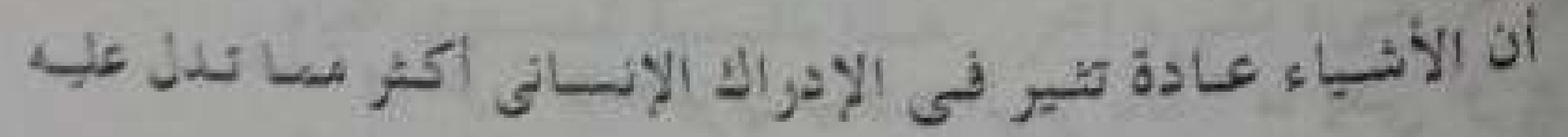
بحسب الظاهر
$-184-$

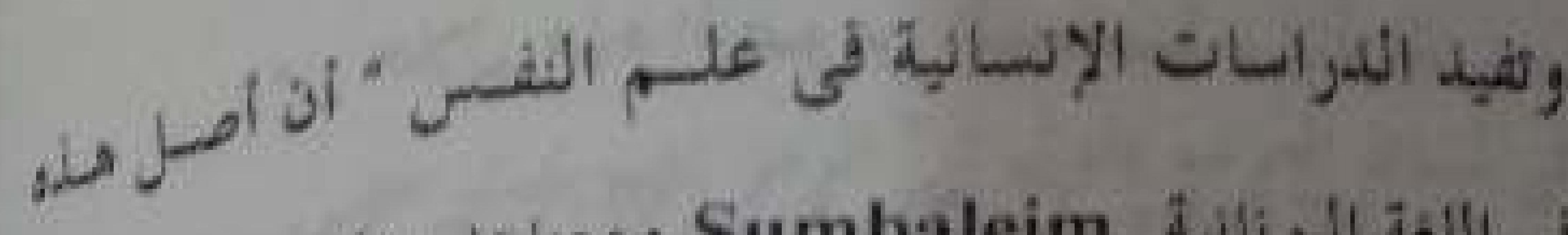

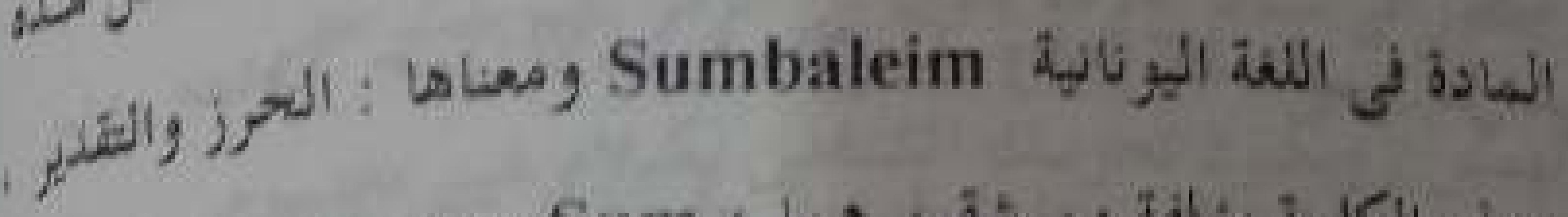

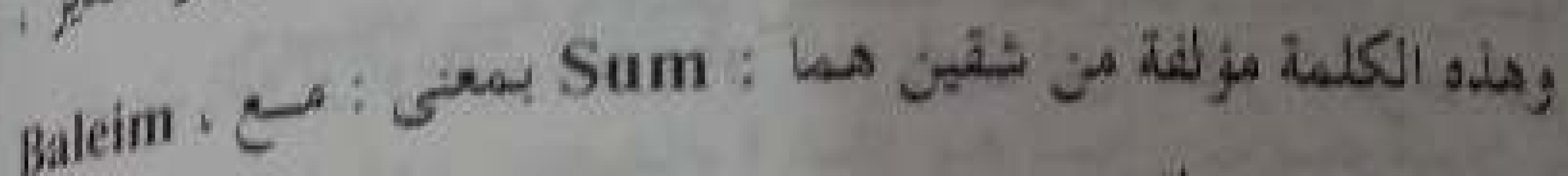

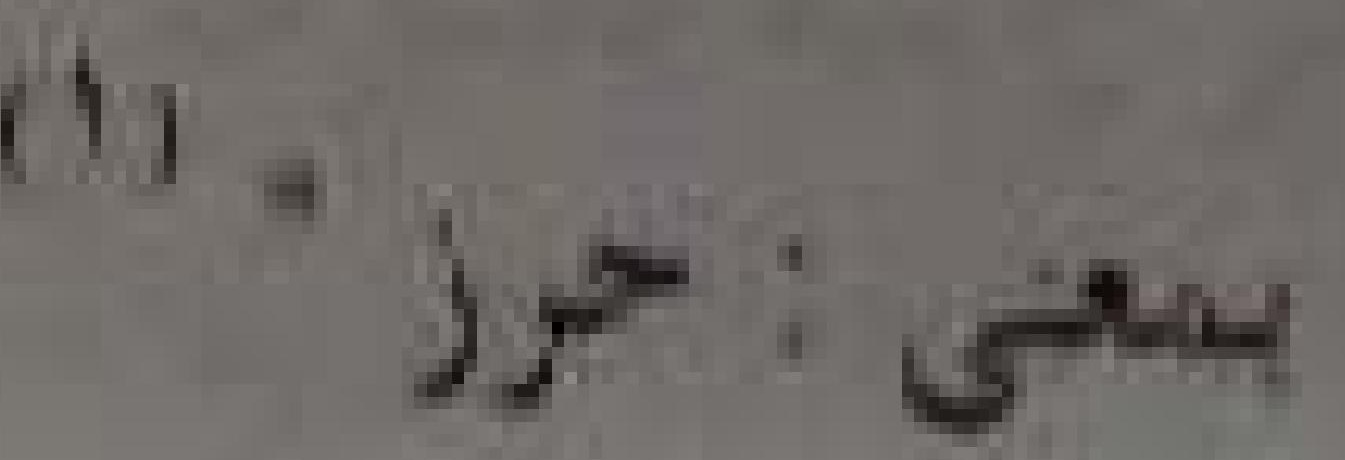

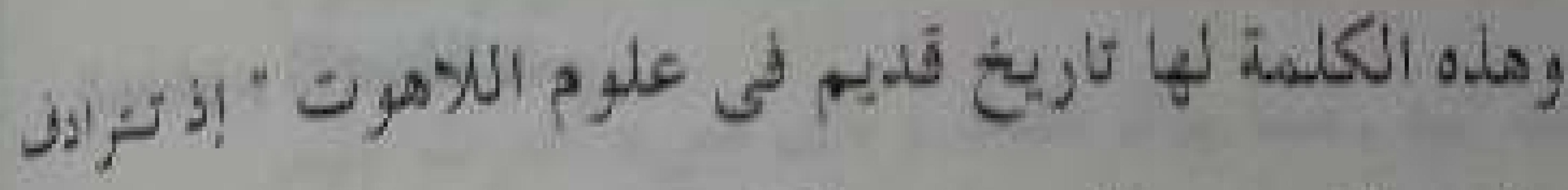

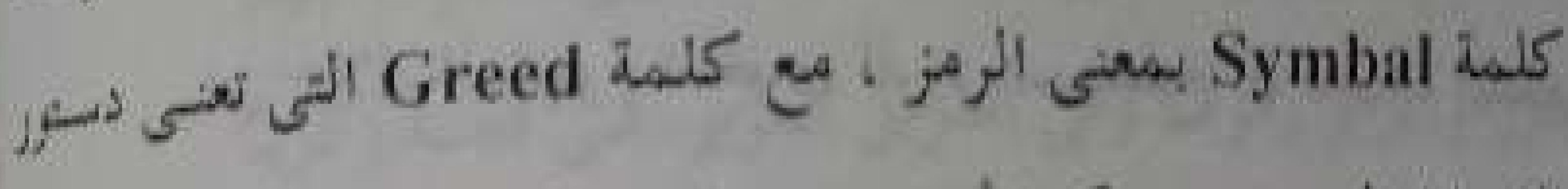

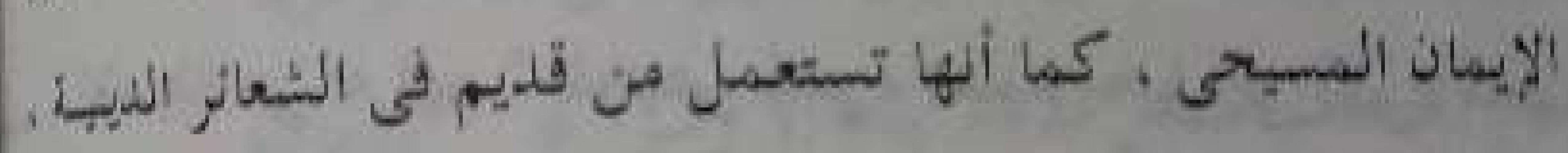

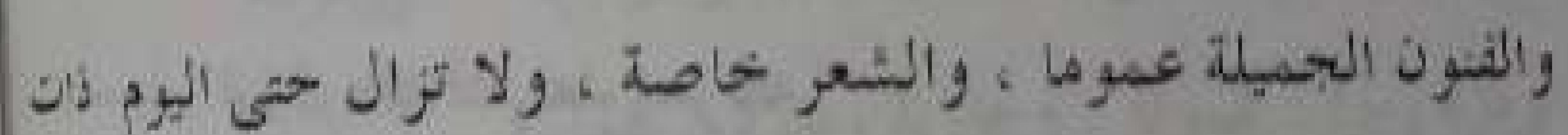

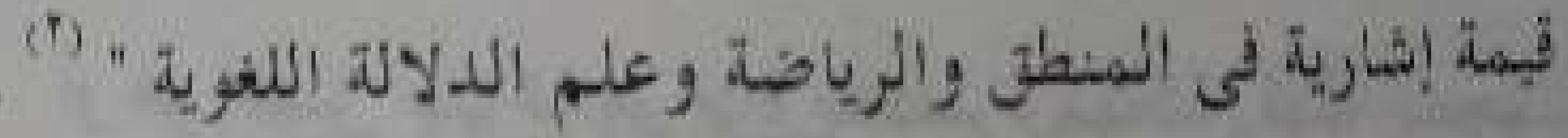
مستويات الرهز

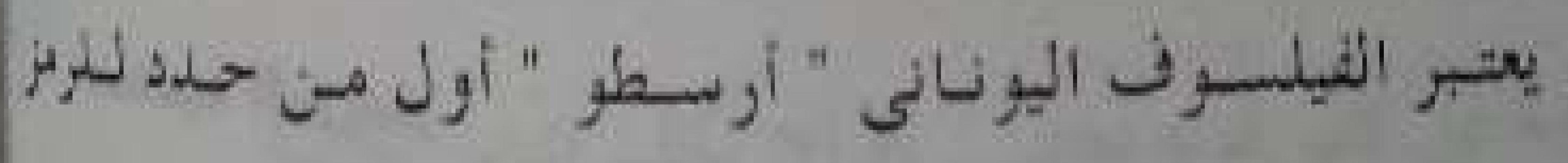

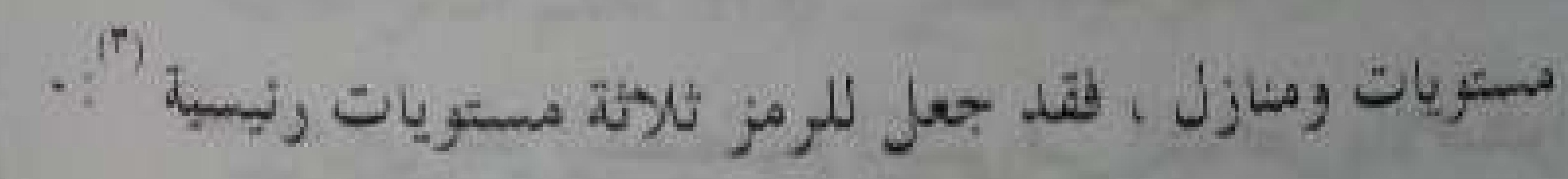

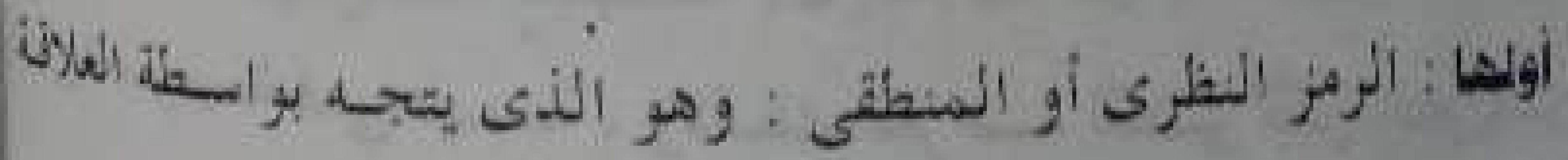

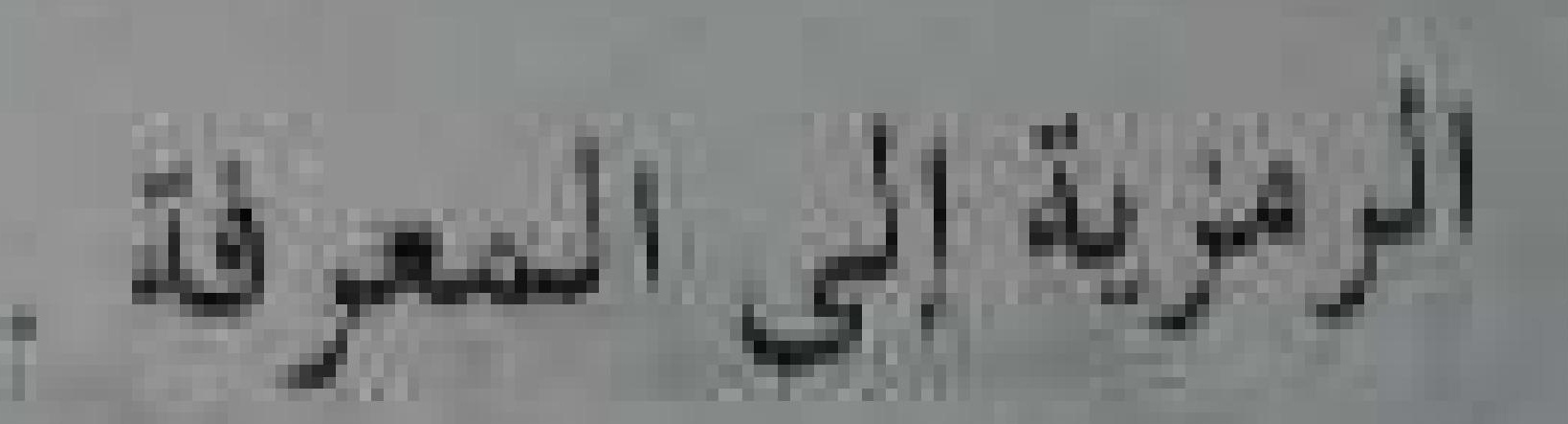

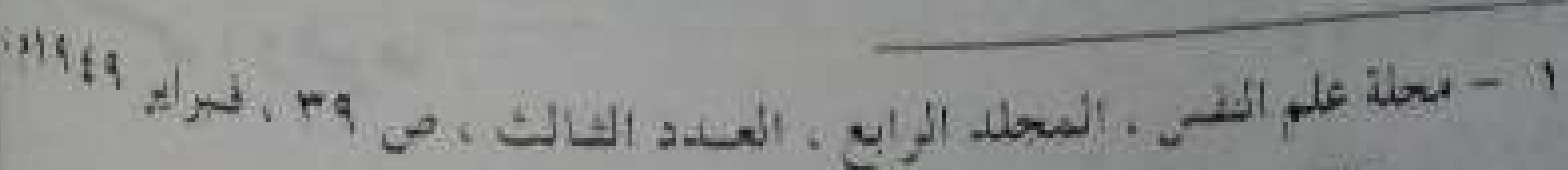

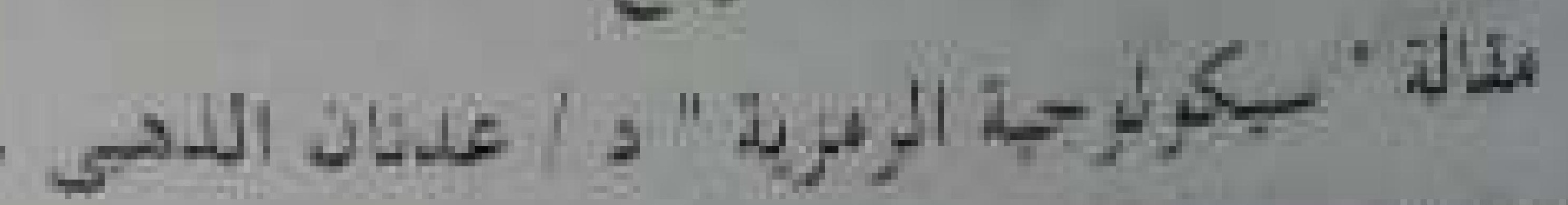

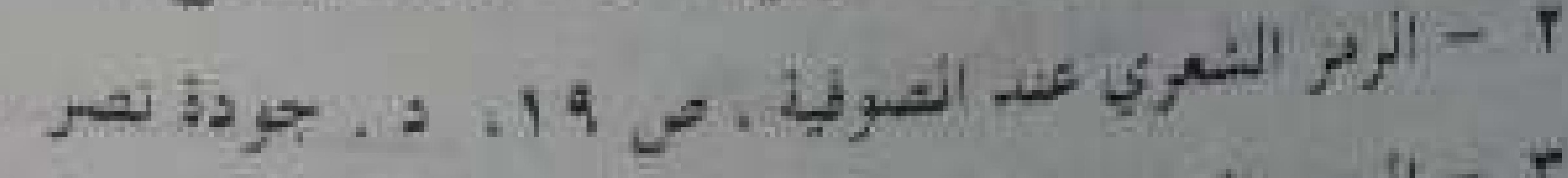

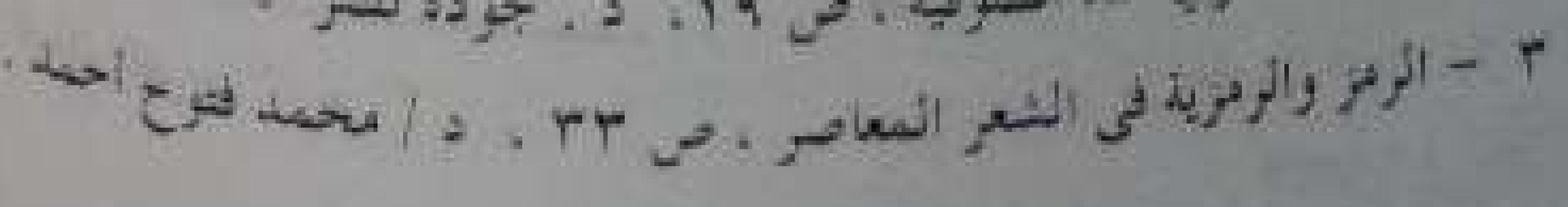


$-19 V-$

(1)

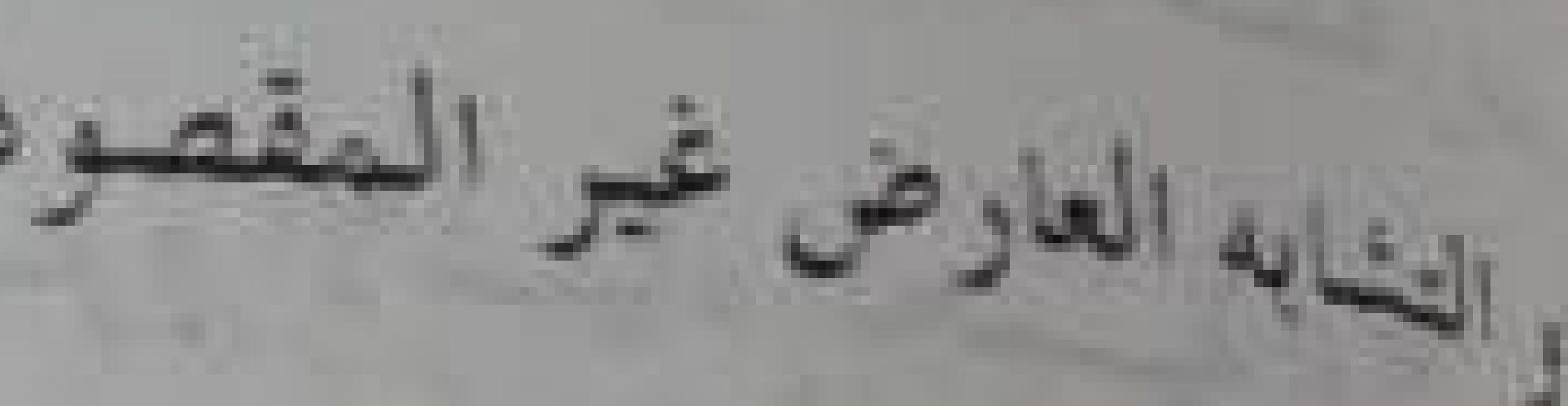

ريرى الأديب الفرنسي " كاسريه " أن الإنسان حيوان رمـزى

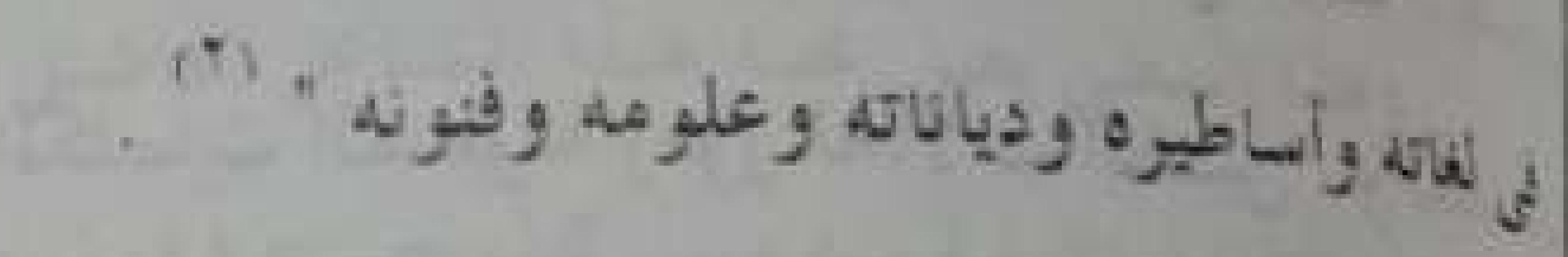

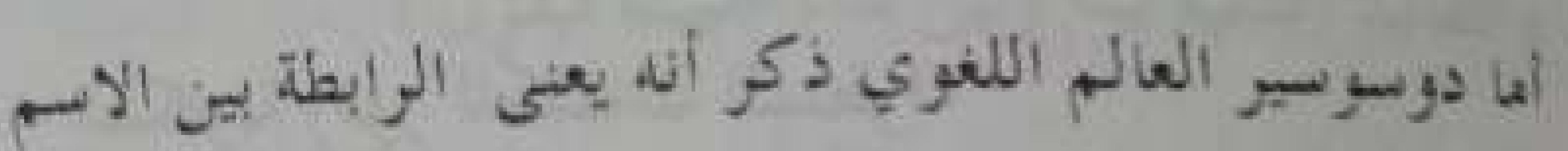

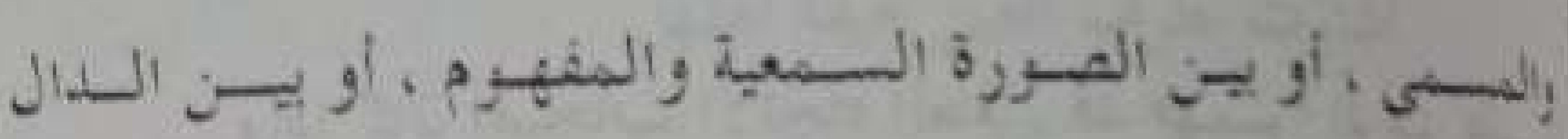
الستلول، ، إذ إن الوحدة اللغوية أو الرئز اللغوى في نظره : " كيان

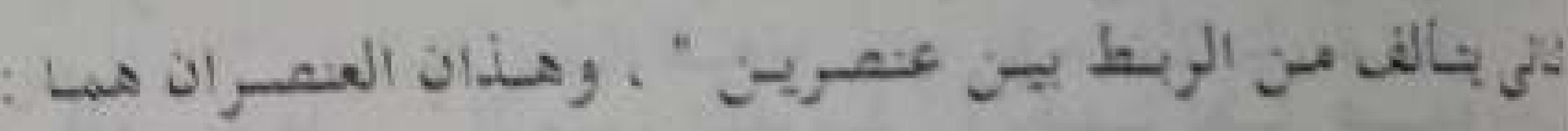

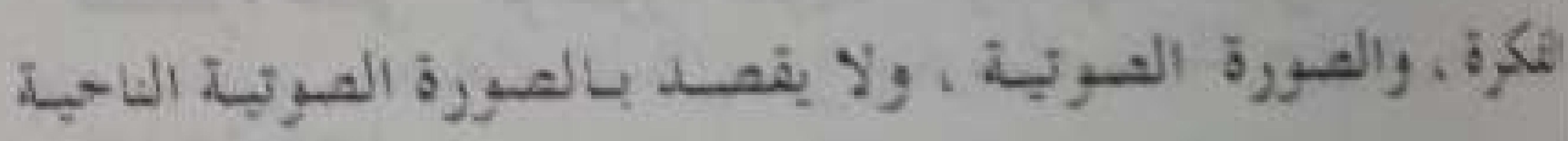

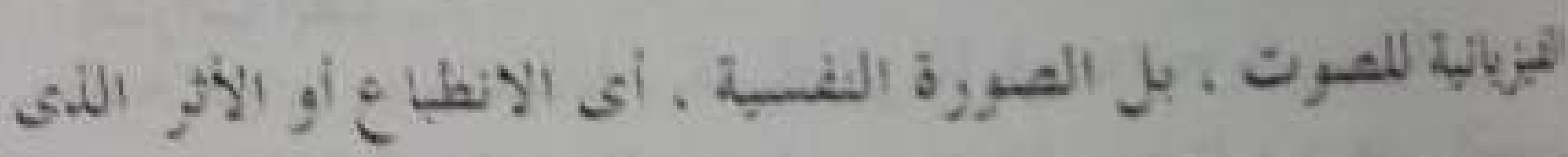

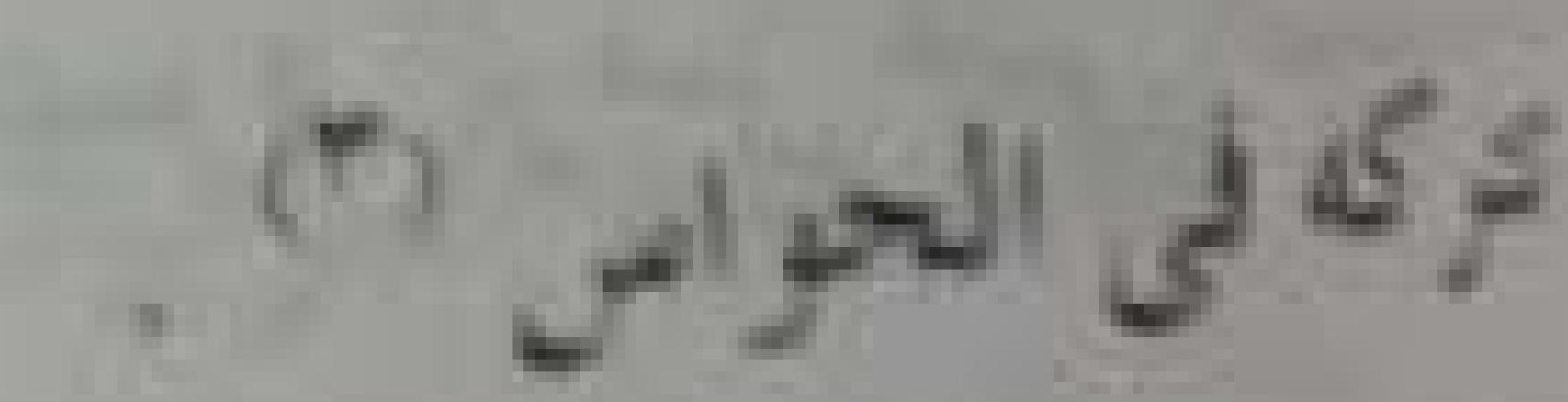

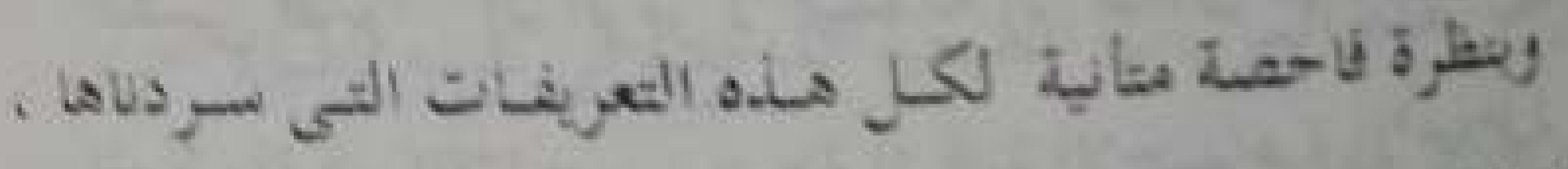

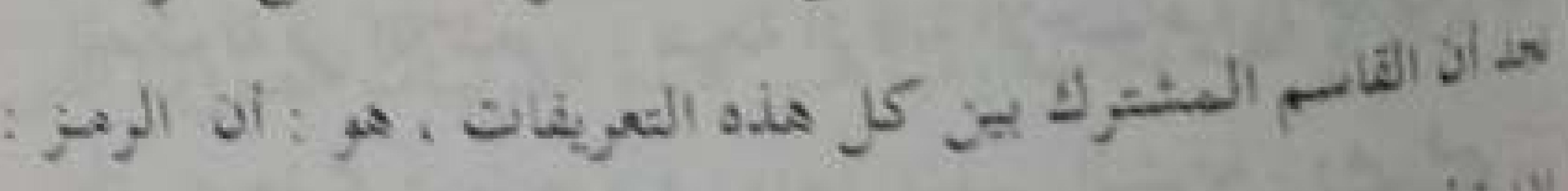

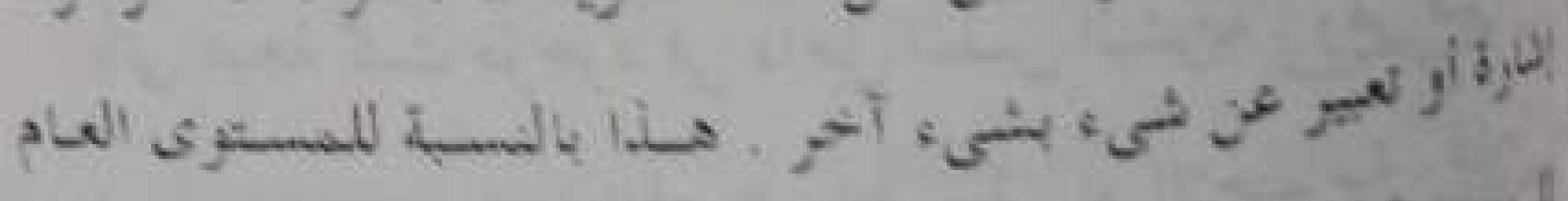

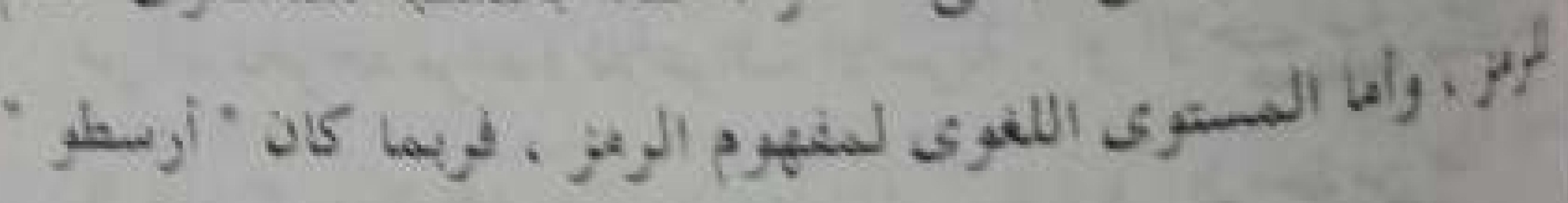

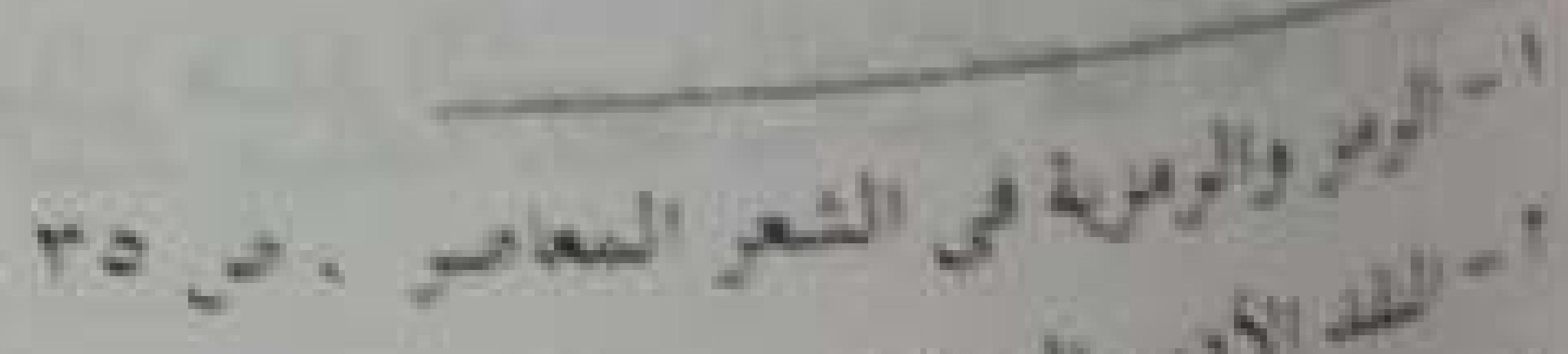

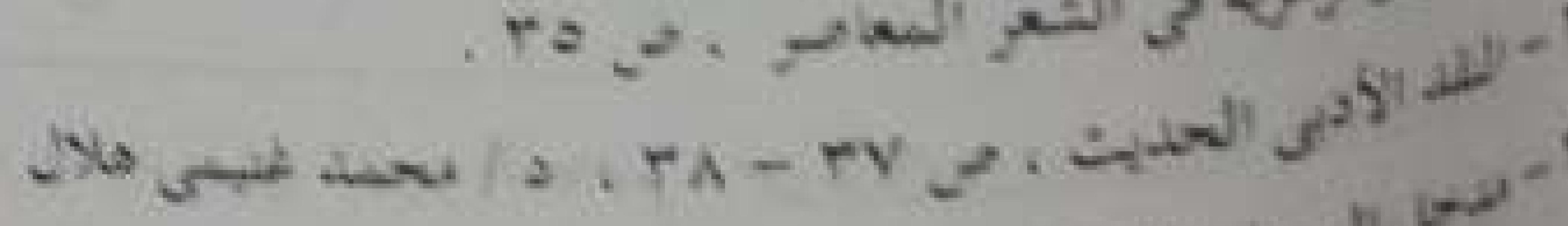
systest

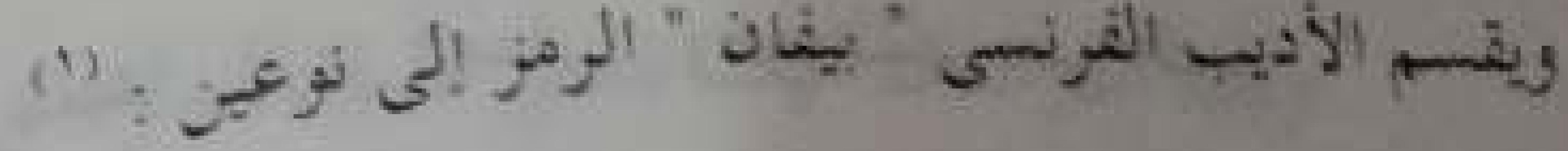

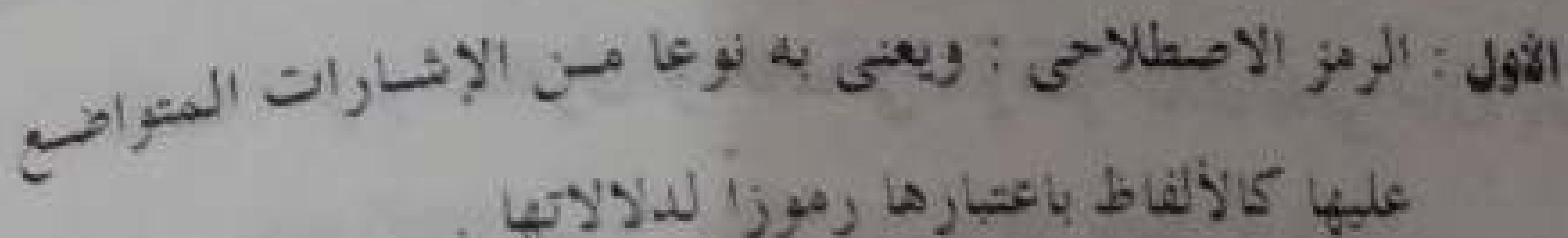

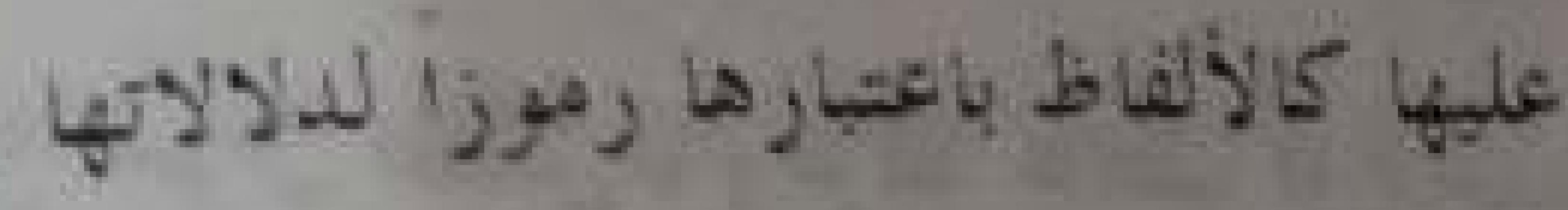

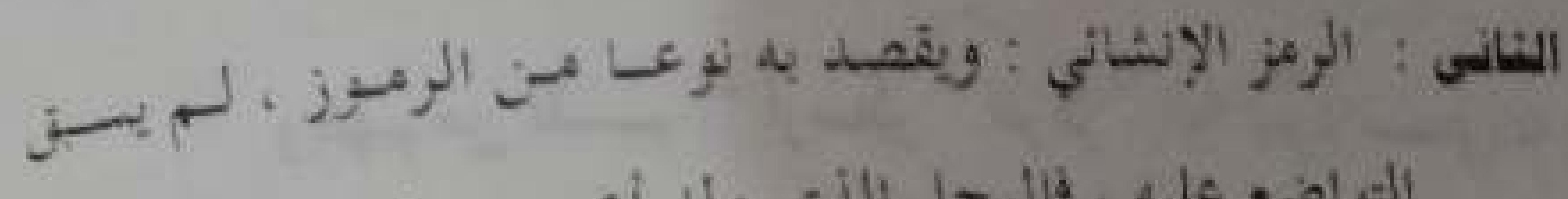

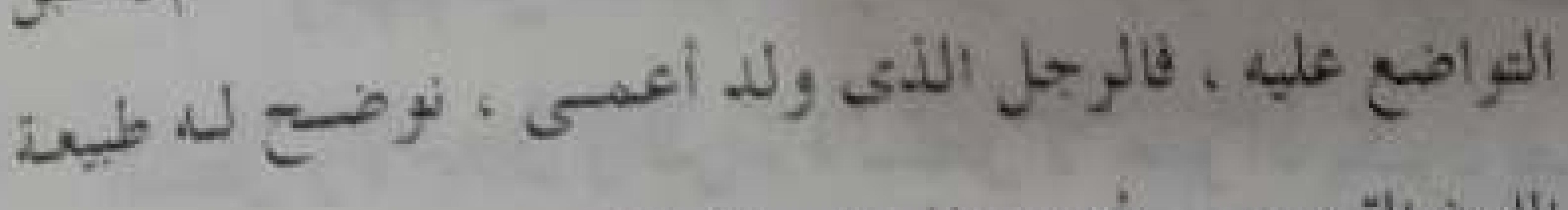

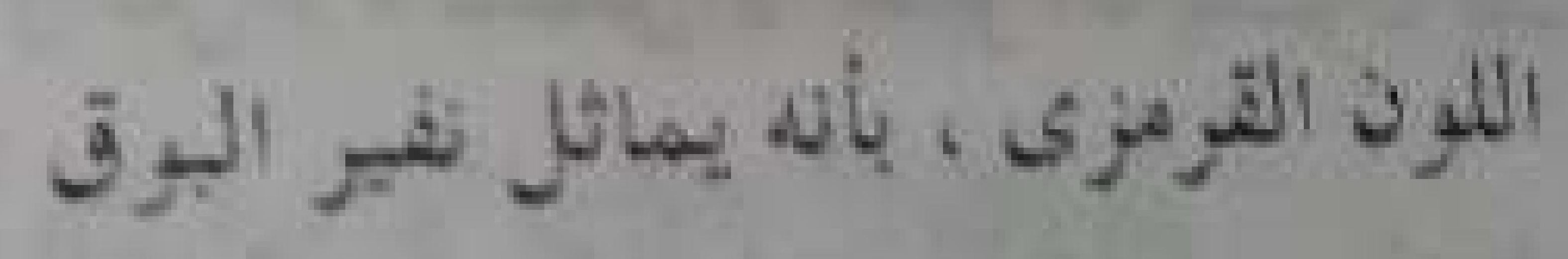

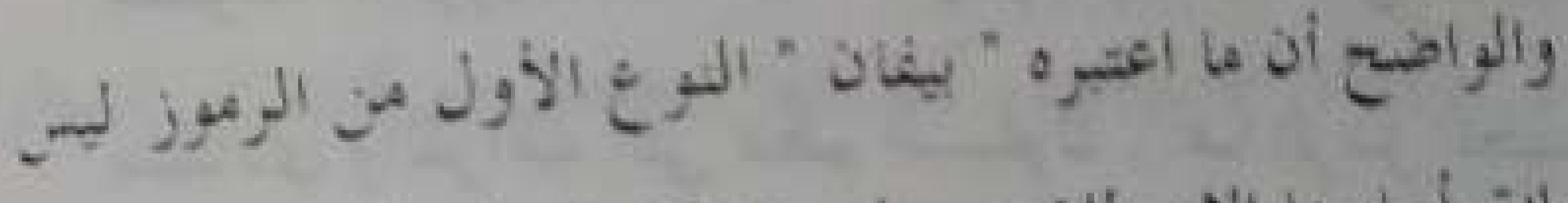

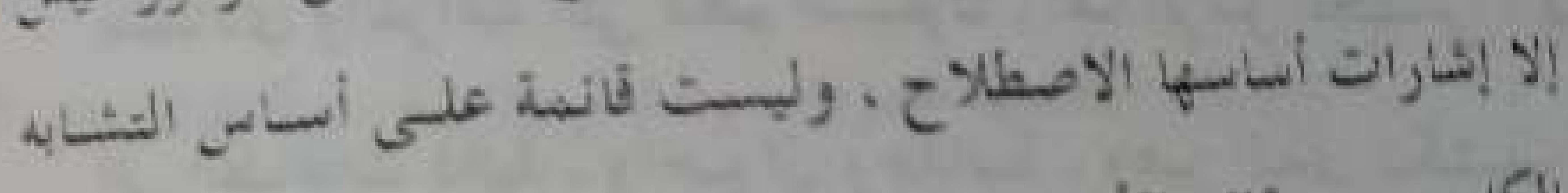

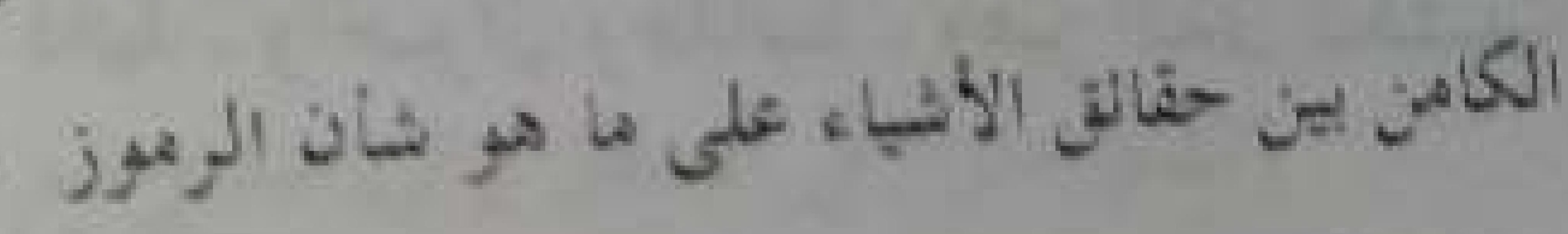

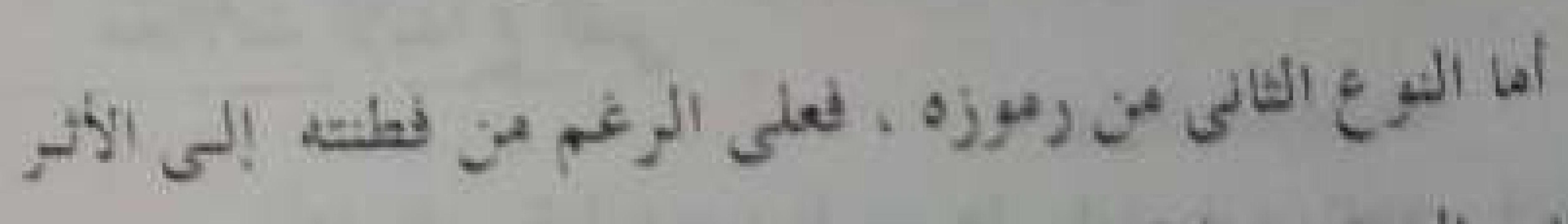

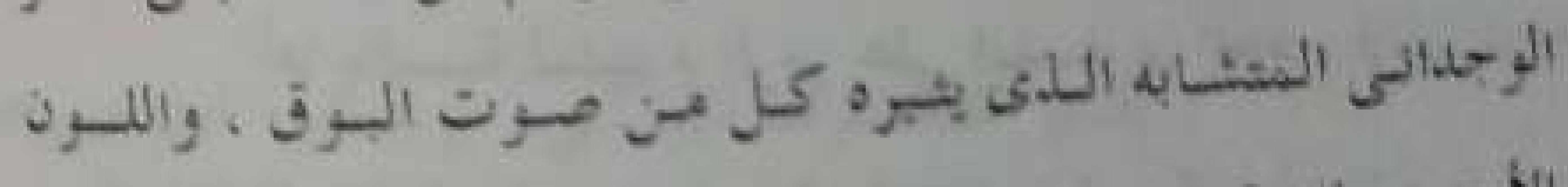

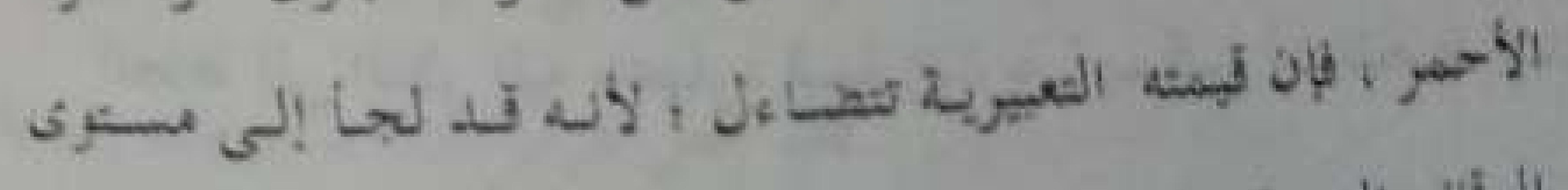

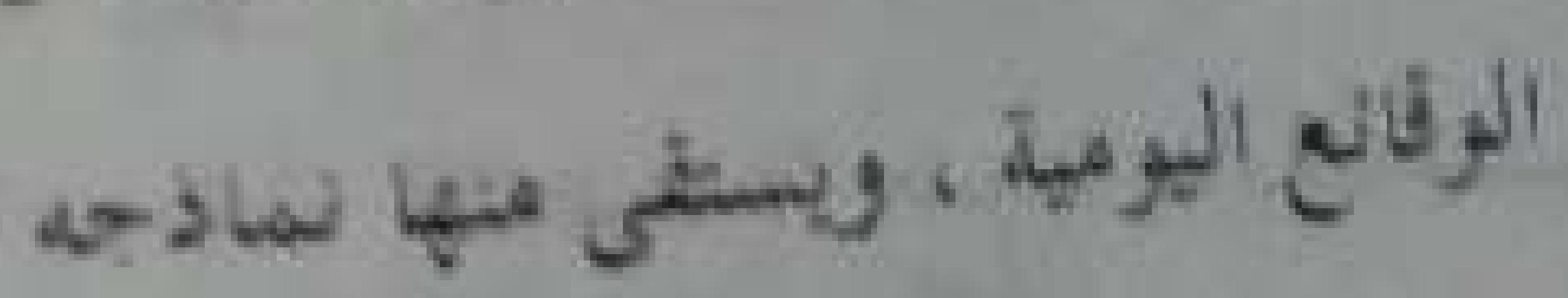

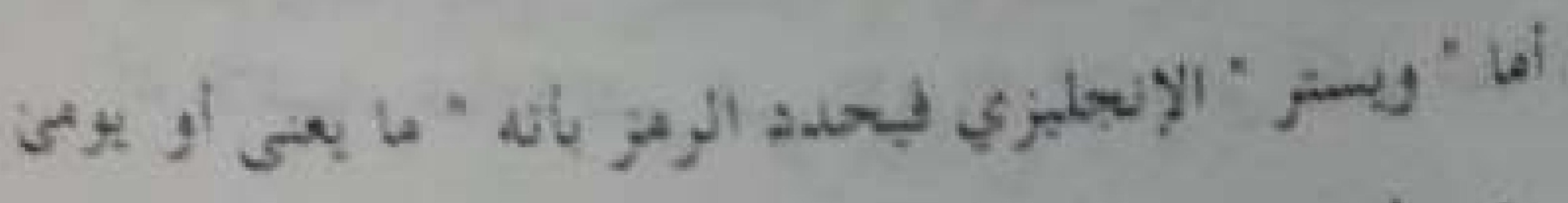

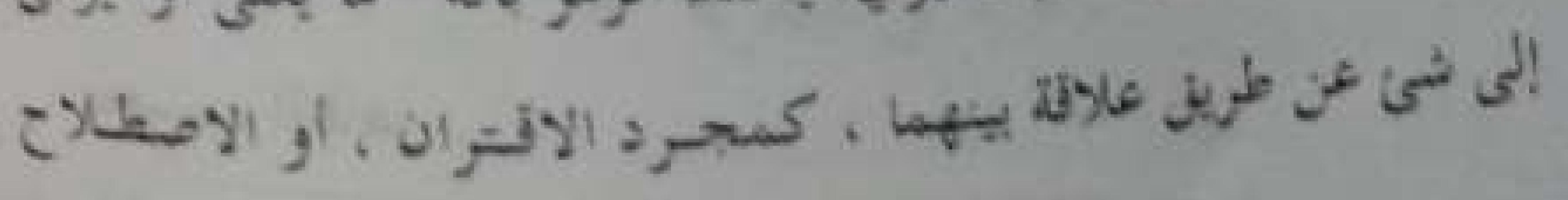

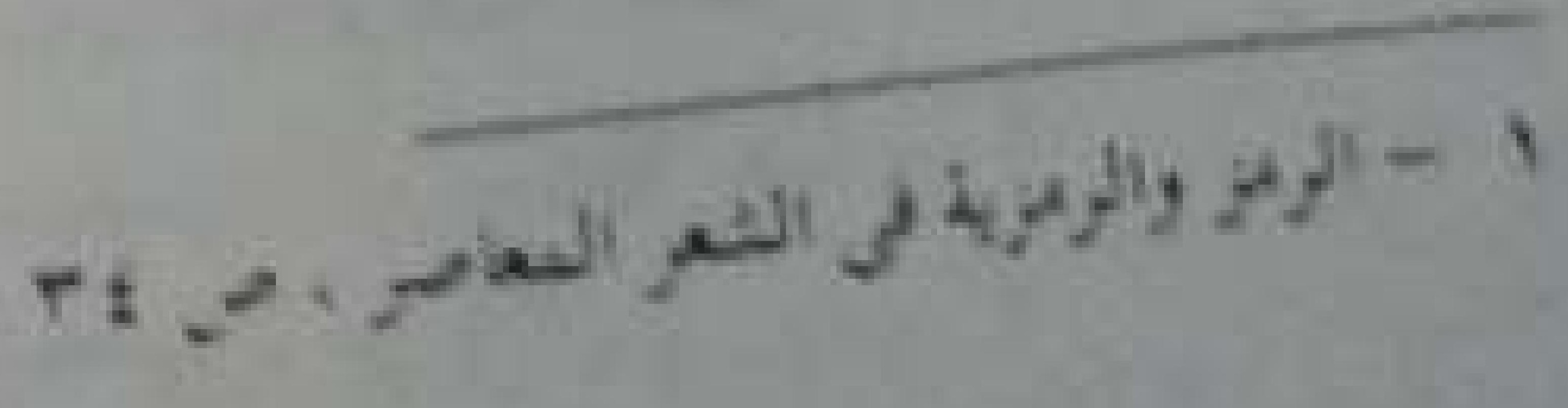




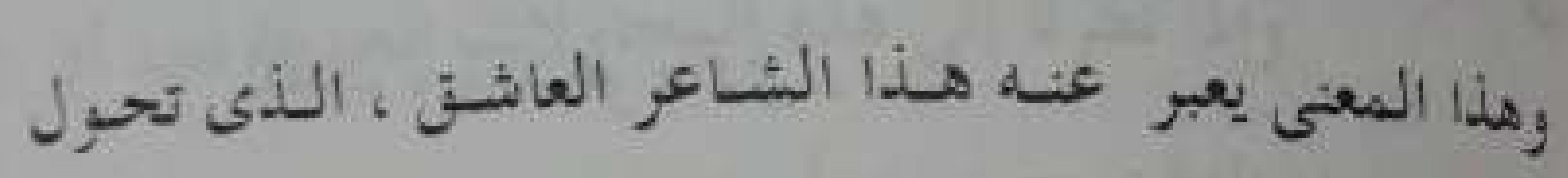

(1) "

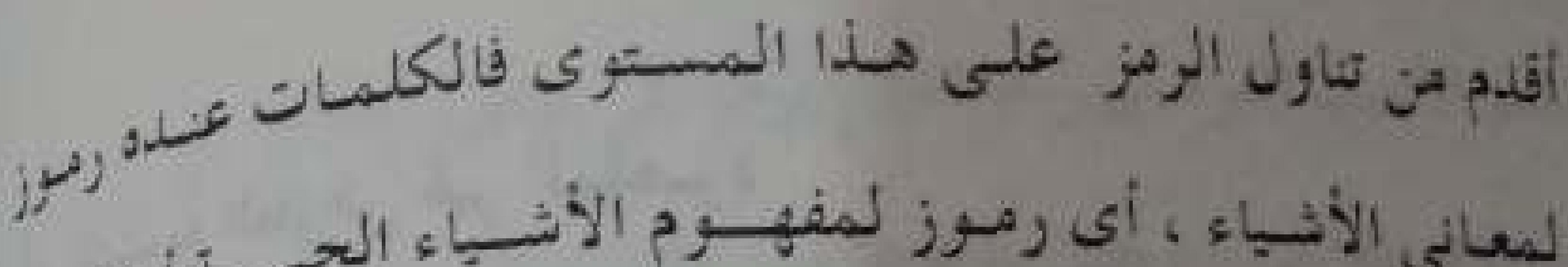

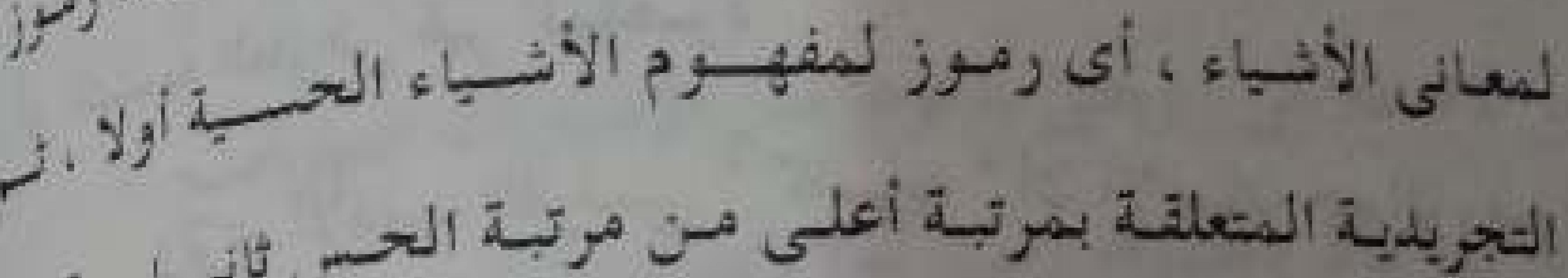

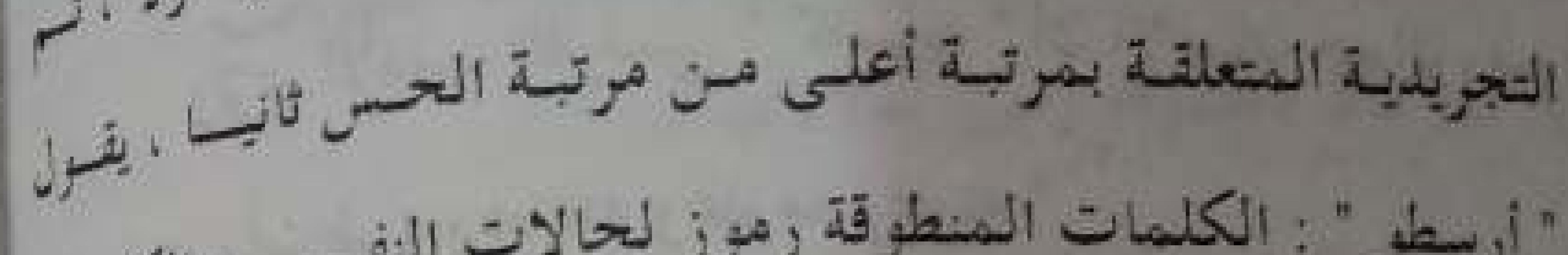

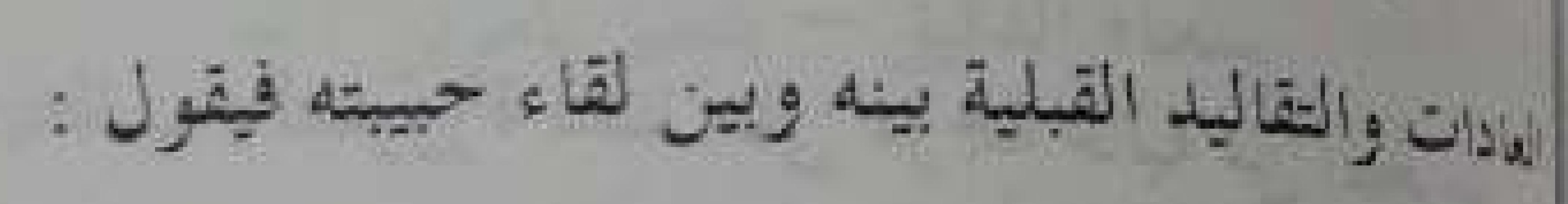

$$
\text { أشارت بطرث العين خيفة أهلبا }
$$

إشارة محزون ولم تتكلم

كما شرلك الأدباء فى بيان ماهيدة الرمبر فقالوا : " إن الرمبر

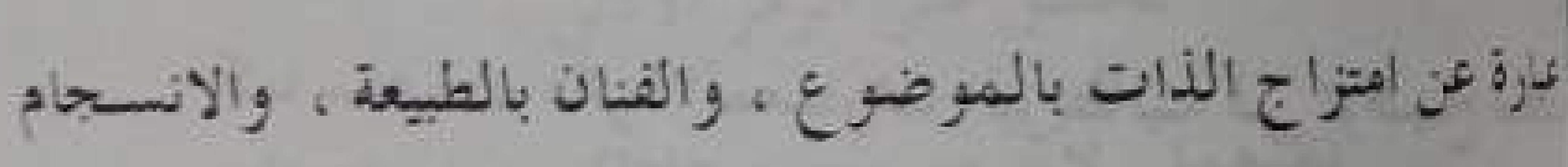

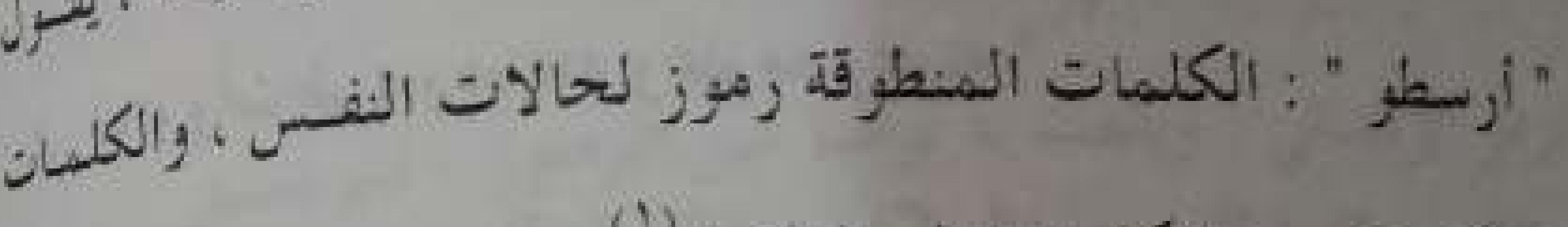

(1) = المكتبرة رموز للكلمات المنطو

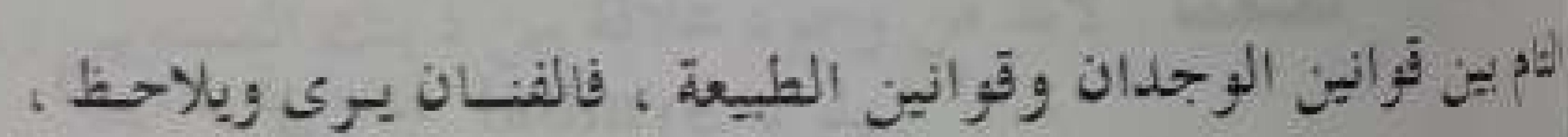

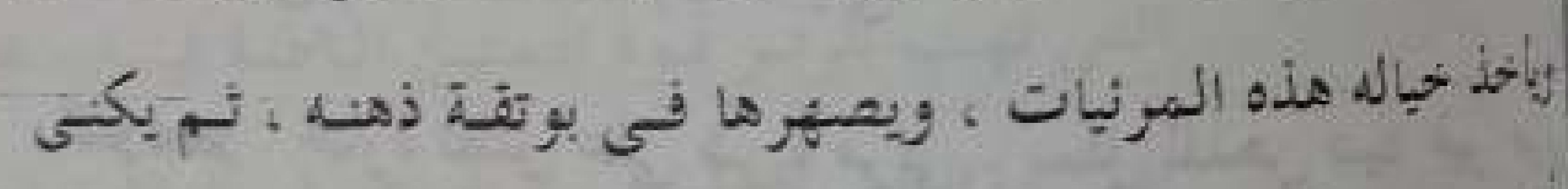

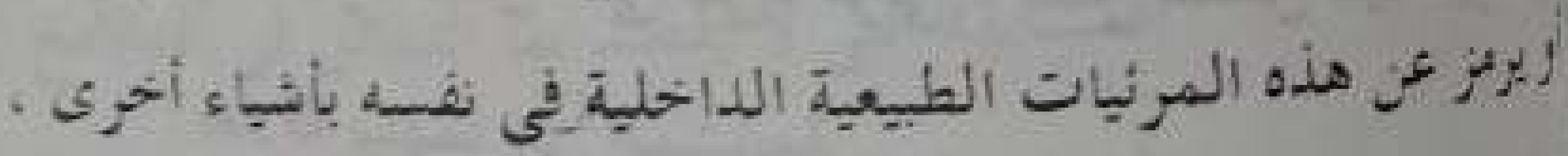

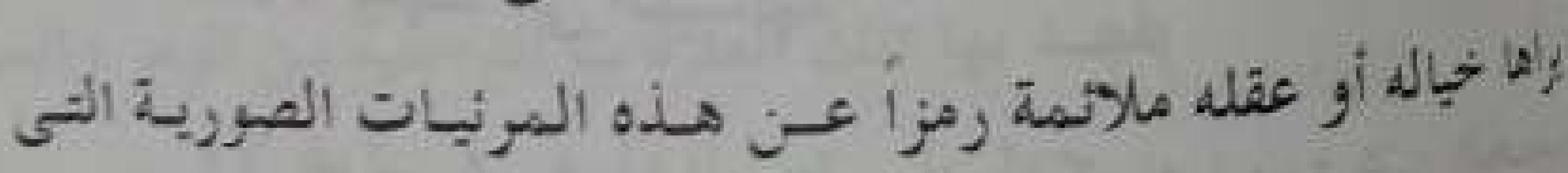

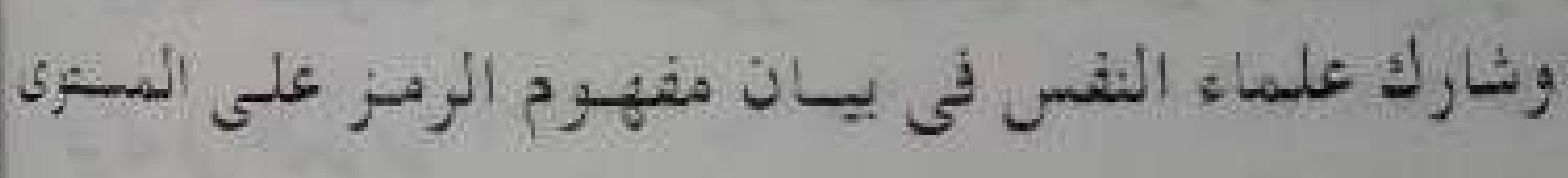

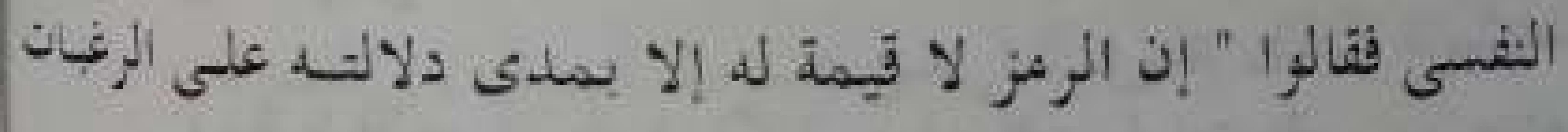

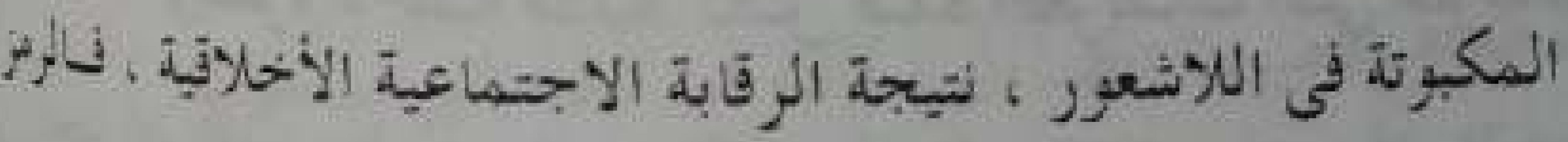

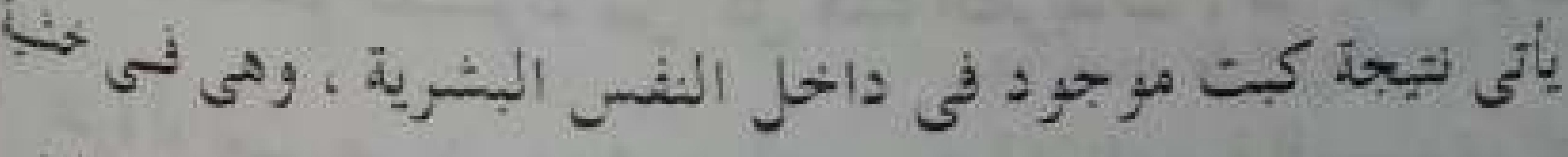

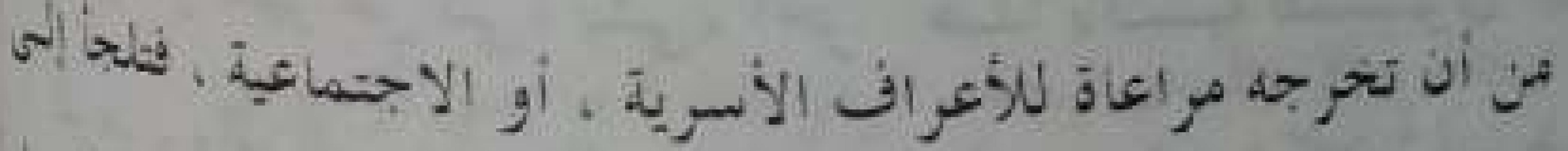

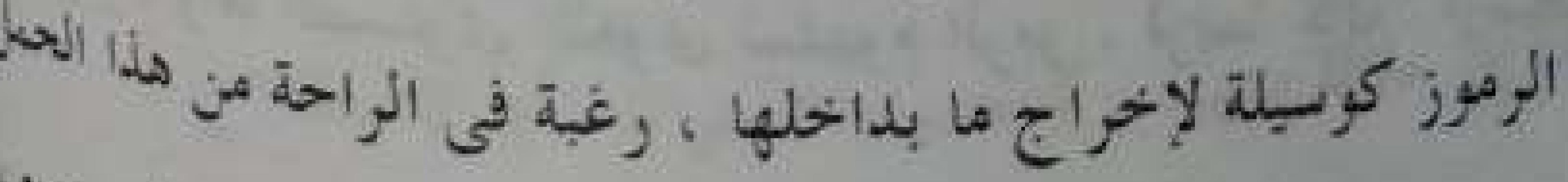

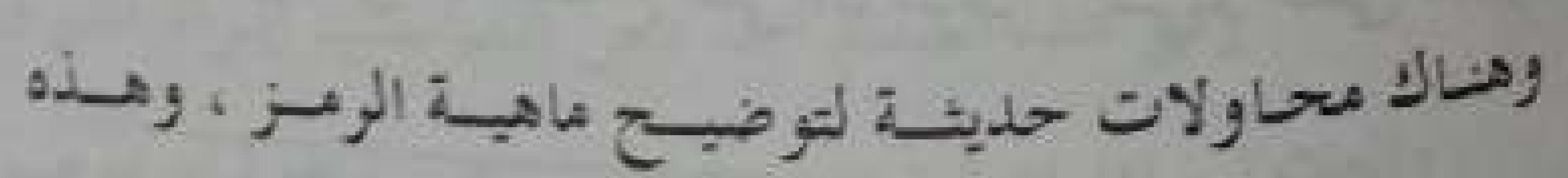

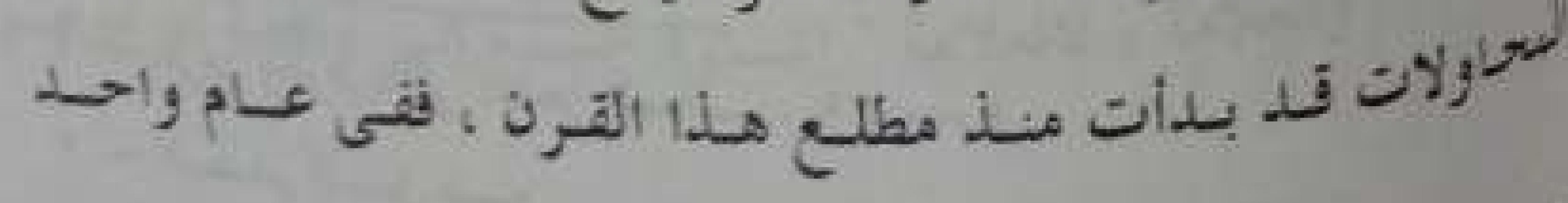

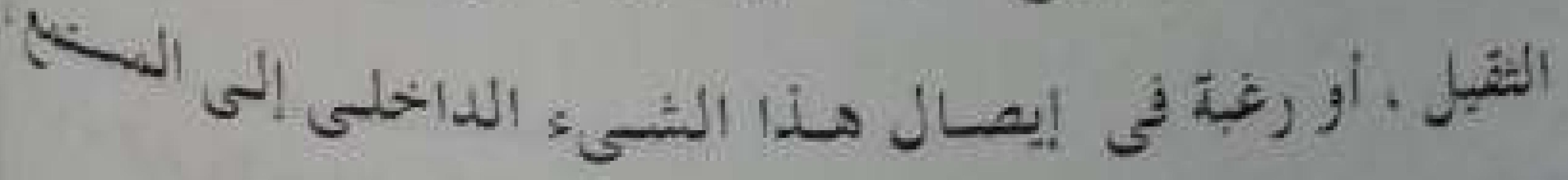

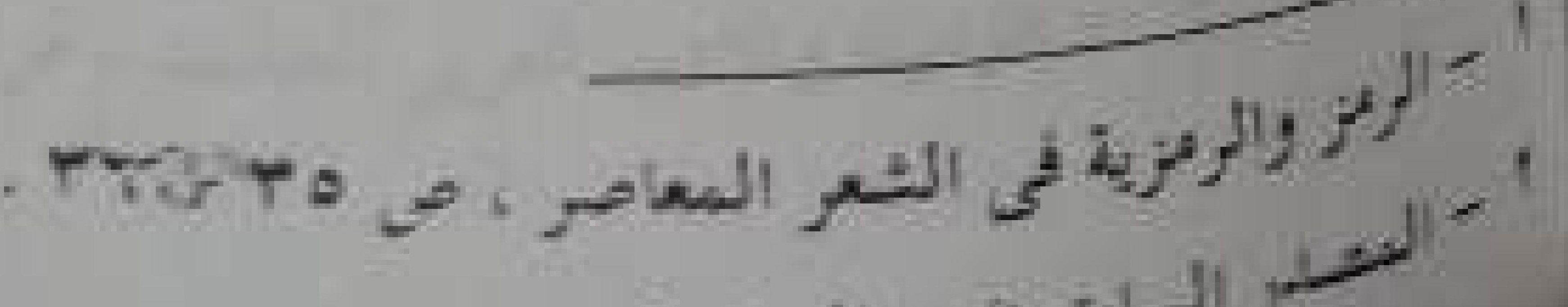

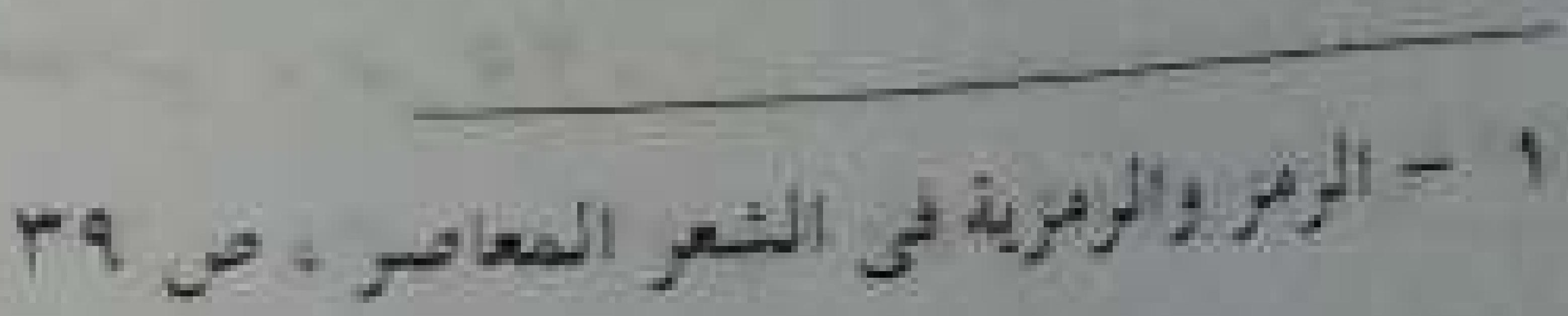




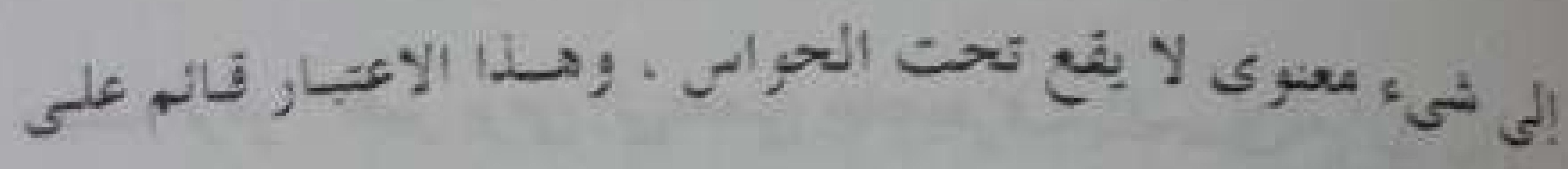

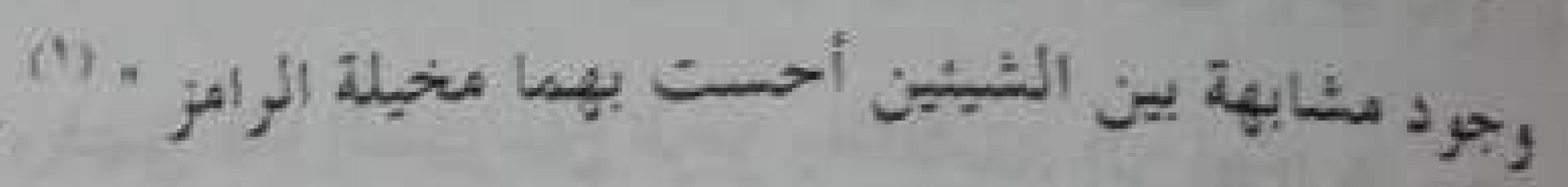

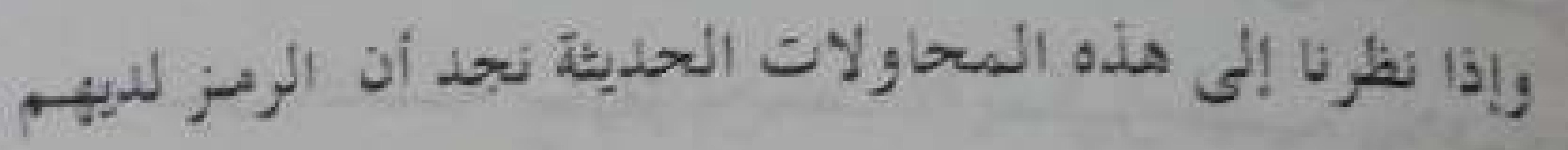

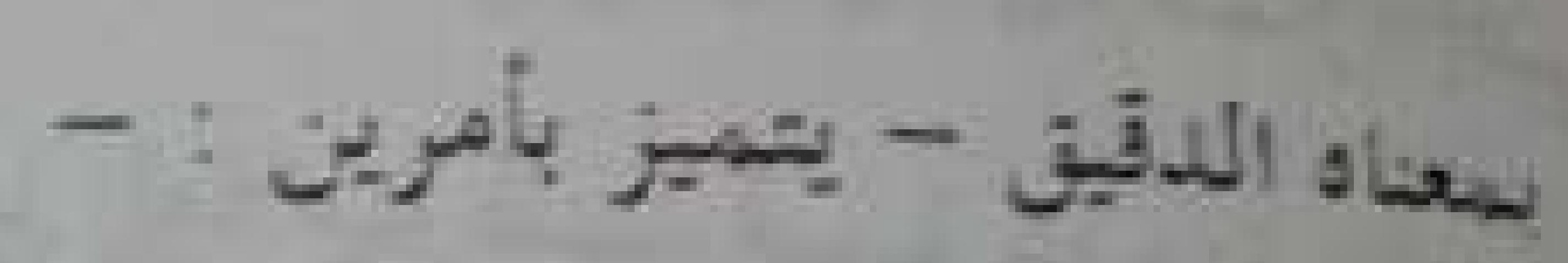

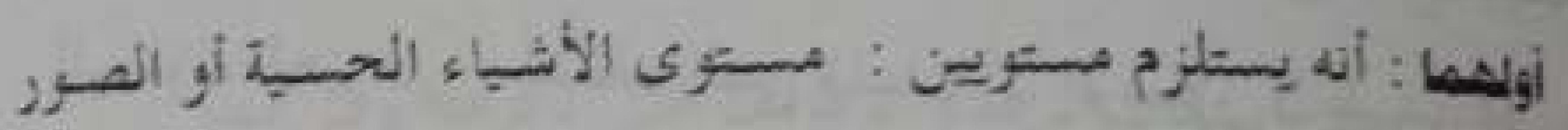

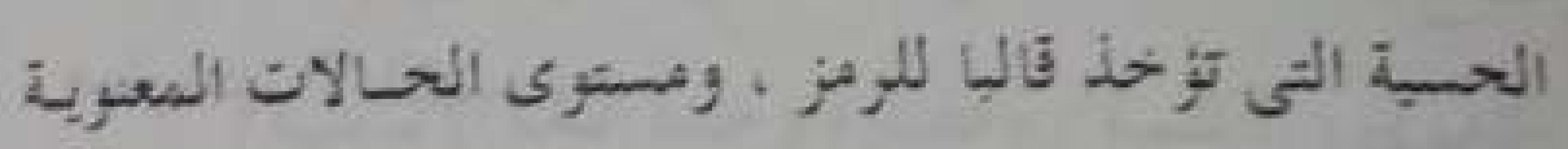

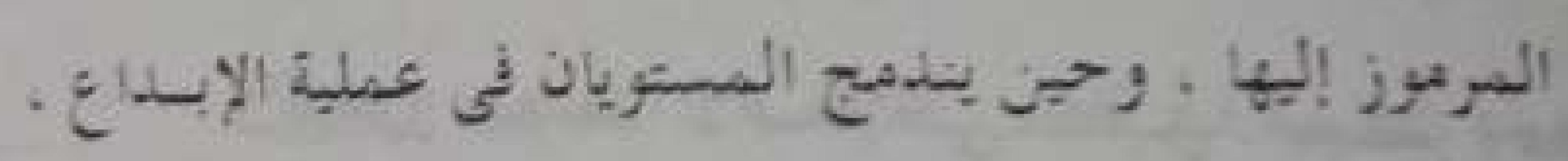

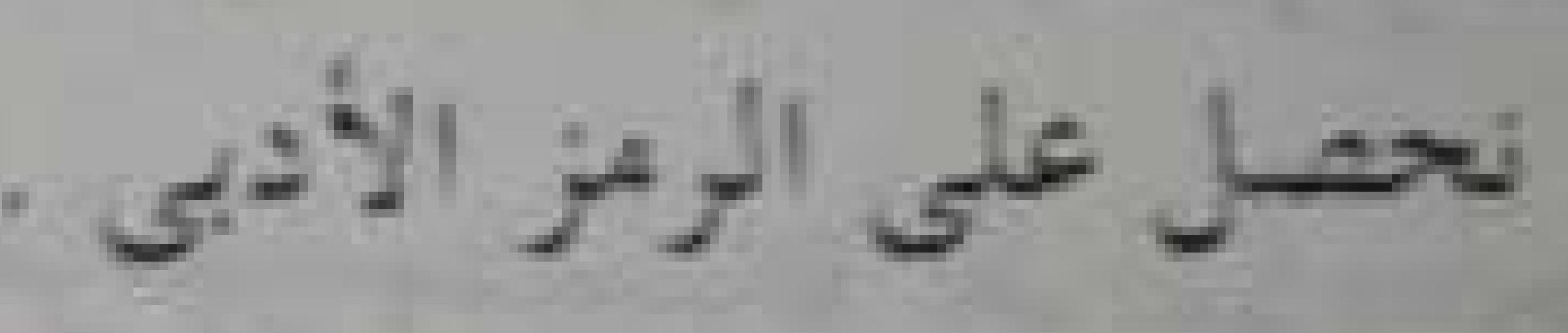

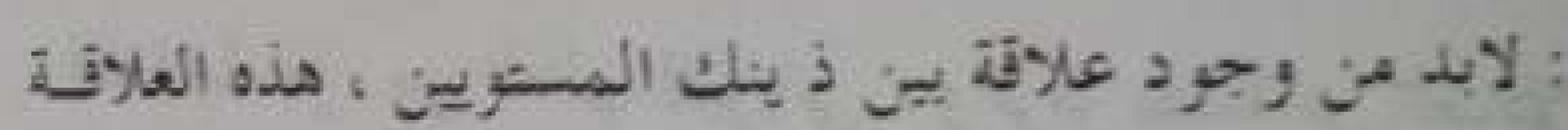

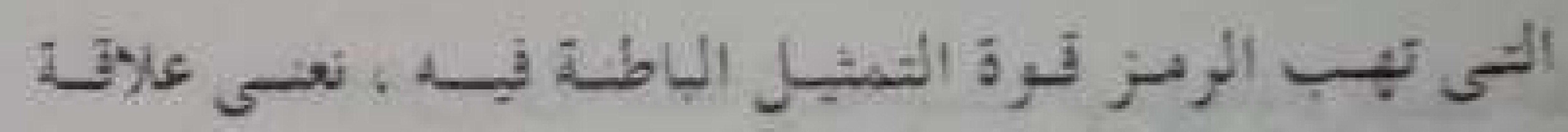

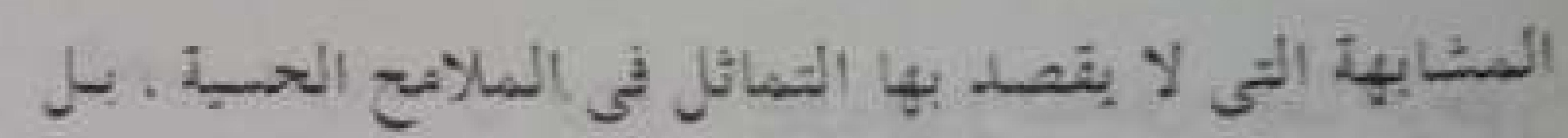

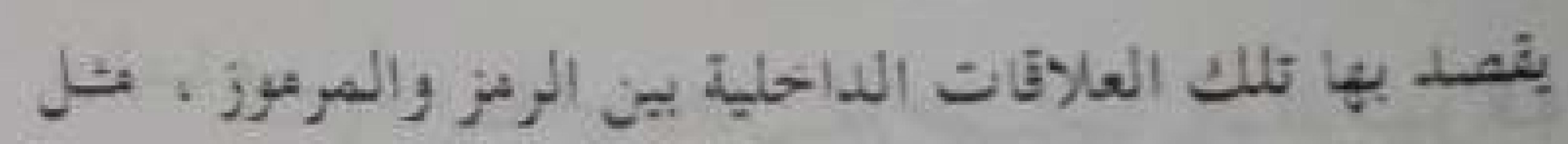

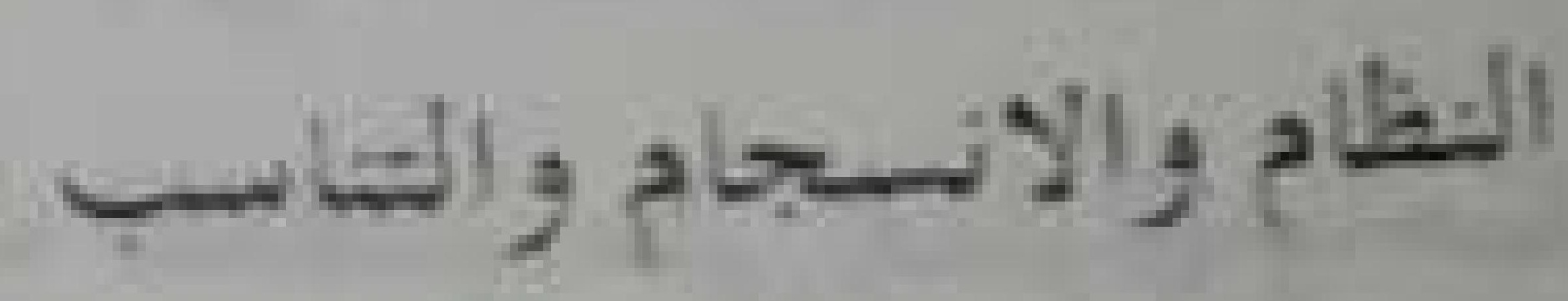

\section{بِ المبر والملامة}

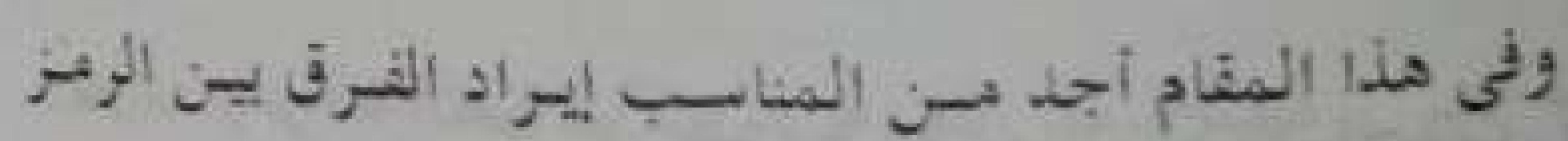

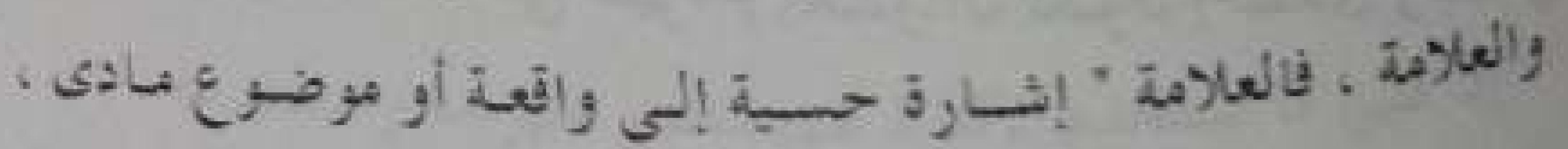

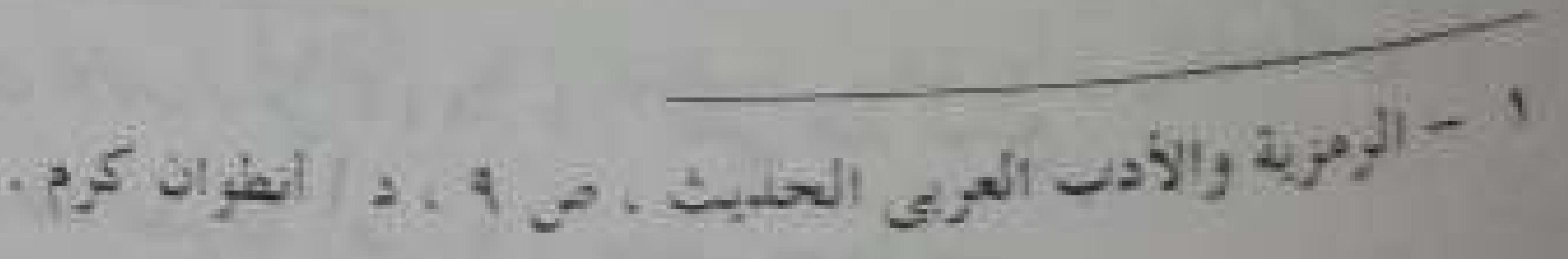

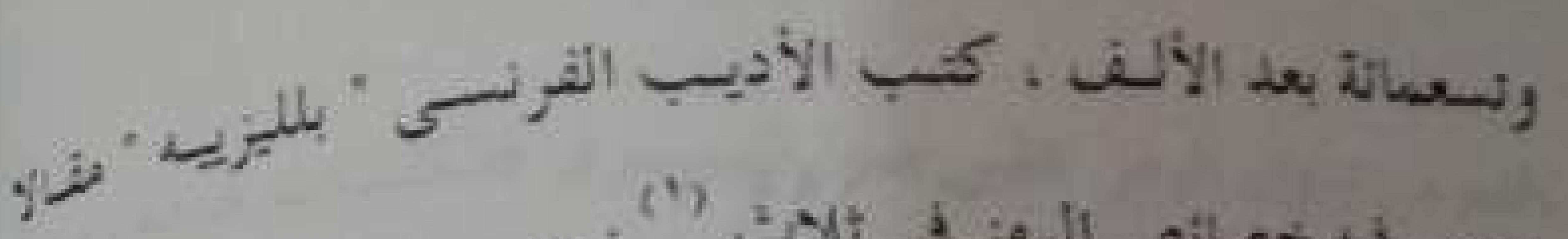

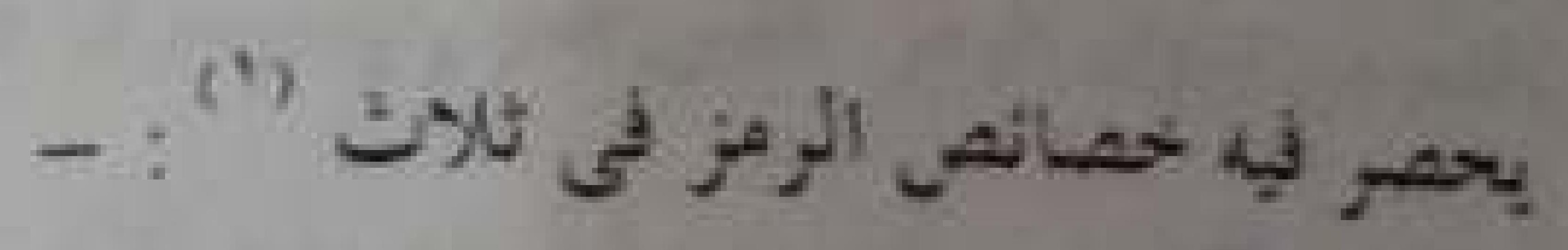

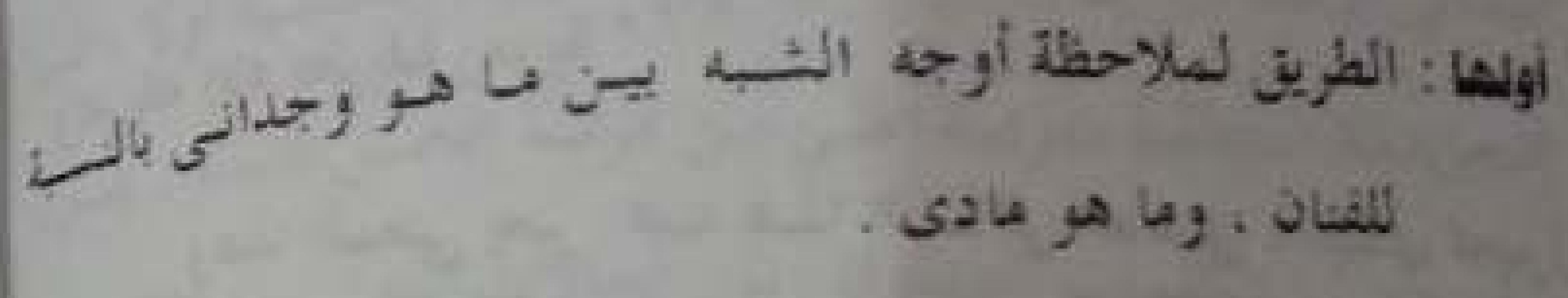

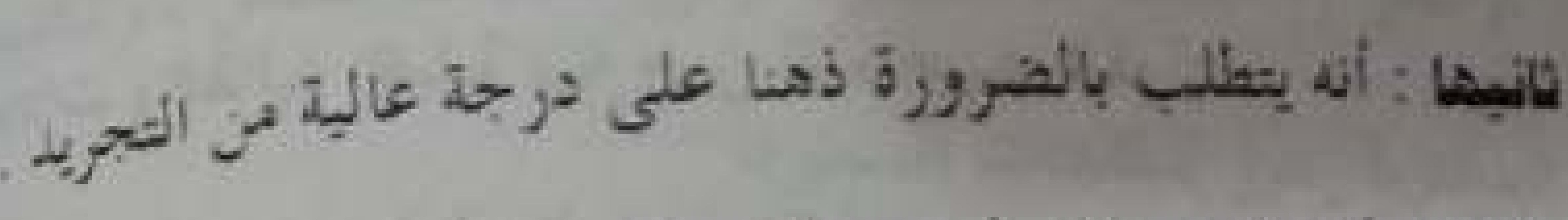

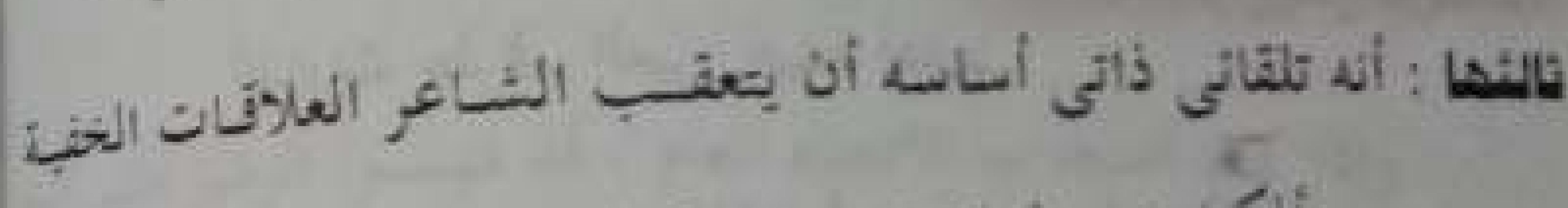

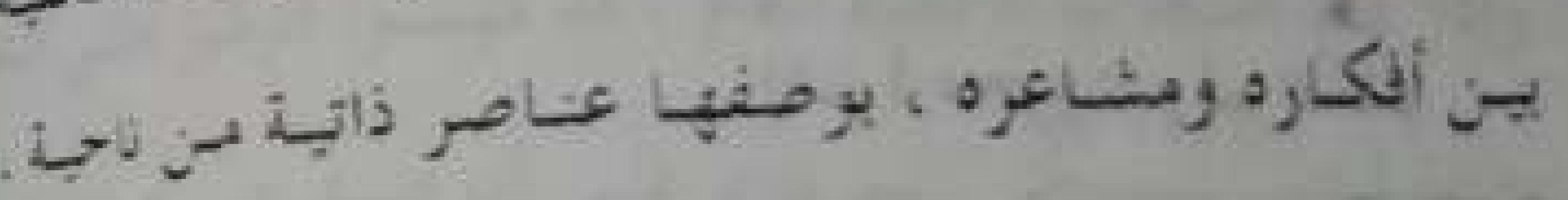

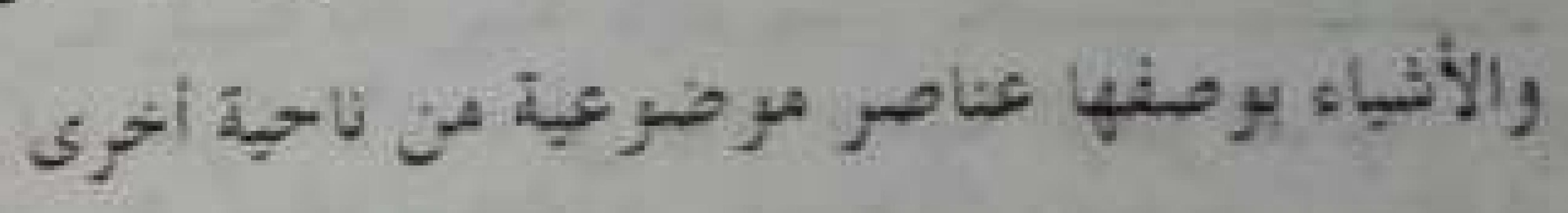

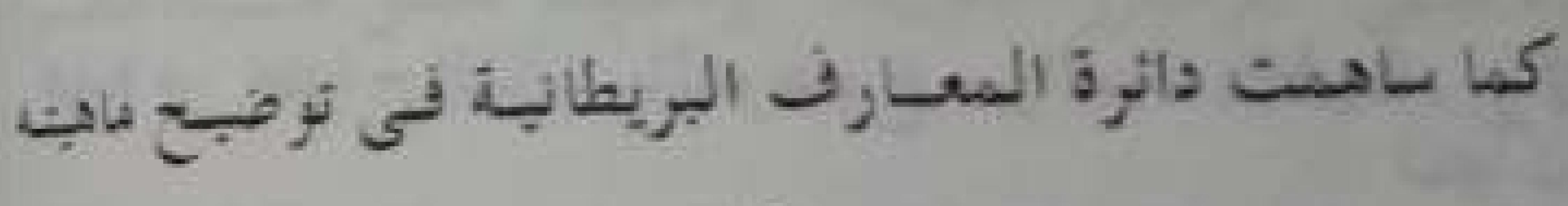

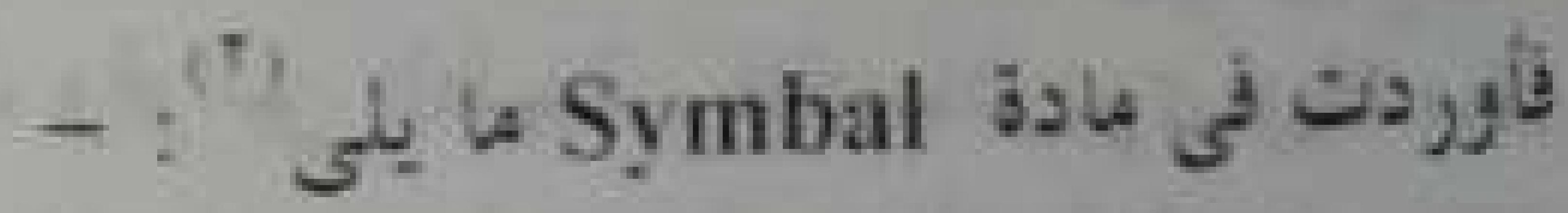

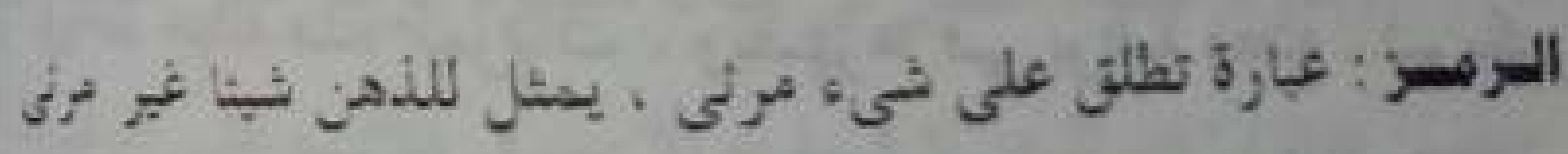

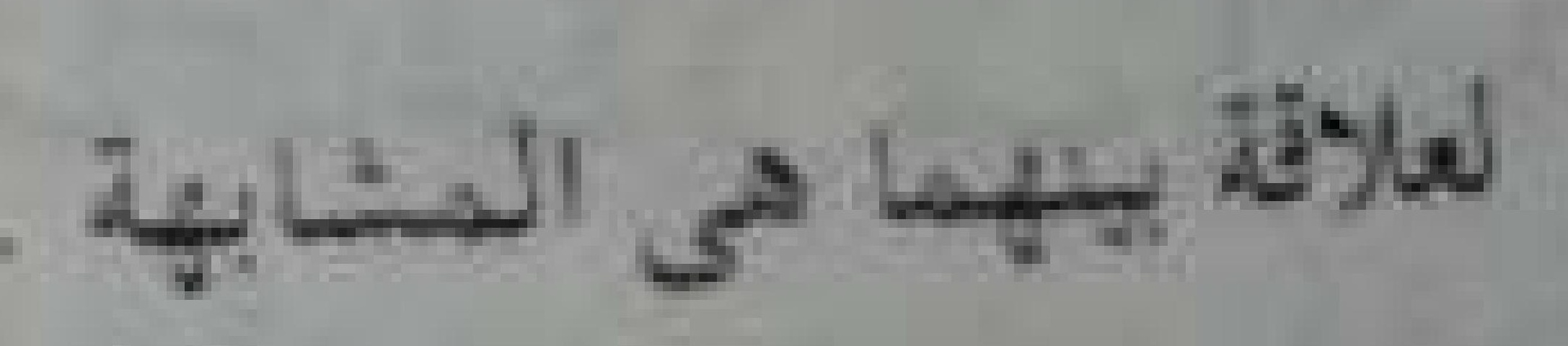

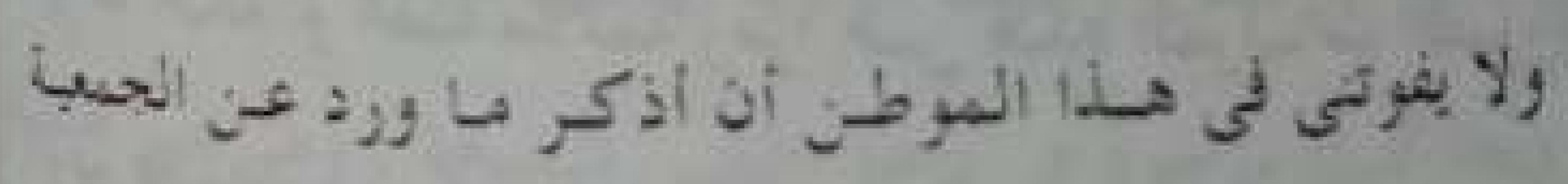

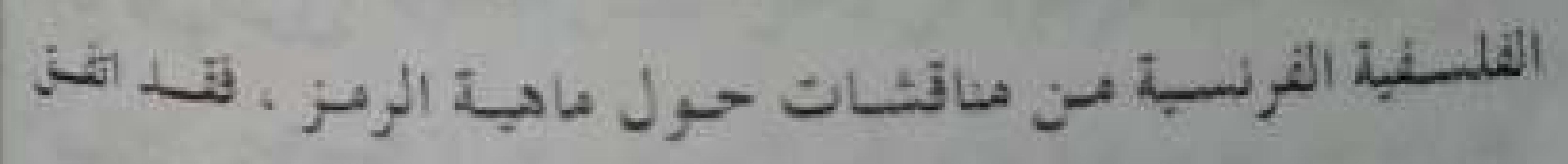

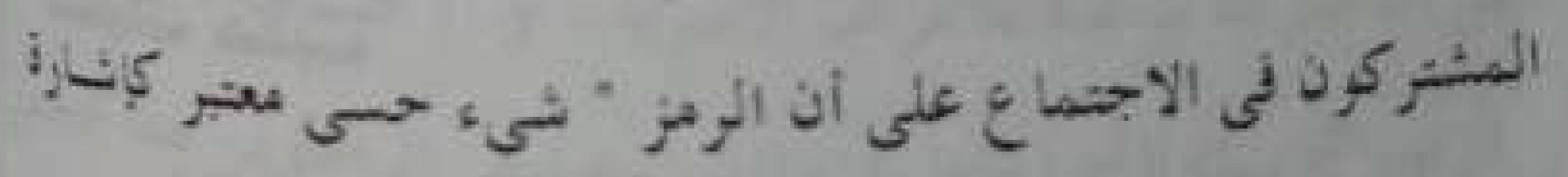

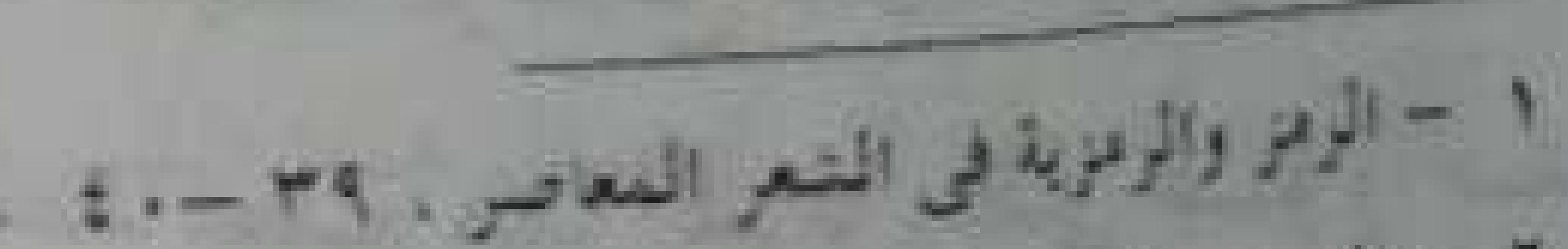

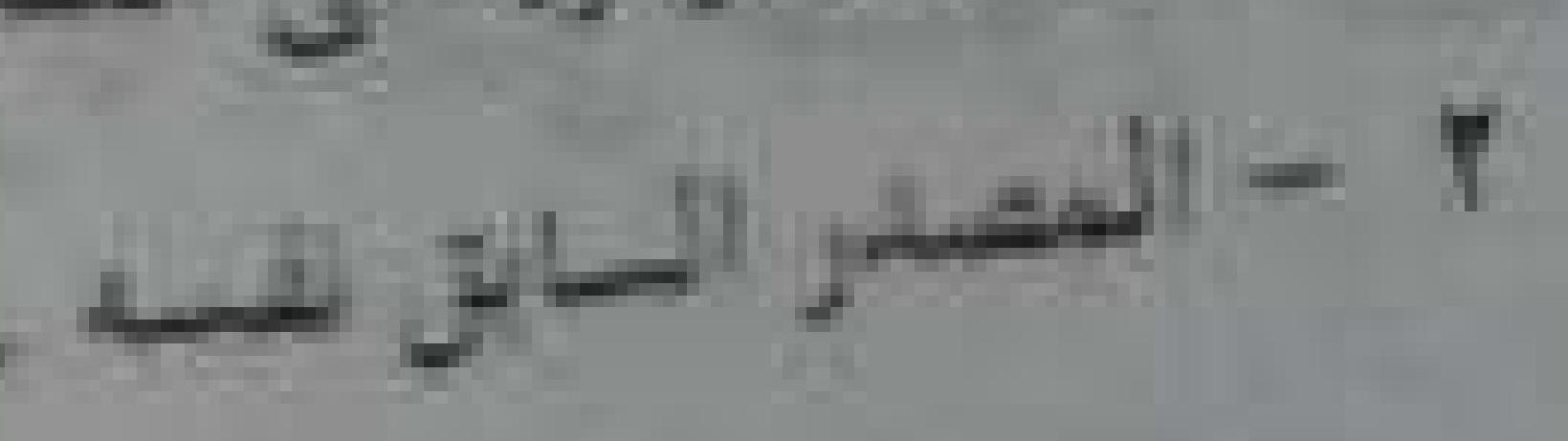




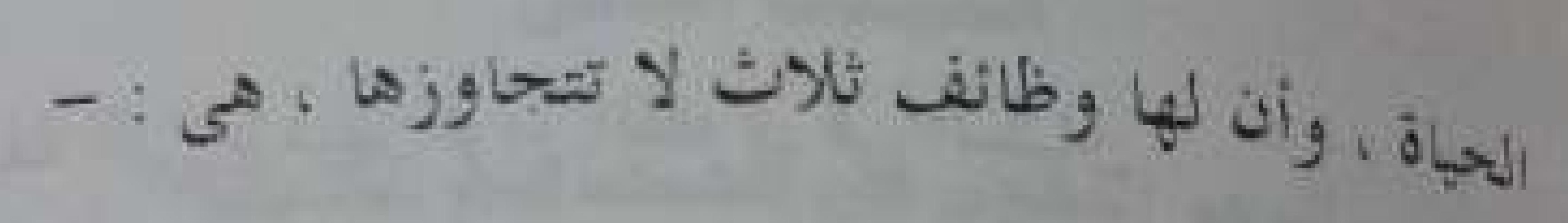
- التعير عن شي ما ، أو الإخبر عنه ، ورذا خاص بالمتكلم.

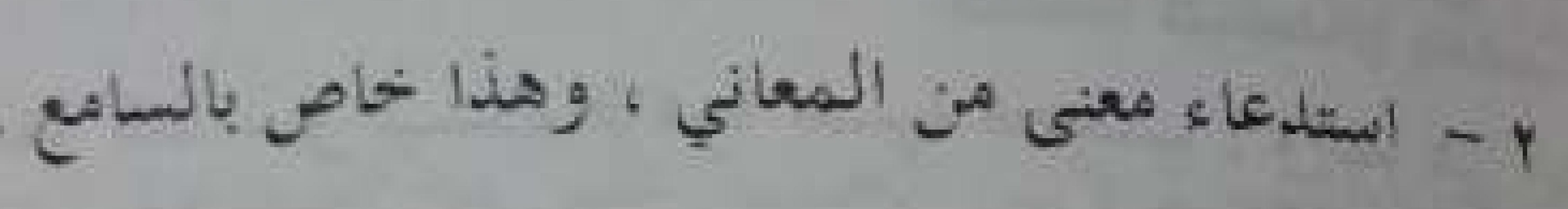

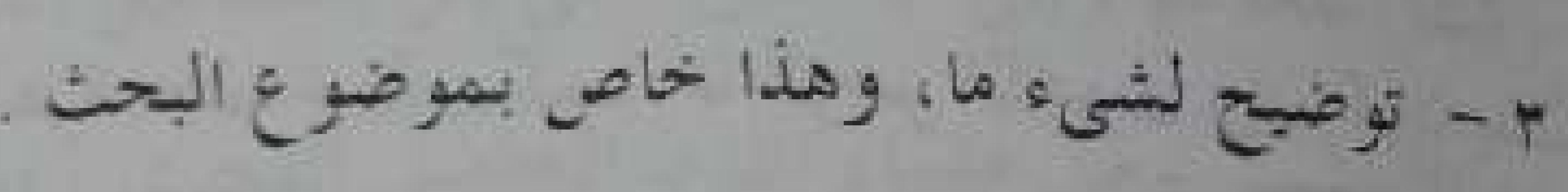

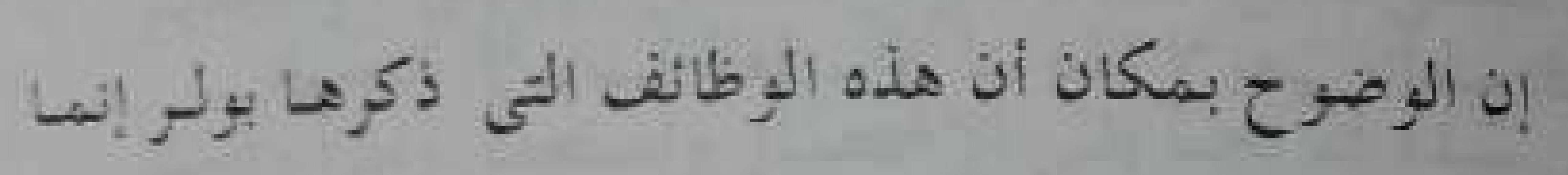

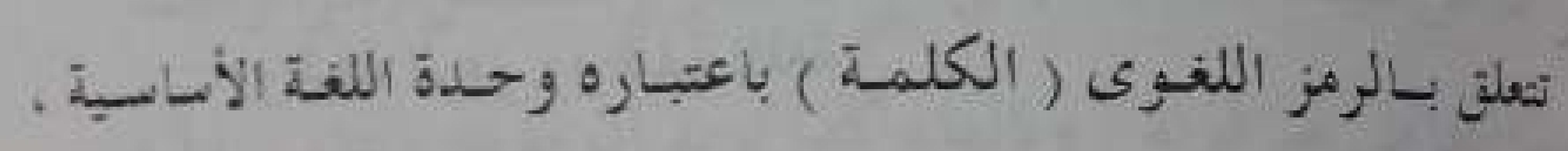

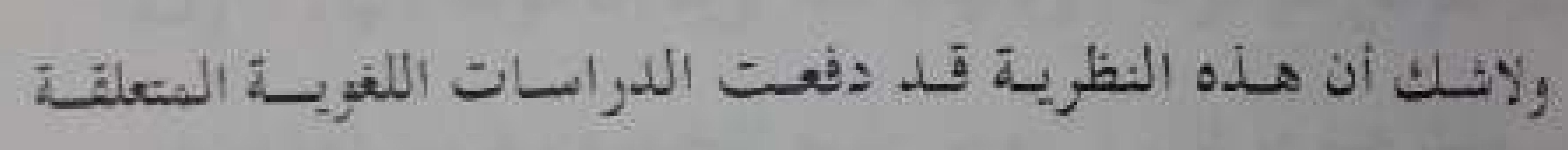

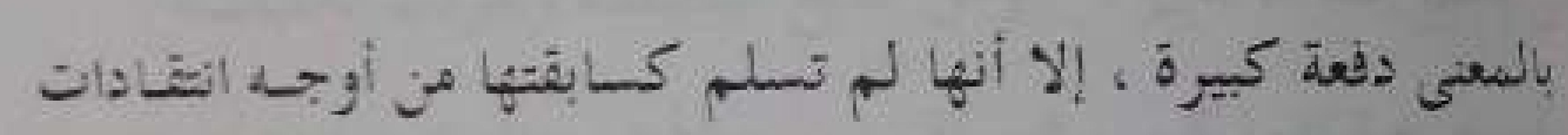
- : عليدة لعل أهن

إن وظيفة الرمز اللغوى لا تقتصر على هذه الأبور الثلاهة، إنما ينبغ أن تصاف إليها وطائف أخرى هي :

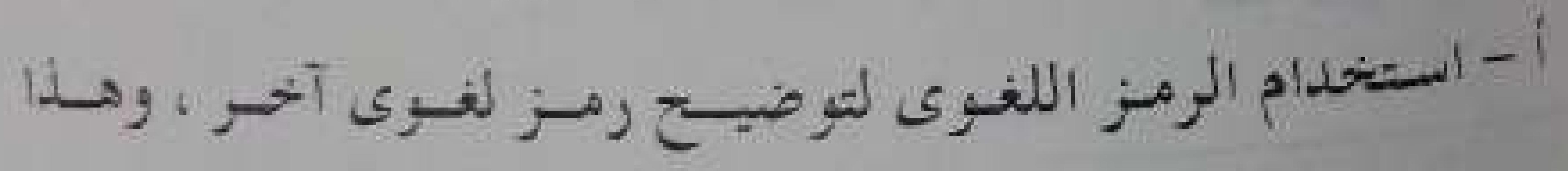

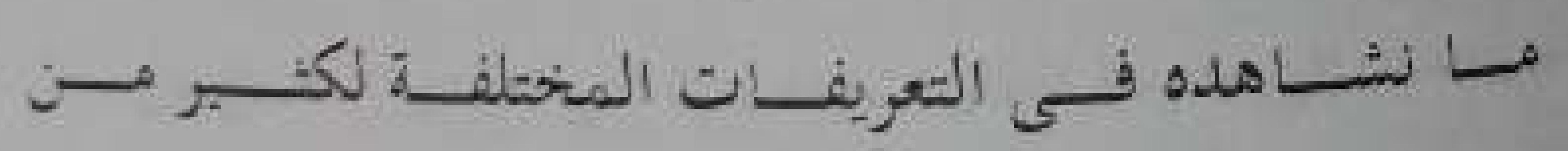
.

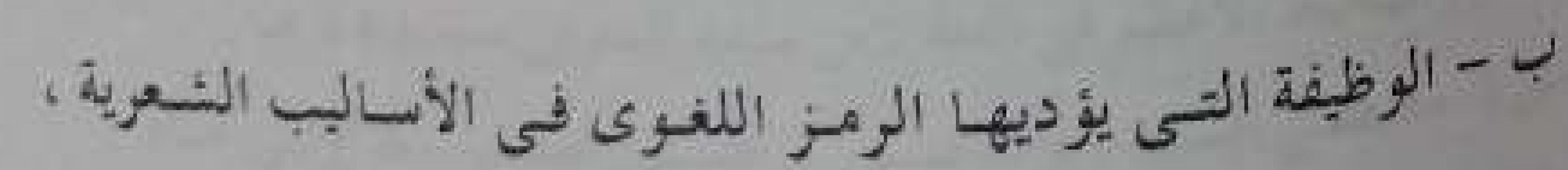

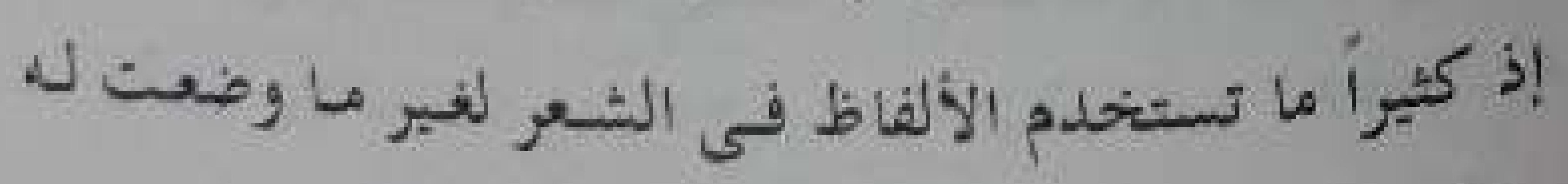

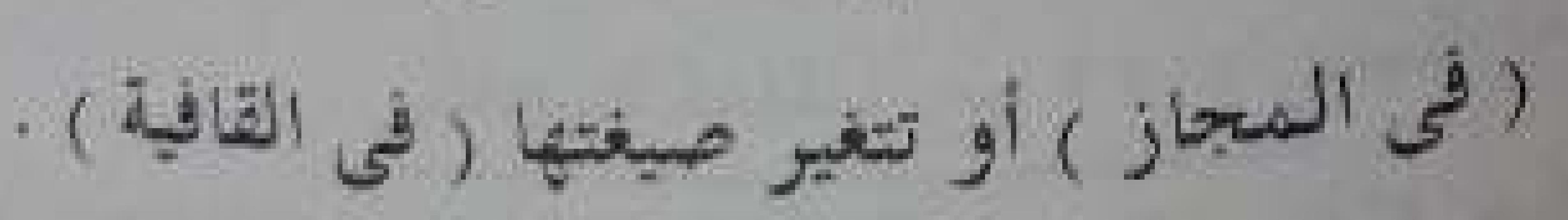

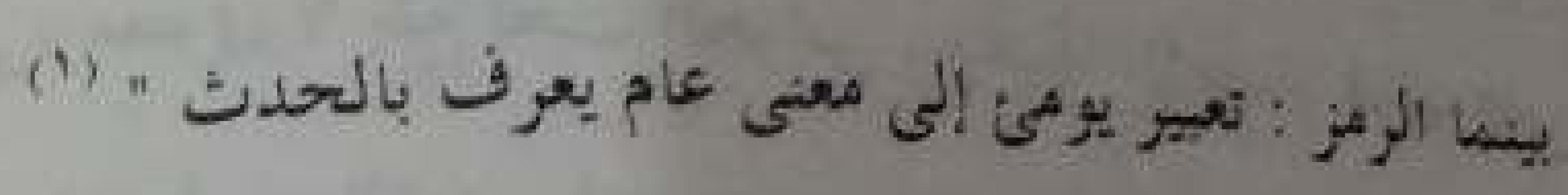
ويفضى هذا التمييز بين الرمز والقلامة ، إلى أن الدعسى تسى

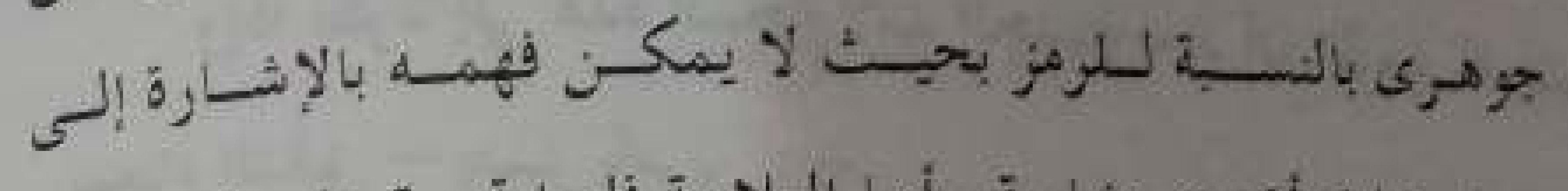

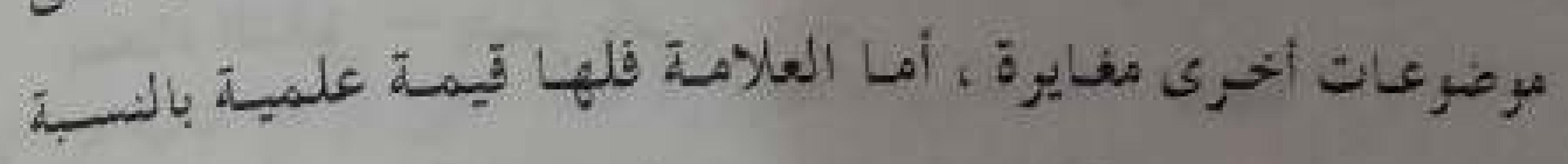

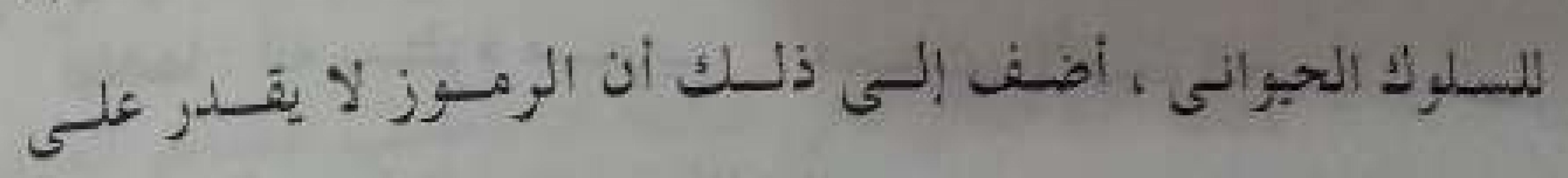
مارستبها الإ الإنسان.

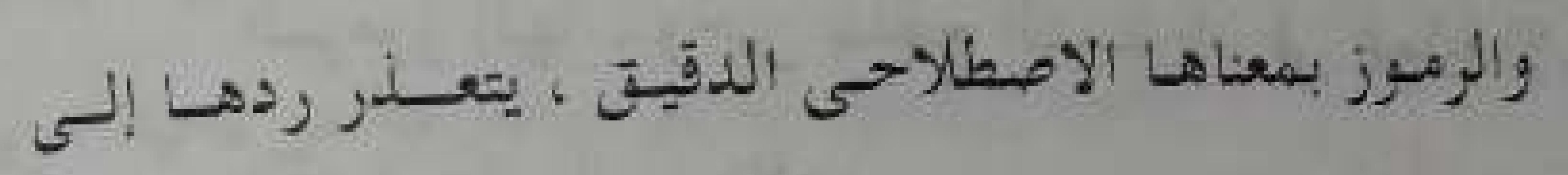

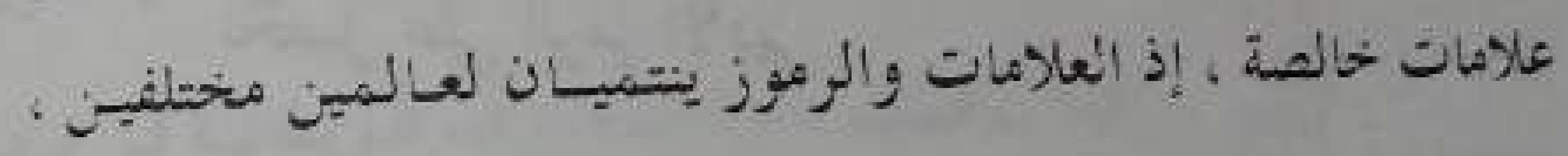

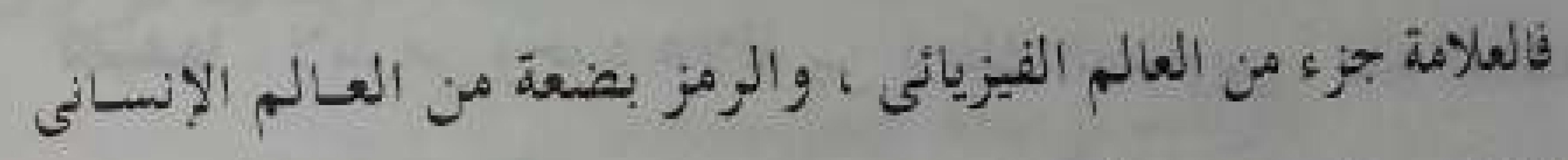

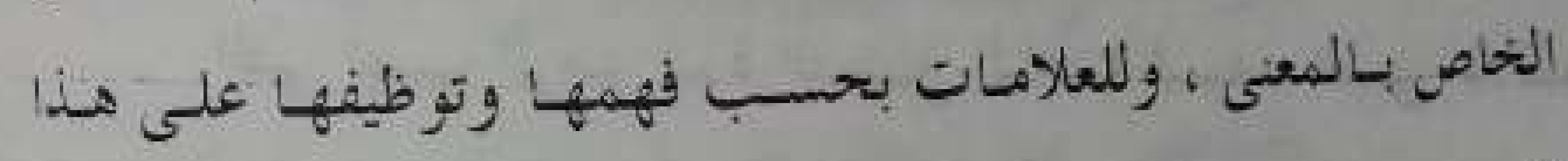

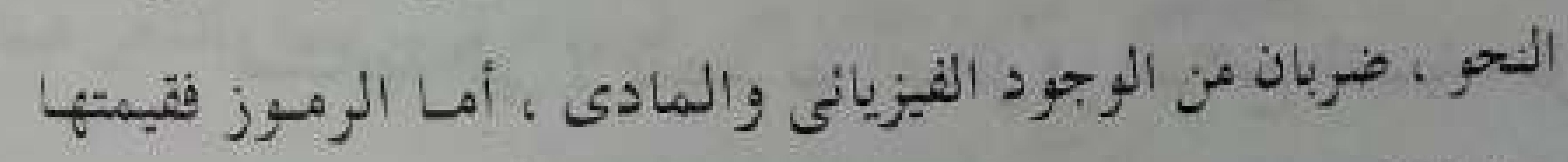

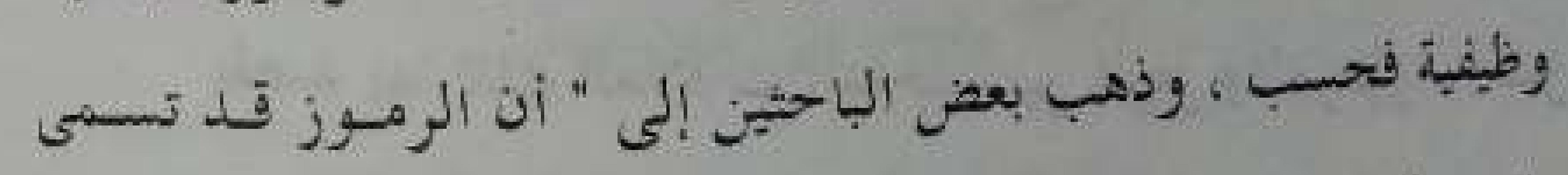

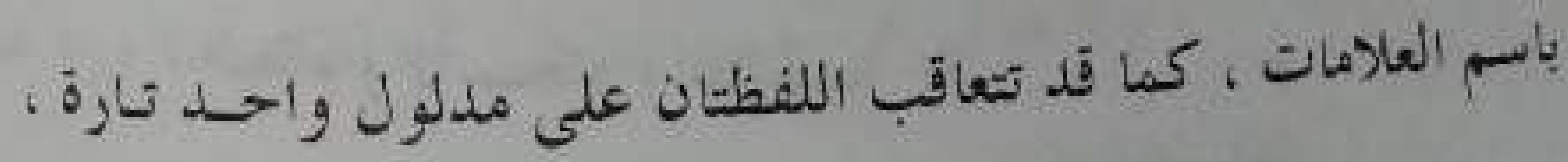

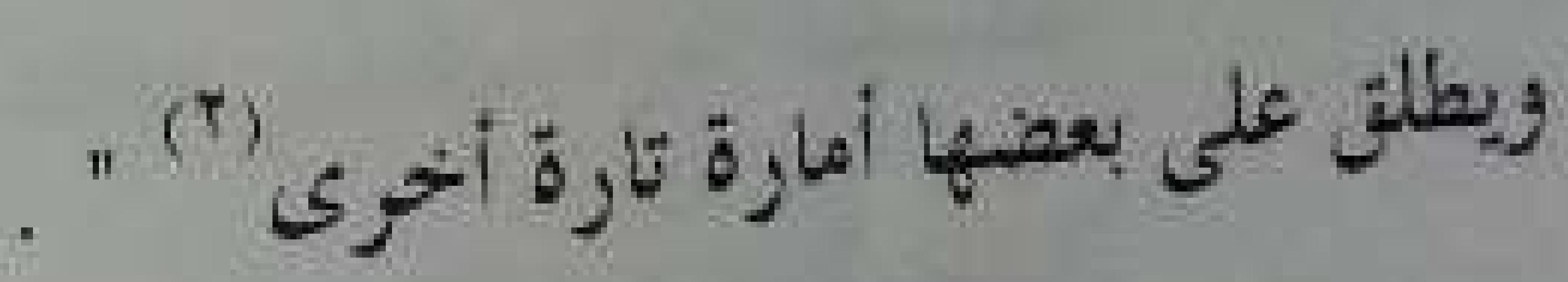
ويتري بولر أن اللغة في نظره لا تعدو أن تكـون إيحسى وبسائل

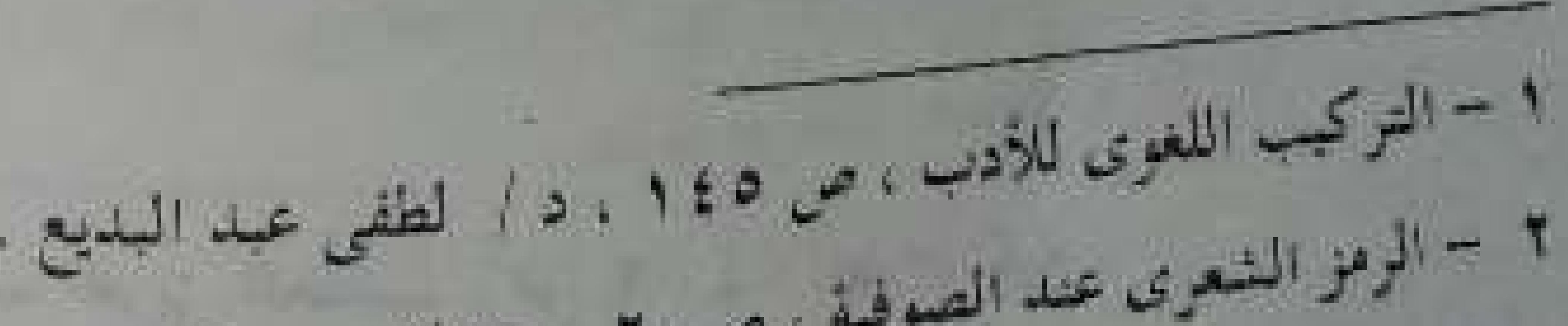

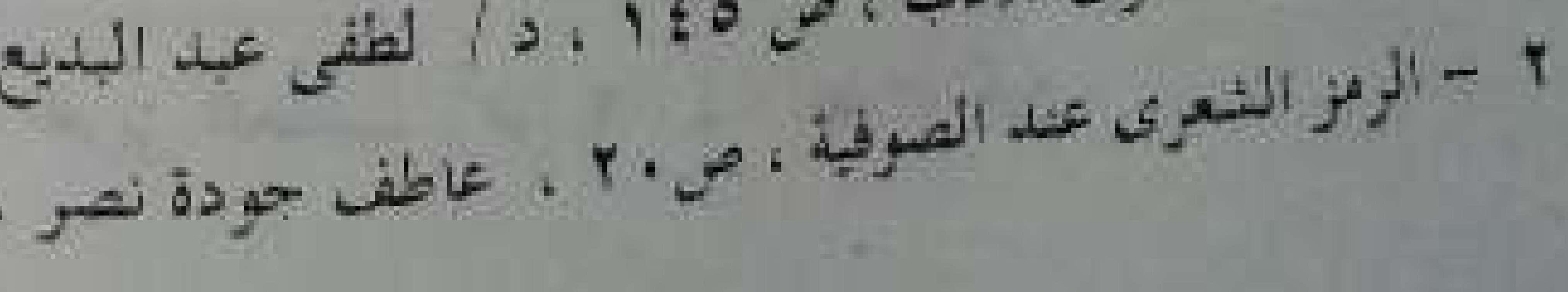




\section{المبرثب الثانى}

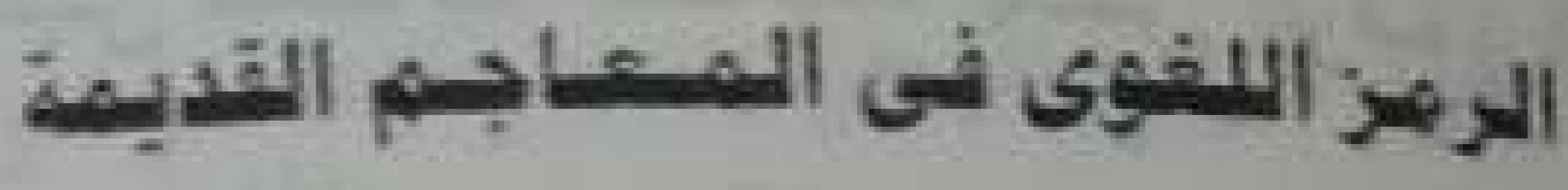

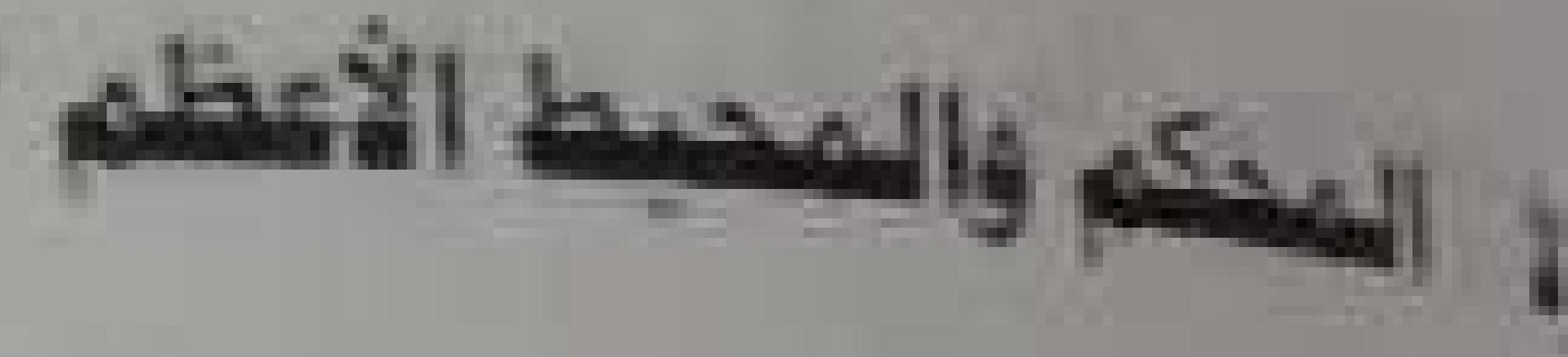

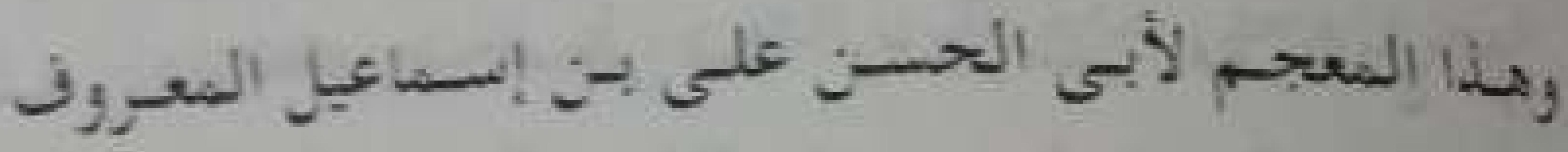

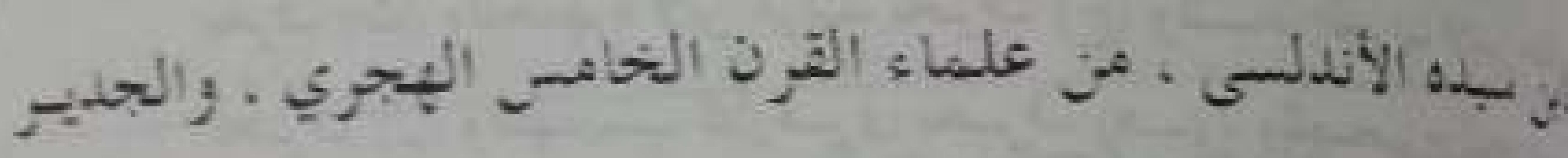

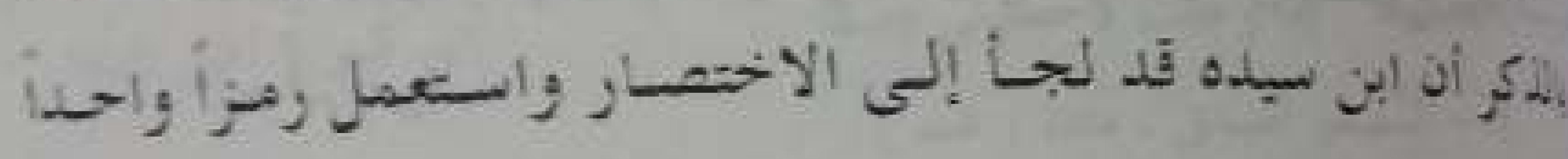

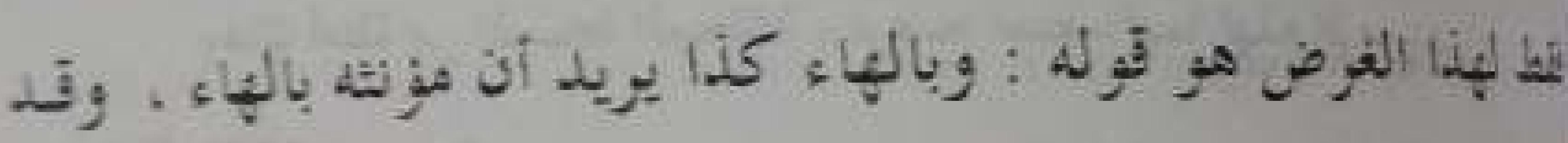

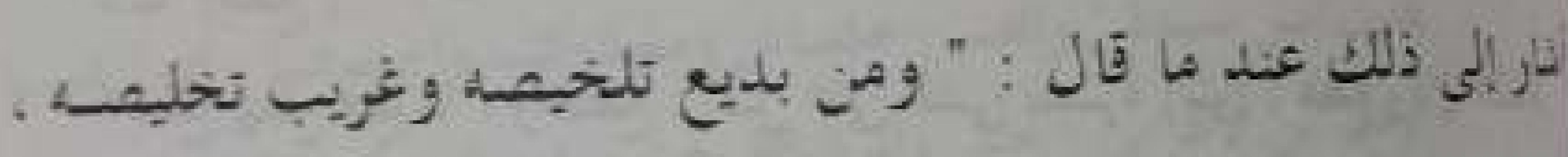

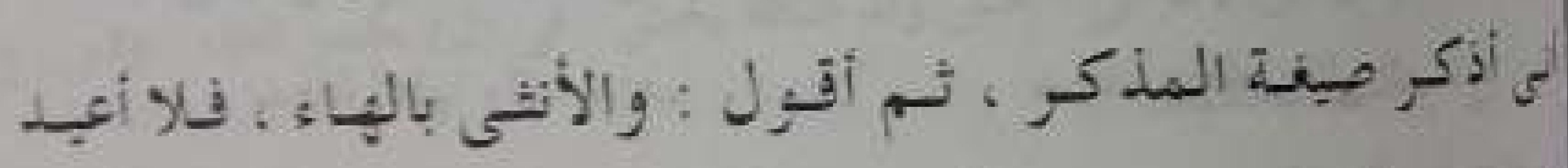

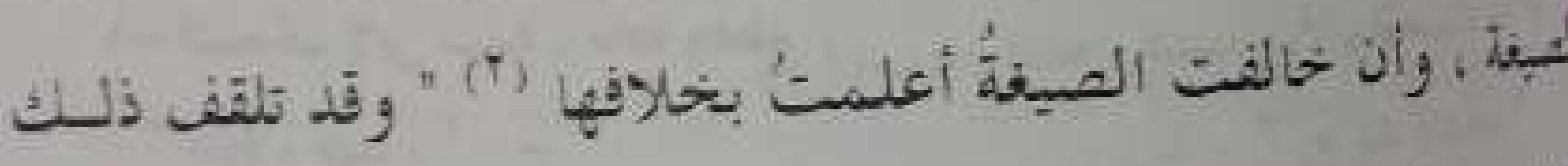

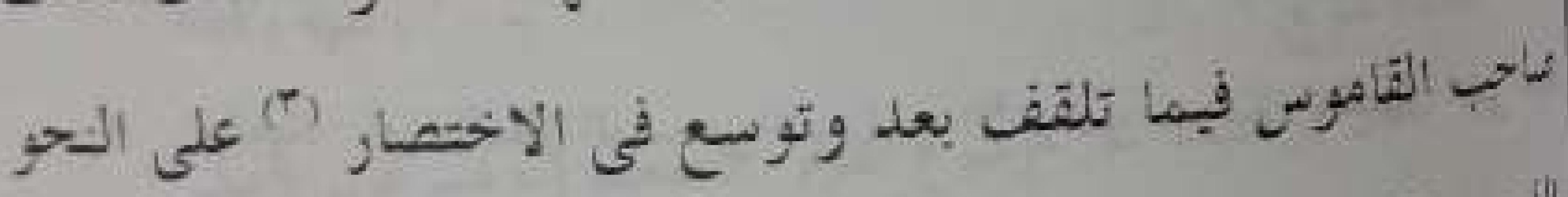

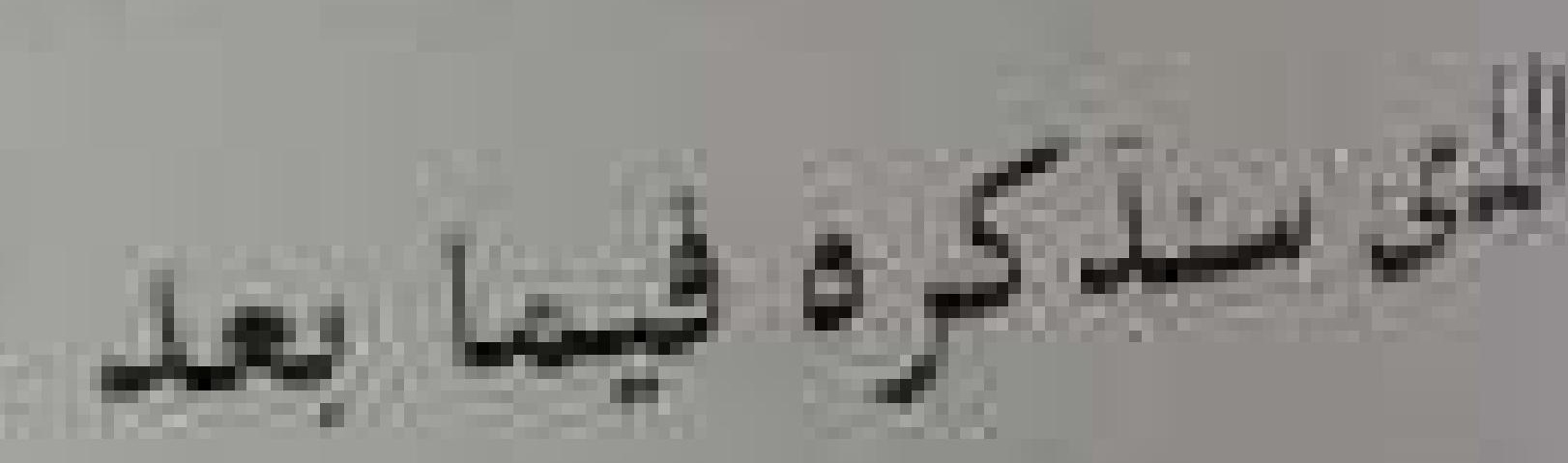

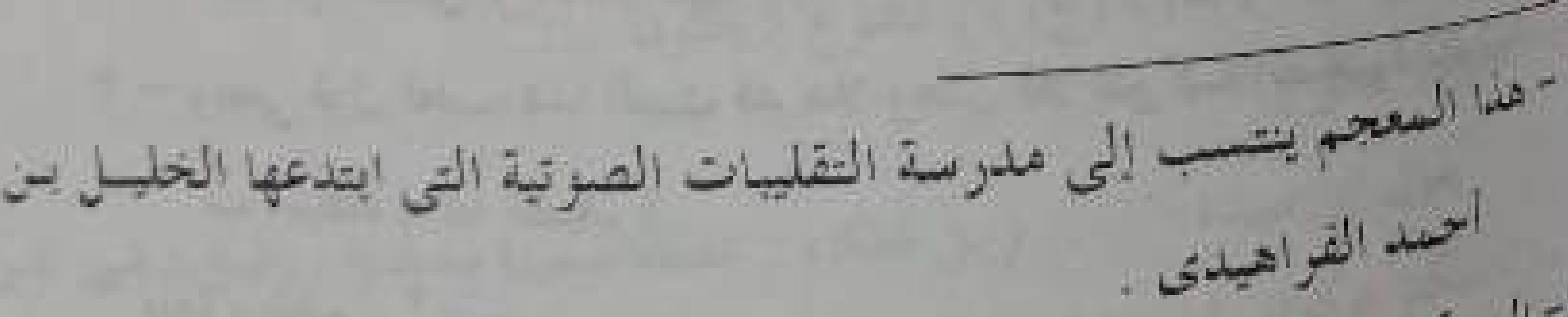

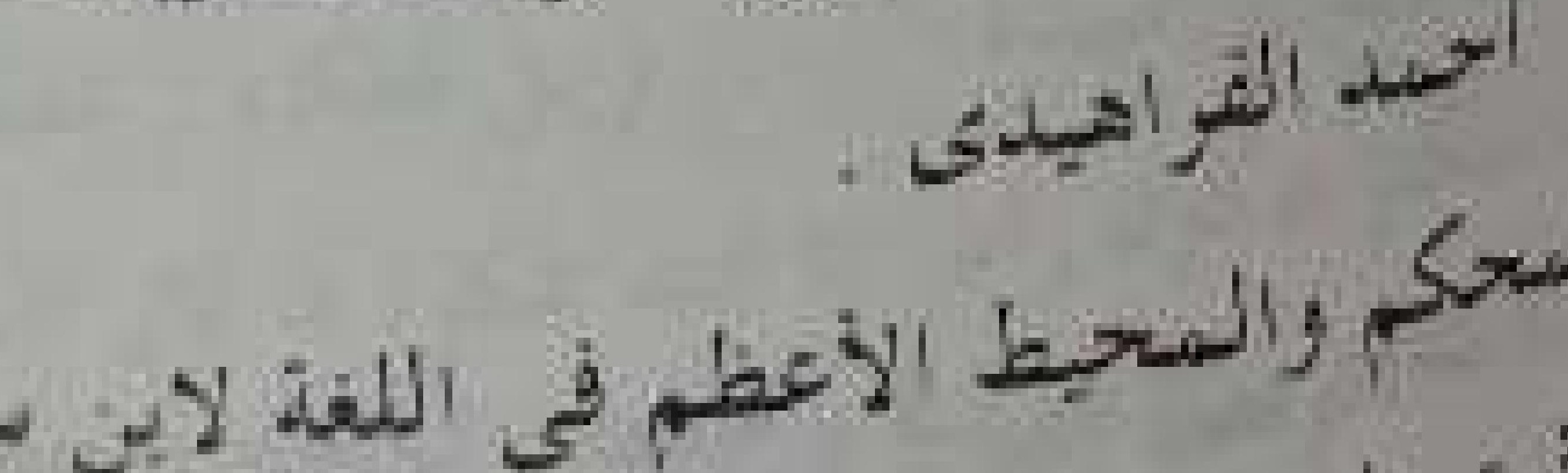

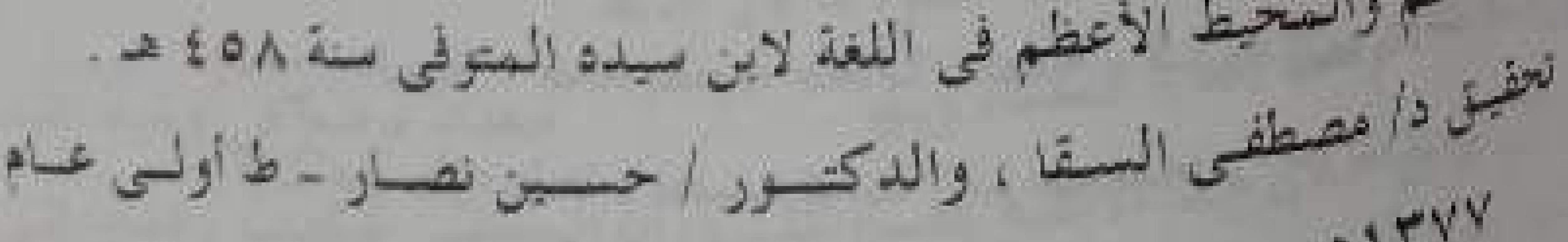

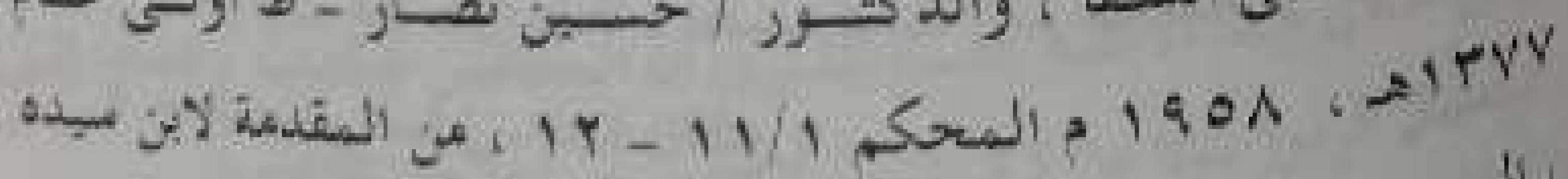

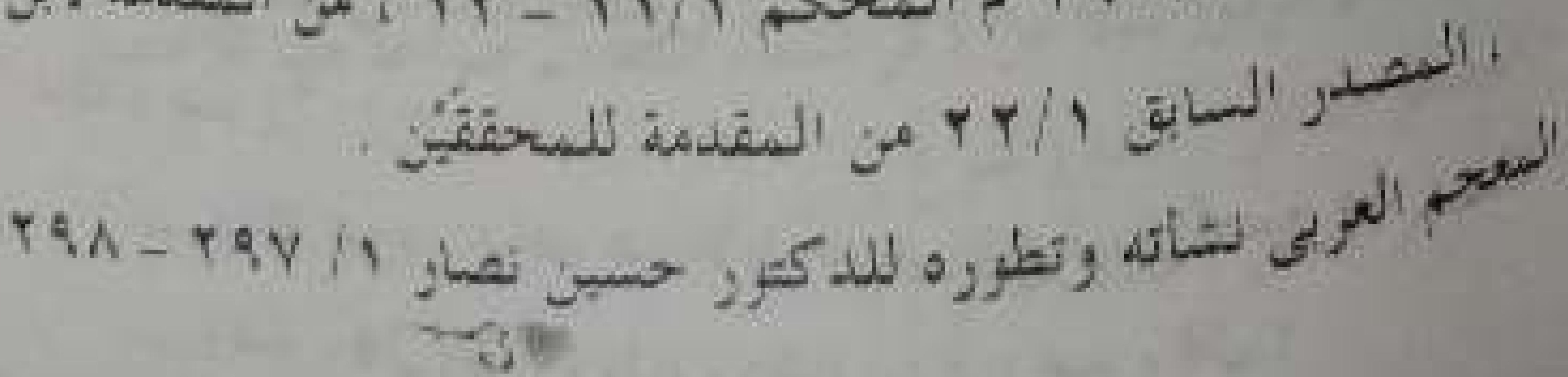

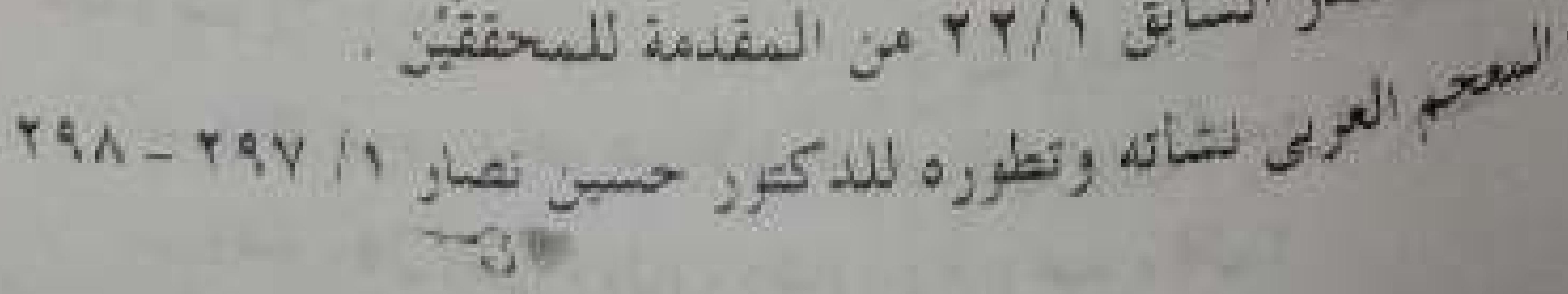

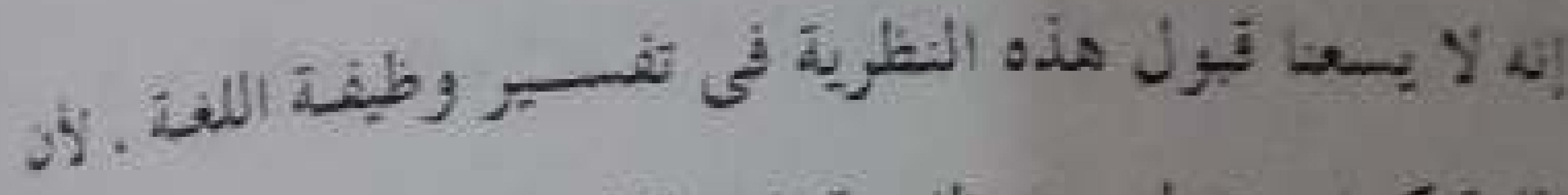

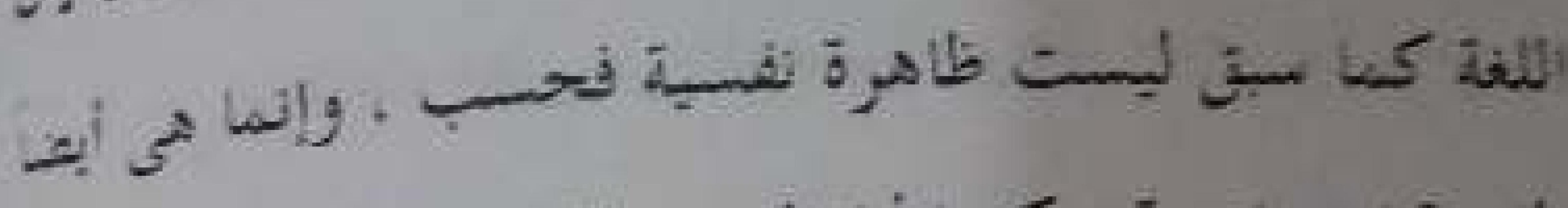

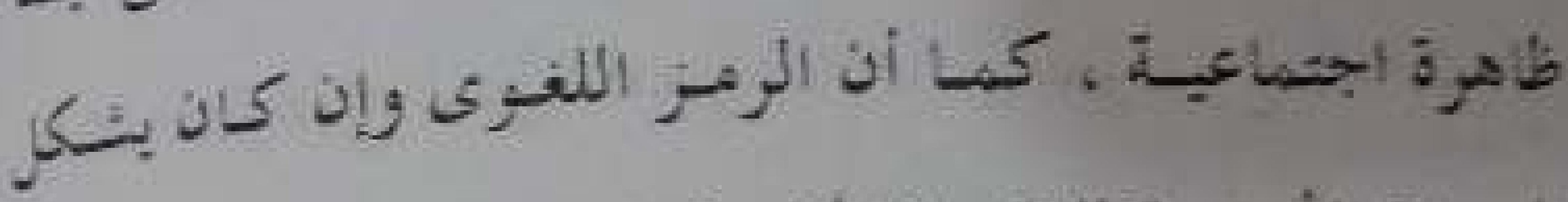

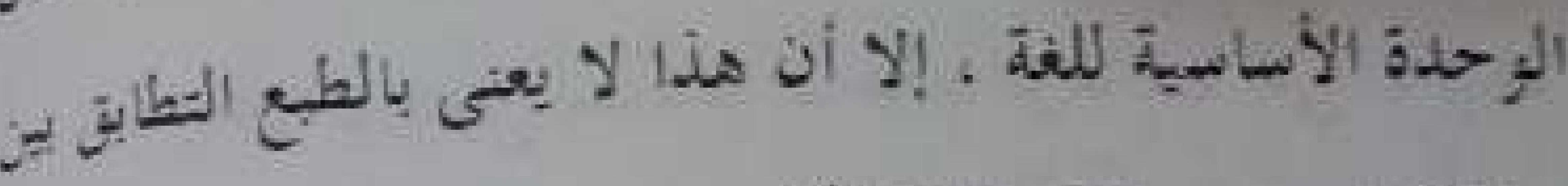

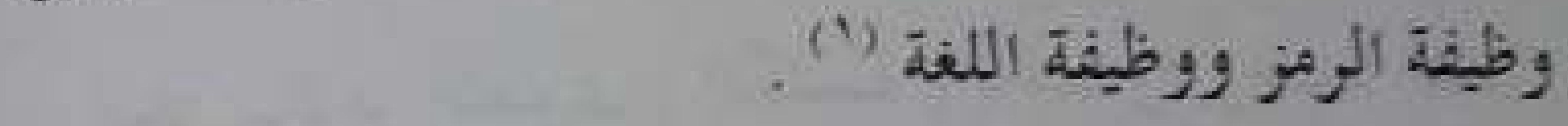

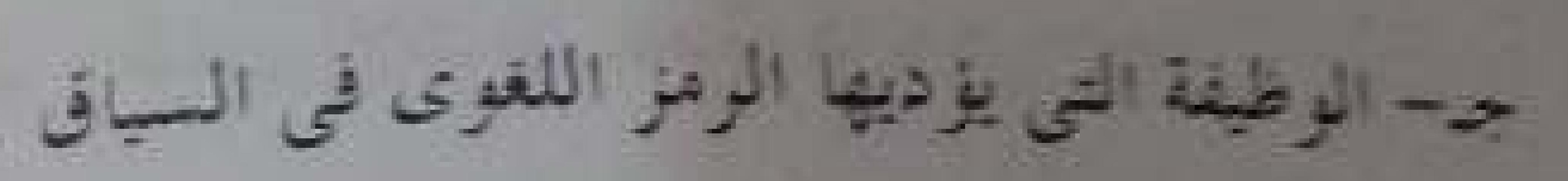




\section{क्al unglat}

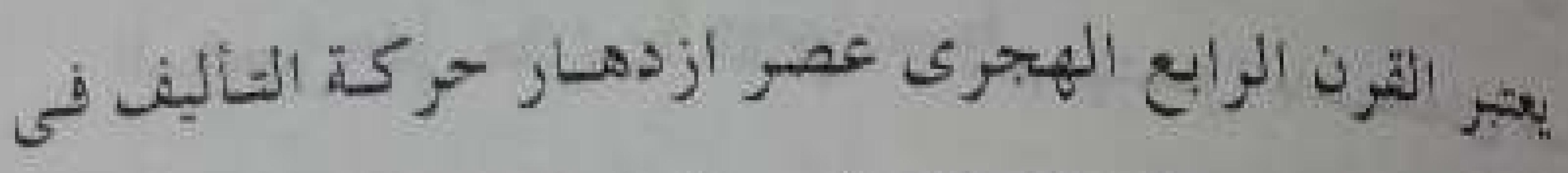

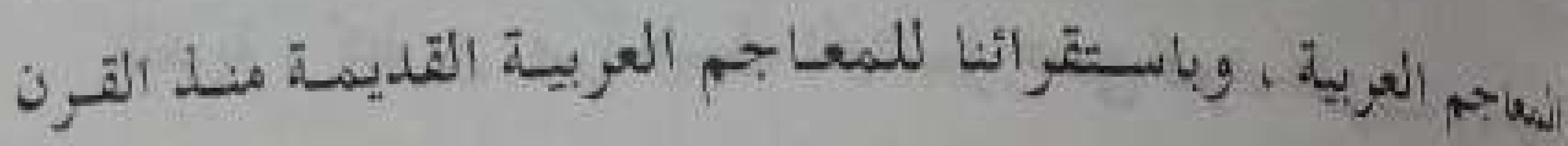

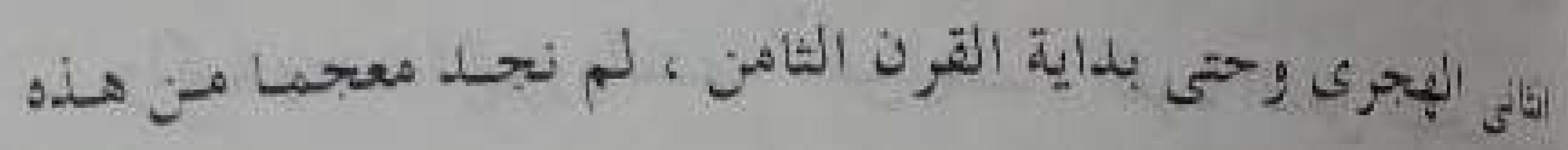

ألى كير لا أطئ الفنا.

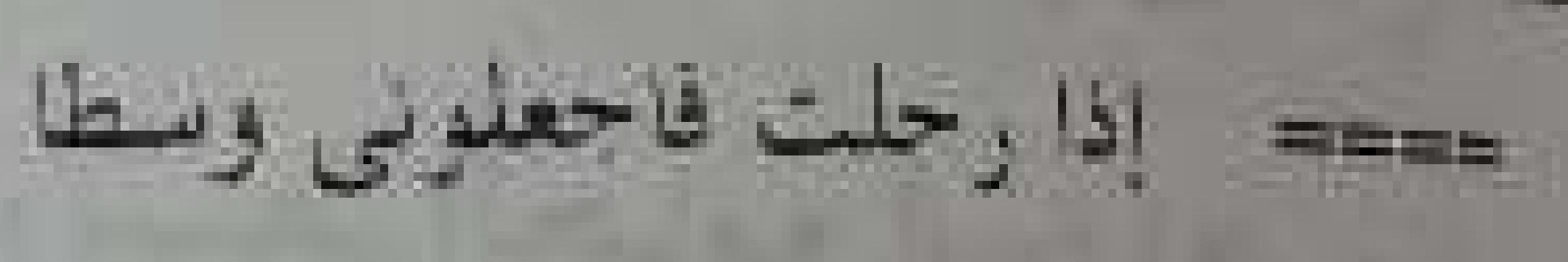

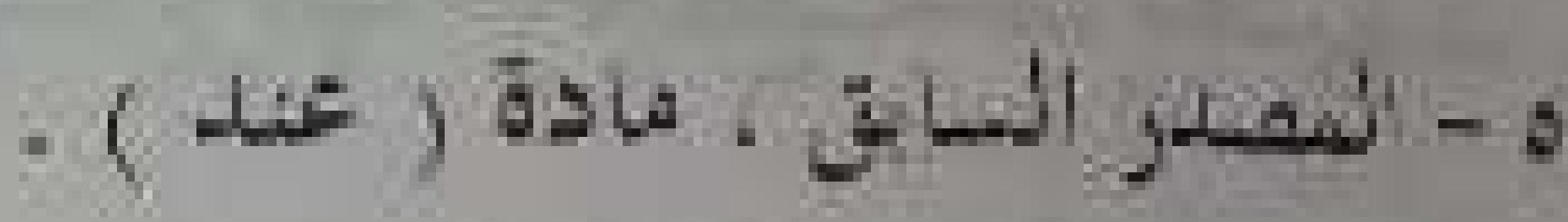

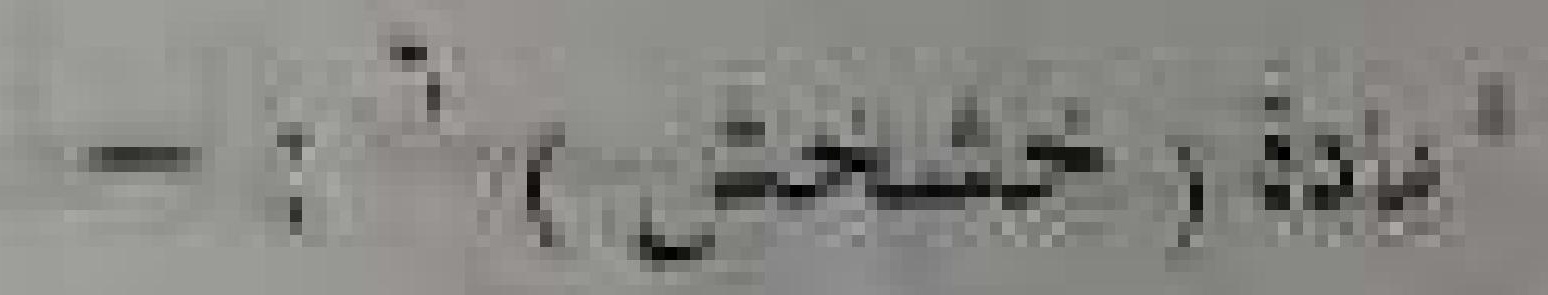

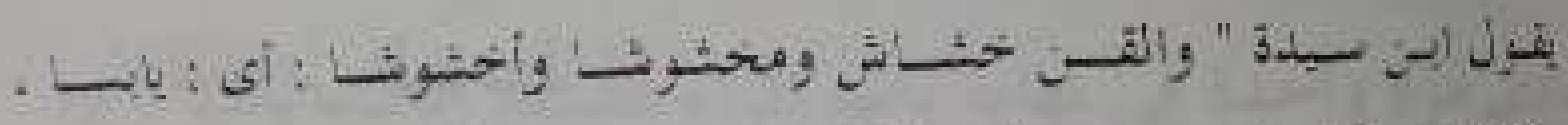

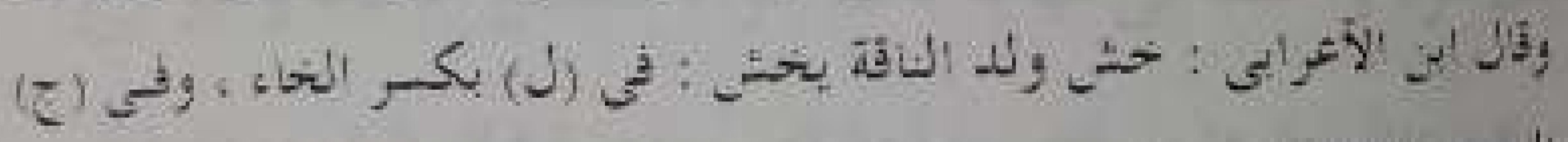

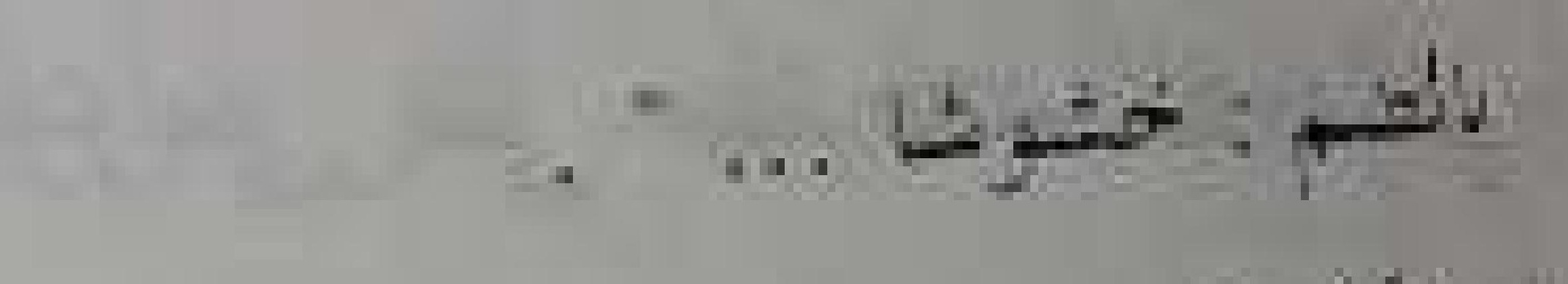

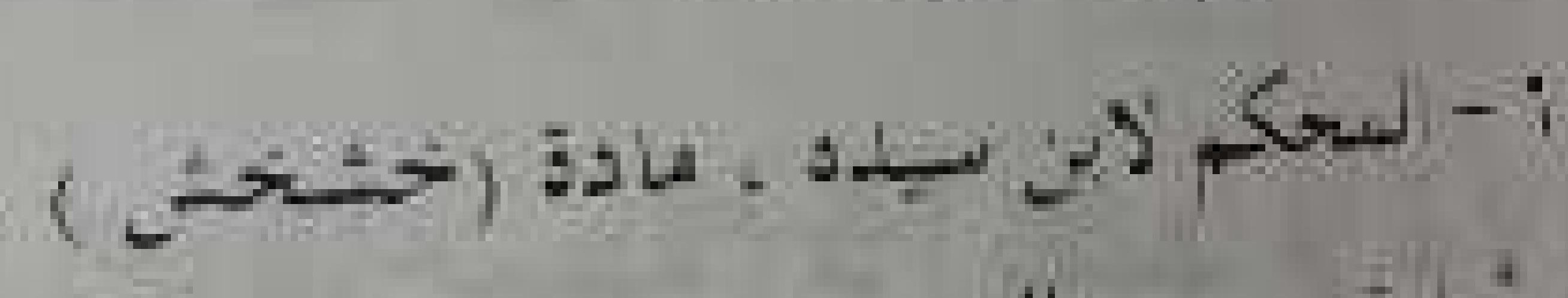

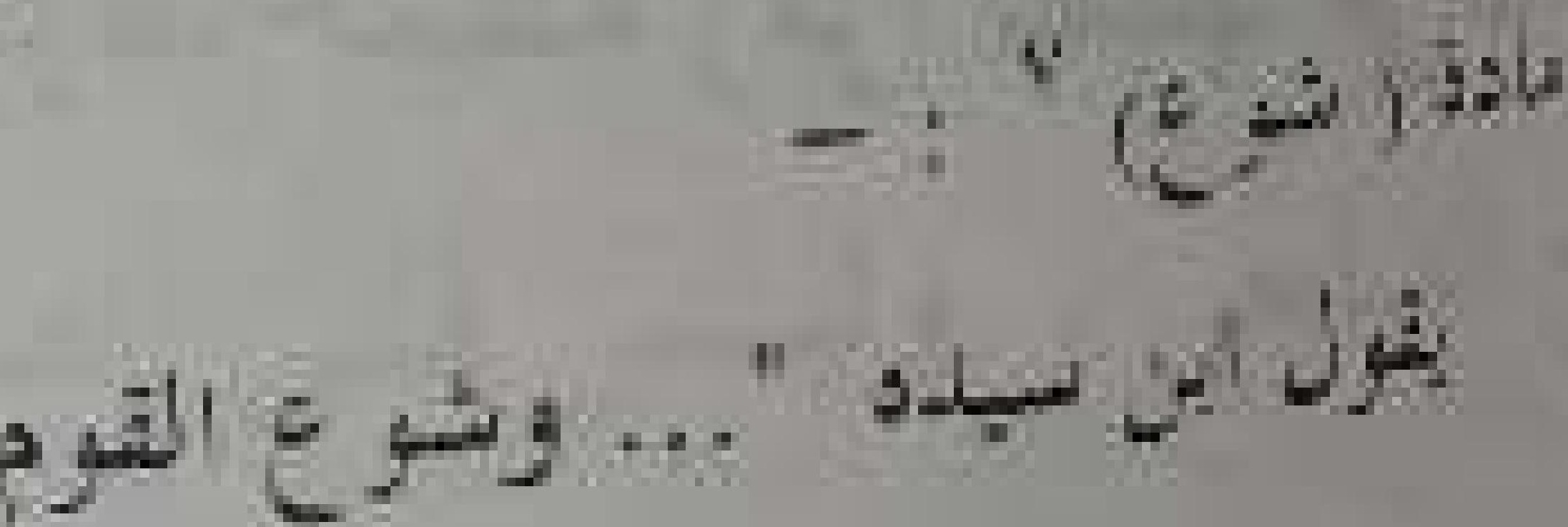

"

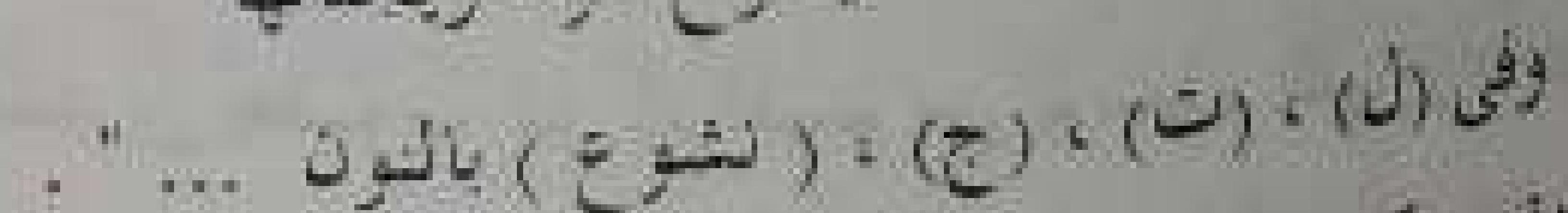

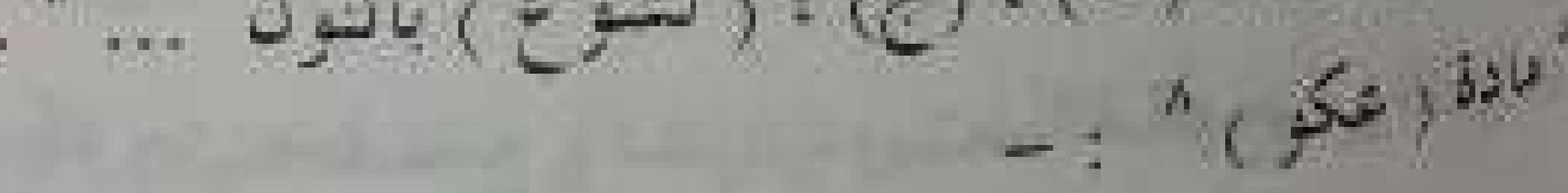

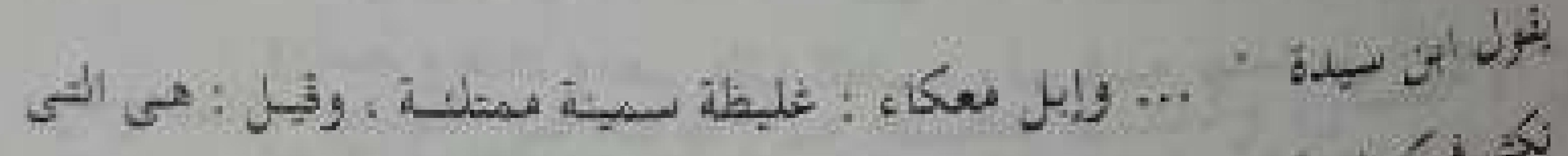

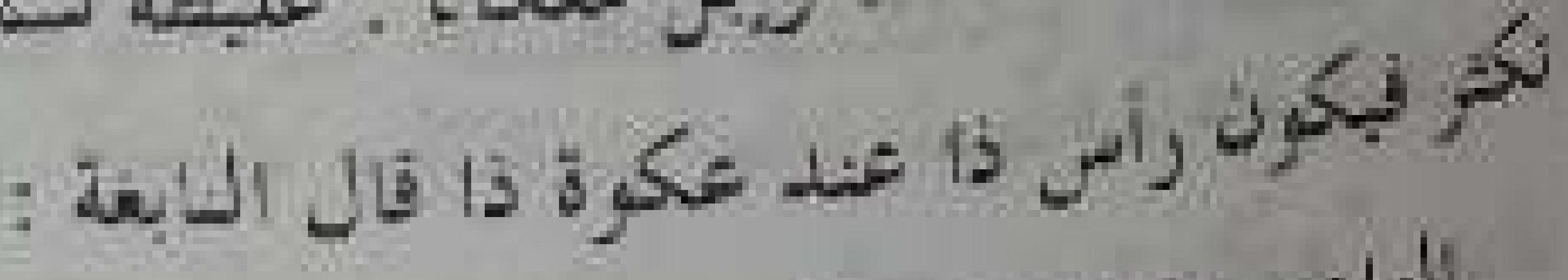

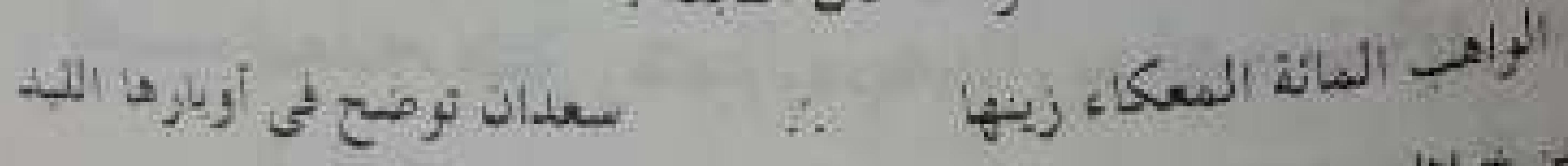

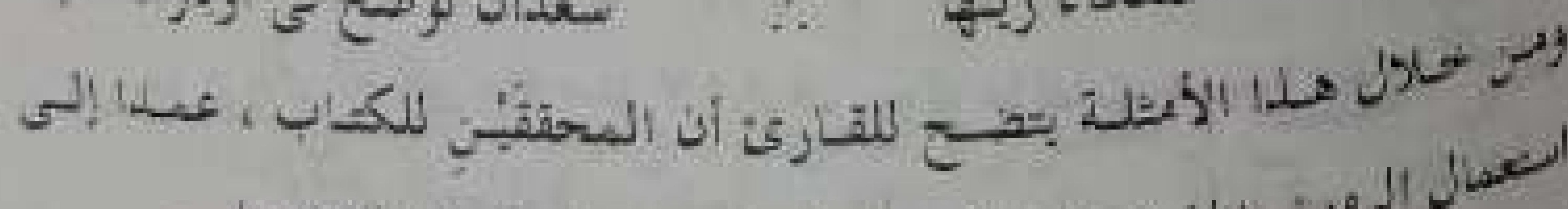

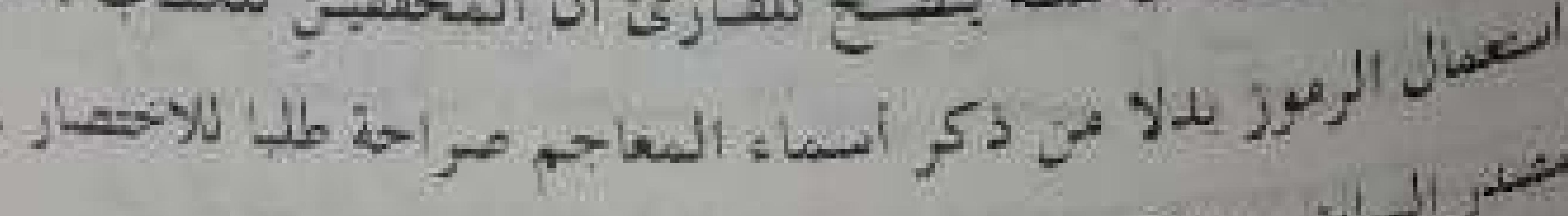

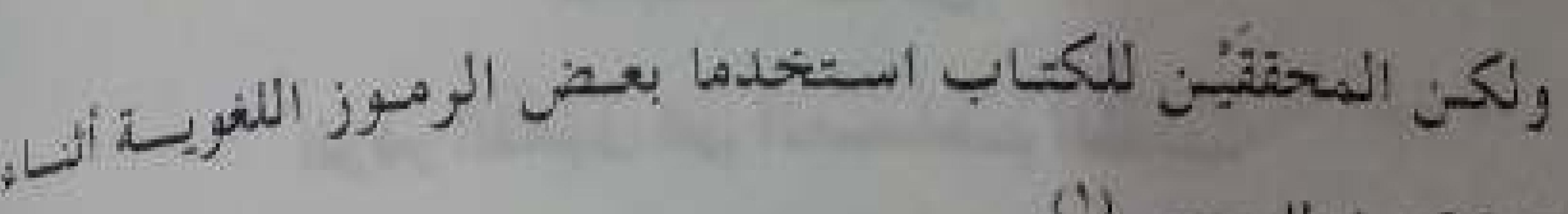

(1) تحفيقها للمبحتم

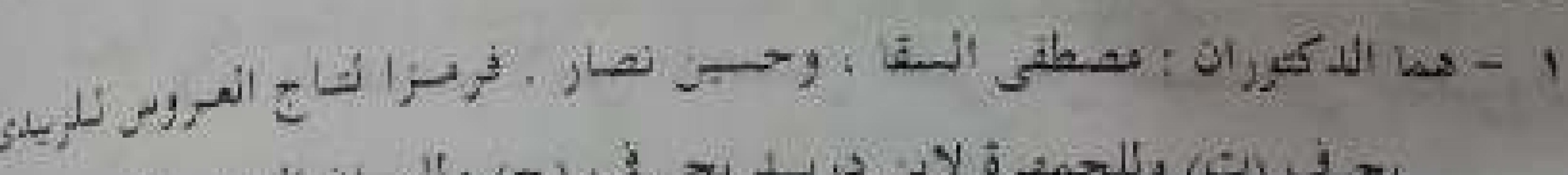

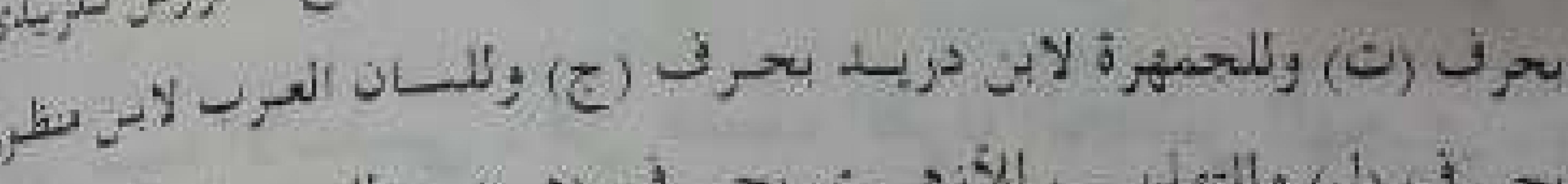

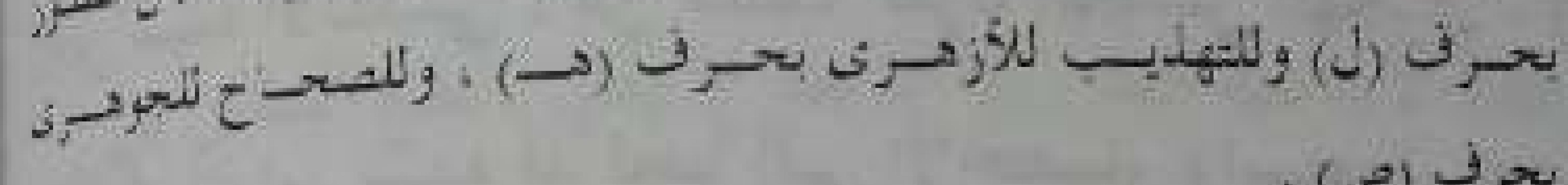

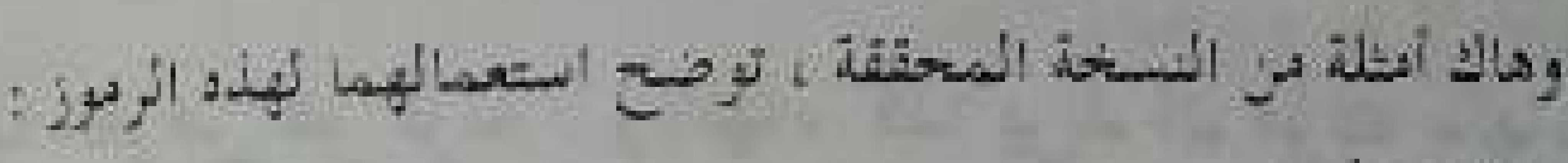

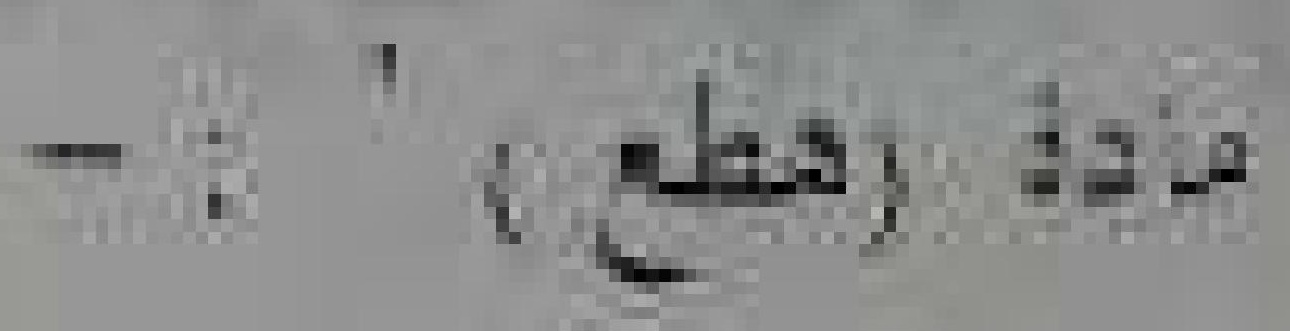

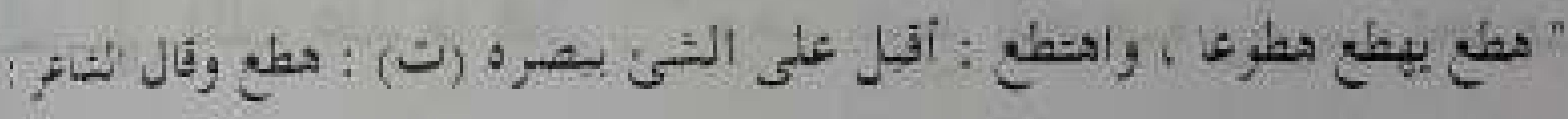

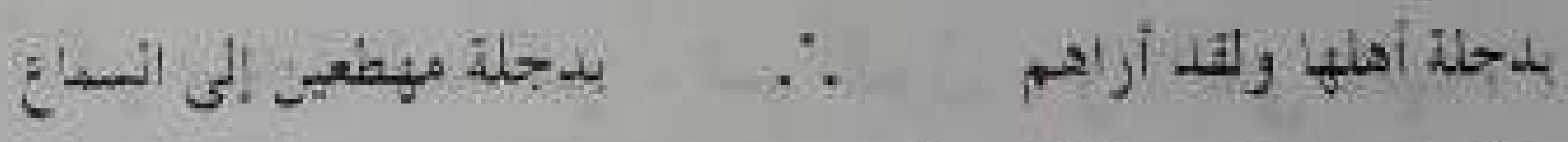

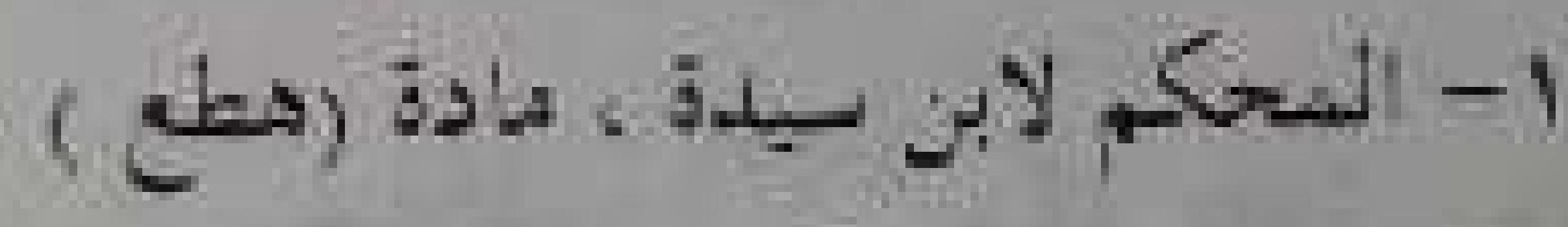

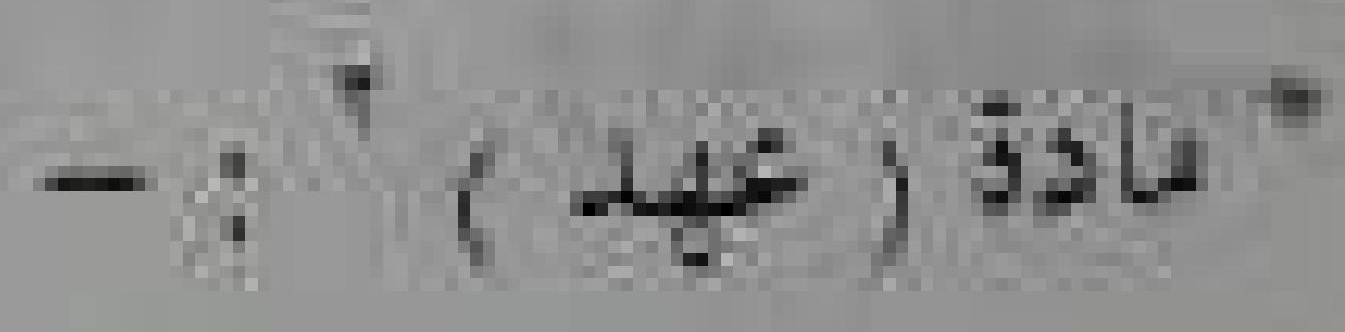

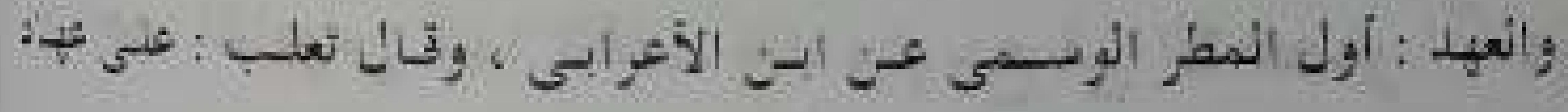

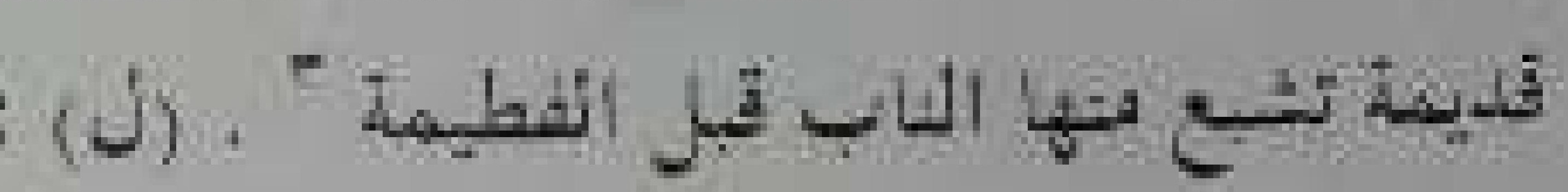

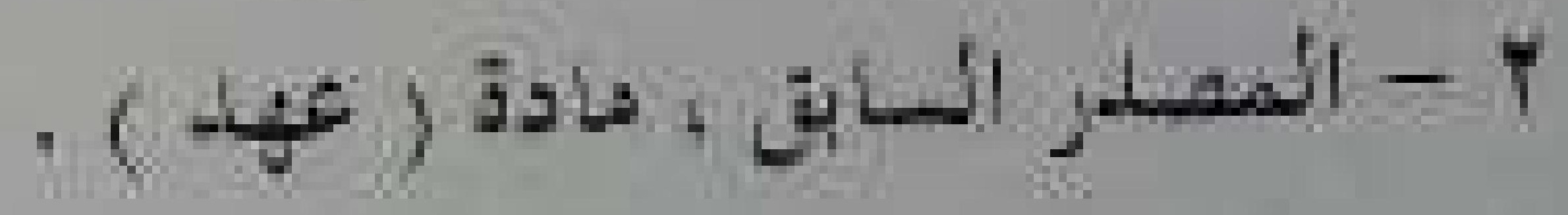

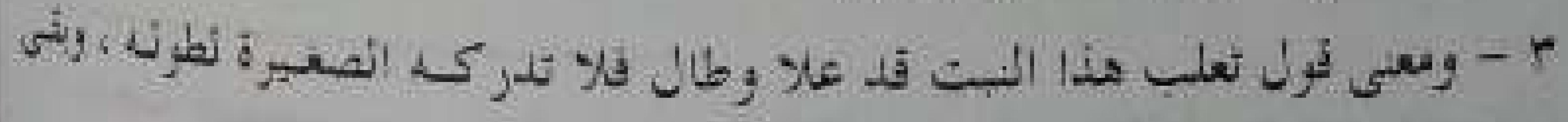

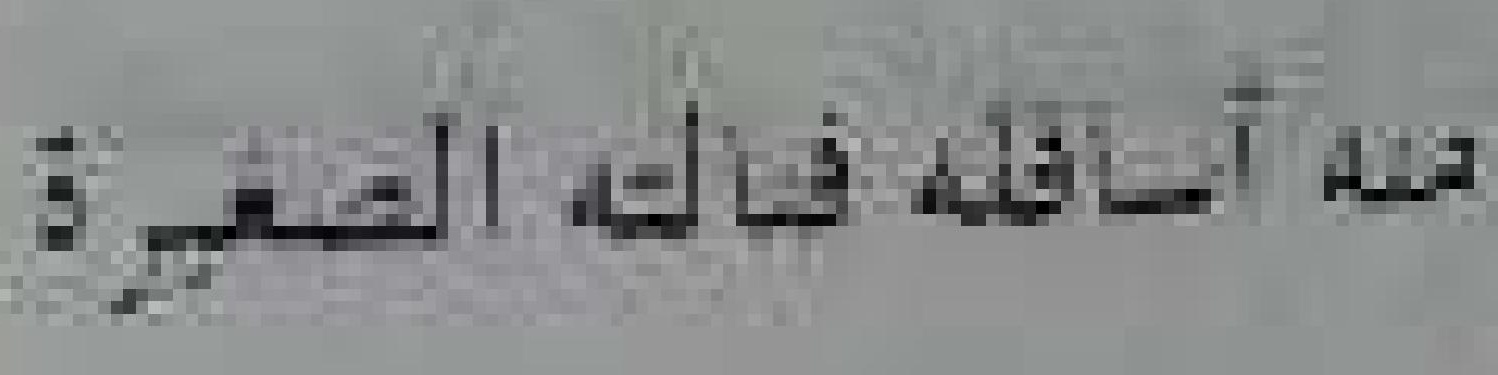

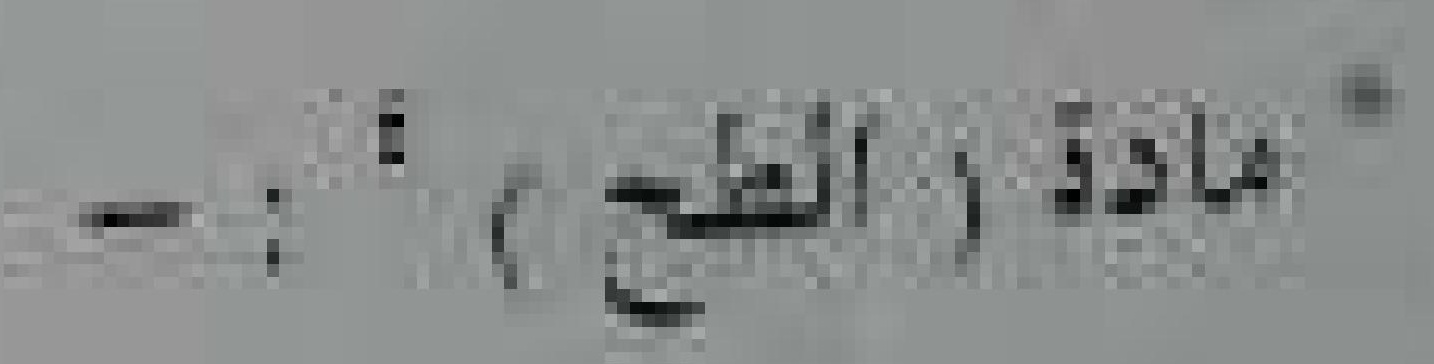

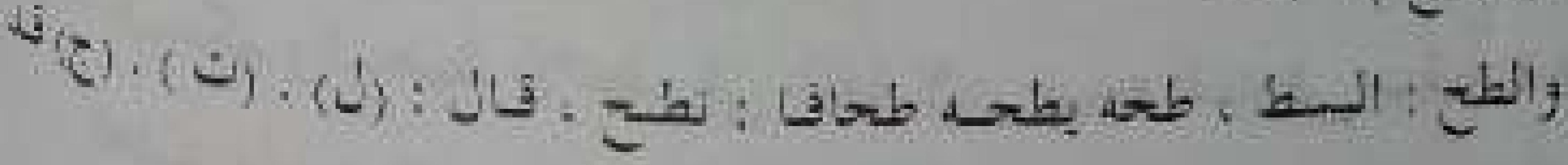

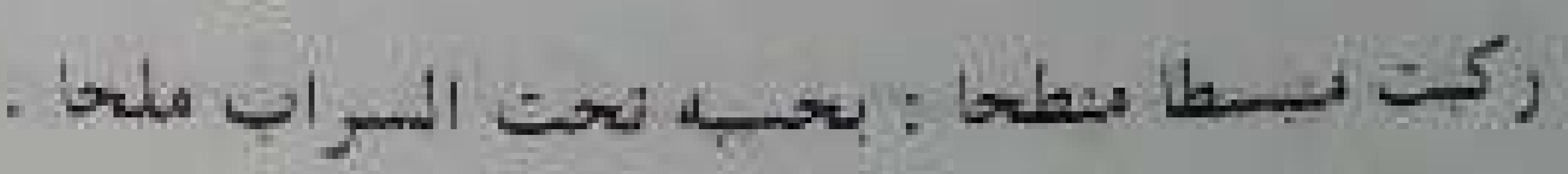

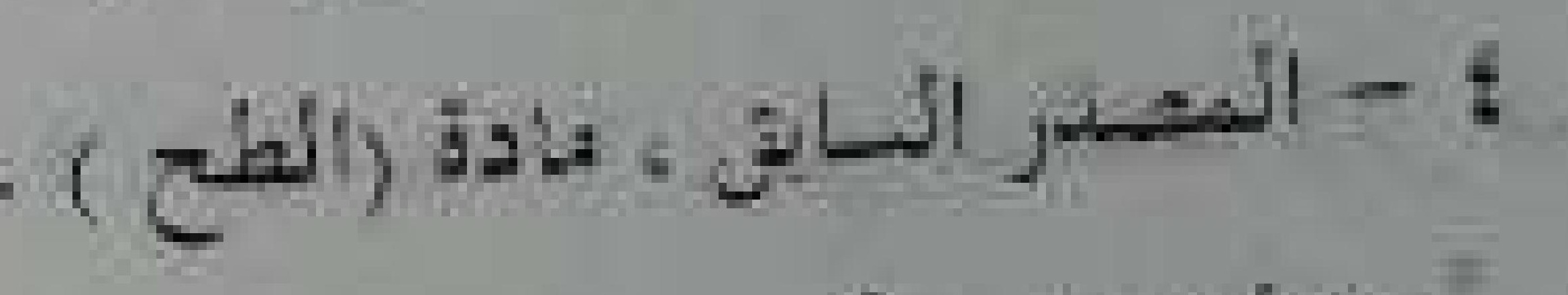

$\left.\left.-*_{1}^{*}+\right)^{3}\right)^{3}$

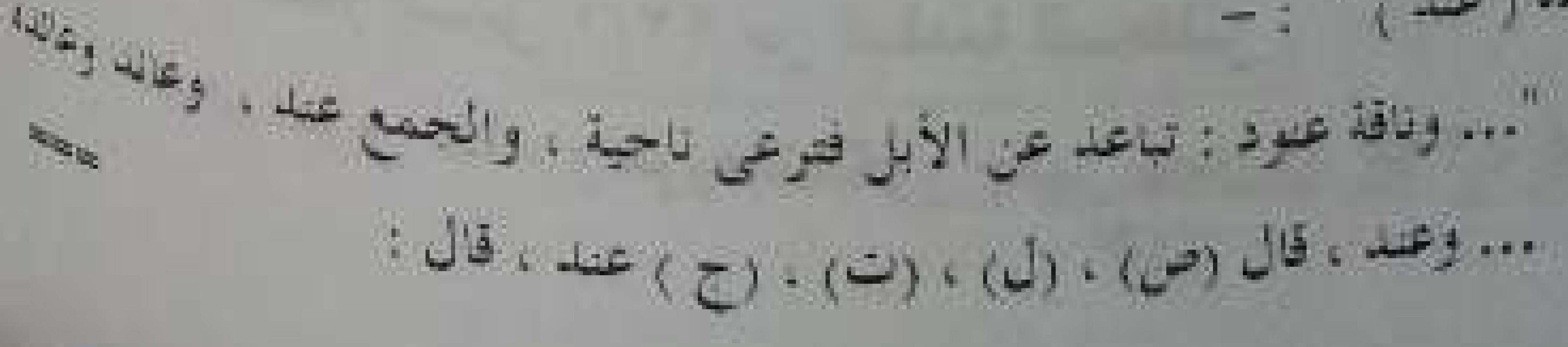




\section{$-r \cdot 9-$ \\ وما فيه من رمز فختمسية أحرف}

فميم لمعروف وعين لهبوضن

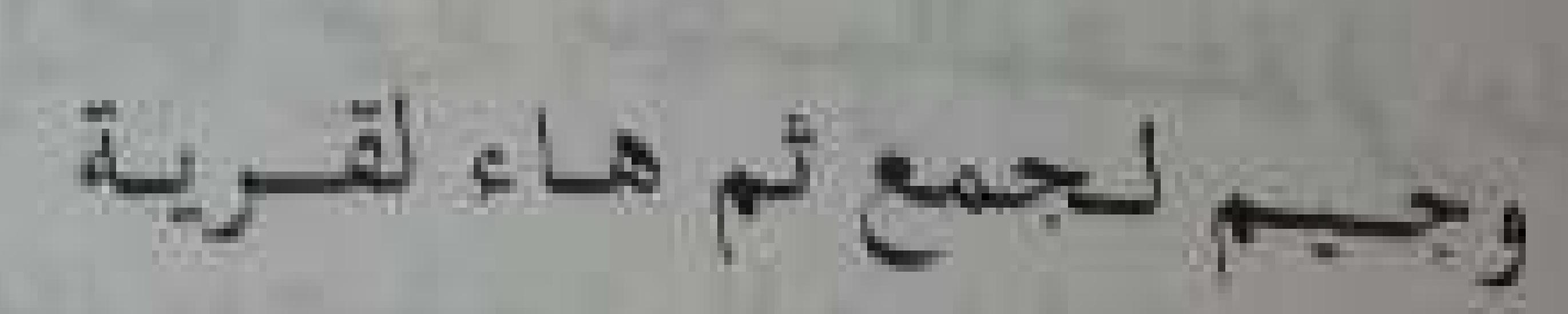

ولمبلد الــلـال التى أهملت في

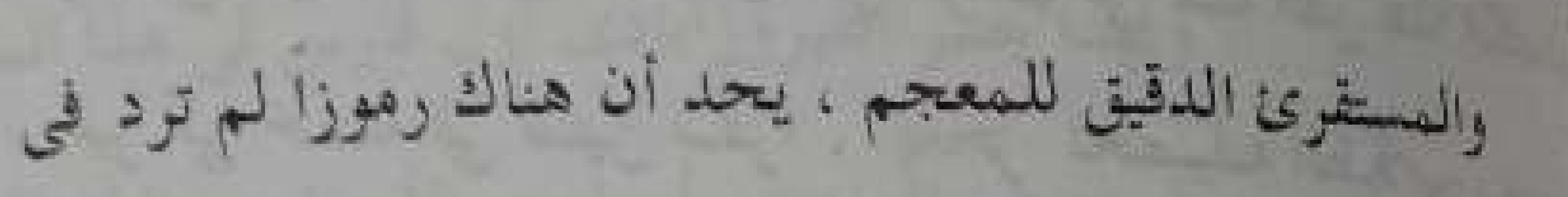

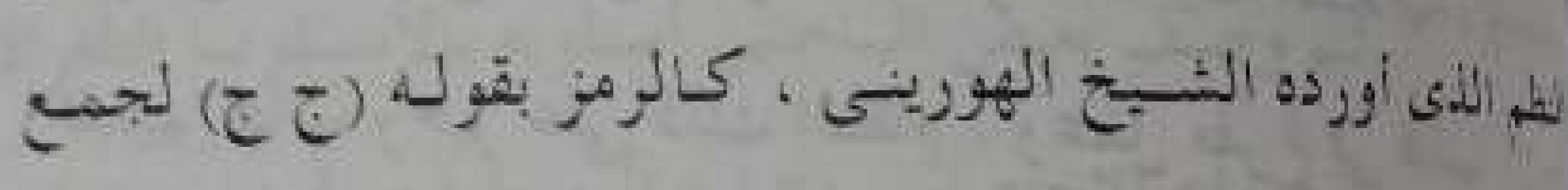

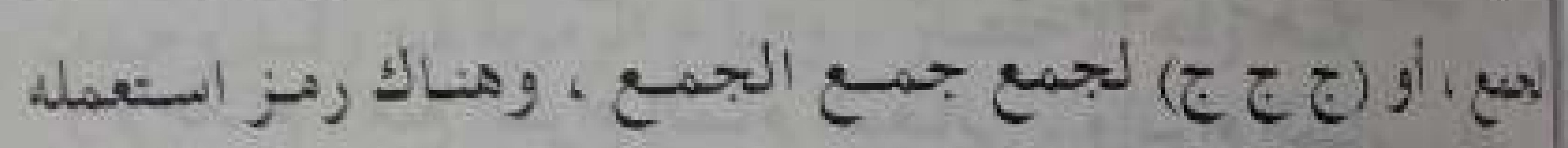

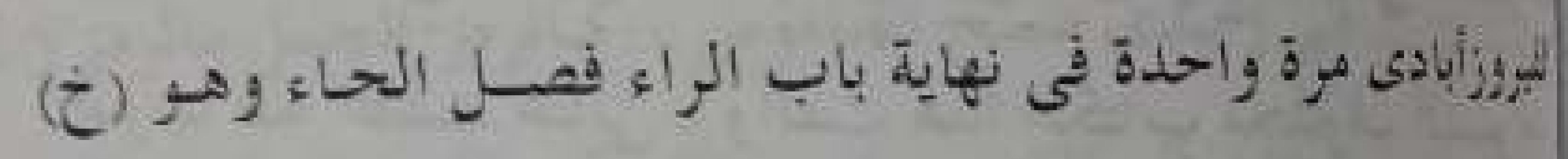

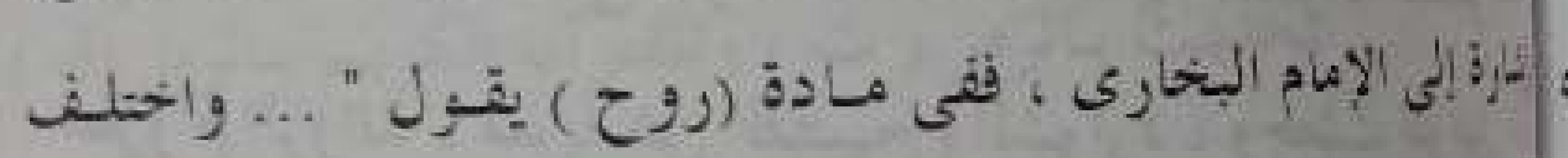

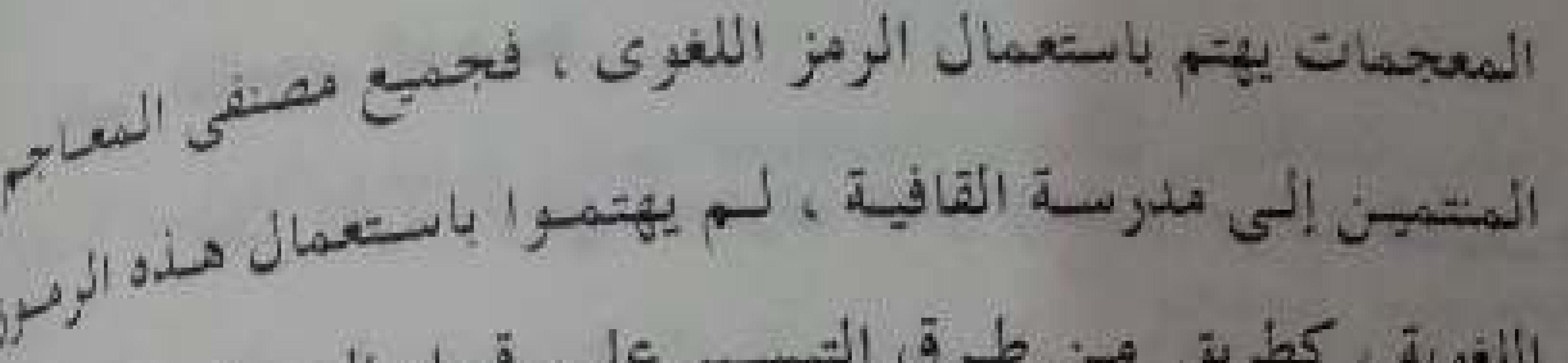

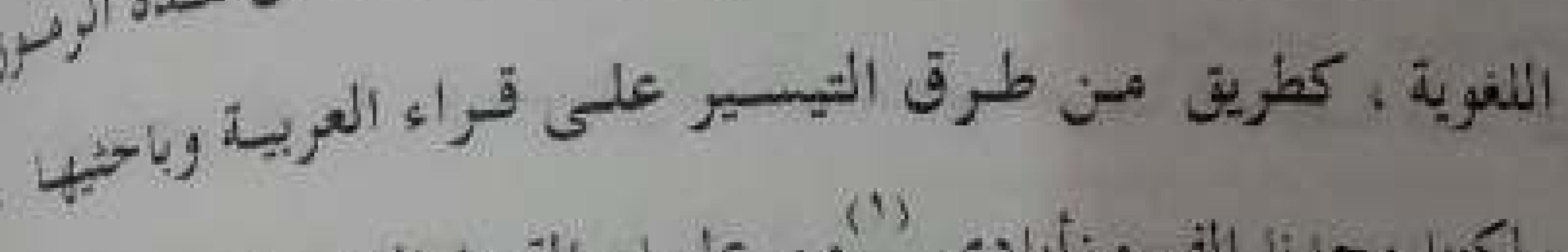

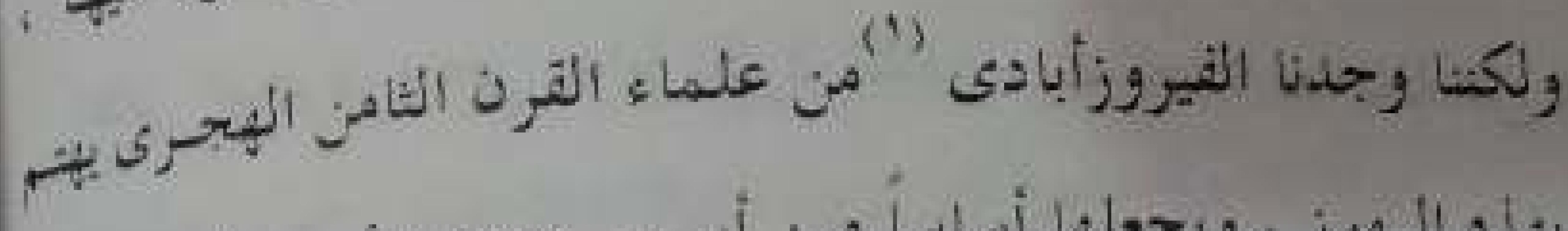

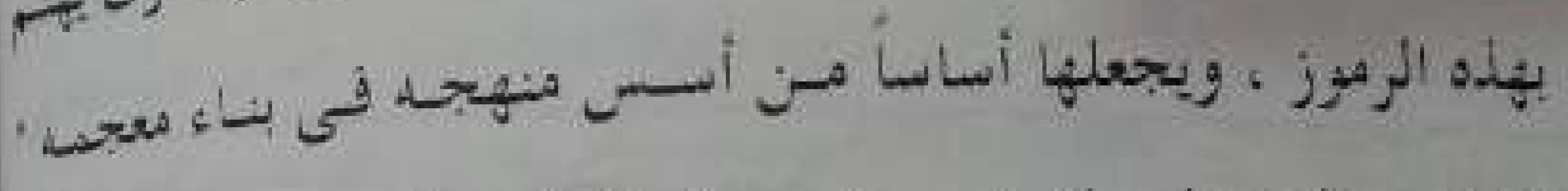

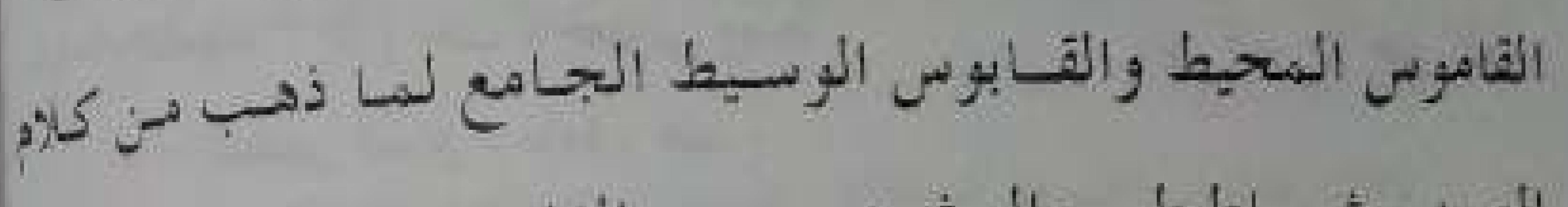

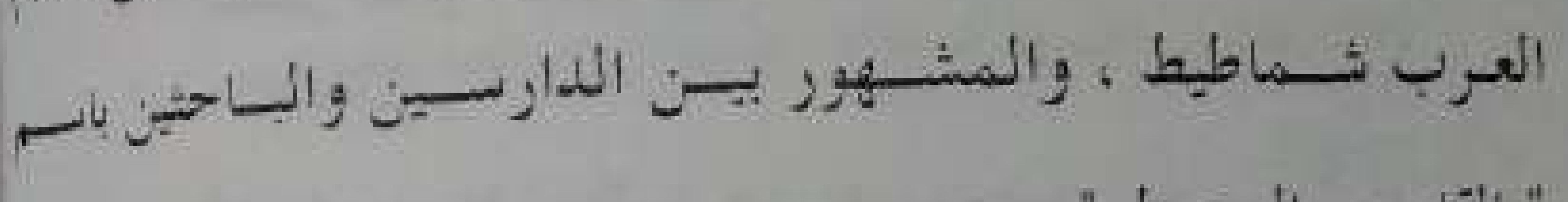

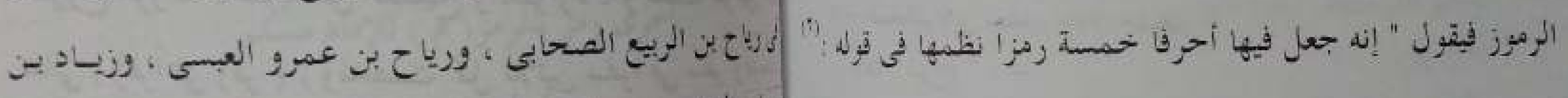

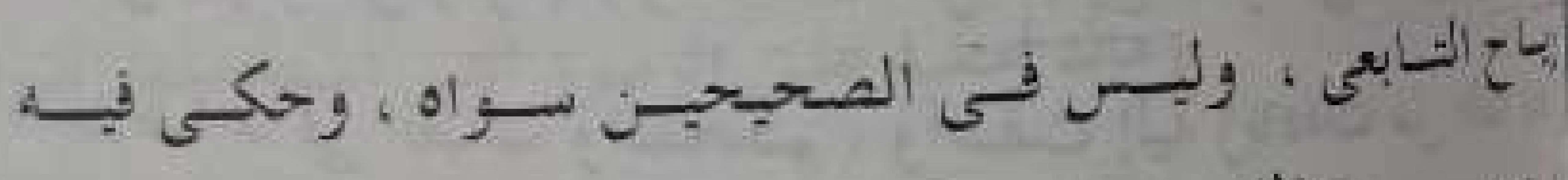
(1) (1)

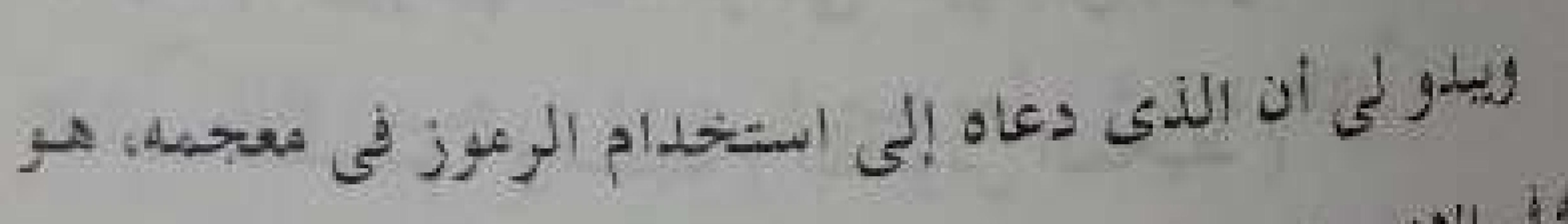

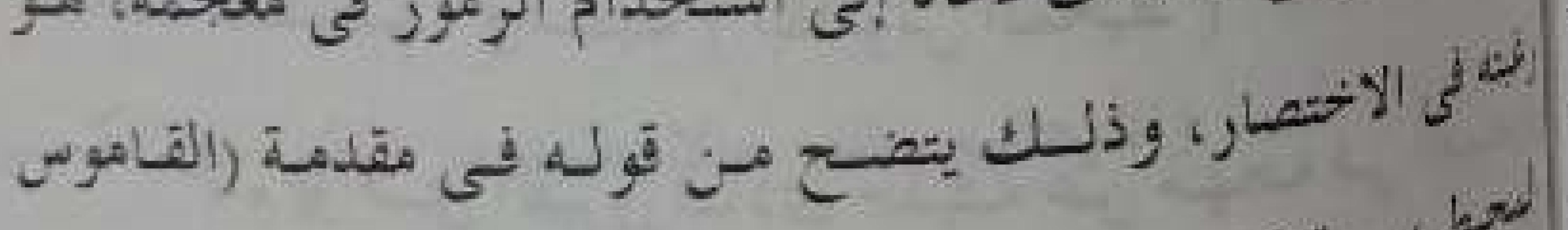

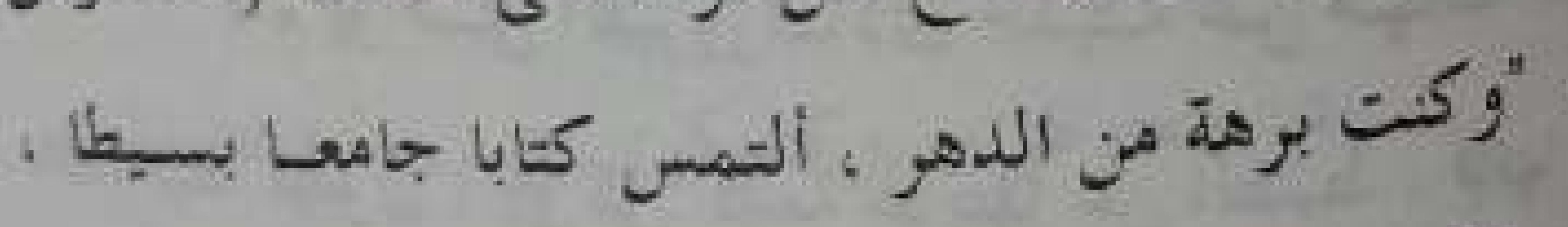

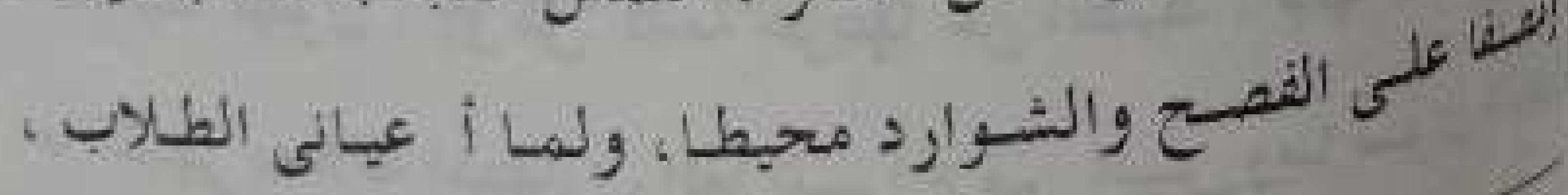

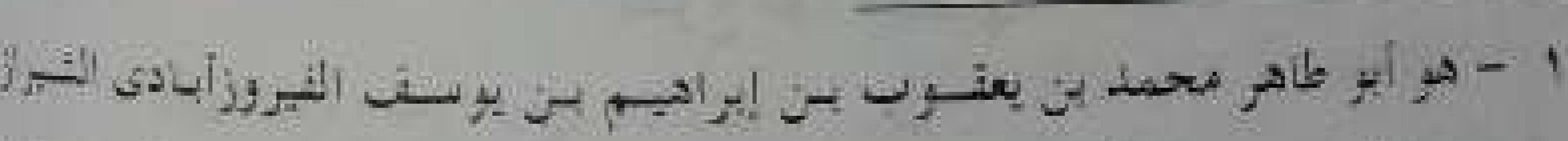

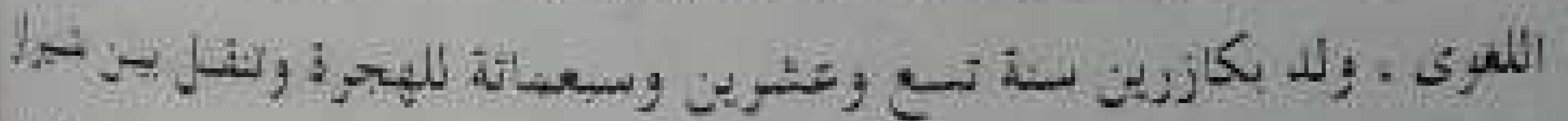

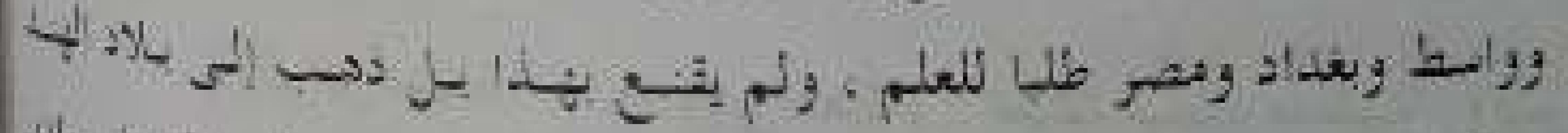

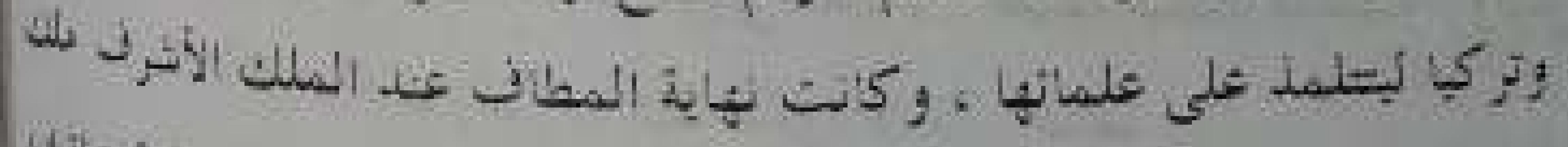

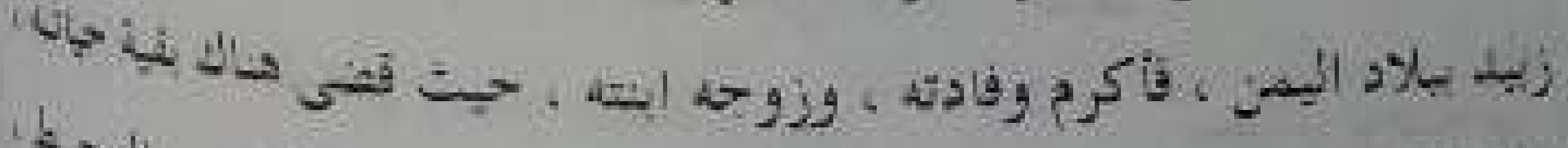

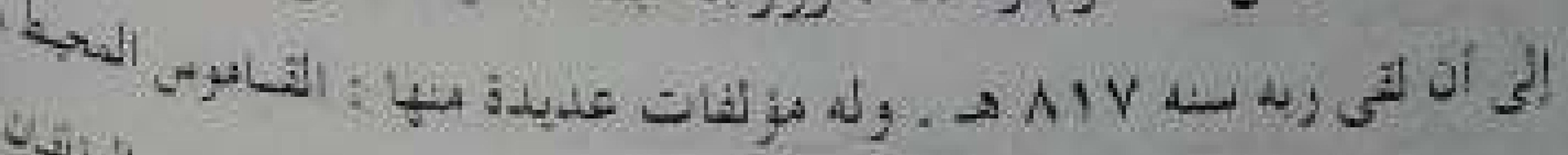

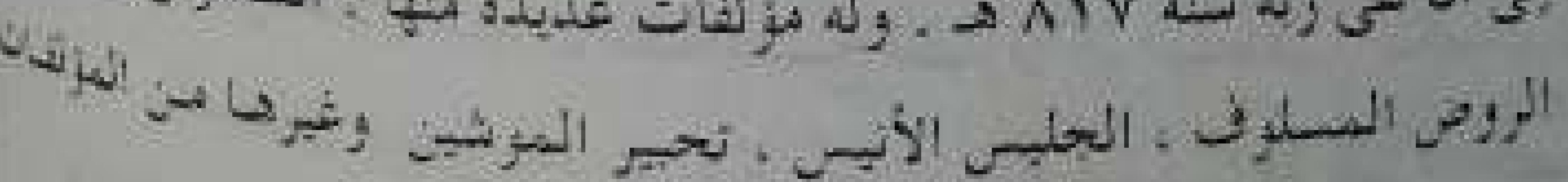

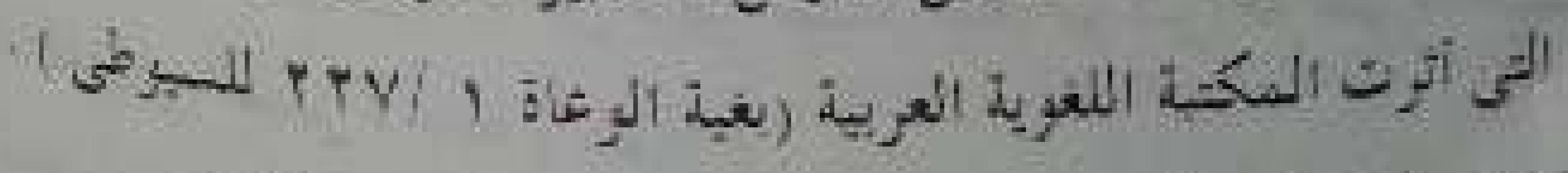
$(z g)$ (2)

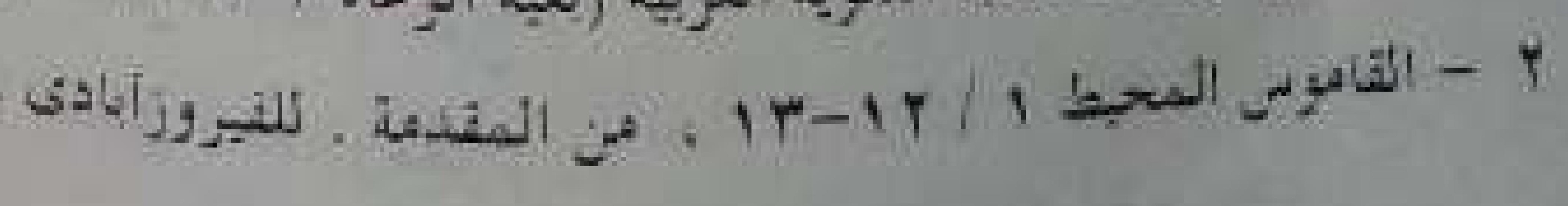




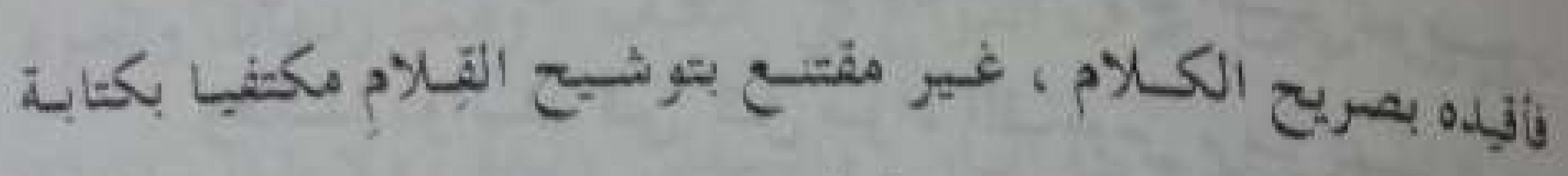

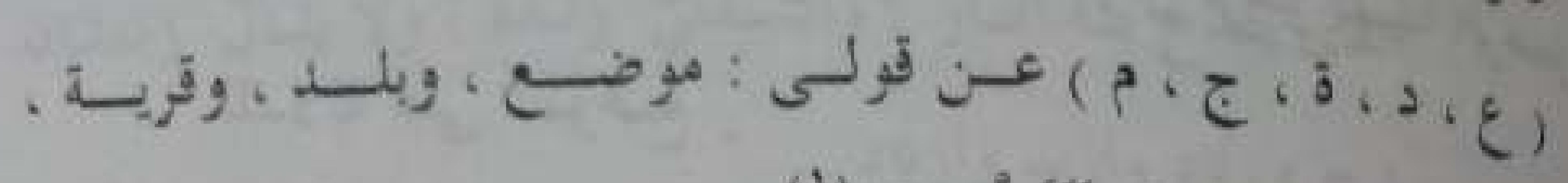

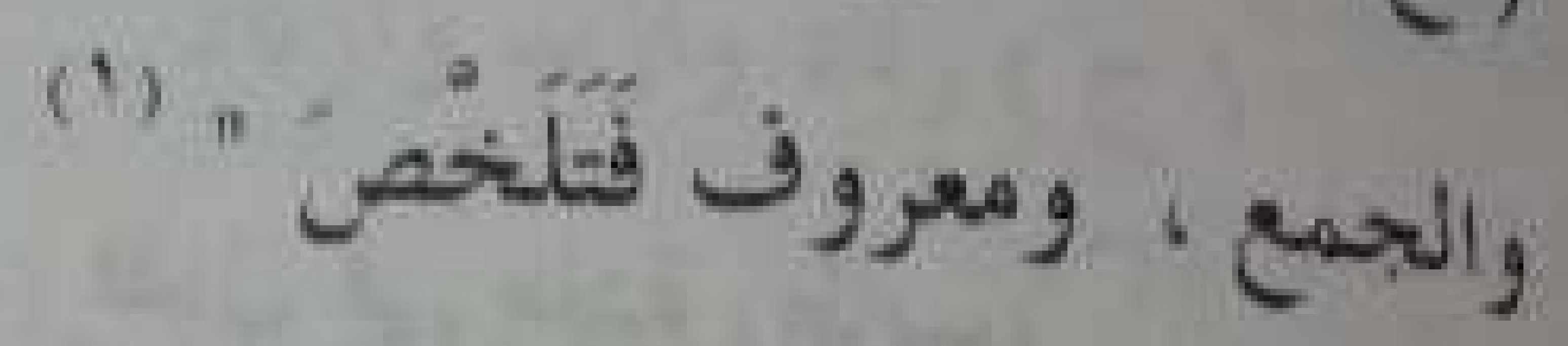

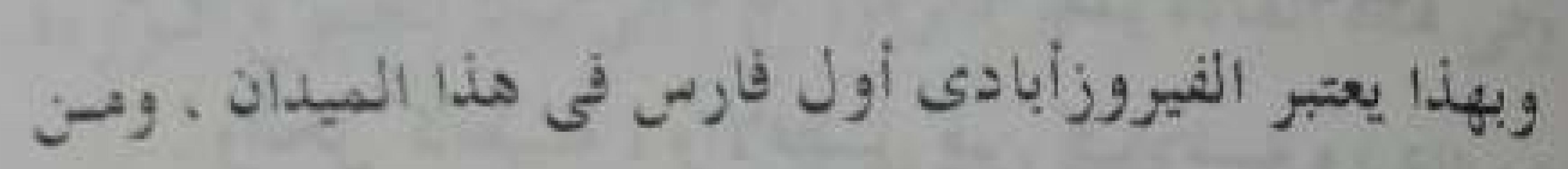

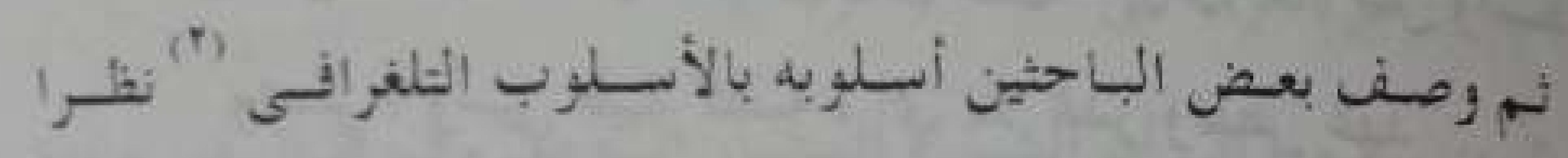

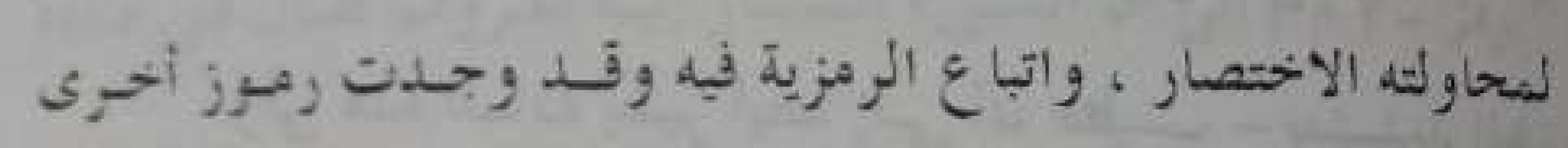

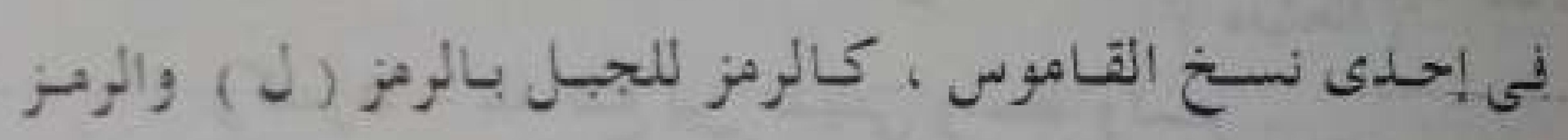

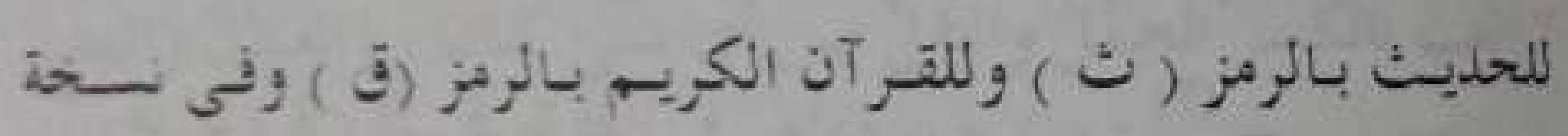

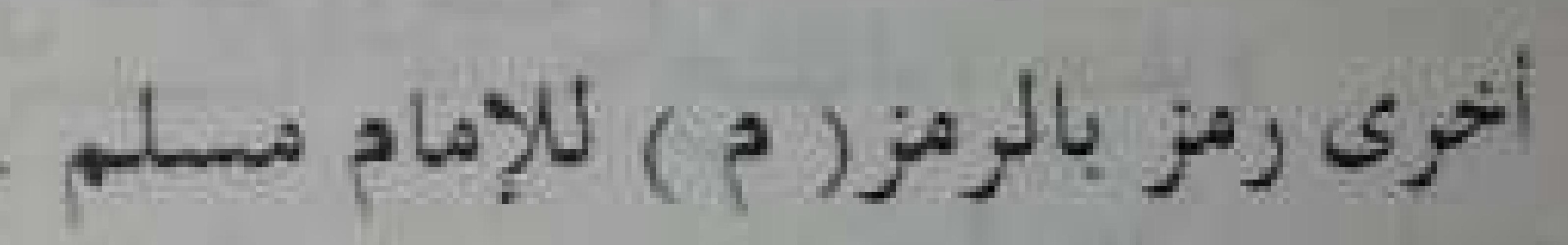

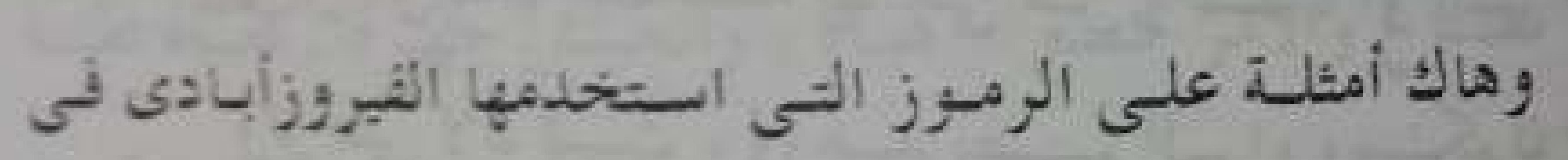

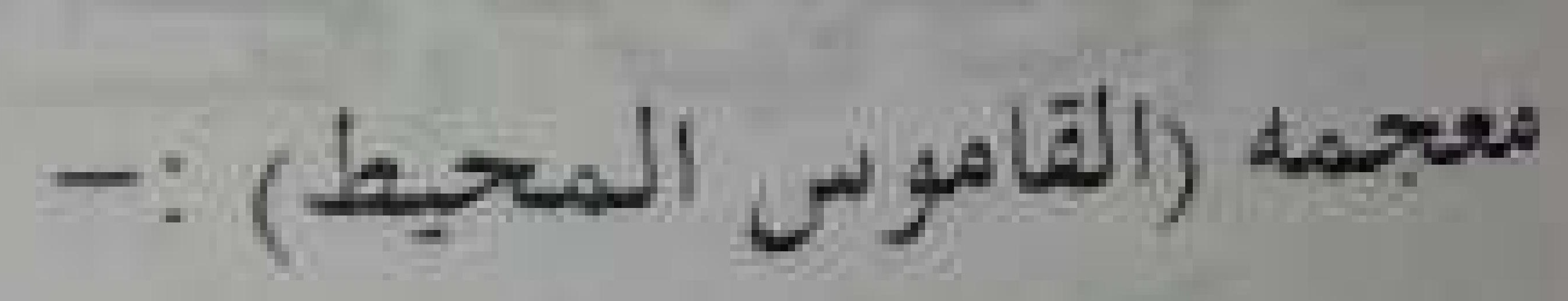

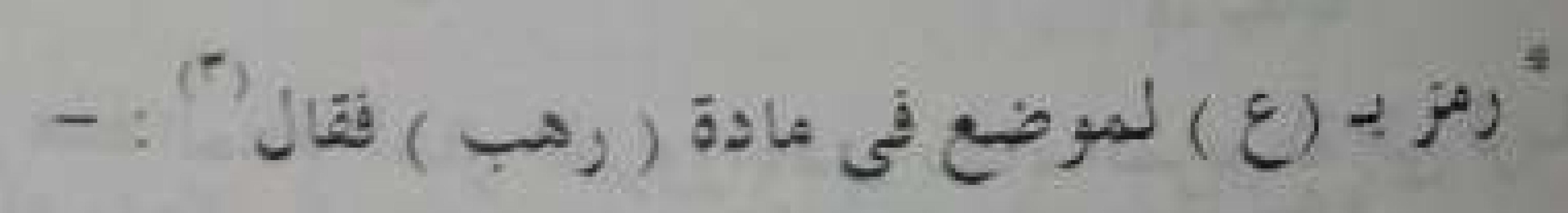

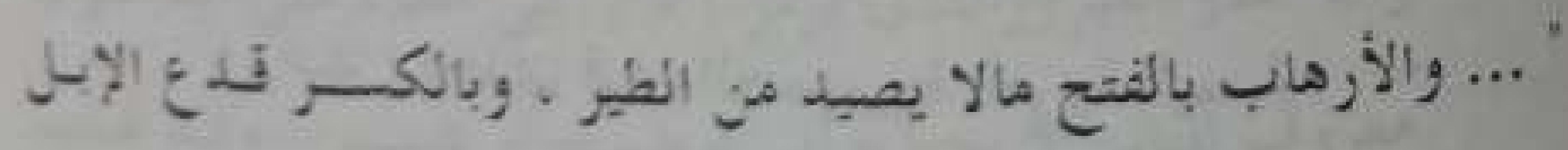

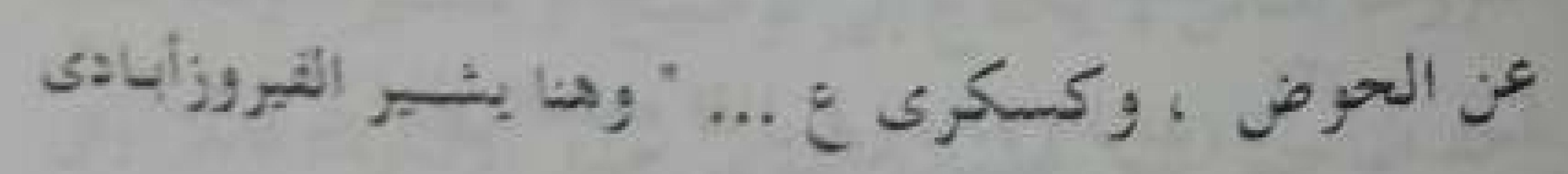

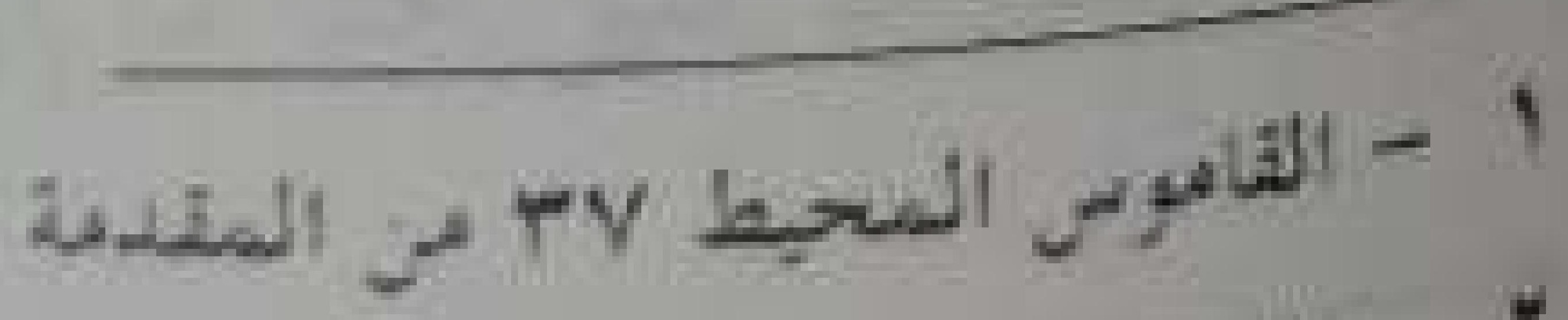

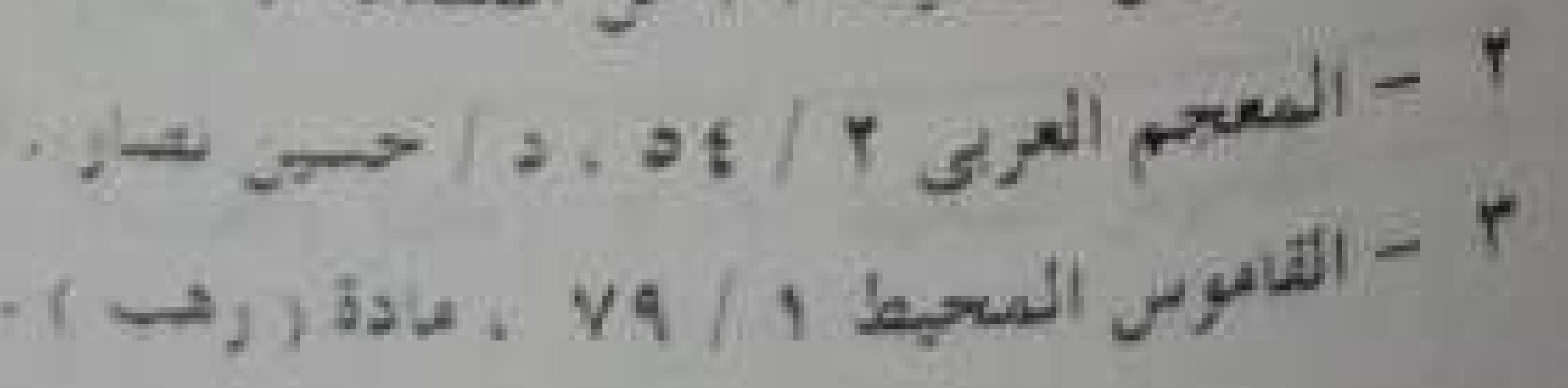

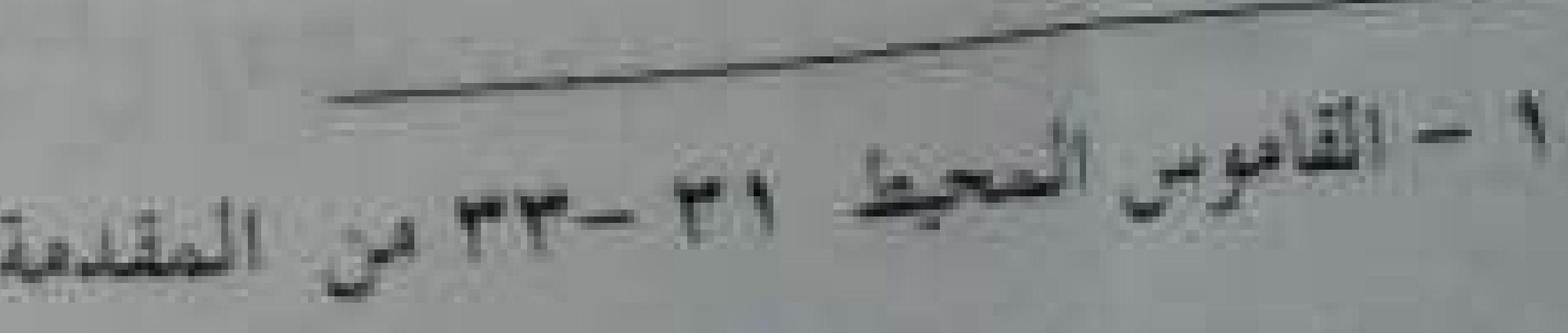

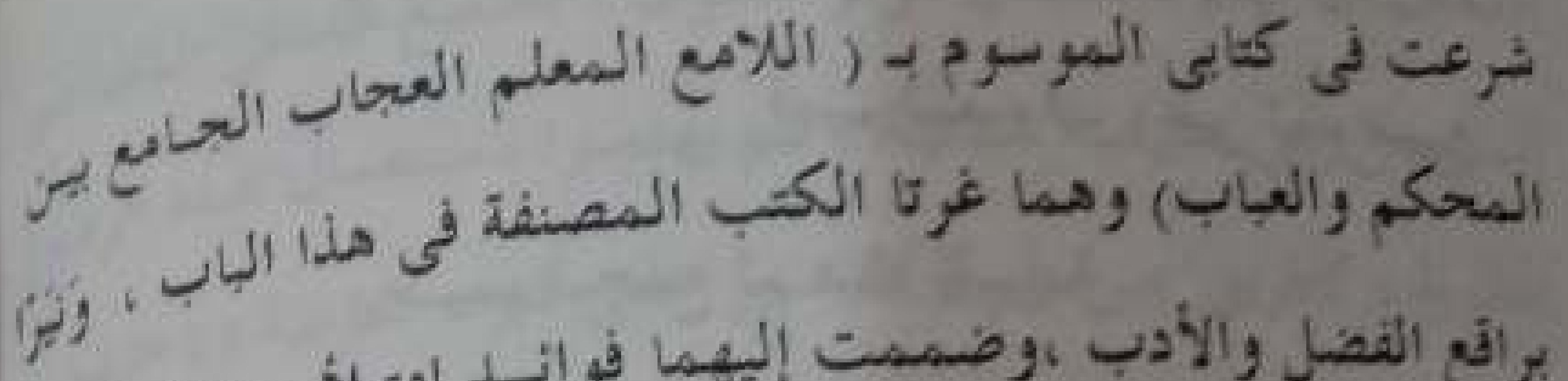

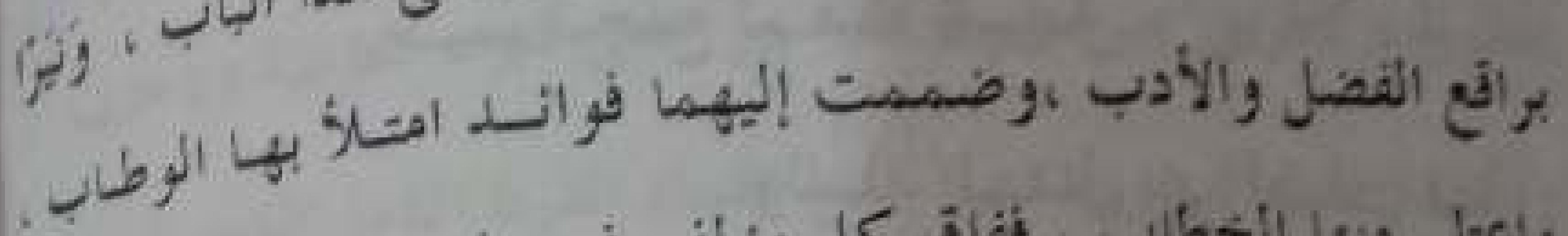

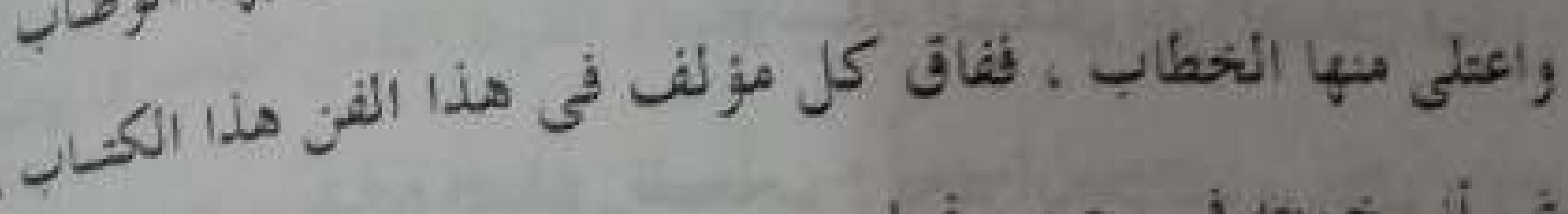

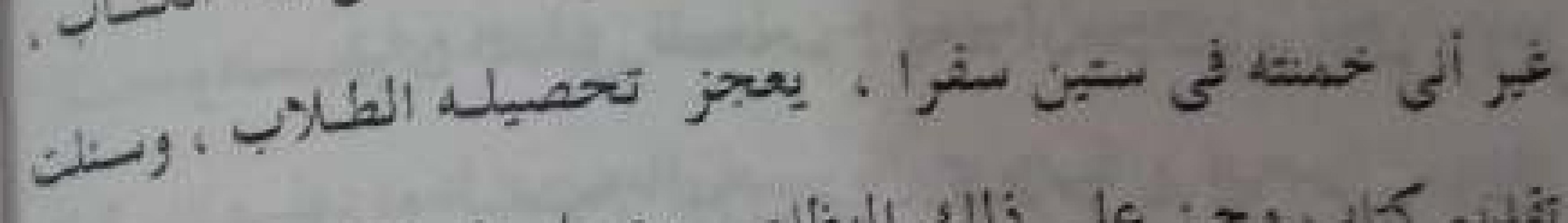

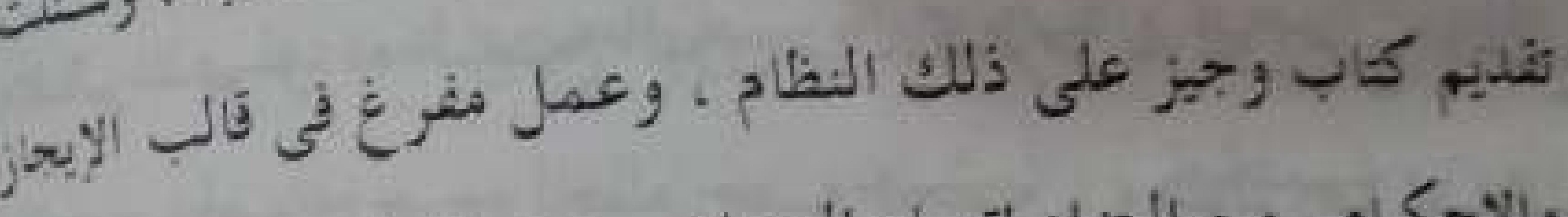

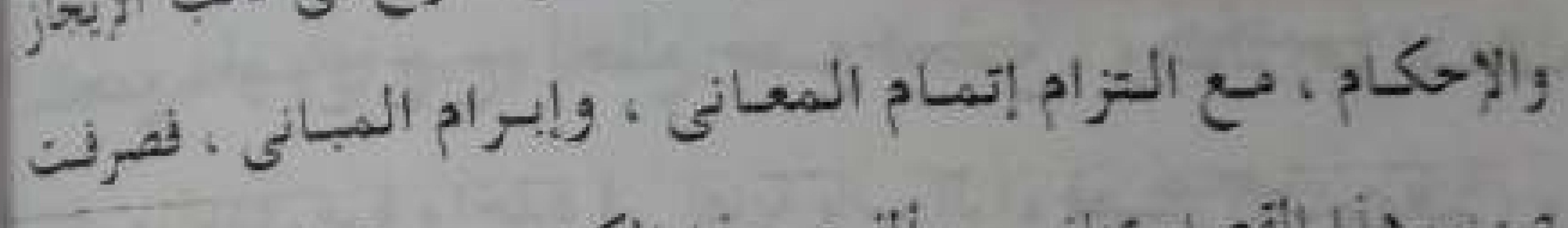

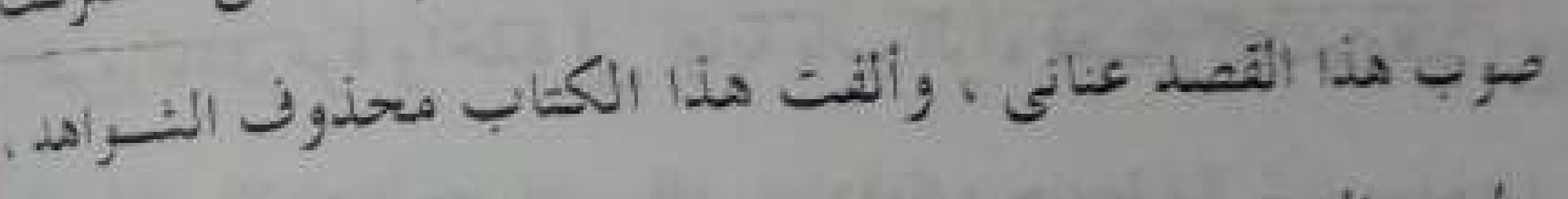

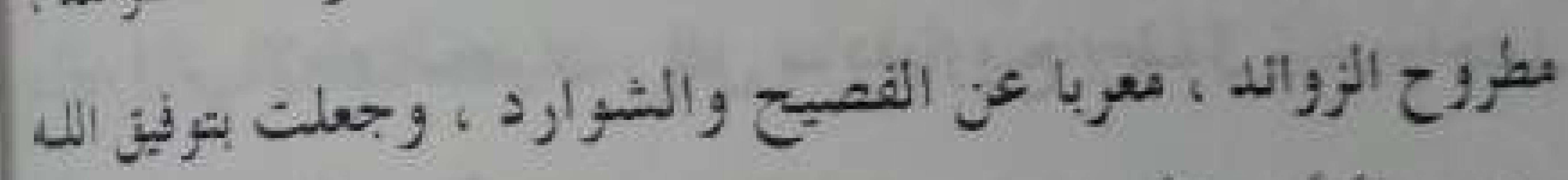

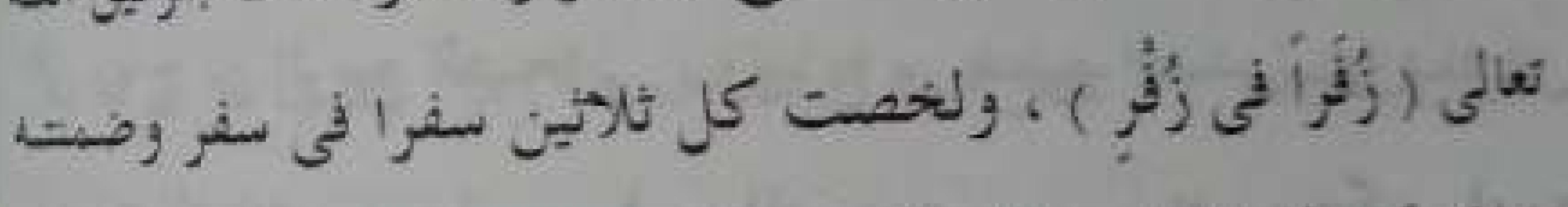

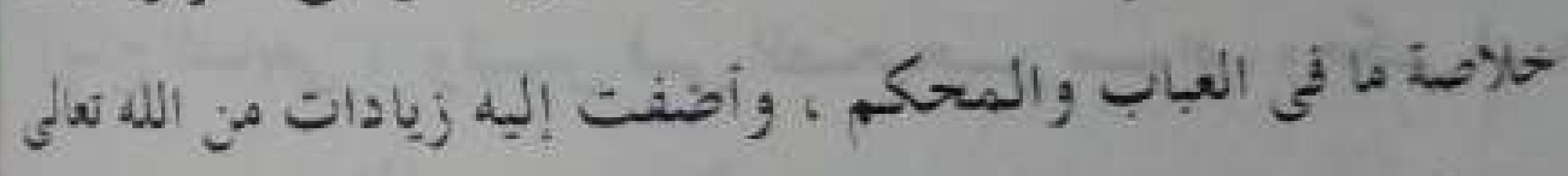

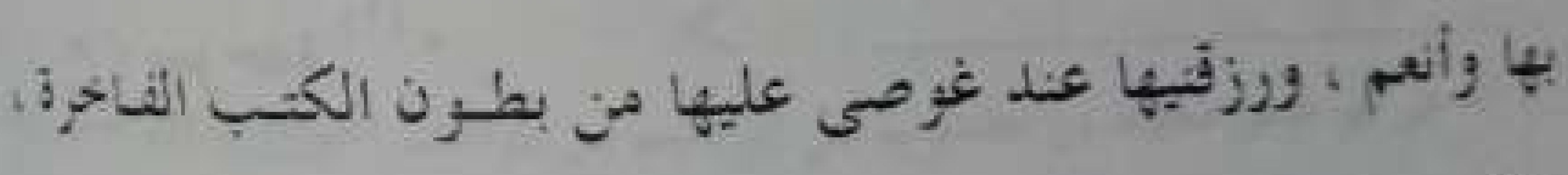

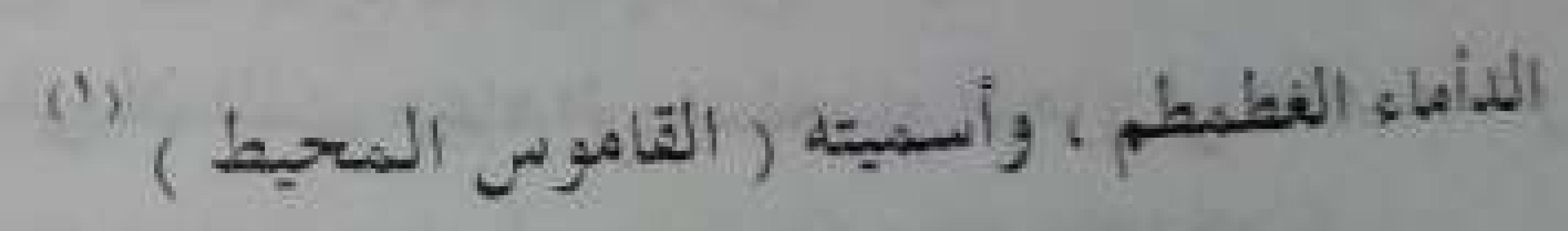

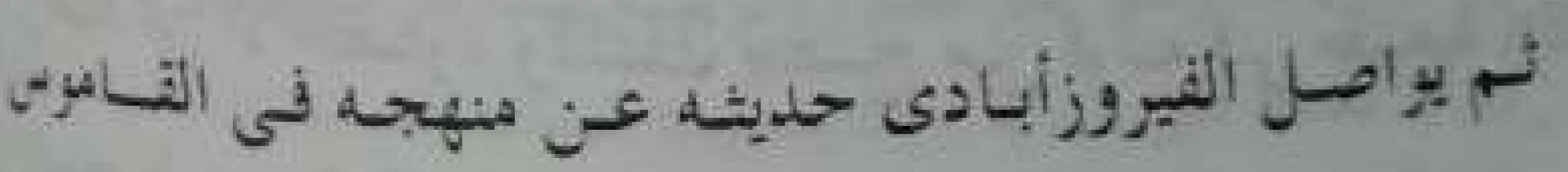

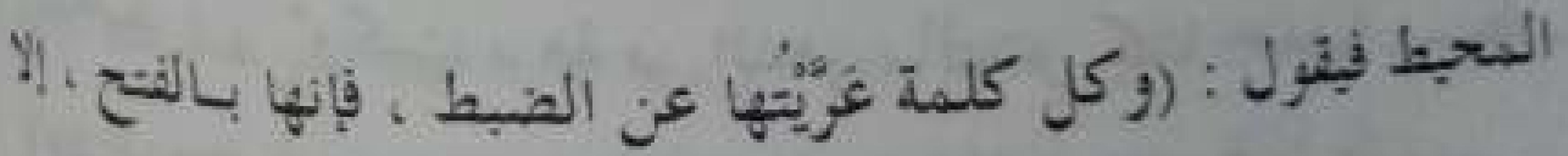

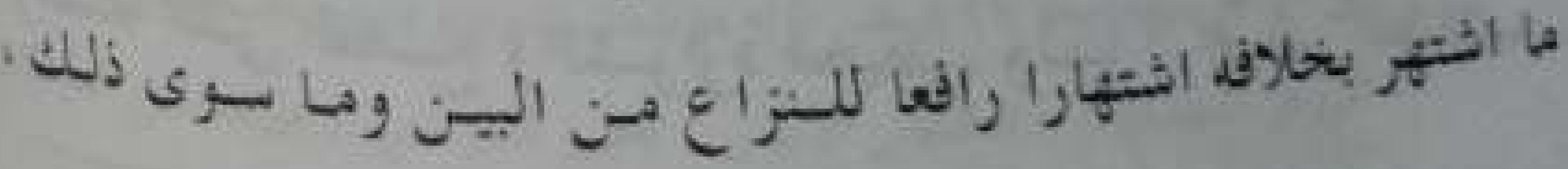




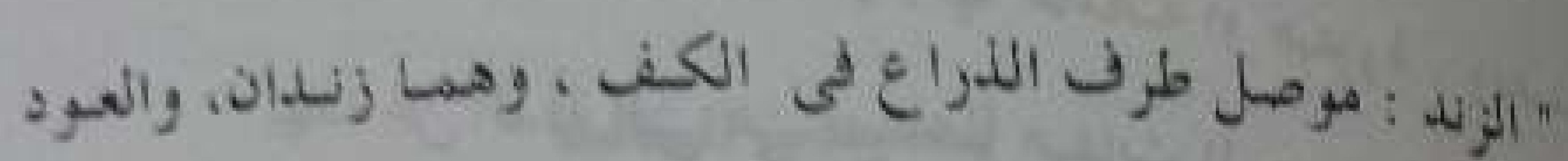

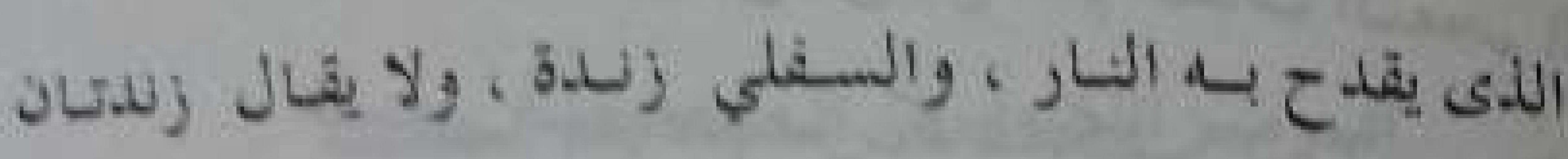

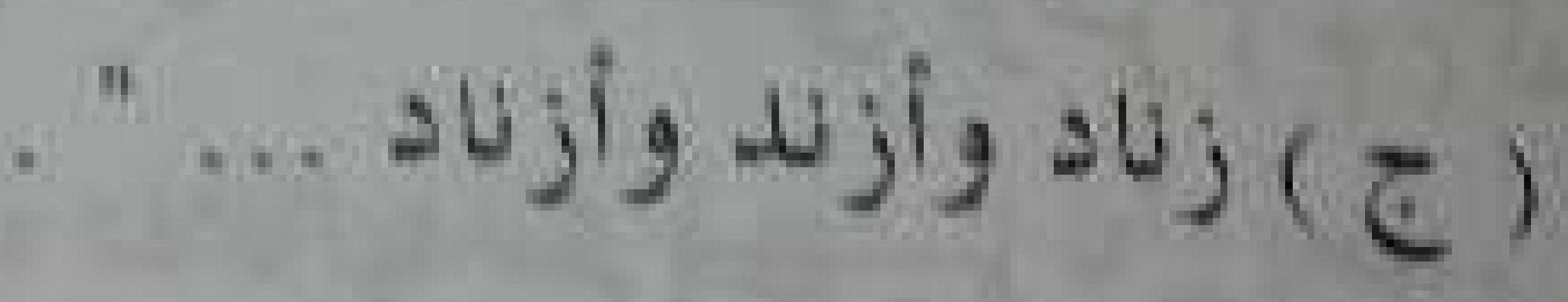

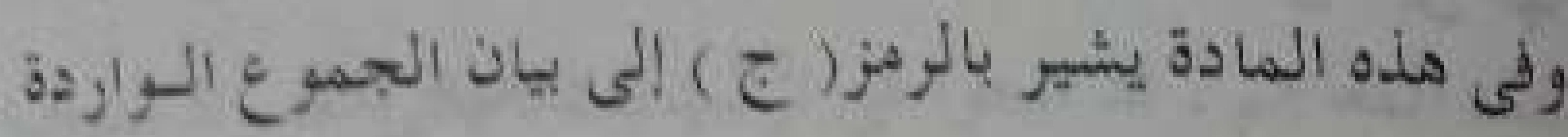

$$
\text { عن العرب في كلمة (الزبند ) ملئ }
$$

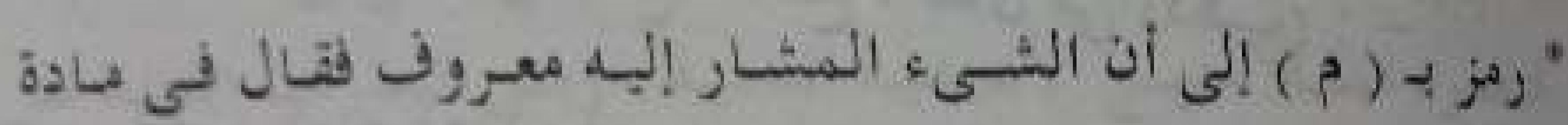

$$
\text { (1) : (العبs) }
$$

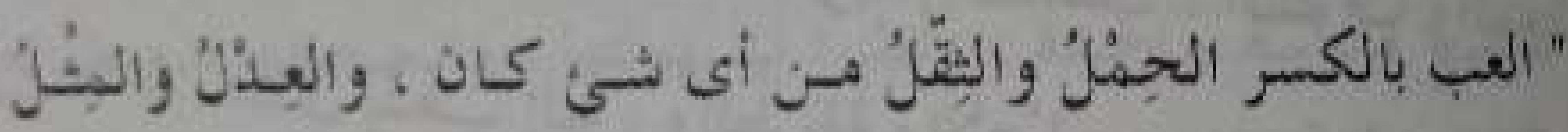

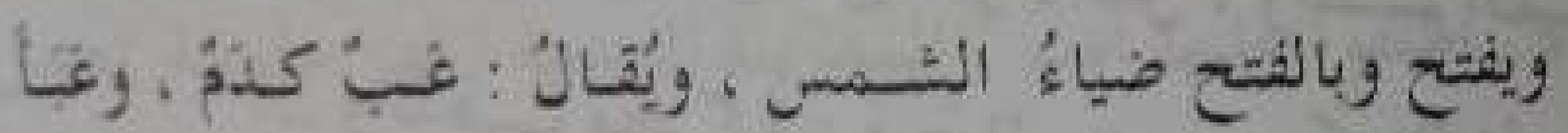

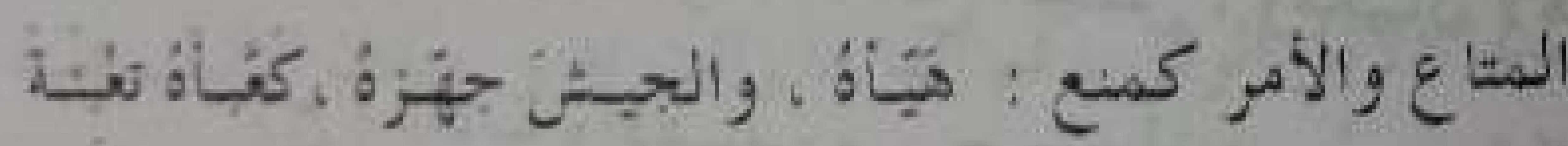

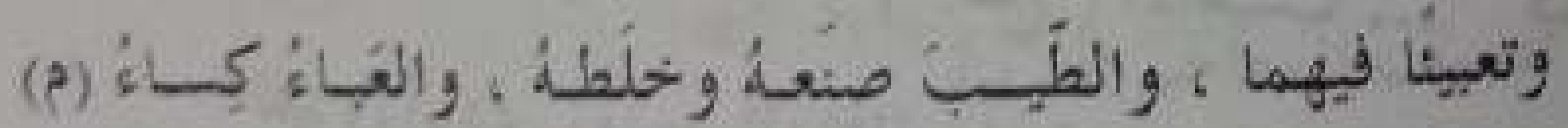
كالعباعة... وهنا أشار الفيروززأبادى بومز ( م) إلى العباء على أنه كرب

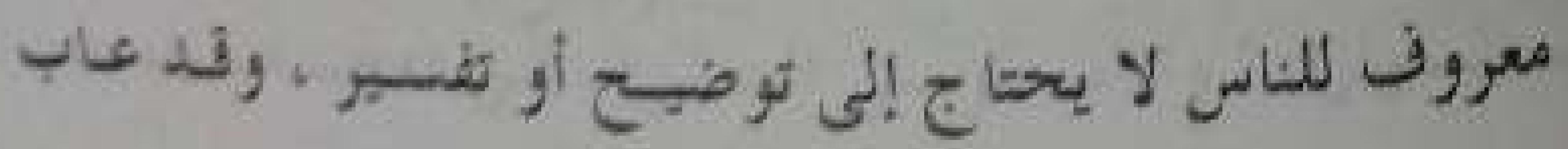

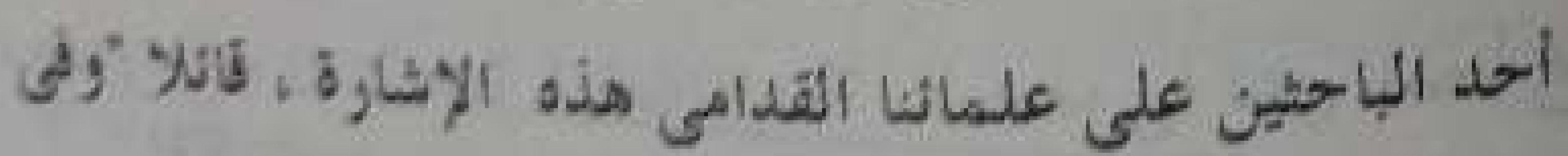

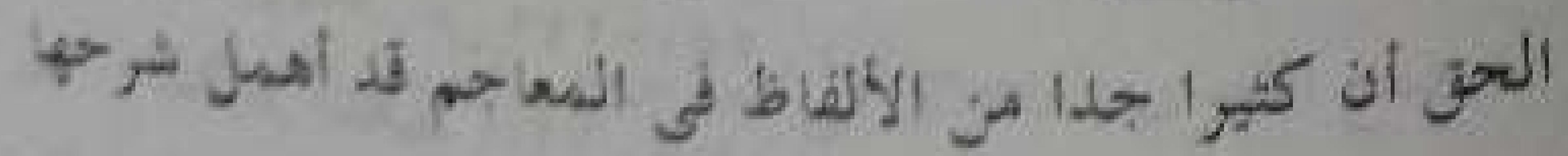

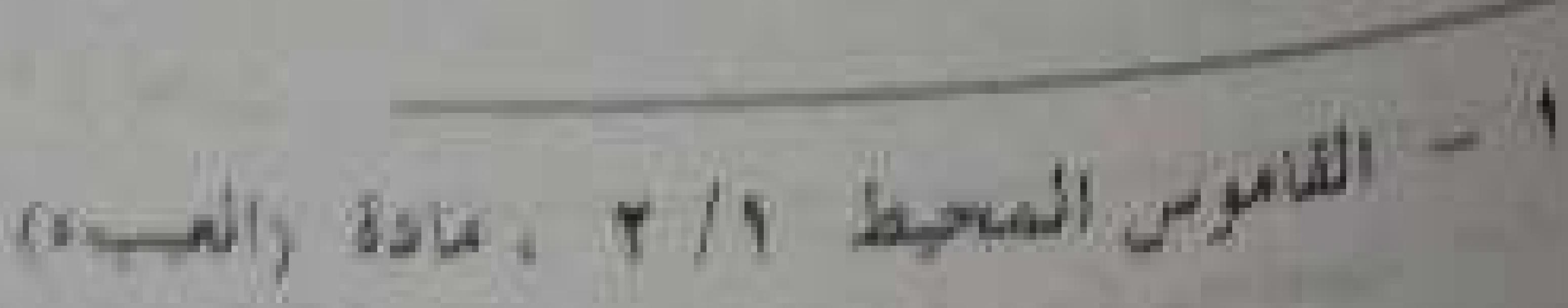

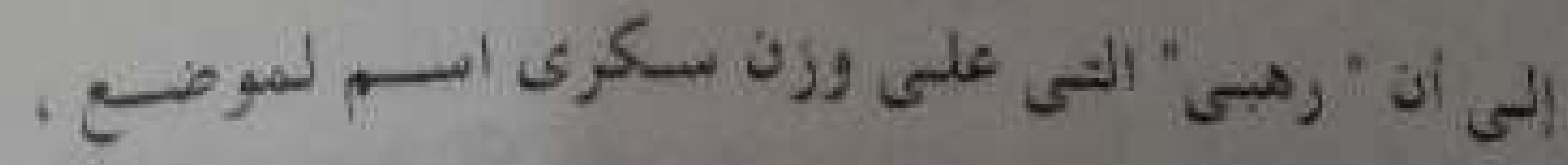

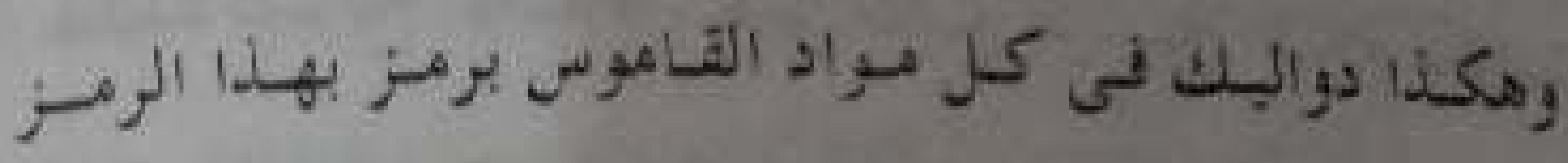

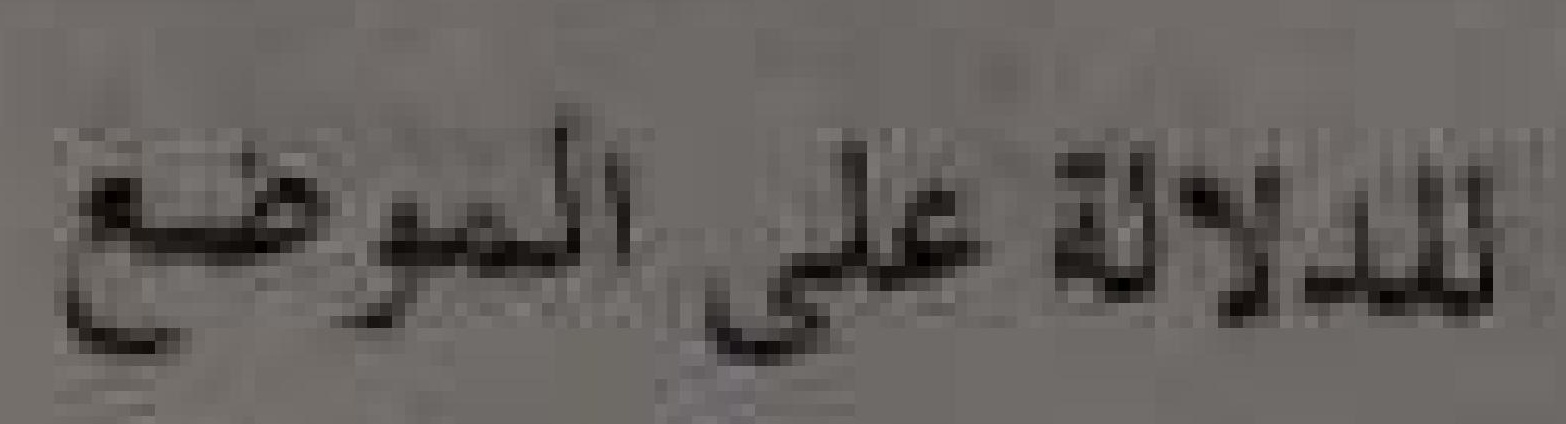

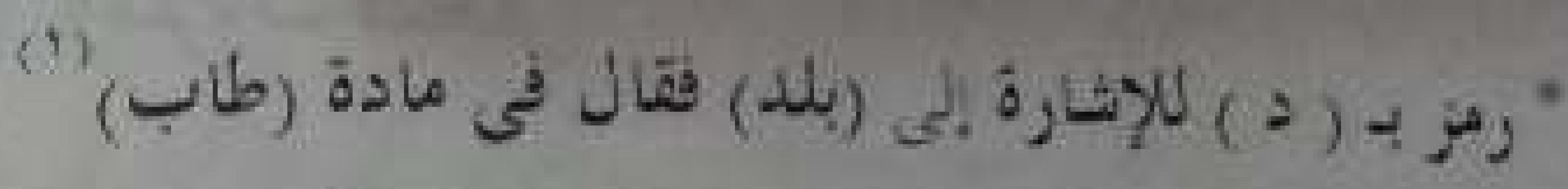

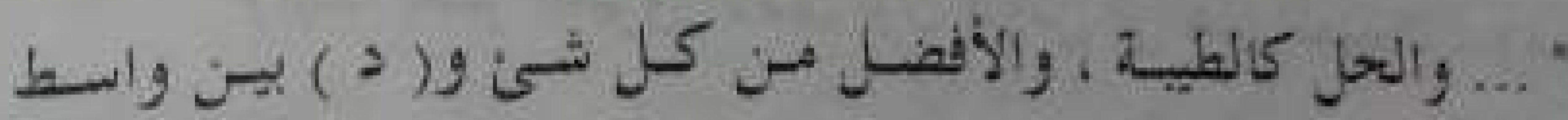

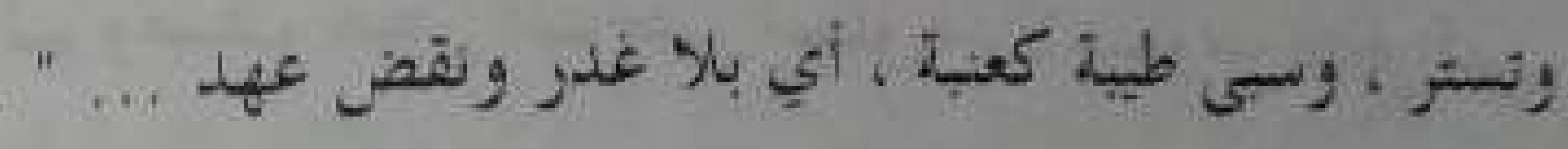

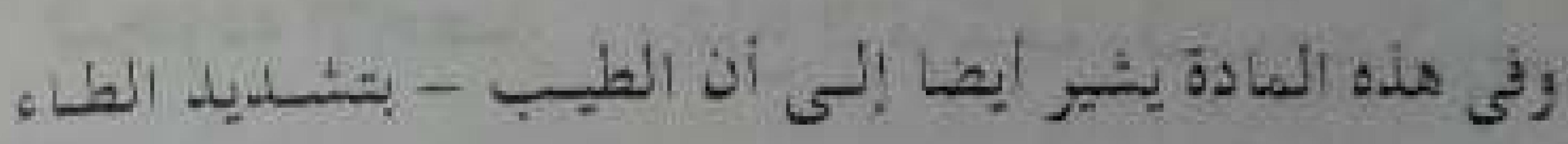

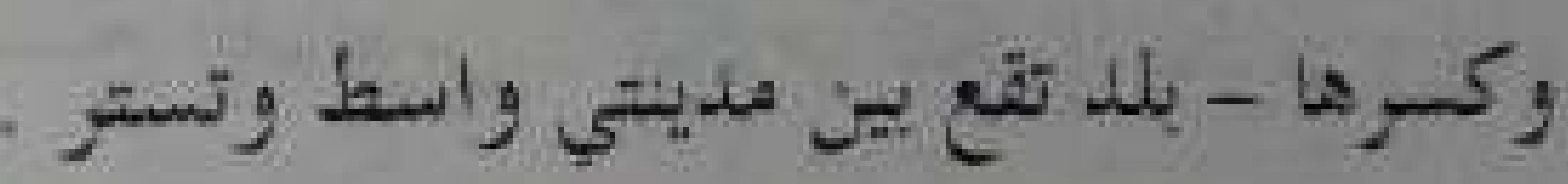

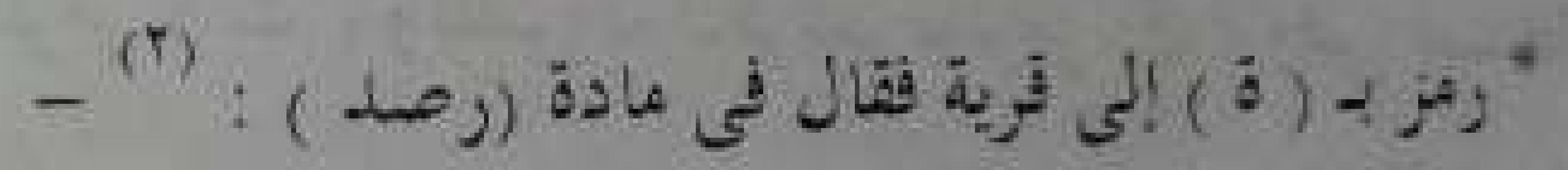

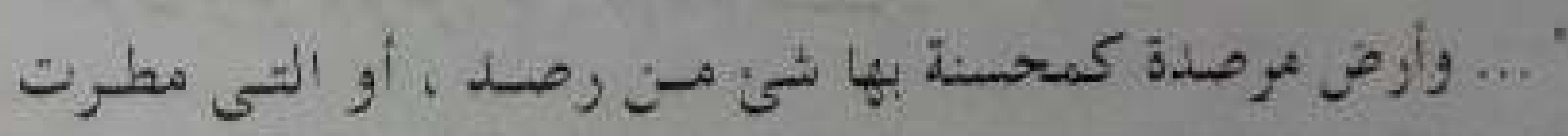

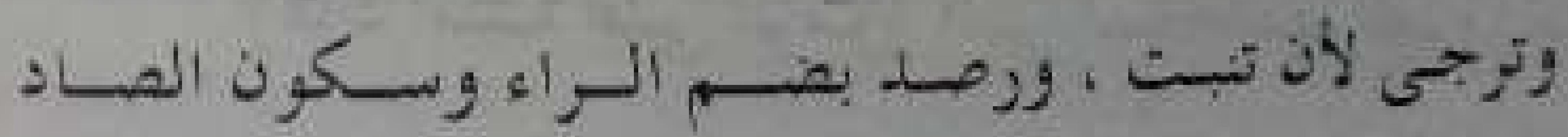

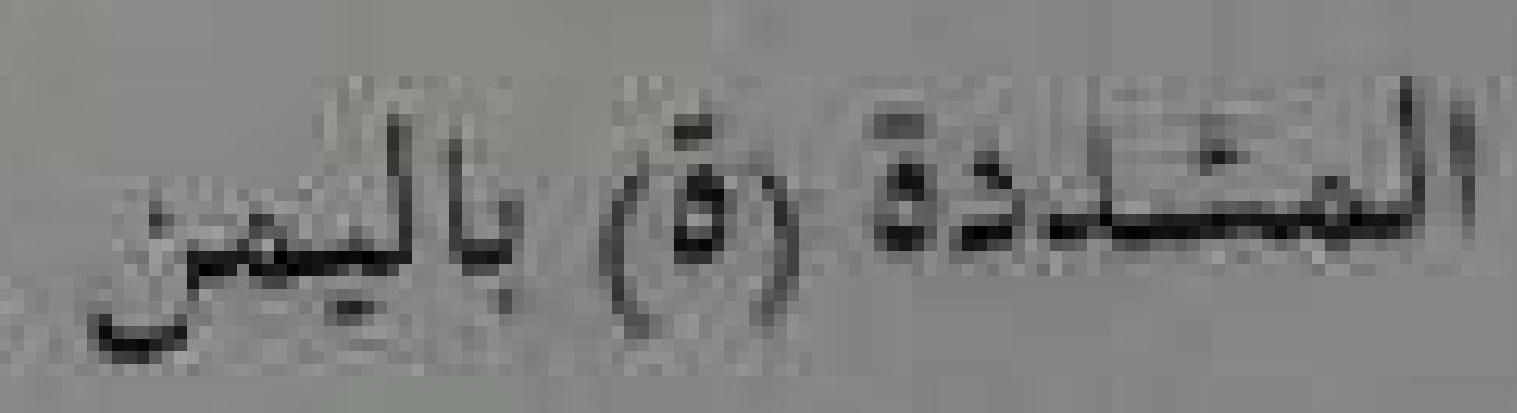
وقى هذه المادة أشيار الفيروزأبادى بالثاء المربوطة إلى قرية )

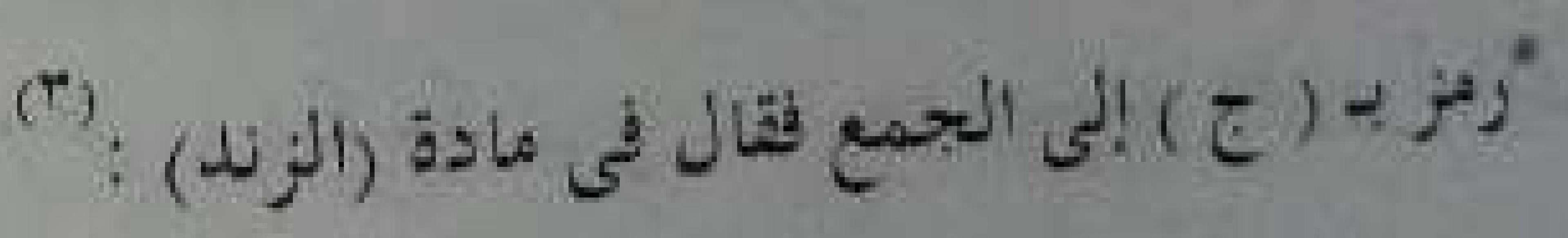

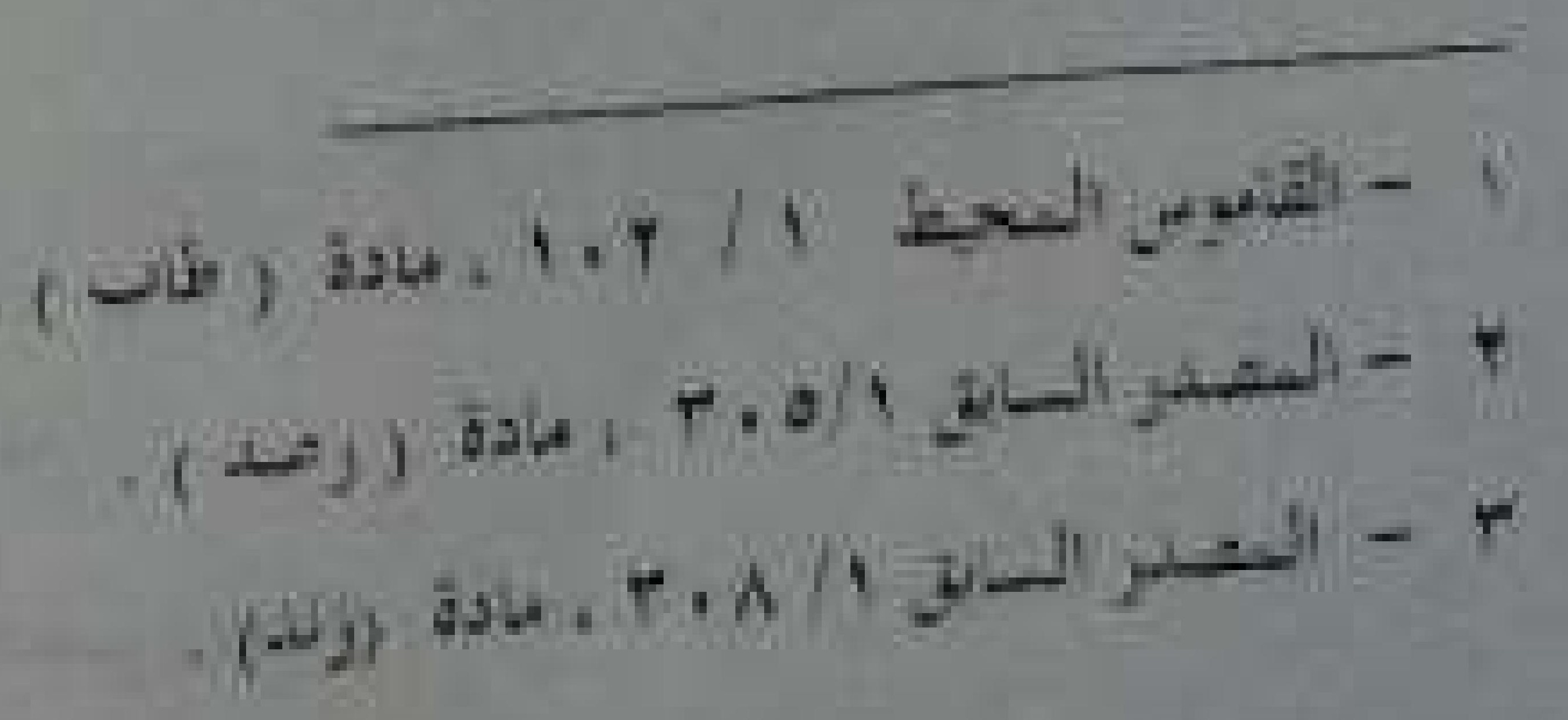




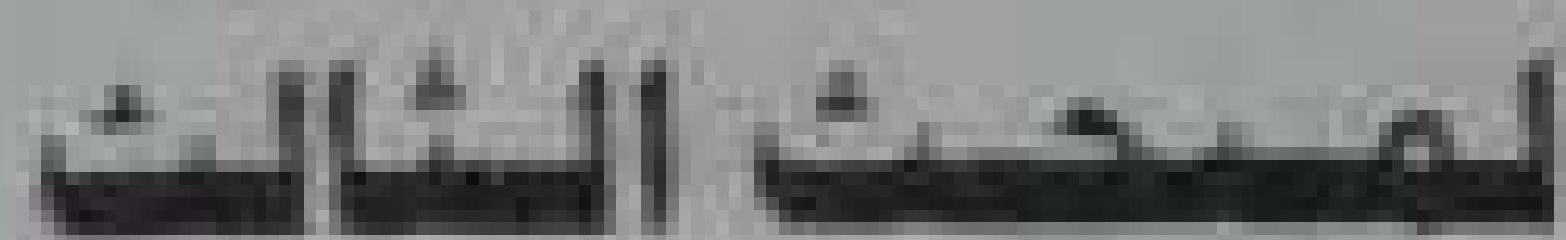

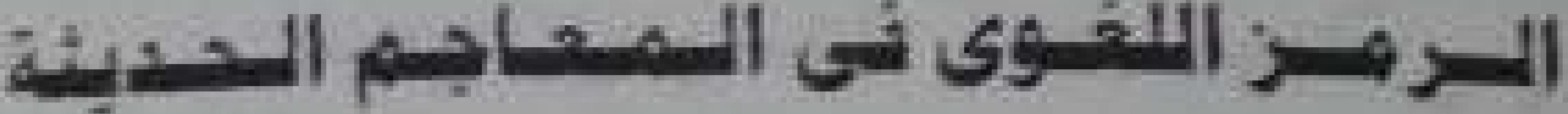

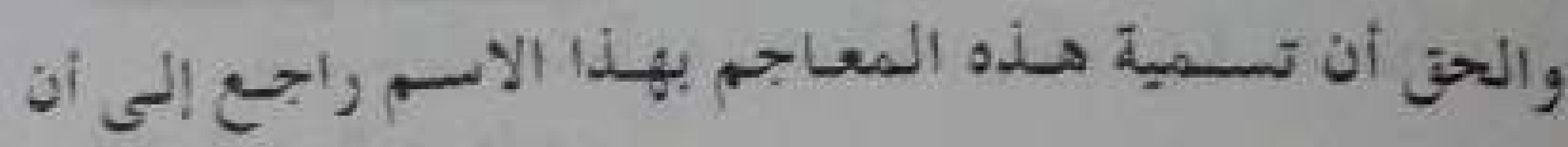

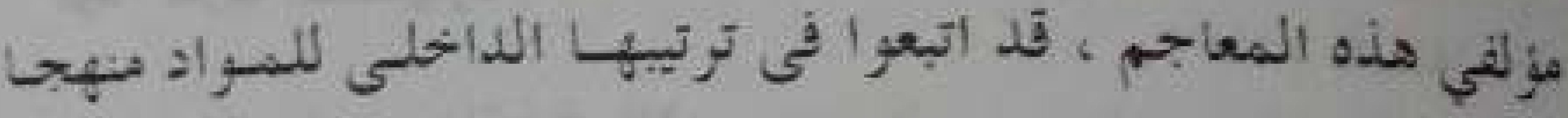

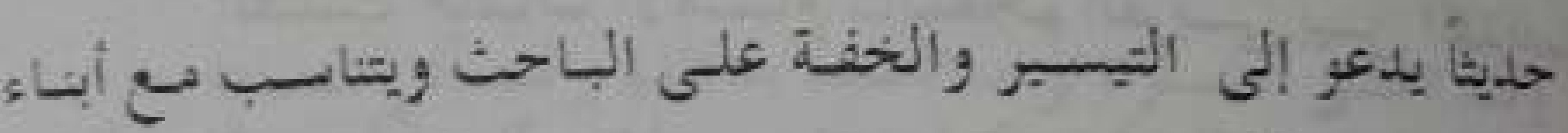

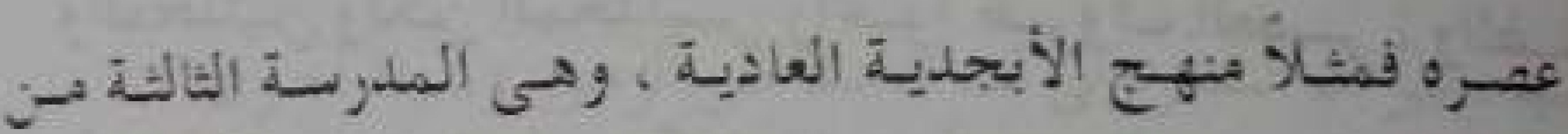

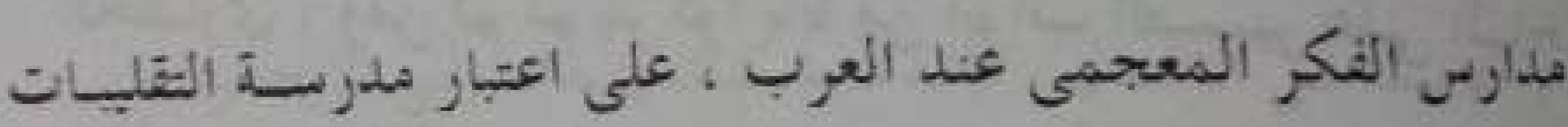

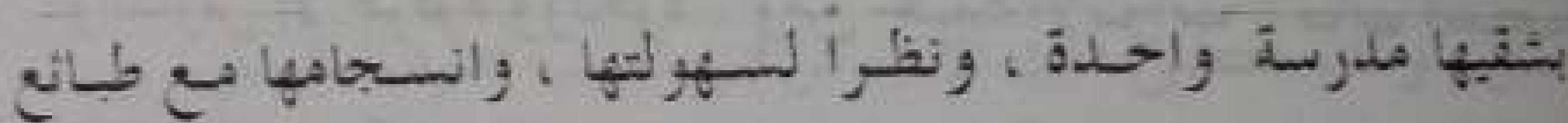

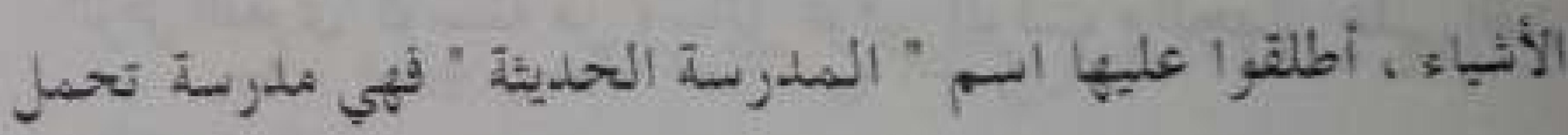

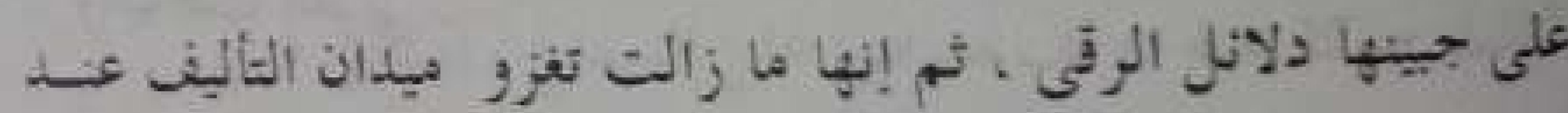

(1) تصجي تصنيف المعاجم العربية

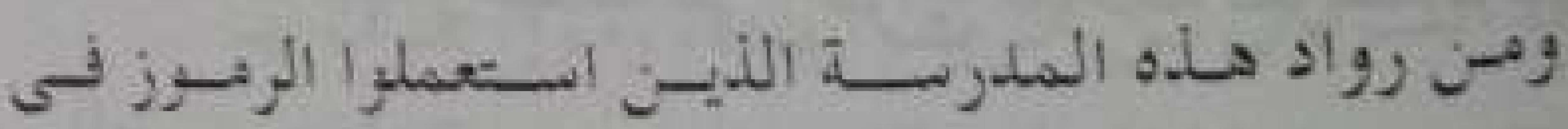

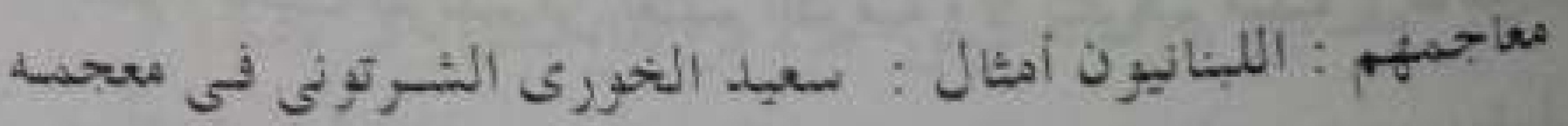

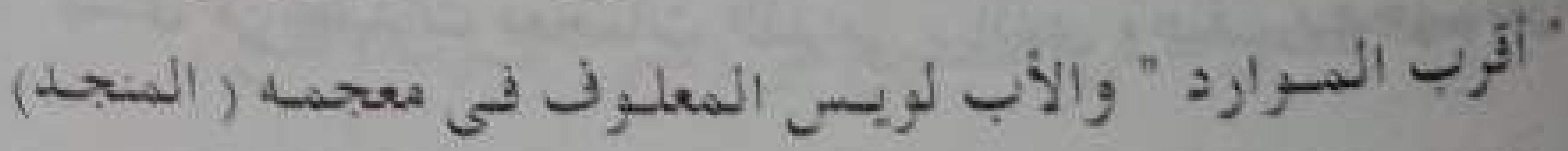

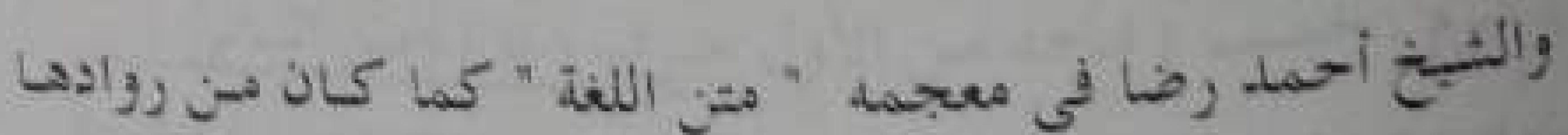

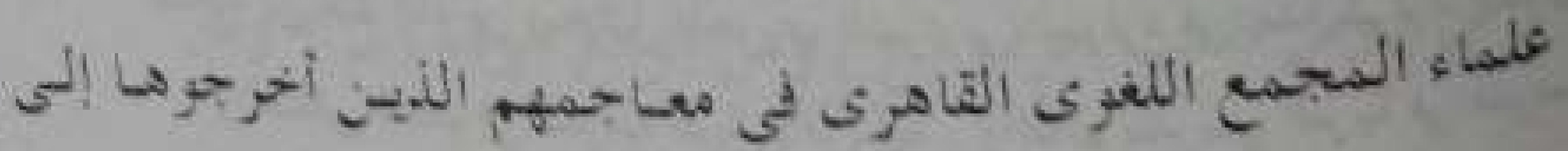

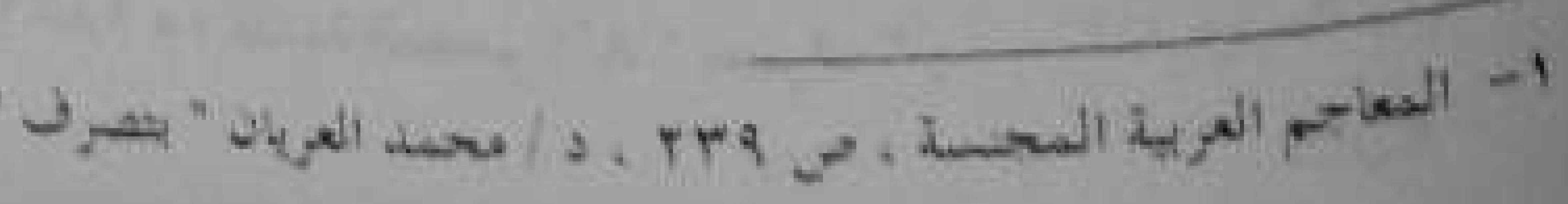

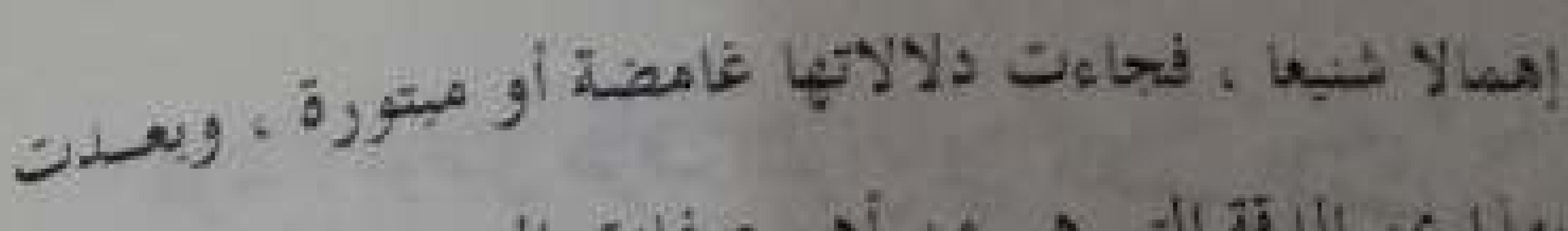

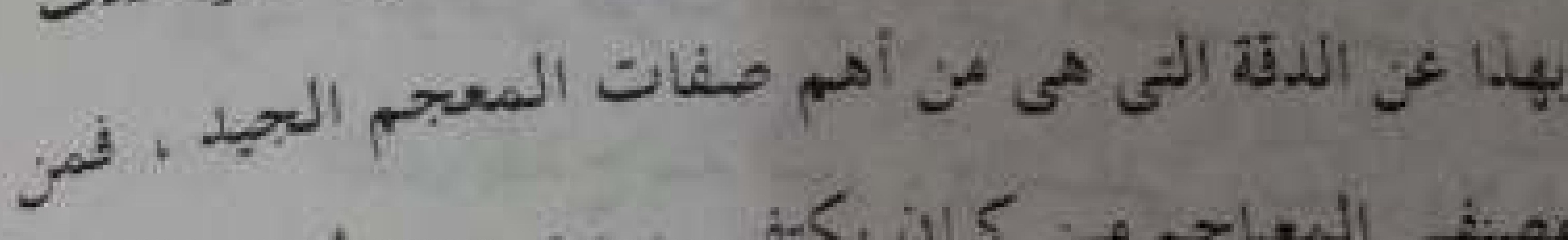

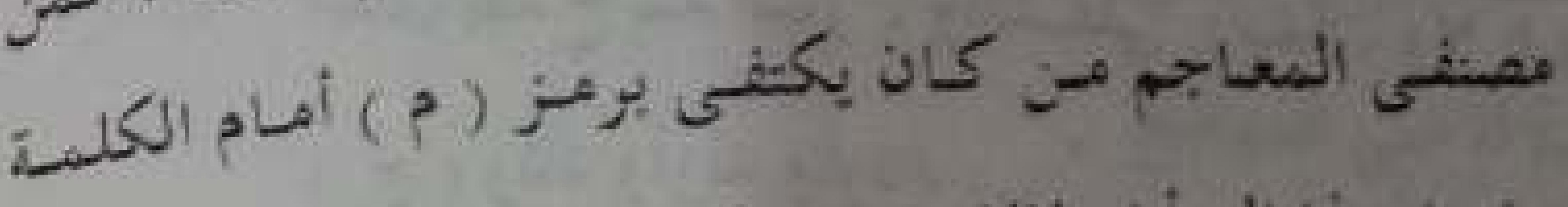

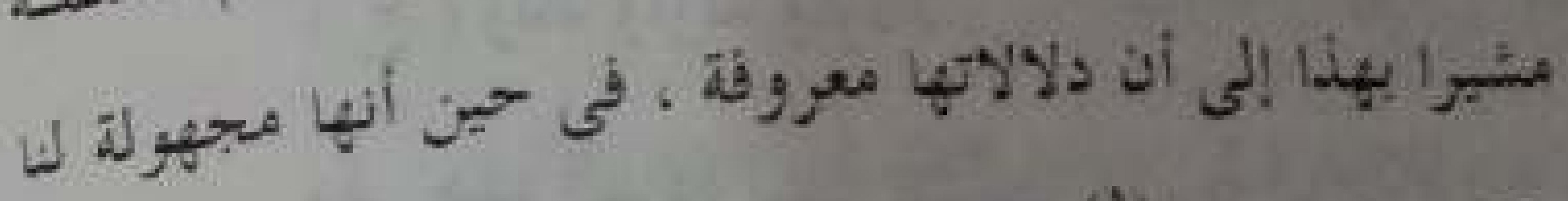
(1) "

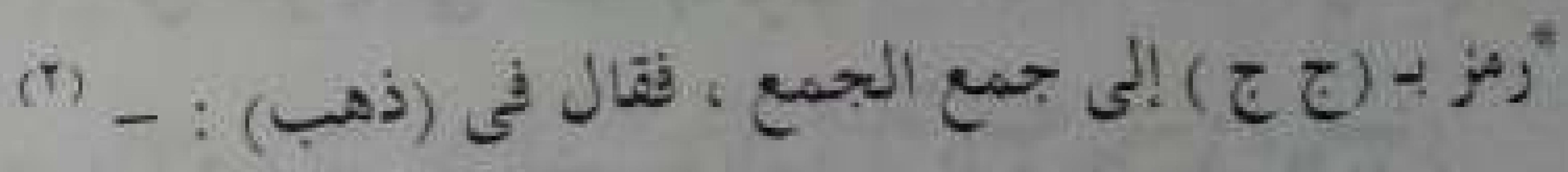

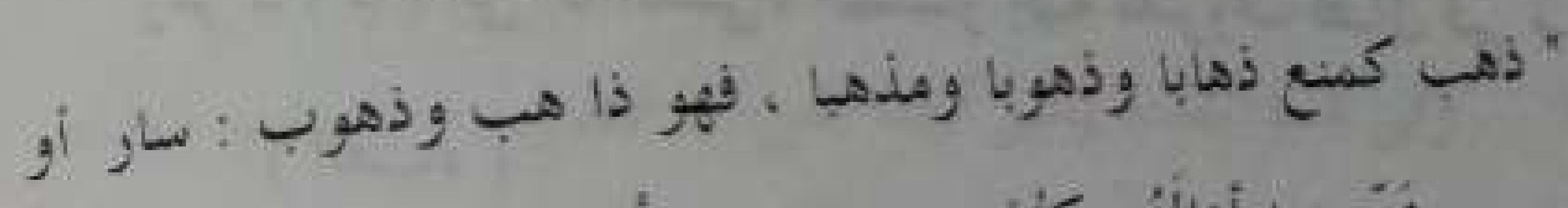

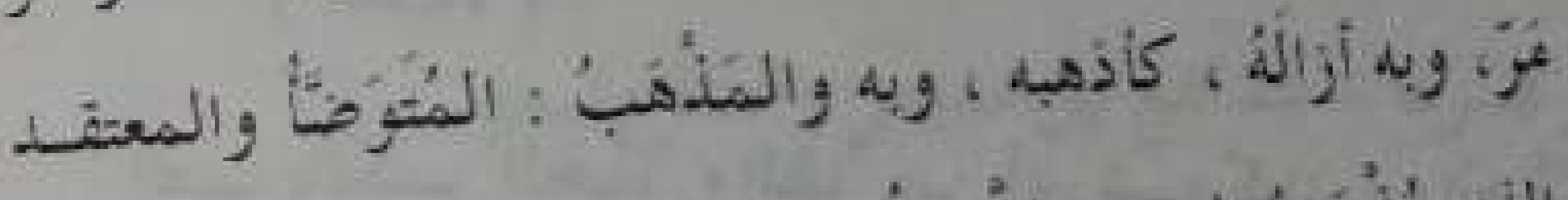

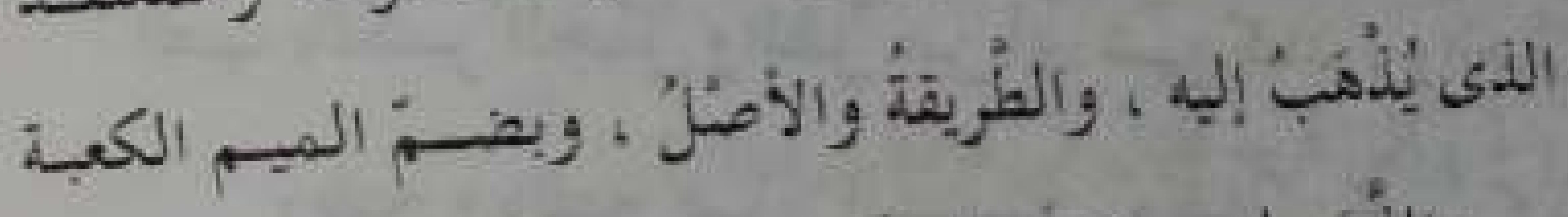

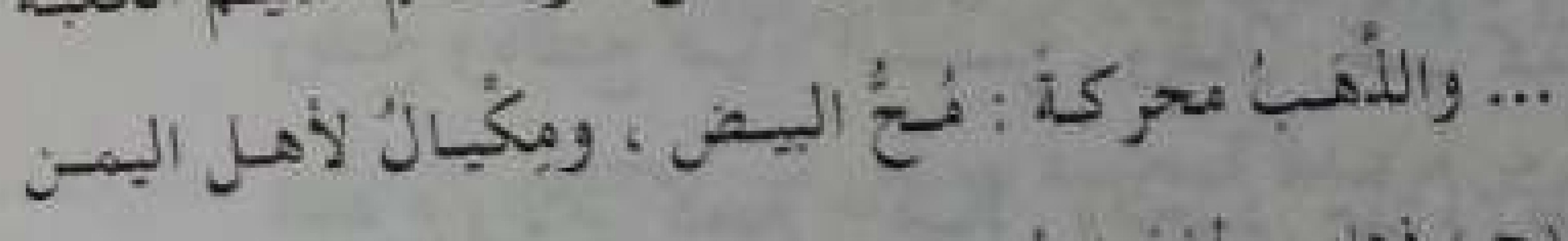

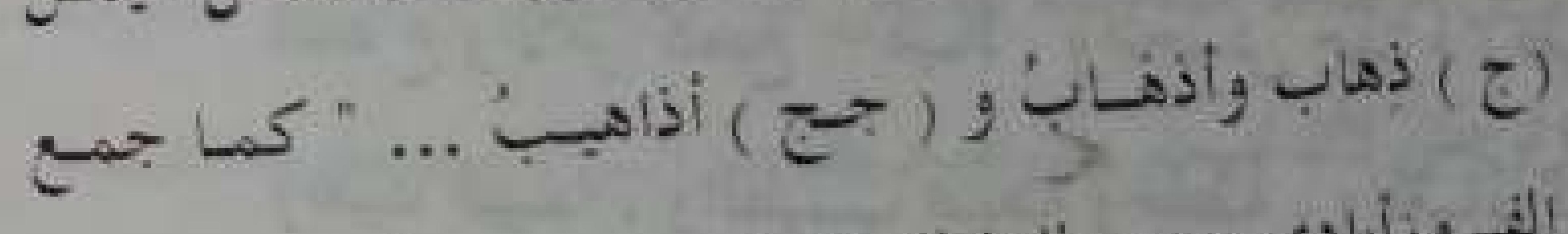

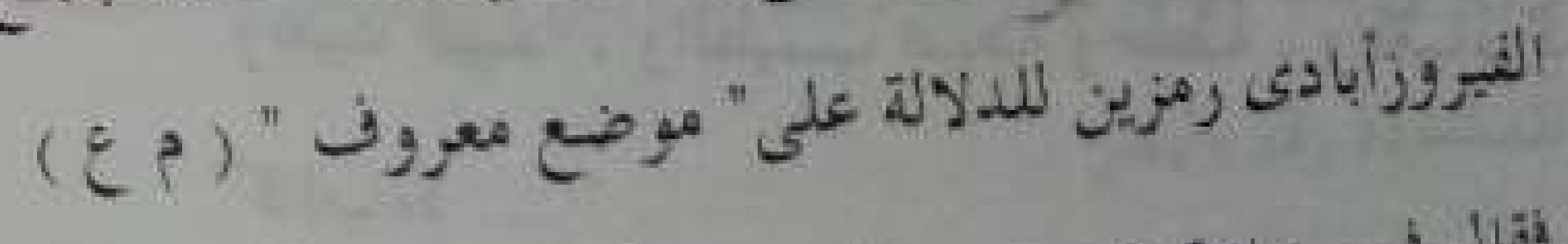

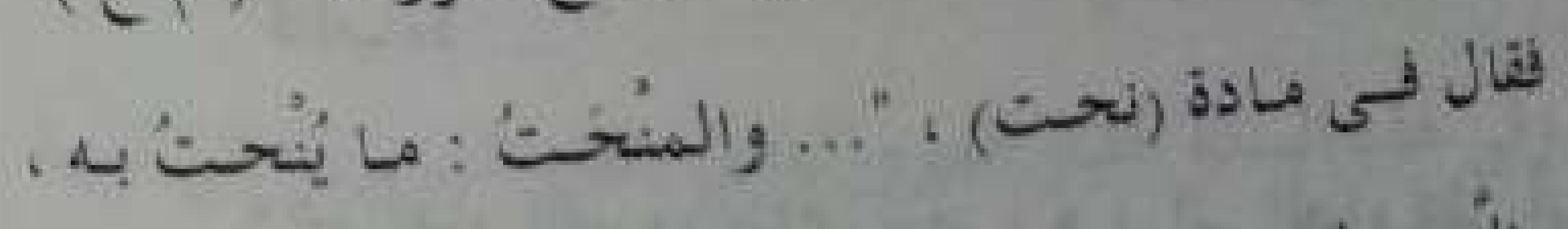

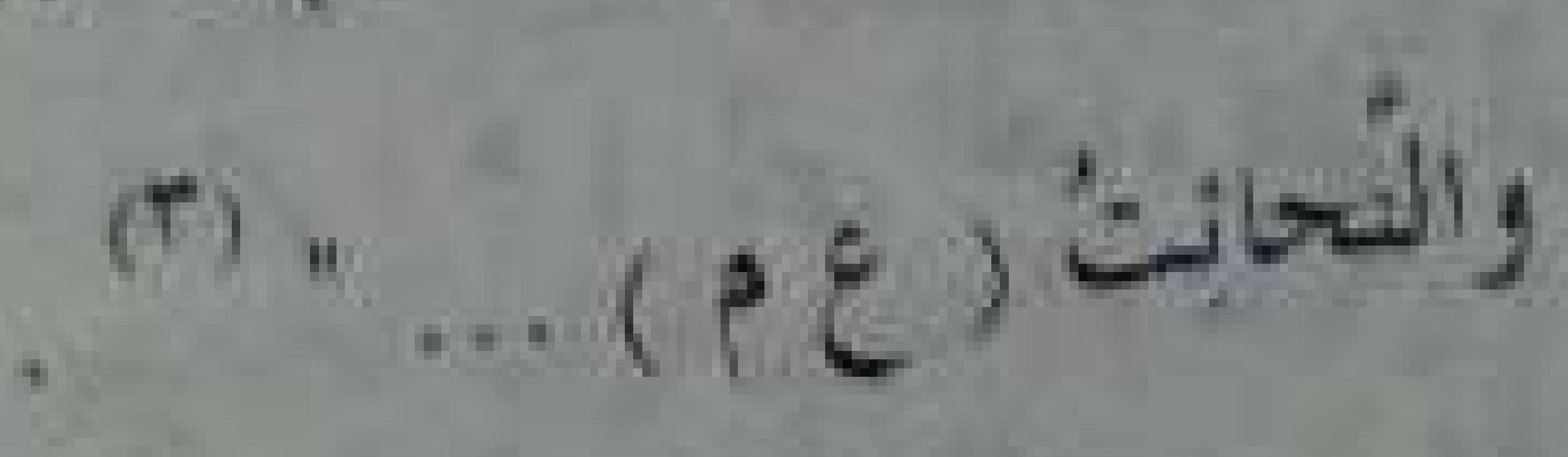

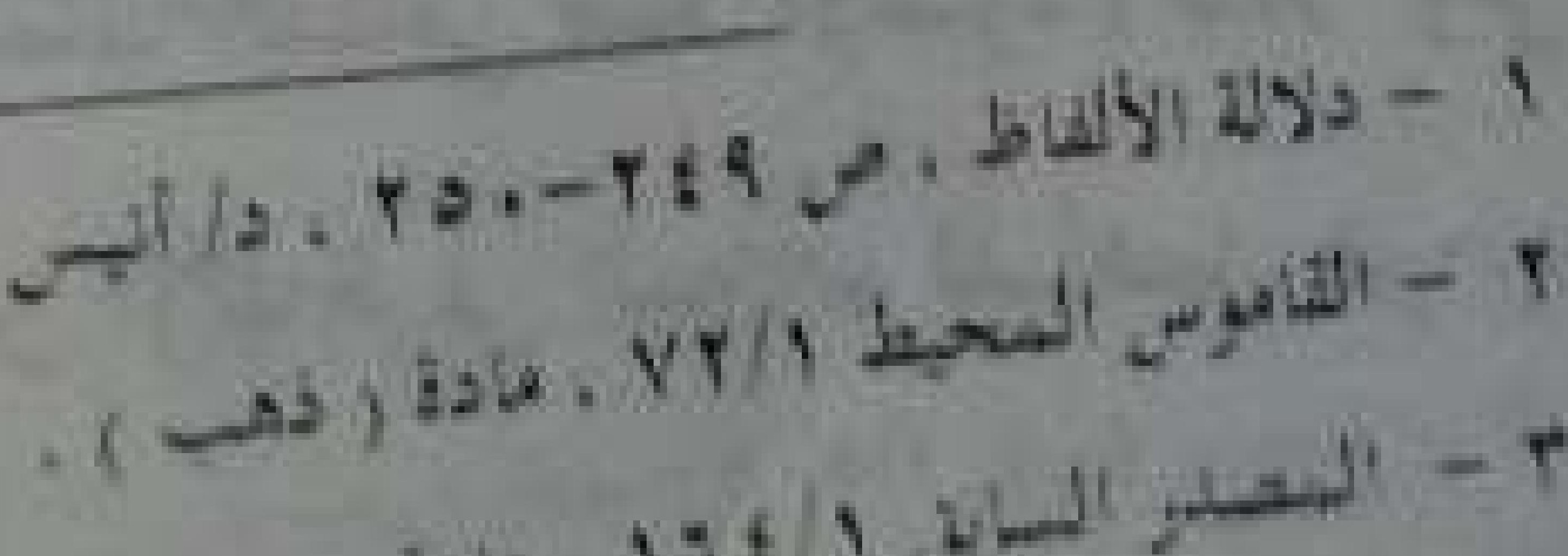

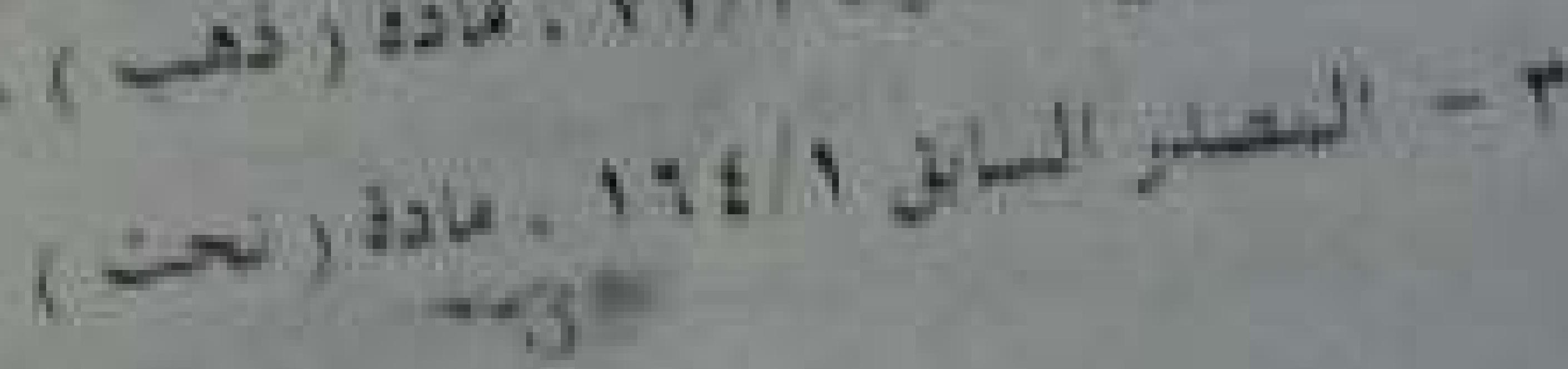




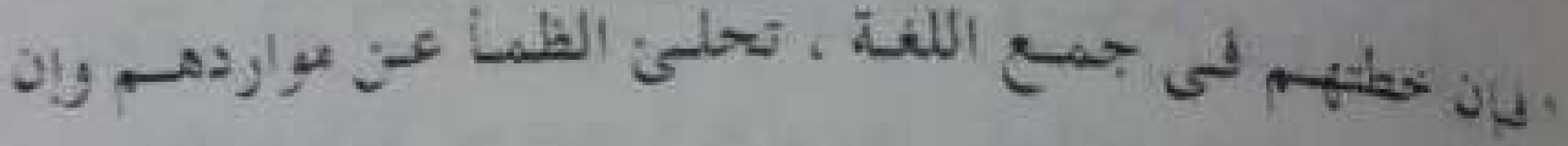

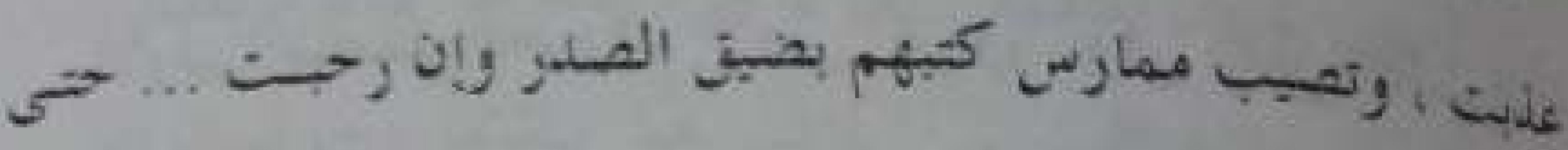

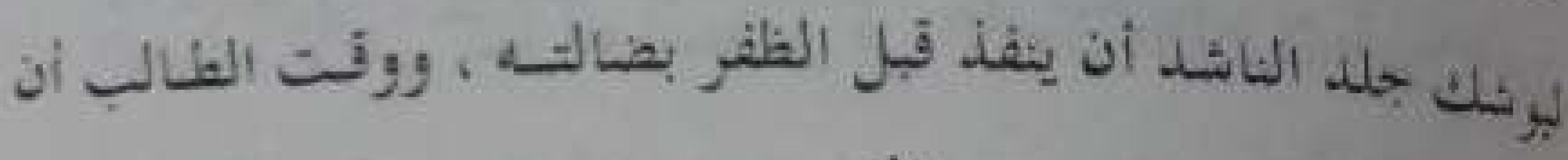

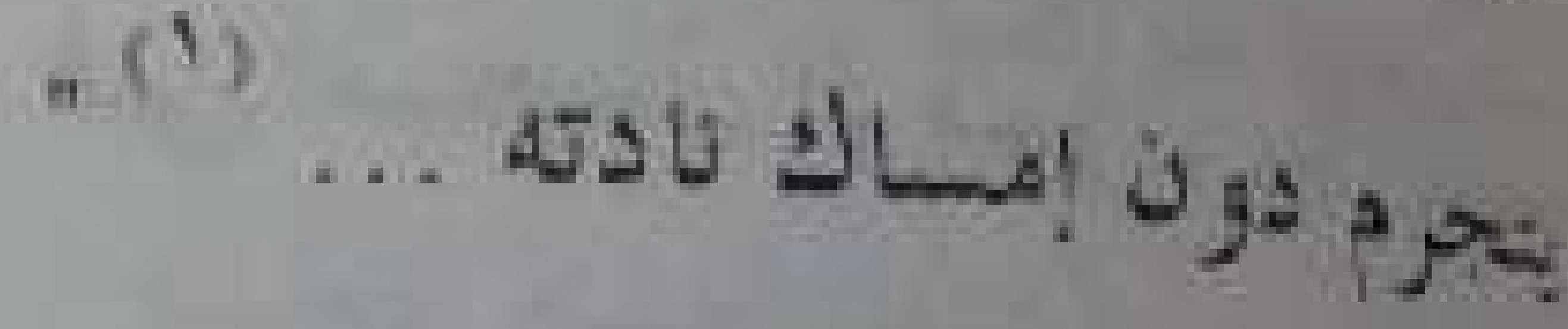

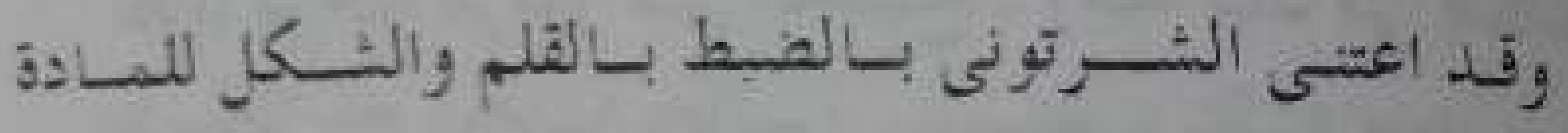

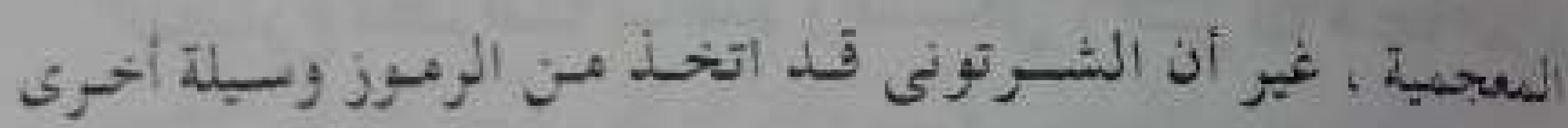

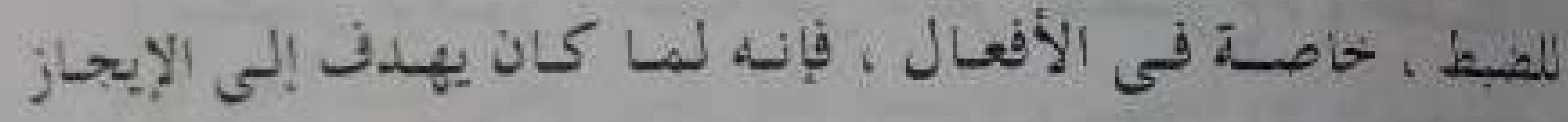

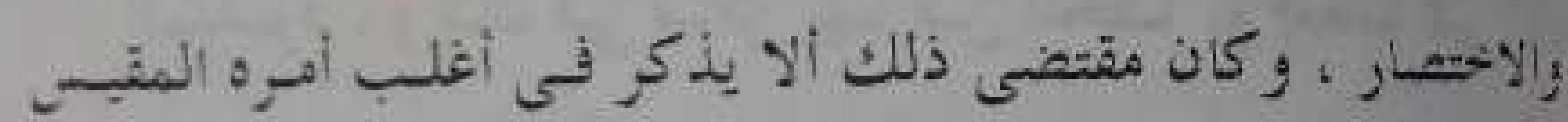

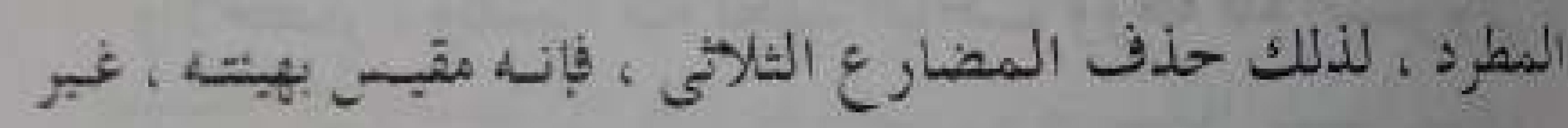

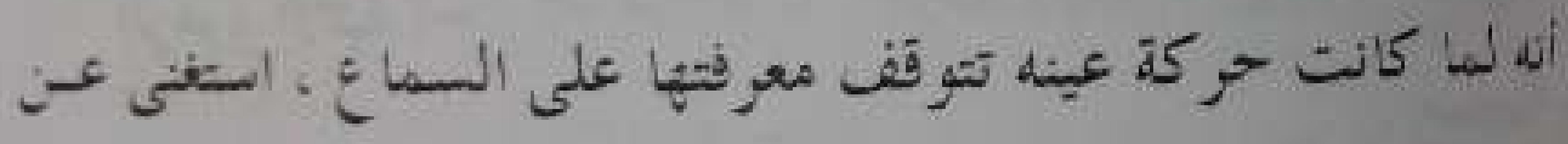

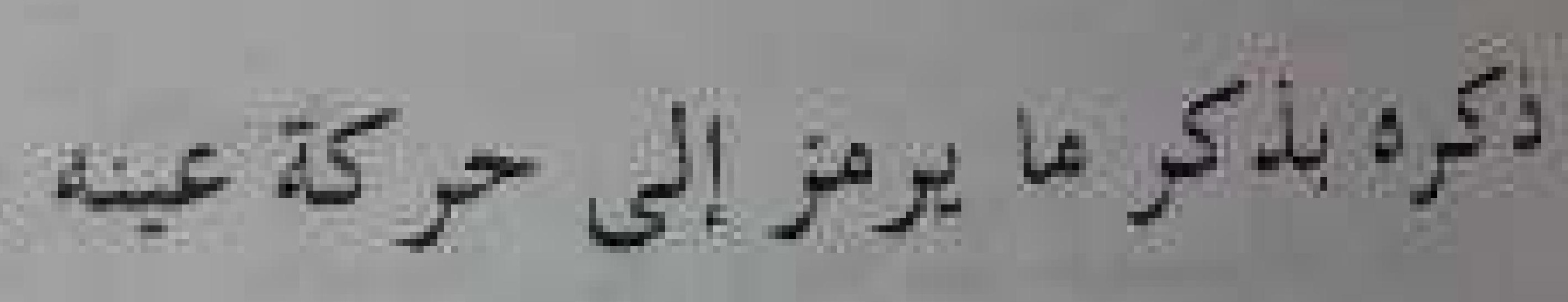

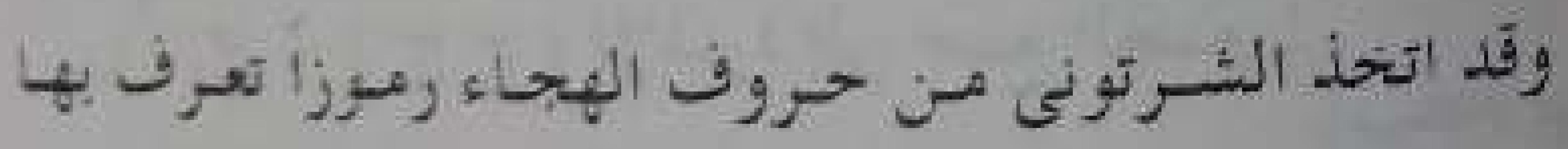

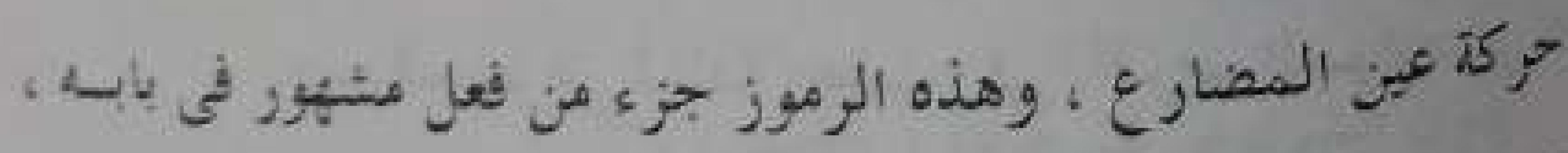

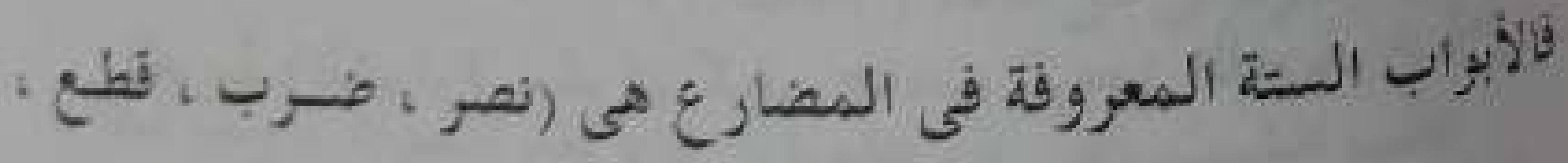

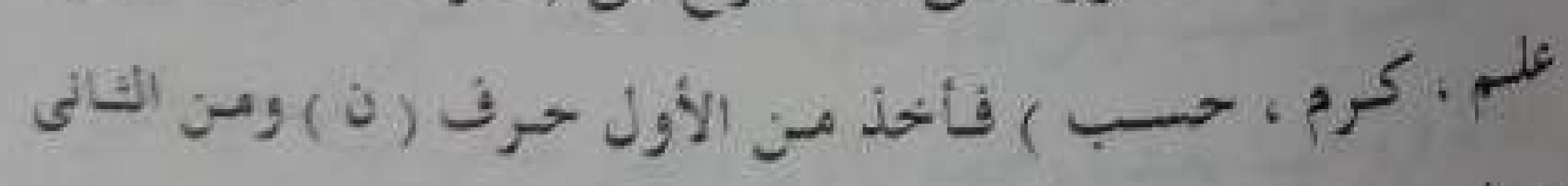

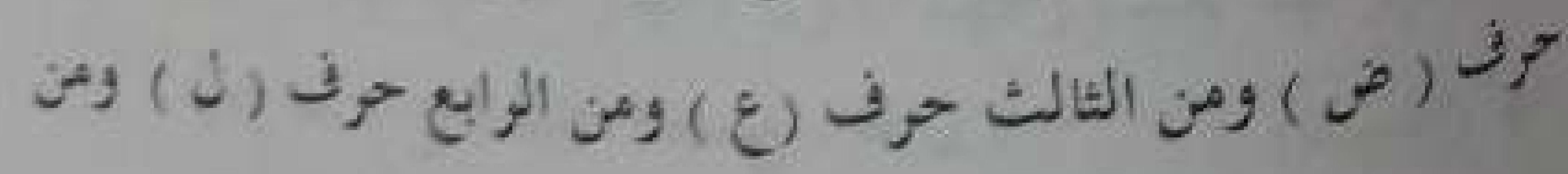

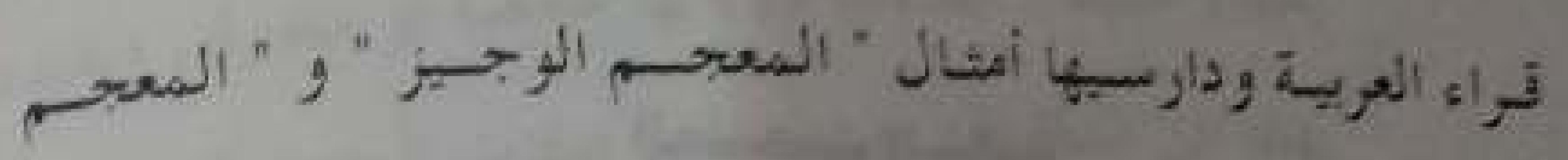

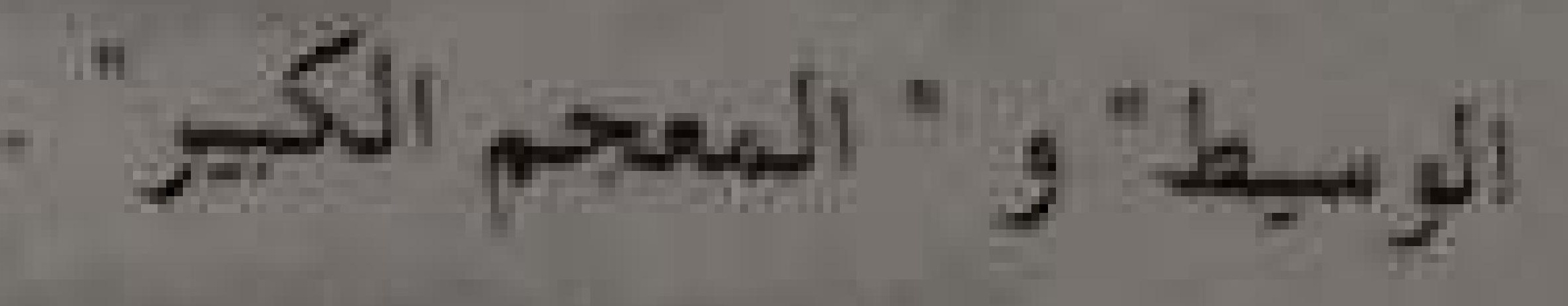
المشابير البنبانية

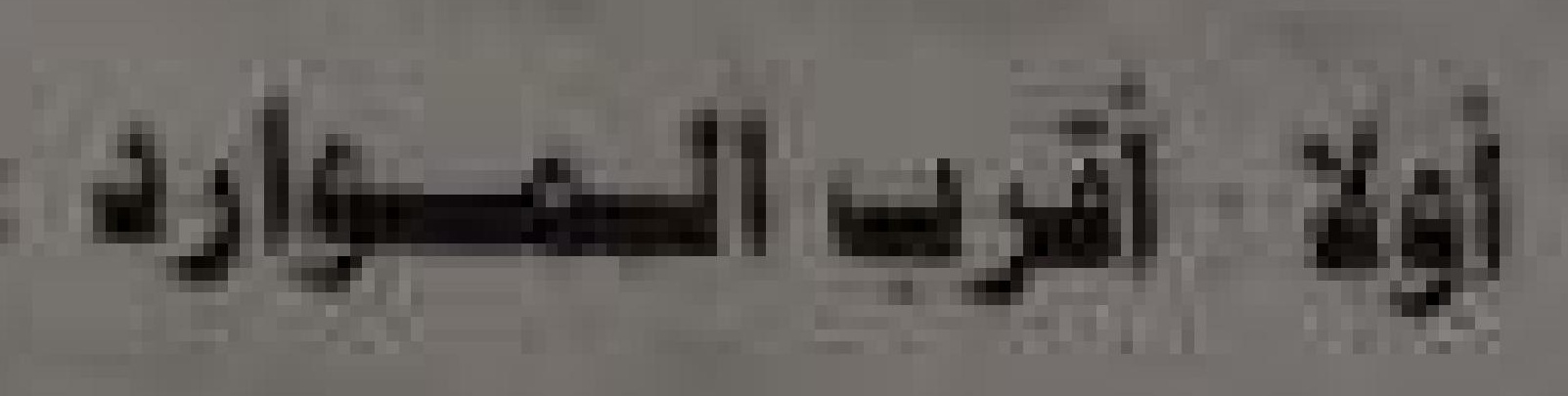

اتتصلت حلقات الاهتيـام بـالسعجم العربـى بيـن القدامسى

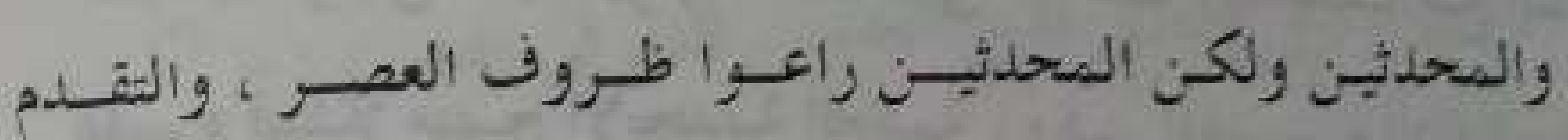

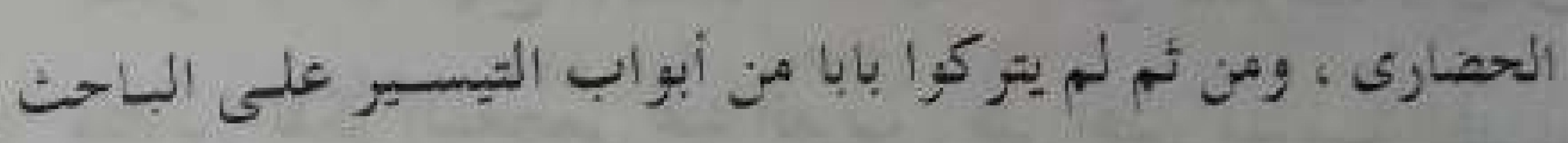

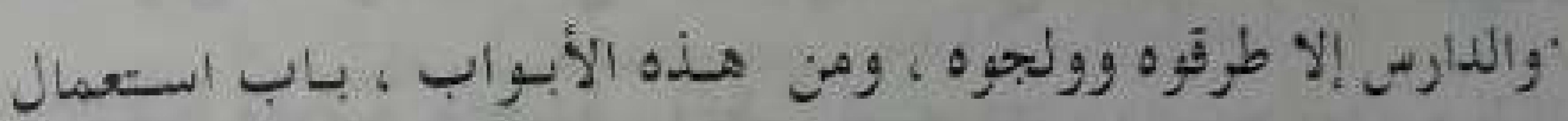

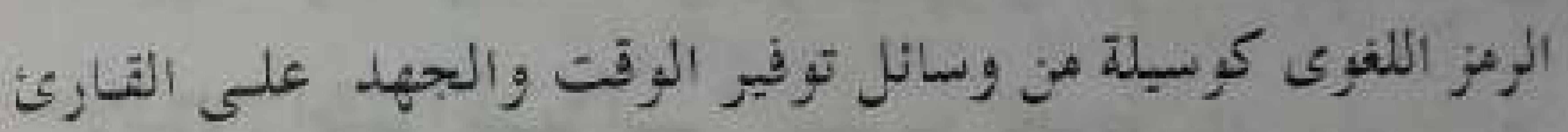
والبأي العبوبى

والناظر إلى اسم السعجم وعنوانه ، يتيح له - لأول وهلة -

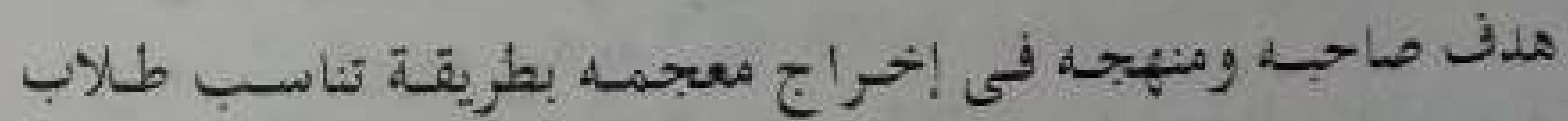

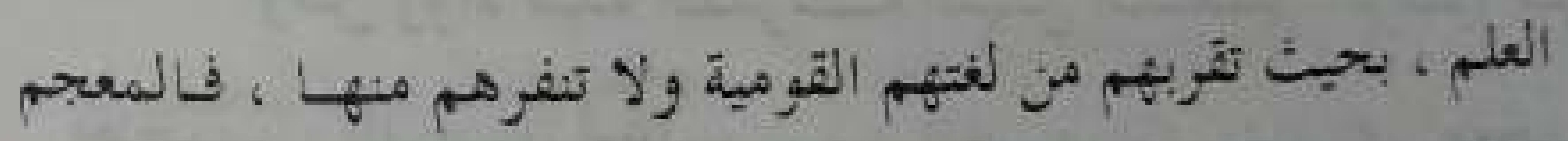

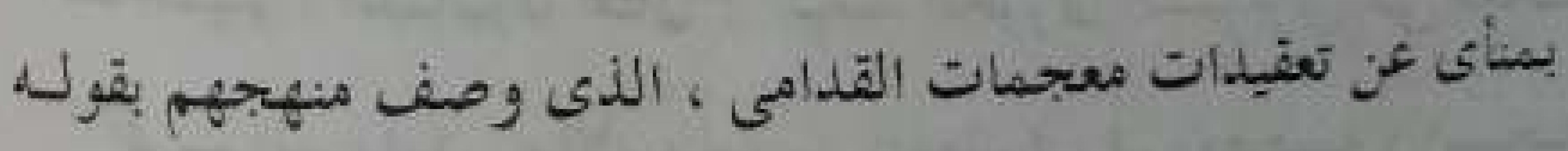

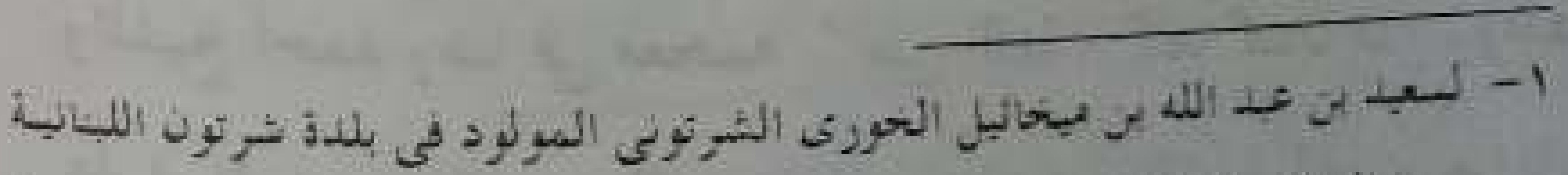

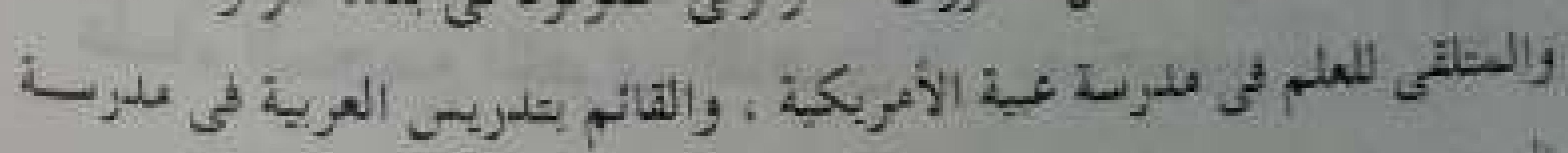

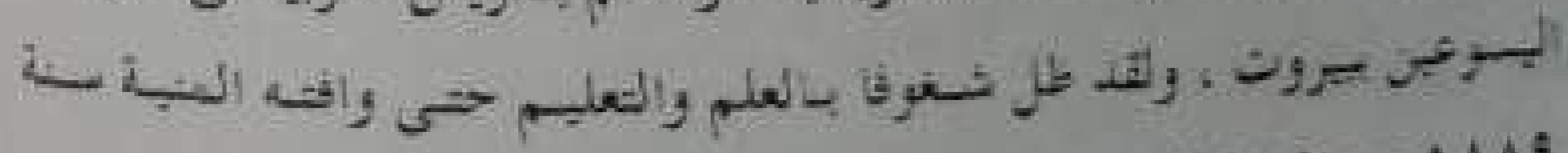

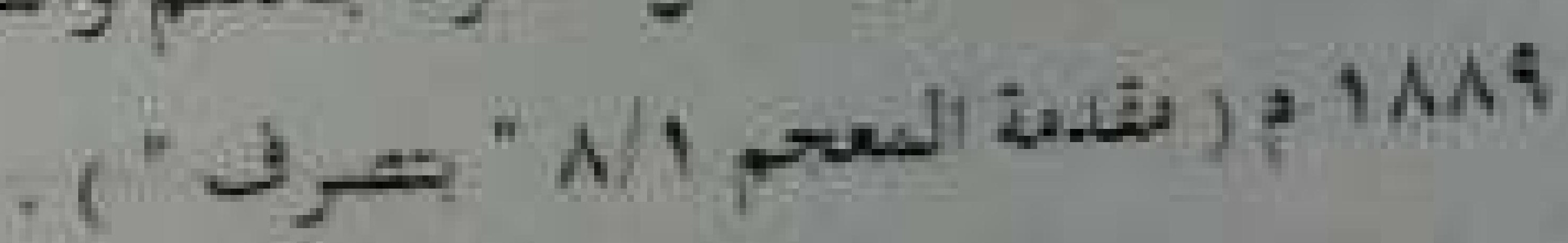




\section{$-+19=$}

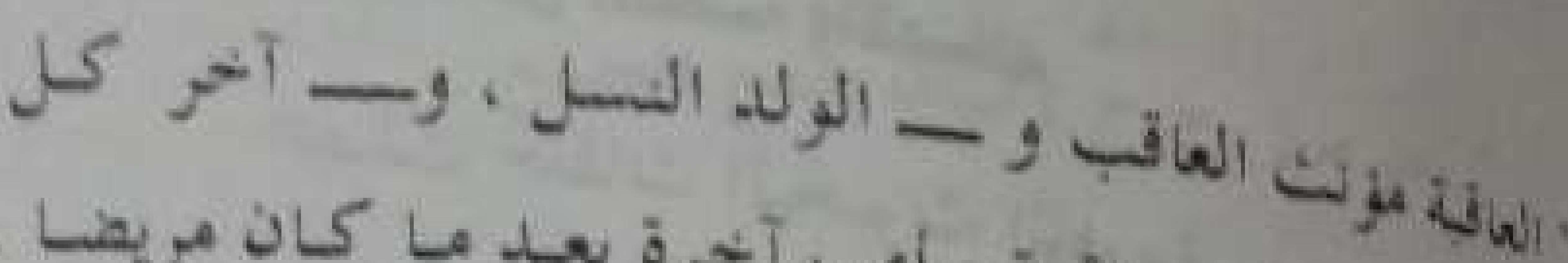

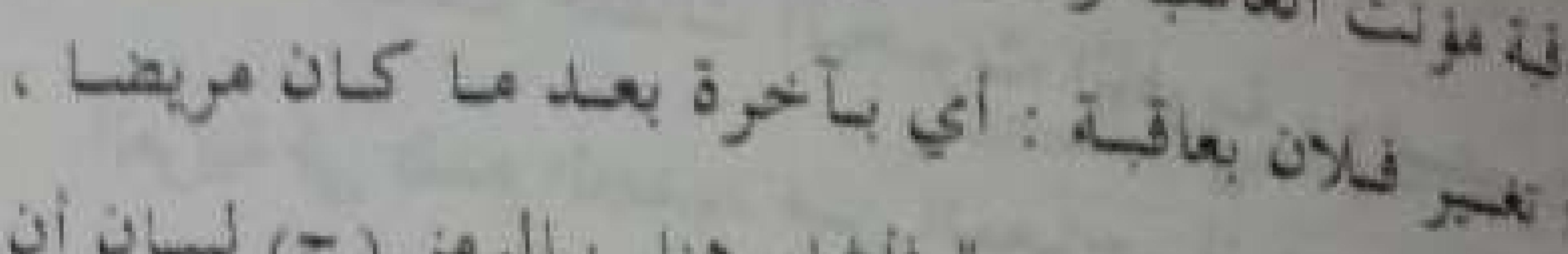

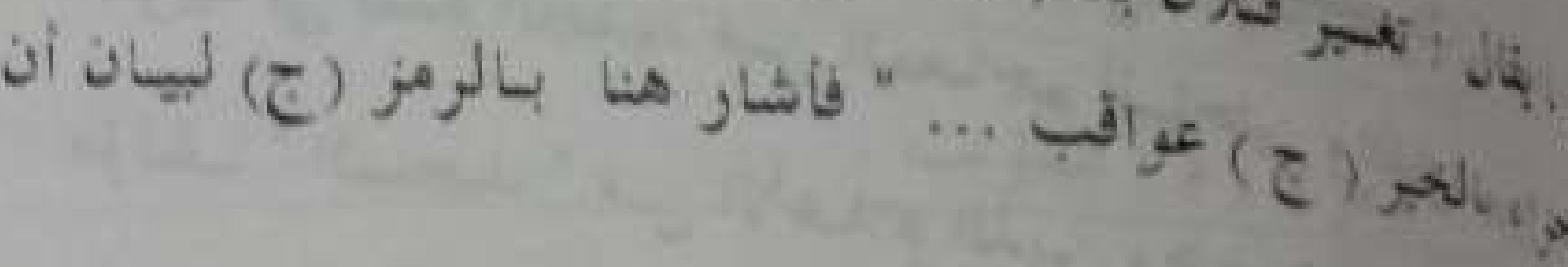
if of thas $u_{4}$

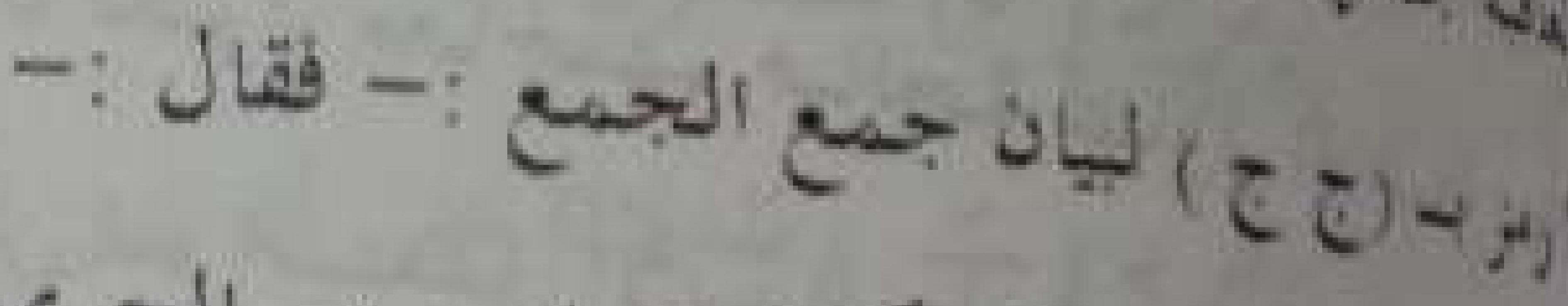

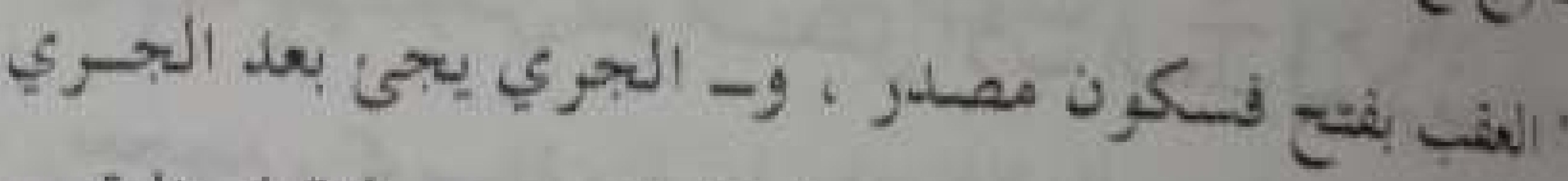

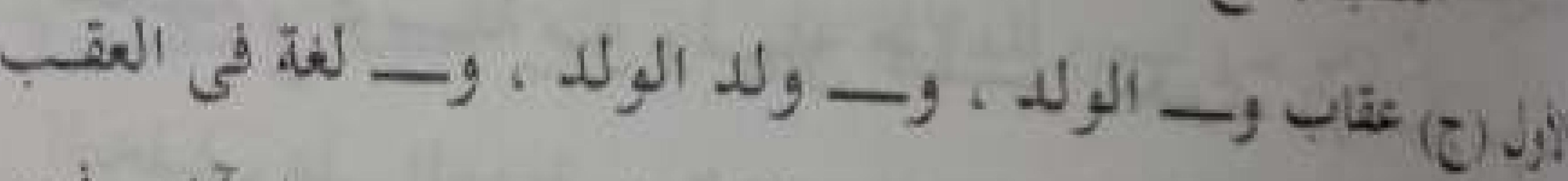

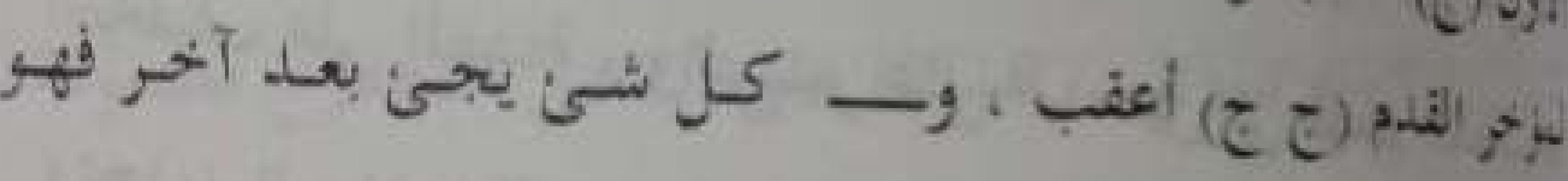

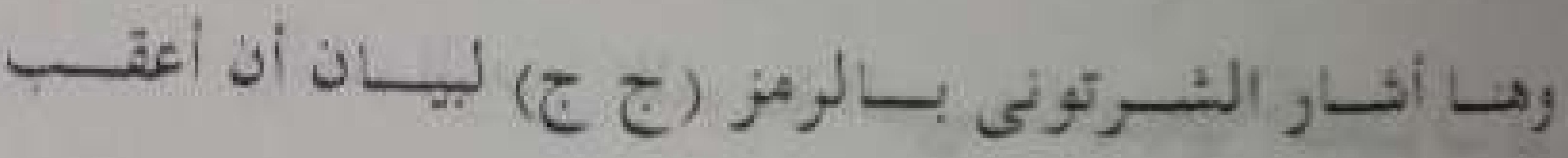
$\Leftrightarrow$

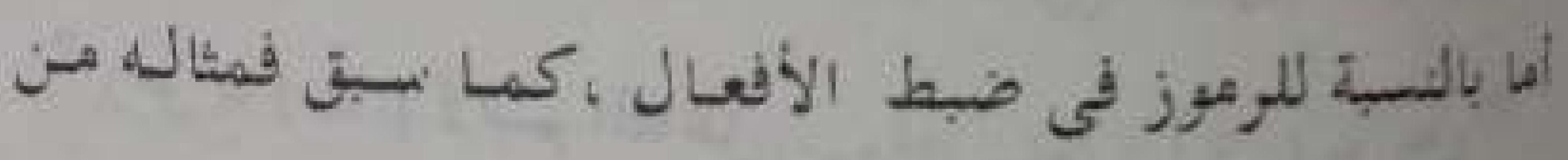
(1) (عنب)

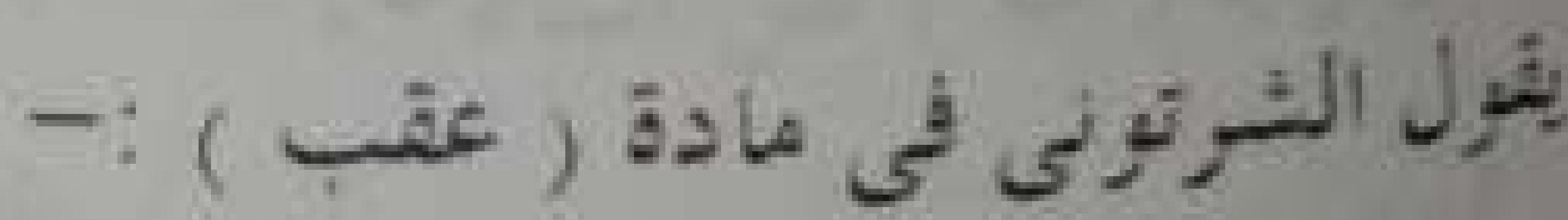

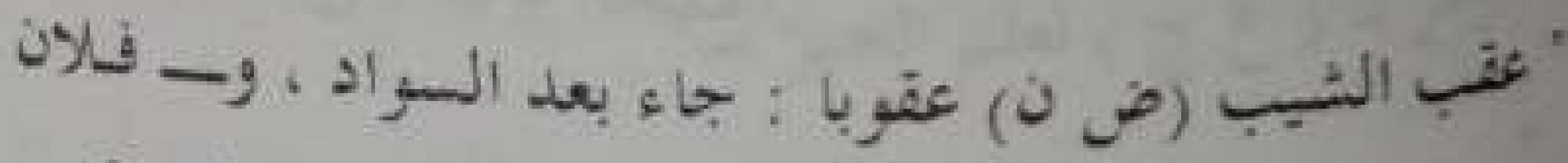

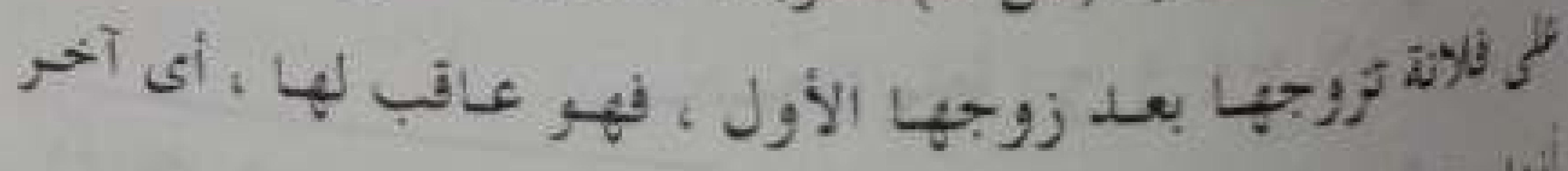

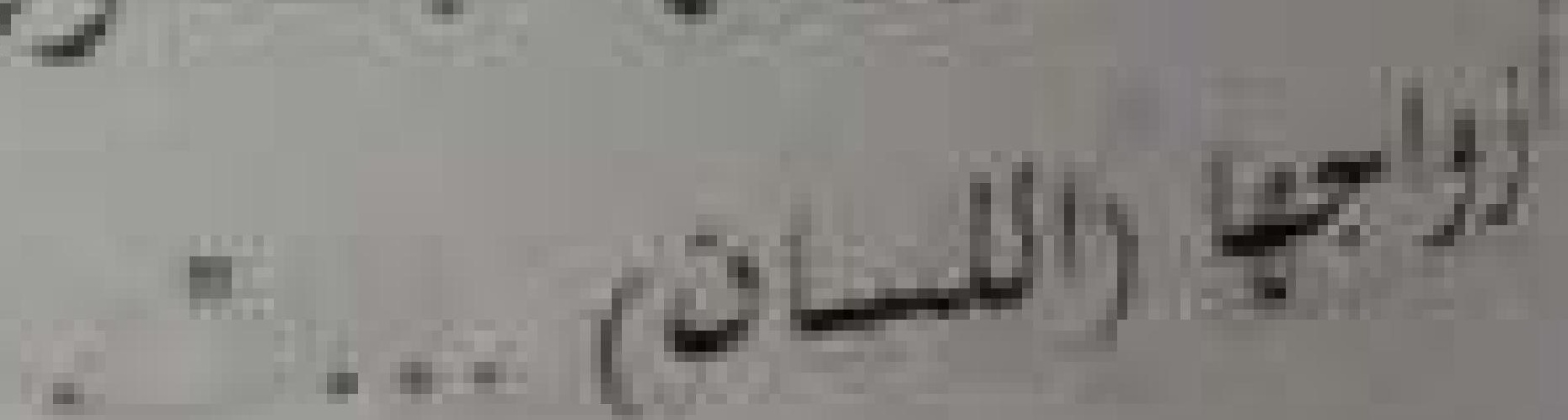

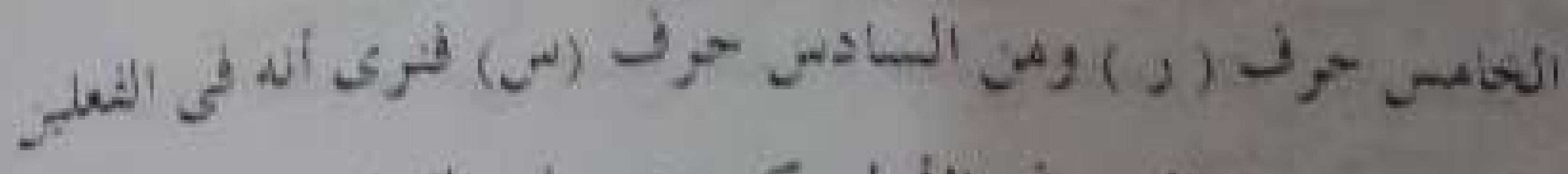

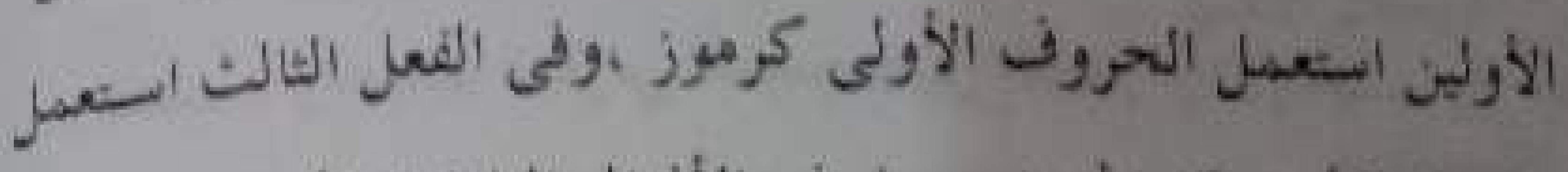

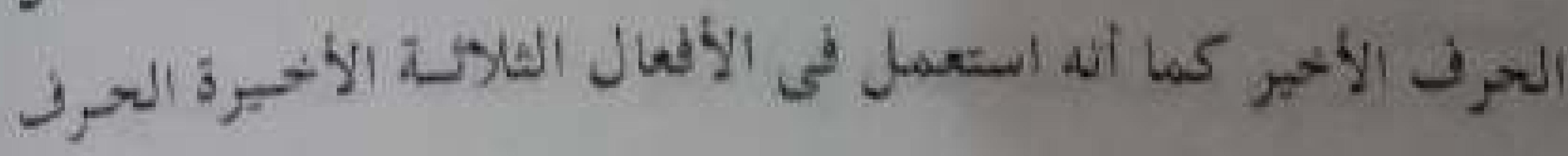

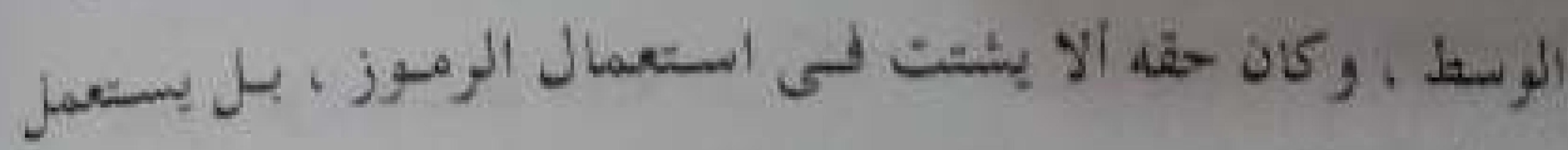

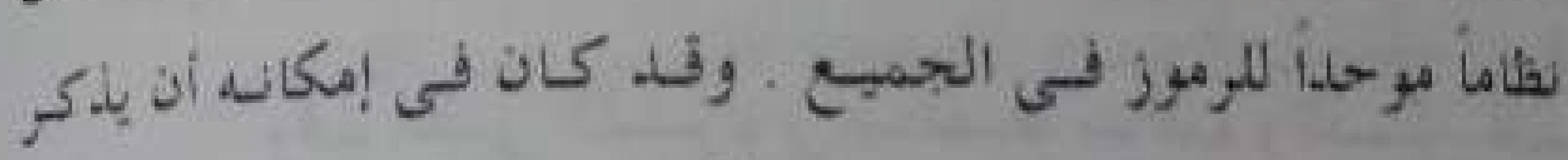

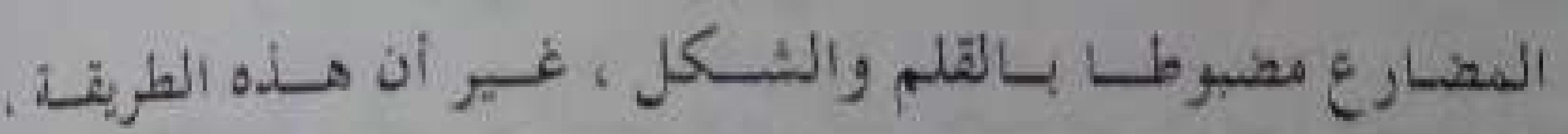

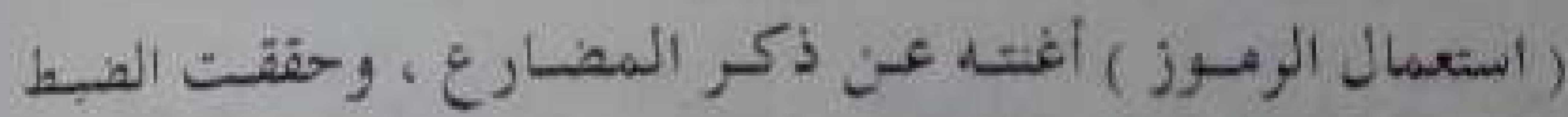

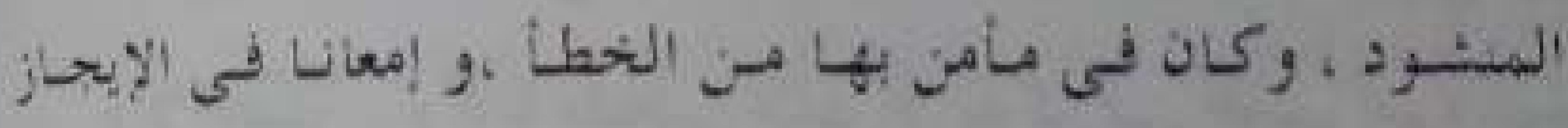

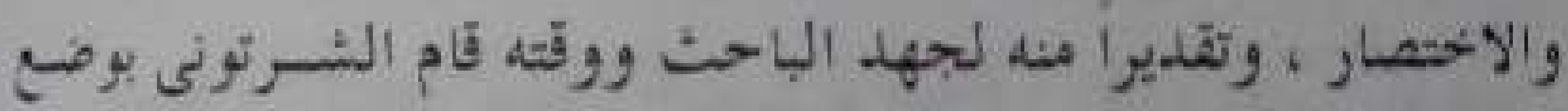

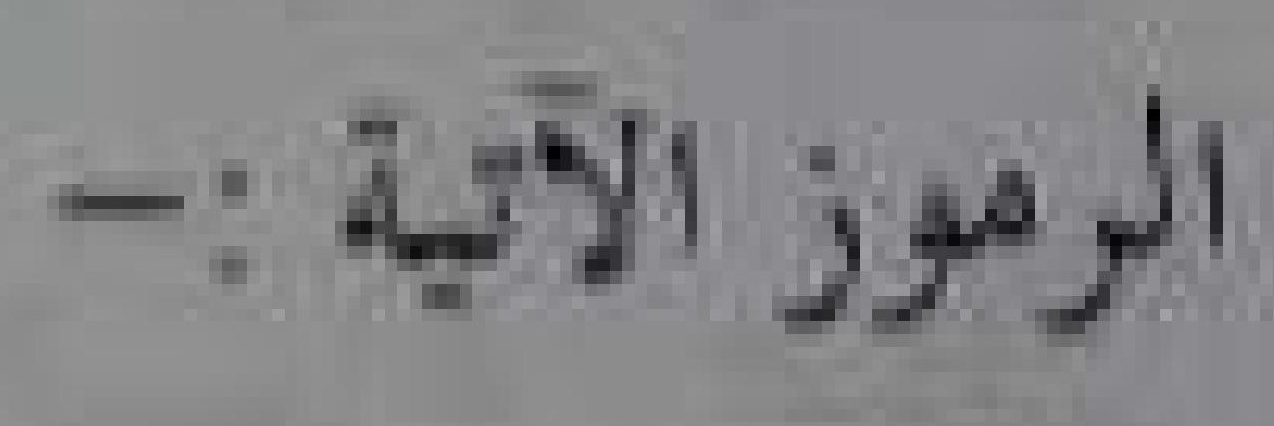

$$
\text { ( }
$$

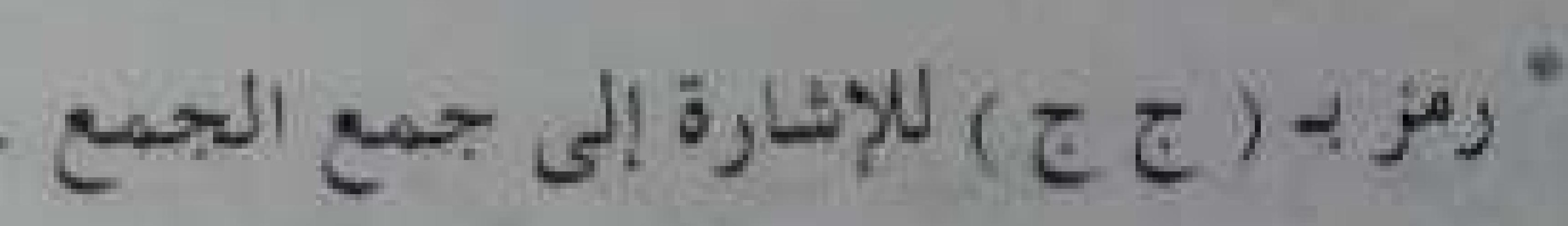

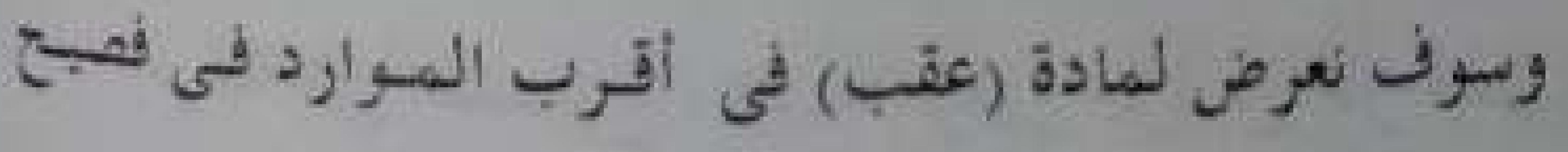

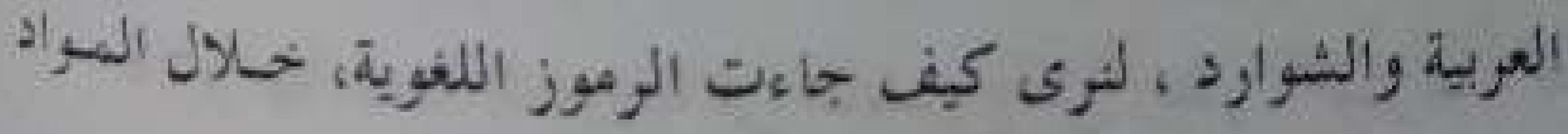

(1) Itrowl

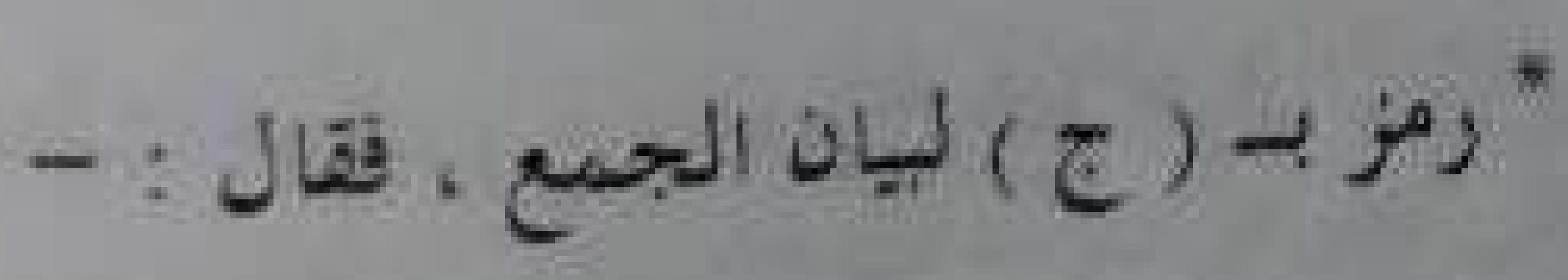


$-P T_{1}-$

$$
\begin{aligned}
& \text { رمز بـ ( ج ج ) لبيان جمع الجمع : }
\end{aligned}
$$

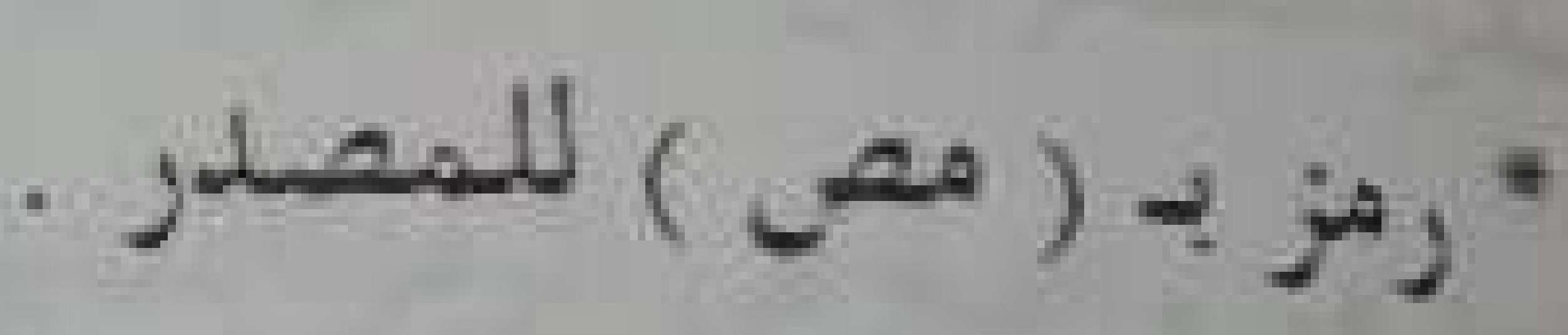

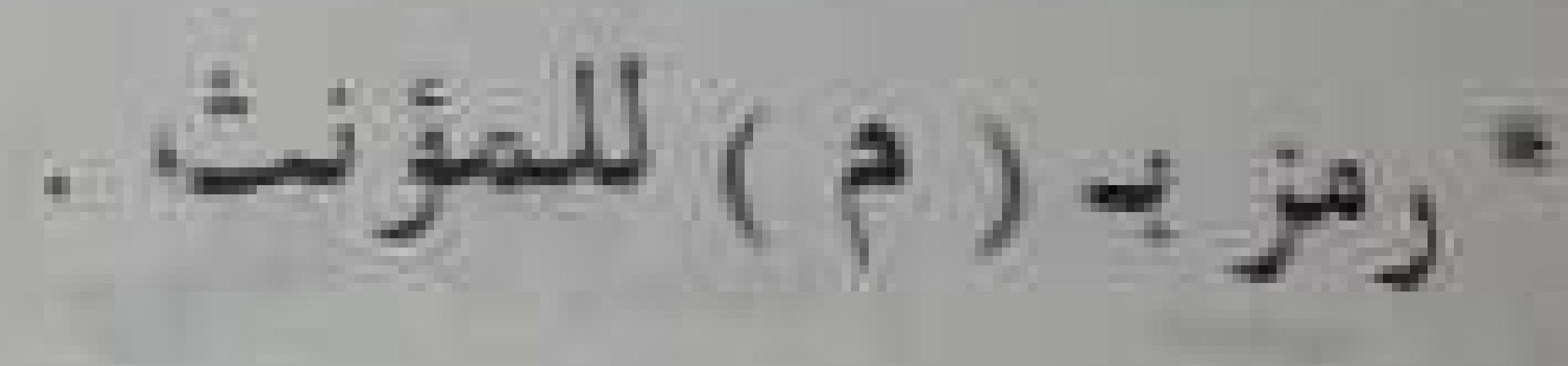

$$
\begin{aligned}
& \text { "رمز بـ (0) للمفعول به . }
\end{aligned}
$$

" رمز بـ ( ) ) للدلالة على أن عين المضارع مفتوحة.

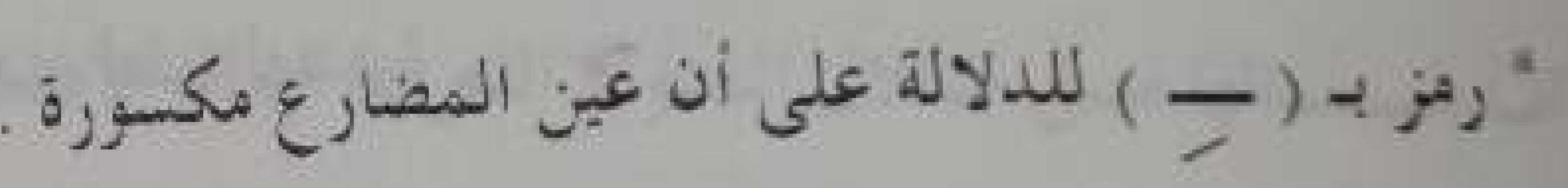

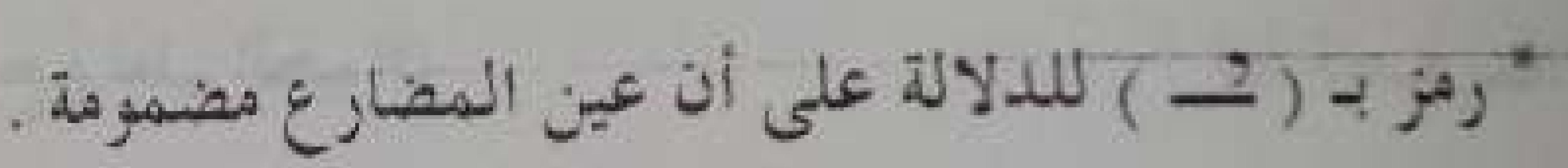

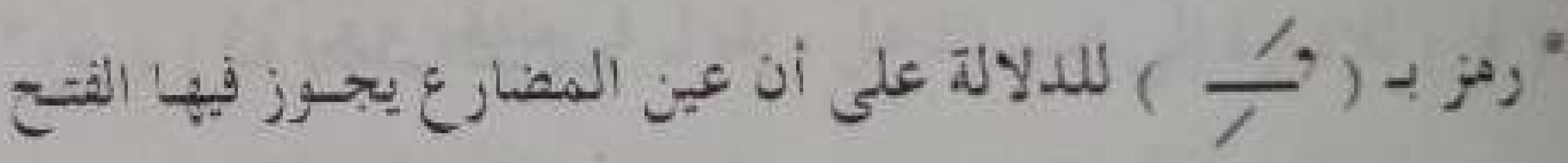

$$
\begin{aligned}
& \text { والكسر والضم } \\
& \text { "ر مز بـ (ز ) للزراعة. } \\
& \text { " رمز بـ (ع أ ) لعلم الأعضاء. } \\
& \text { " رمز بـ (ب) )لفن البناء. }
\end{aligned}
$$

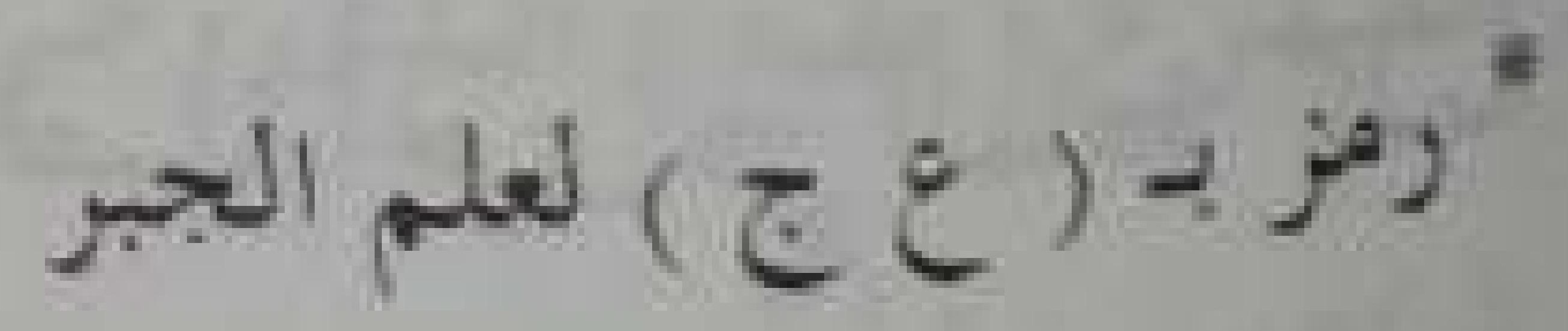

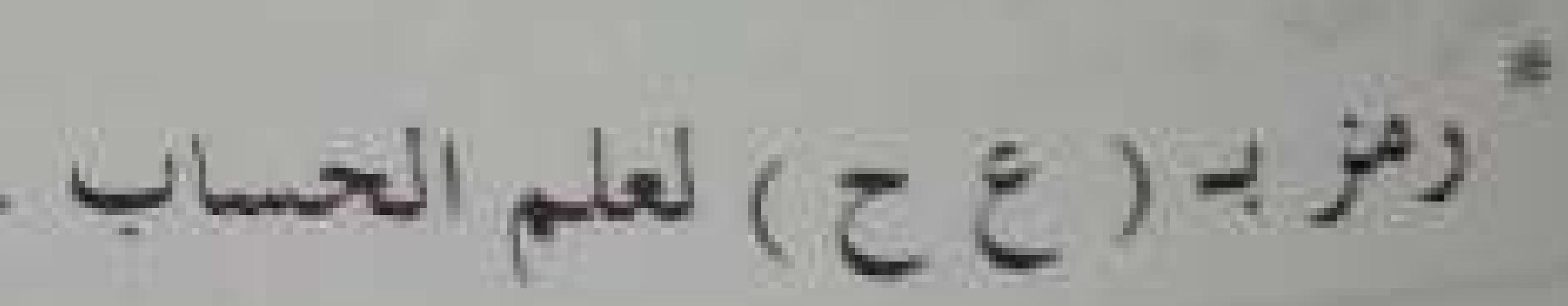

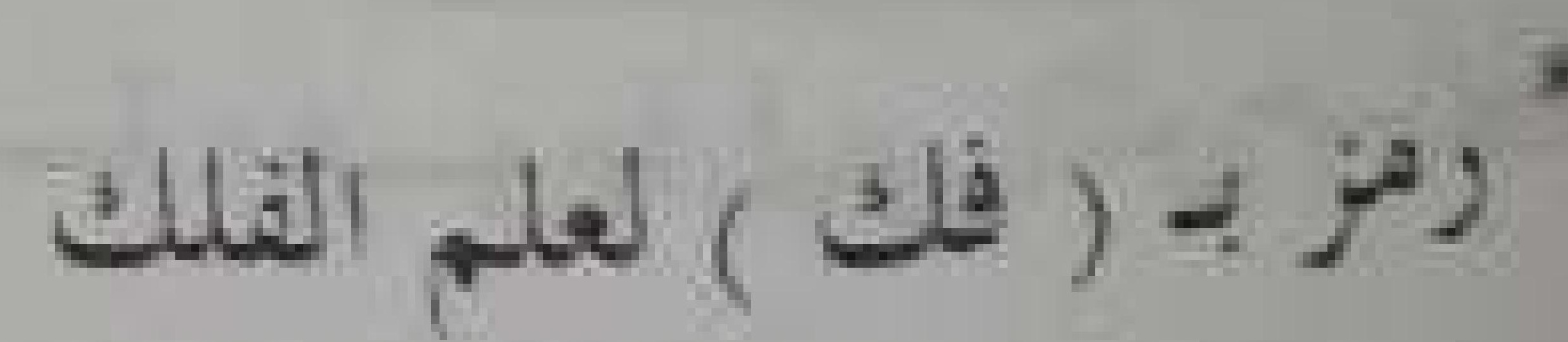

$$
\begin{aligned}
& \text { " ومز بـ (ن ) ملعم النبات. }
\end{aligned}
$$

$-\% T .-$

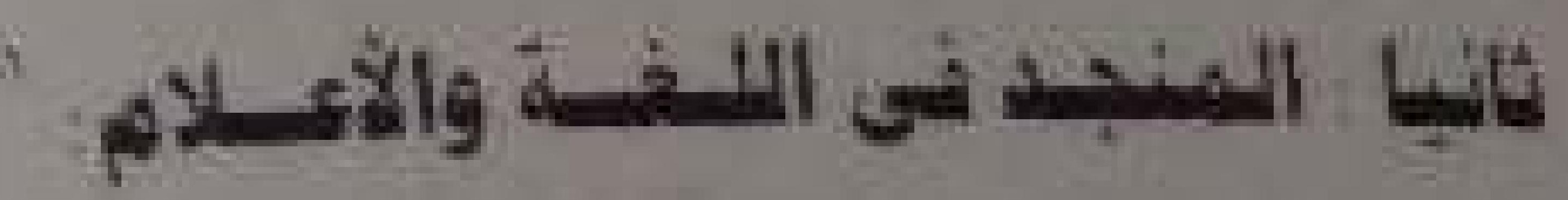

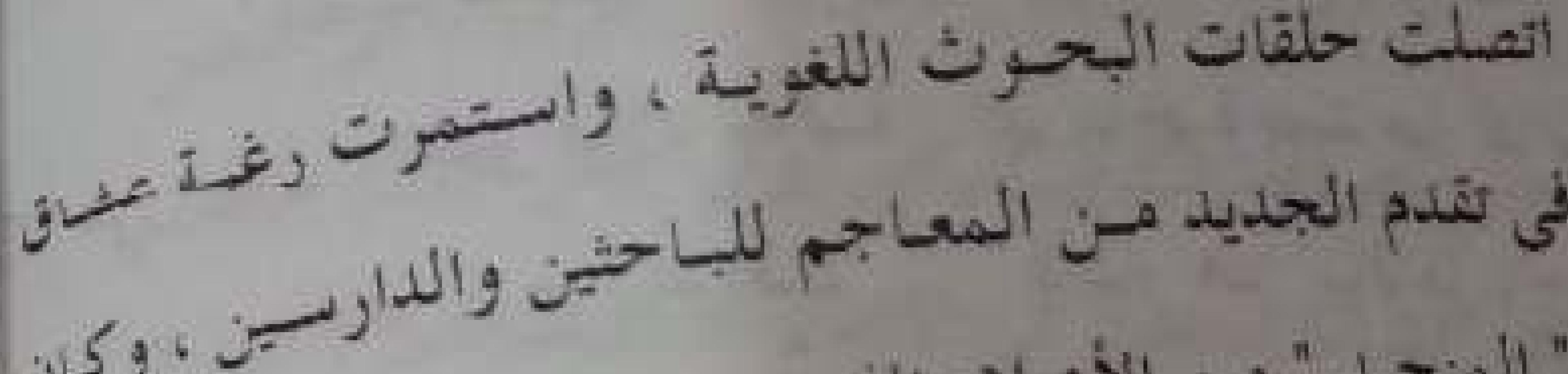

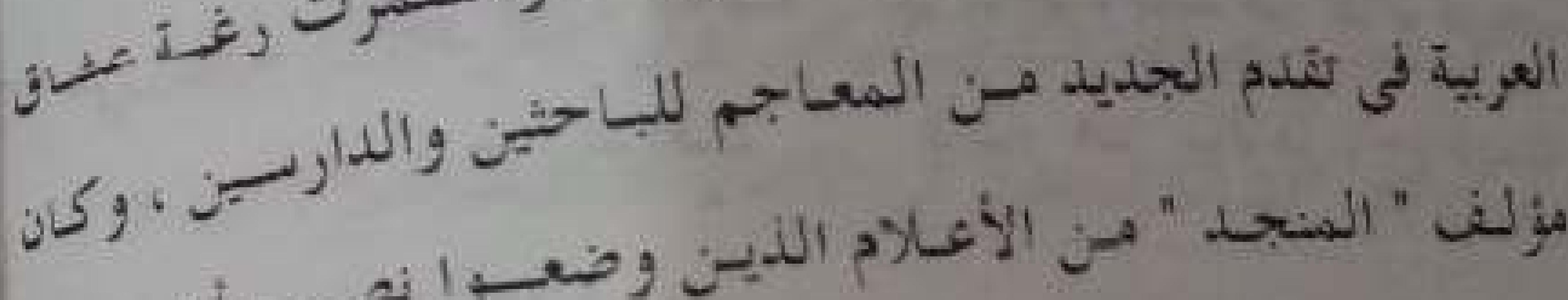

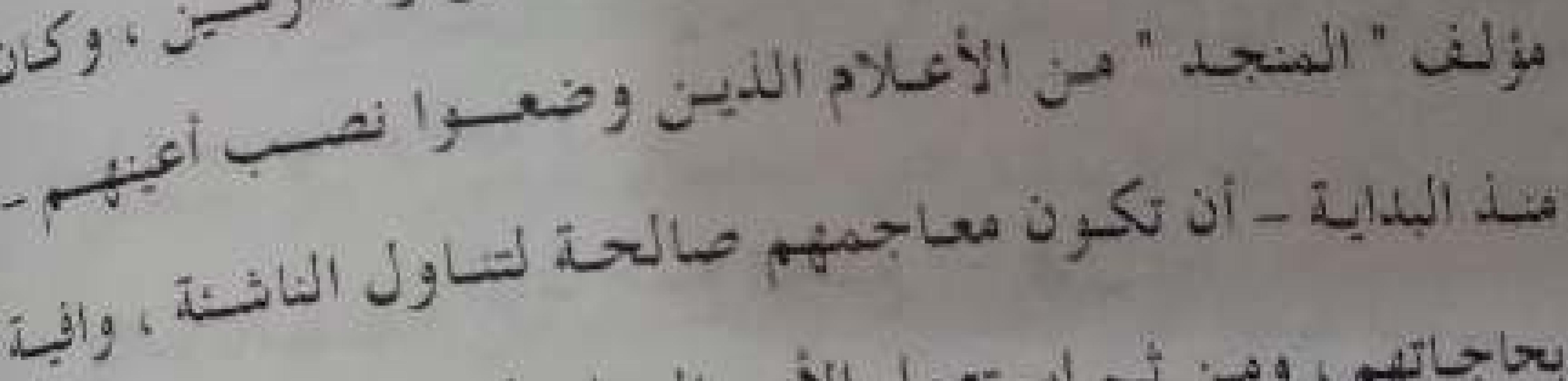

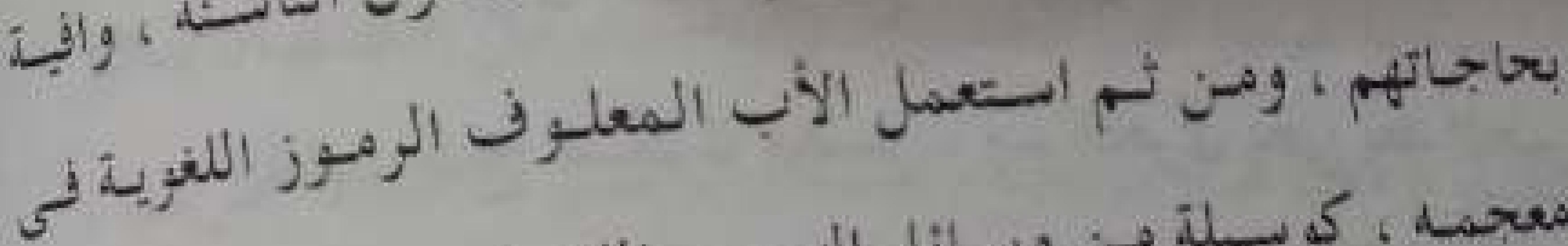

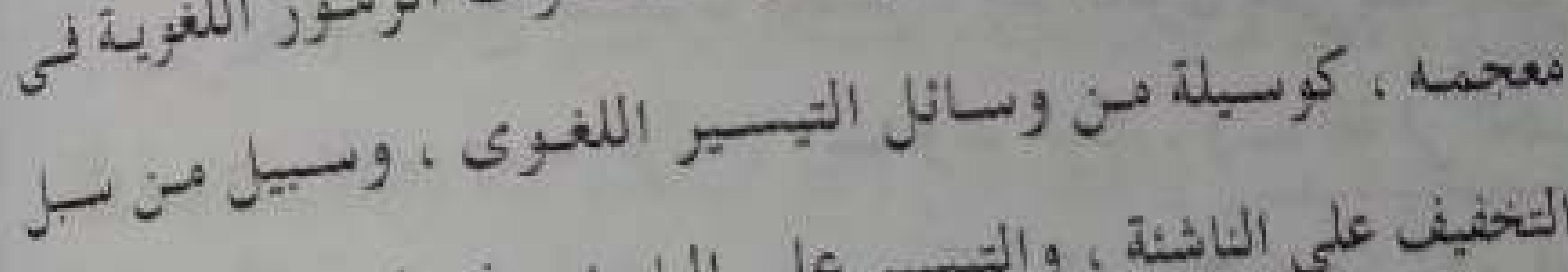

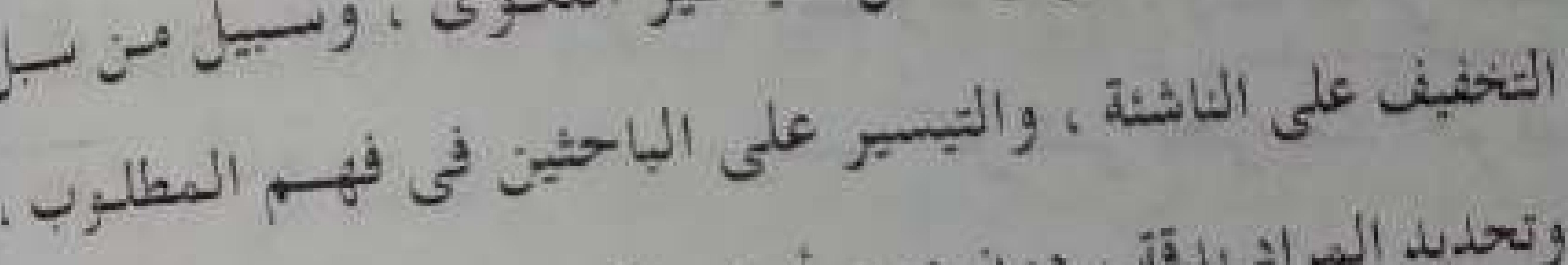

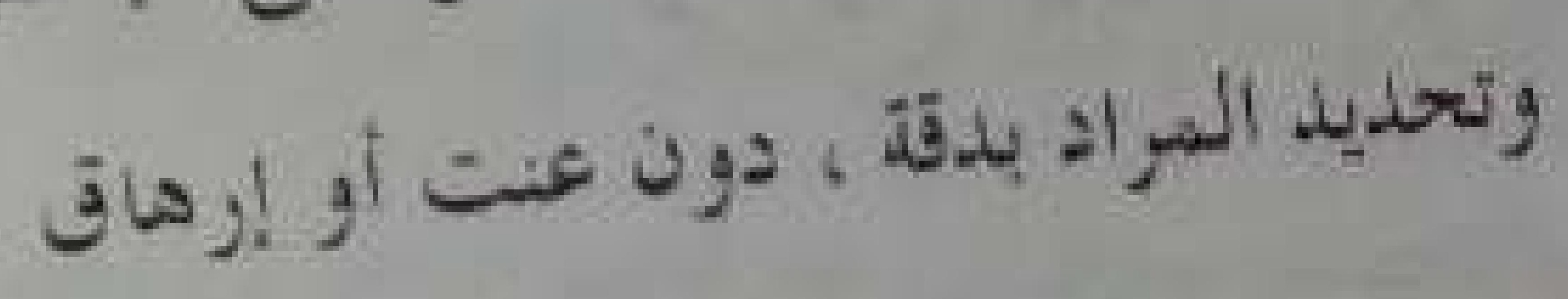

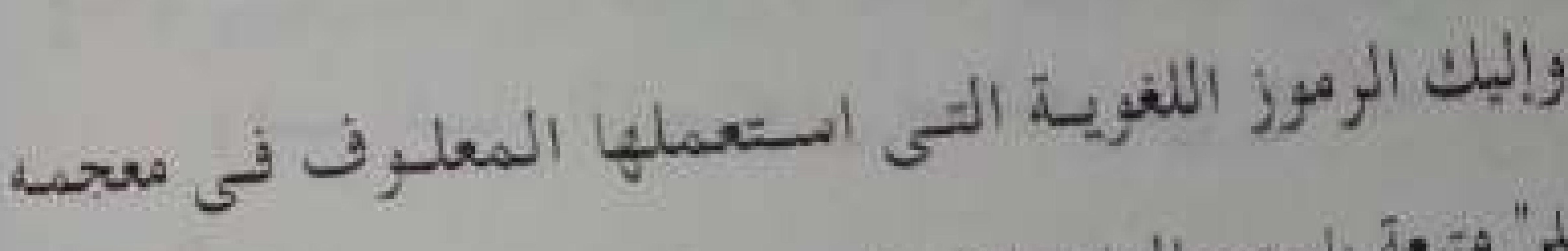

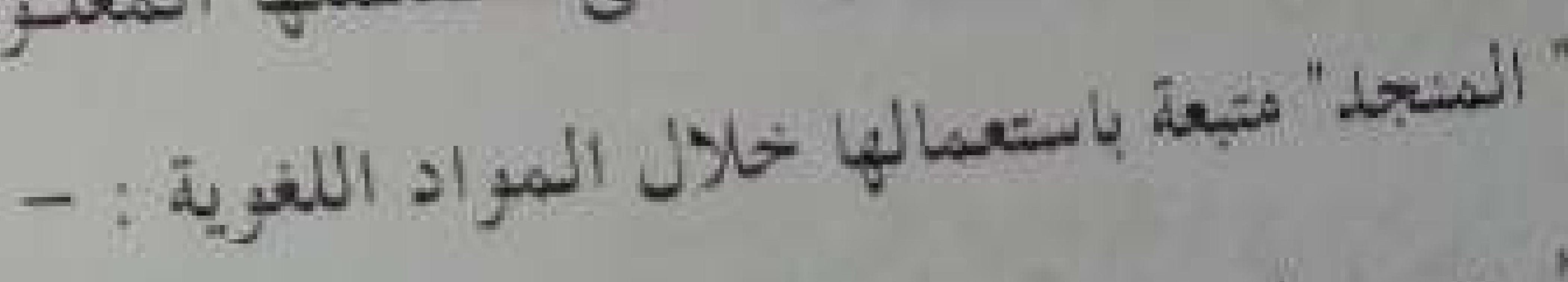

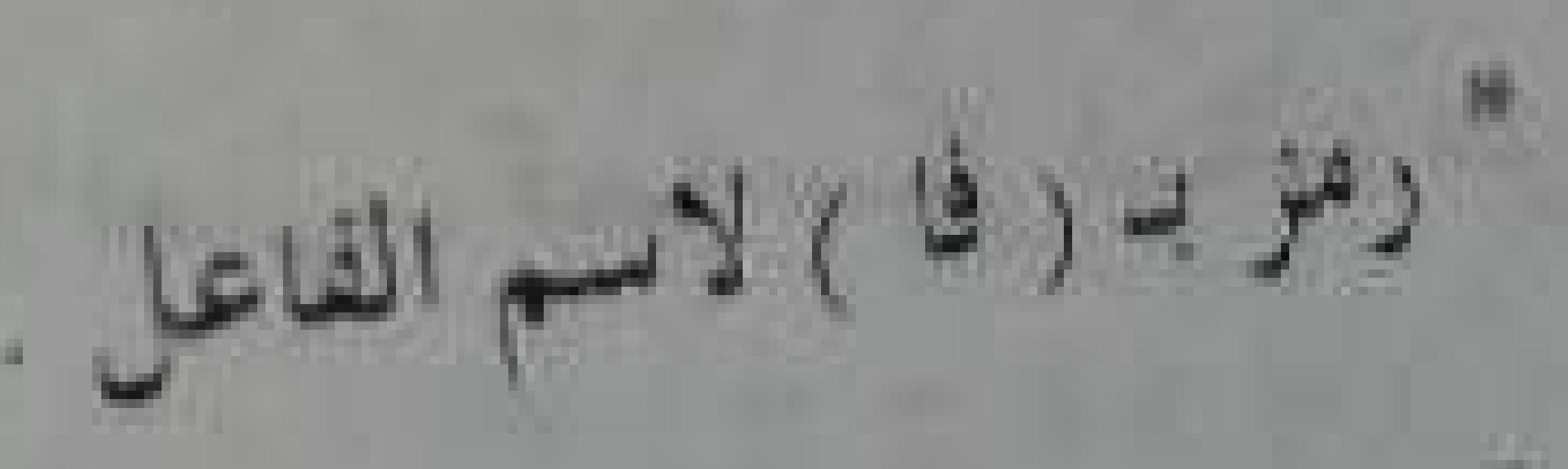

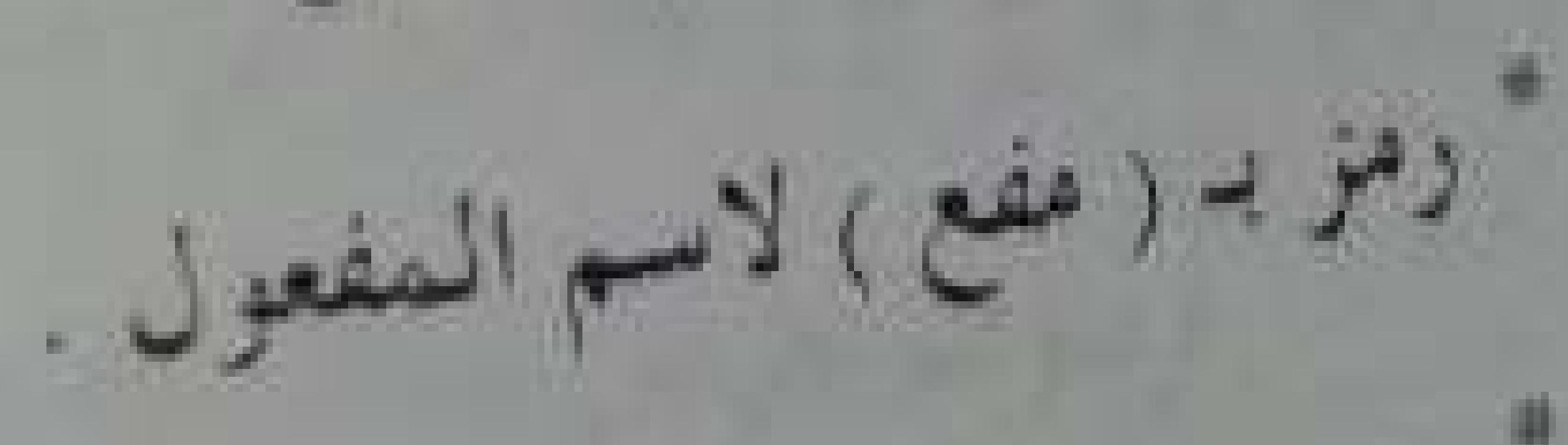

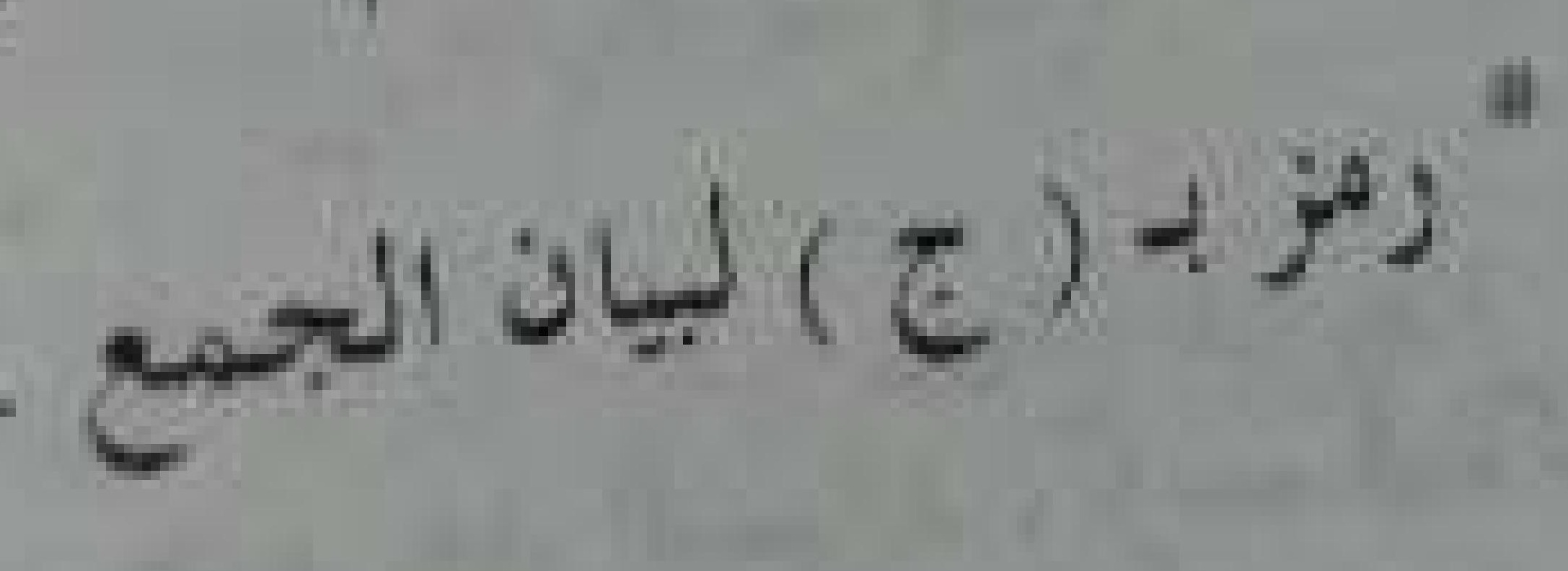

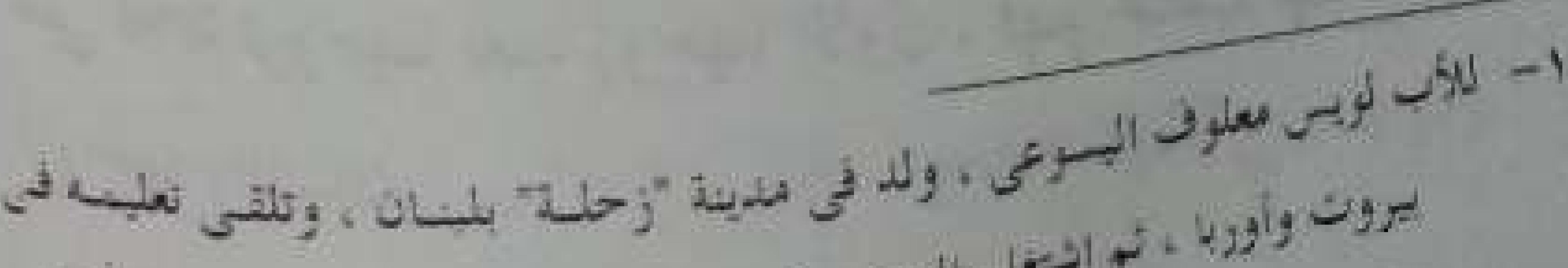

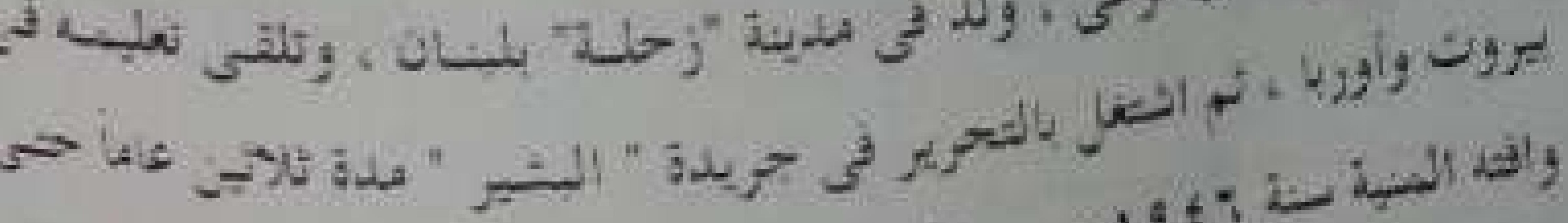

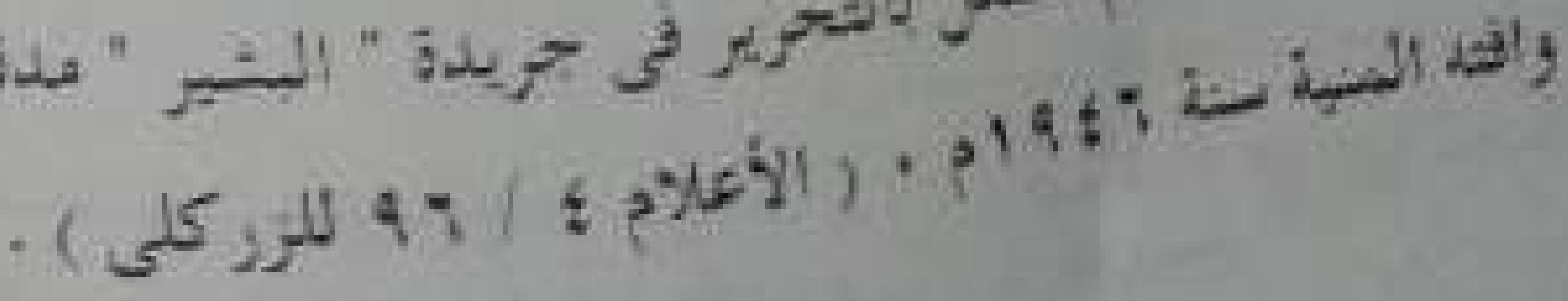




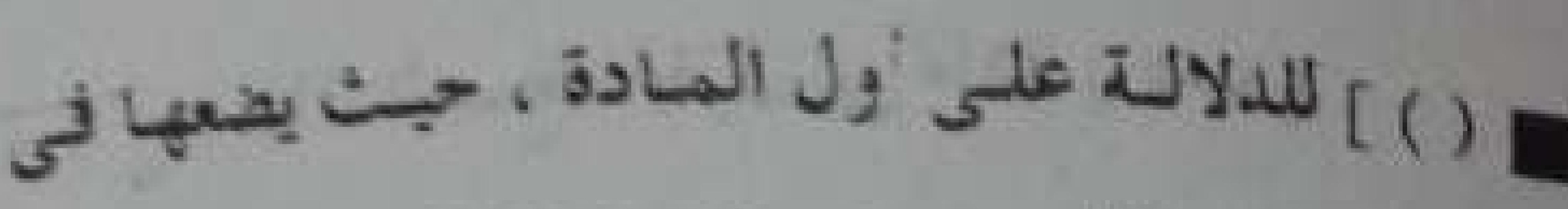

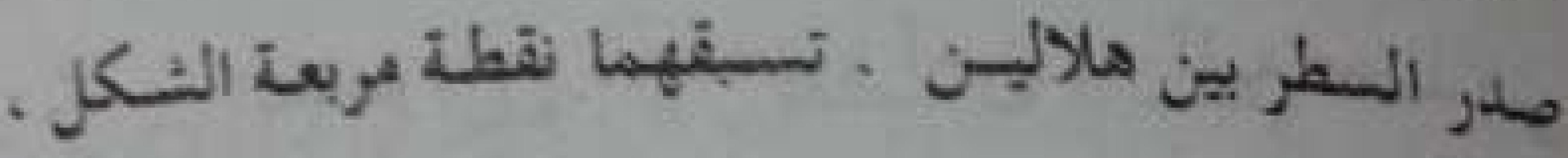

$$
\text { كيا هر واضح في الرمز السنابق . }
$$

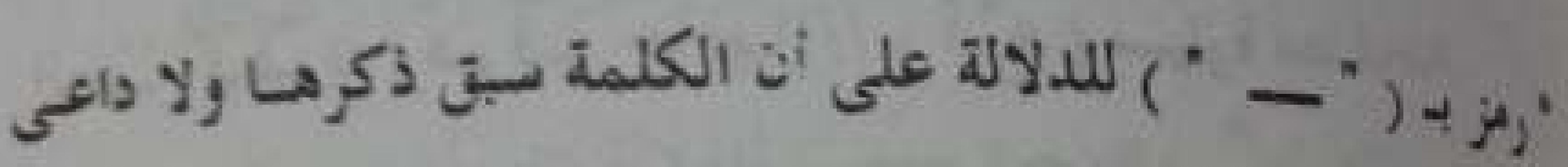

(1)

tiscy

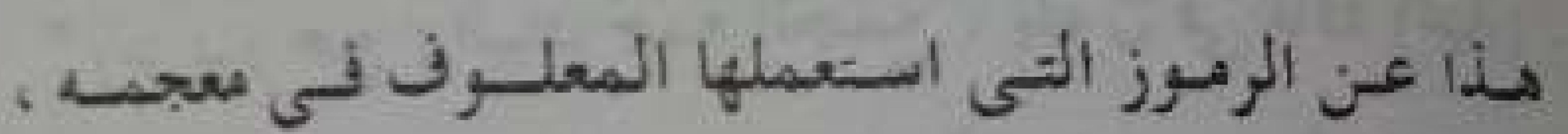

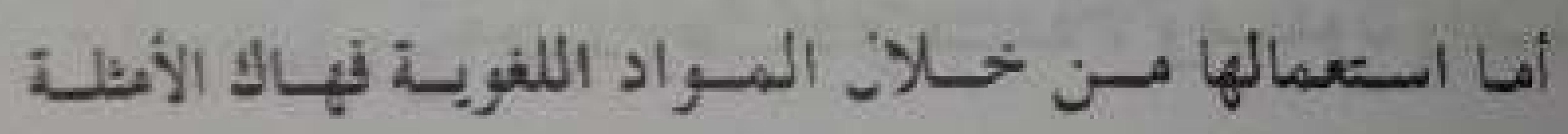

$$
\text { المبرضحة لها : - }
$$

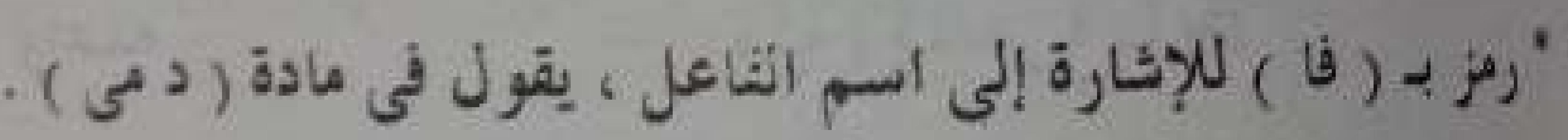

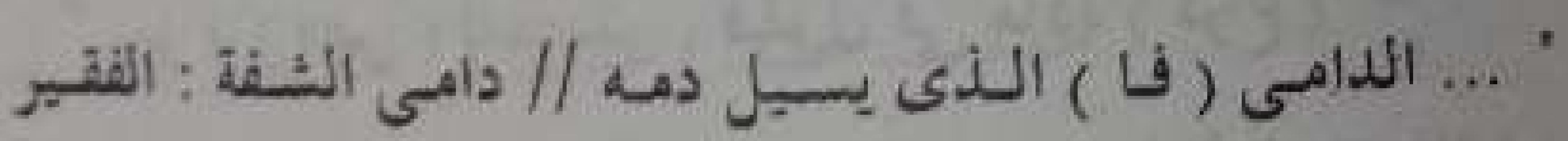

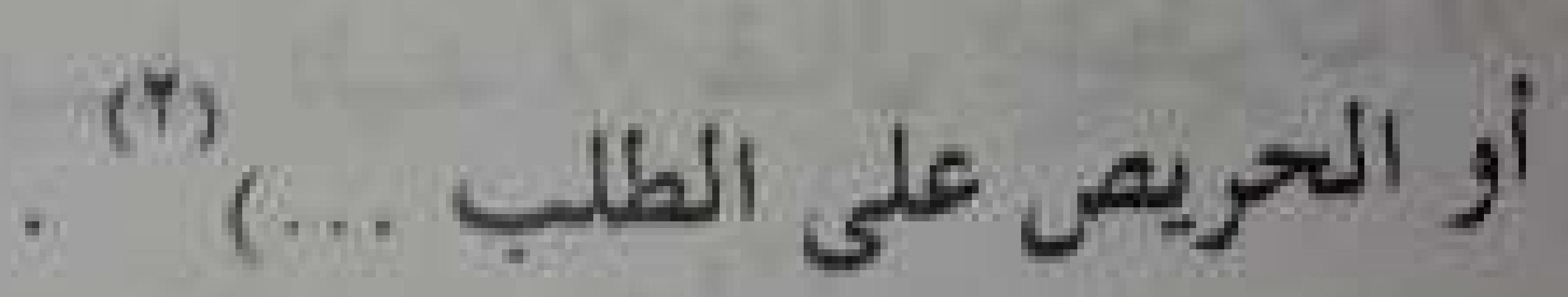

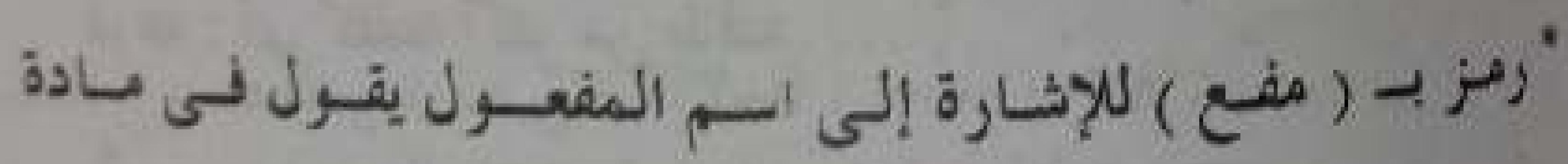

$$
-:(\varepsilon, j)
$$

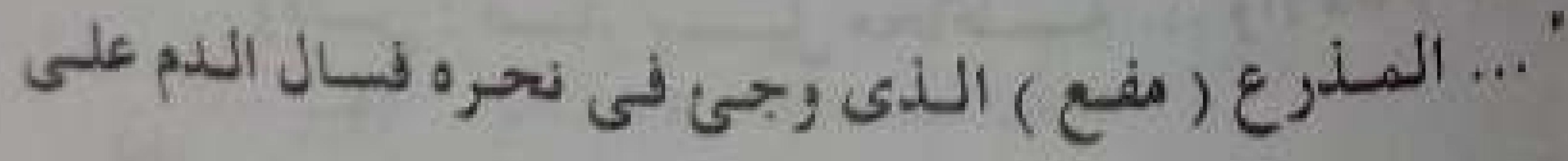

$$
\text { .... }
$$

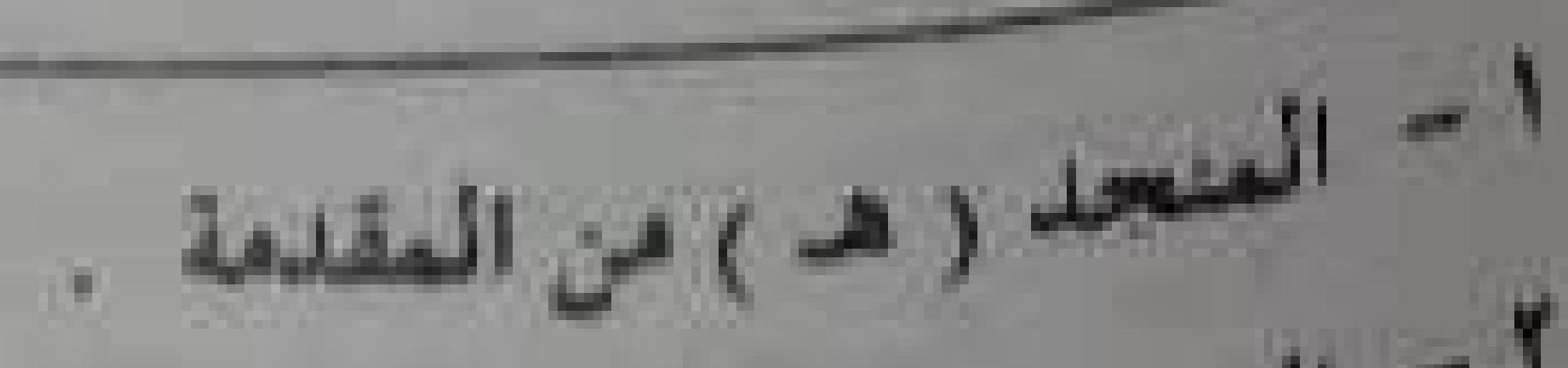

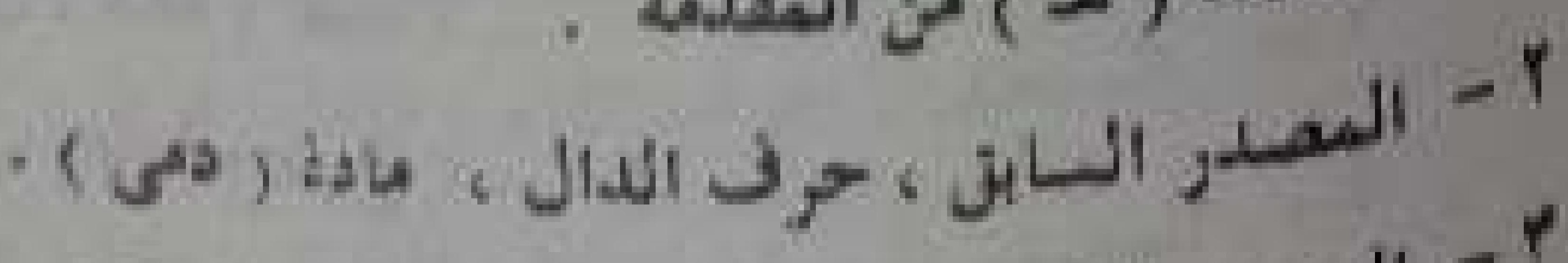

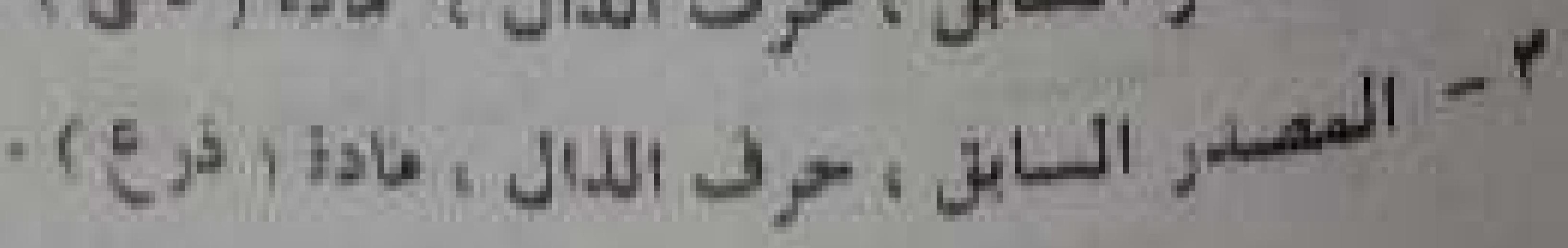

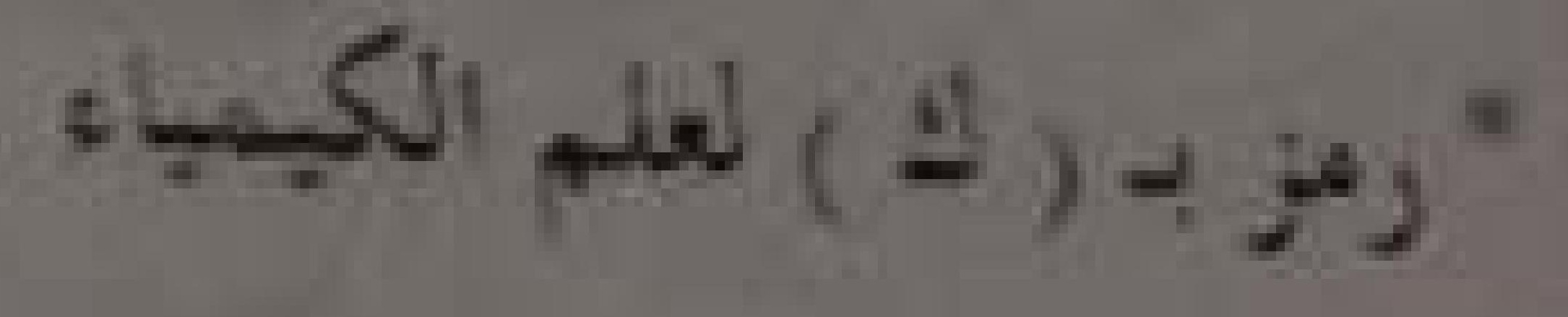

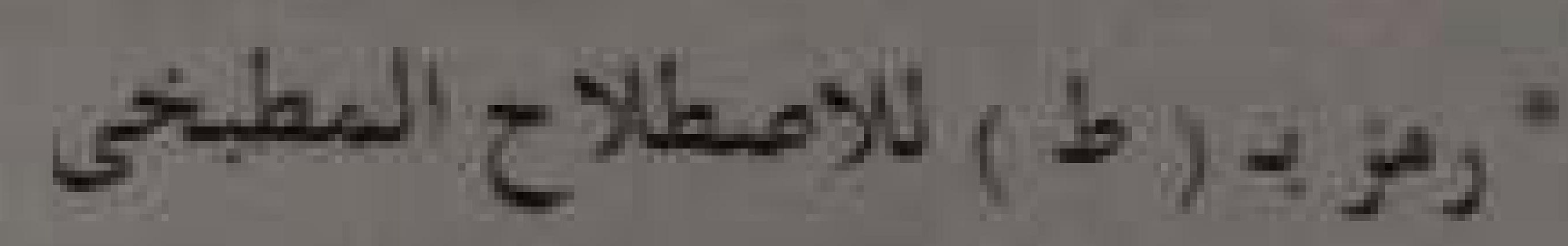
istor

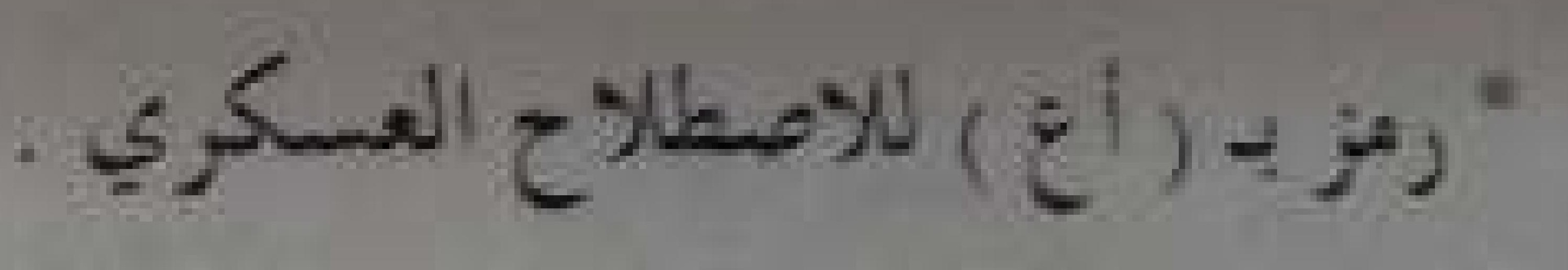$$
\text { " ريز بـ (طب العلم الطب }
$$

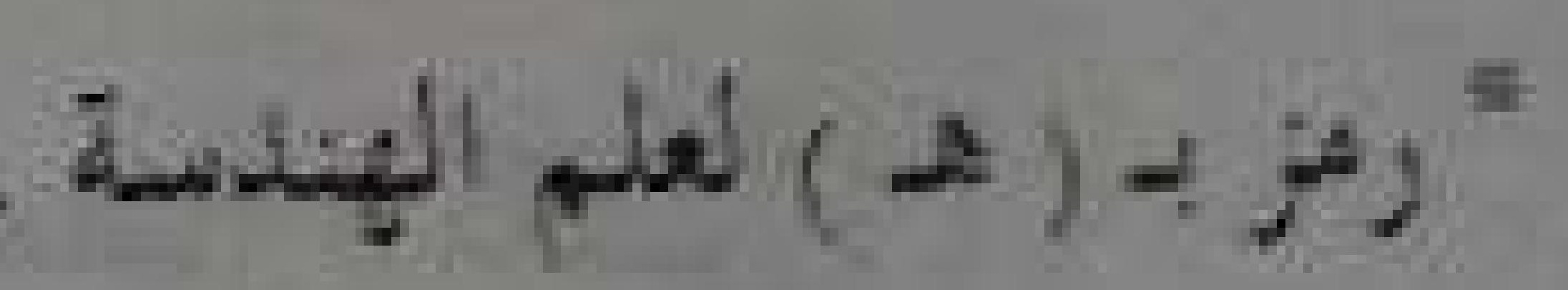

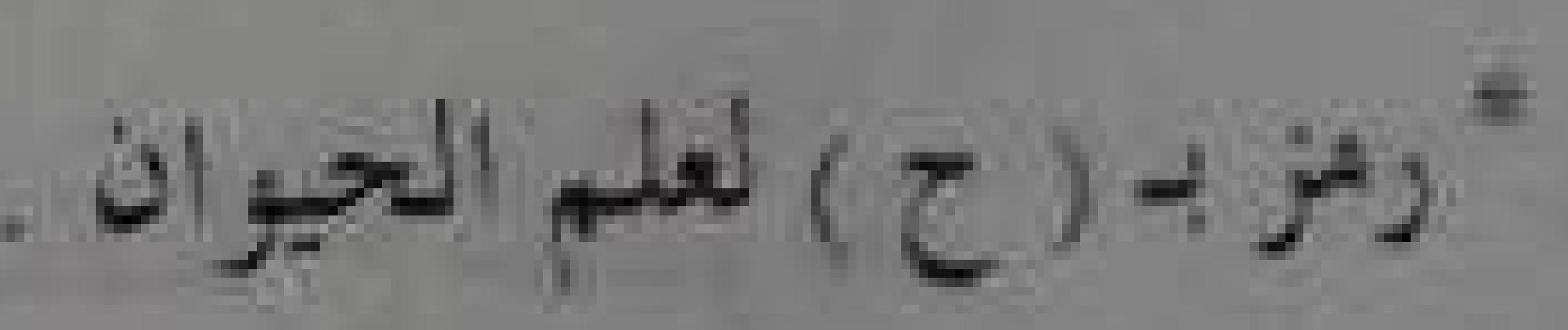

"رثز ب)

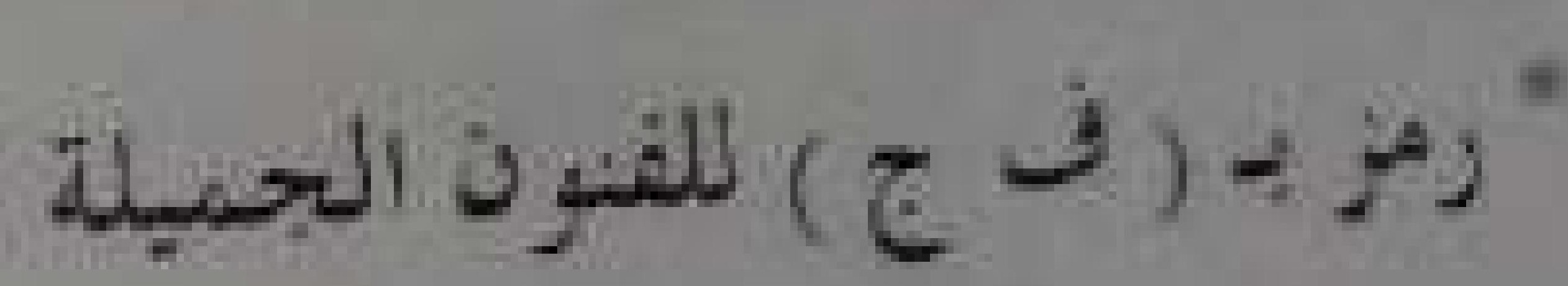

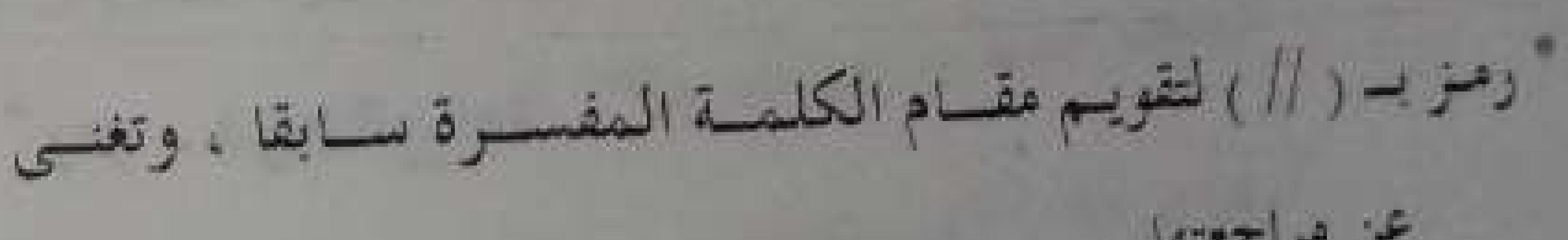

$$
\text { tose }
$$

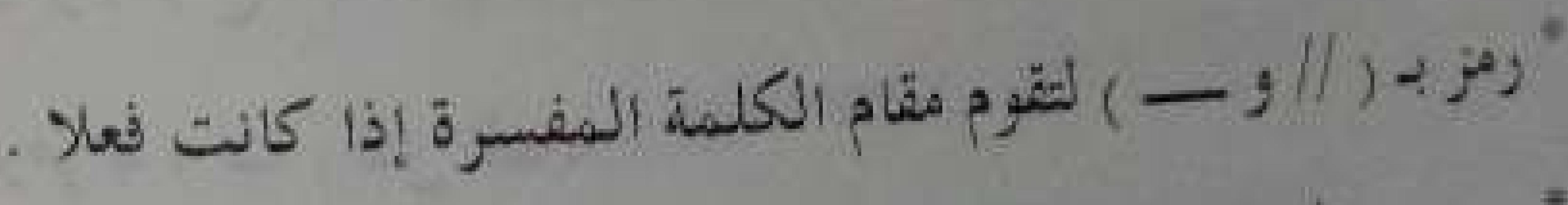

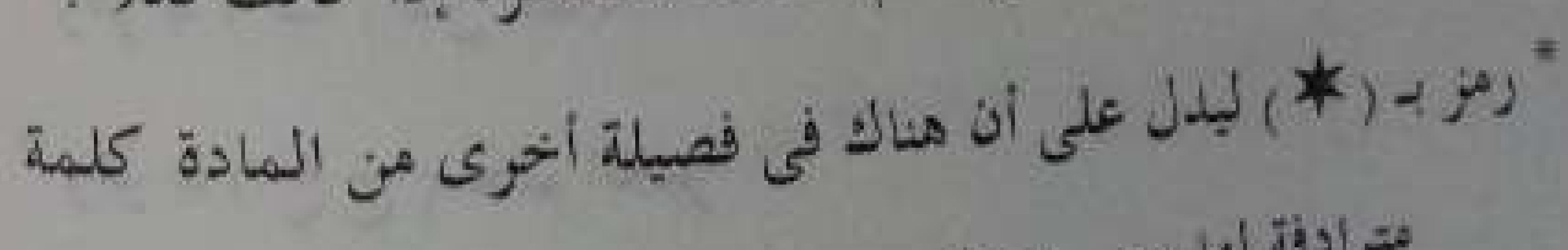

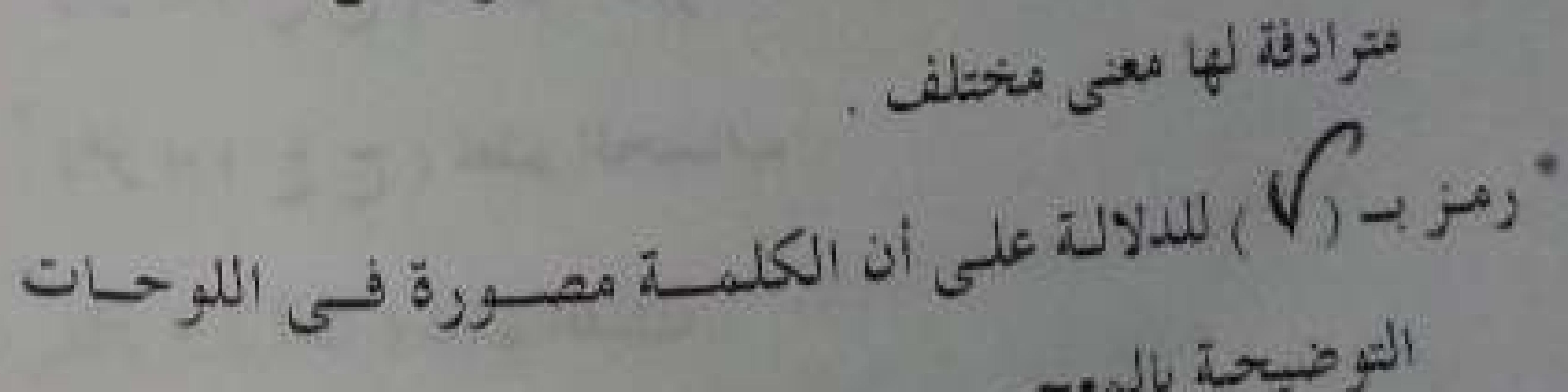

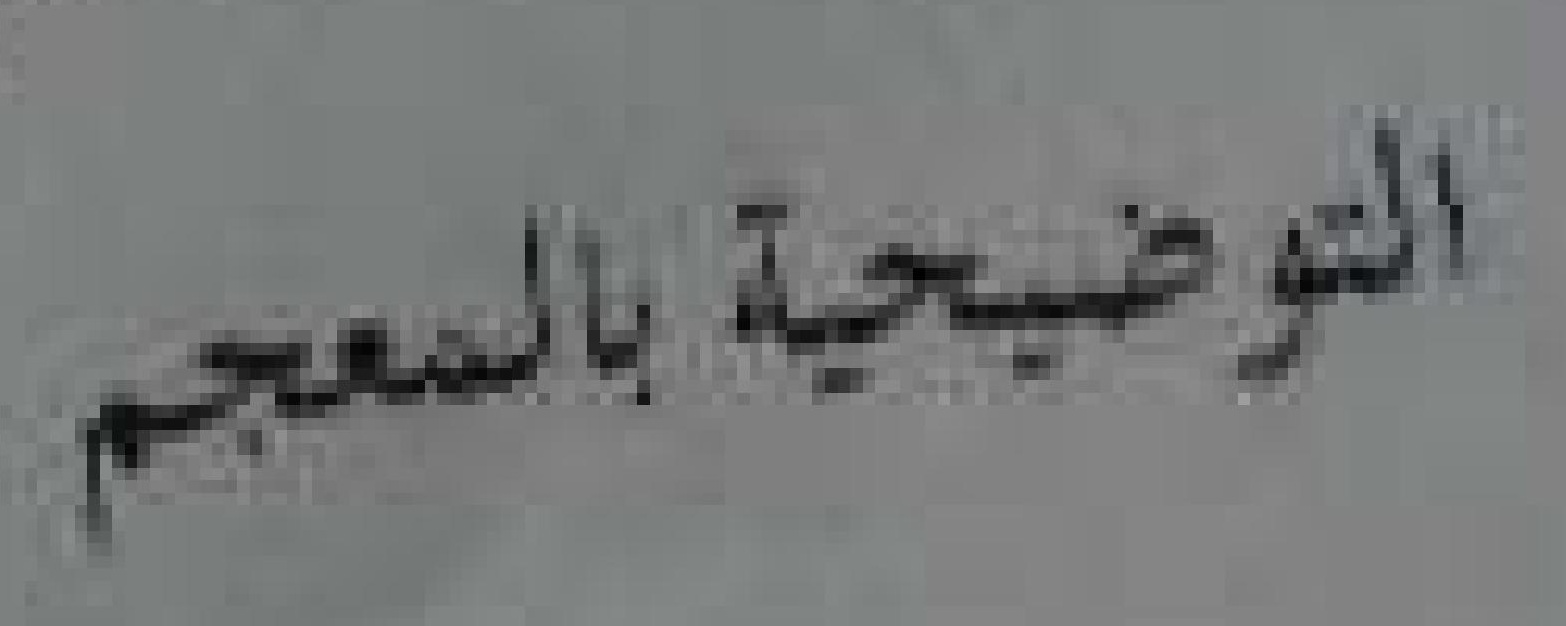




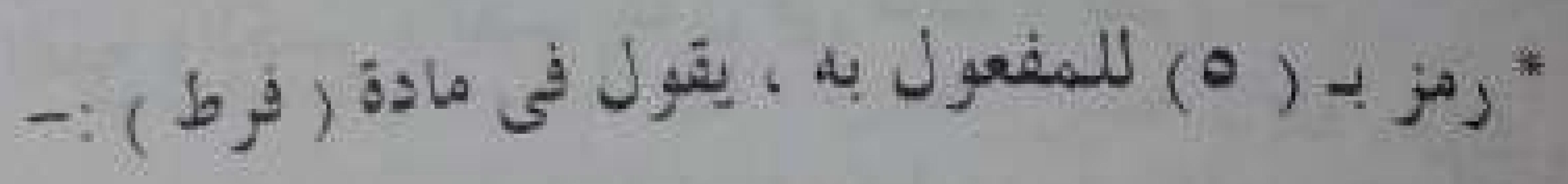

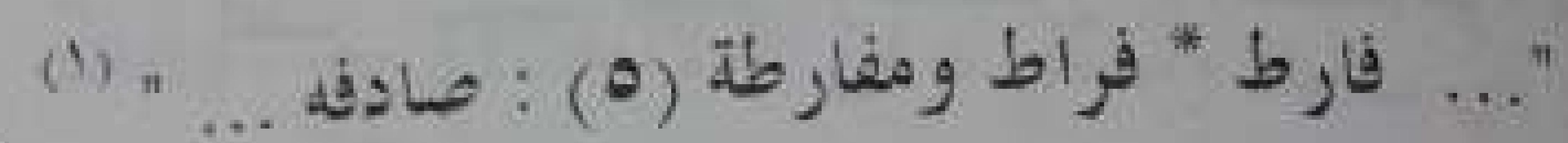

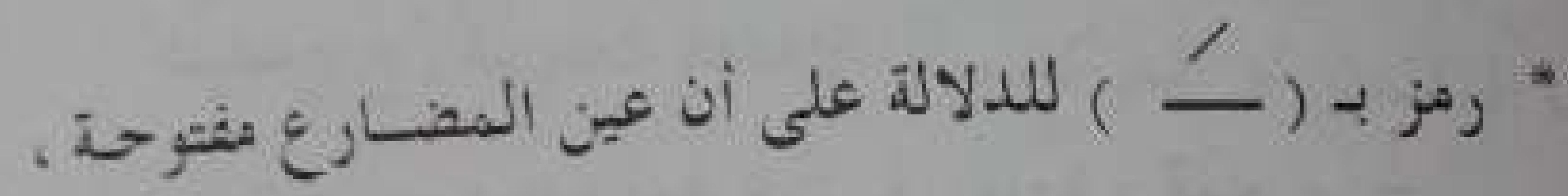

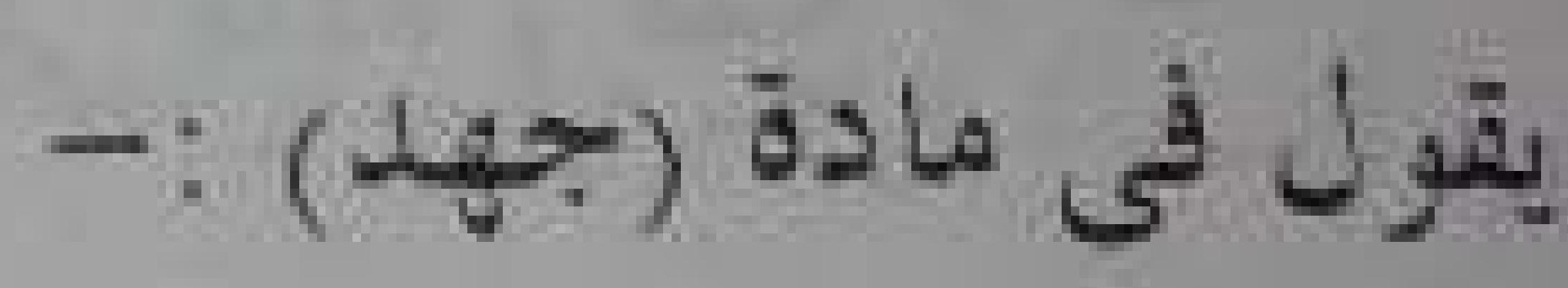

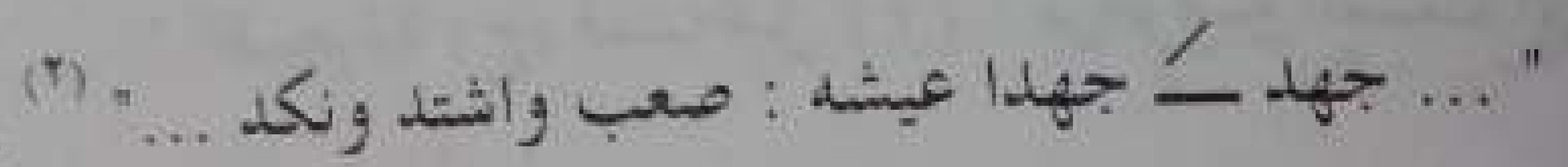

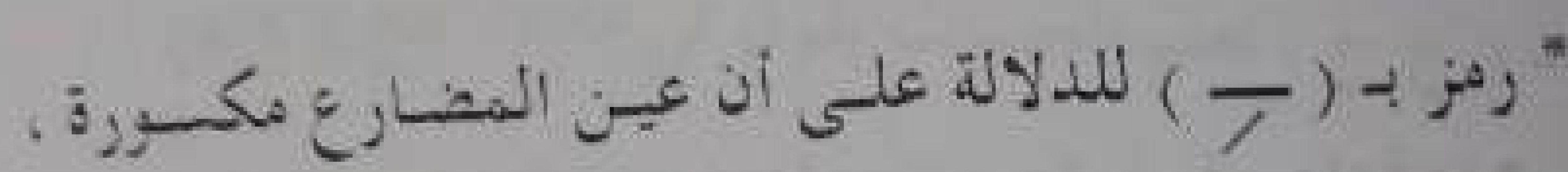

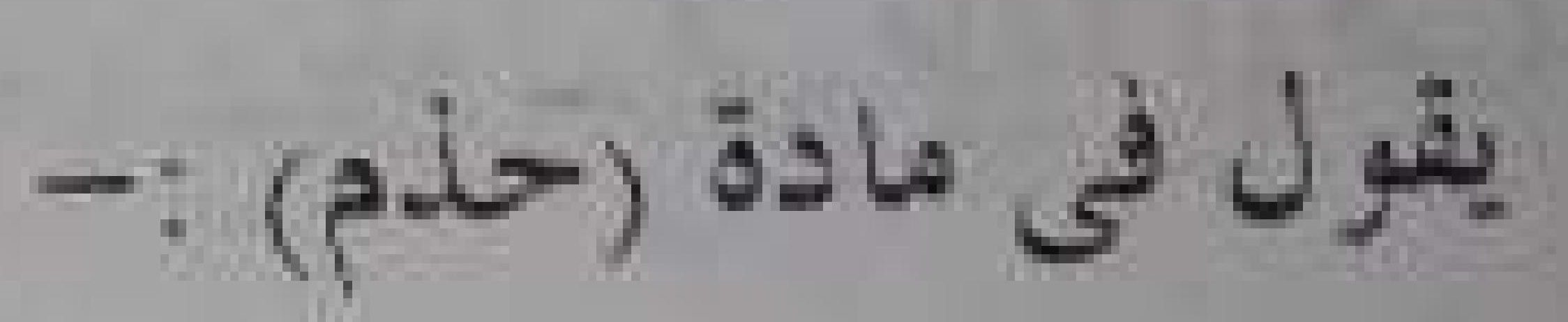

||

(T) " ... ت

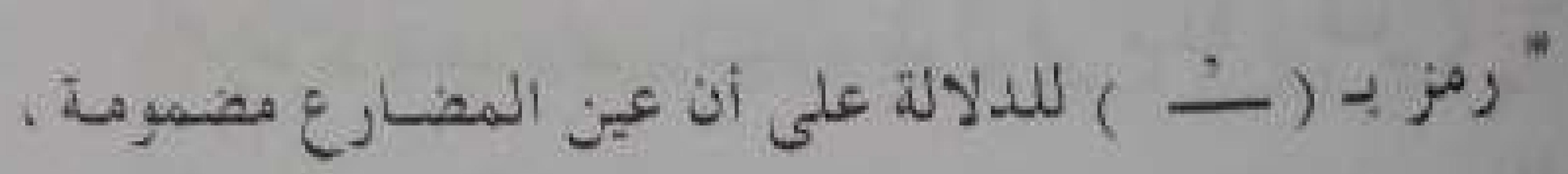

يقول في مادة (جلف) :-

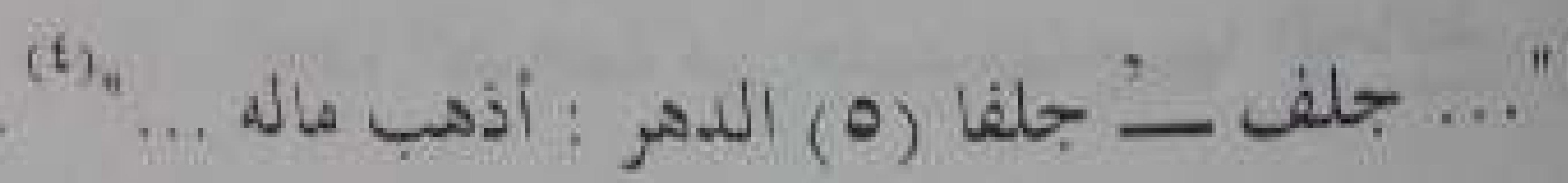

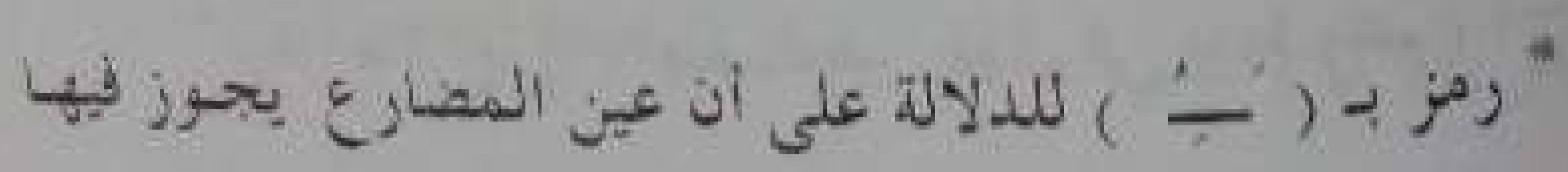

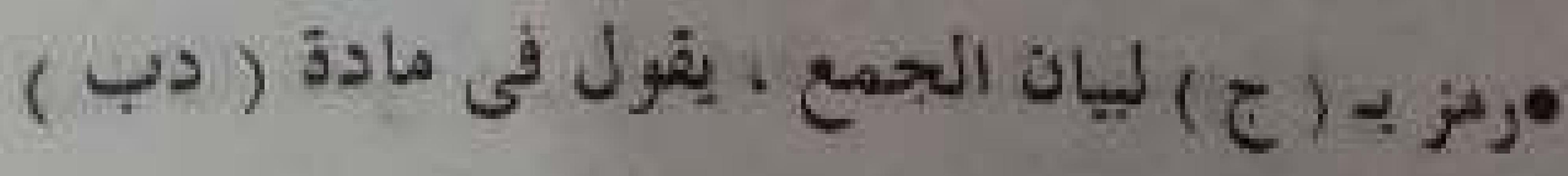

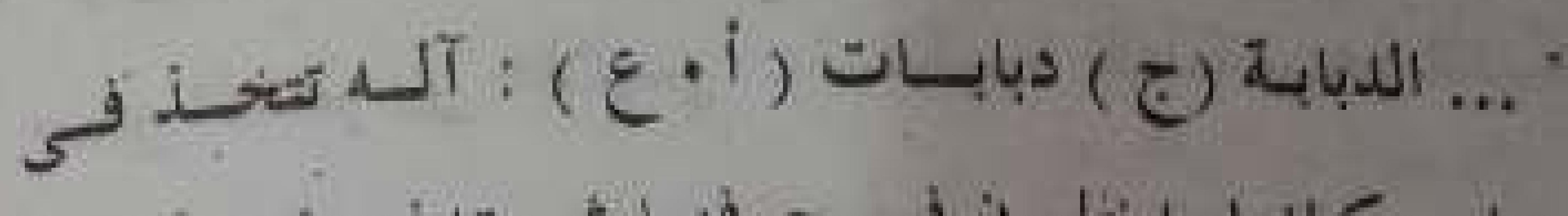

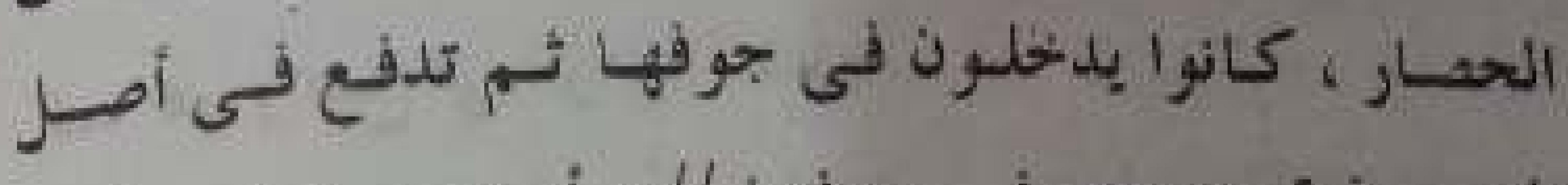

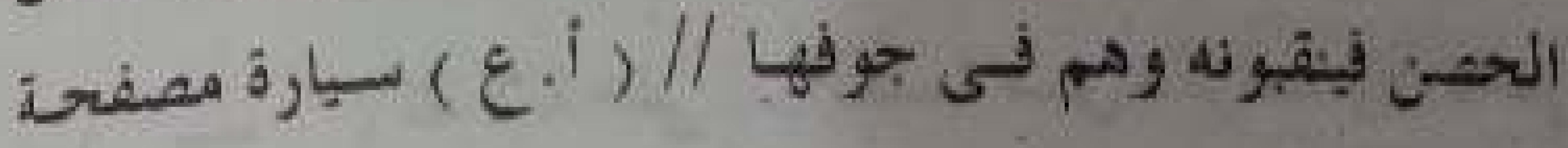

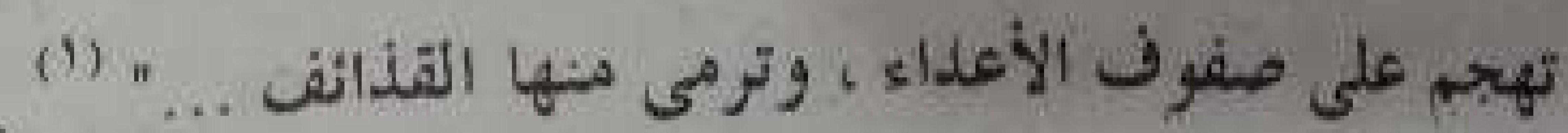

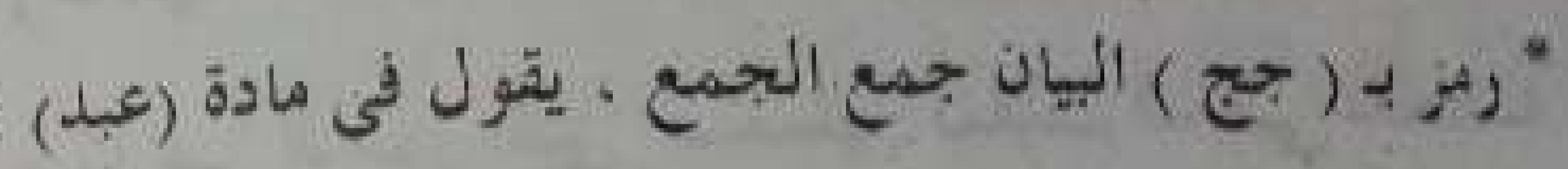

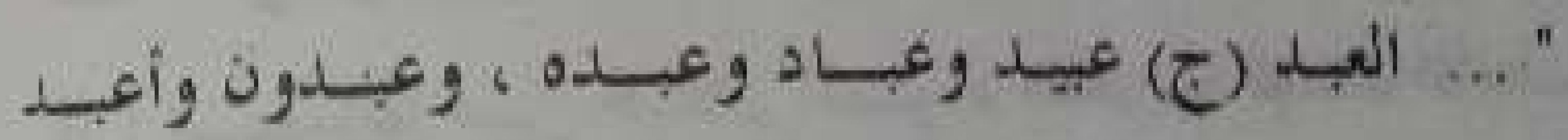

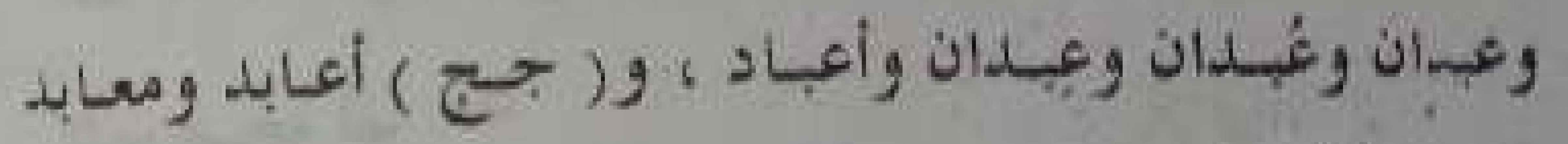

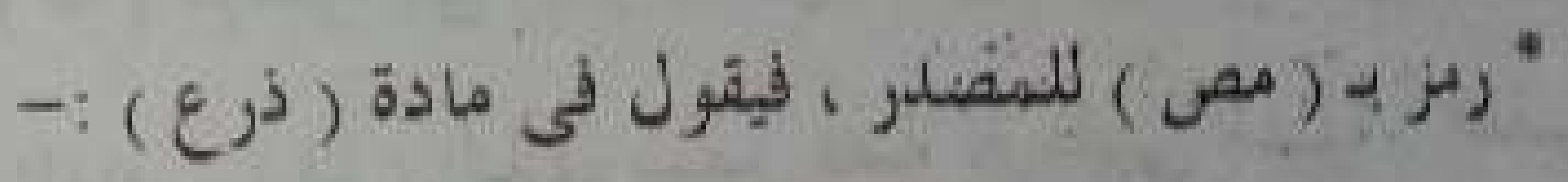

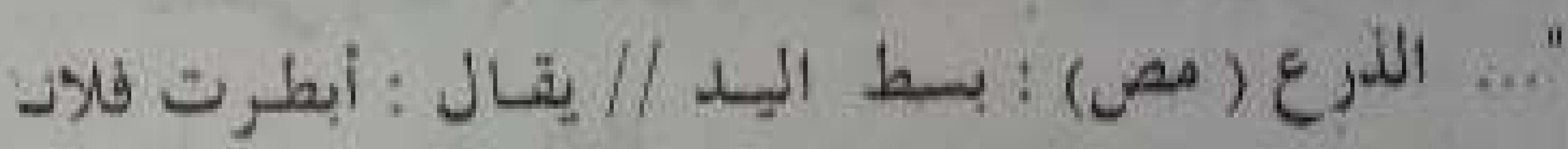

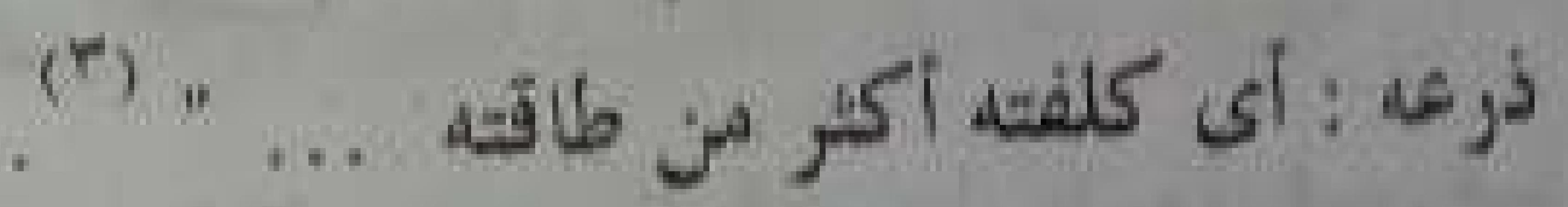

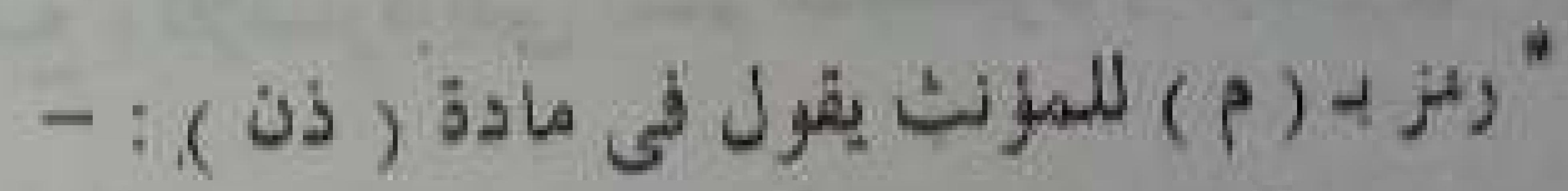

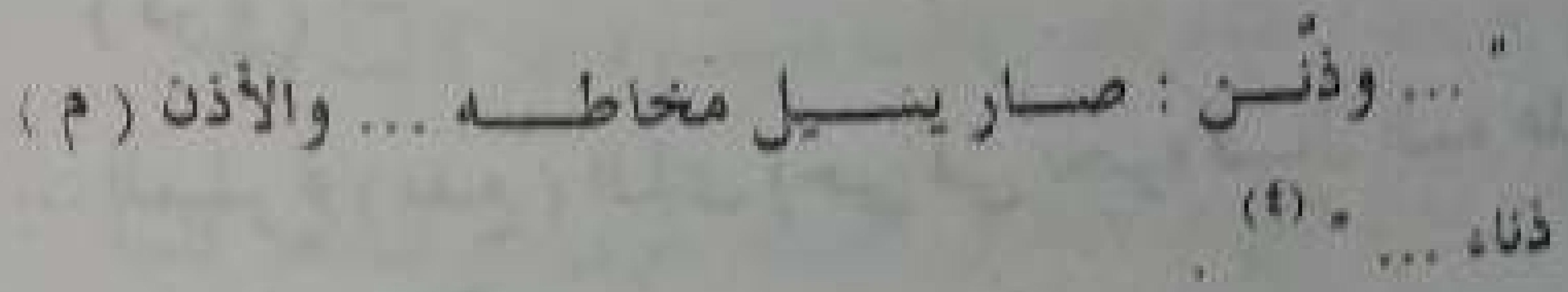
(د) ب

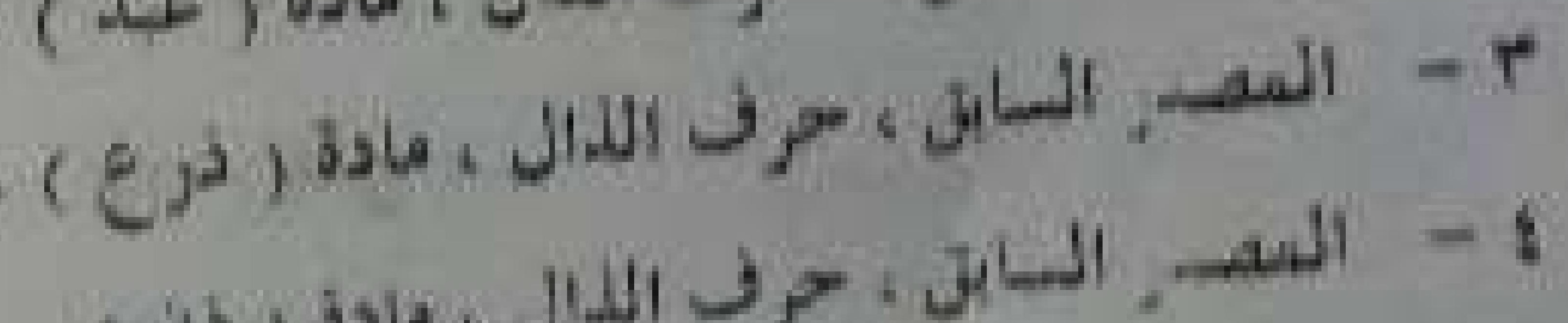

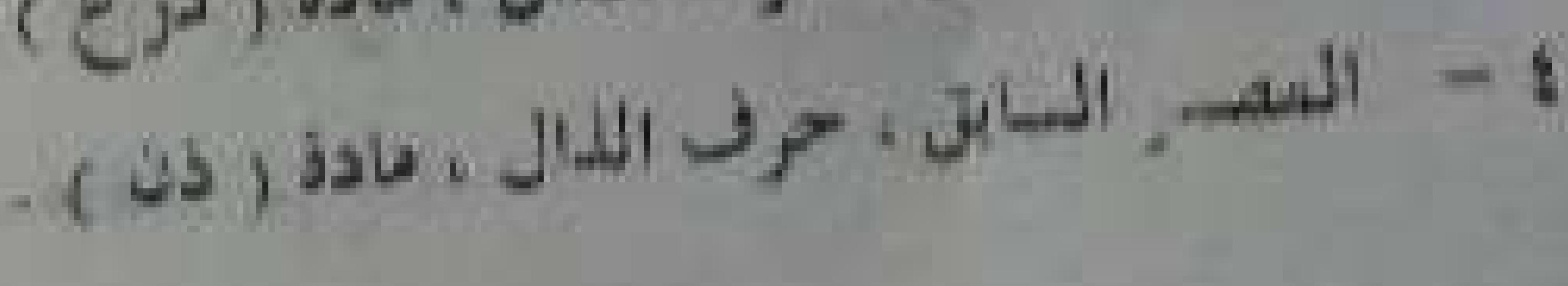




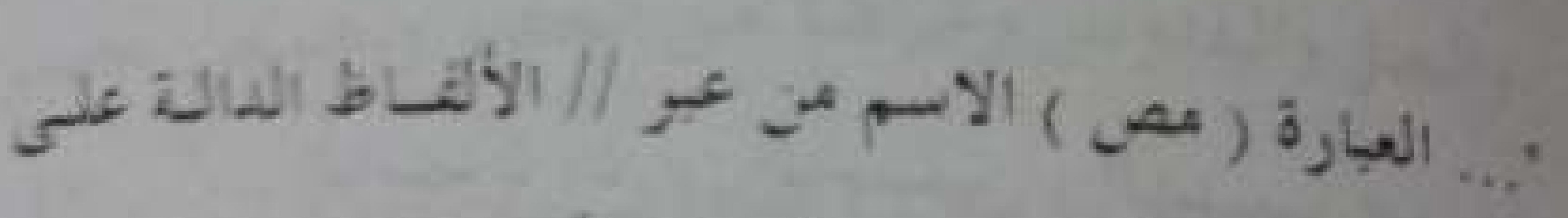

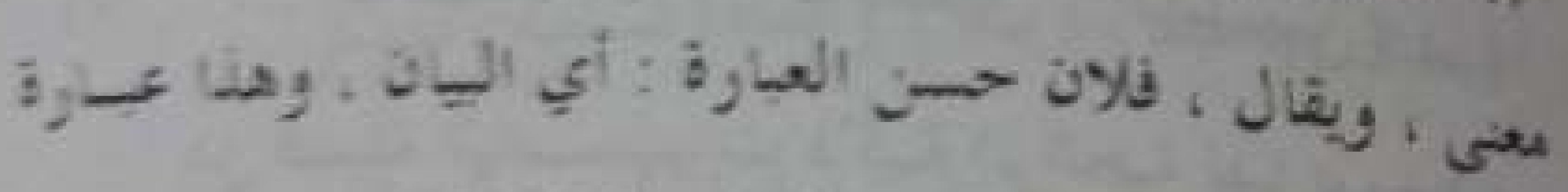

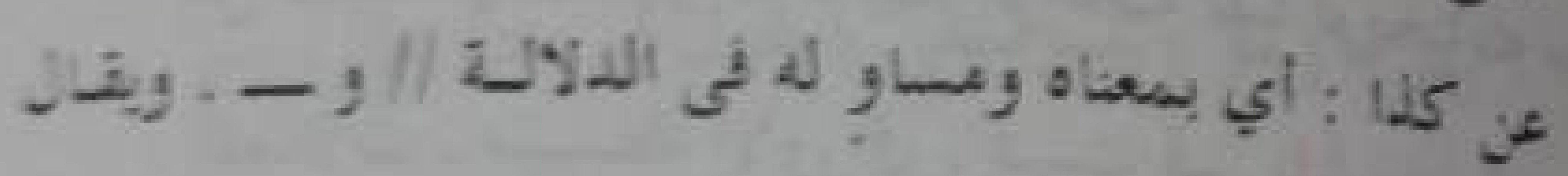
A

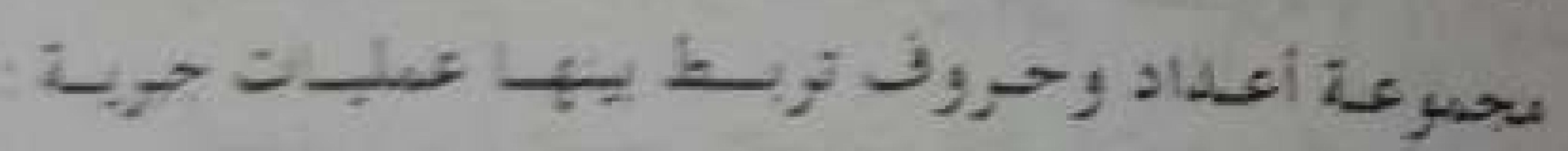

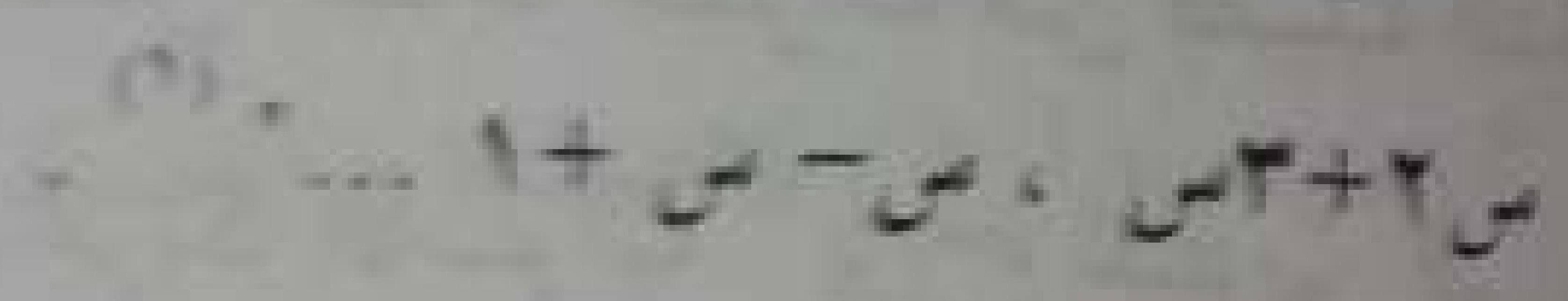

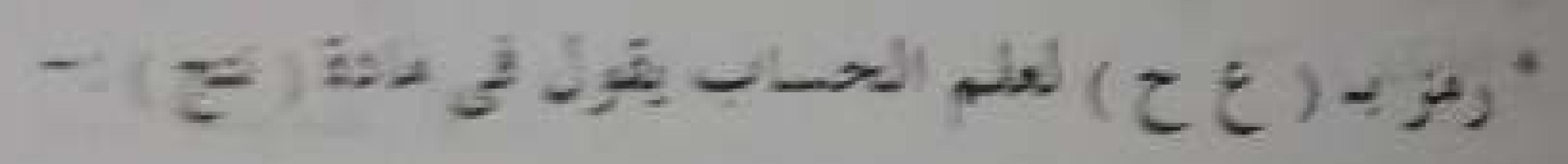

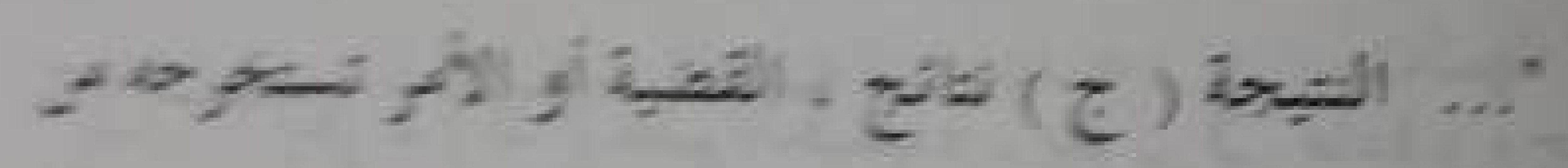

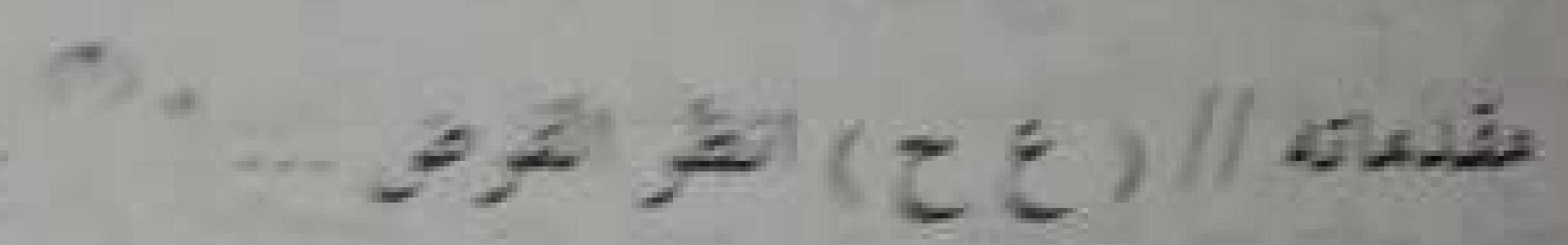

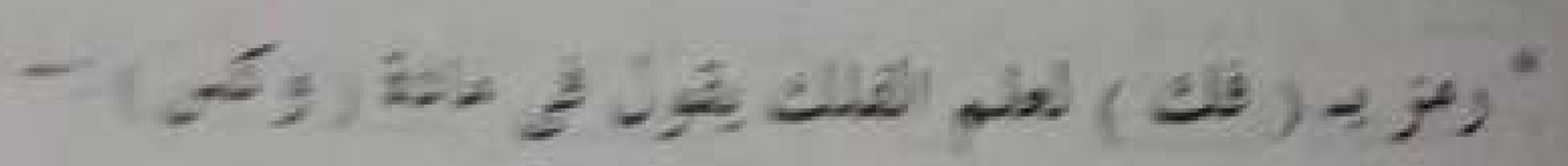

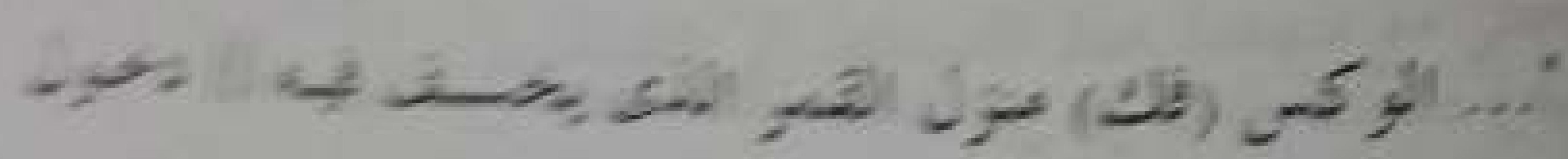

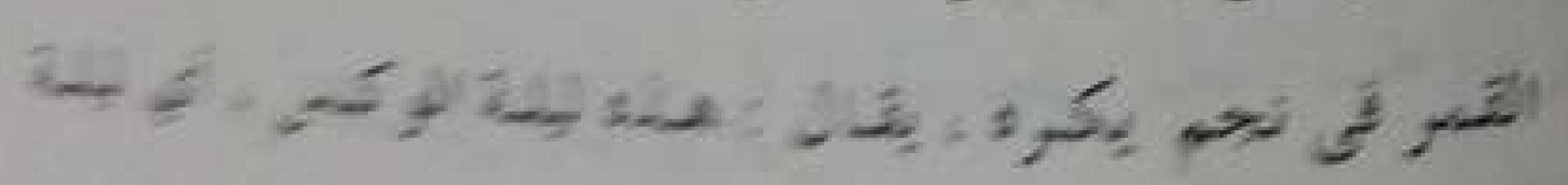
l.

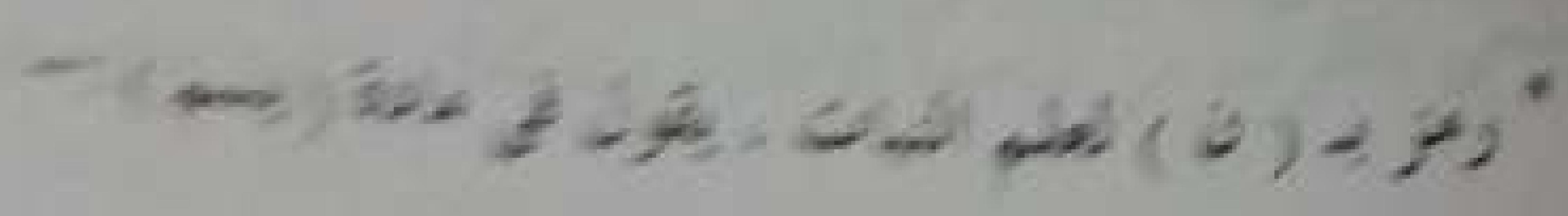

\section{$-r r q-$}

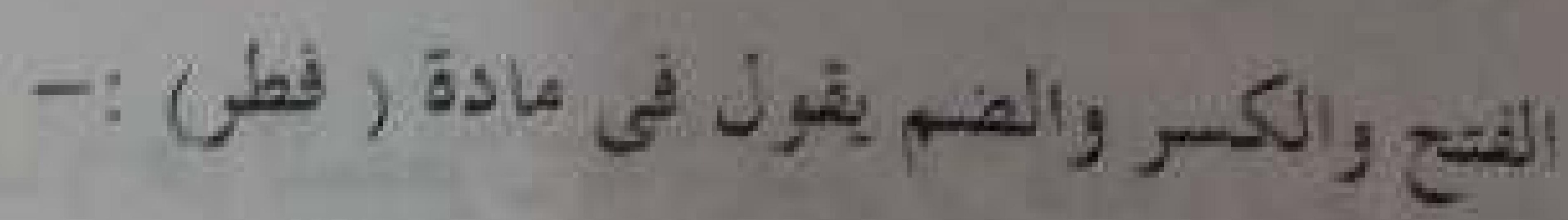

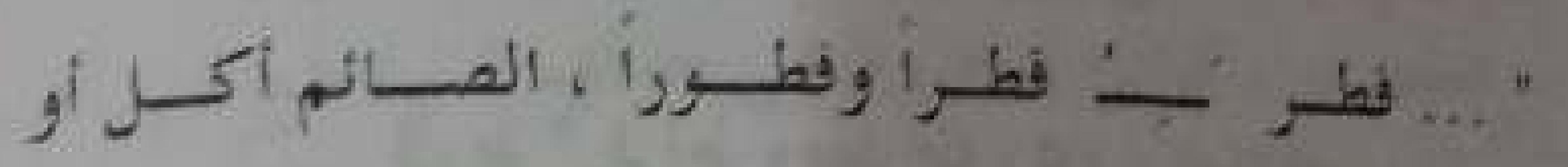
(1) $\ldots+4$

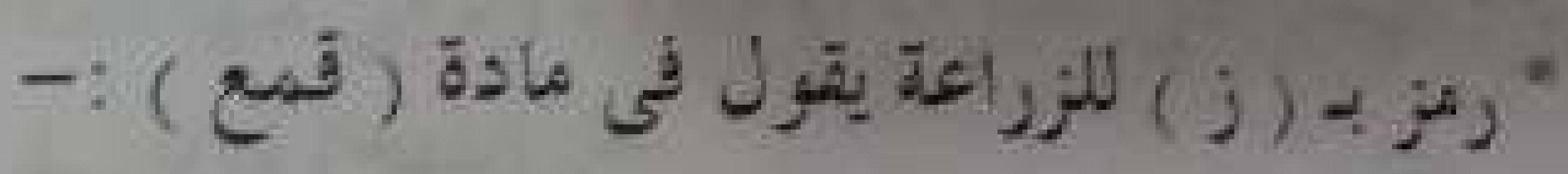

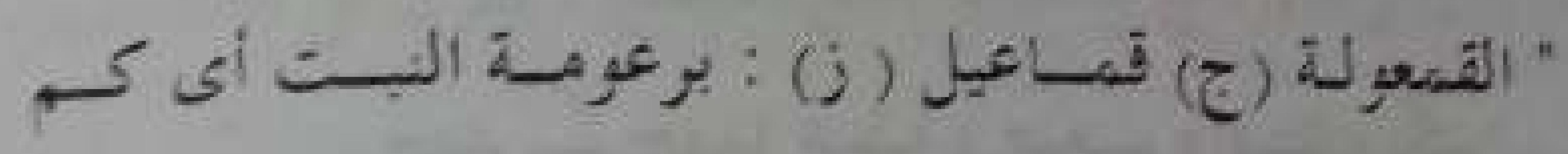
(5). $0, j$

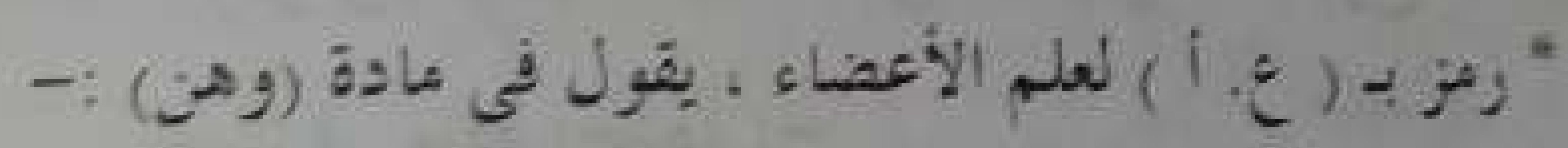

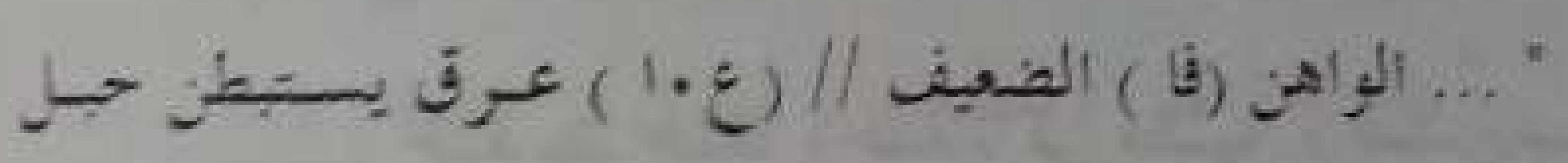

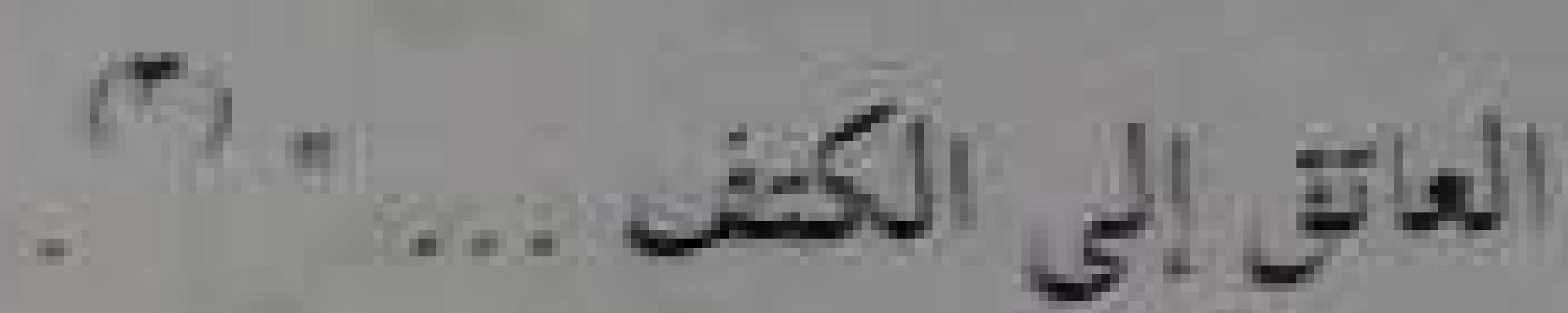

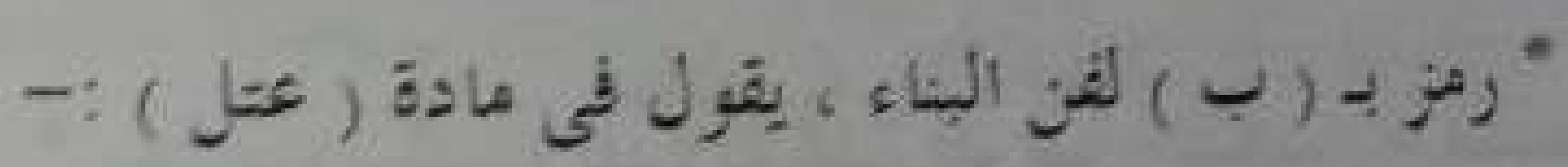

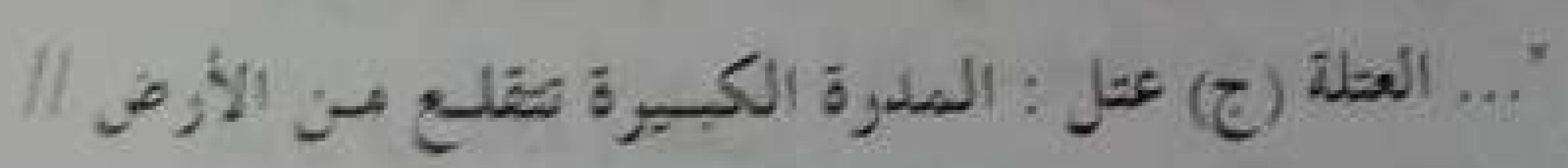

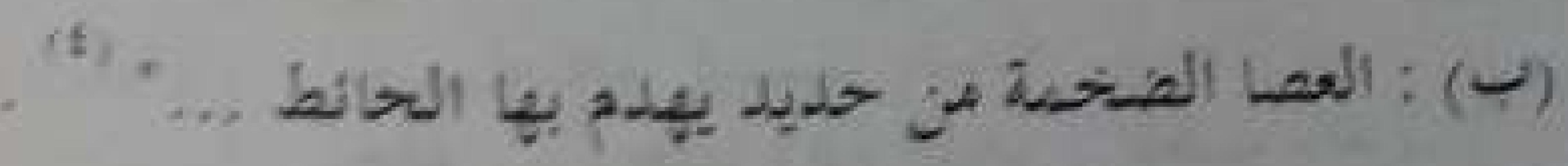

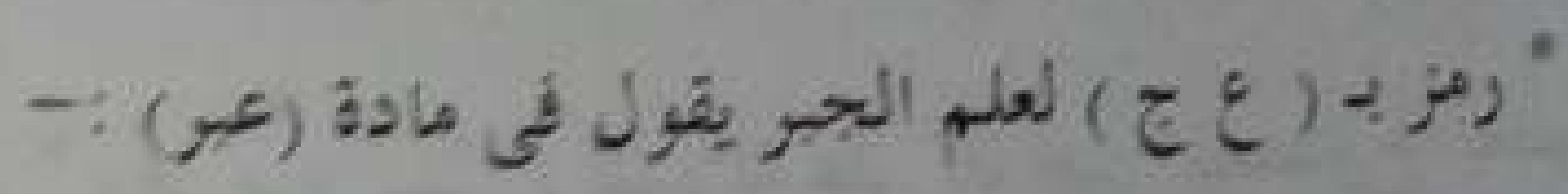

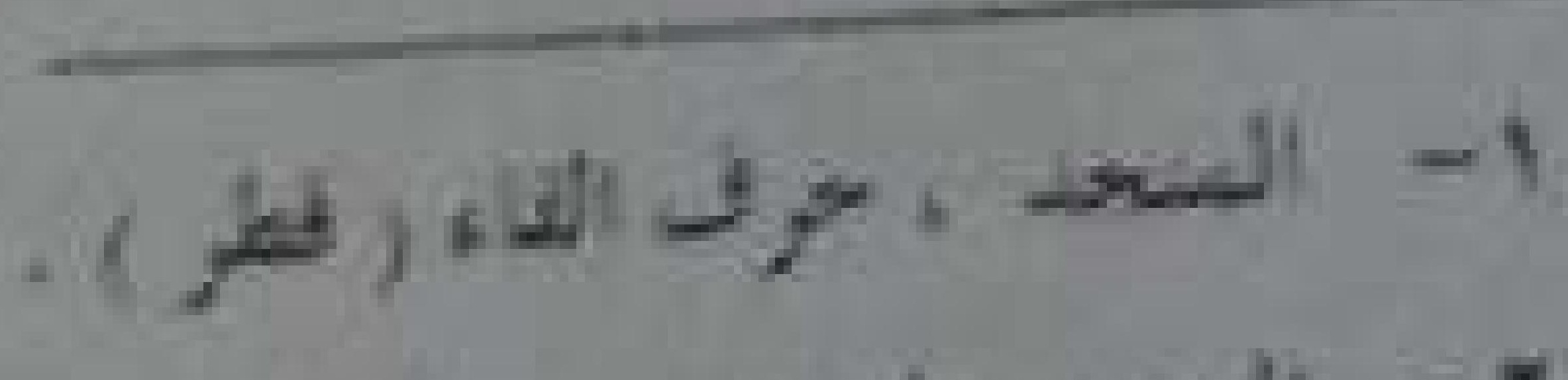
(c) (A) ) (A) (t) - 
والبمل والبقدونس وغيرهـا من الخضر ويحمـ بعصير

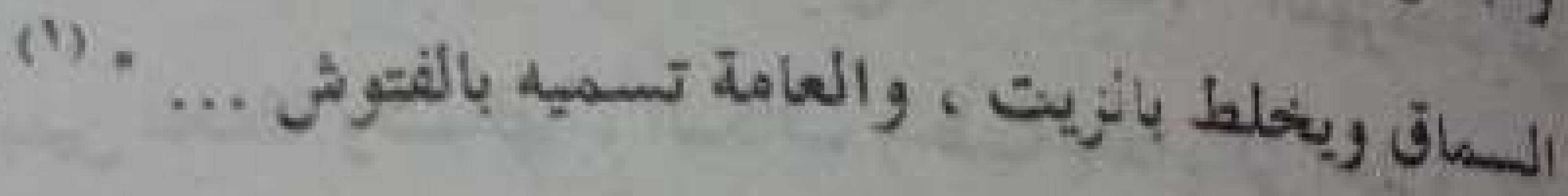

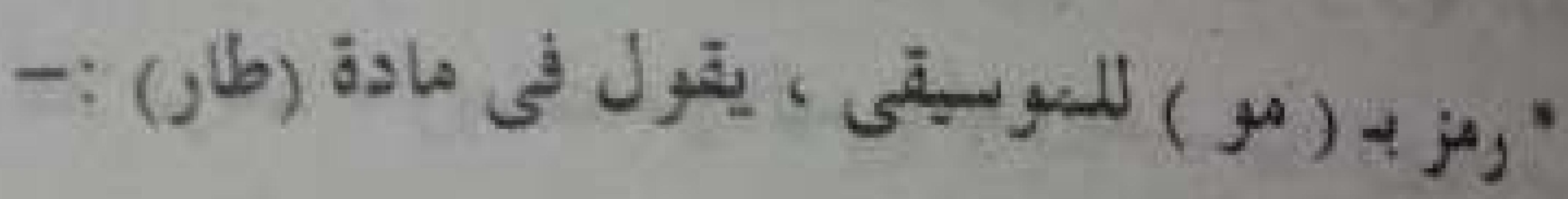

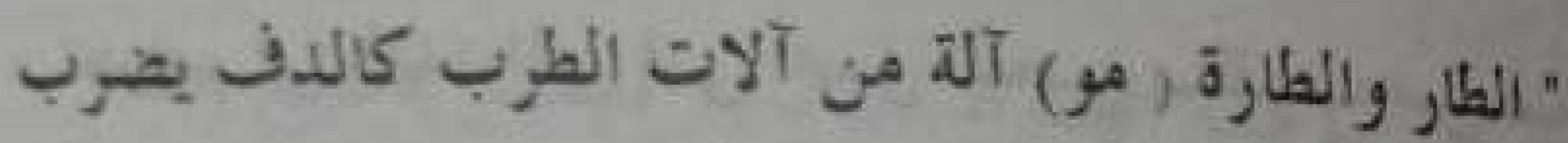

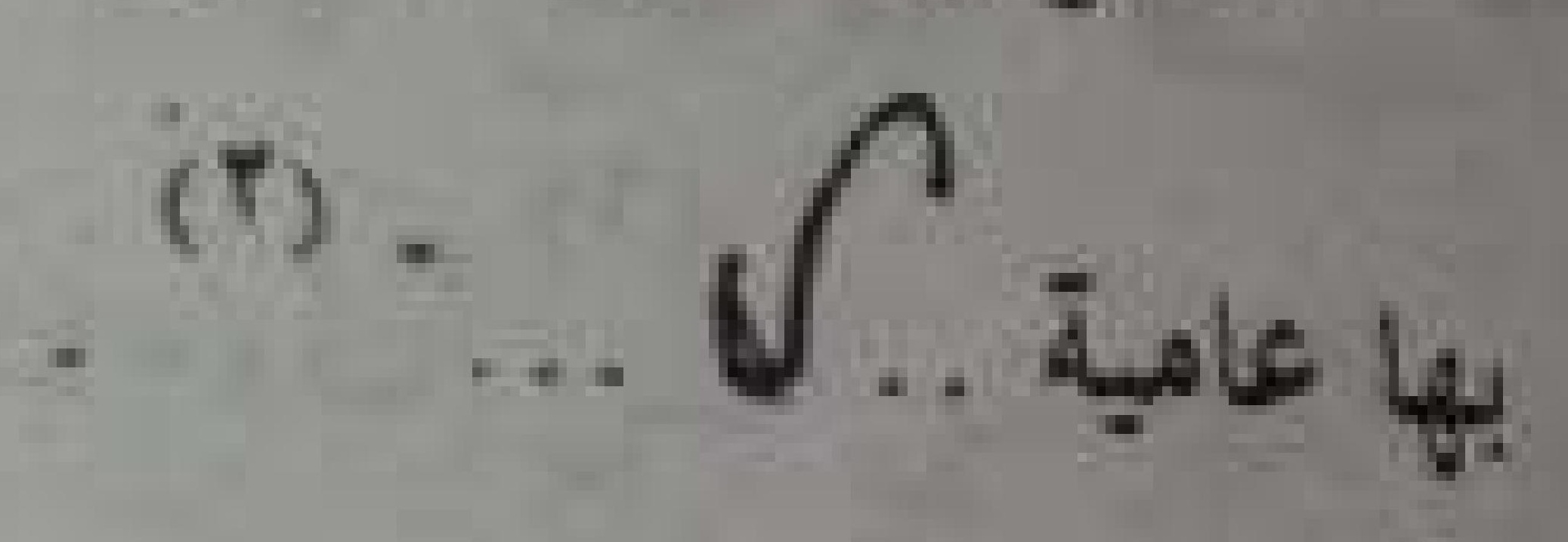

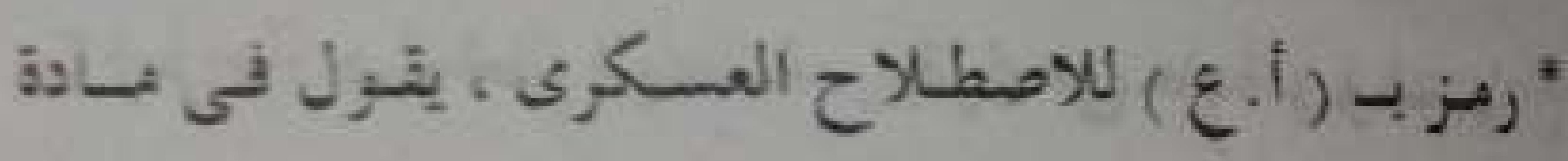
$-:(s+s)$

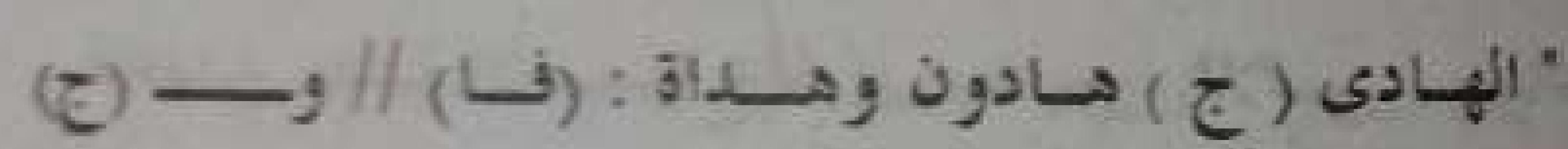

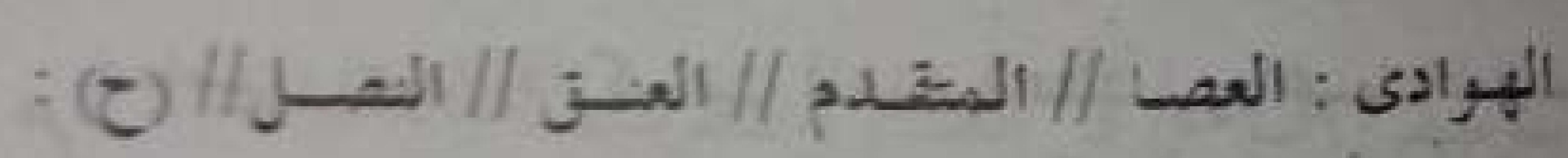

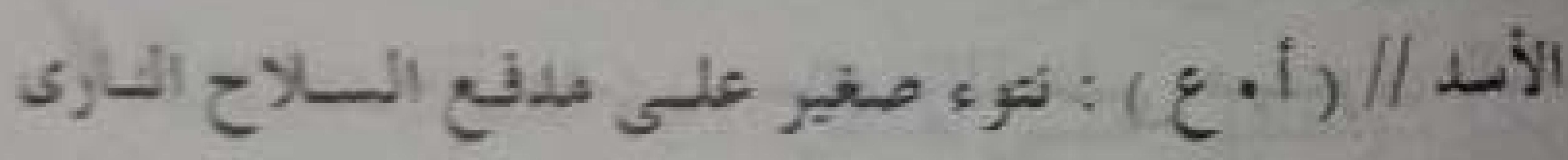

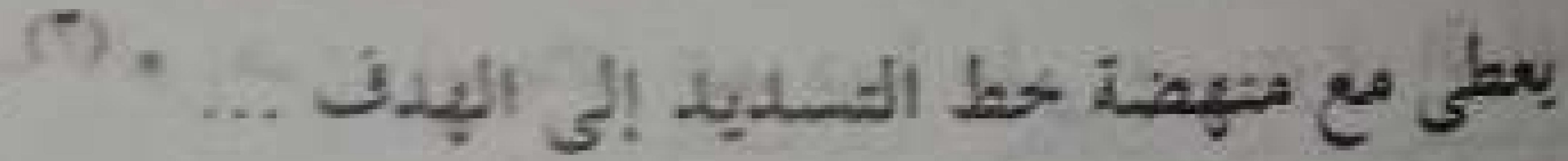

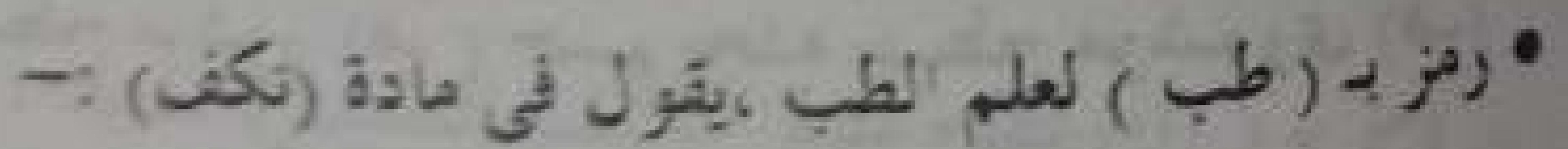

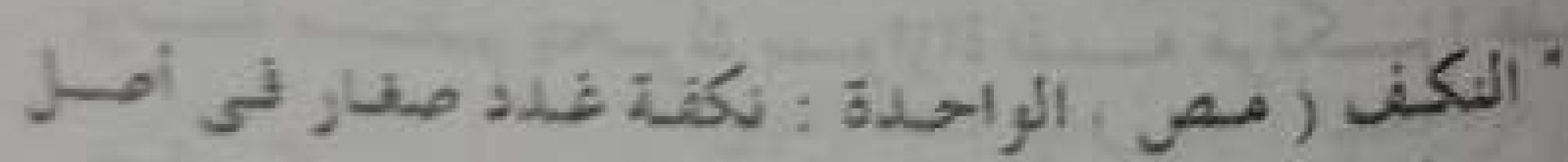

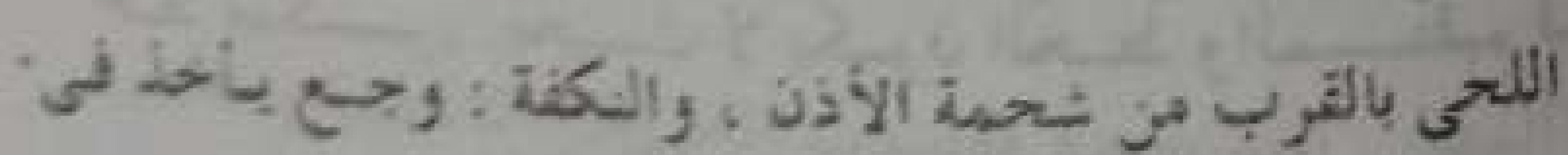

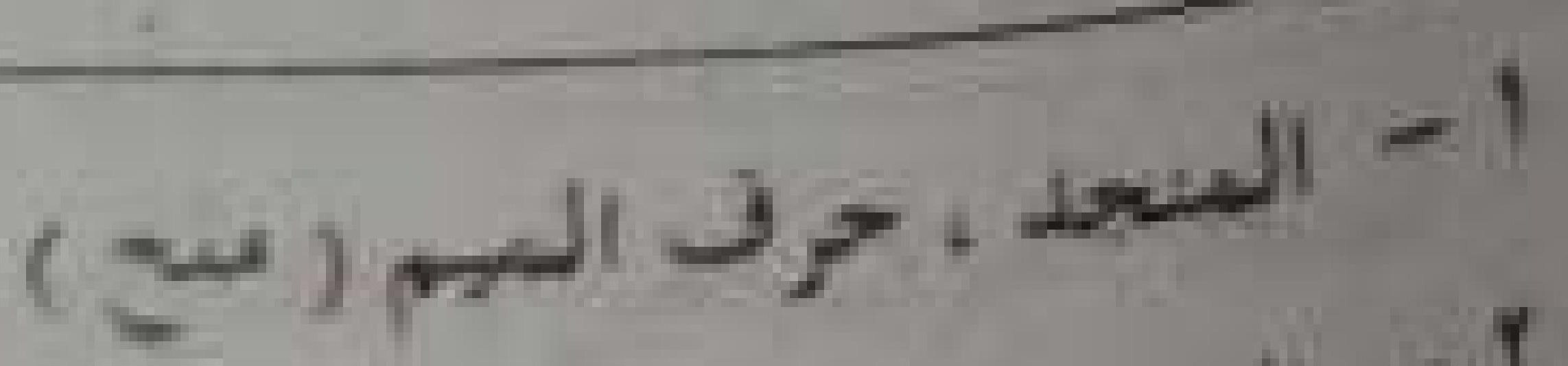

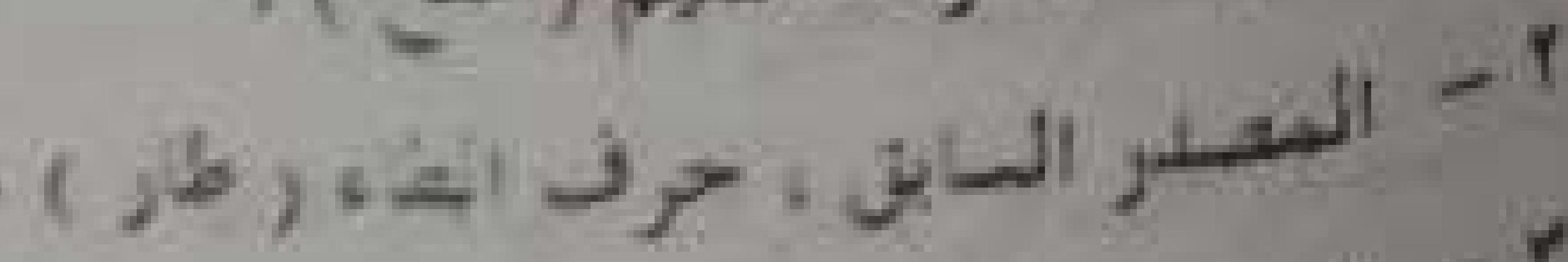

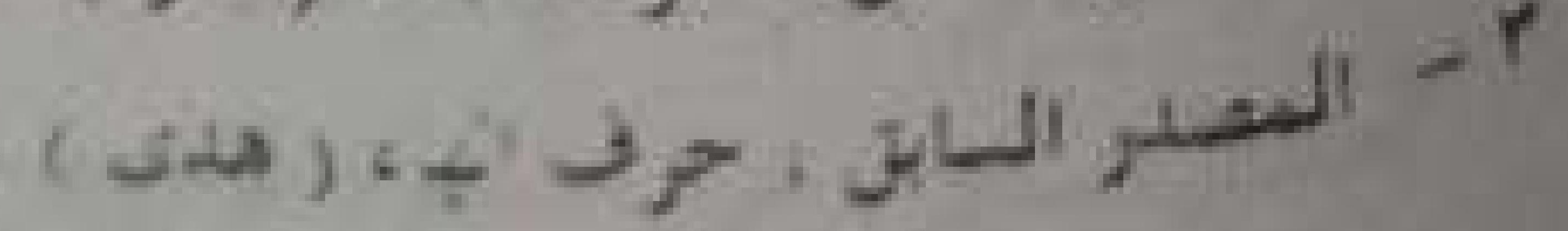

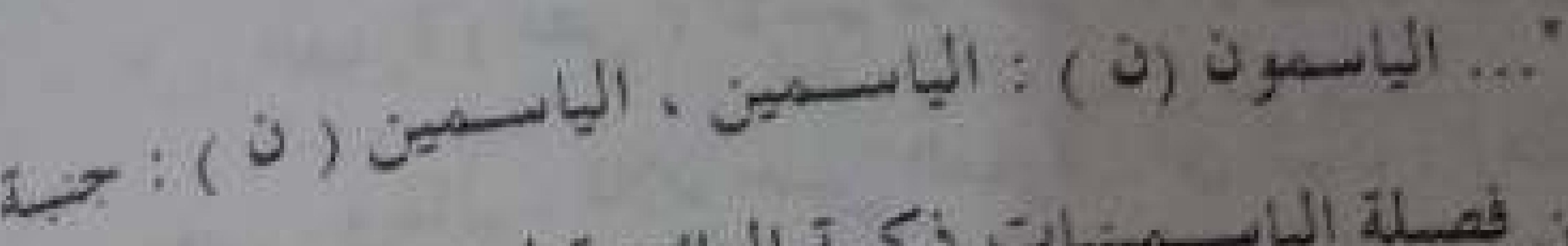

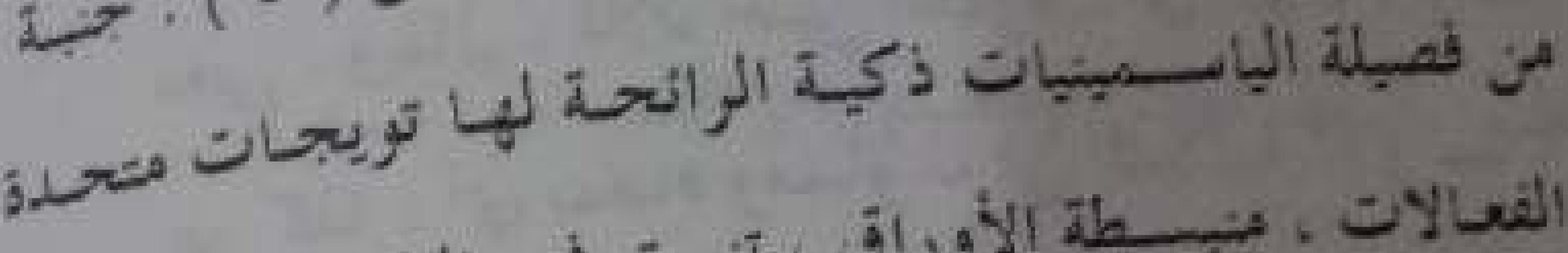

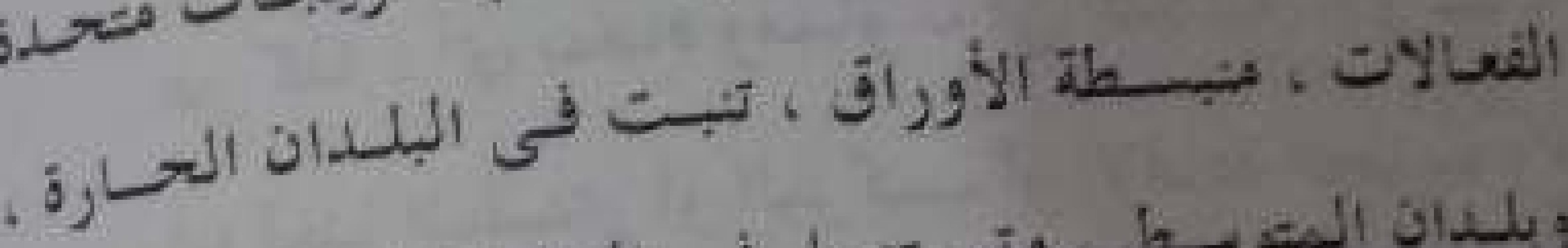

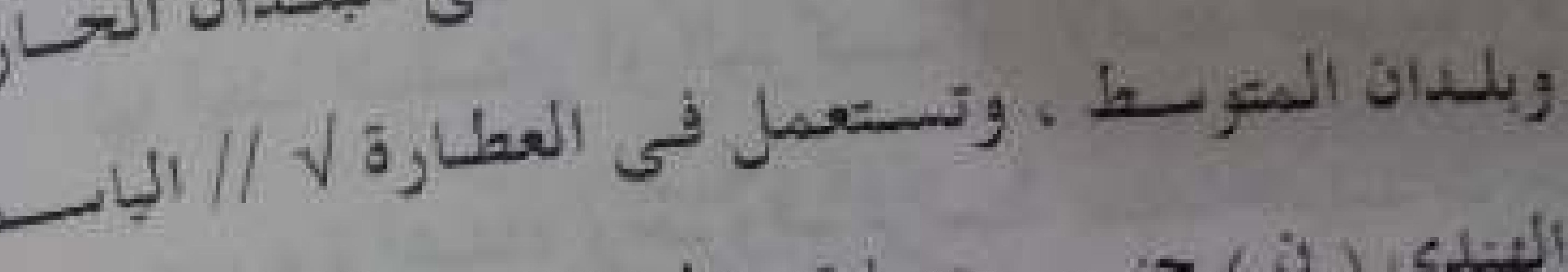
أليندى (ن) ) جسب جنبات علطرات مر فصيلة الدفليات

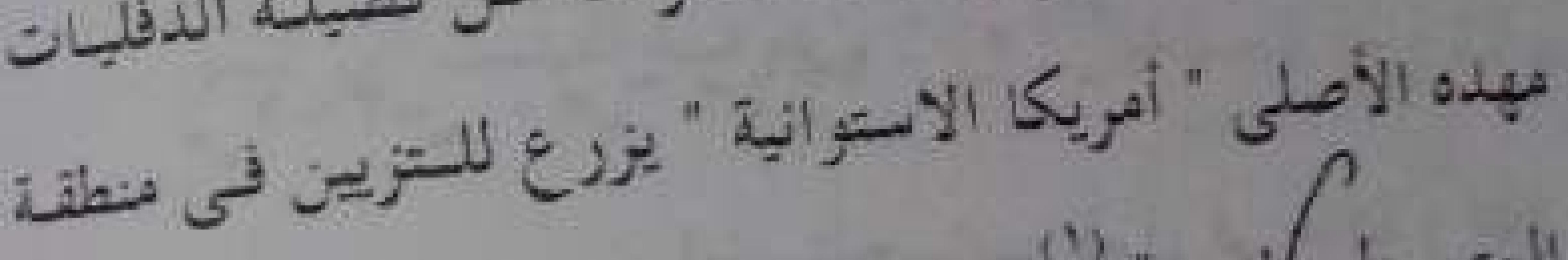

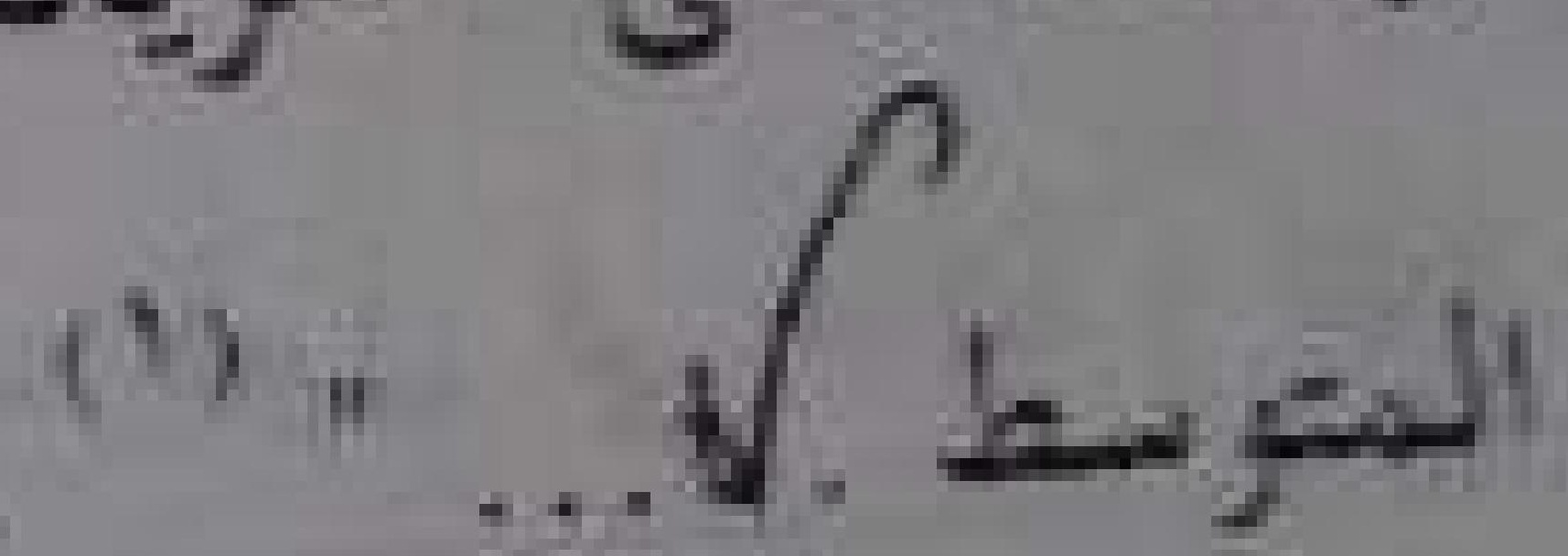

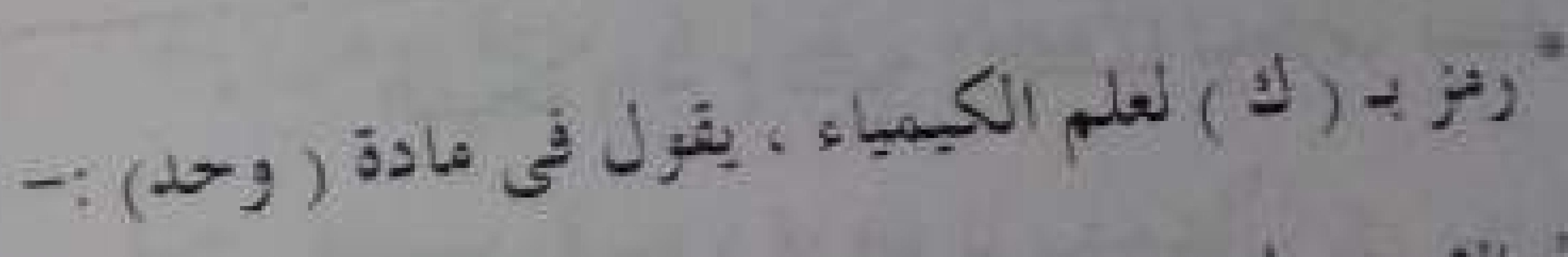

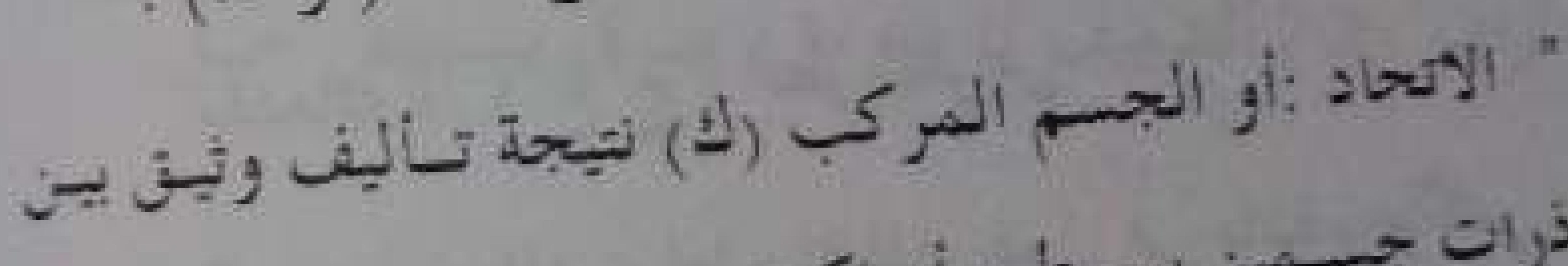

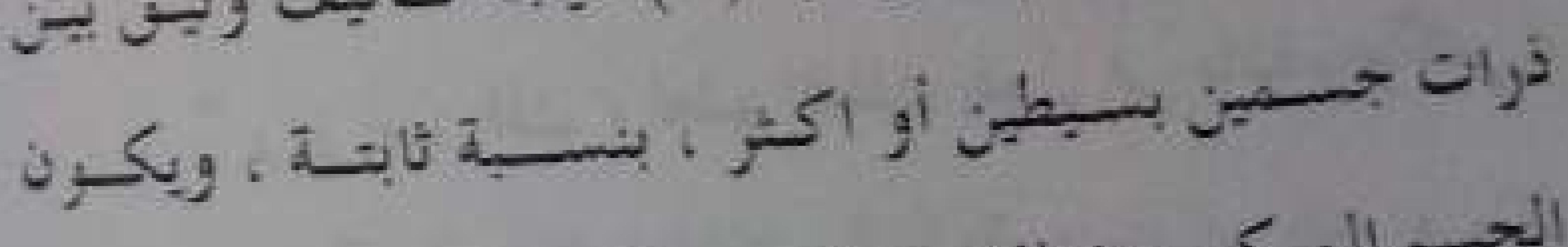

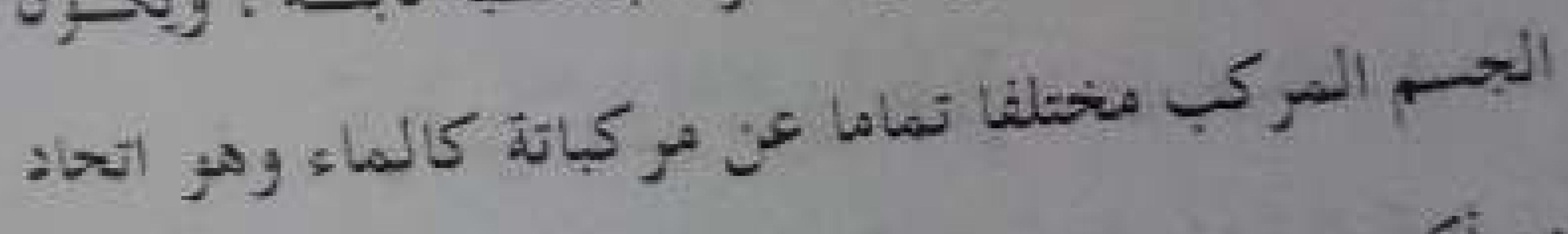
(i) ..... ند $-: 2 \cos$

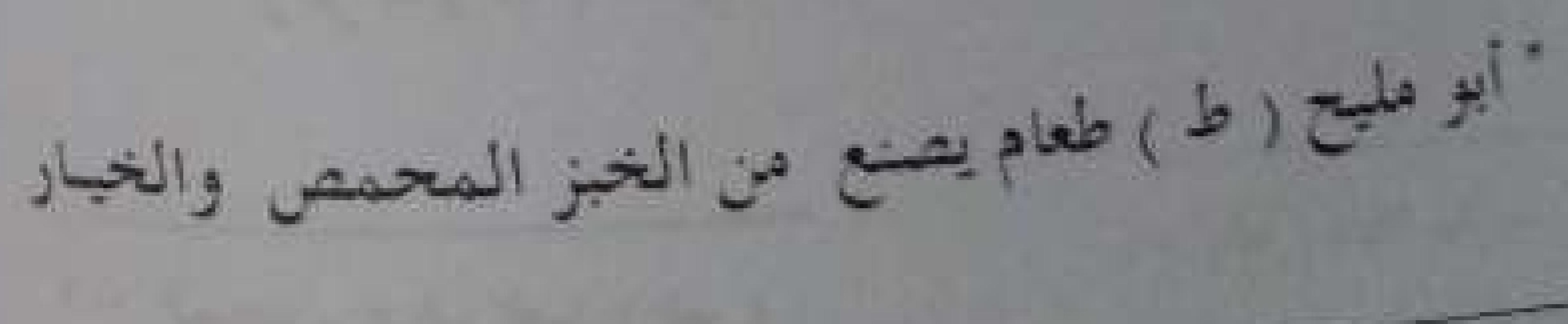

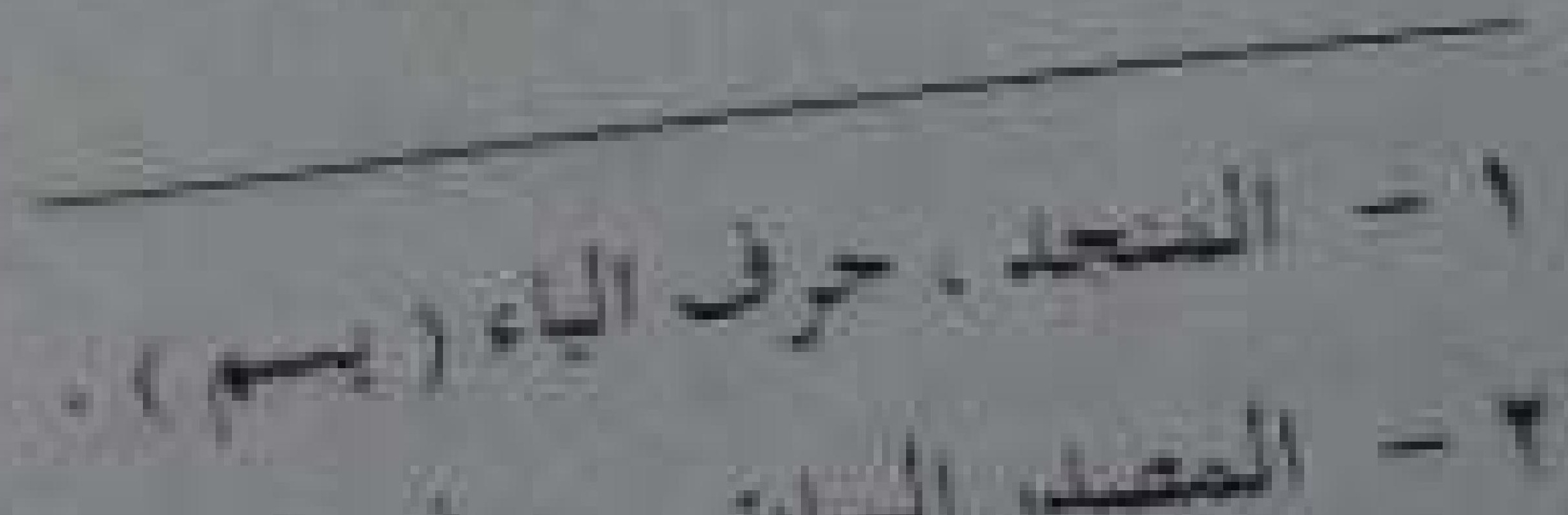

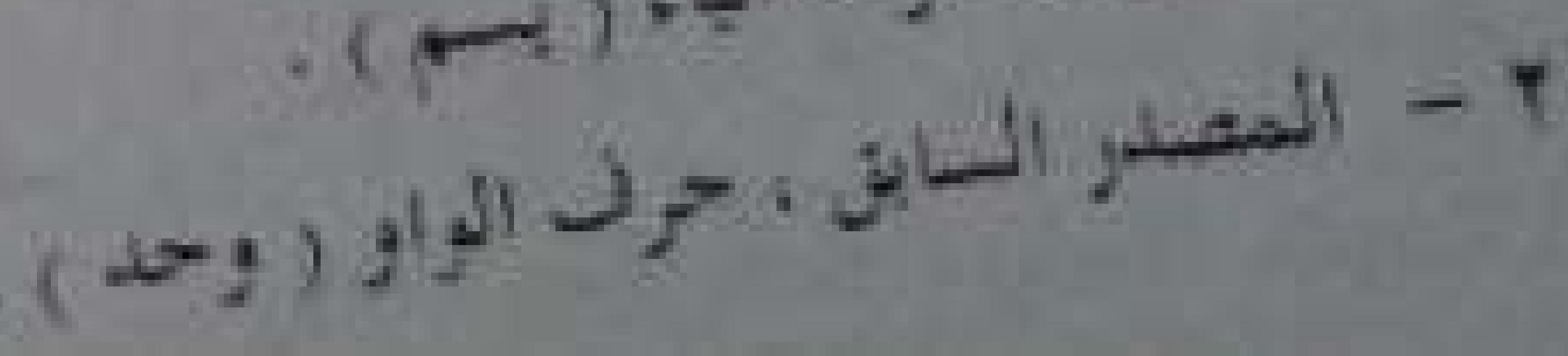




\section{$-r+1=$}

"رمز بـ (ح) العلم الحيب ان ، يقول في مادة (عكس):(4).

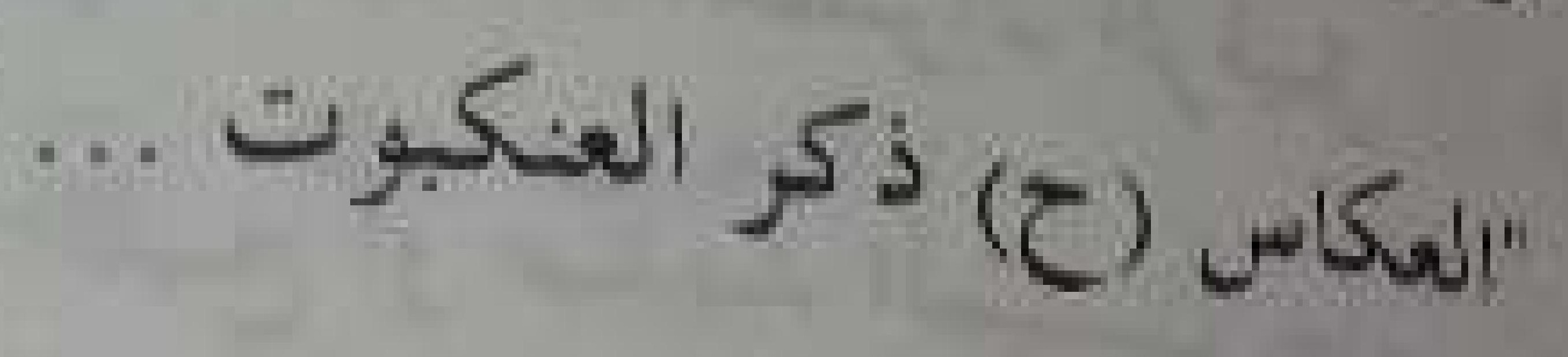

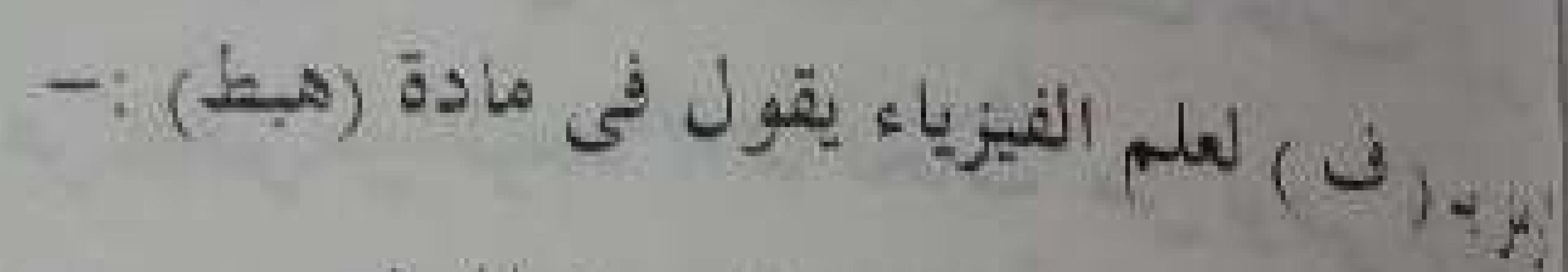

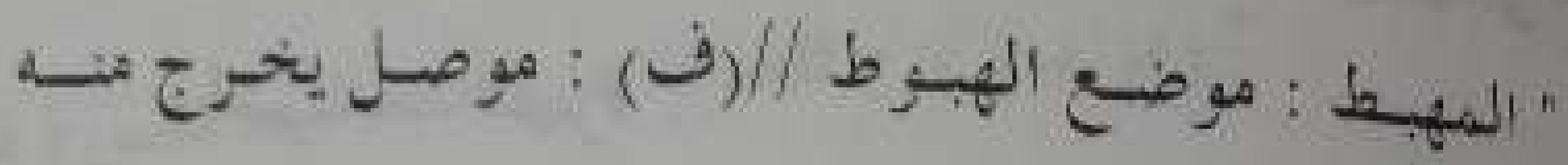

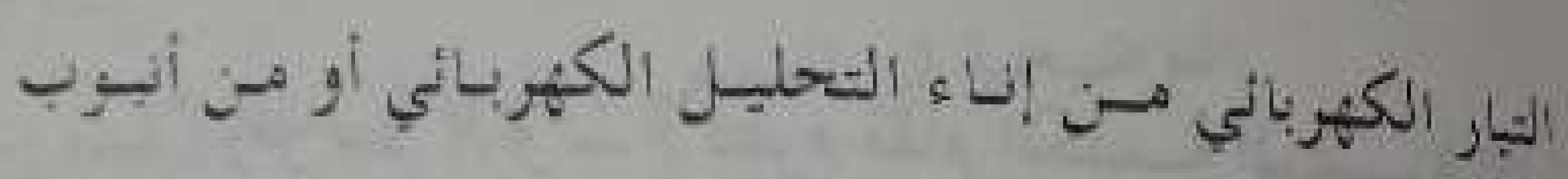

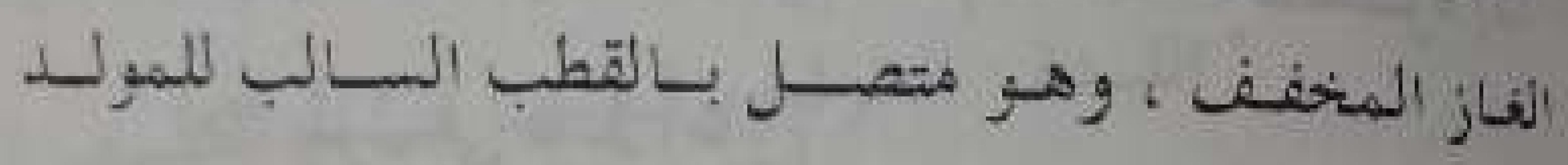
(*) ".... اكني

ربز بـ (ف ج ) للفنو ن الجميلة يقول في مادة (موس ) :

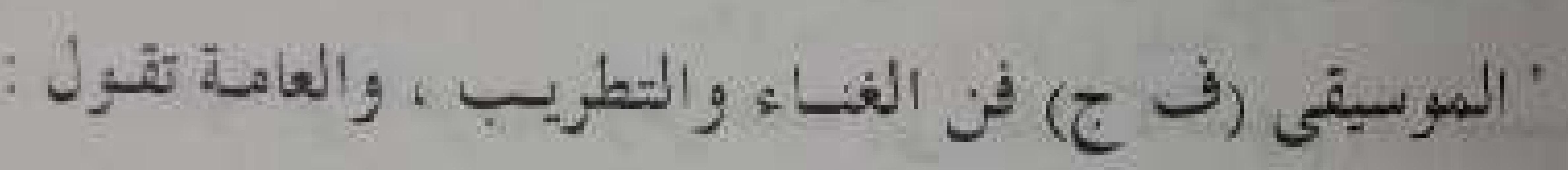

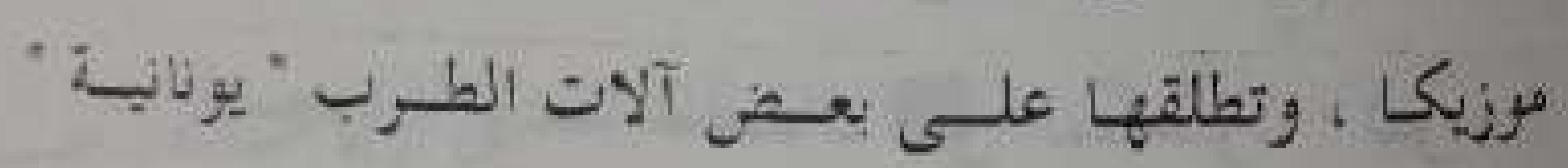

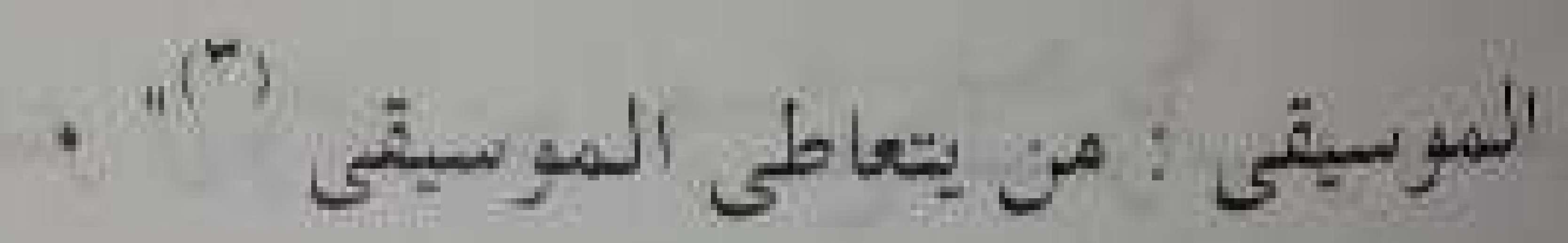

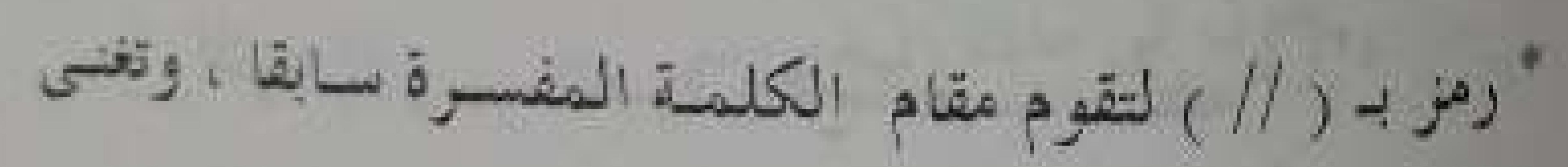

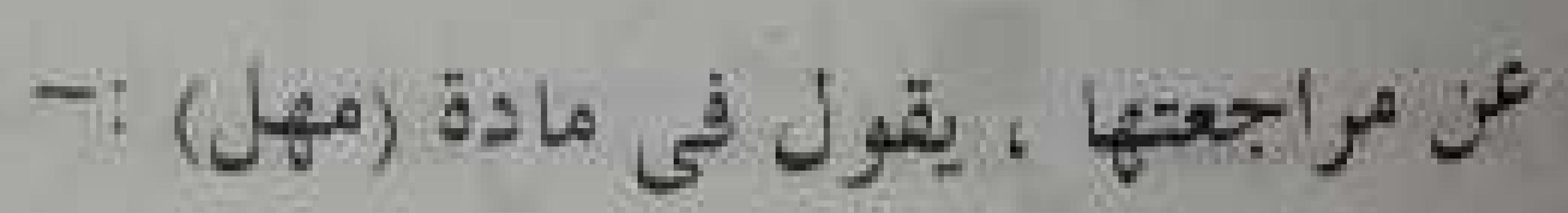

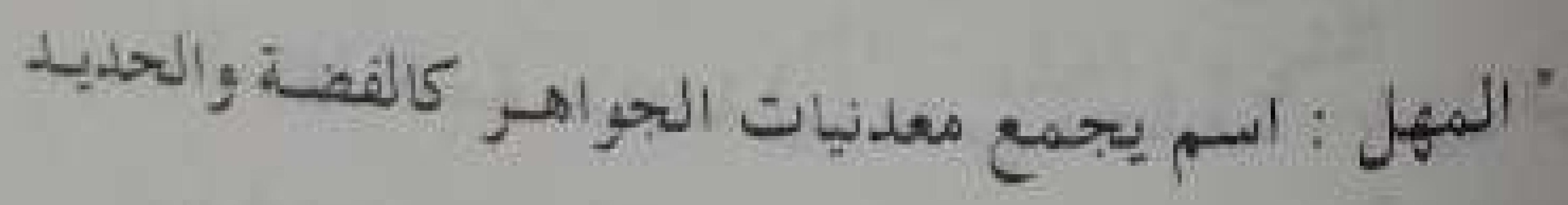

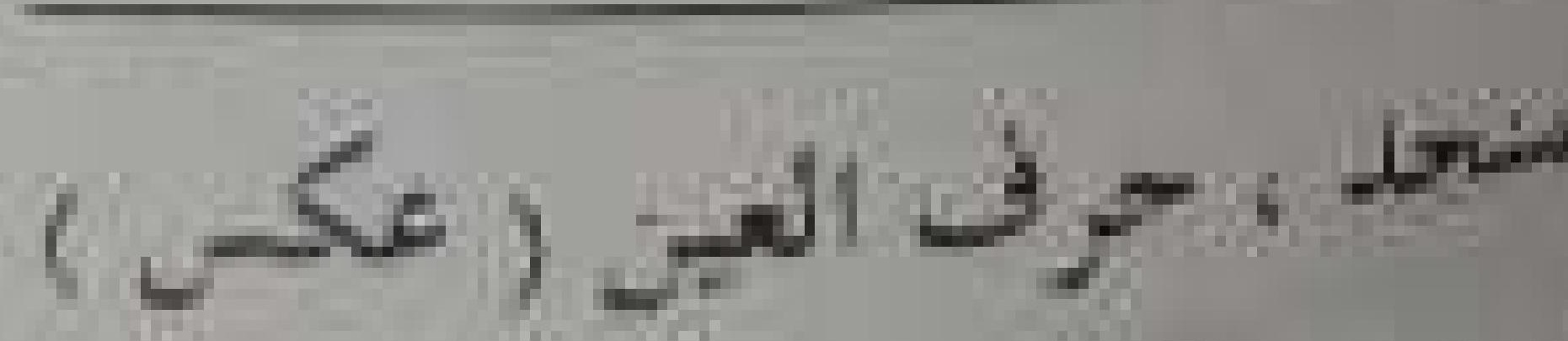

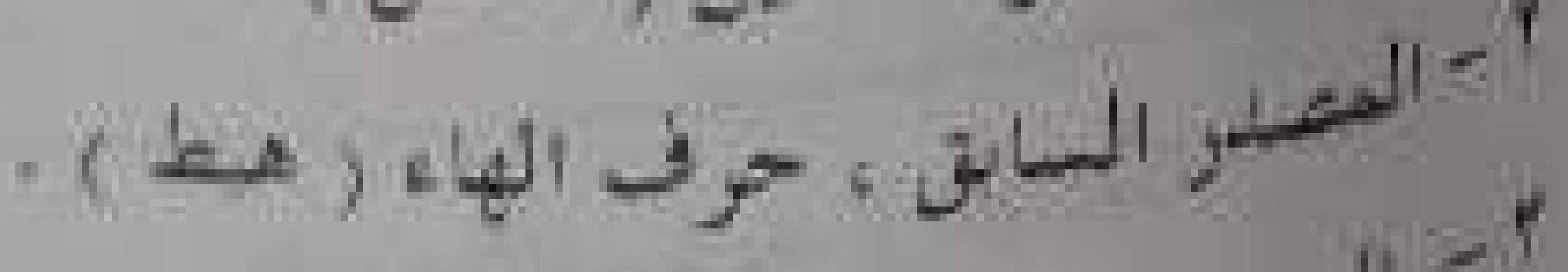

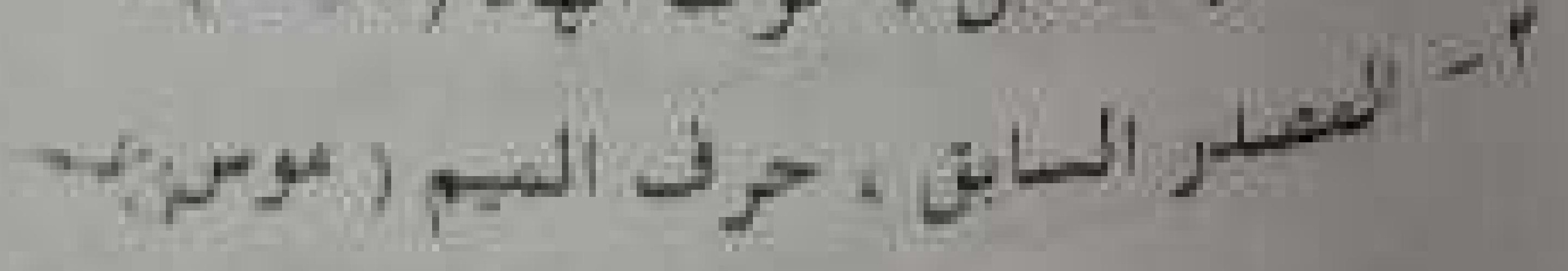

$-r r \cdot-$

الأذن ، والككتان والنكفتان ( ع ) نكفات) : اللهزمتان عز

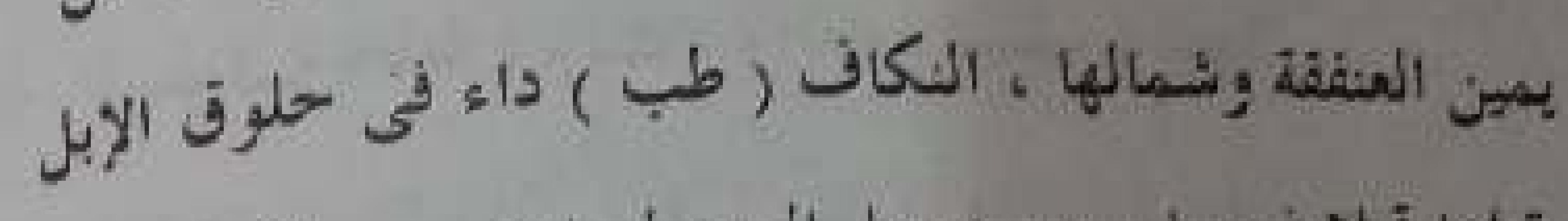

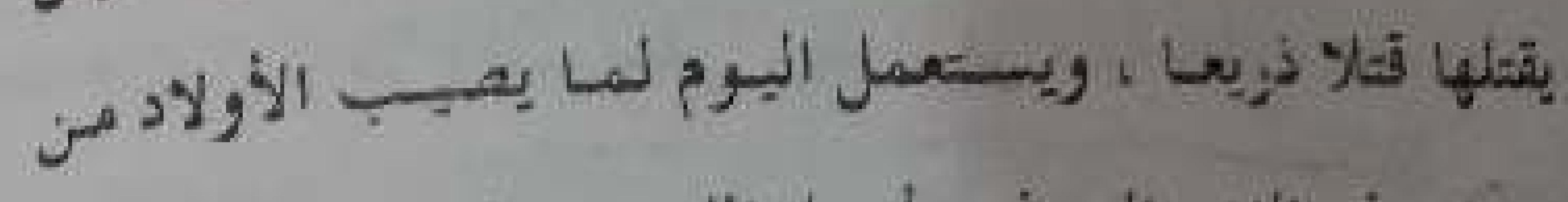

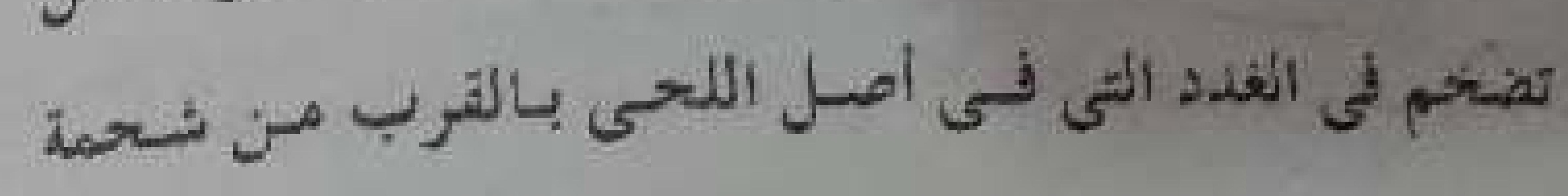

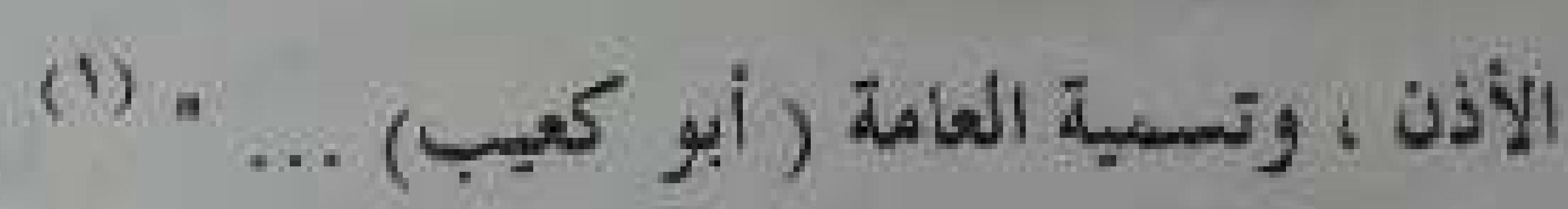

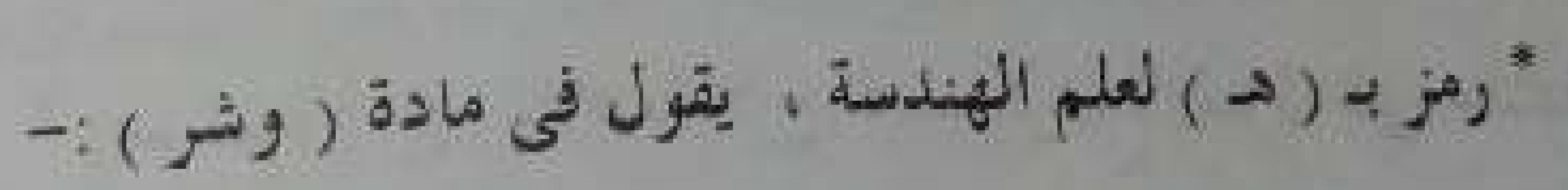

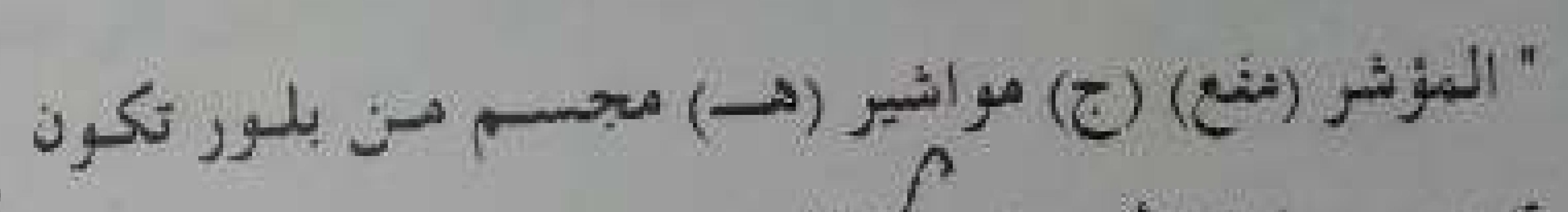

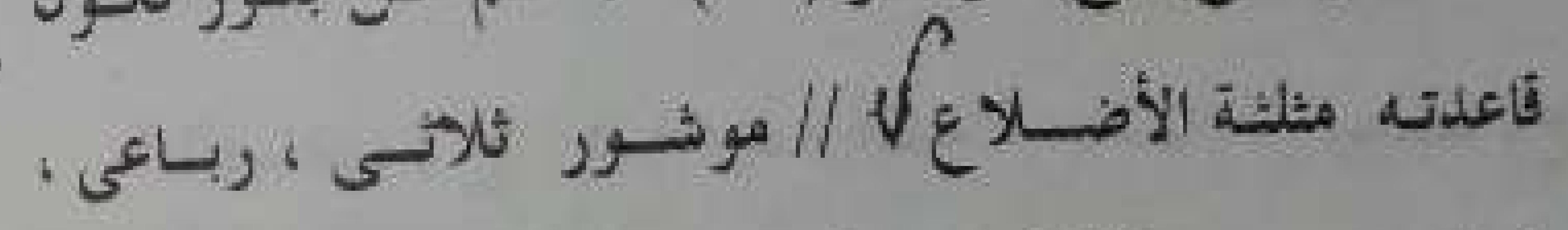

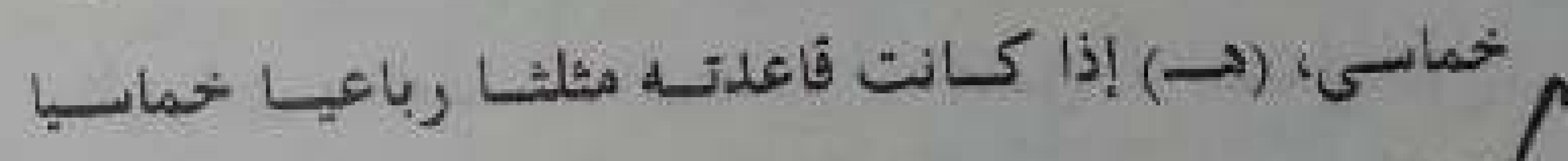

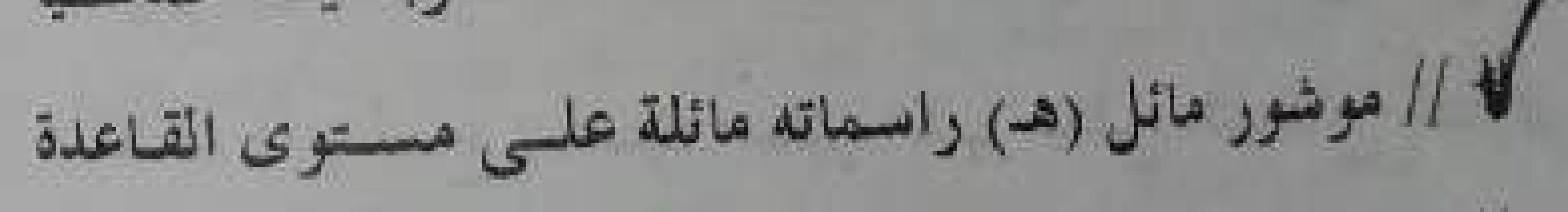

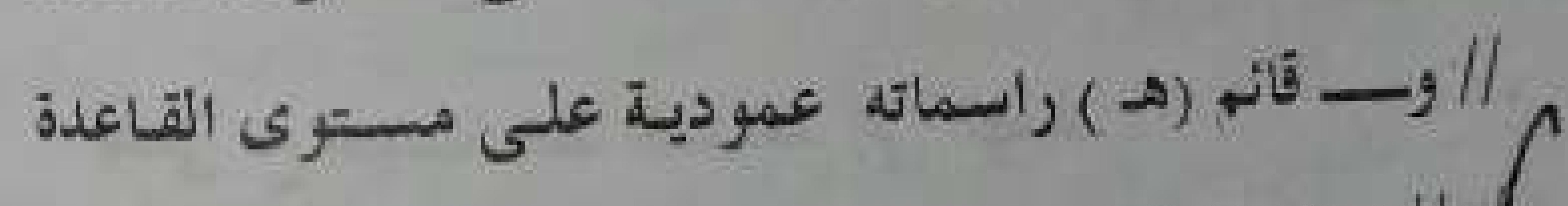

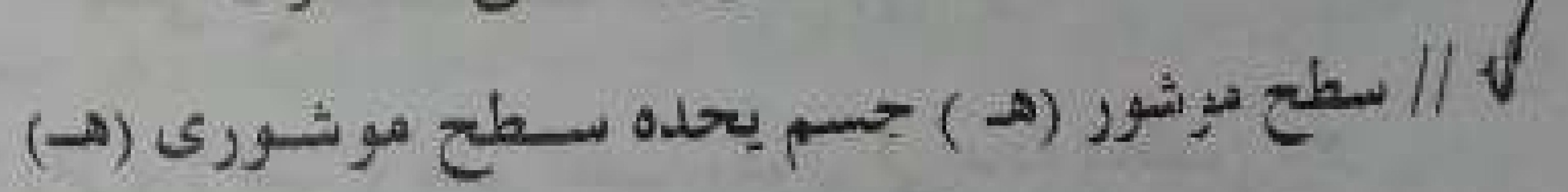

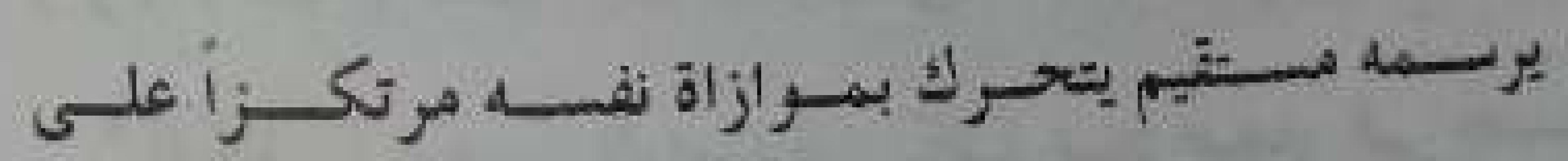

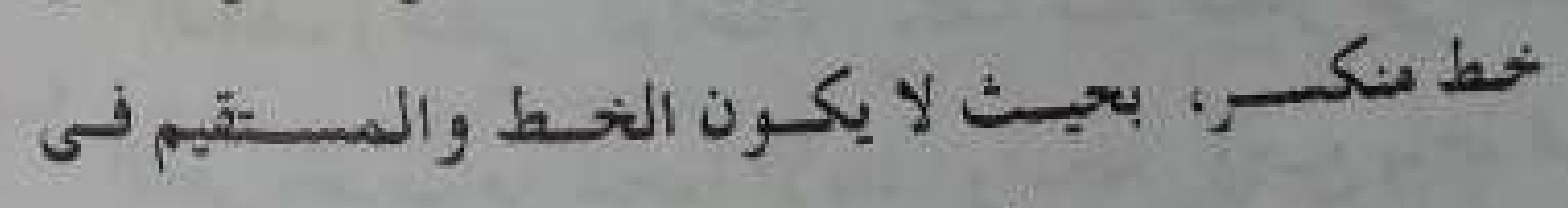
(i) . ...

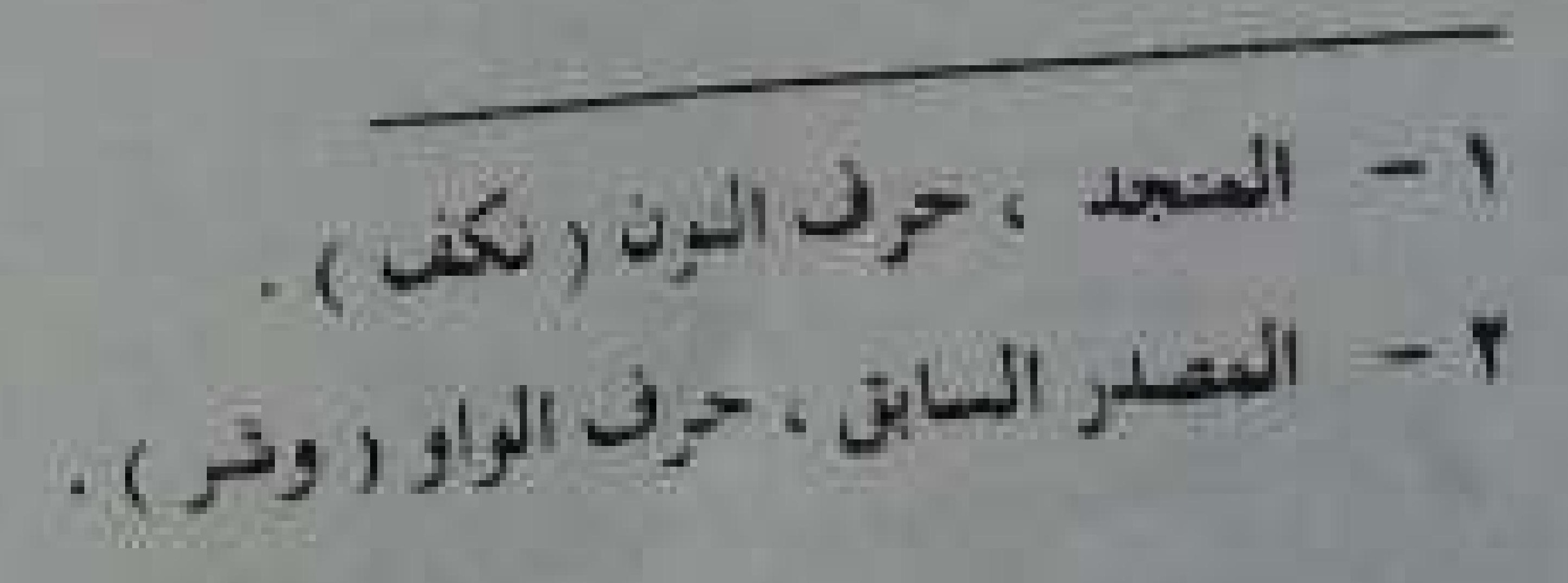




\section{- rrF-}

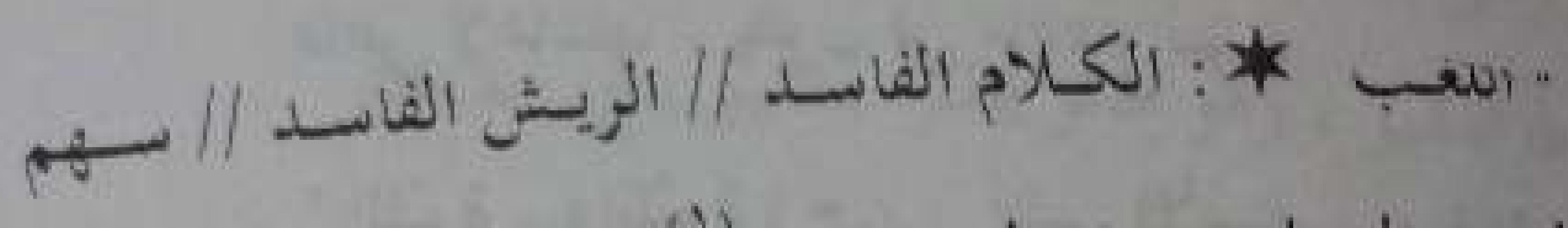

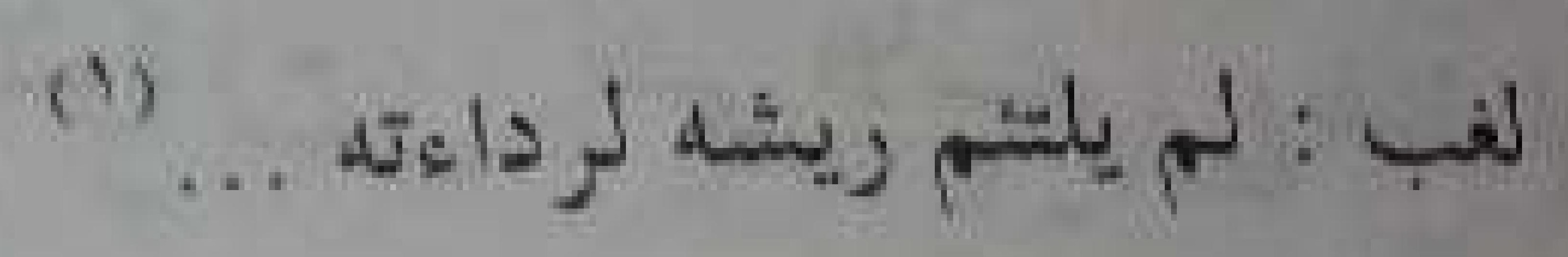

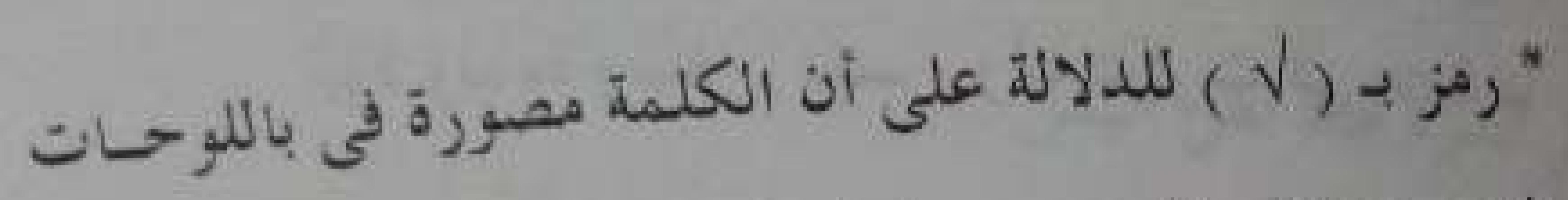
التو ضبحية في المعتحم ، يقول في مادة (لبد) :-

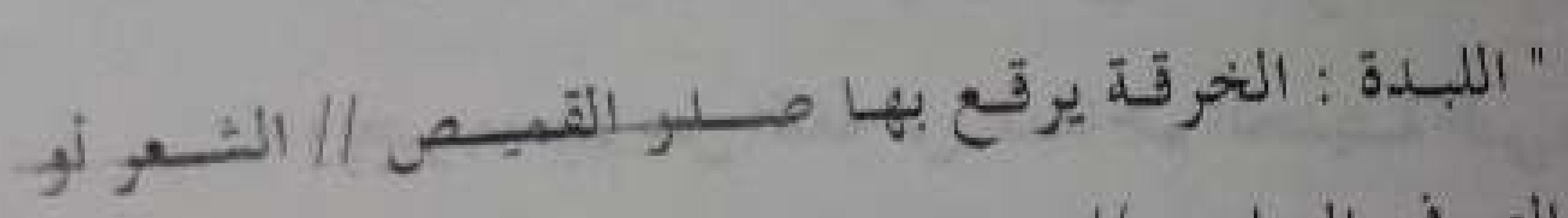

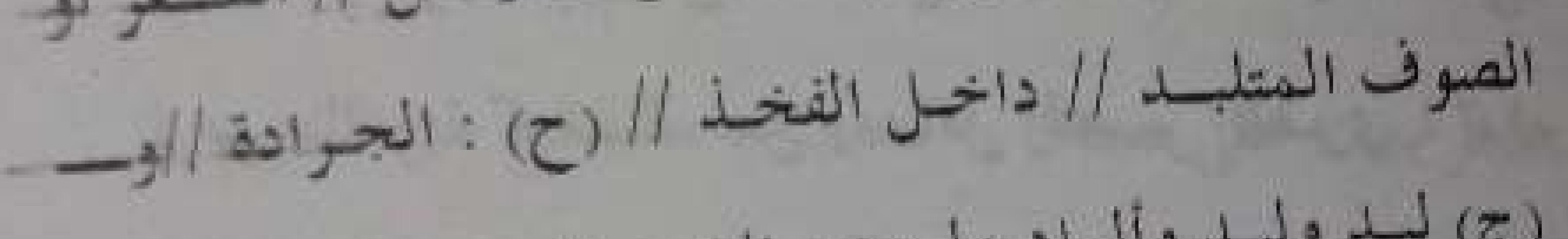

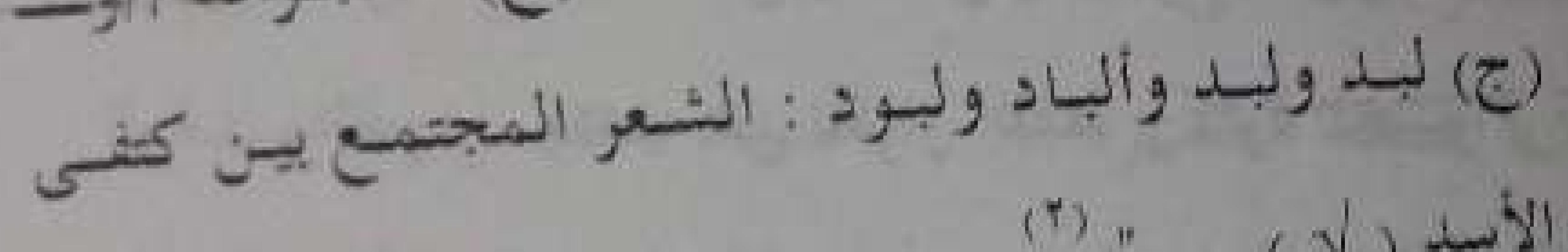

$$
\text { (") "...(V) الأسد }
$$

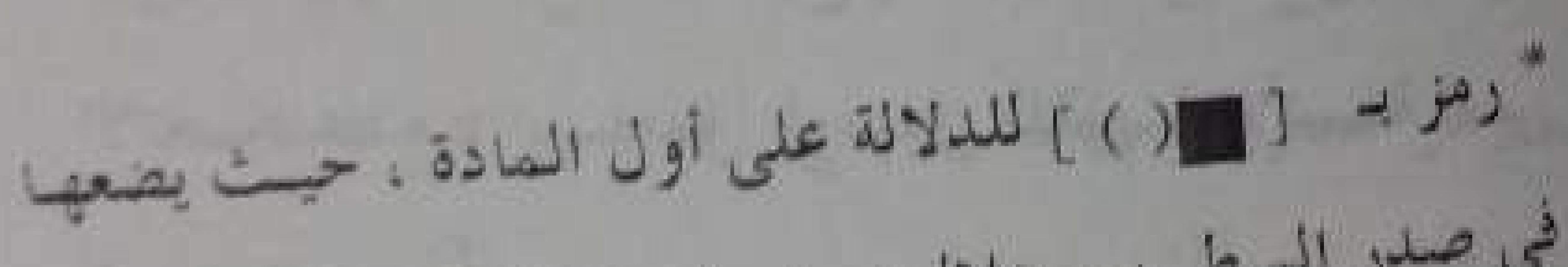

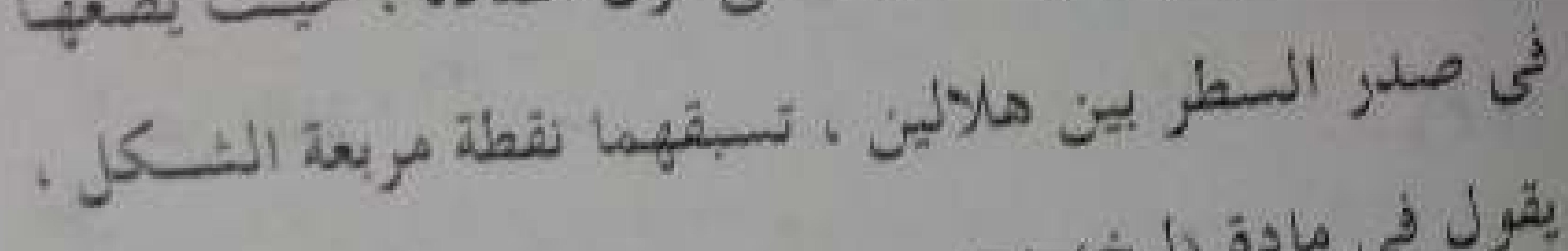

$$
\text { يقول في مادة (لبخ) :- }
$$

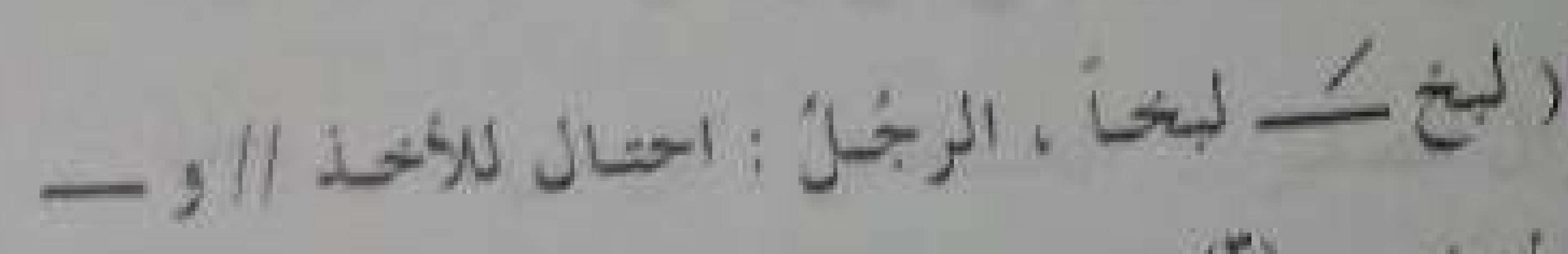

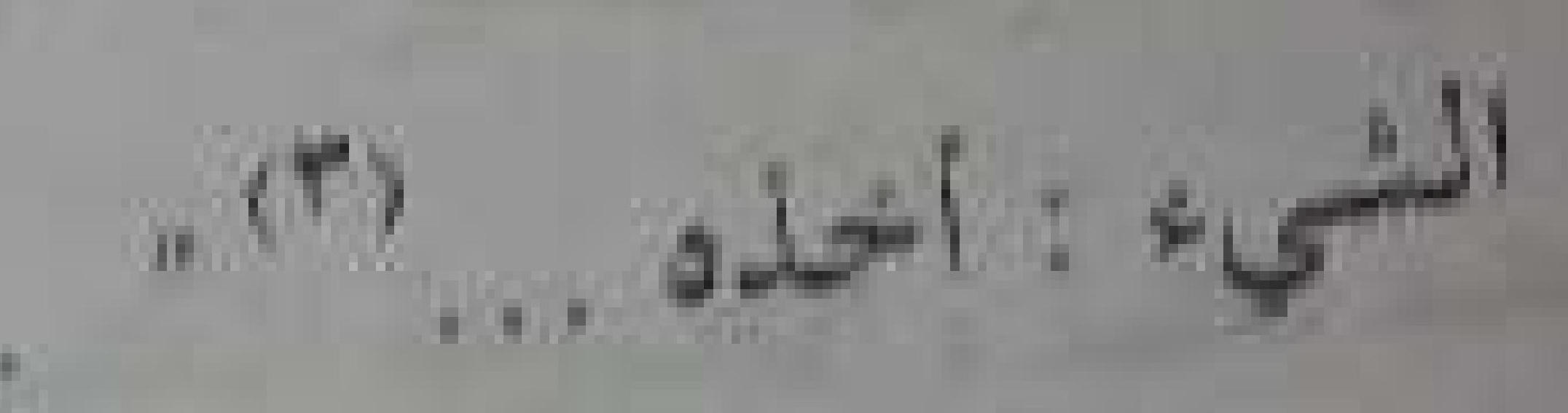

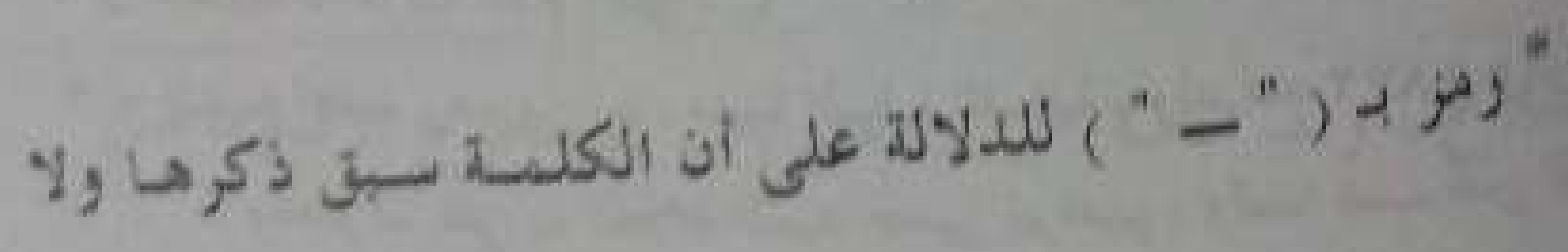

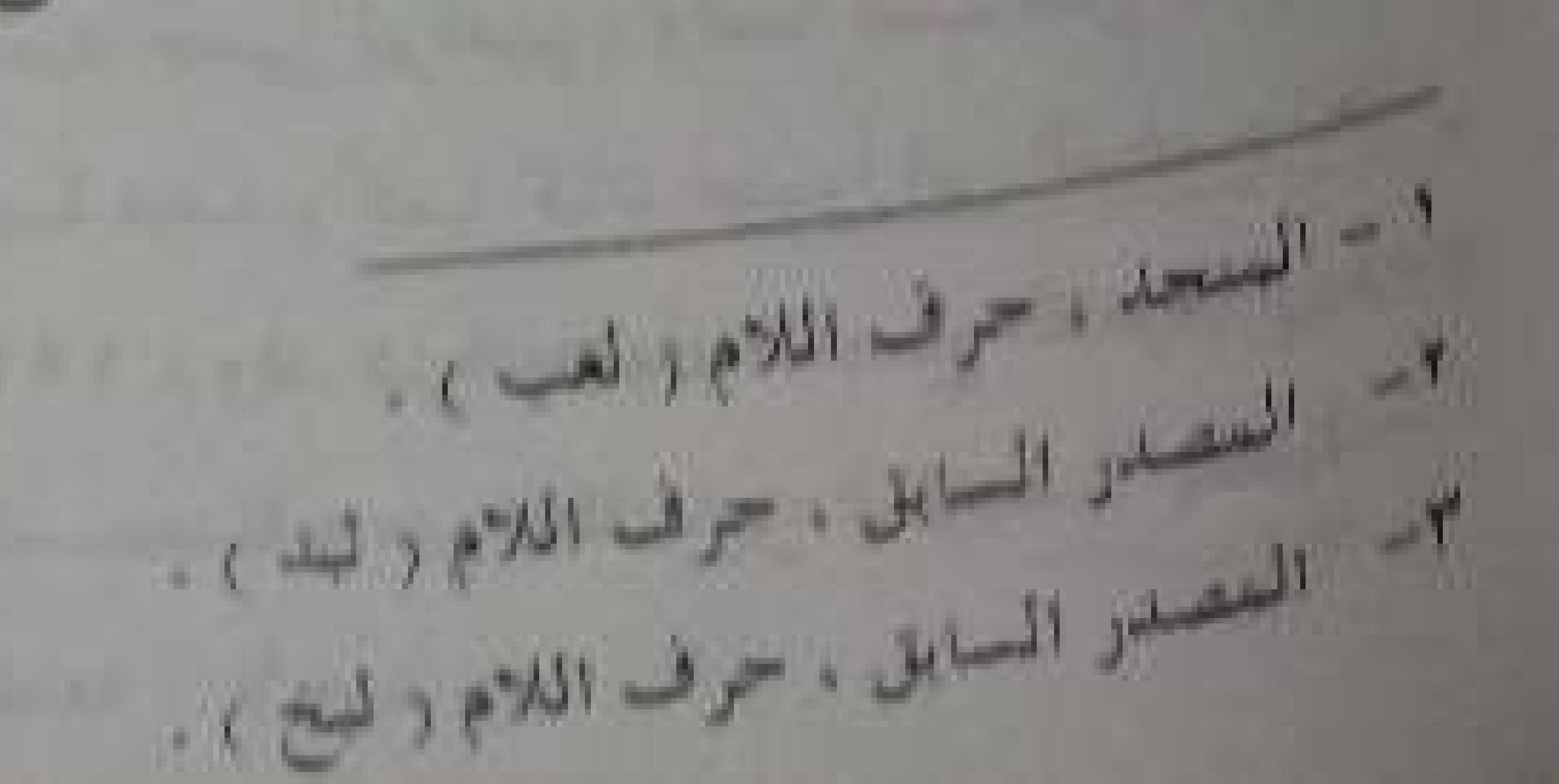

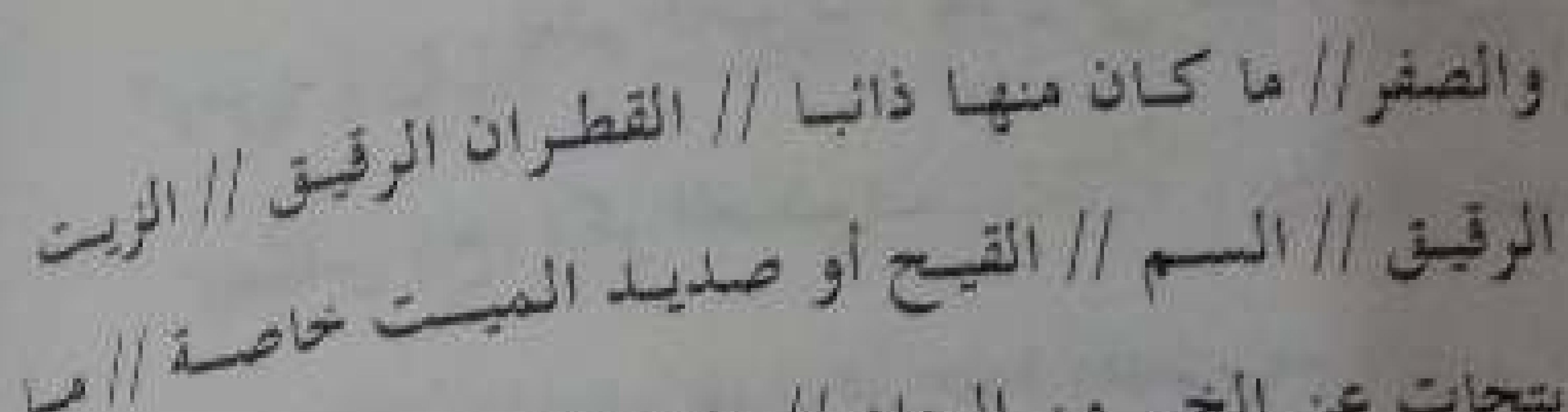

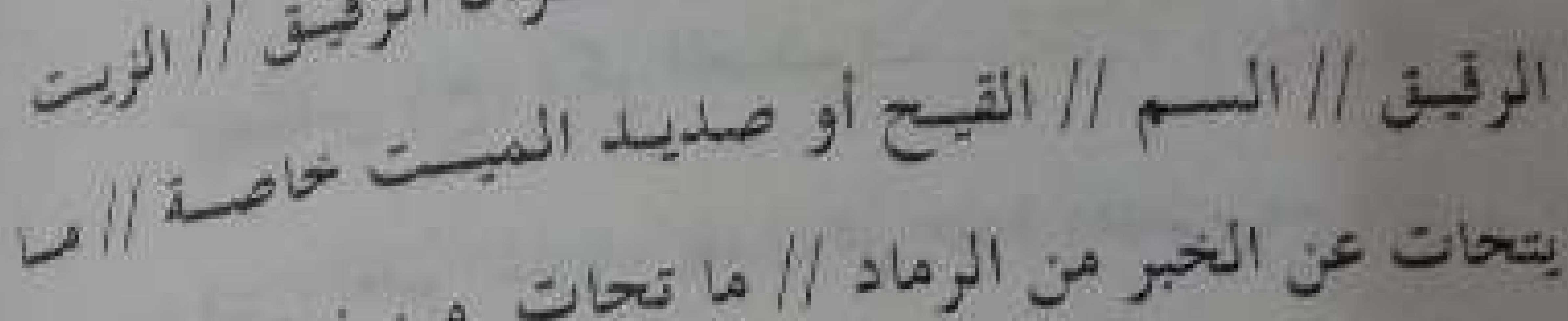

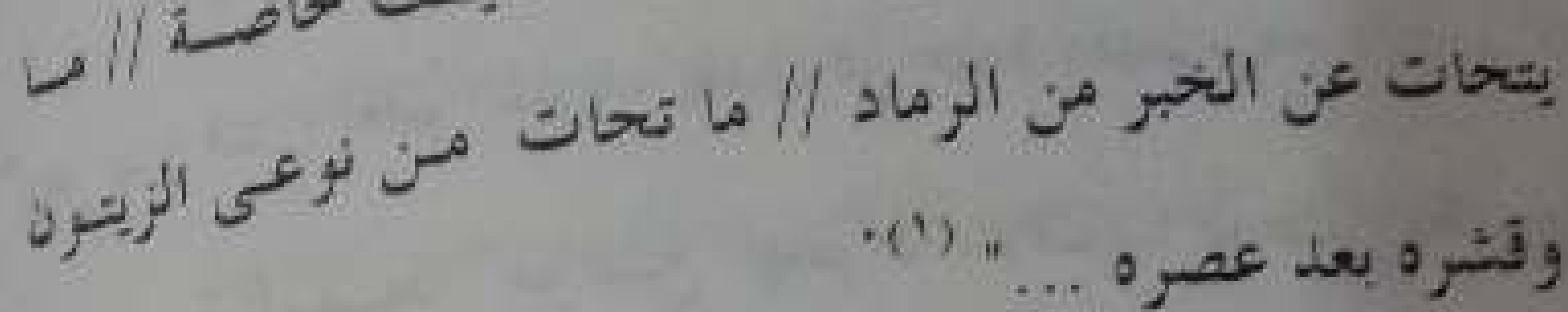

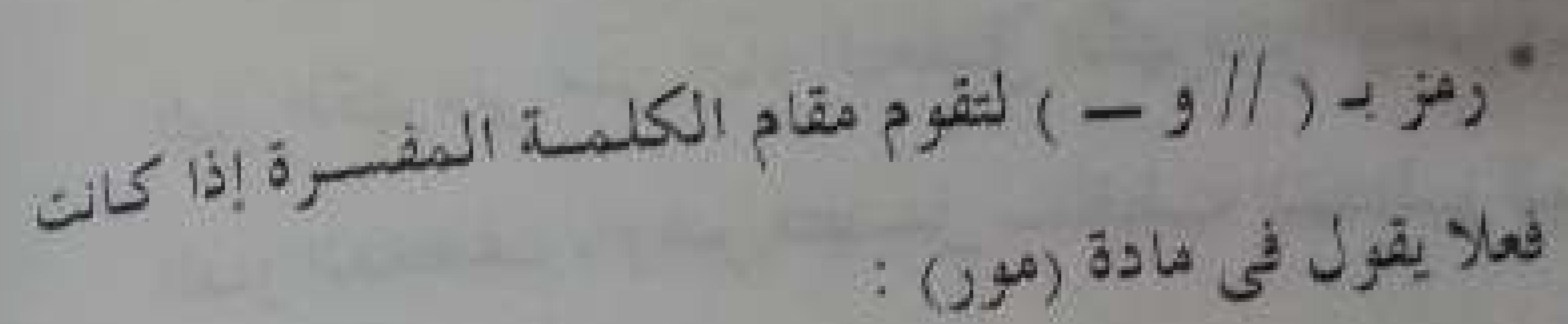

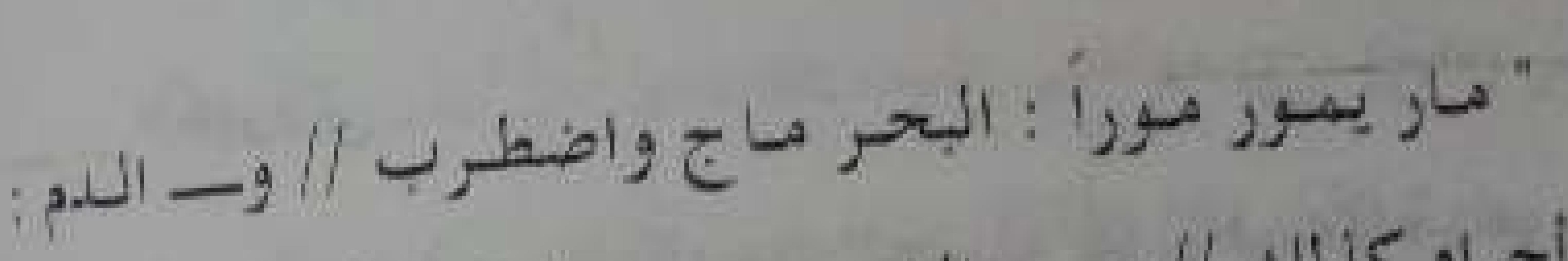

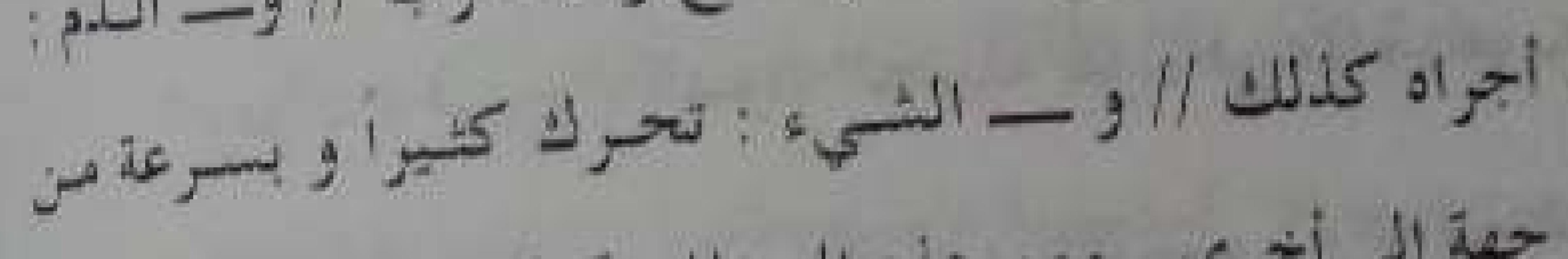

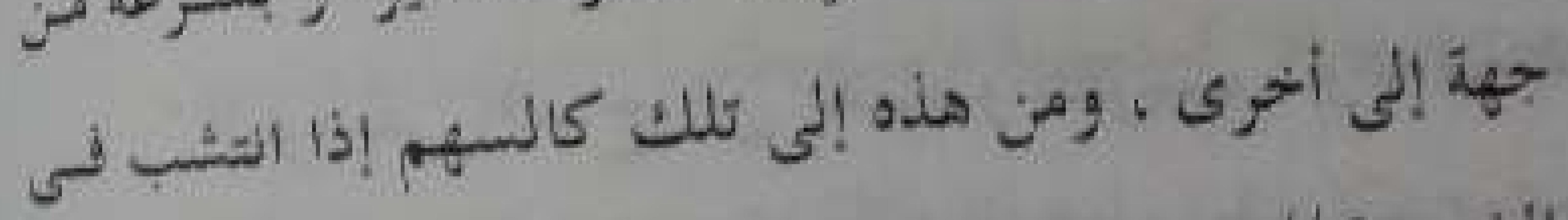

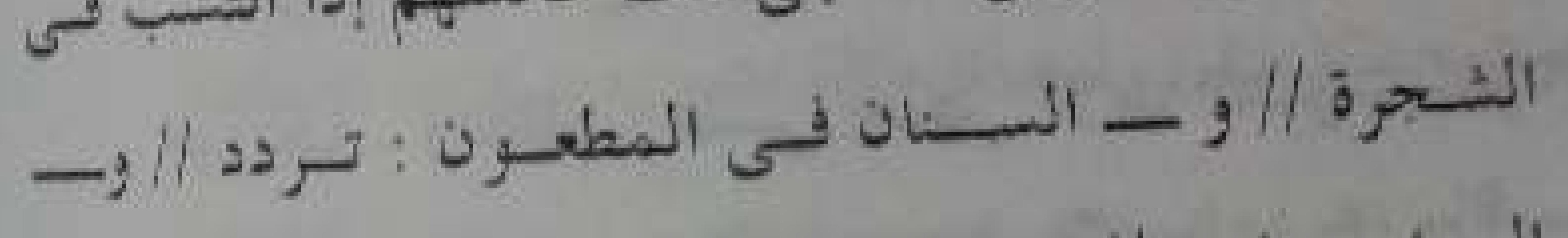

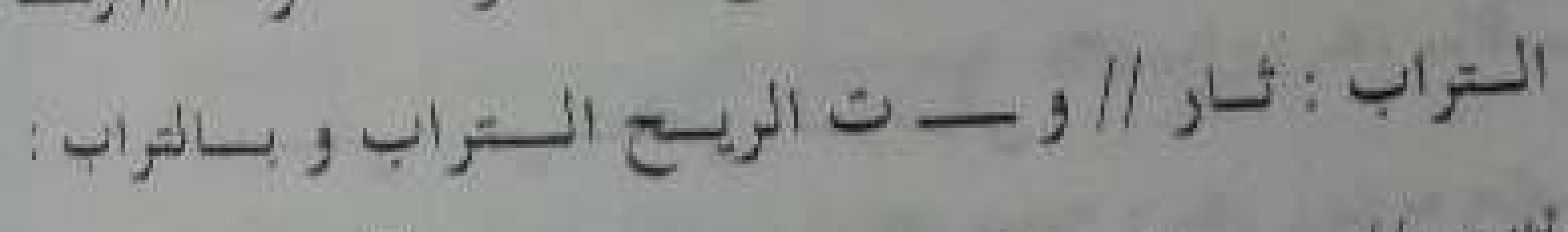

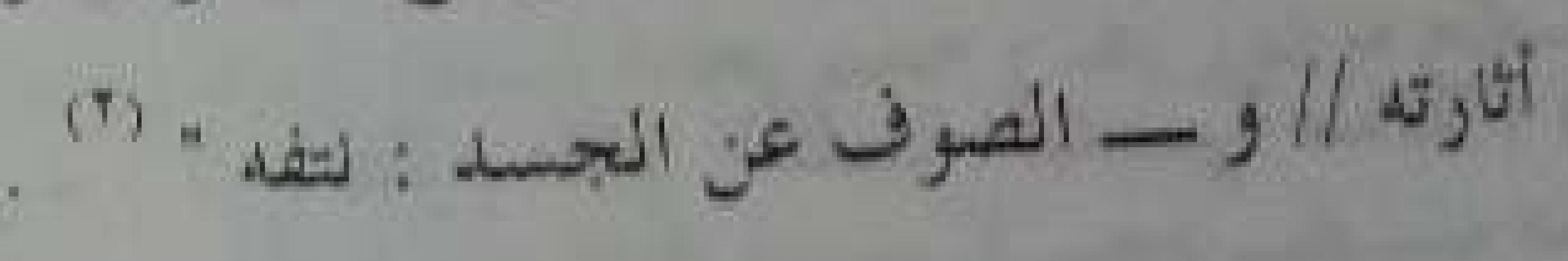

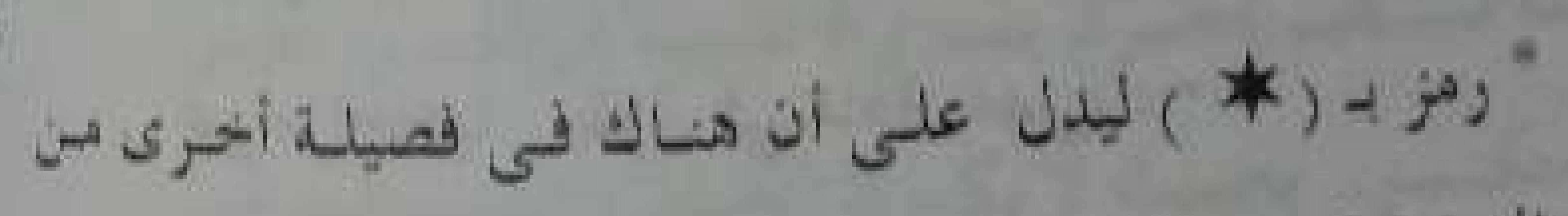

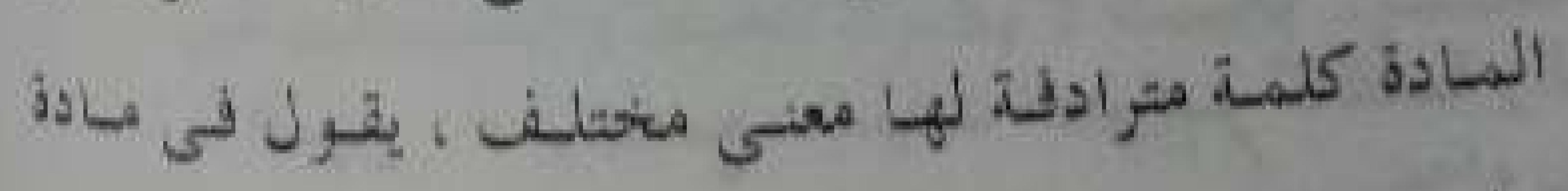

$$
-:(\omega)
$$

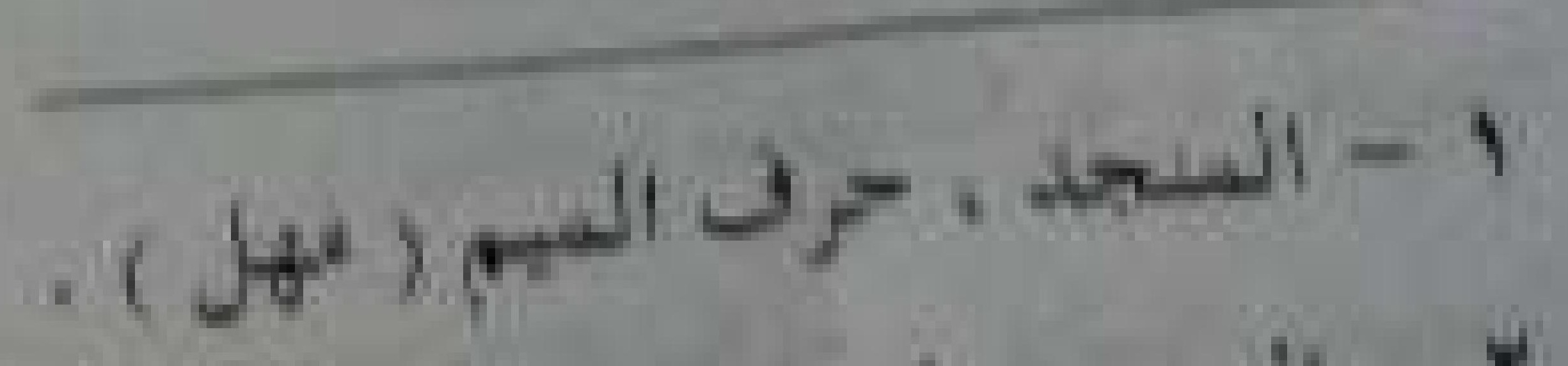

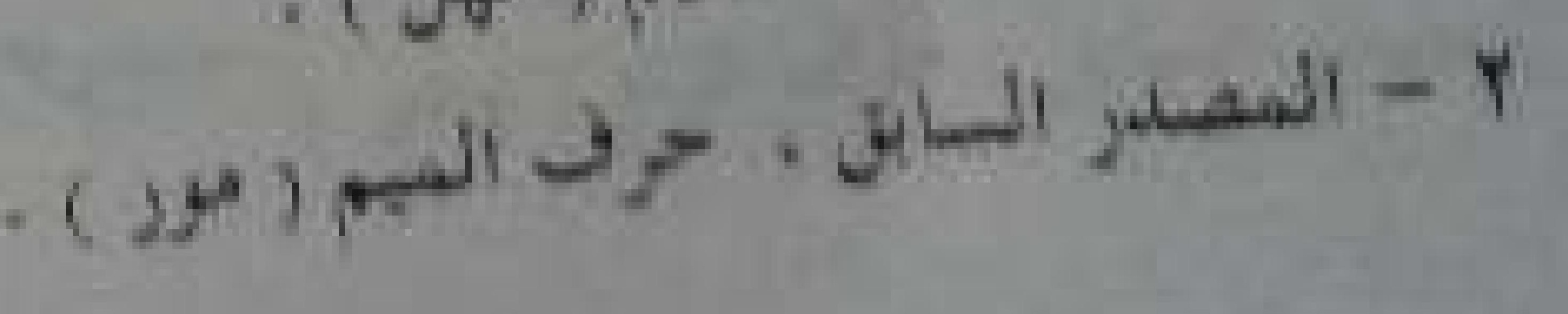




\section{- rol -}

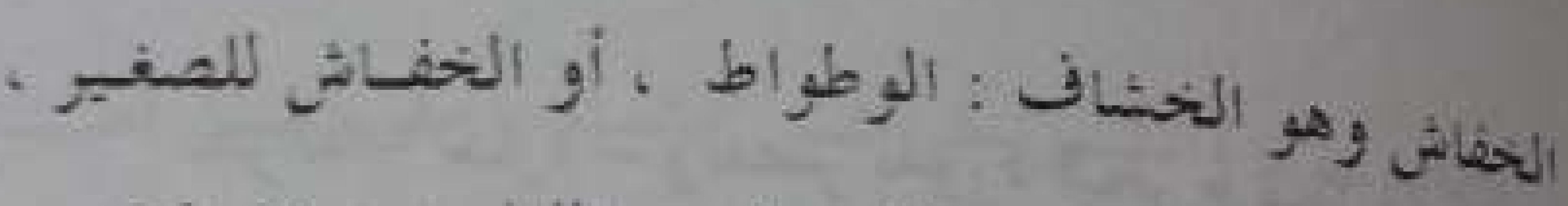

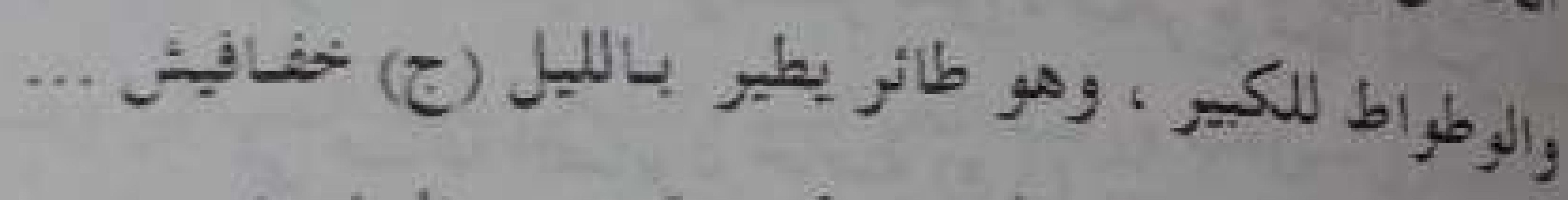

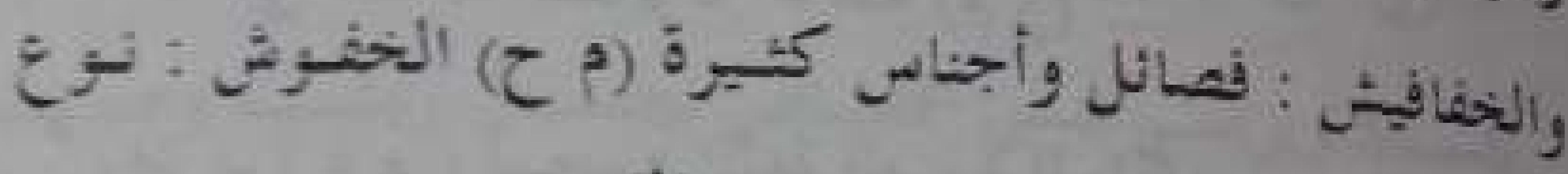

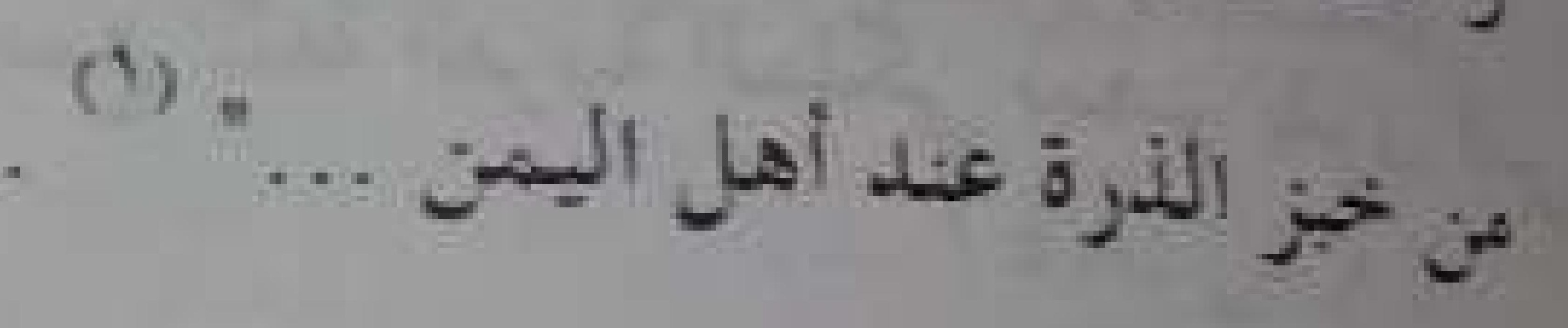

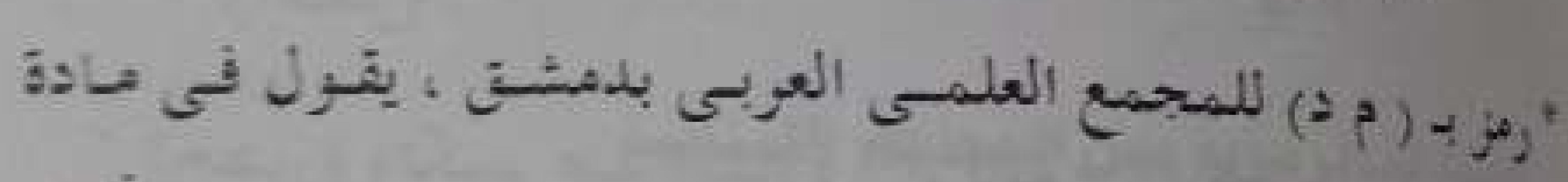
$\because(s+)$

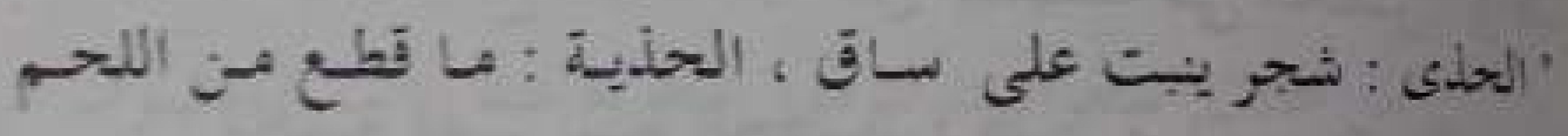

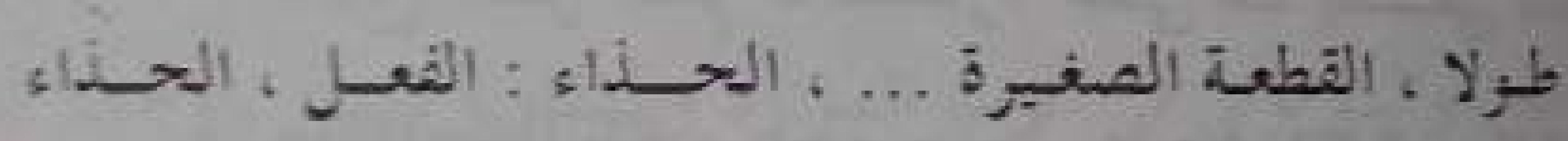

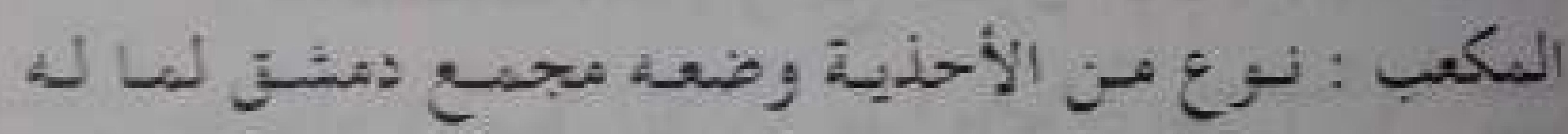

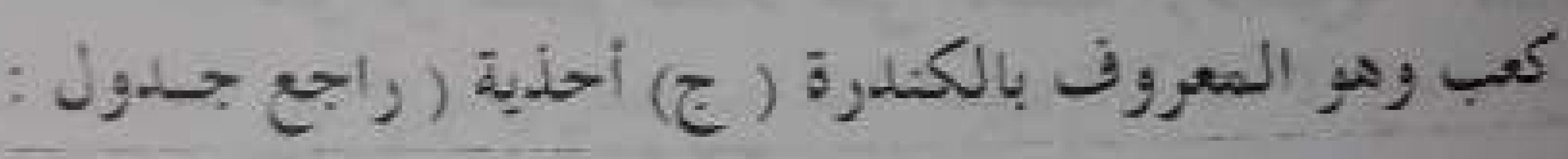

$$
\text { (1) :...(91:20 }
$$

"

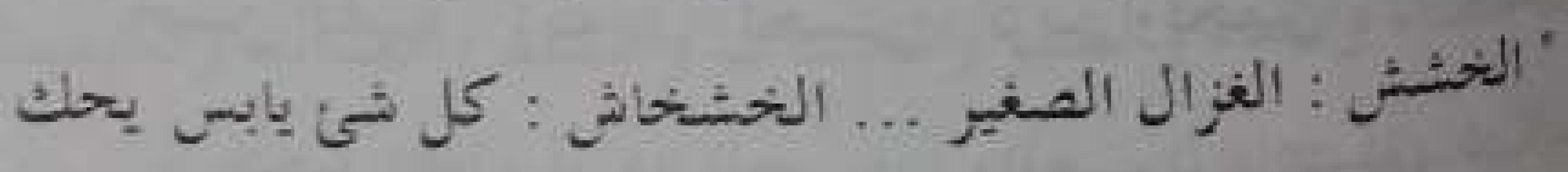

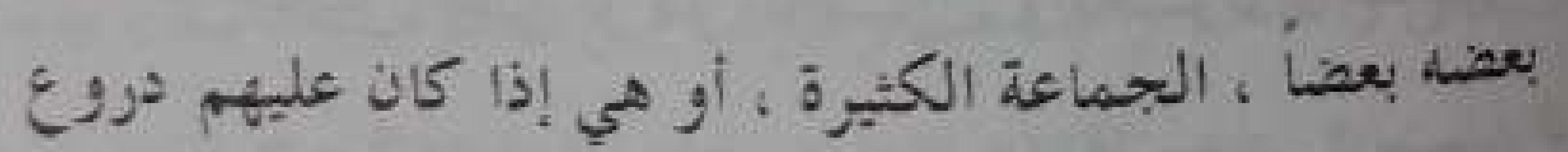

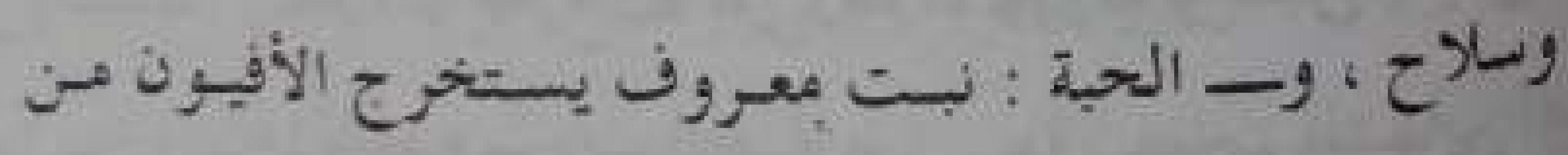

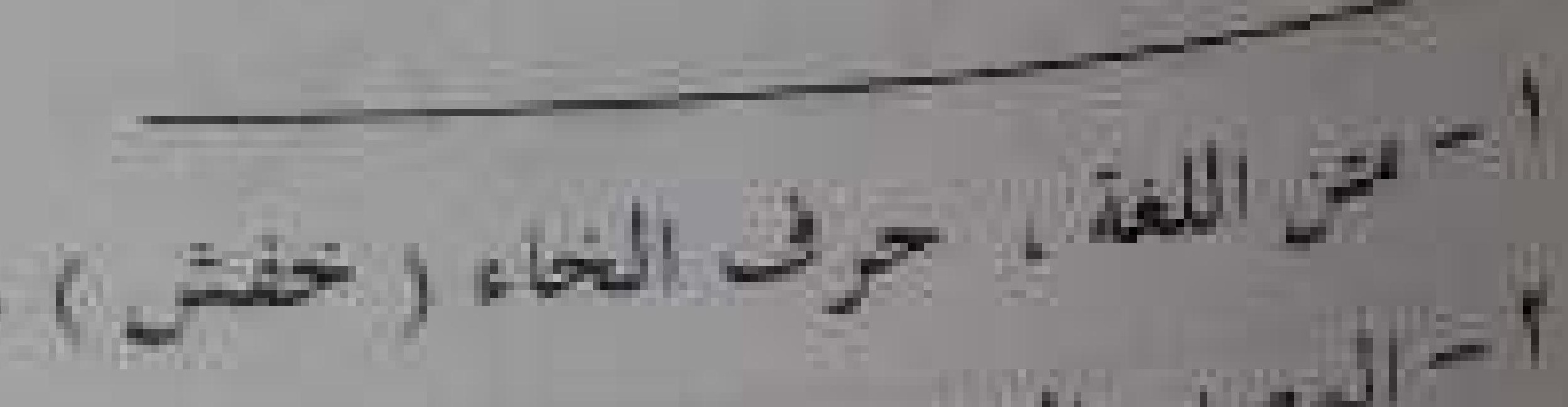

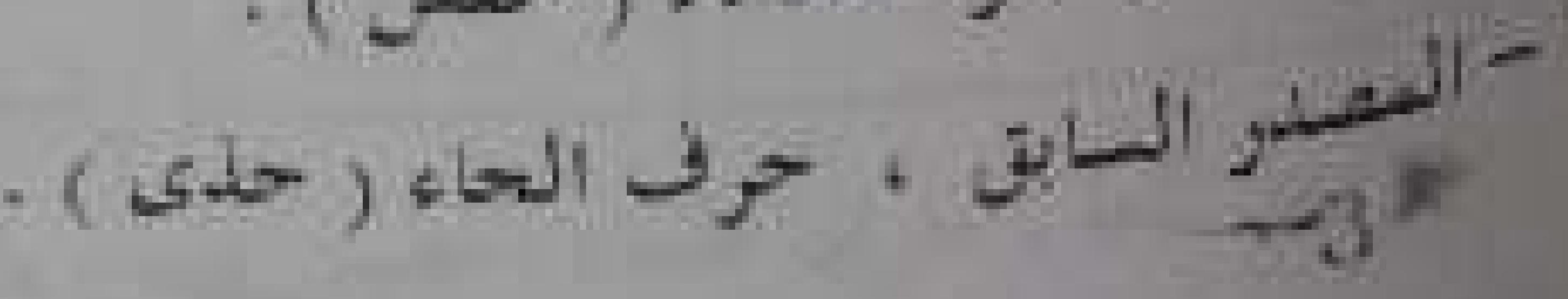

$-r+\varepsilon-$

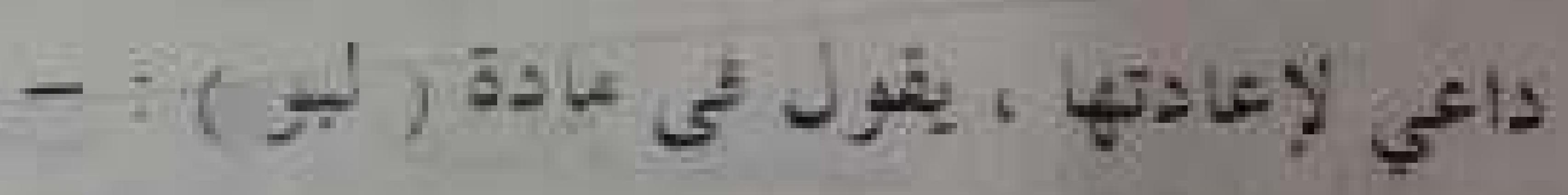

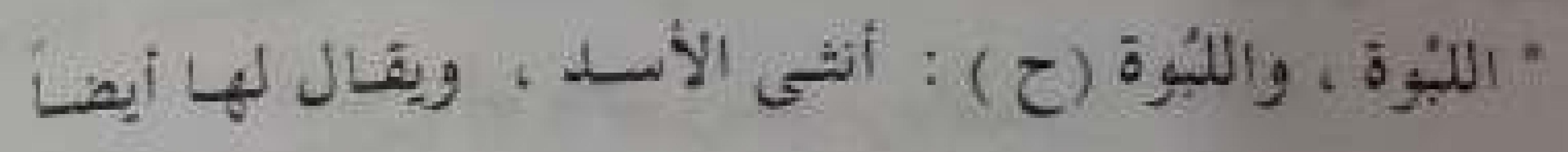

$$
\begin{aligned}
& \text {.... - . 2ala }
\end{aligned}
$$

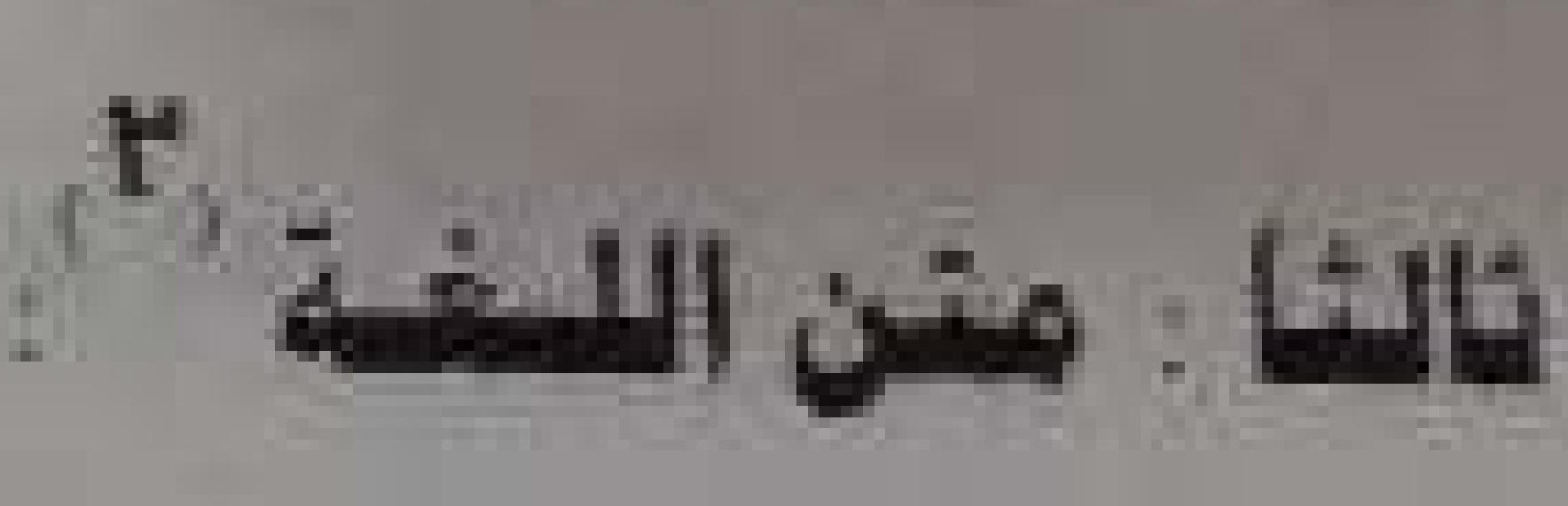

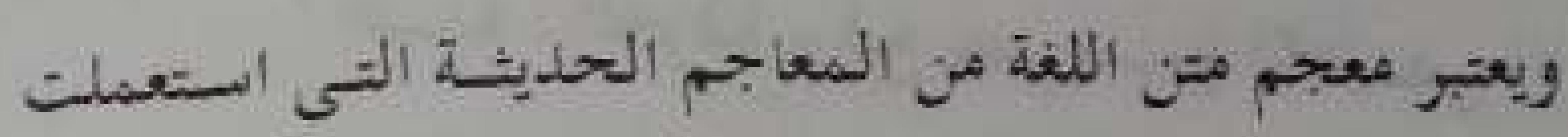

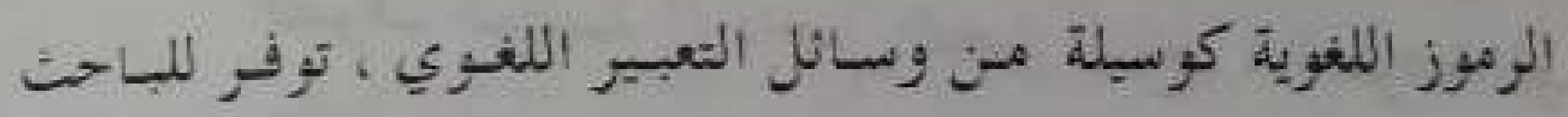

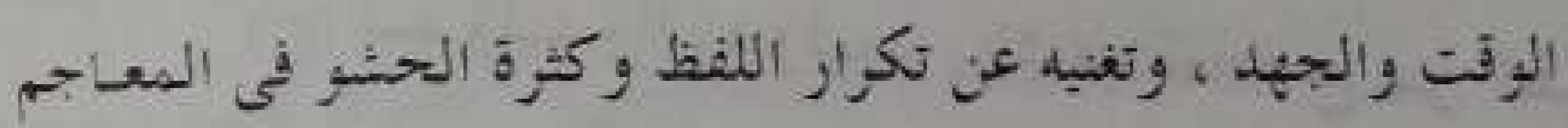

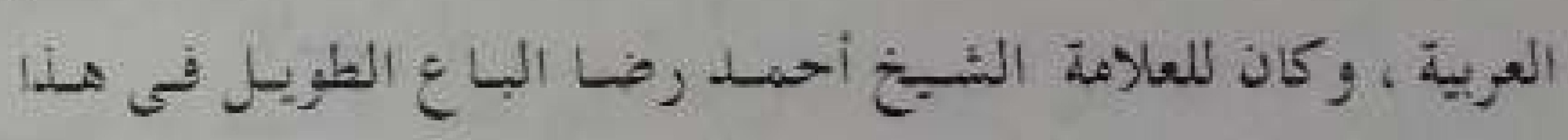

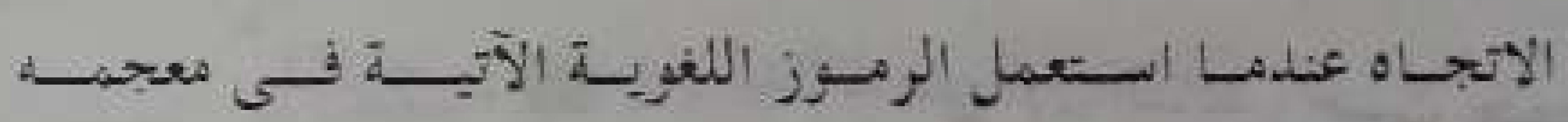

$$
- \text { : }^{(5)} \text { " }
$$

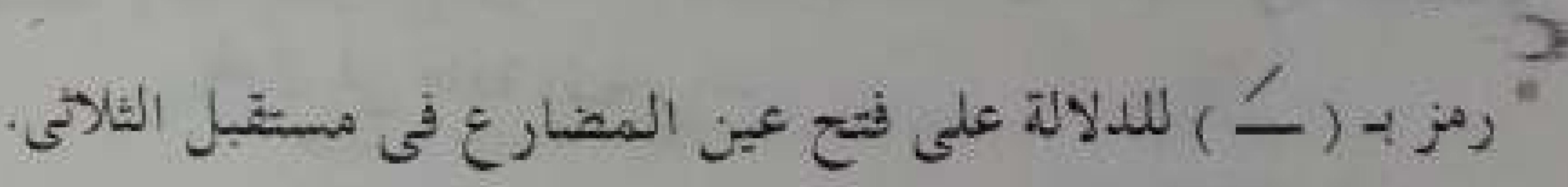

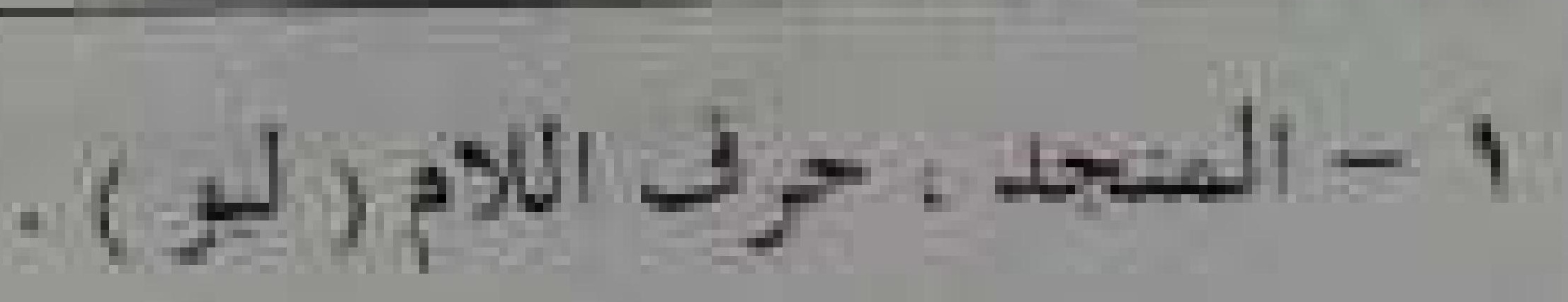

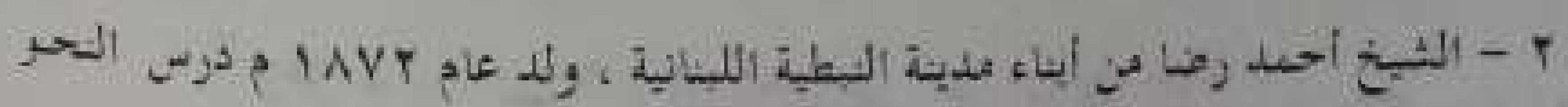

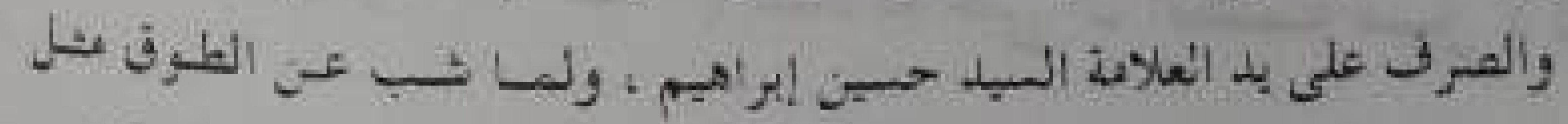

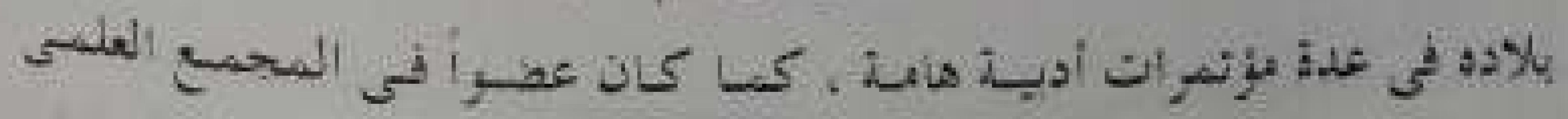

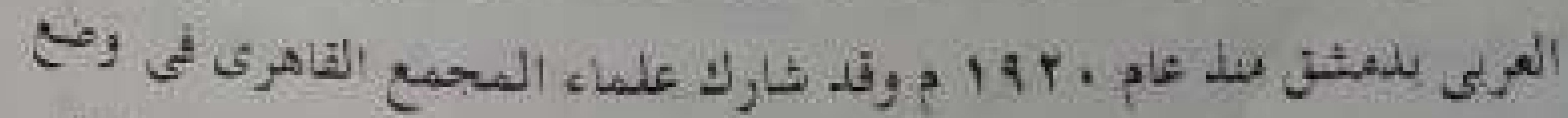

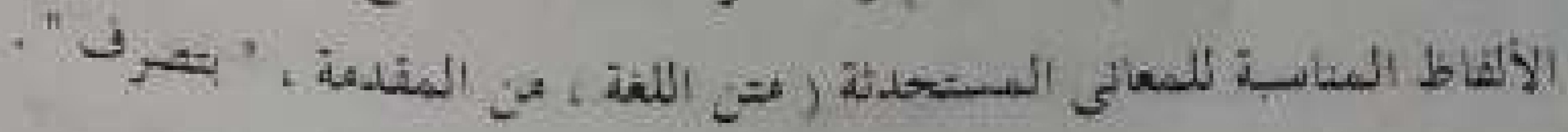

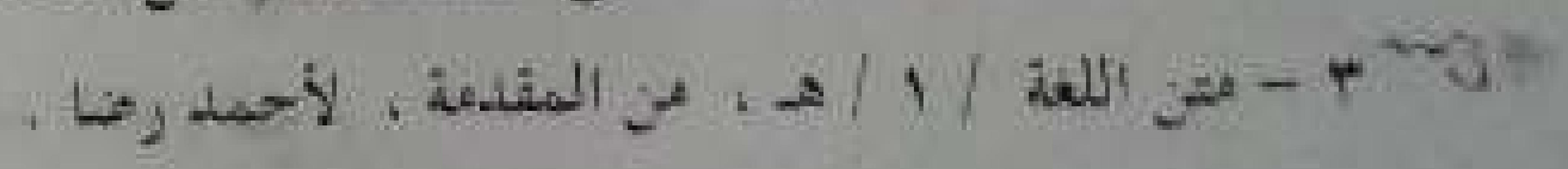




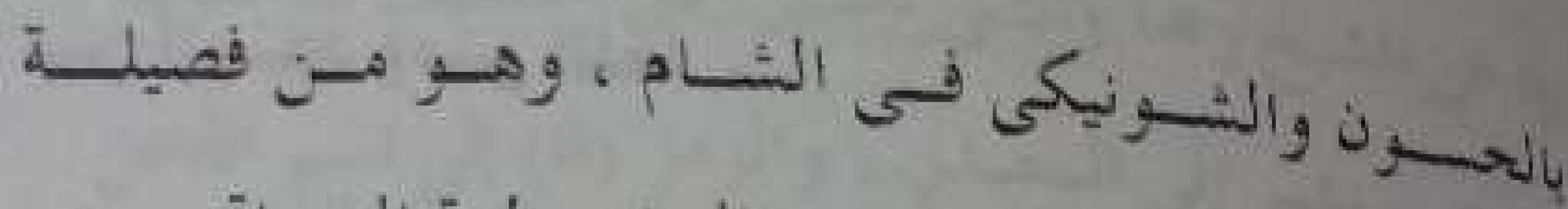

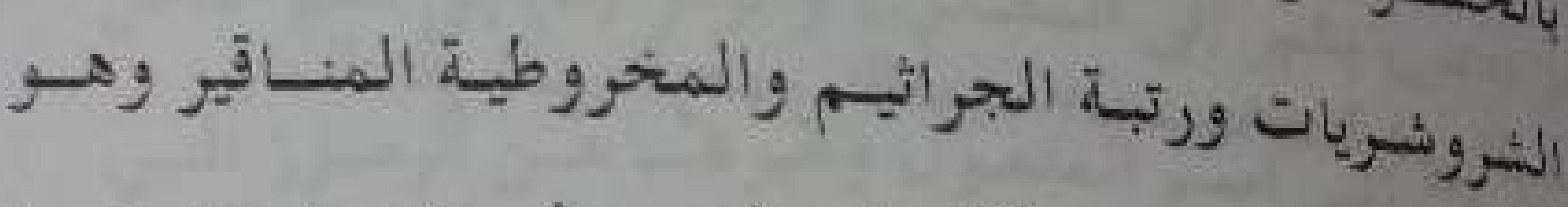

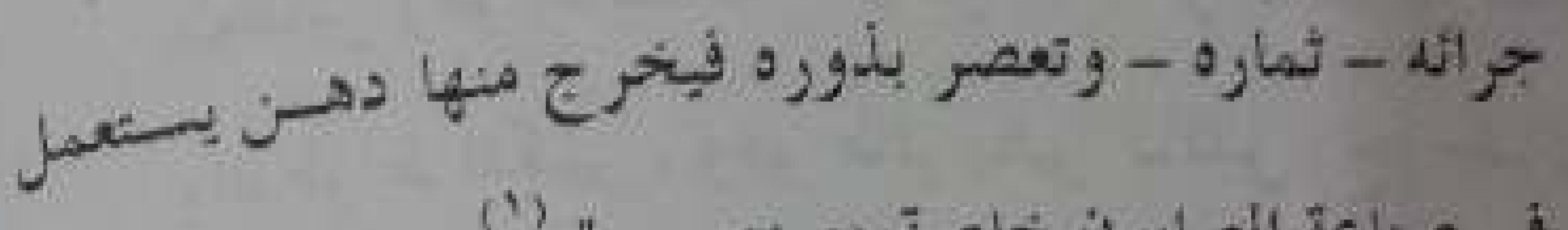

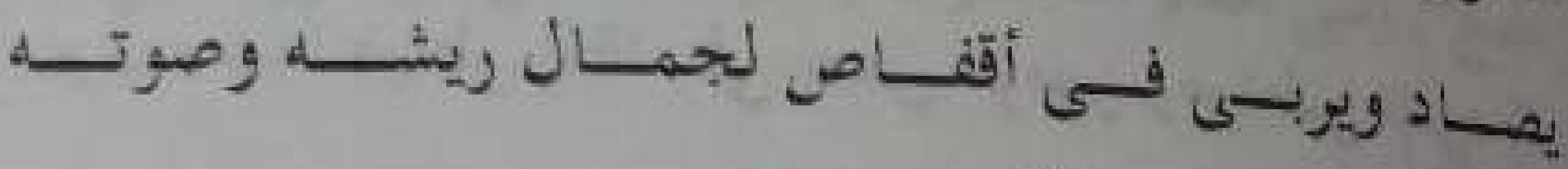

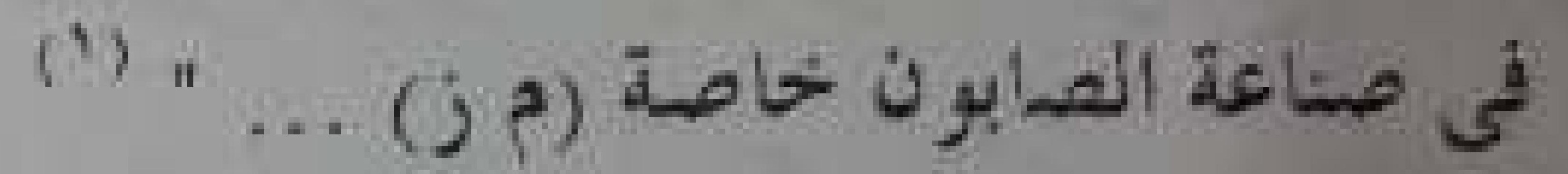

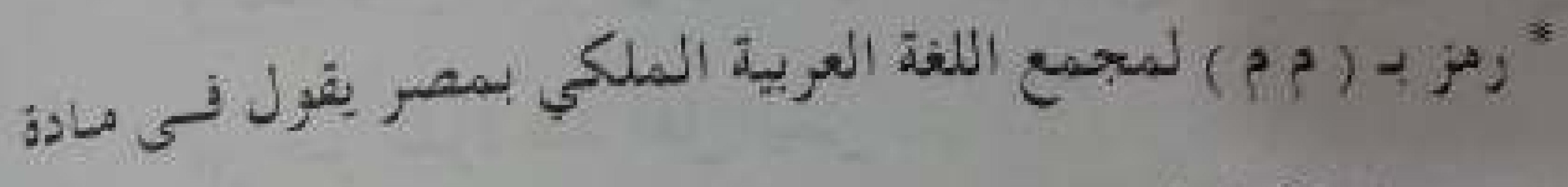

$$
-:(n)
$$

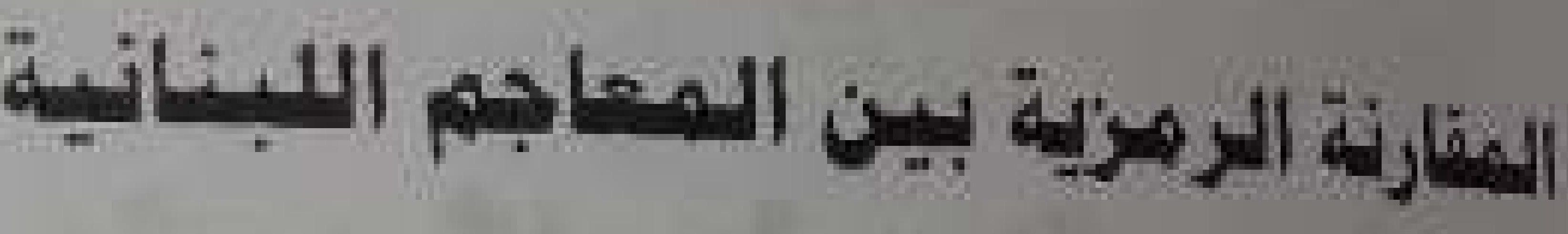

-

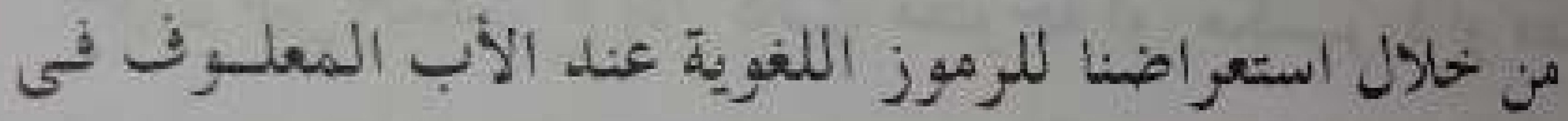

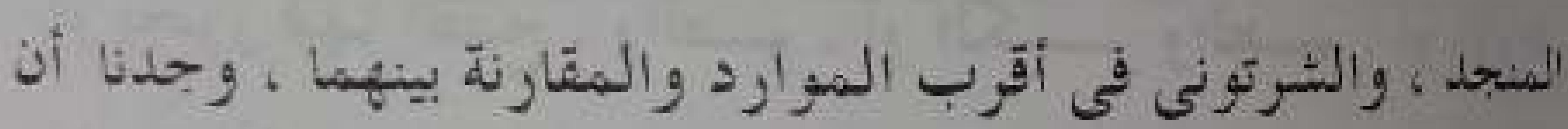

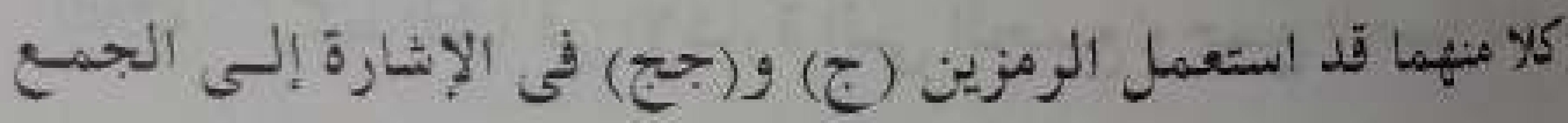

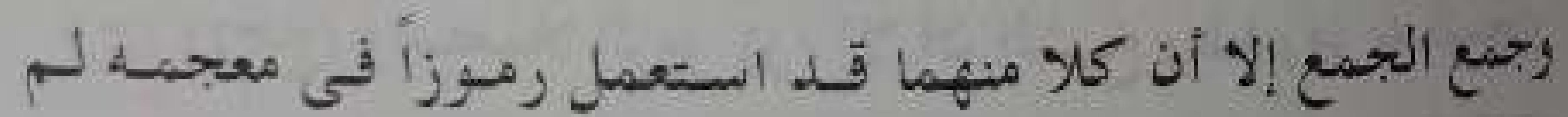

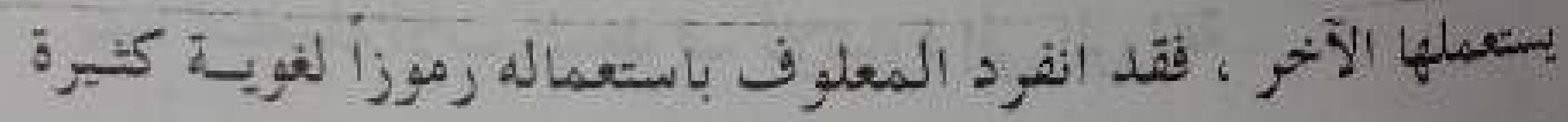

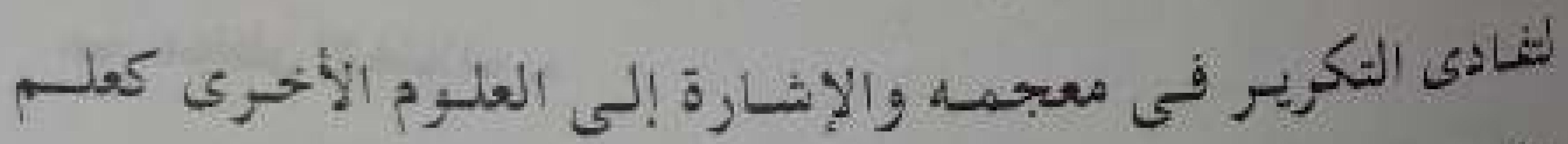

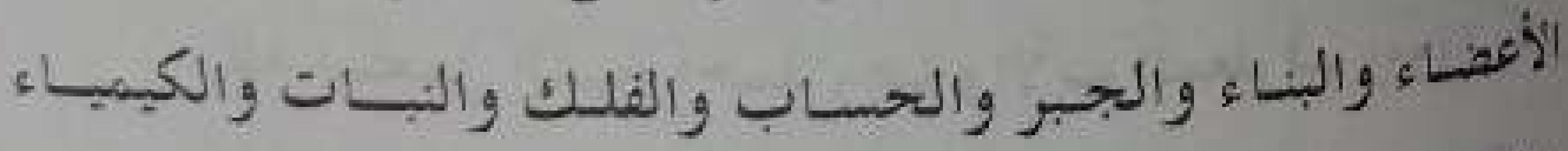

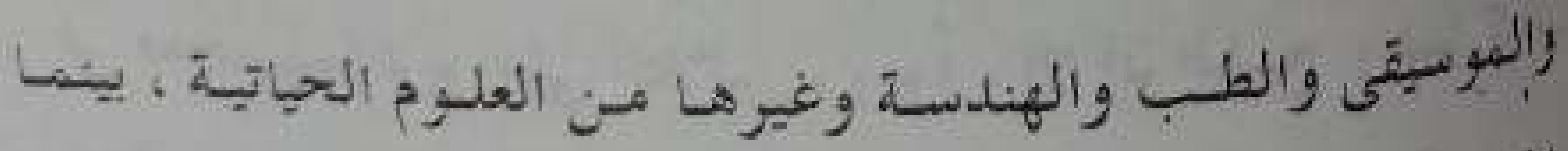

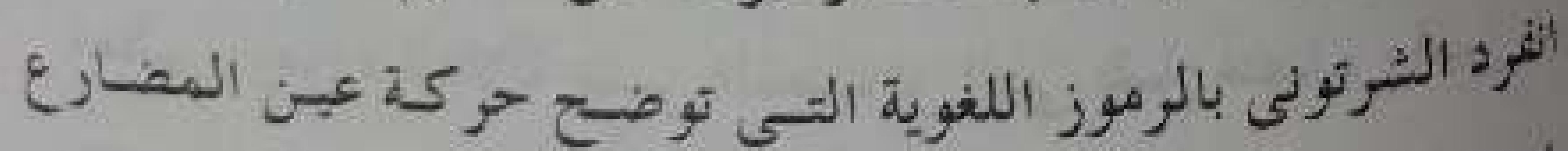

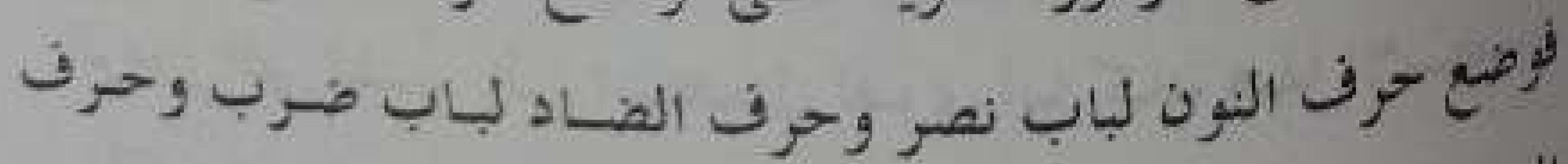

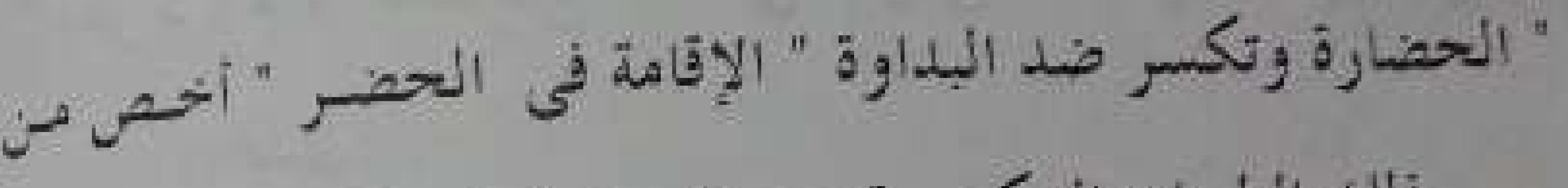

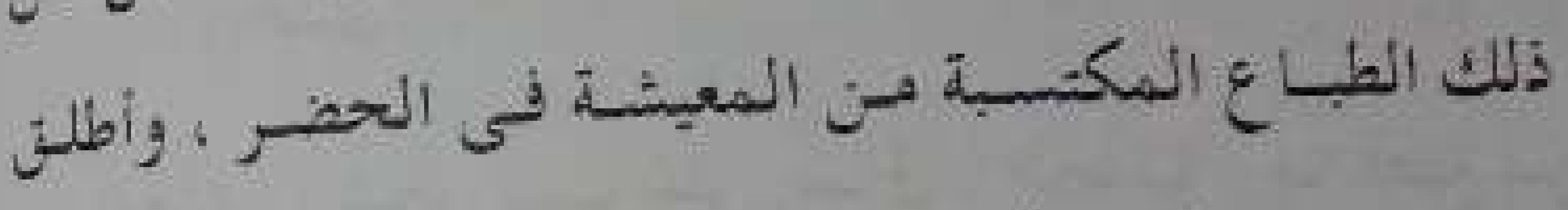

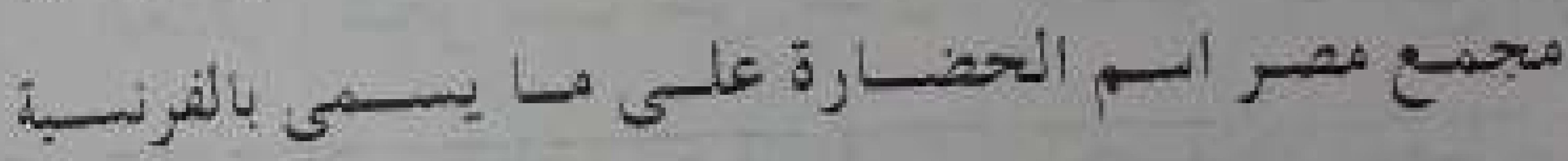
SL Sivilisatiam

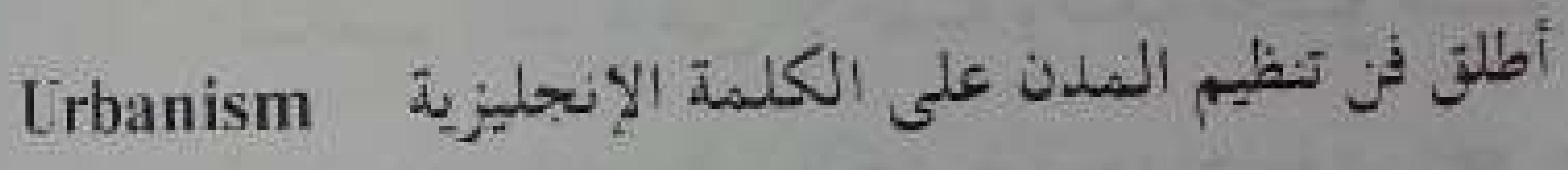

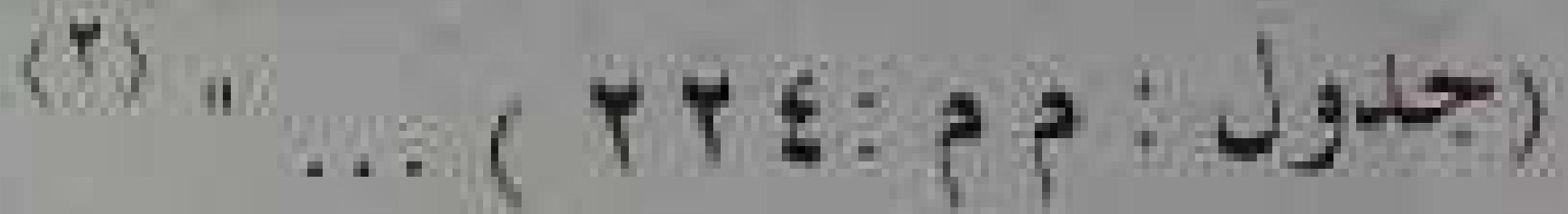

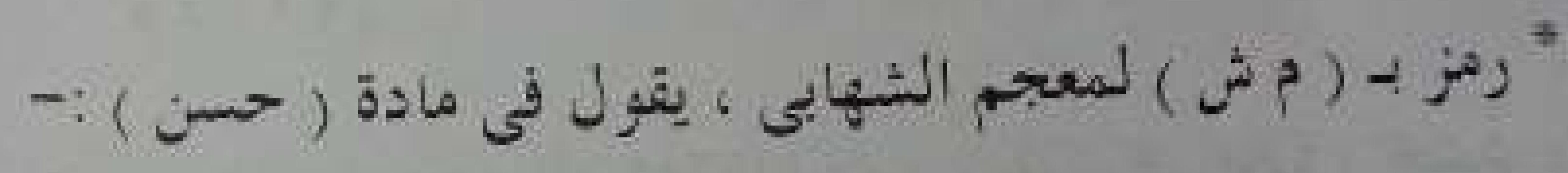

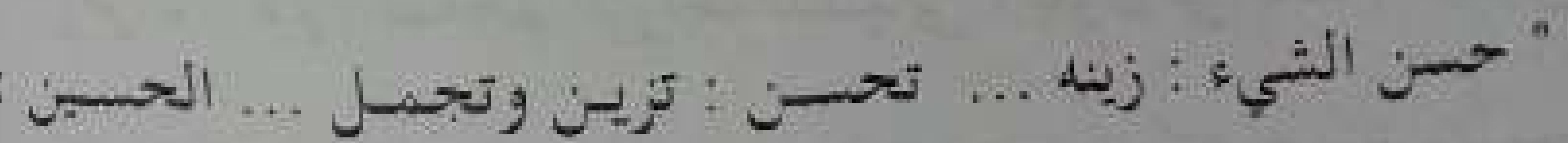

التجل العالى أو هو الحسيز : والحسبون : عصفور ذو ألموان

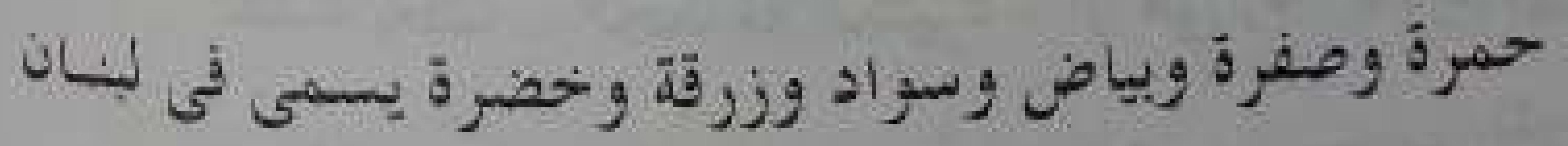

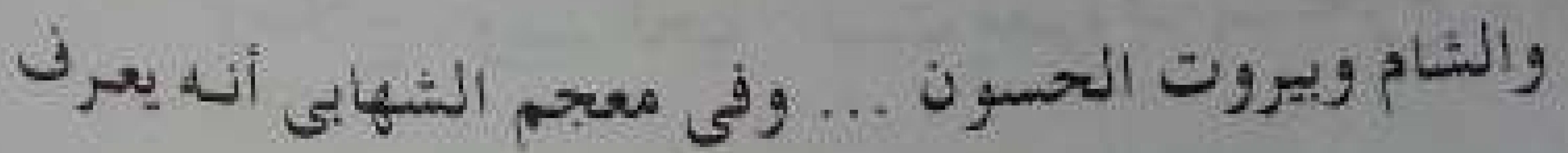




\section{- roe -}

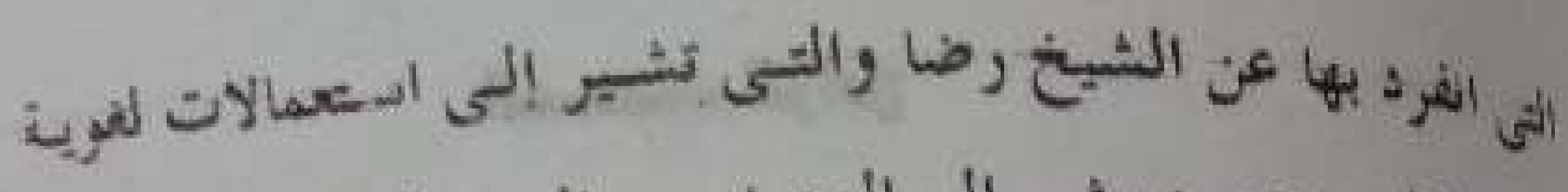

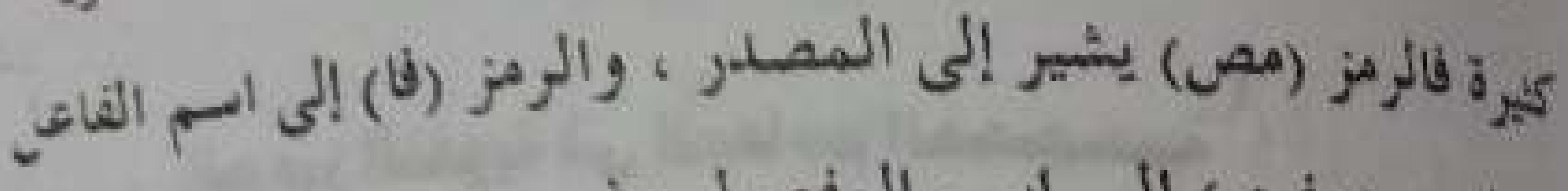

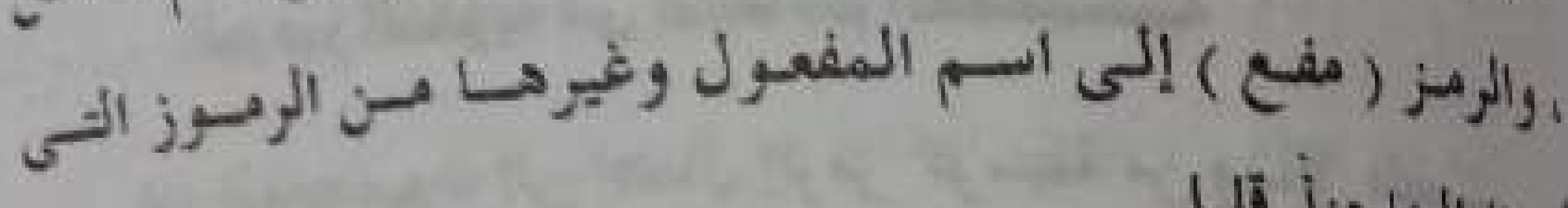

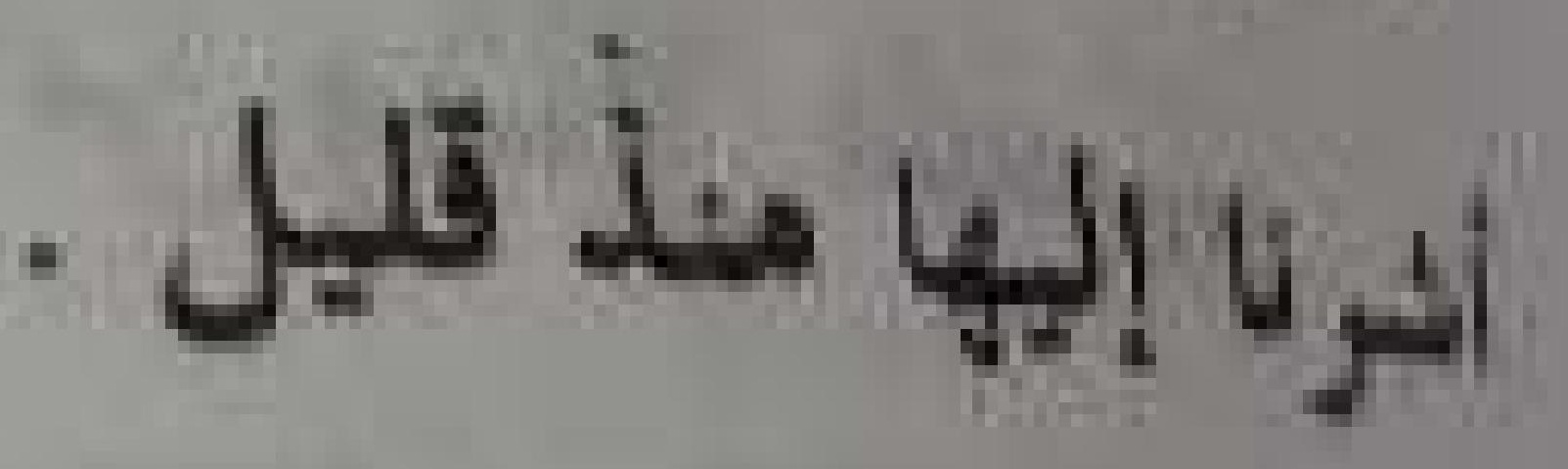

\section{- rog-}

- .

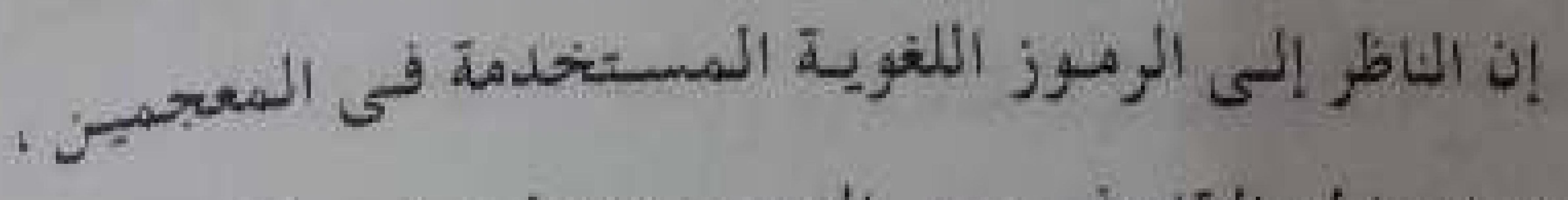

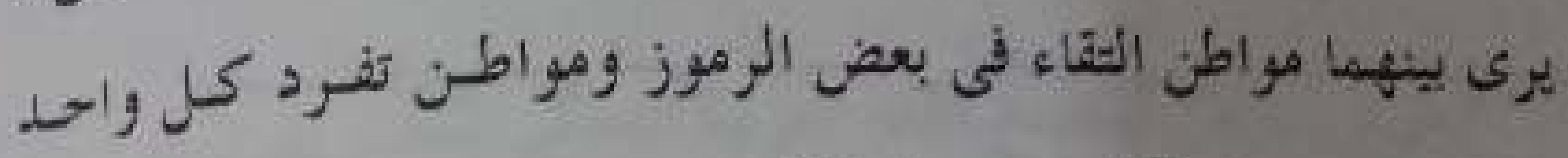

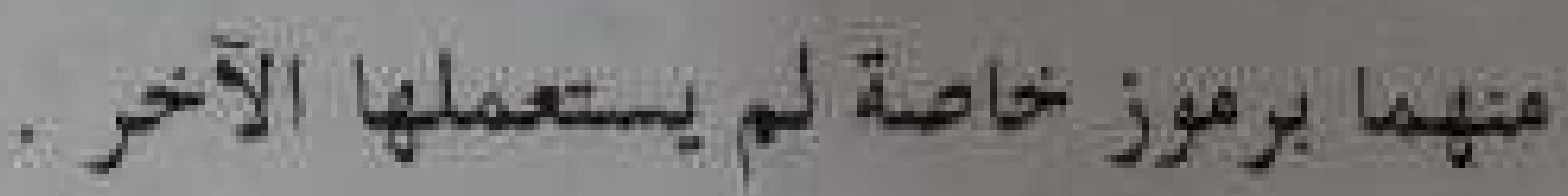

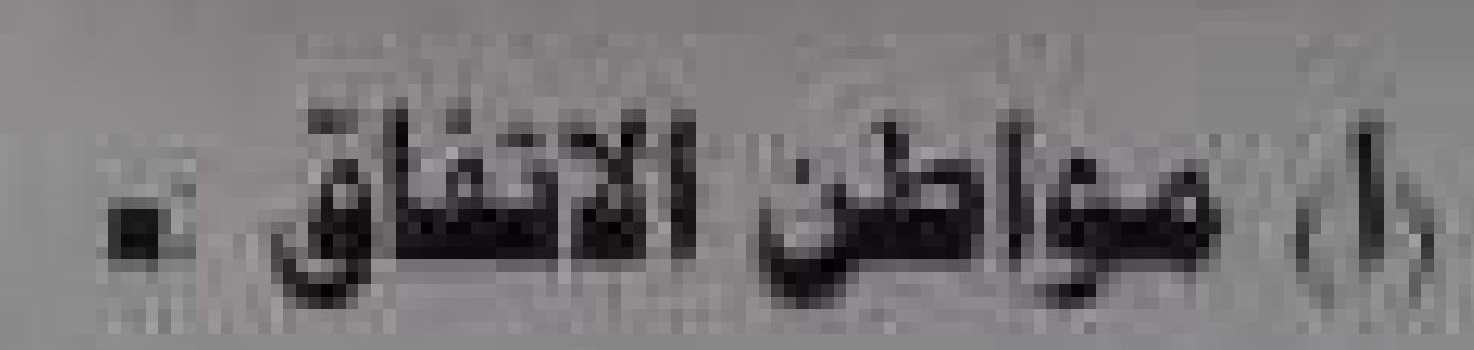

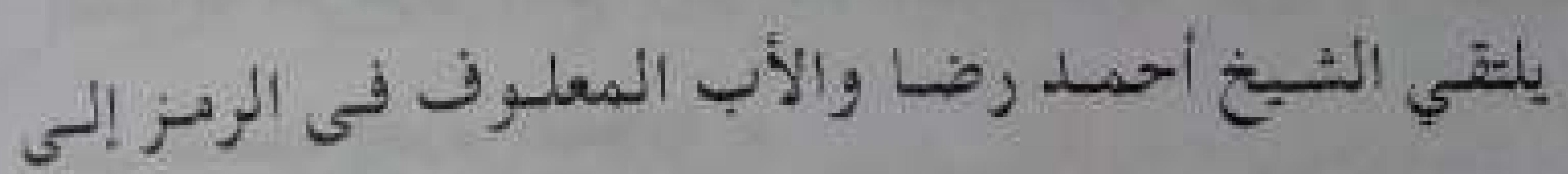

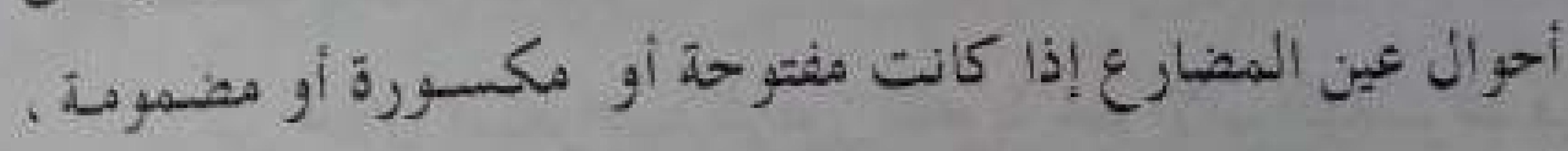

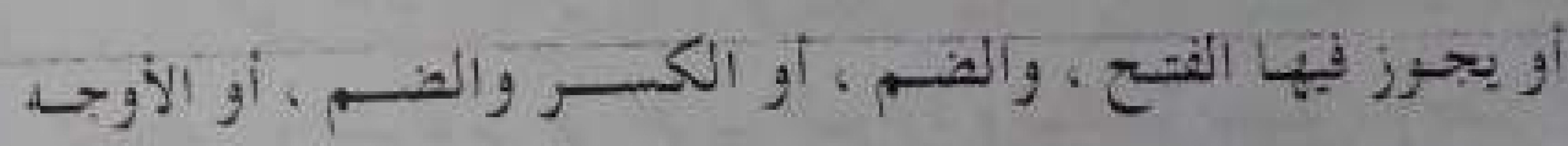

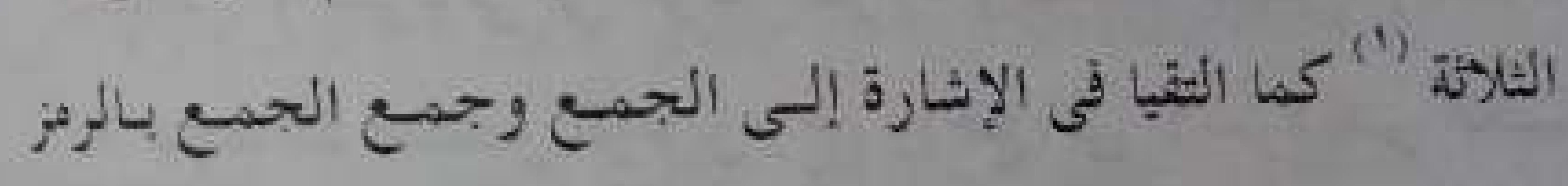

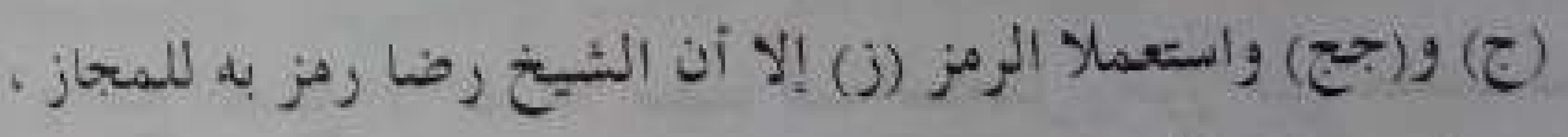

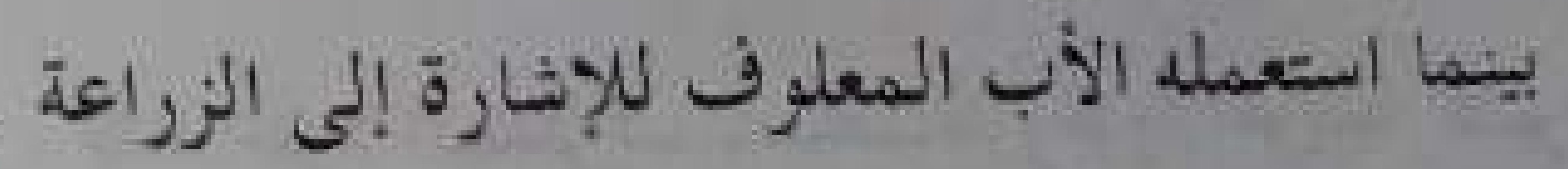
(ب) مواطن الاختلالت .

لق. استعل الثيخ أحسل رقسا والأب المعلوف رموزأ كيرة

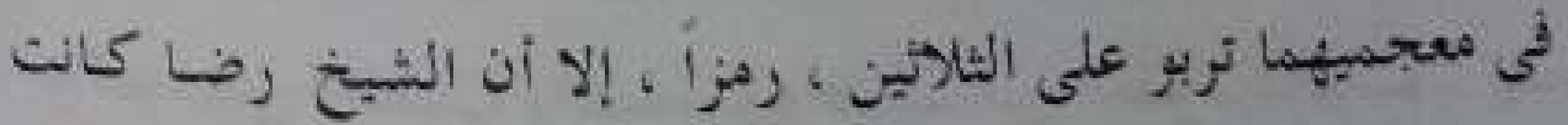

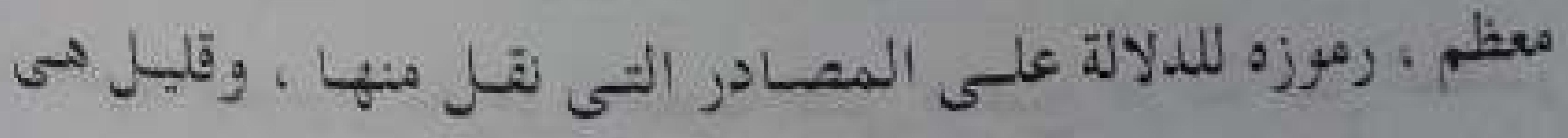

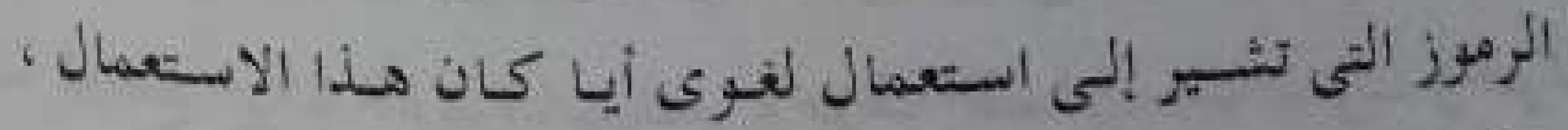

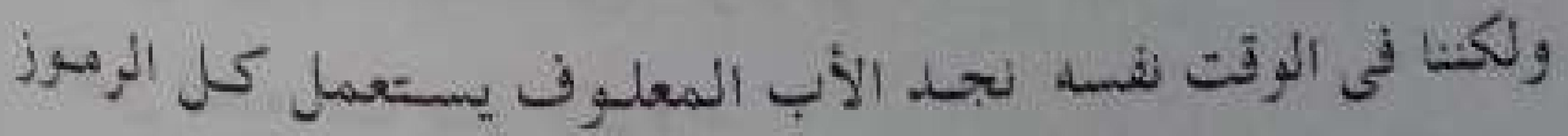




\section{- rov -}

وقام السحمع بوابطة أساطين اللفة والفكر بتغيـل ما وكل

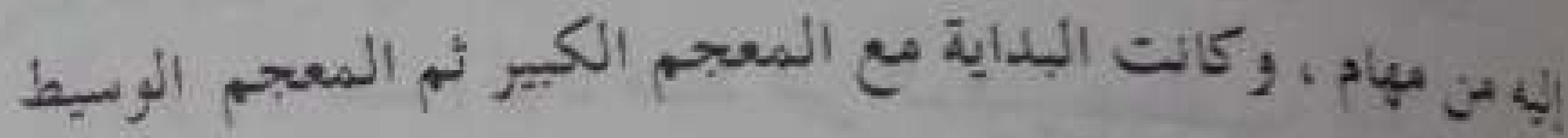

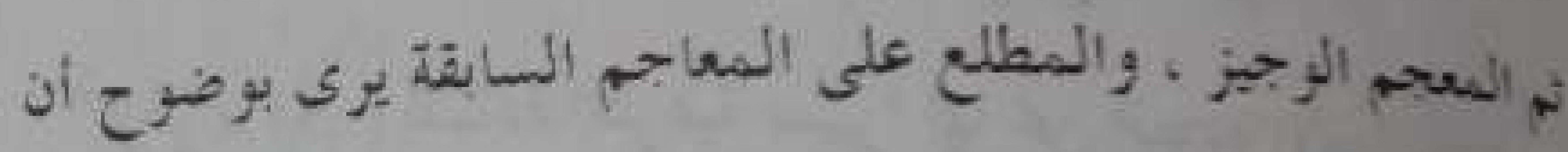

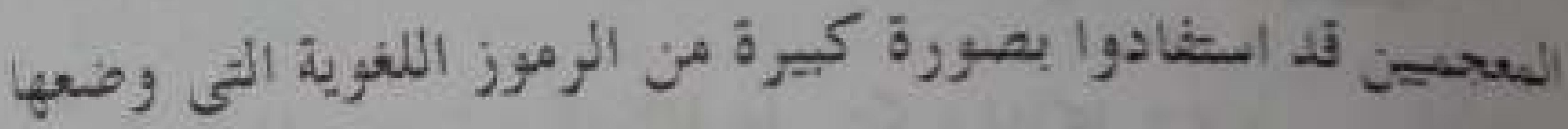

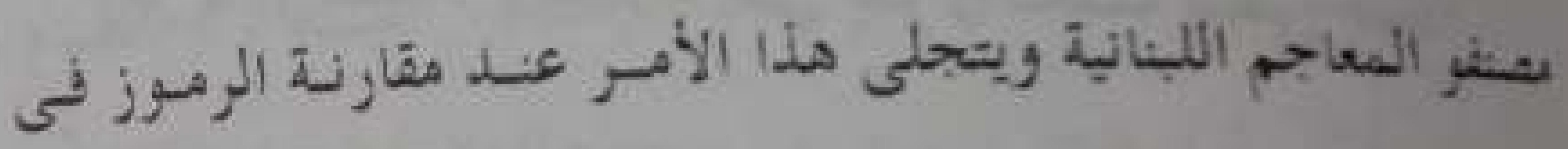

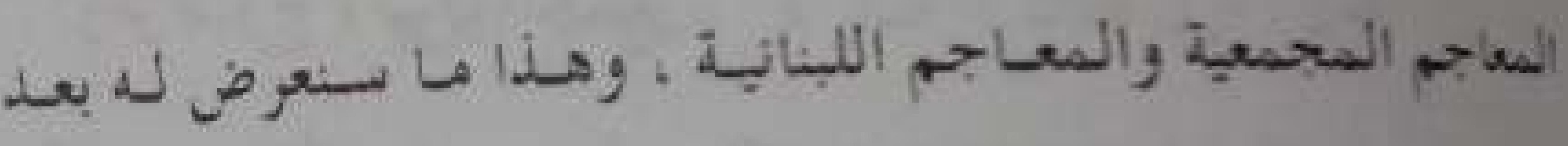

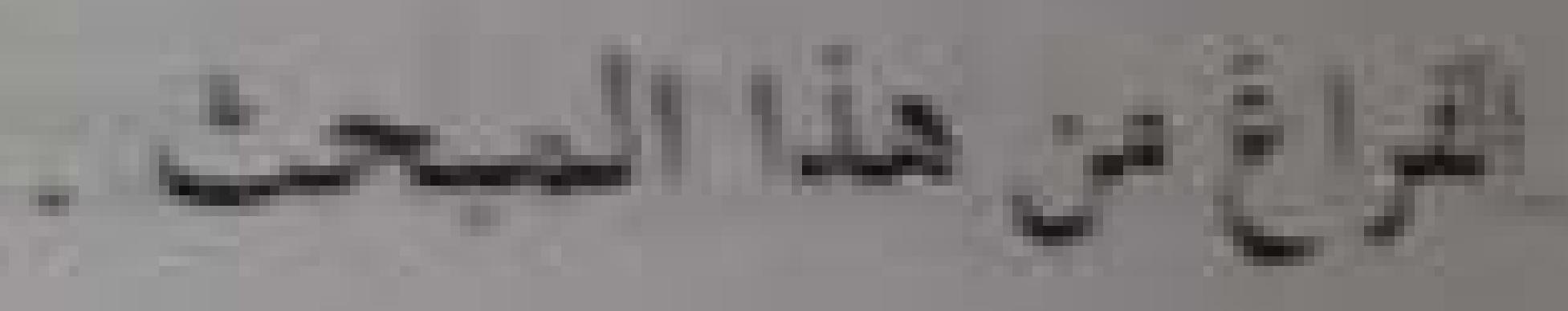

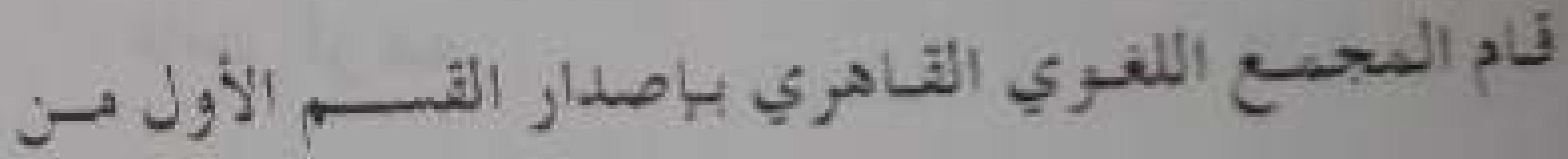

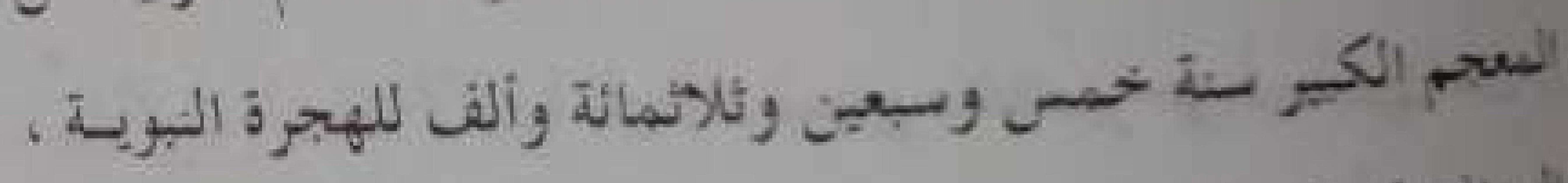

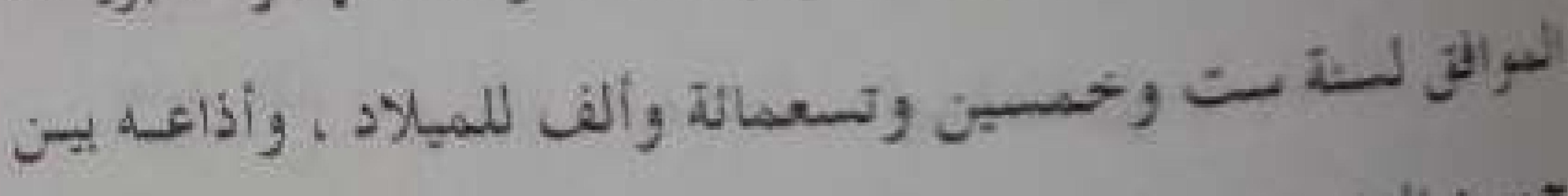

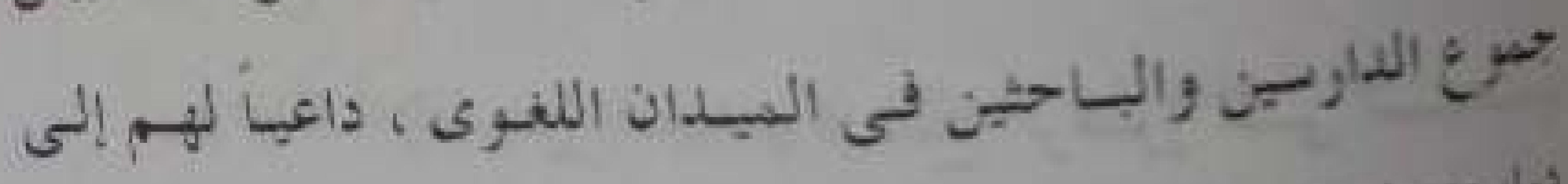

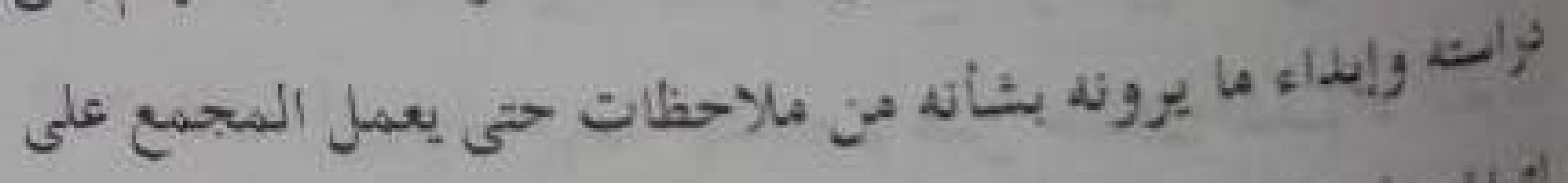

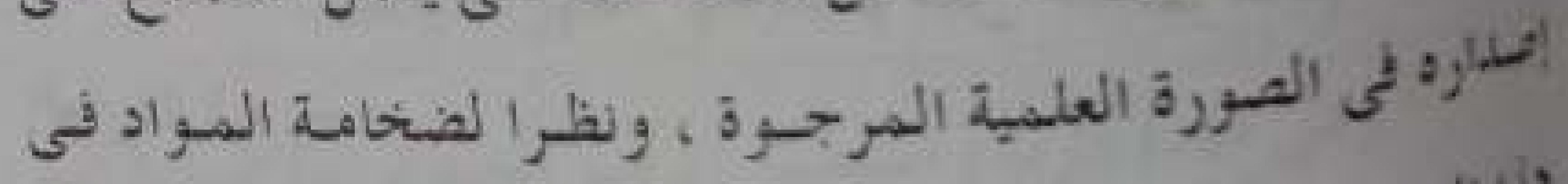

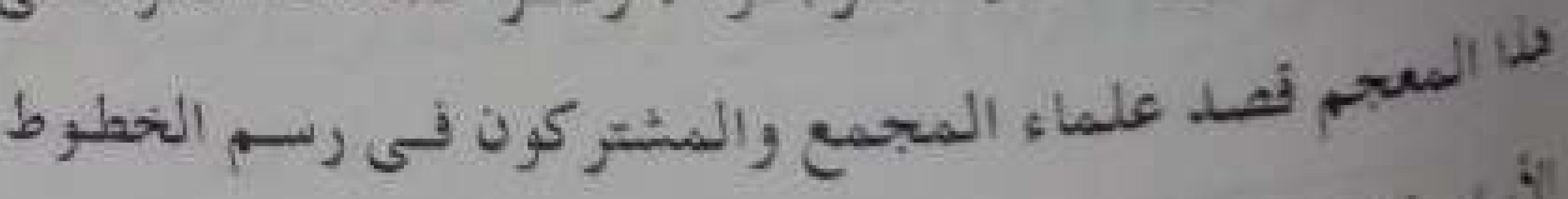

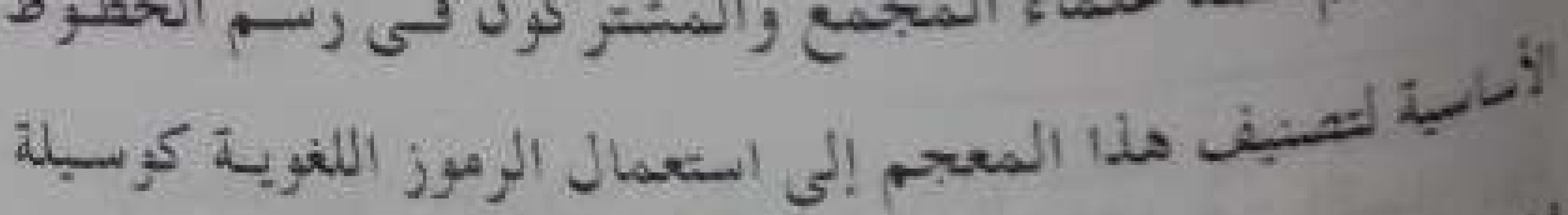

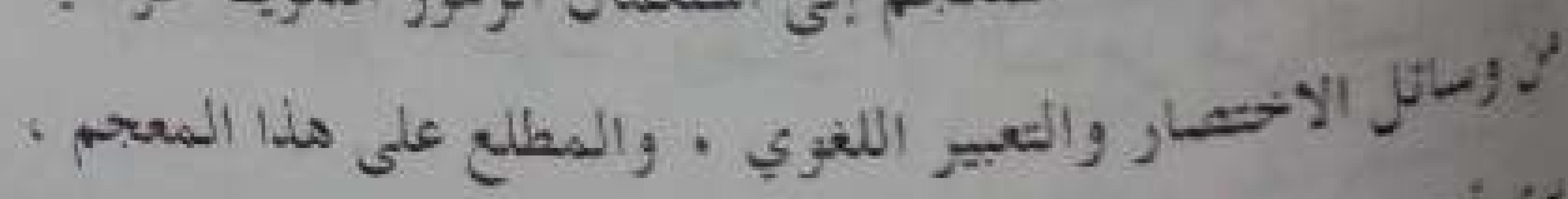

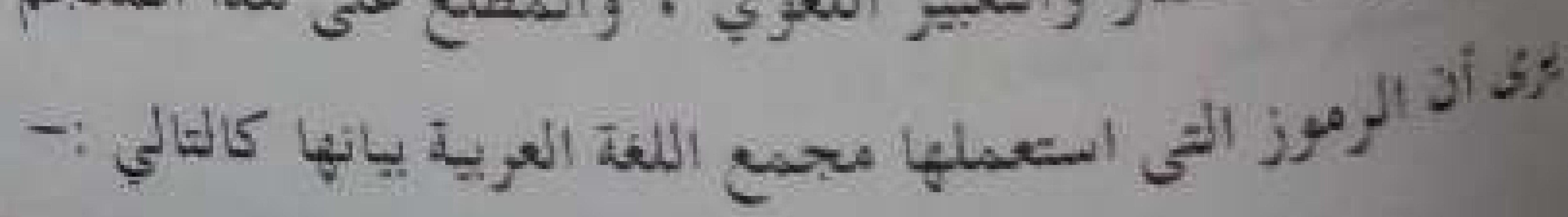

\section{المبيدث اليرابي}

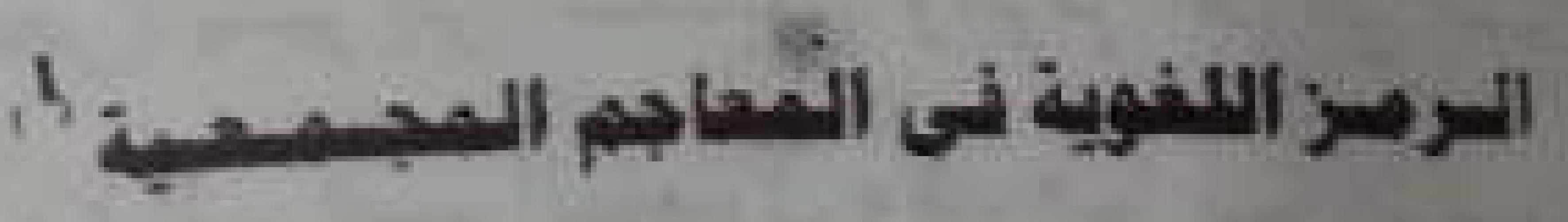

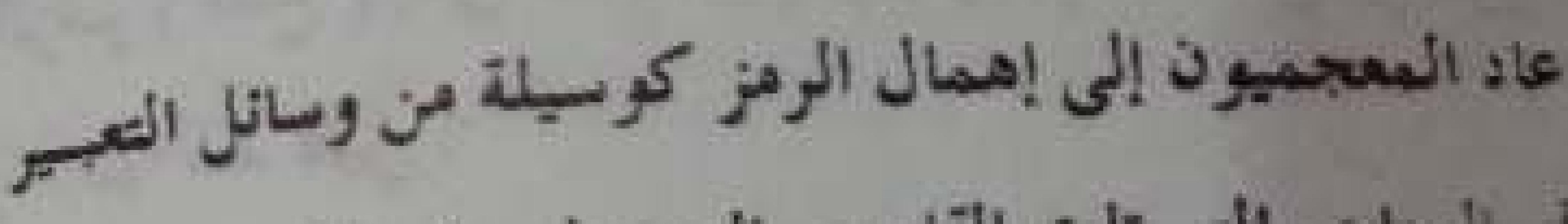

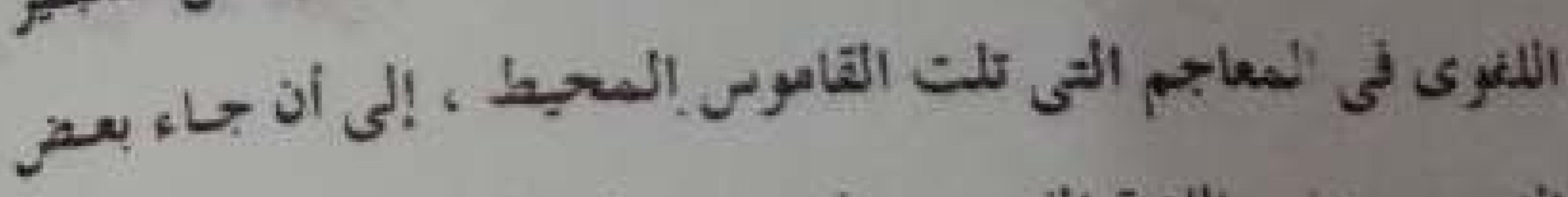

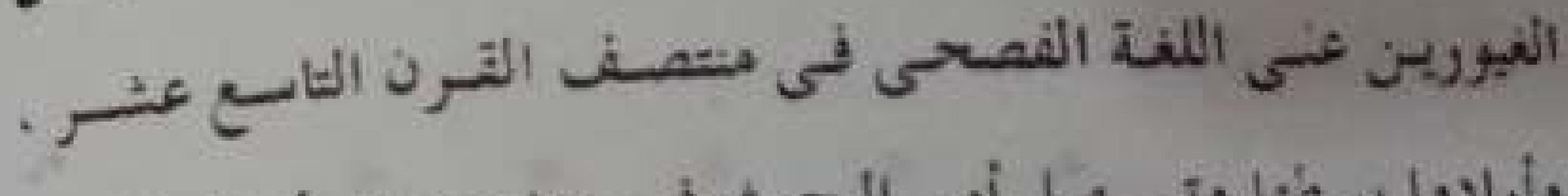

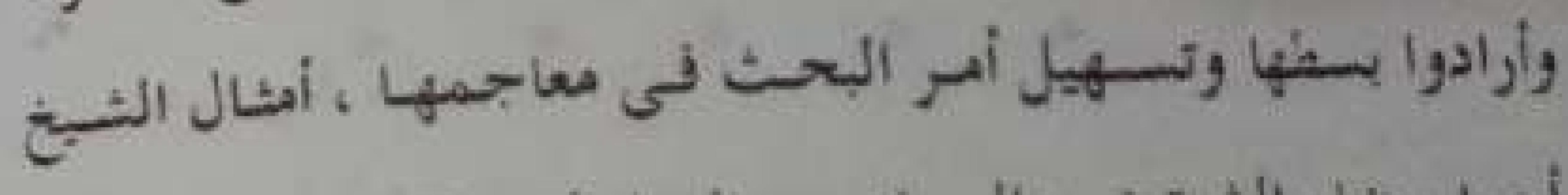

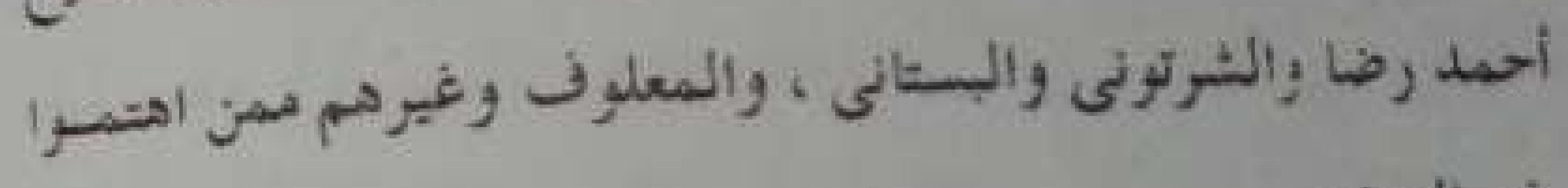
بلَ المعاجي.

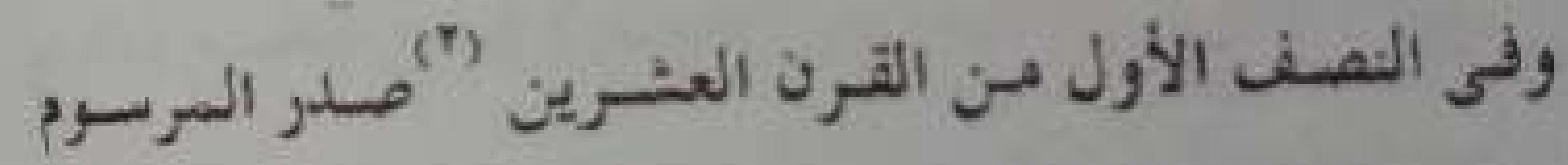

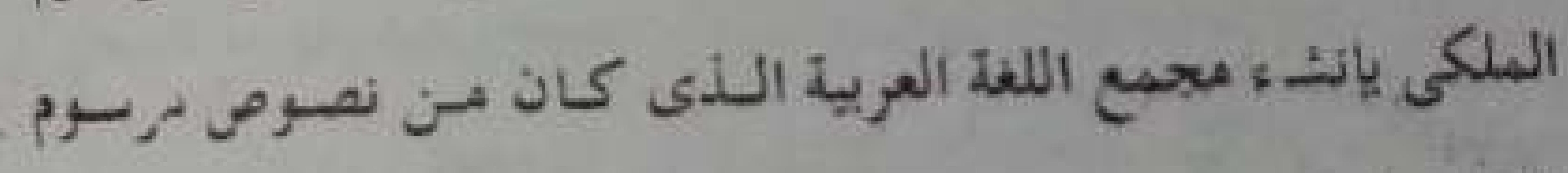
إنشاته ما يلى :-

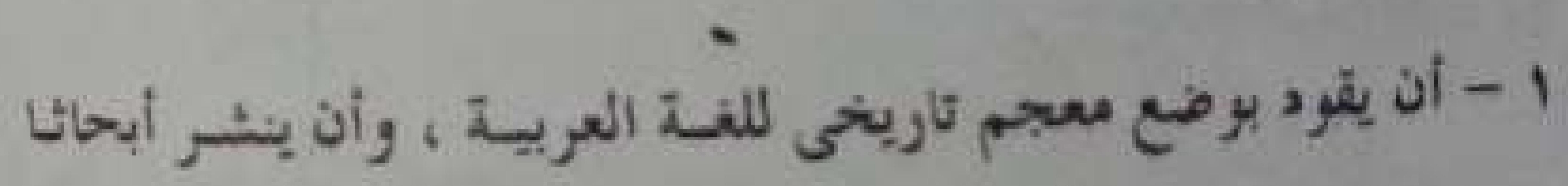

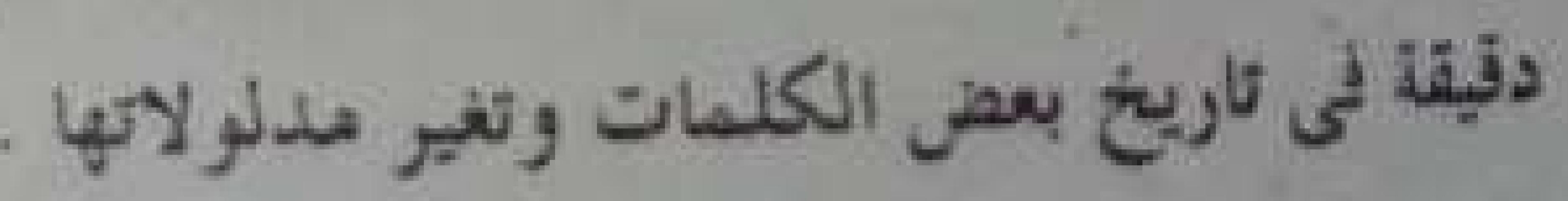
Y - وضع معحمات صغيرة لمصطلحات العلوم والفون

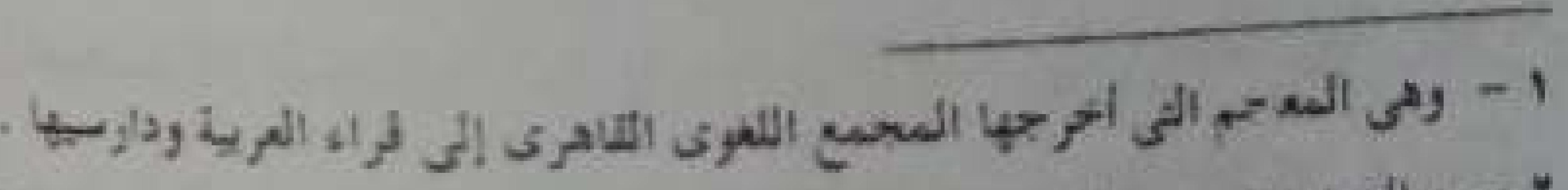

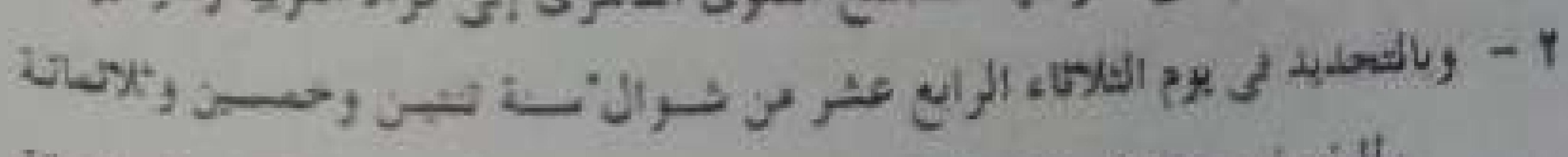

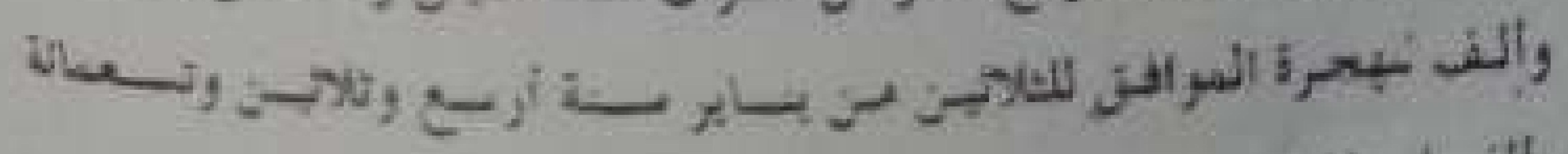
xlly 


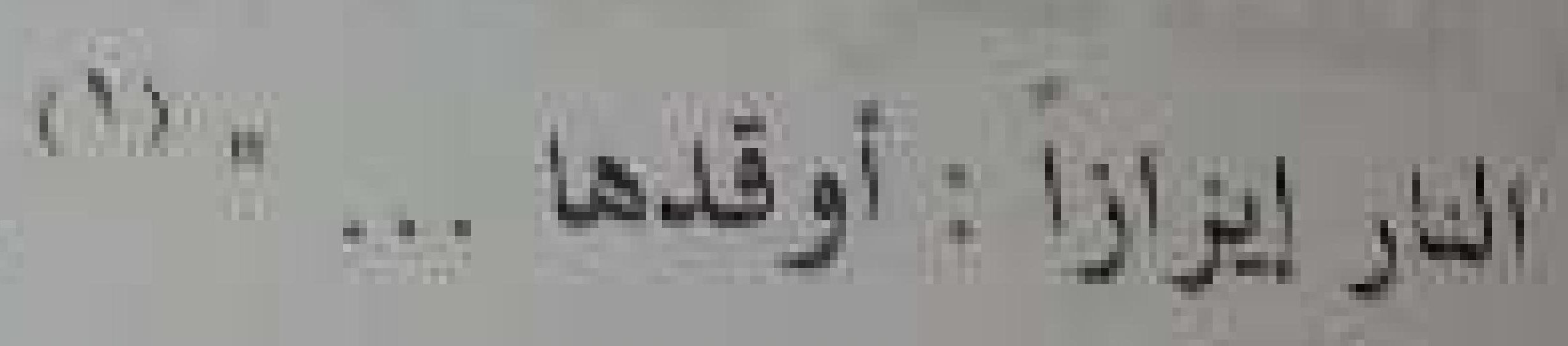

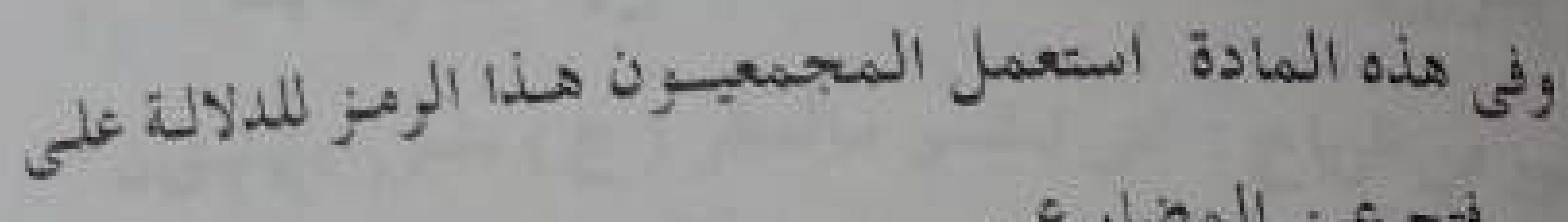

$$
\text { 2 }
$$$$
-:\left(J_{j}\right) \text { ște }
$$

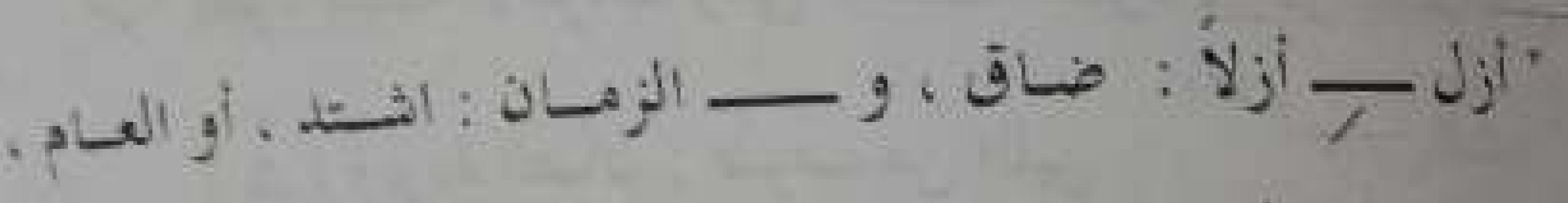

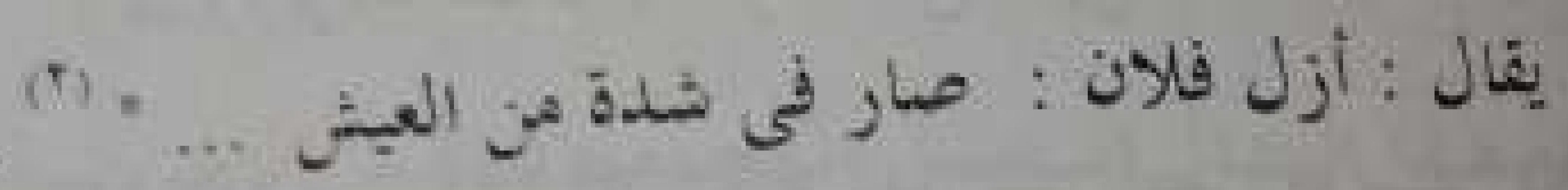

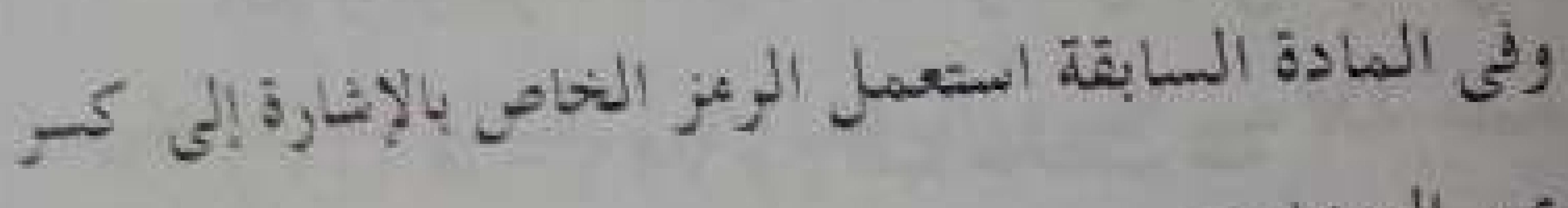

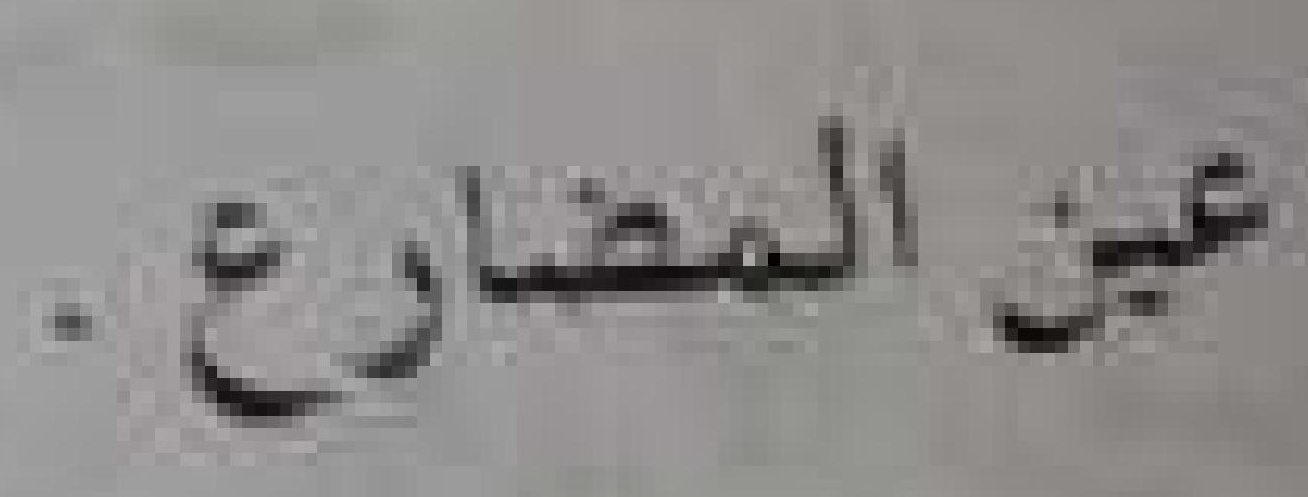
$-:(0, i)$ isse

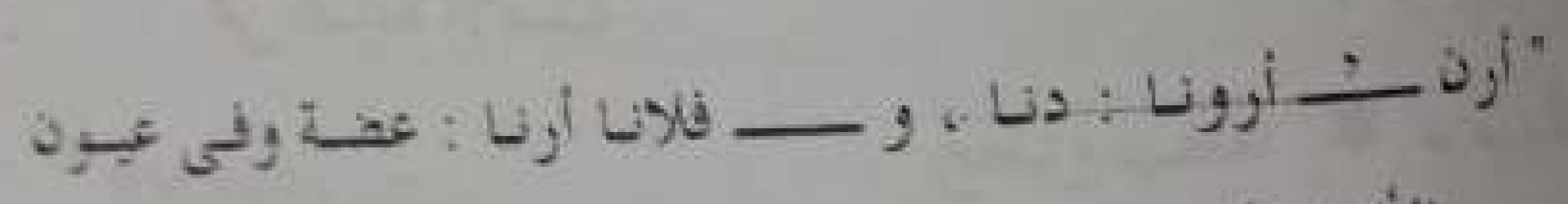

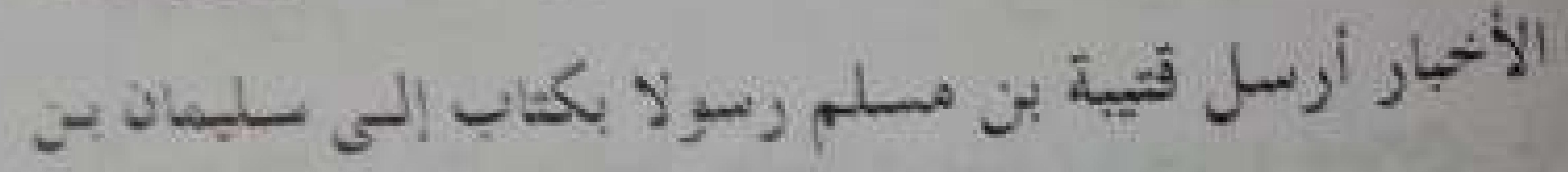

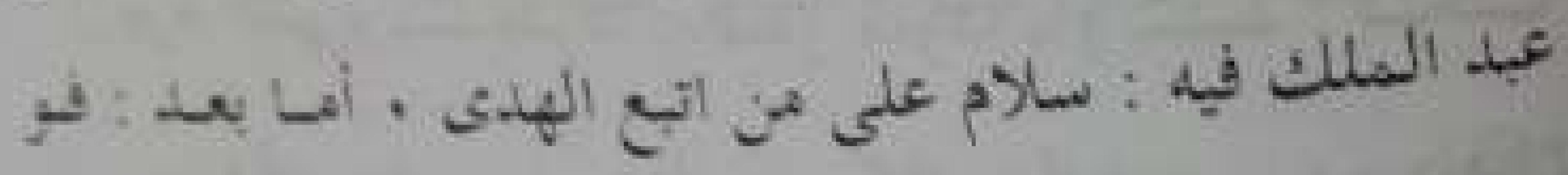

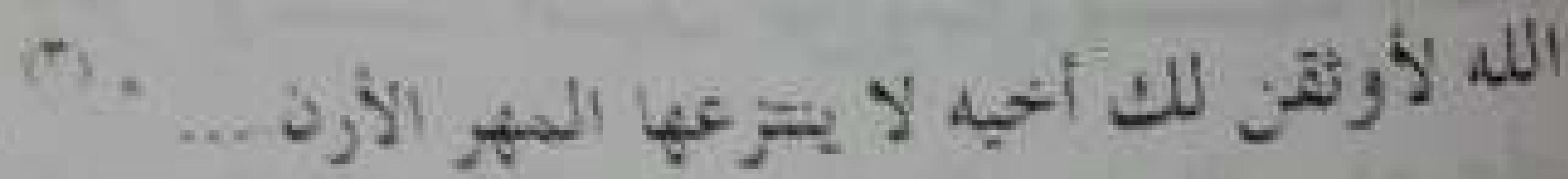

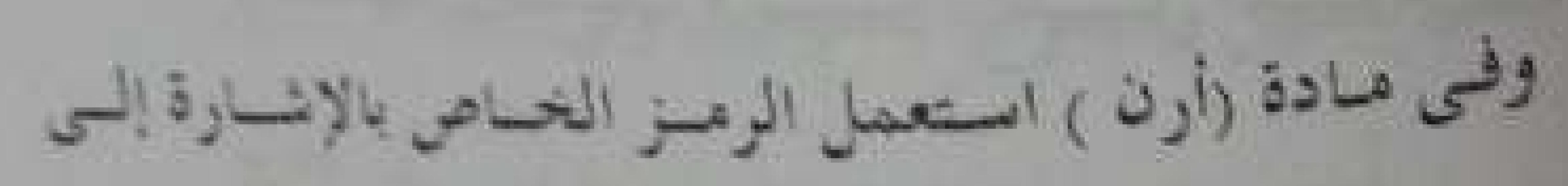

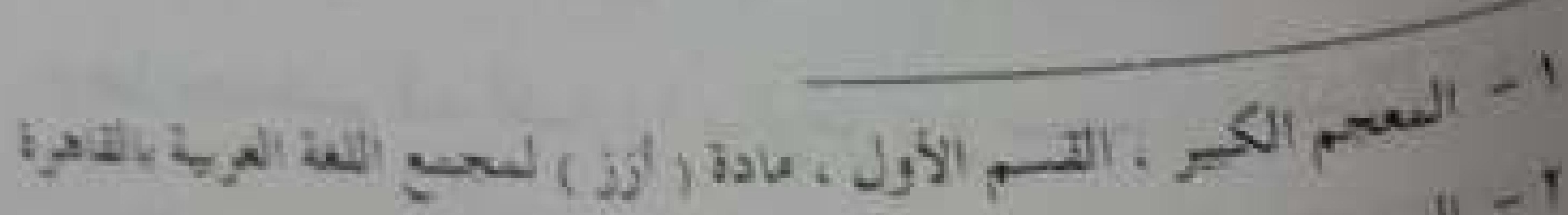

$$
\begin{aligned}
& \text { - (Ji) } \\
& (0, j) \text { isb . }
\end{aligned}
$$

$-\operatorname{ron}-$

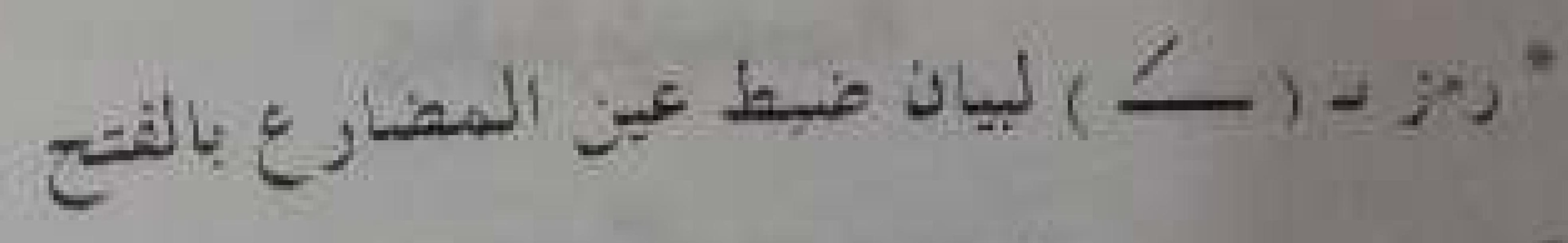

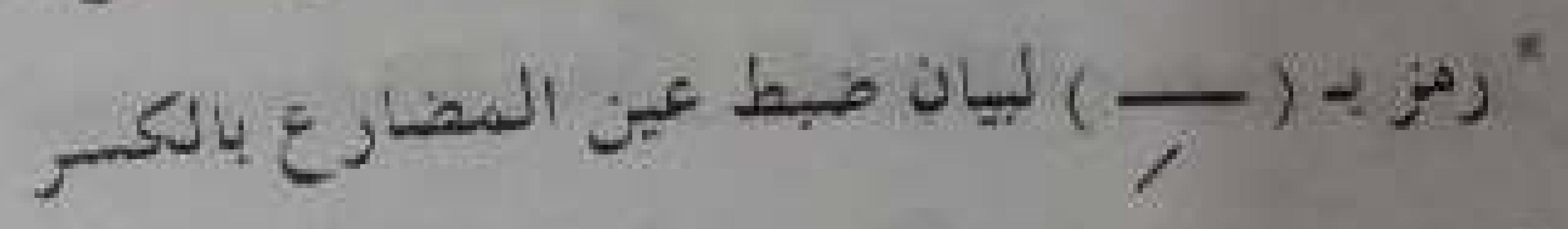

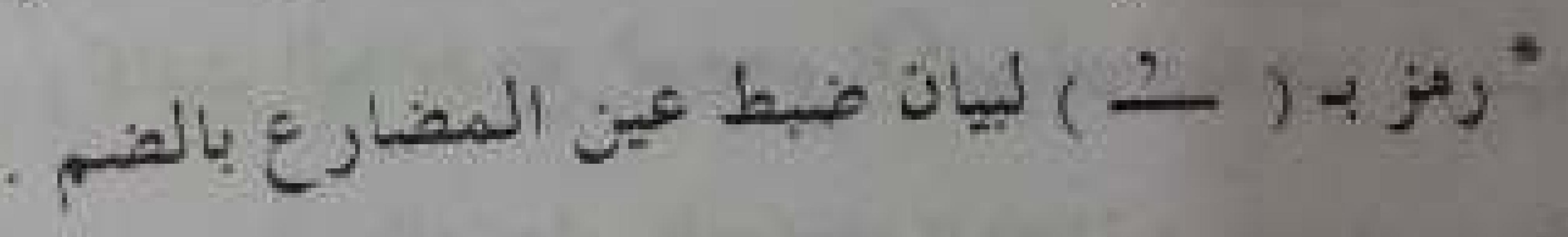

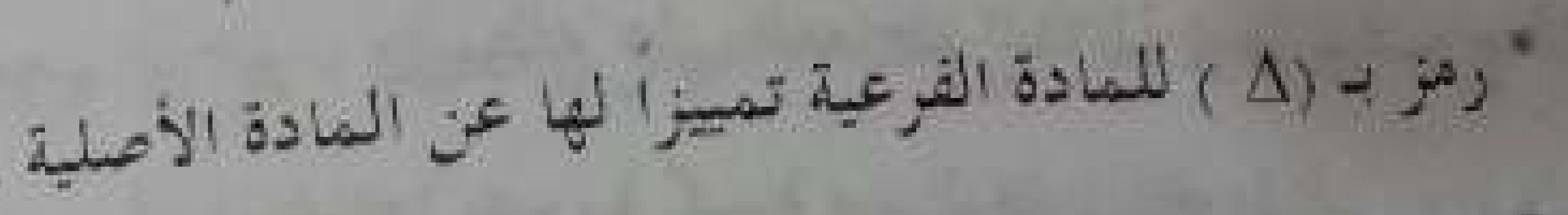

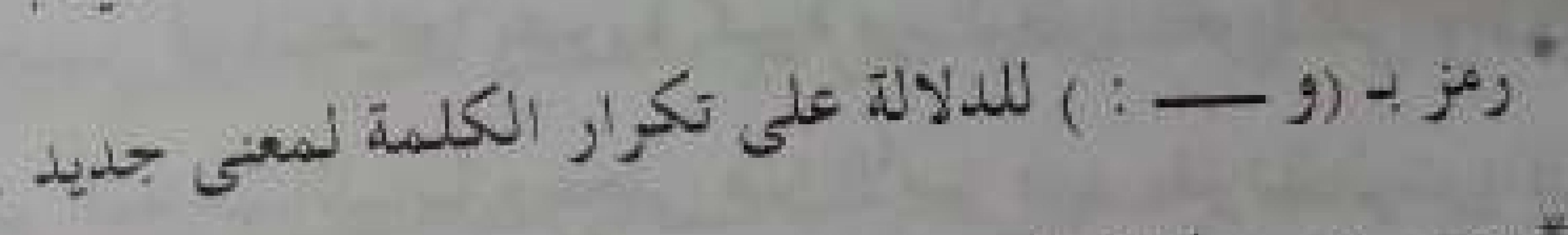
.

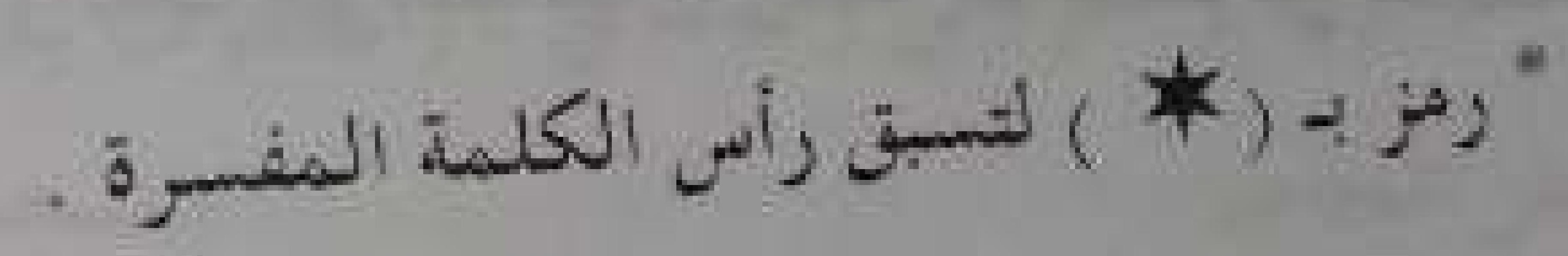

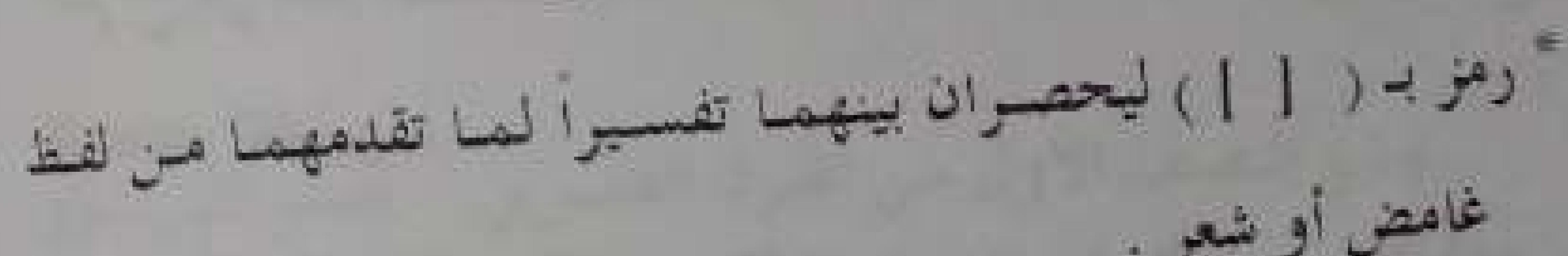
- is

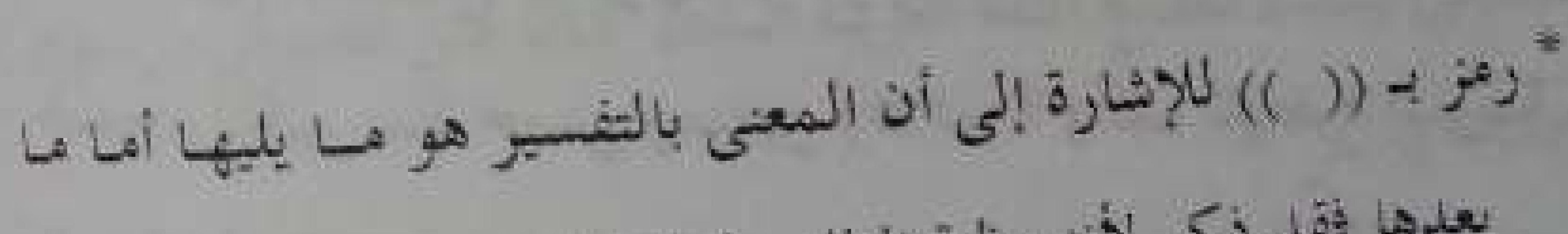

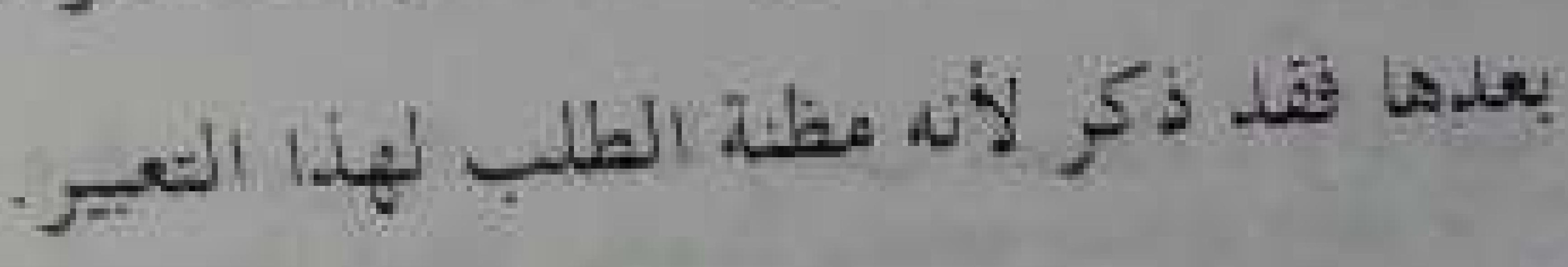

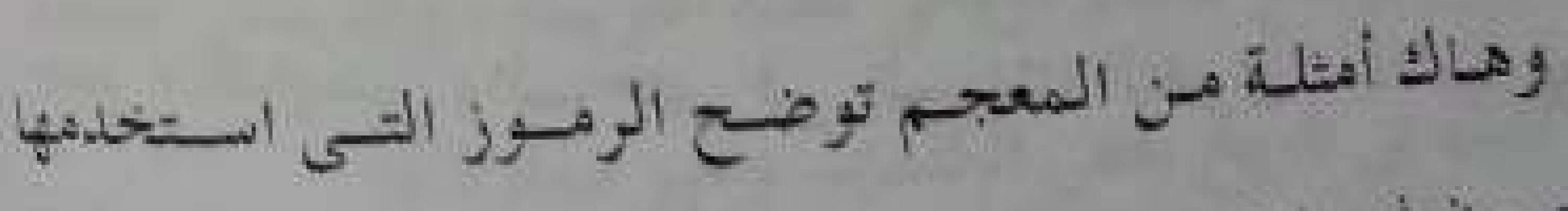

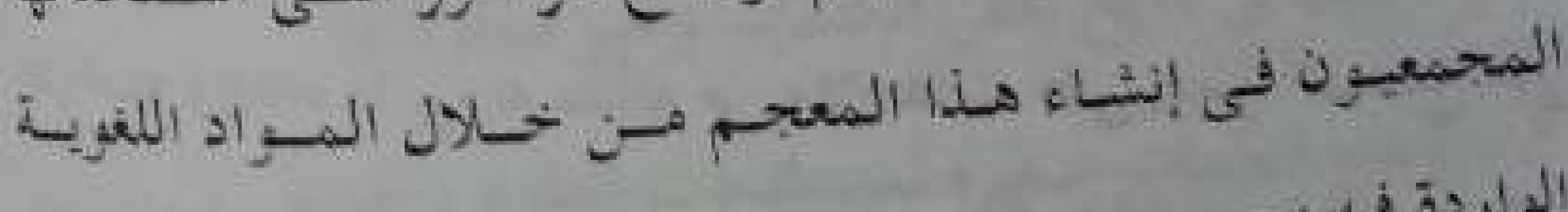

$$
-\therefore \text { is }
$$$$
-:(j j i) \text { ise }
$$

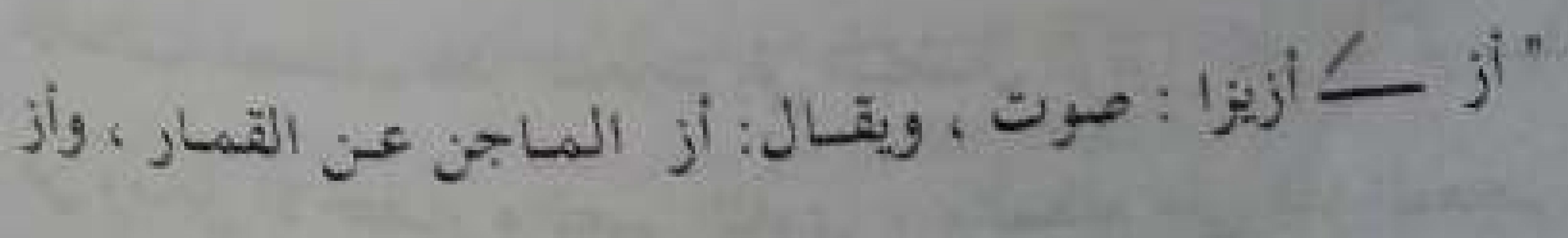




\section{$-\$ 41-$}

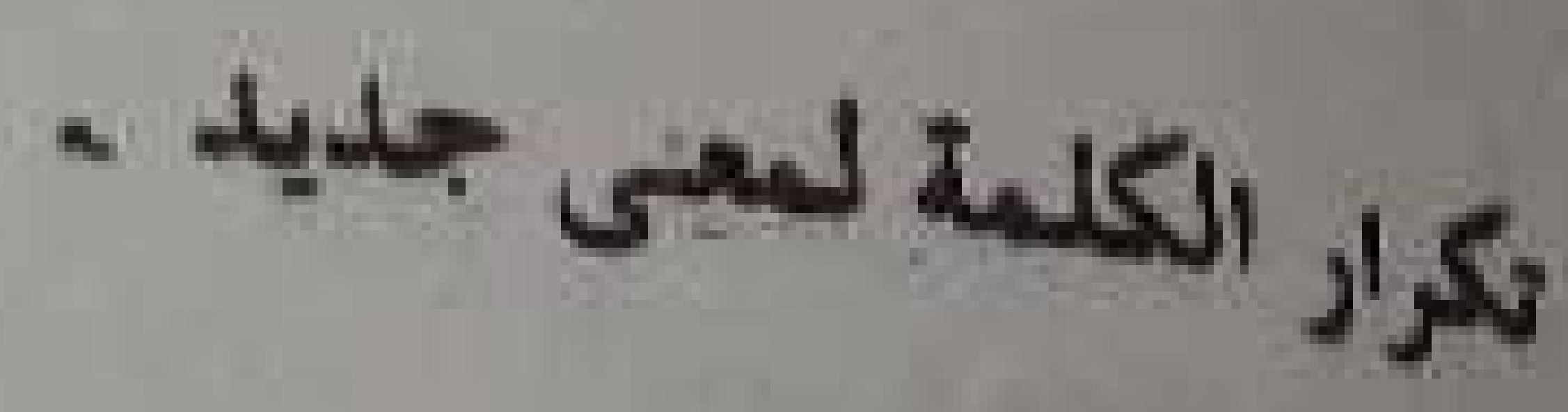

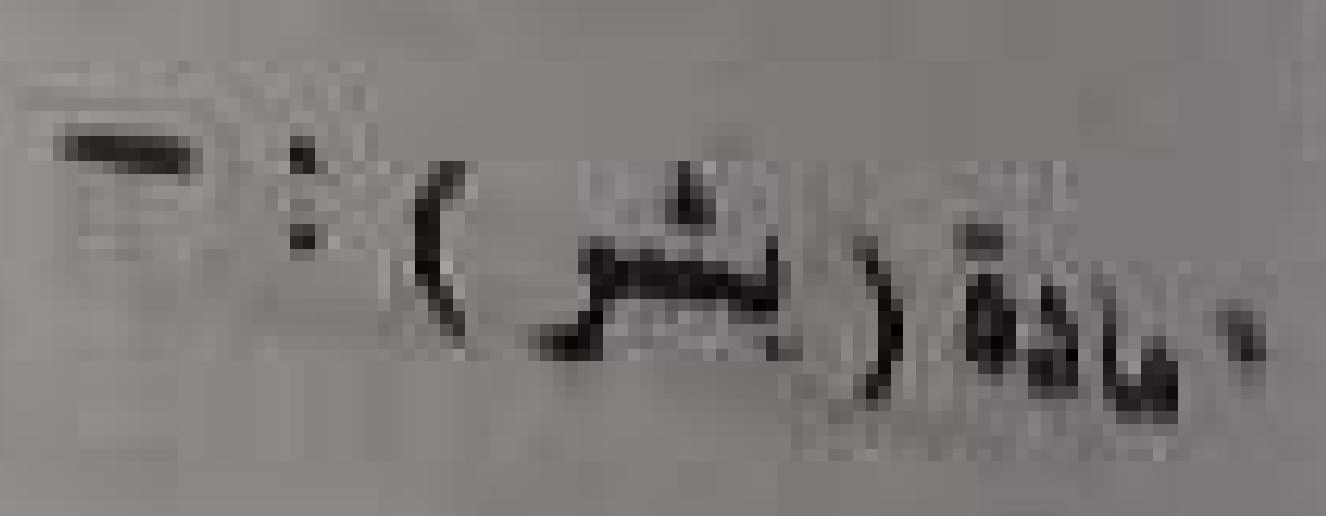

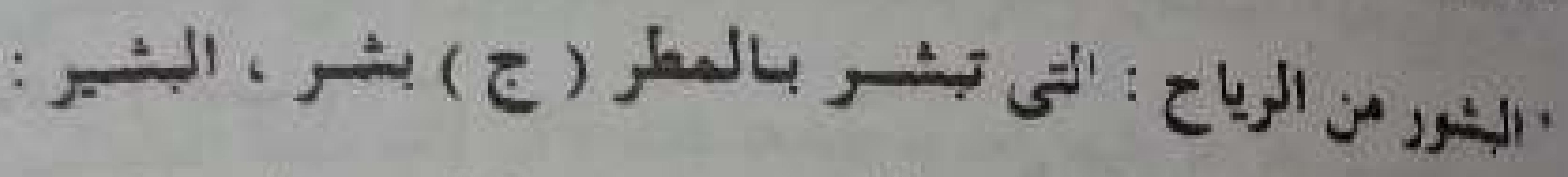

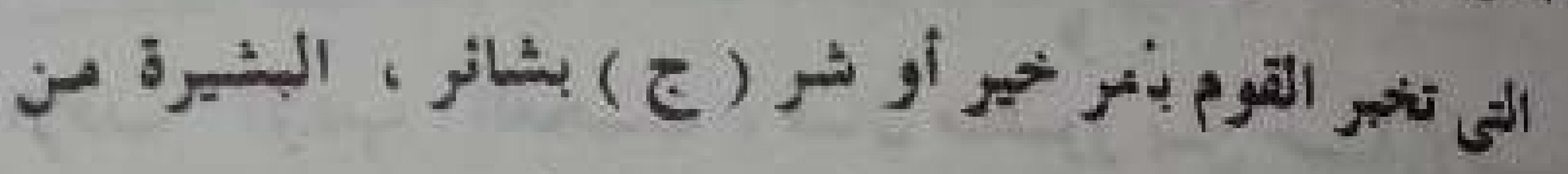

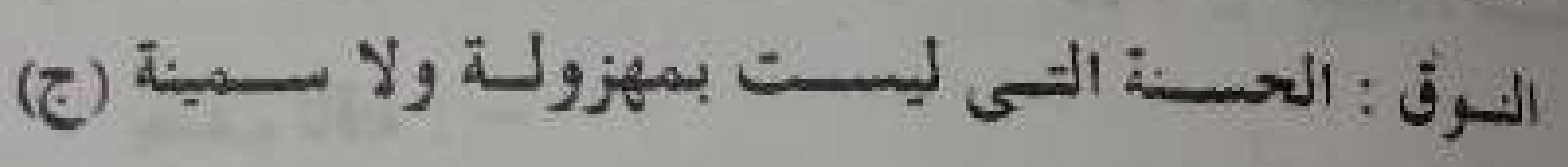
(1). .... شائر

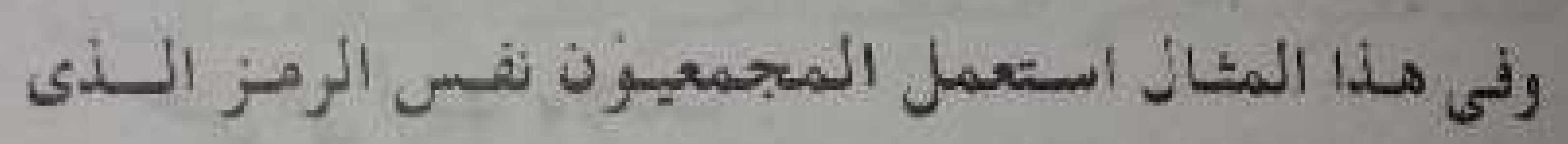

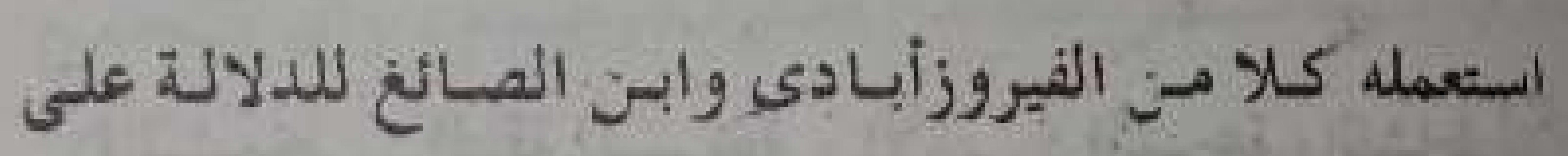

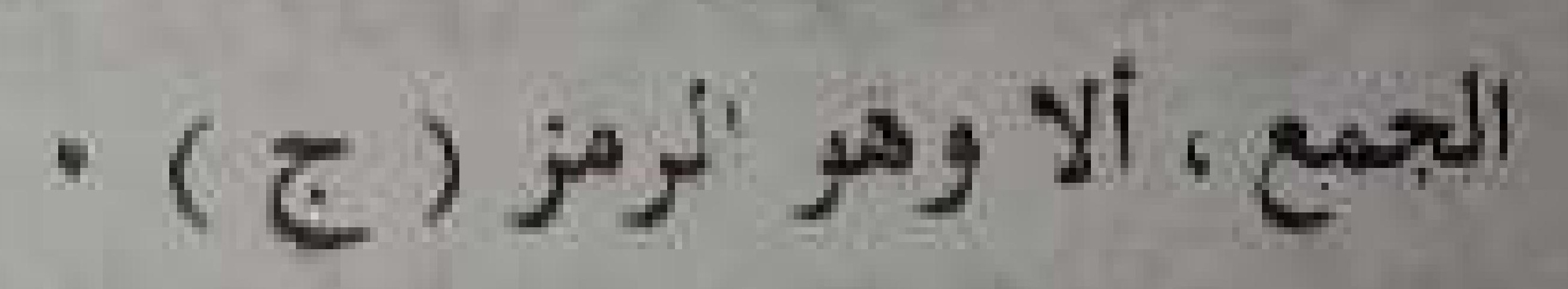

$$
\text { - : (أبر (ب) }
$$

\section{"ن}

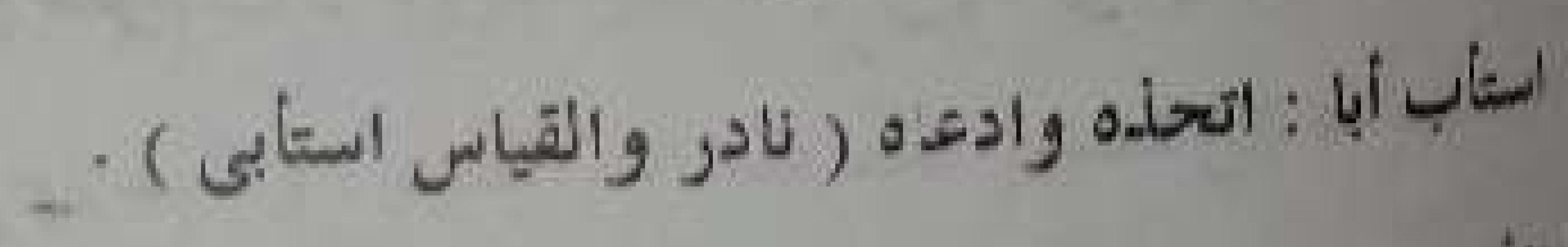

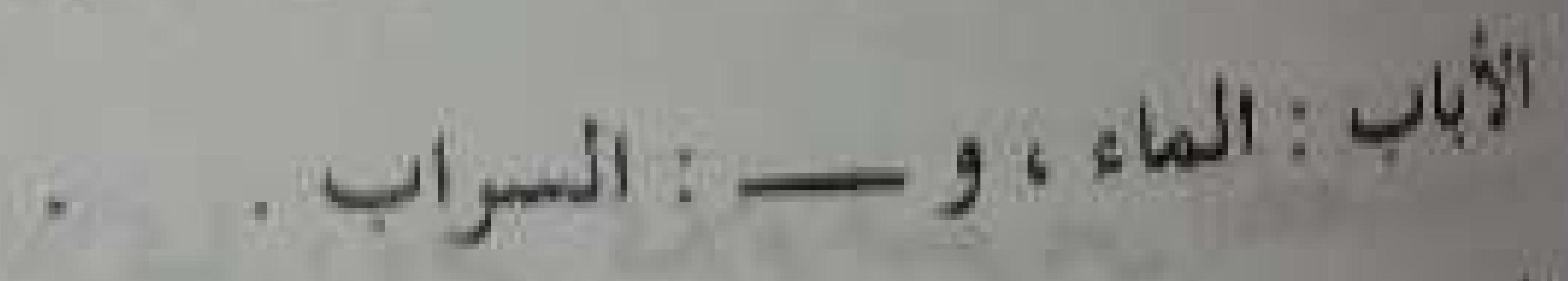

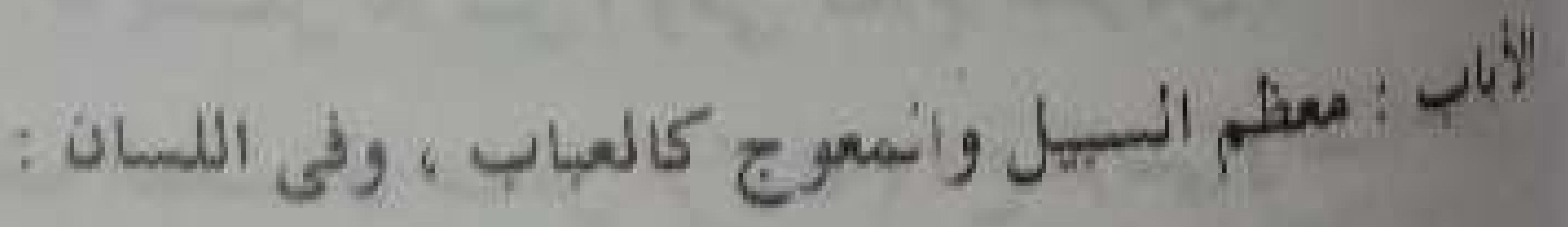

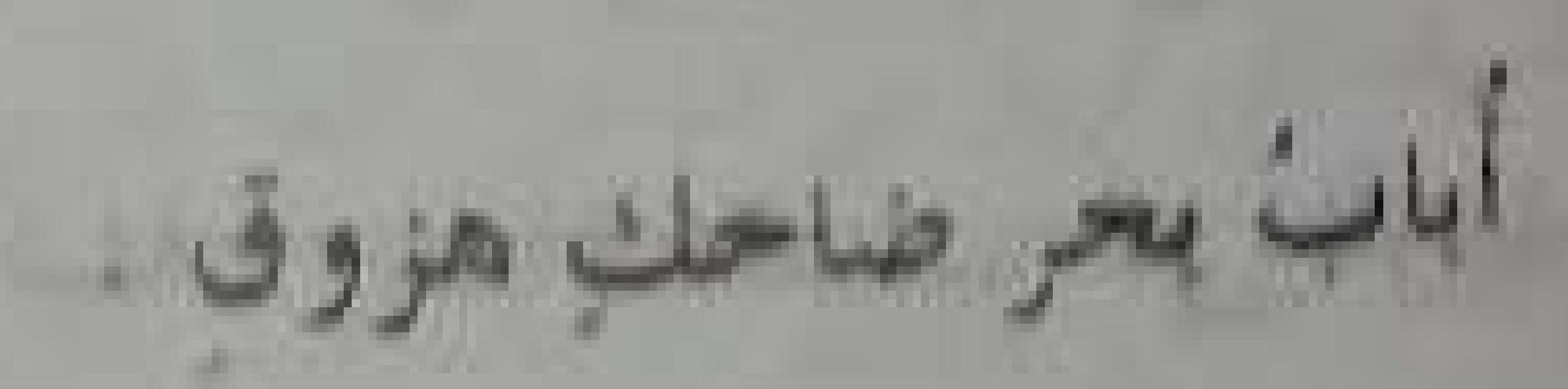

$-x+=$

$$
\begin{aligned}
& \text { م- عي المصارع } \\
& -:(2,0) \text { ist }
\end{aligned}
$$

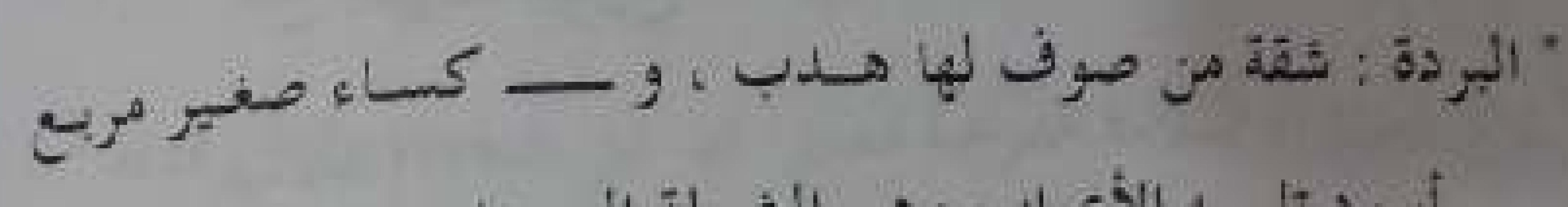

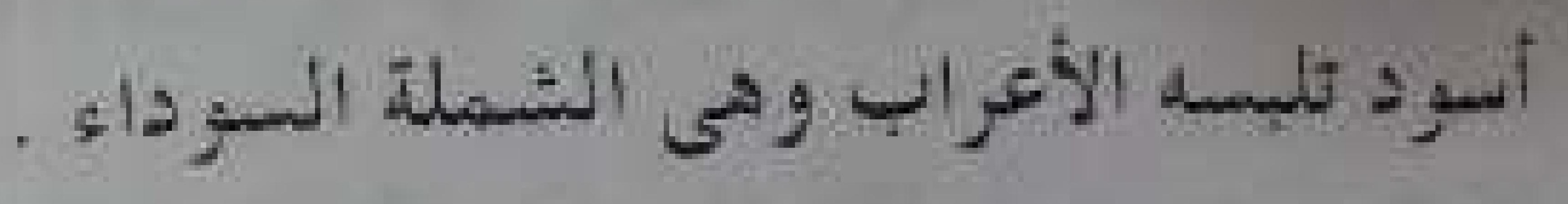

$$
\text { ( وبردة الضأن : ضرب دم الللن. }
$$

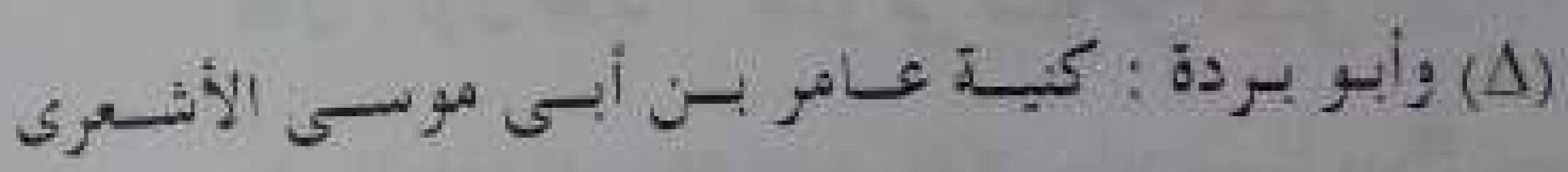

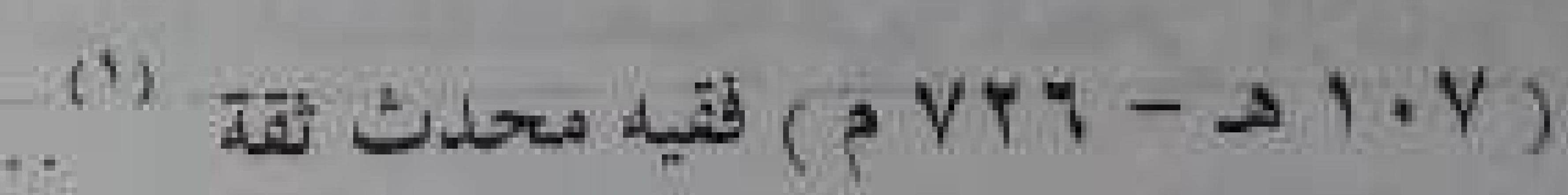

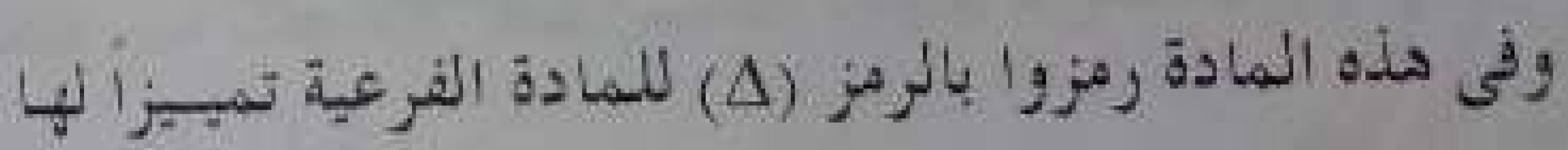
عن المادة الأصلية.

$$
-:(2, y) 3260
$$

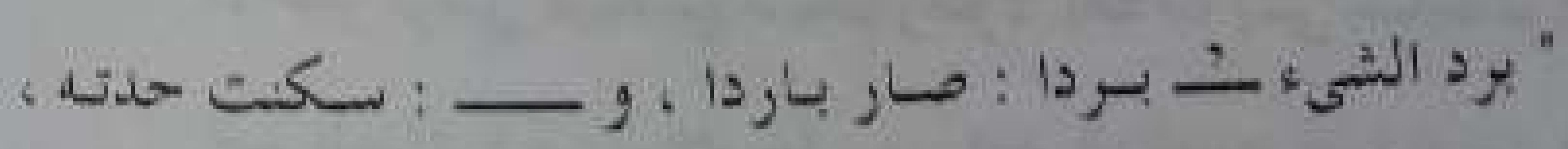

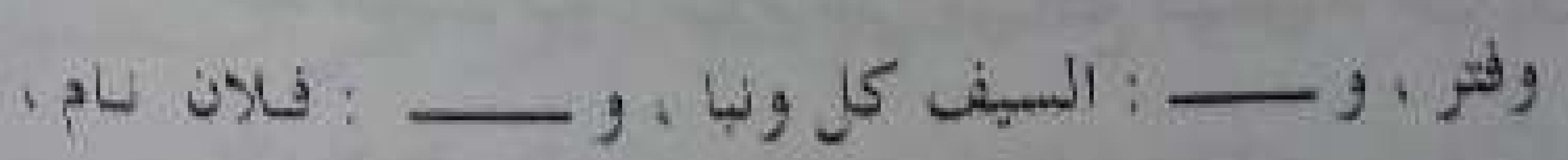

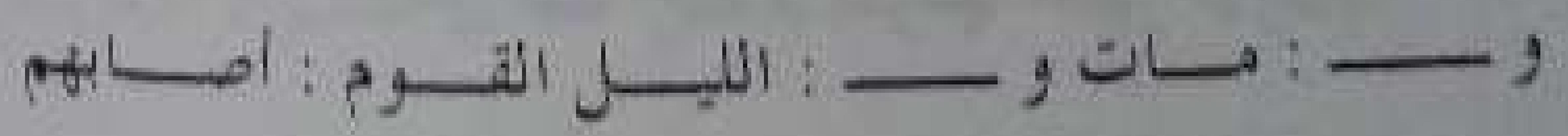

$$
\text { (7) } 11 . . .025
$$

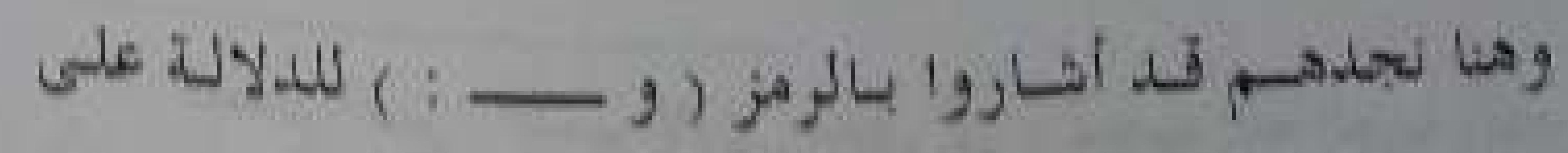




$$
+\cdots-
$$

$\left\langle v^{2}=\ldots+2+x y\right.$

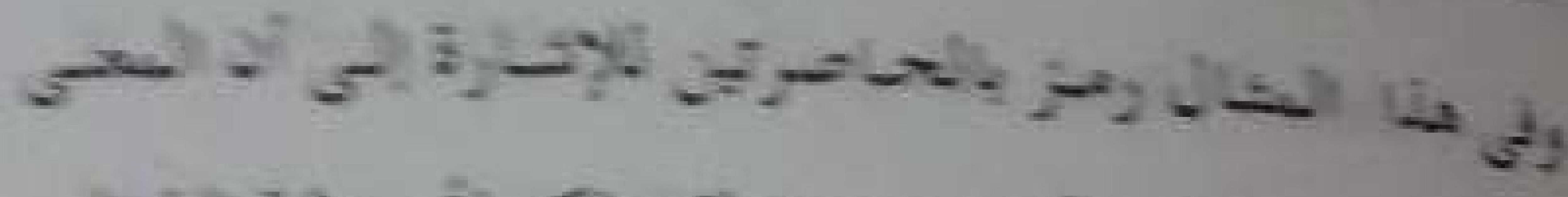

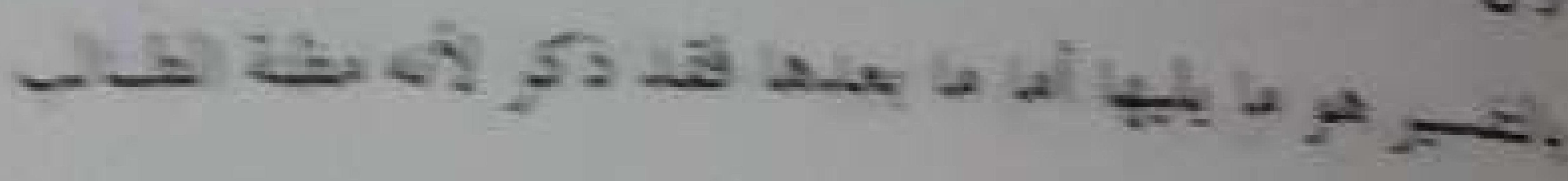
$x+4$

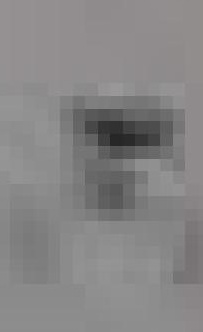

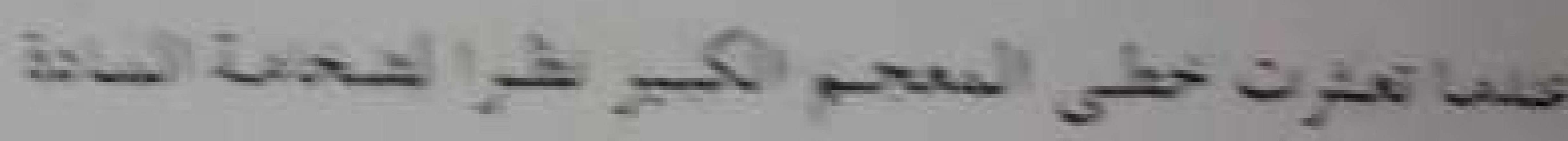

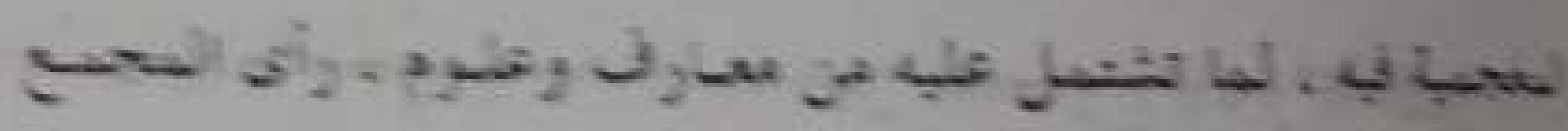

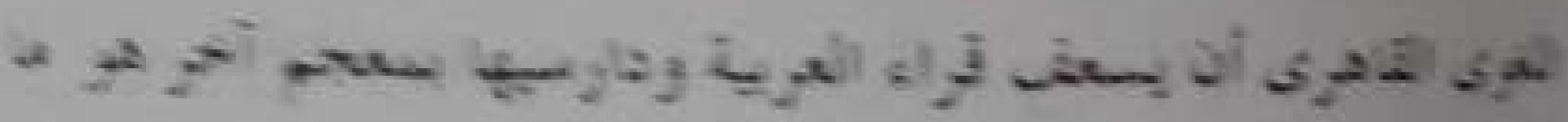

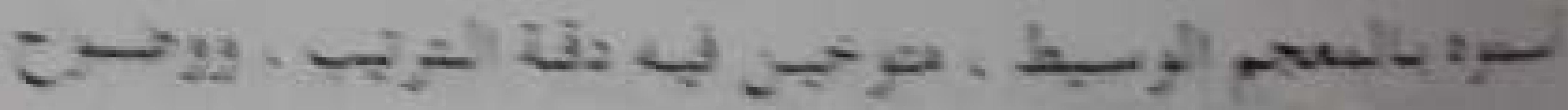

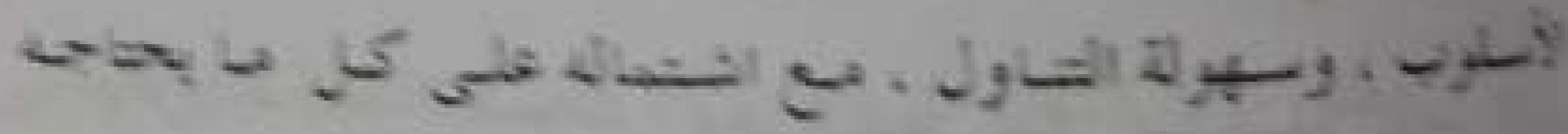

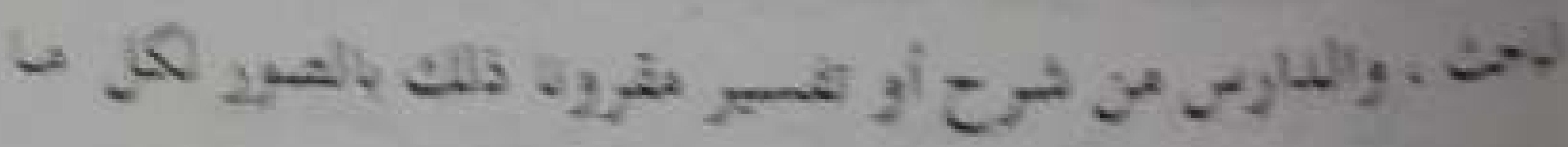

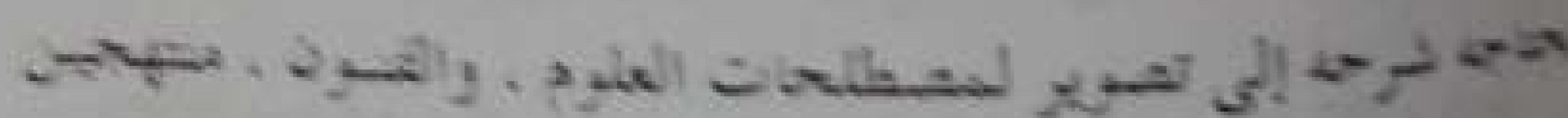

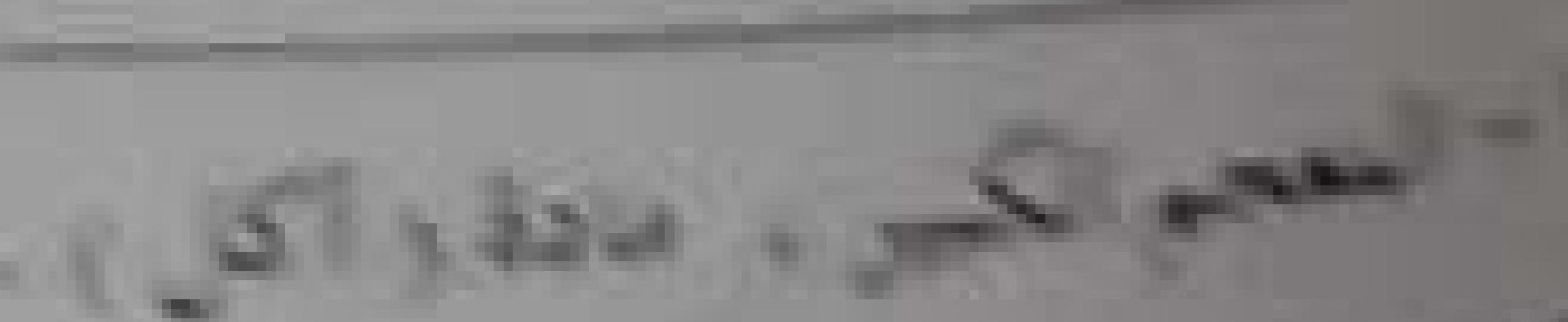

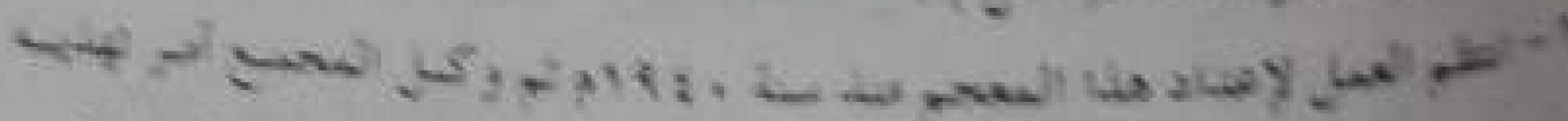

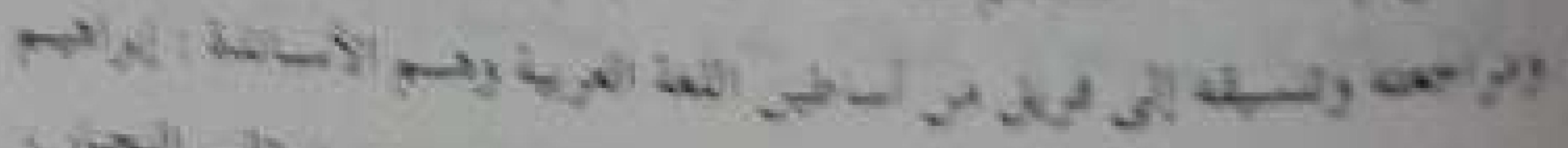

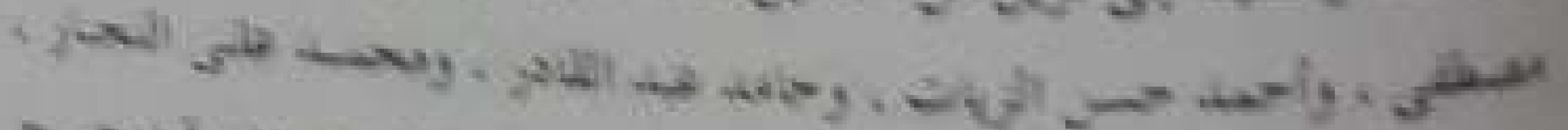
in

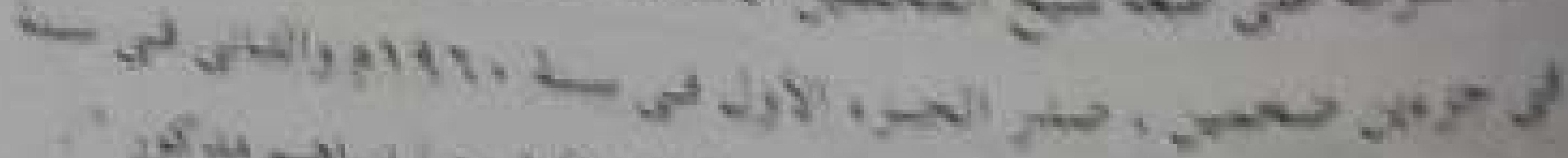

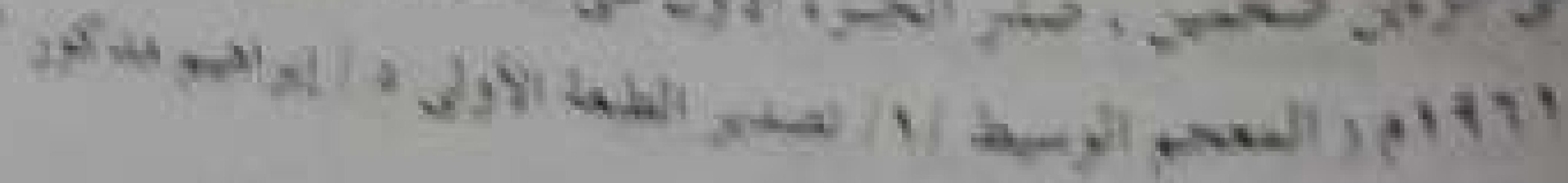

$$
-\pi T-
$$

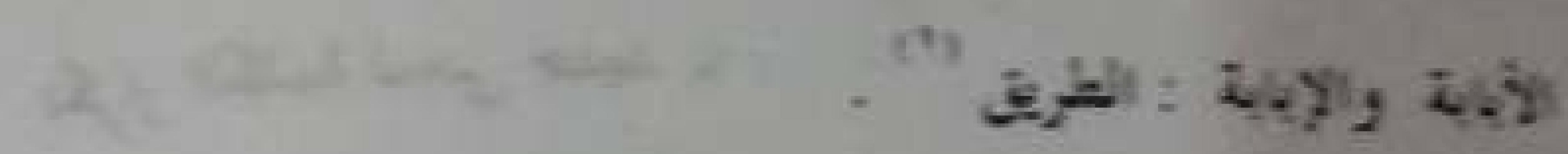

iglo

s-jil

$$
- \text { S. }
$$

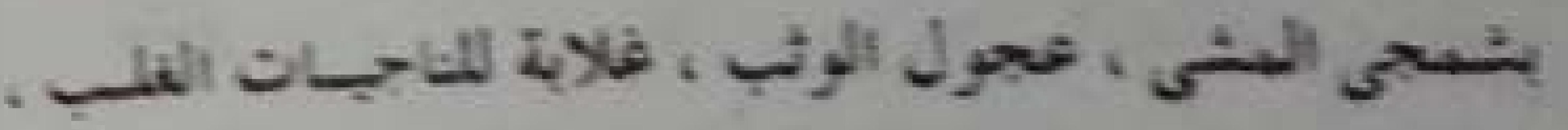

$$
-294+50 j 5
$$

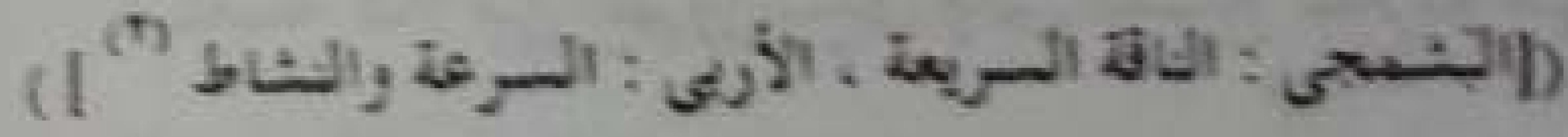

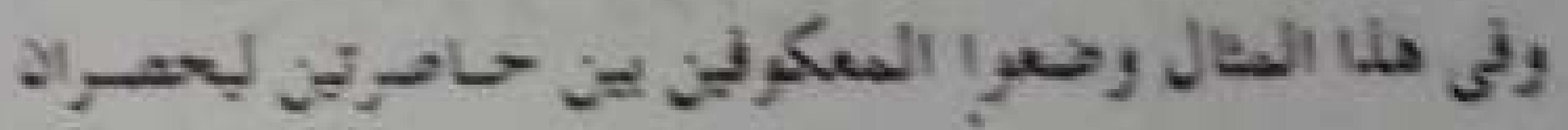
ousily

$$
\begin{aligned}
& \text { ing alis } \\
& -\left(J^{1}\right) 520^{\circ}
\end{aligned}
$$

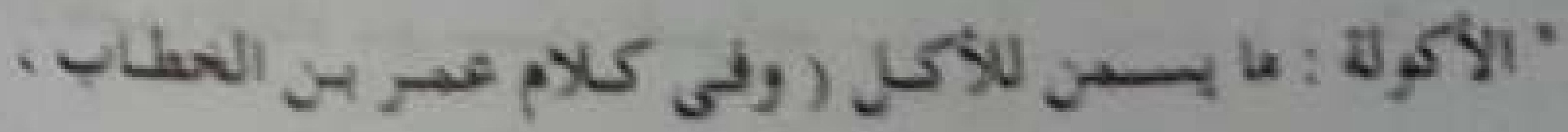

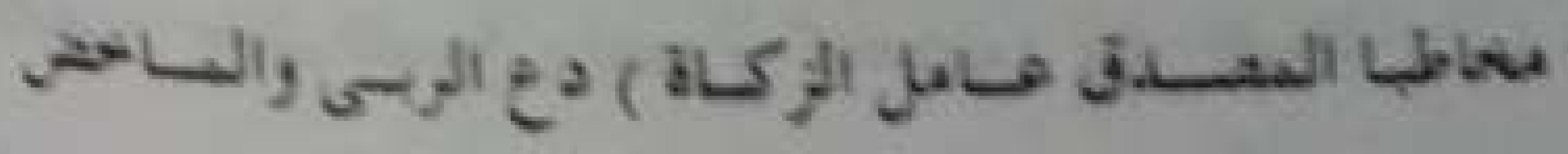
4 24 إل

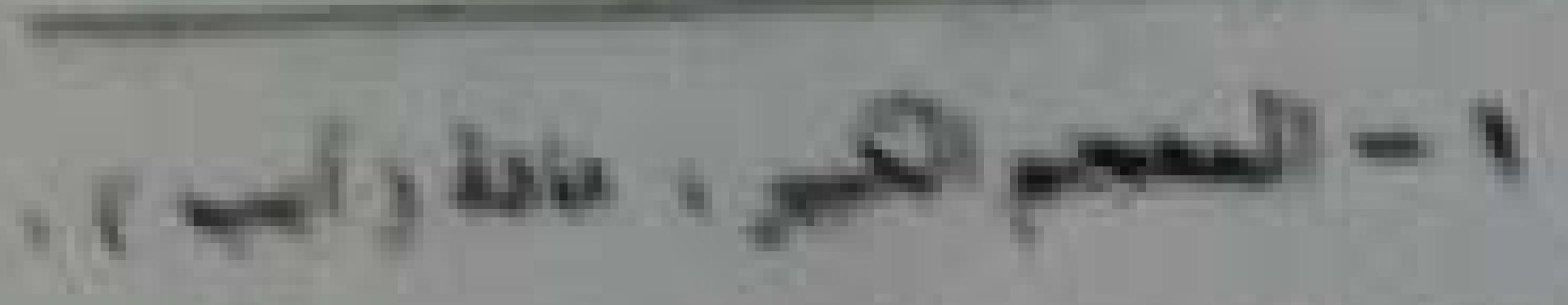

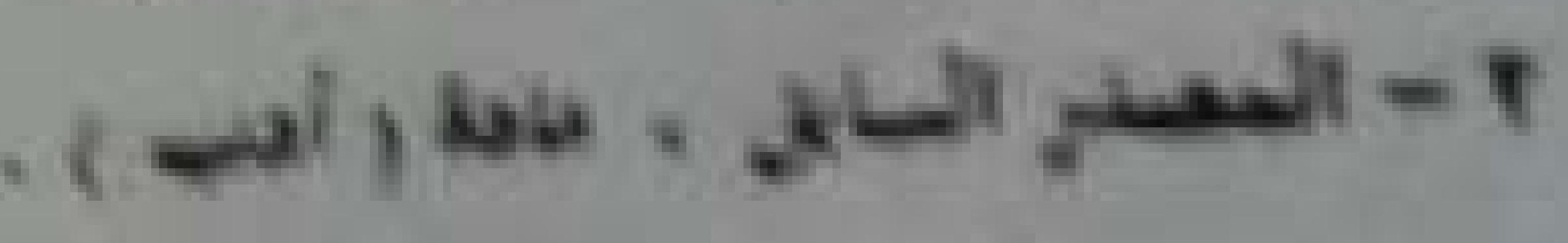


a.s.

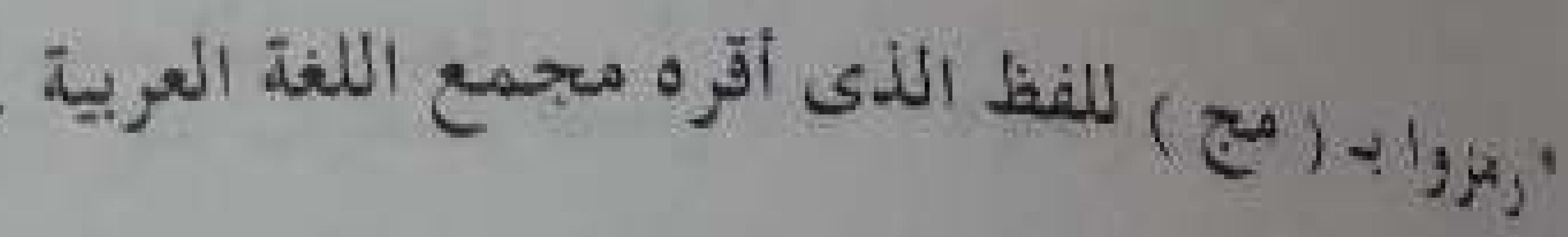

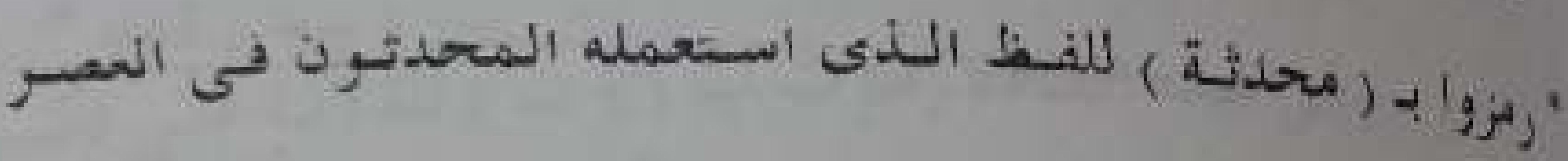

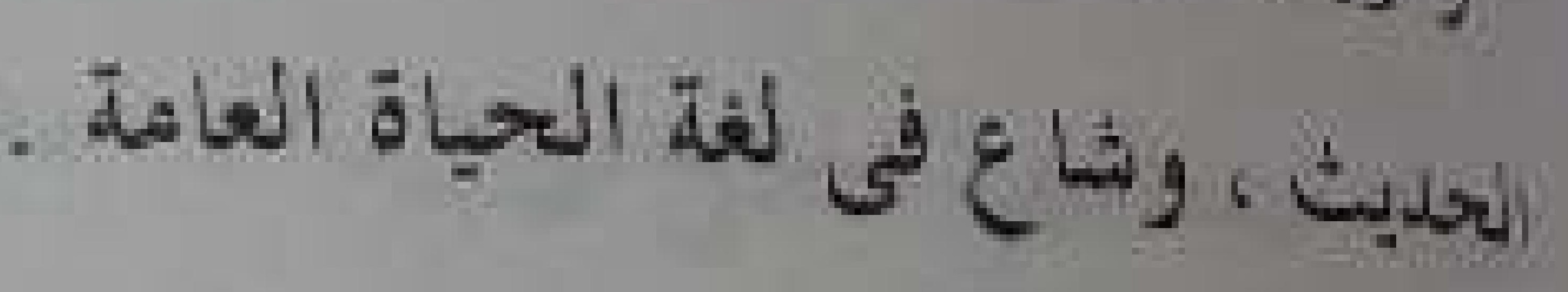

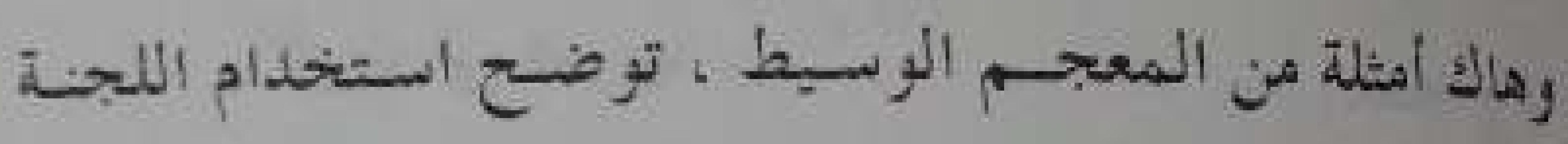

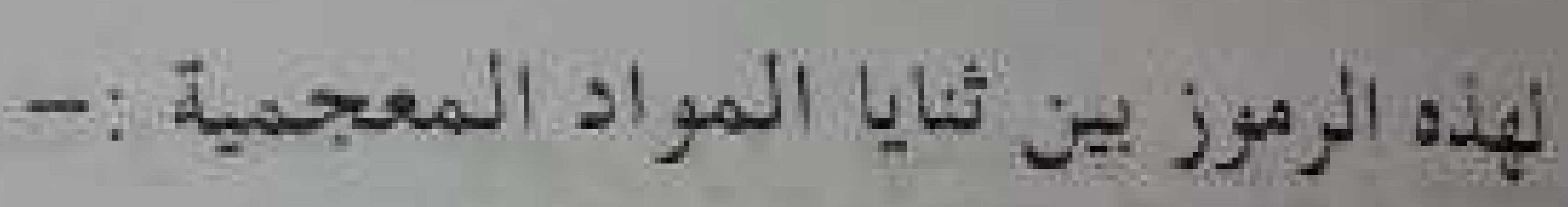
$-:(\varepsilon))^{3 s+6}$

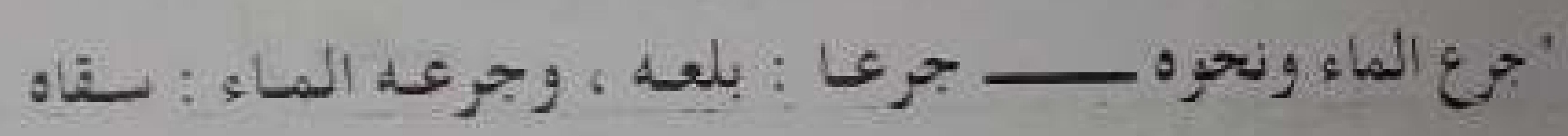

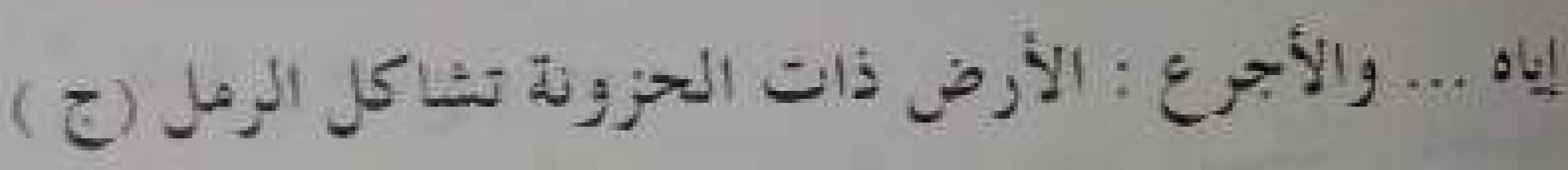

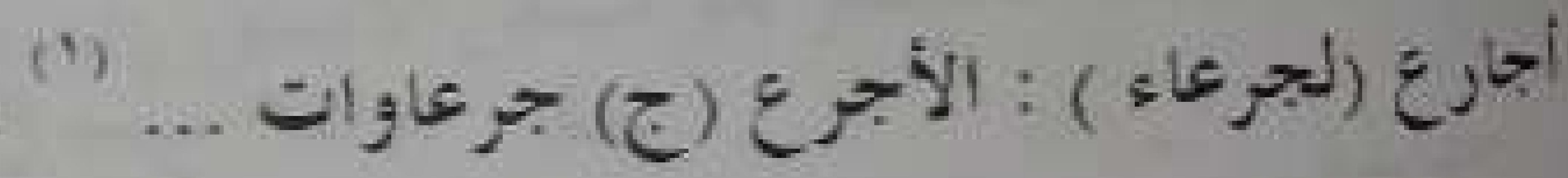

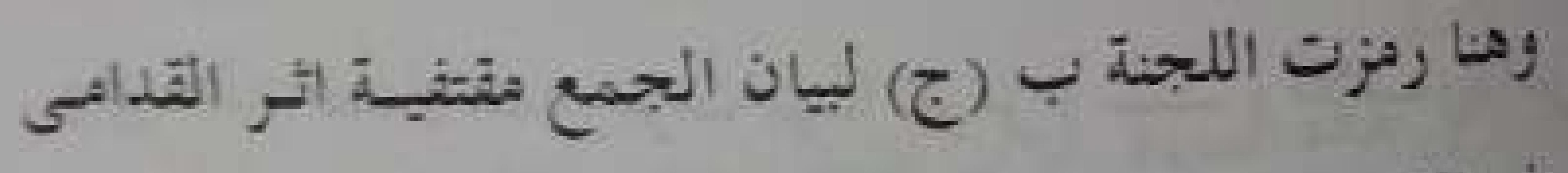

في الإشارة إلى الجهع بهـا الرثز

$$
-:(x)^{32} x^{\prime}
$$

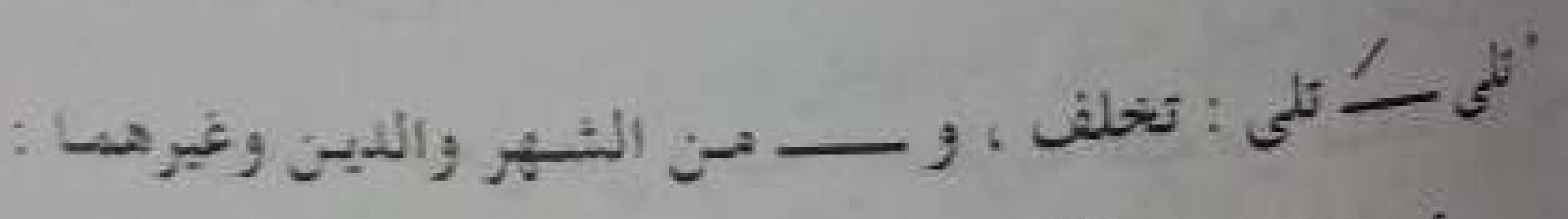

$$
\text { (i) }=\text {.... }
$$$$
-:(x)^{32}, x^{\prime}
$$

- Y7t -

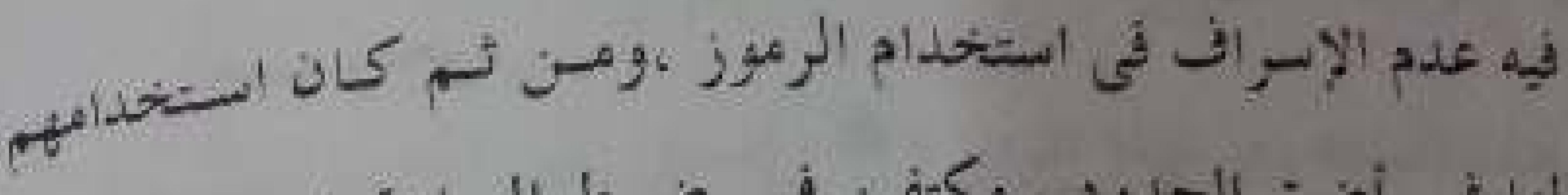

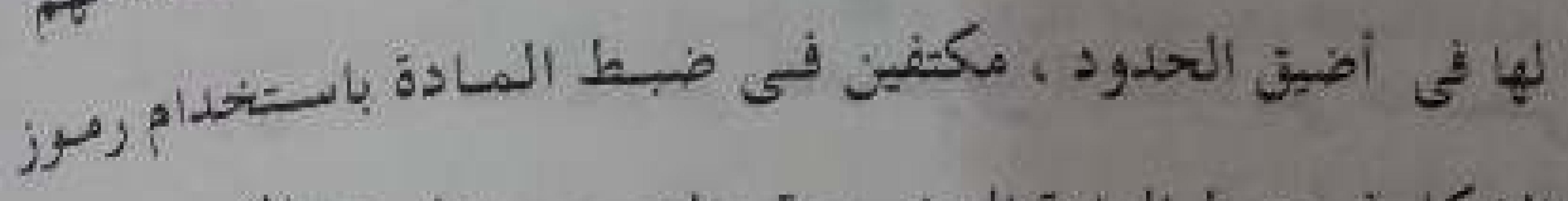
(1) السكل في ضبط المادة المشروحة والنصوص الأدية

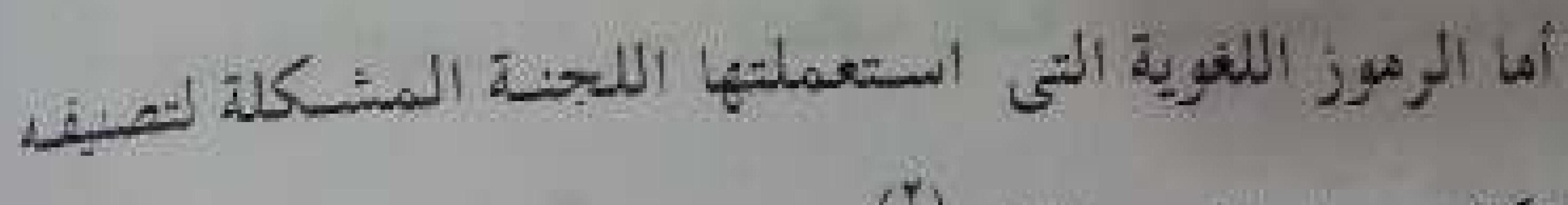

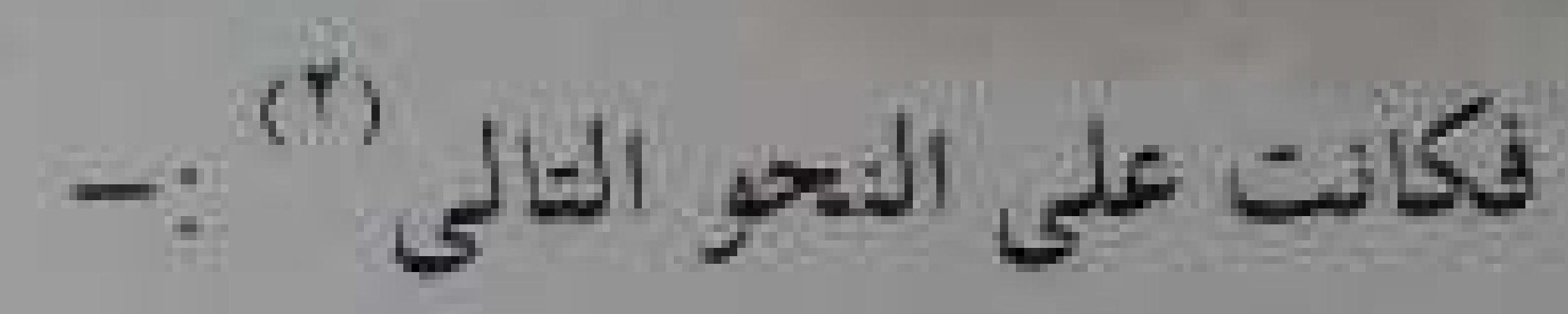

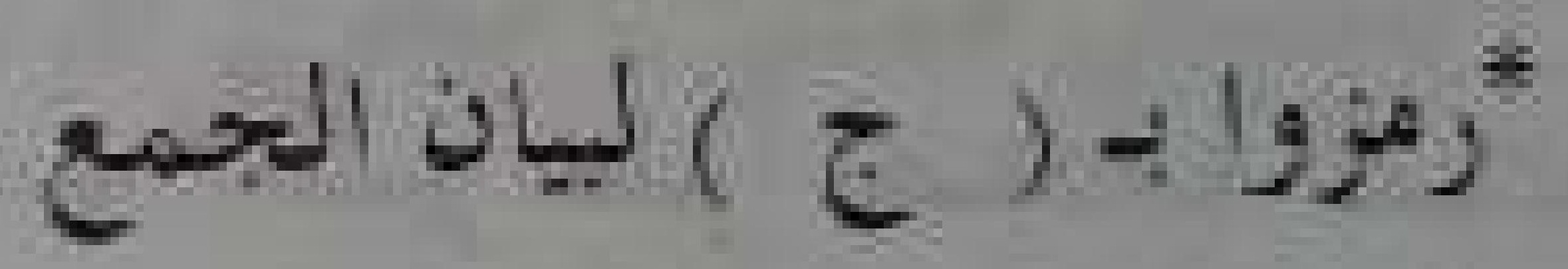

"رهزوا بم

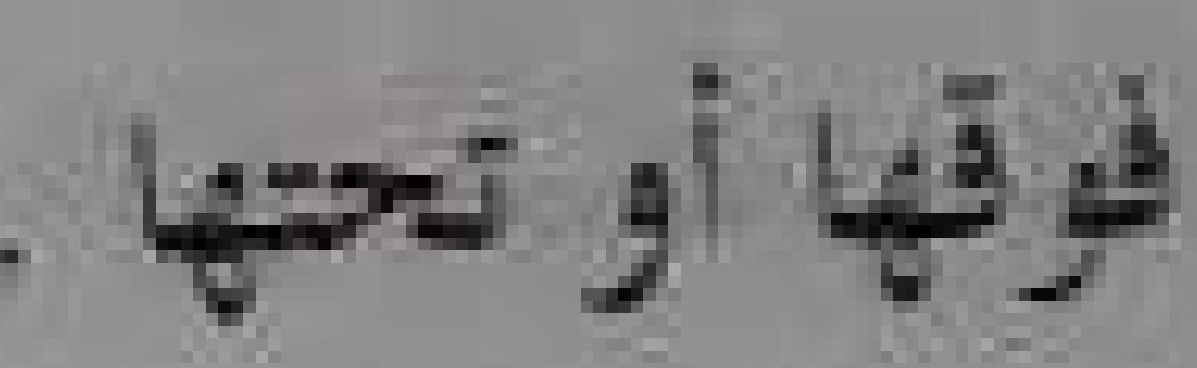

" رمزوا ب- (و - مل ) للدلالة على تكرار الكلمة لمعنى حدبيد.

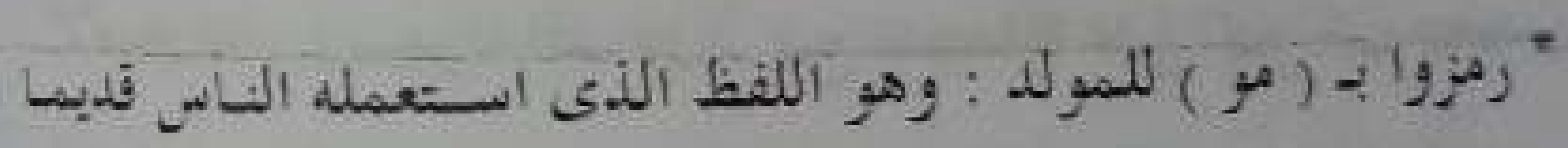

$$
\text { بع عهر الرواية }
$$

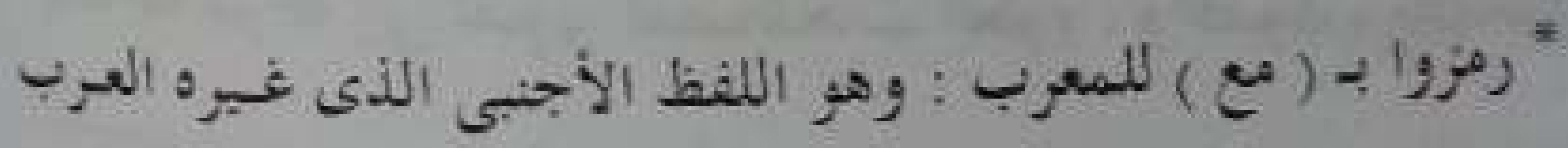

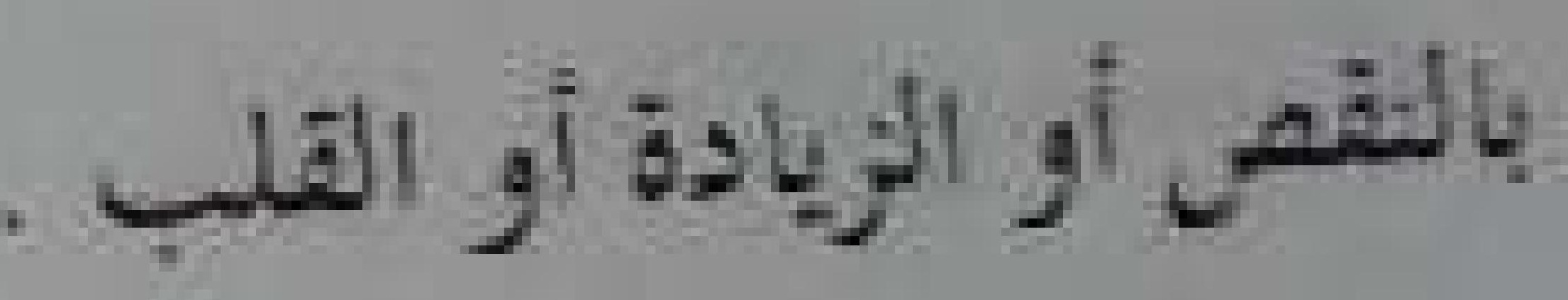

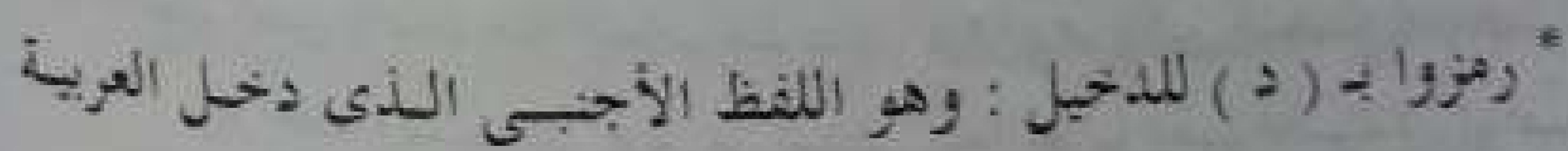

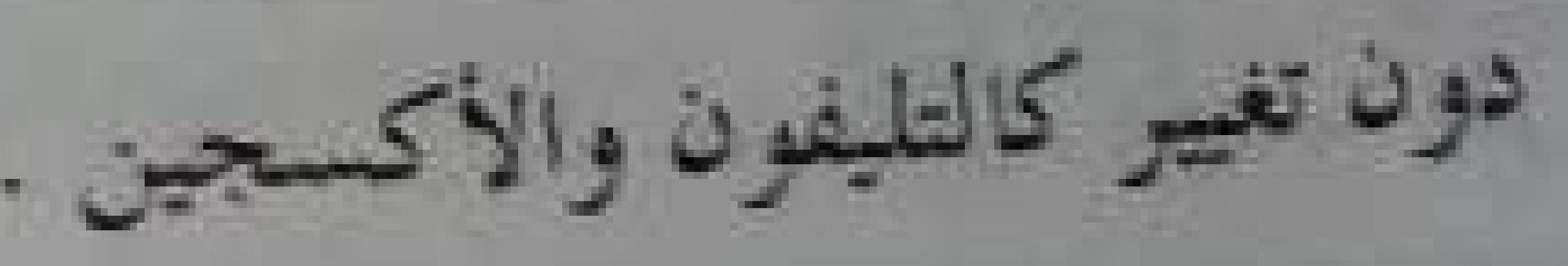




$$
-7 V-
$$

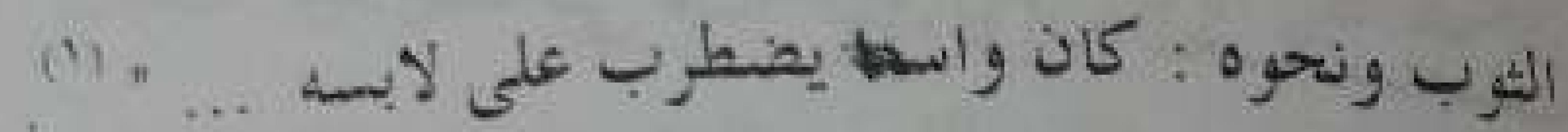

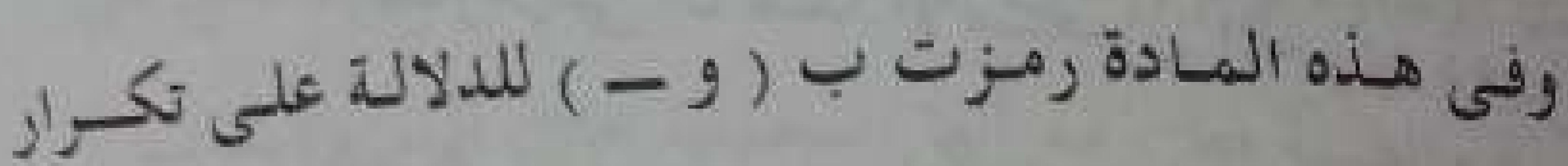
الكلمة لمعنى جديد .

$$
-:(\operatorname{Lar}) \text { as }
$$

"الجماد : القسم الثالث هم الكائنات (مو).... " وهنا رمزت للفظ المبولد بالرمز (مو ) .

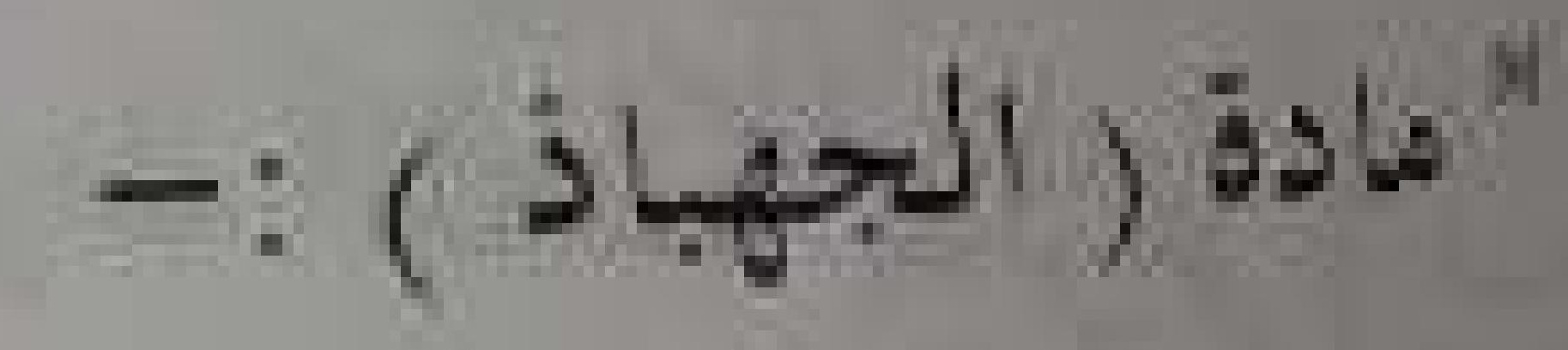

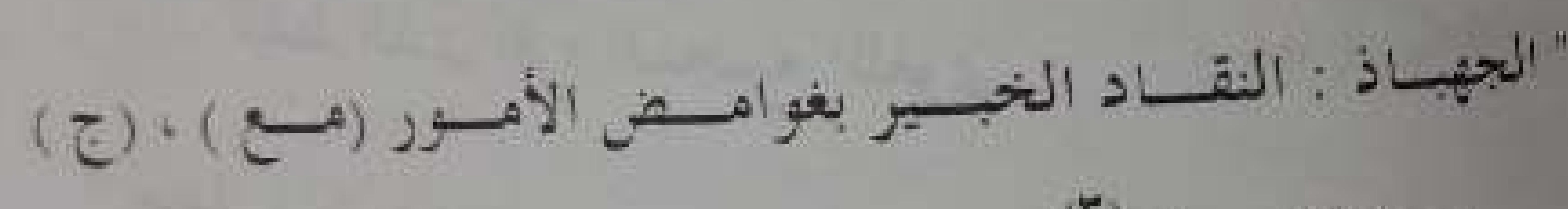
وفى هذه المادة رمزت للفظ المعرب بالرمز (ع) (ع)

$$
\left.-:\left(\omega^{2}\right)^{2}\right)^{j g u^{\prime}}
$$

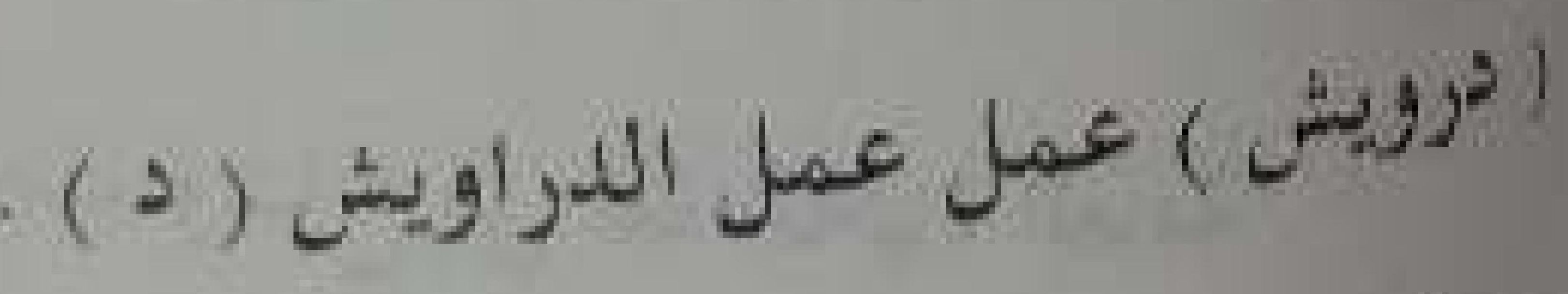

$$
\text { : }
$$

- r77-

(i)

$$
\begin{aligned}
& \text { تبل } \\
& -:(\approx) \text { jsin }{ }^{*}
\end{aligned}
$$

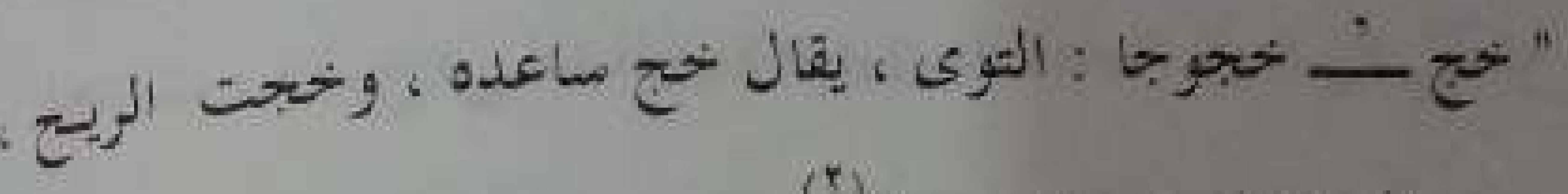

$$
\text { (4) "... التوت في هبئبا }
$$

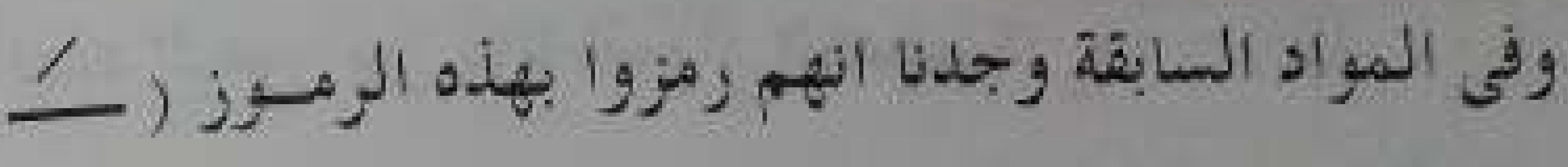

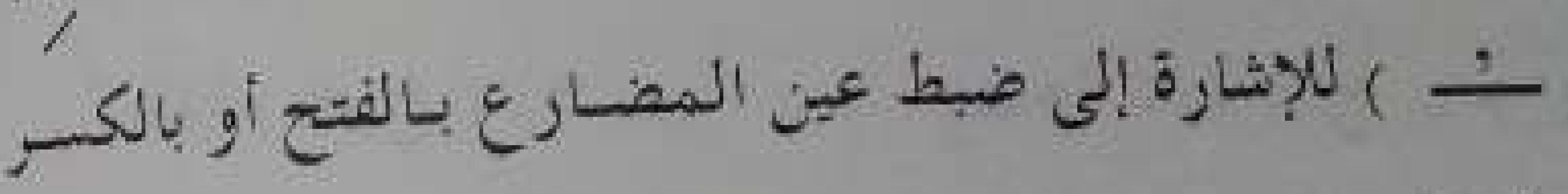

$$
\begin{aligned}
& \text { مol } \\
& -:\left(\tau^{j}\right) \text { islo }
\end{aligned}
$$

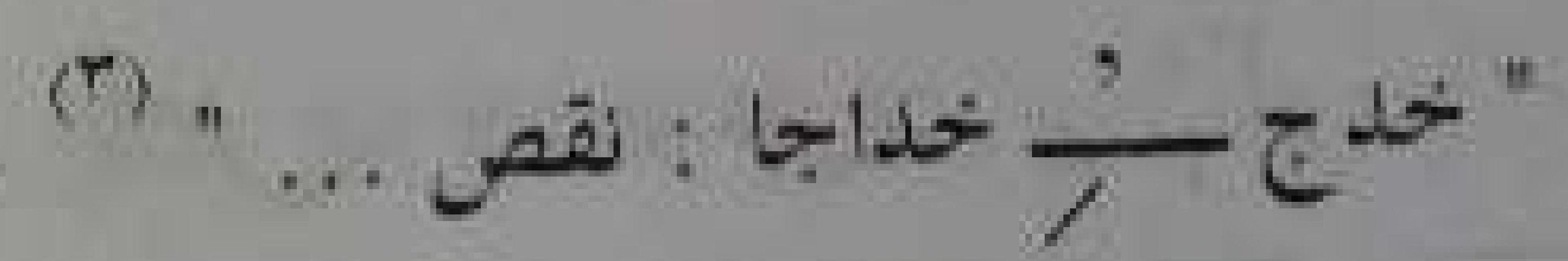

وفى هذا المثال هذا رمزت بهذا المرمز (

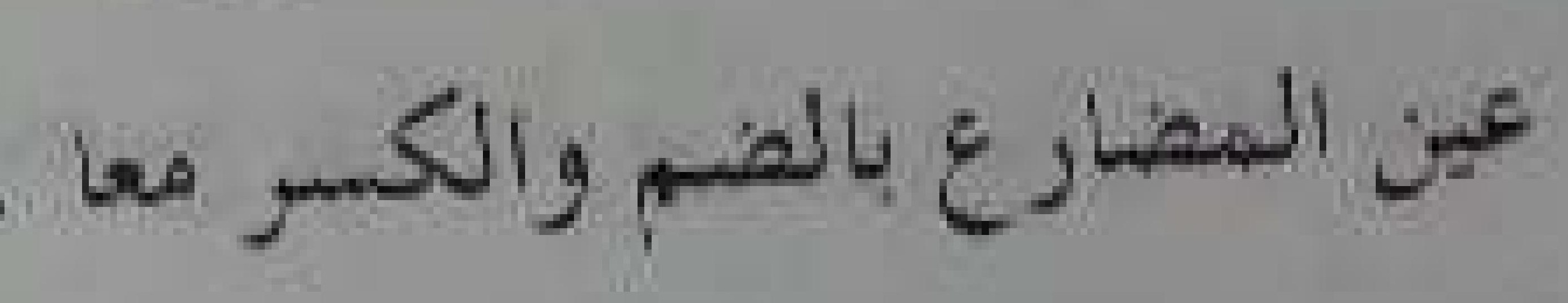

$$
-:(J)) \text { مادم" }
$$

" "... ويقال : خحل على فرسه : اضطرب عليه من سمثته ، ور-

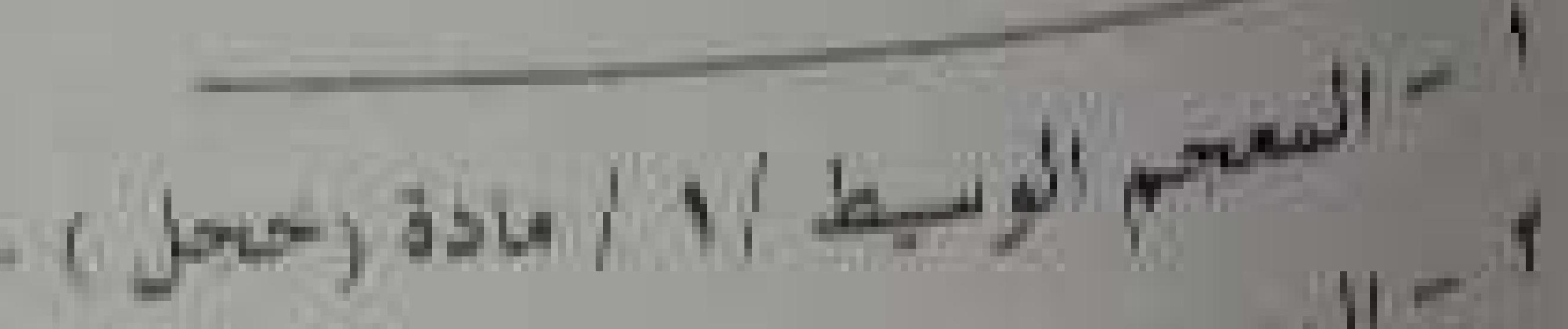

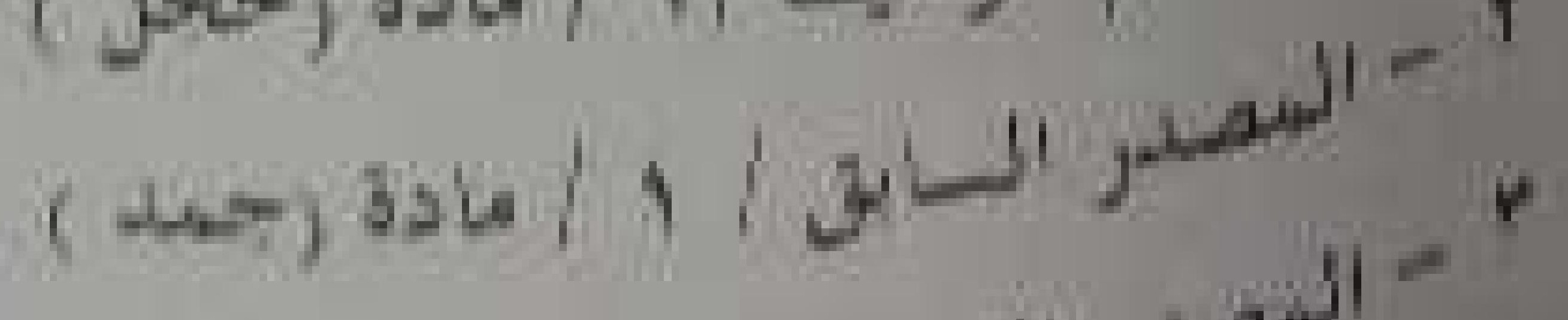

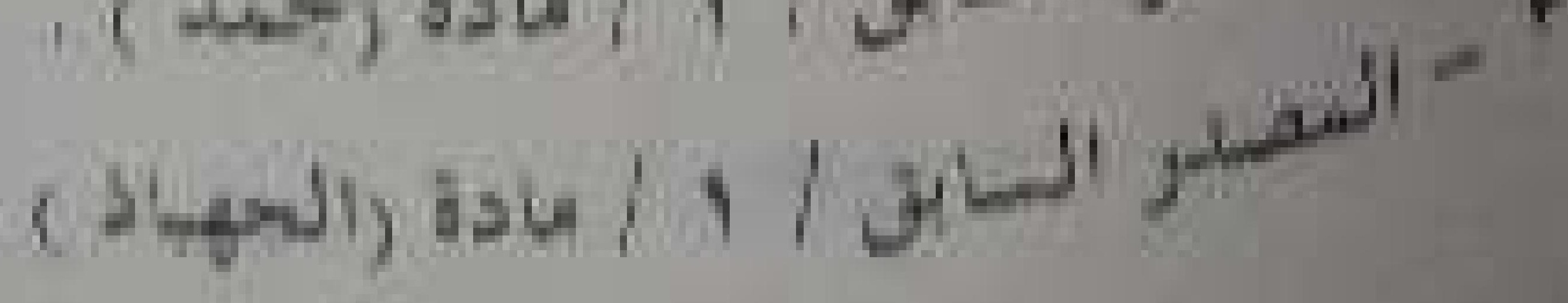

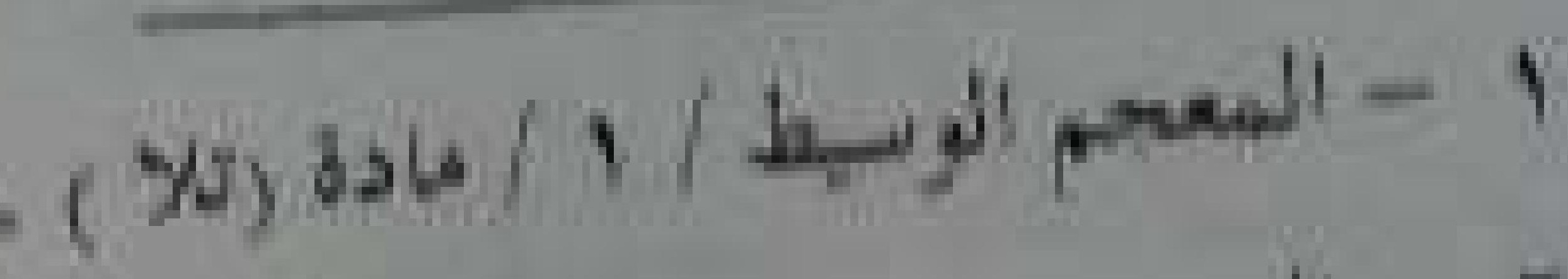
(c)

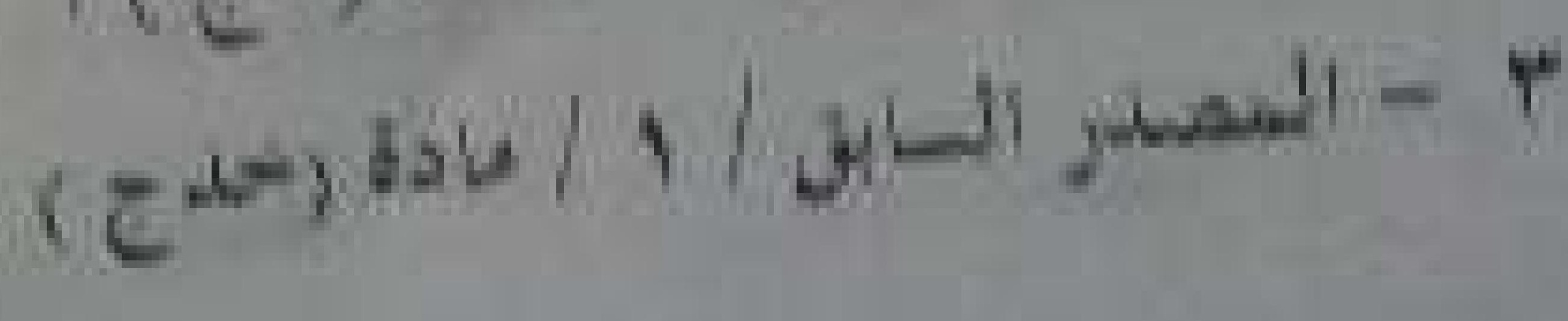




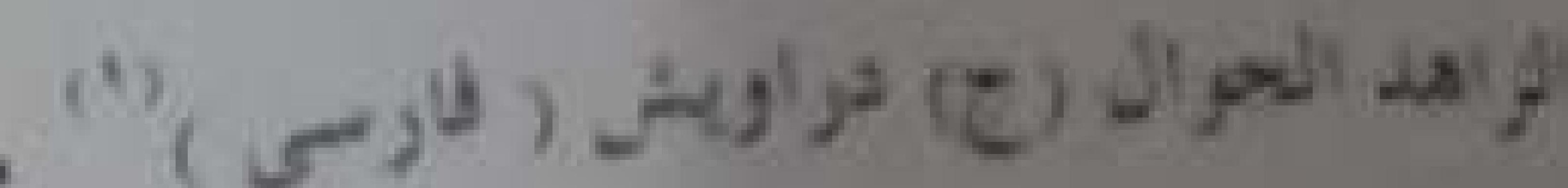

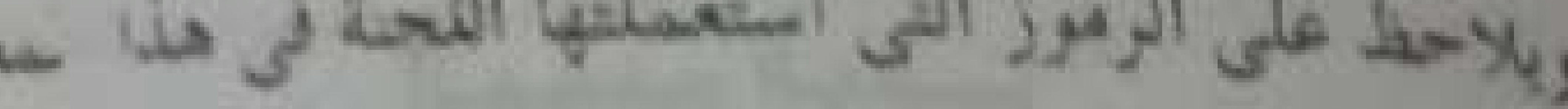

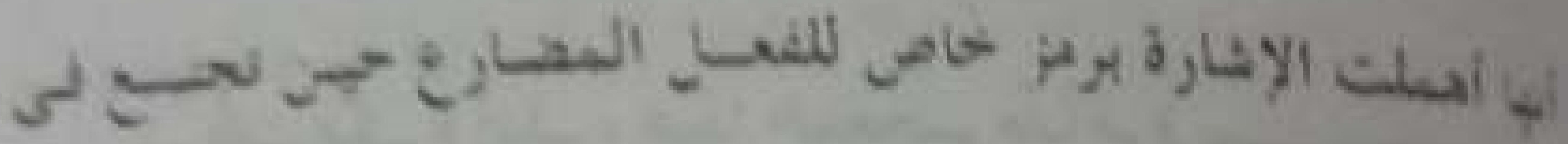

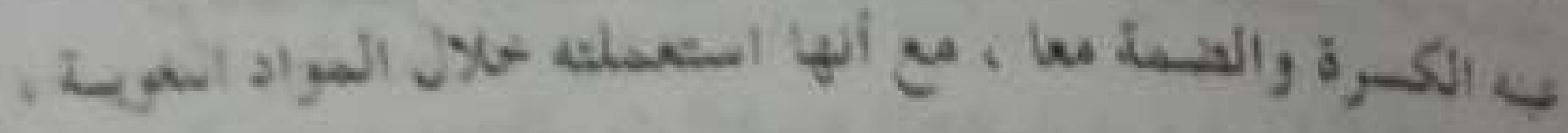

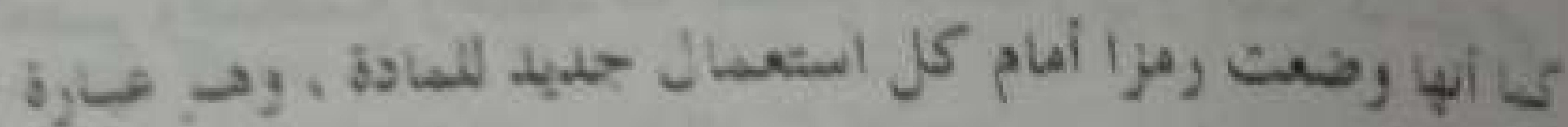

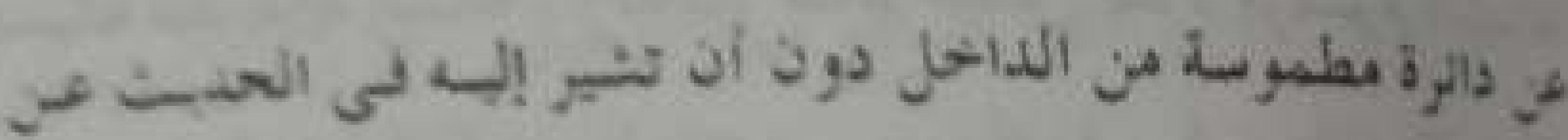

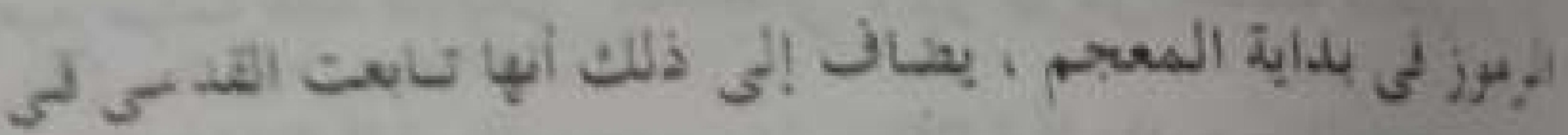

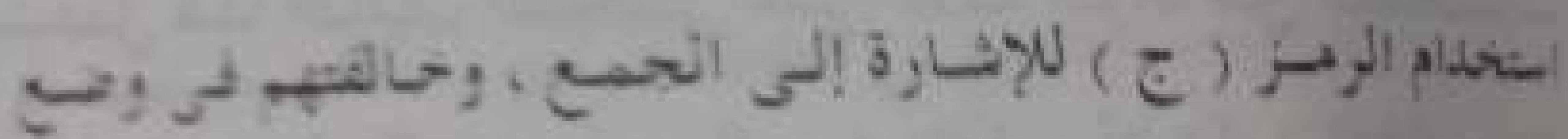

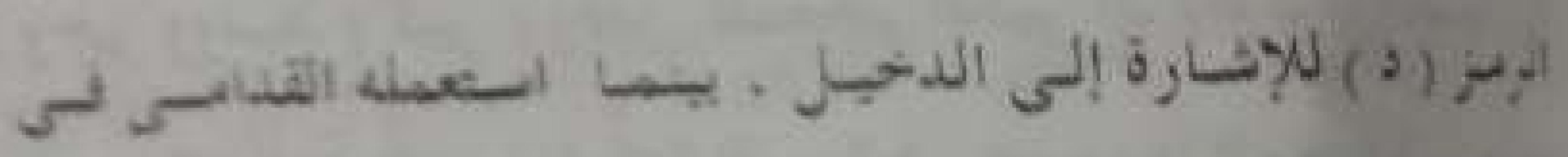

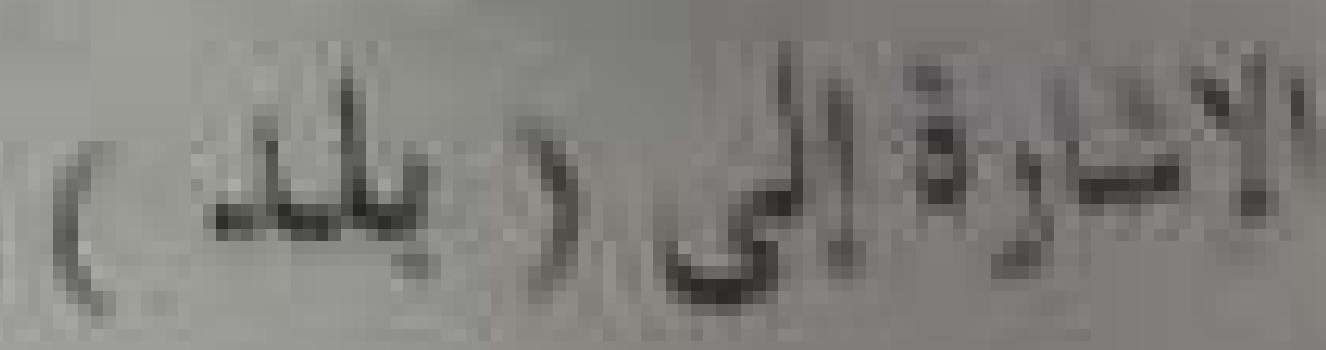

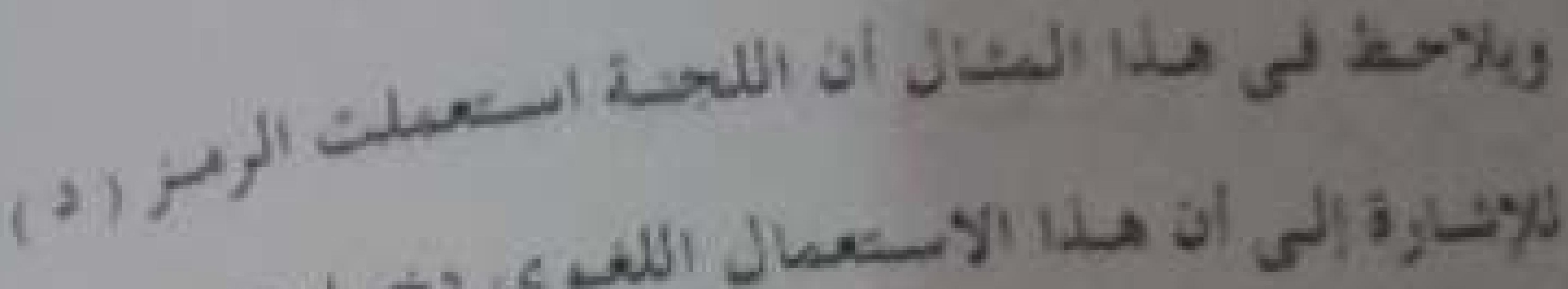

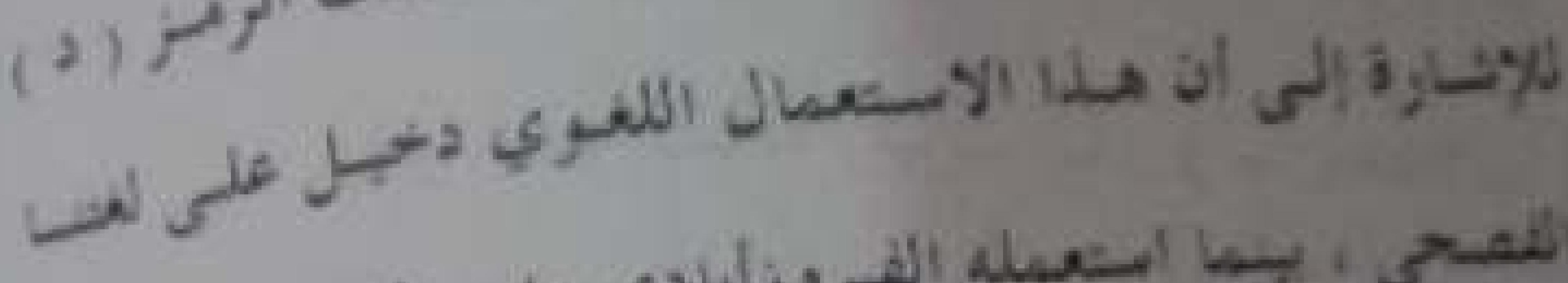

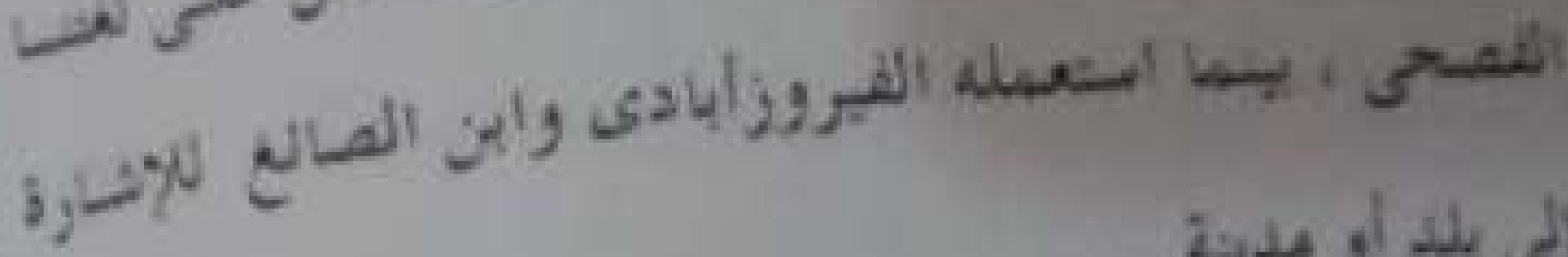

$$
\begin{aligned}
& \text { إلى يلد أو مديني . } \\
& \text { : }
\end{aligned}
$$

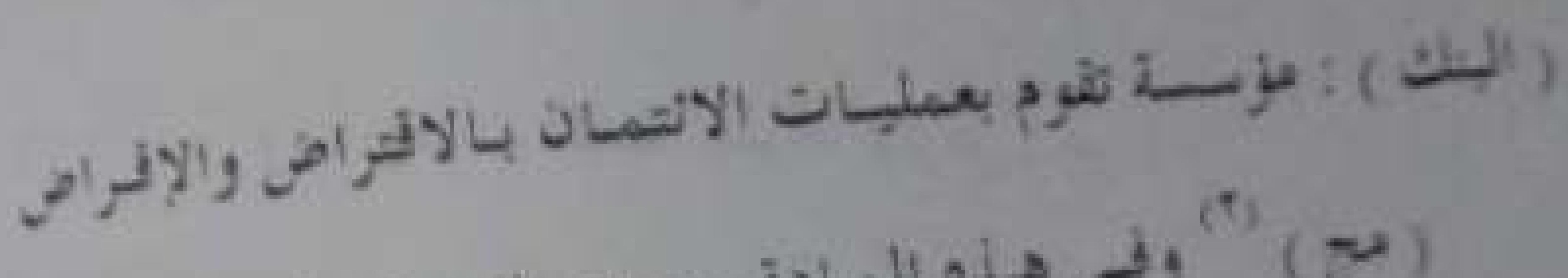

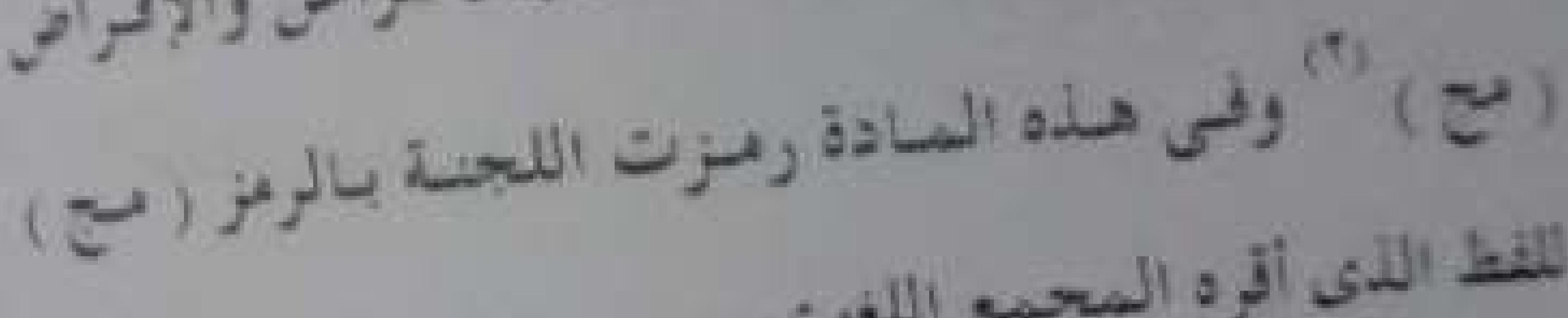

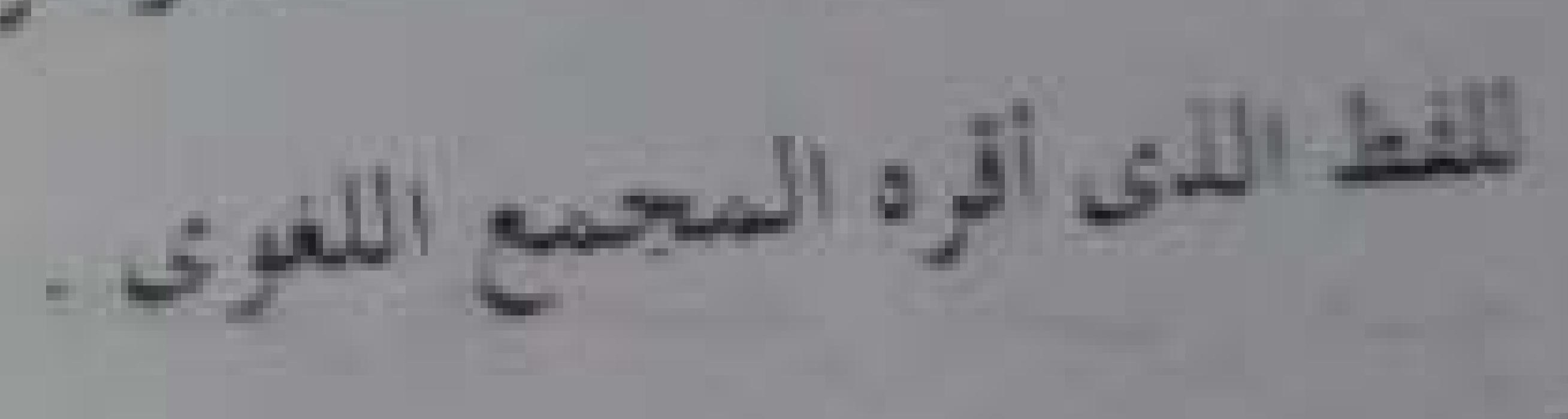

$$
-:(4) \text { ist }
$$

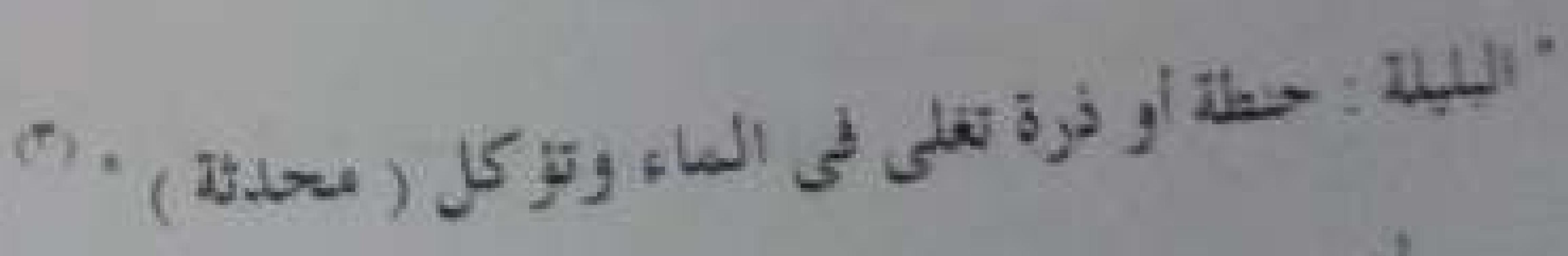

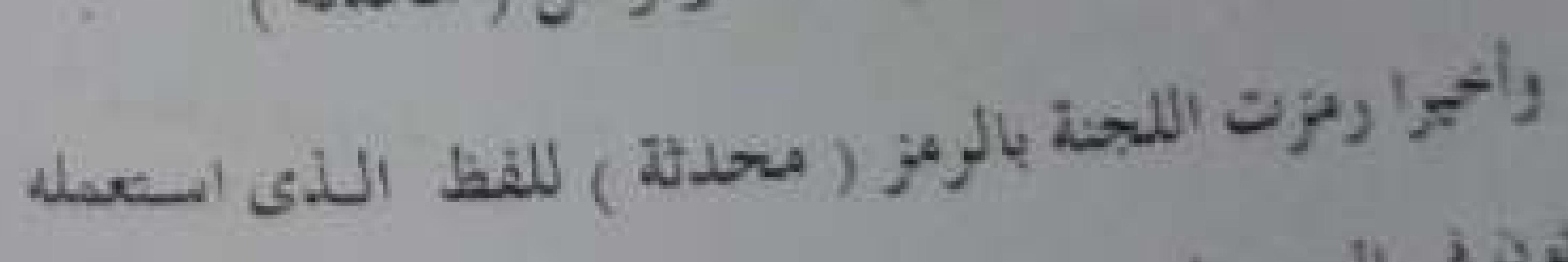

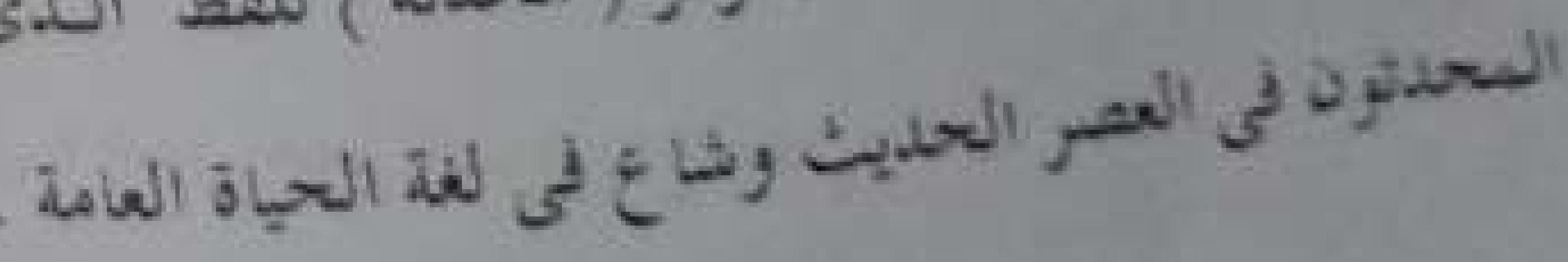

$$
\text { (y) }
$$




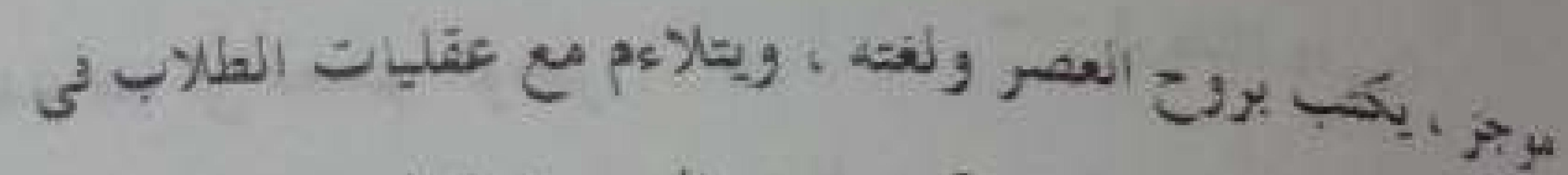

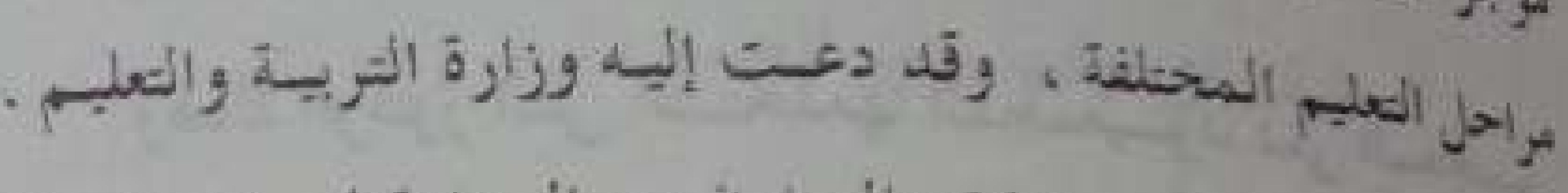

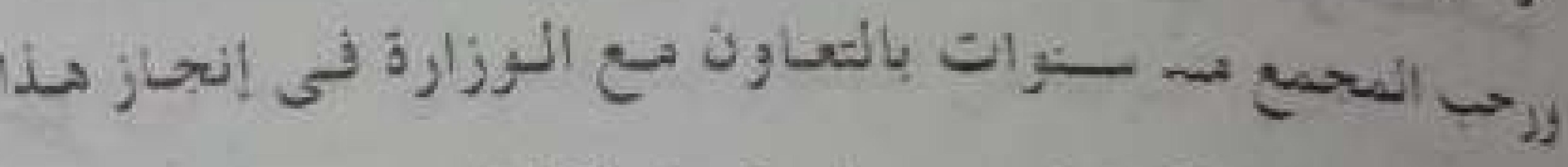

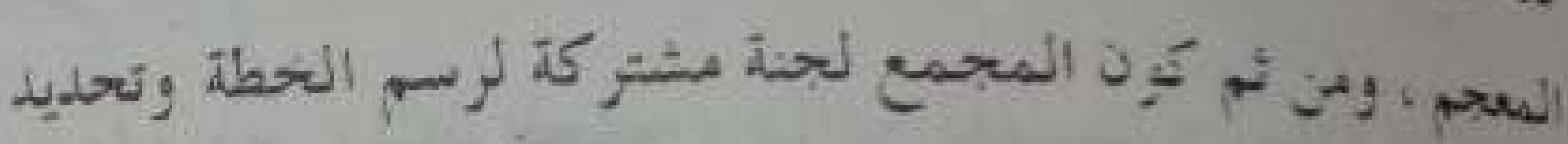

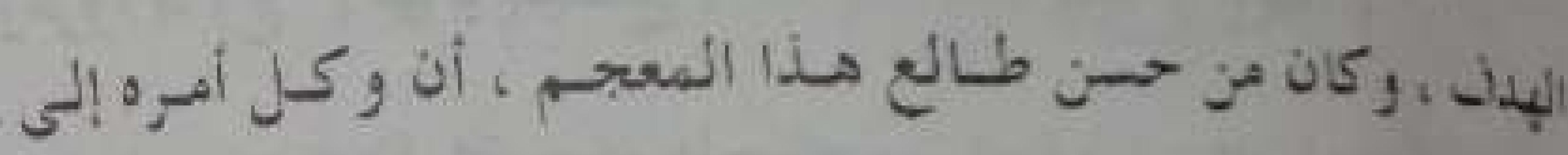

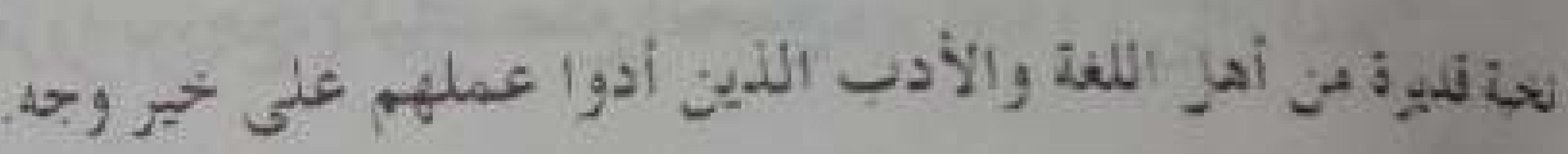

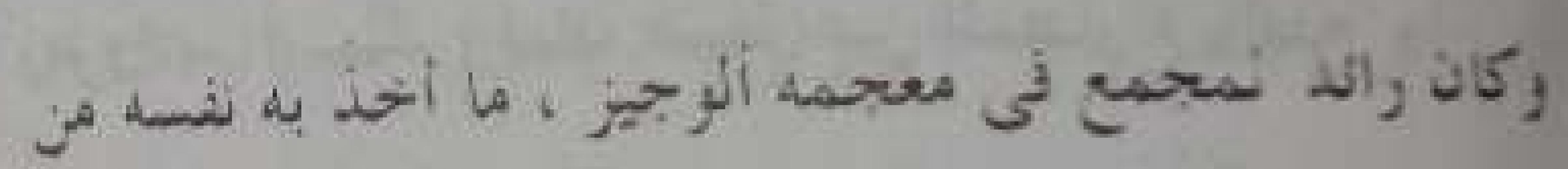

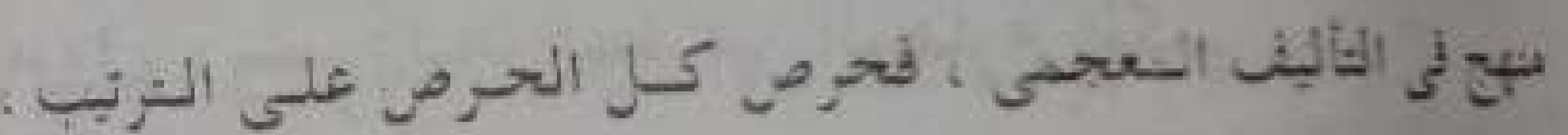

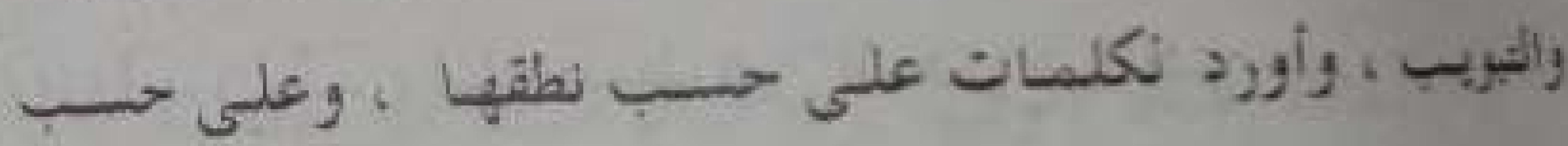

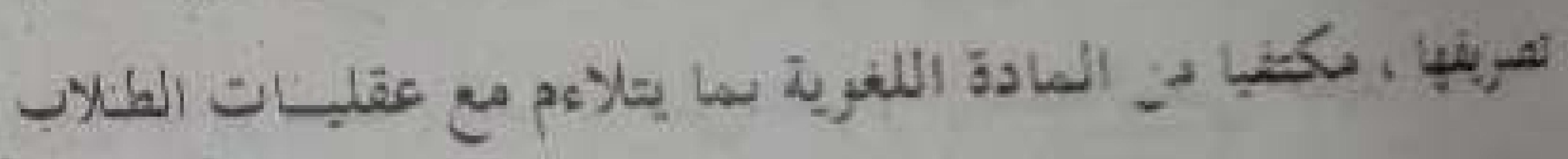

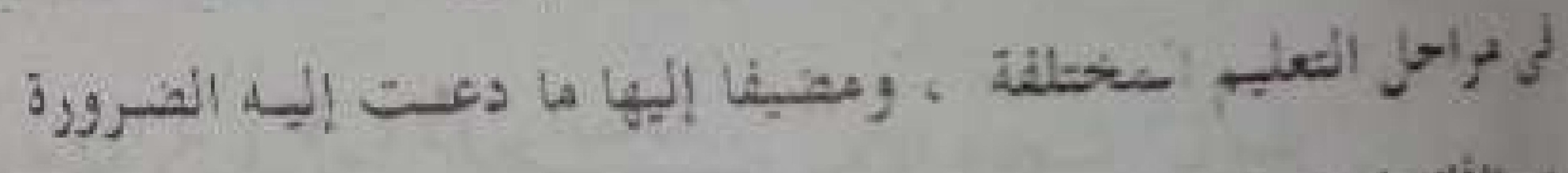

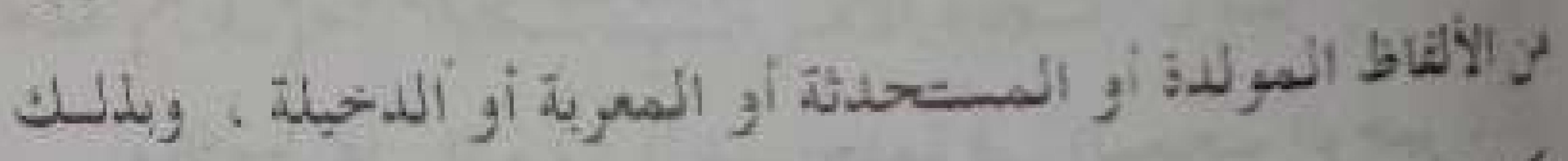

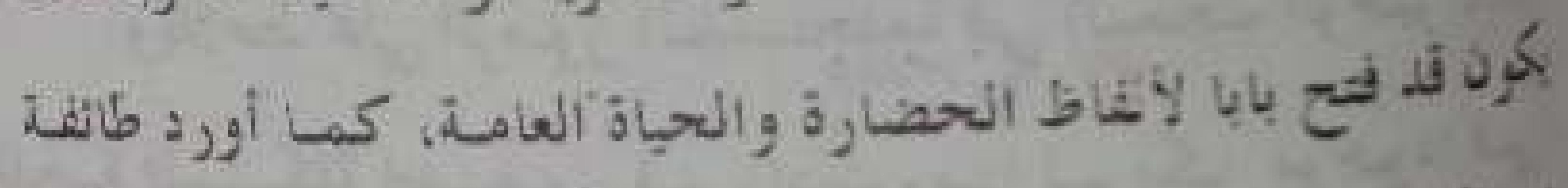

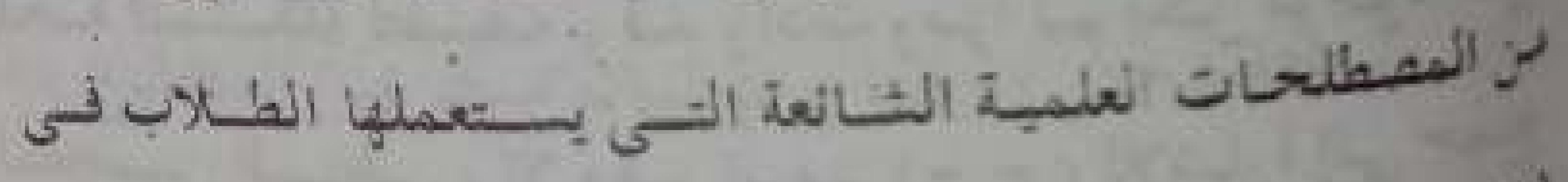

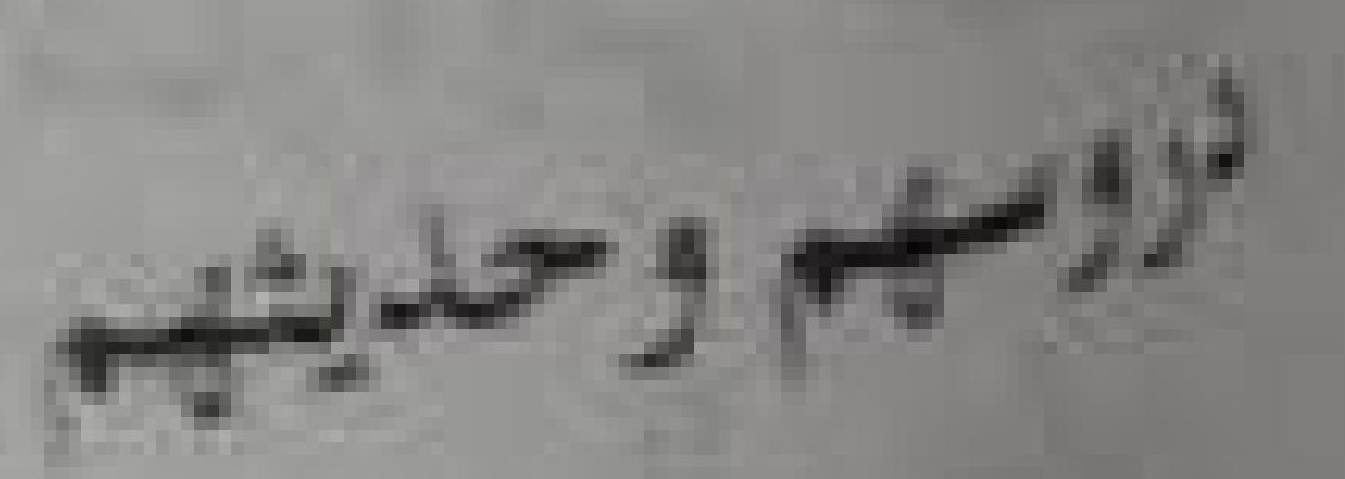

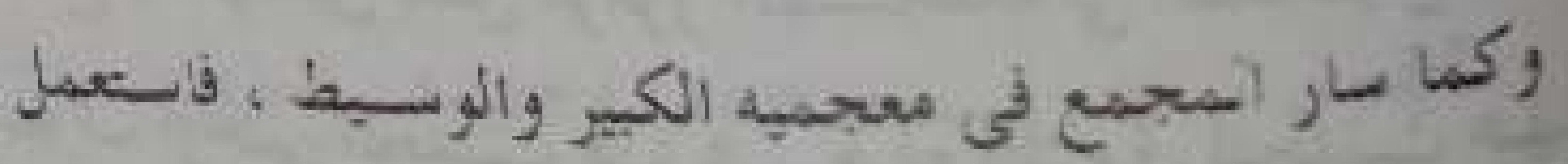

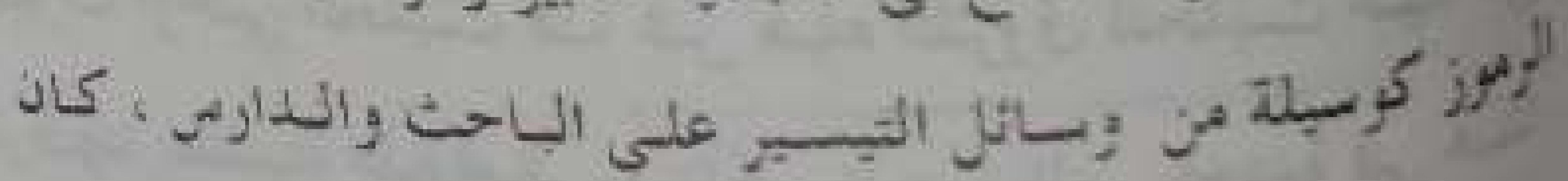

- rV. -

\section{(1)}

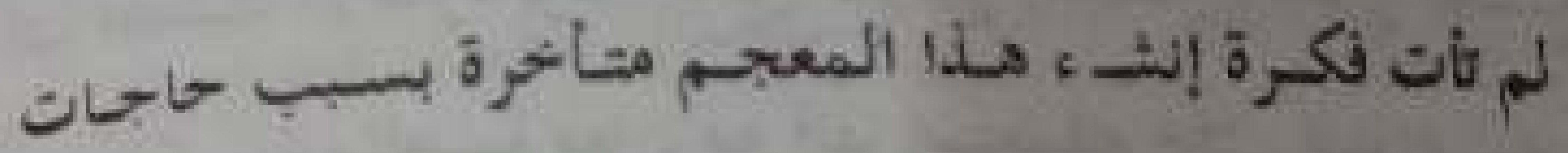

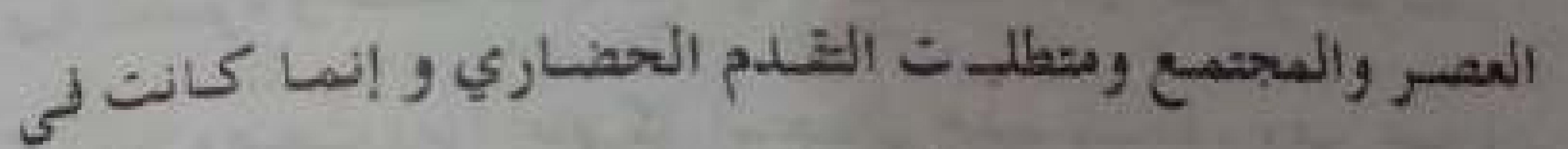

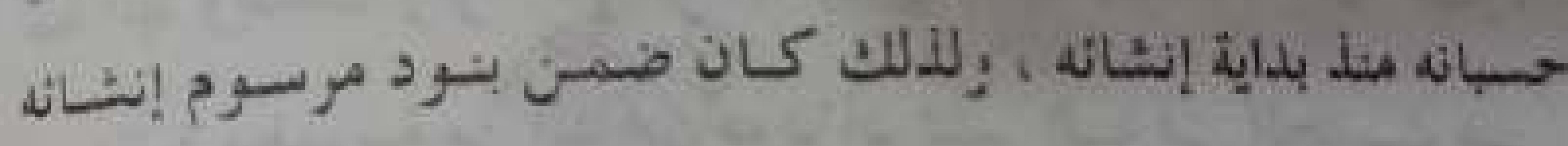

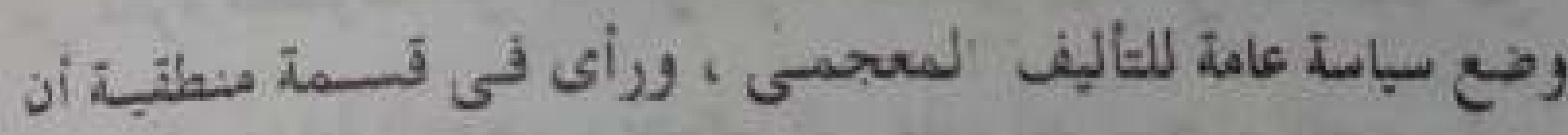

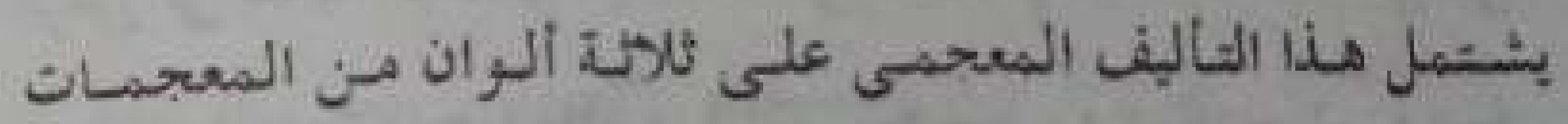

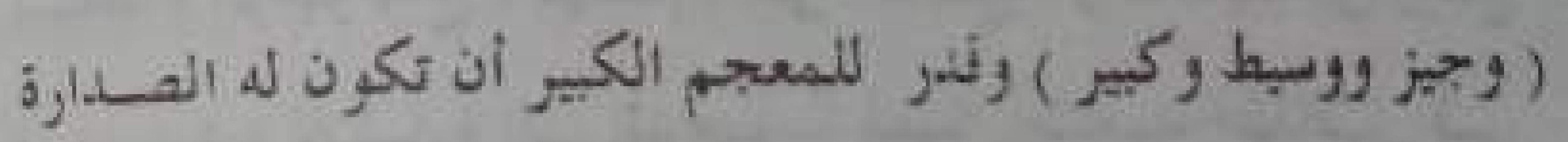

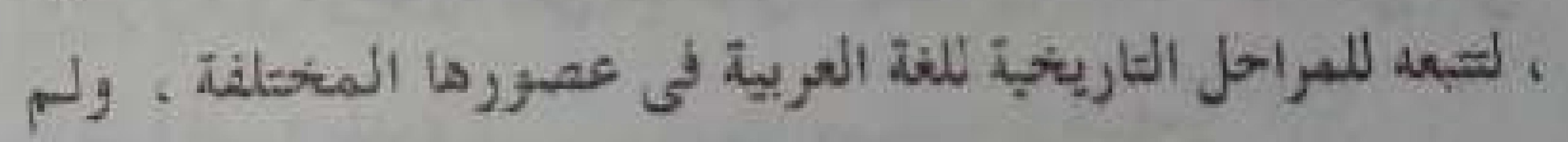

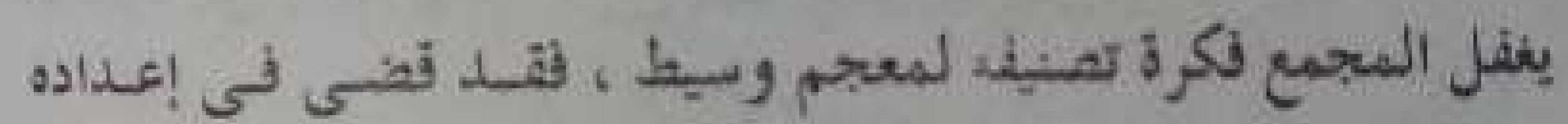

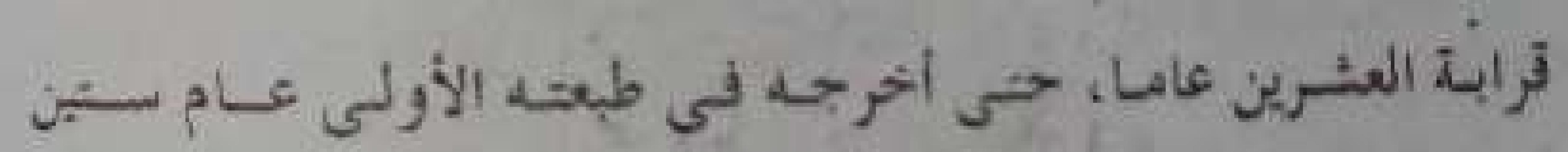

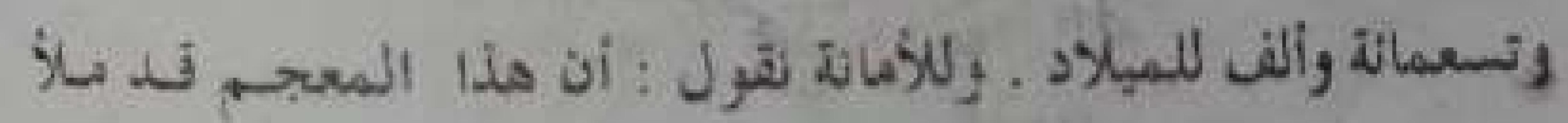

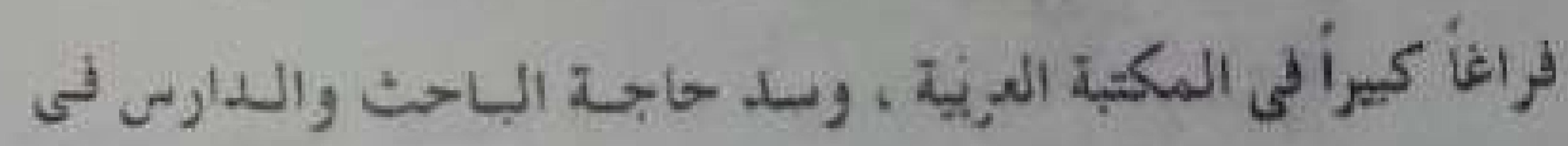

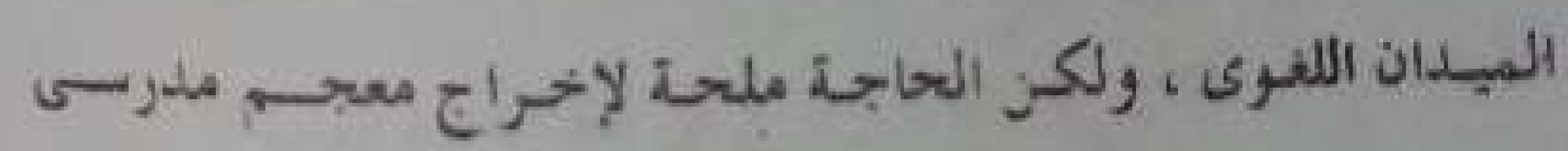

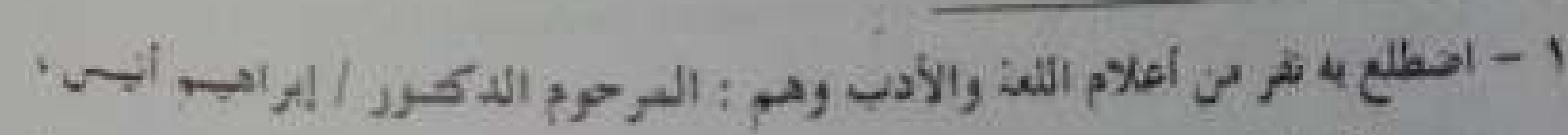

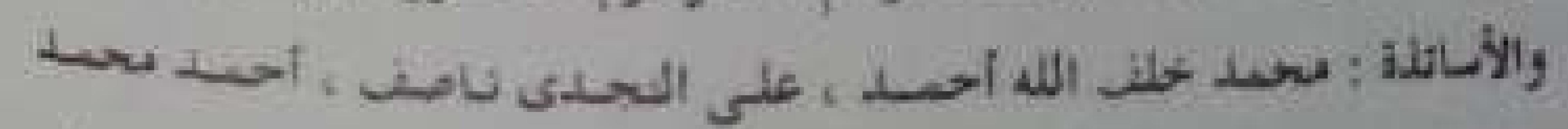

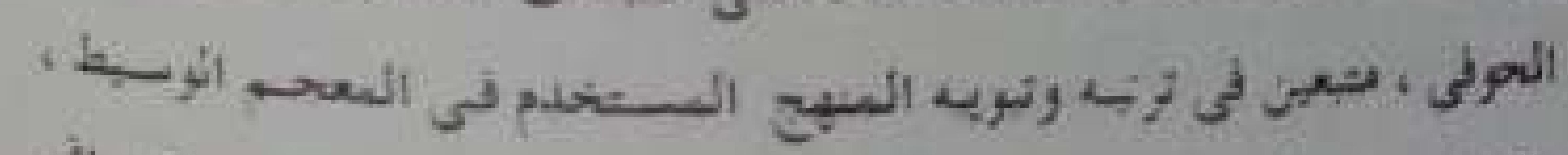

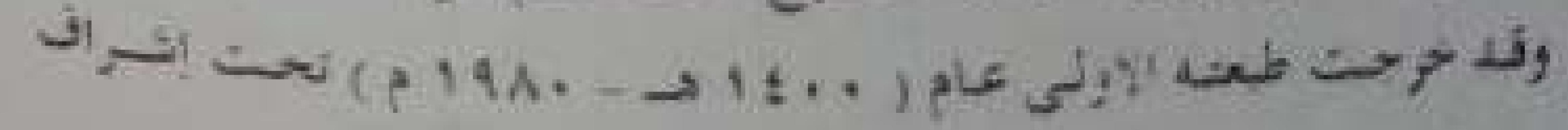

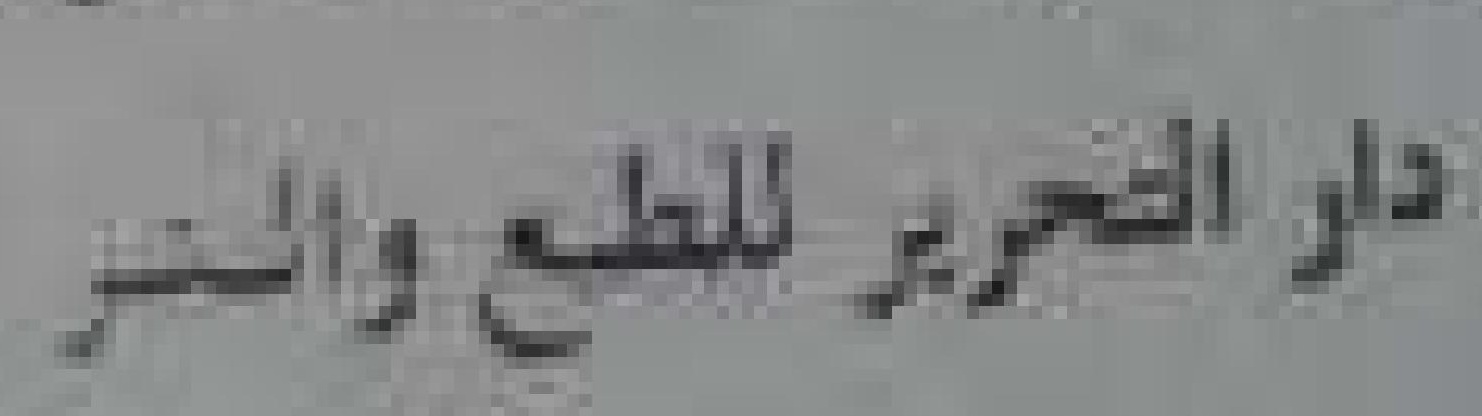




$$
\begin{aligned}
& \text { - rvr - }
\end{aligned}
$$

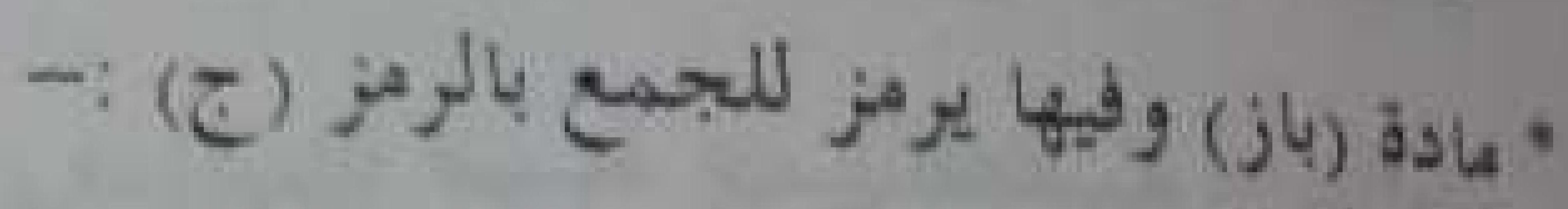

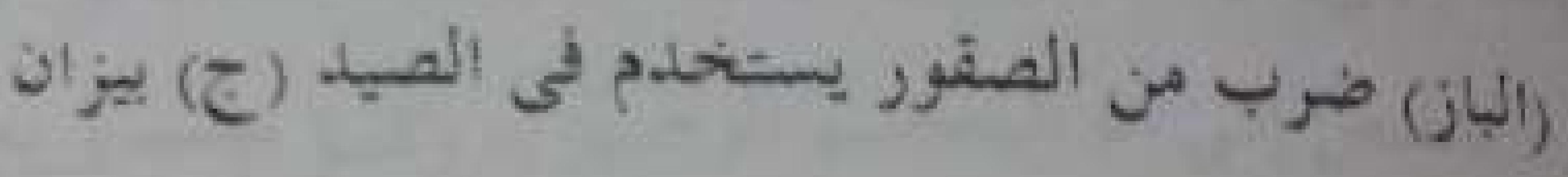

$$
\begin{aligned}
& \text { (1) اليوز ) الفم ووما حواليه (ج) أبواليه }
\end{aligned}
$$

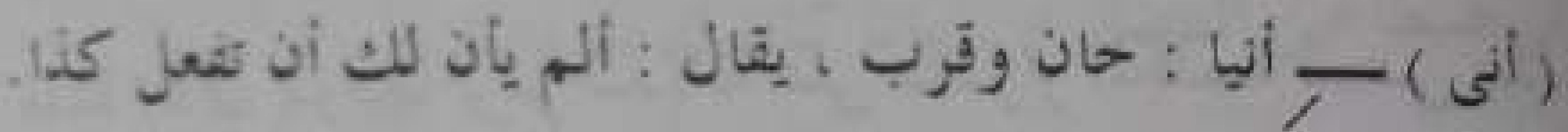

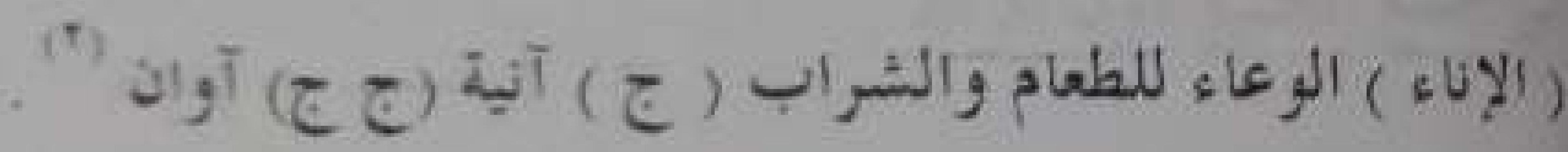

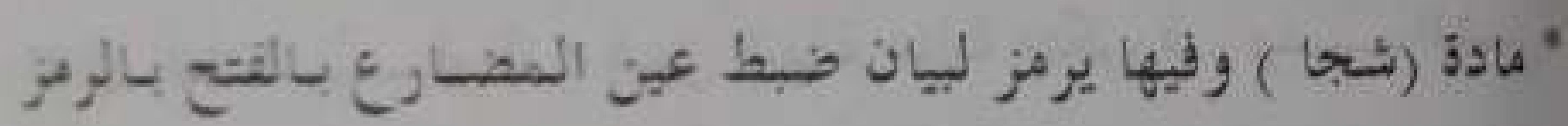

$$
-:(\lfloor)
$$

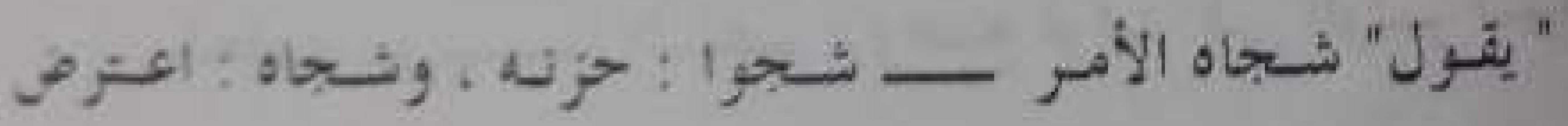

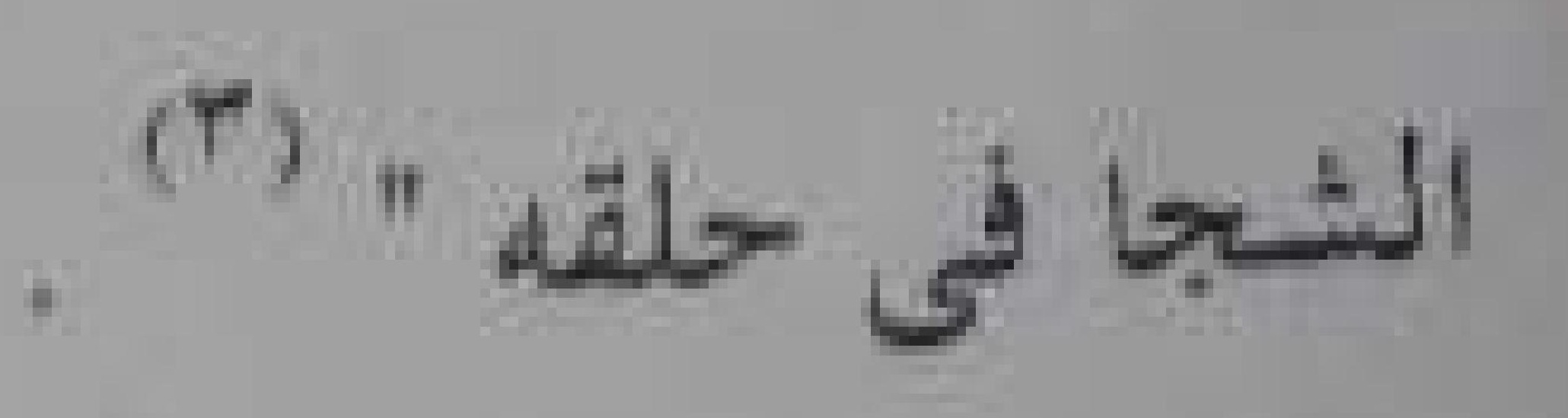

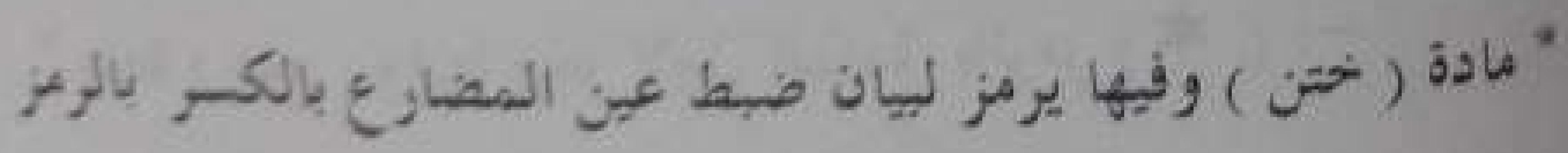

$$
-:\left(\frac{-}{,}\right)
$$

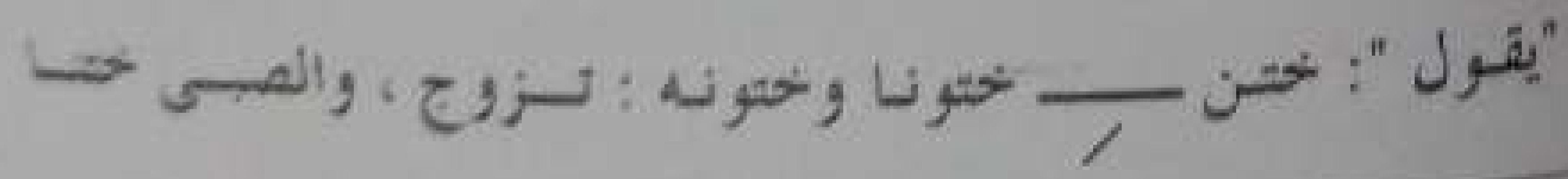

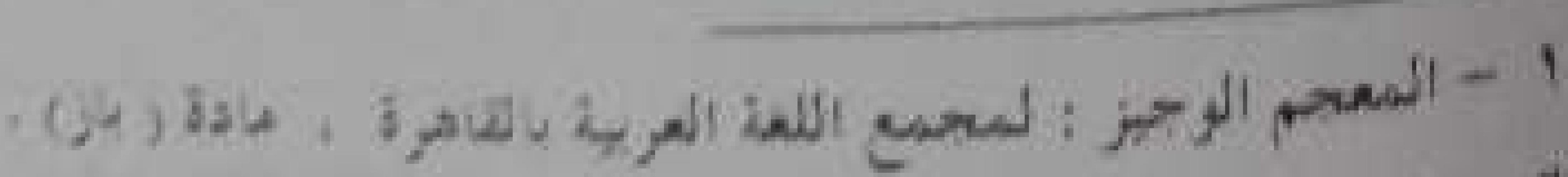

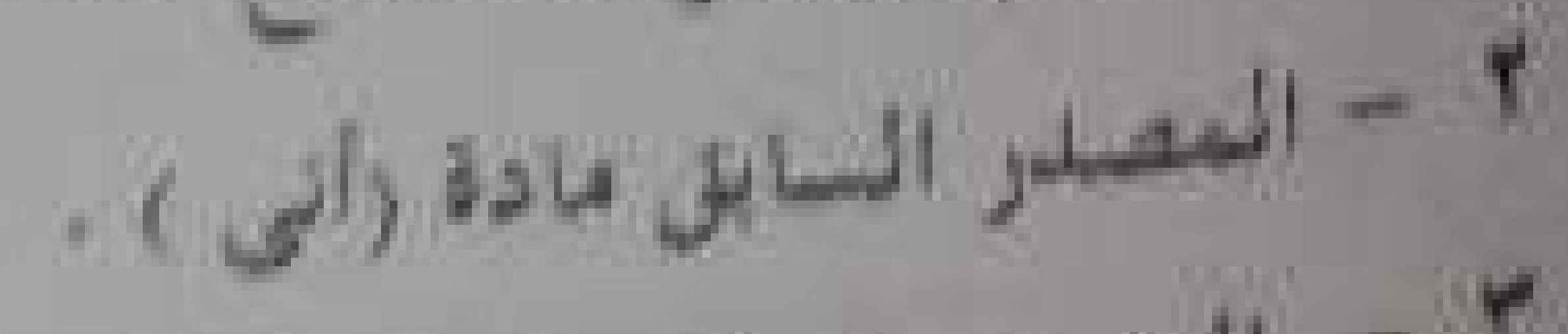
(c)
- rVr -

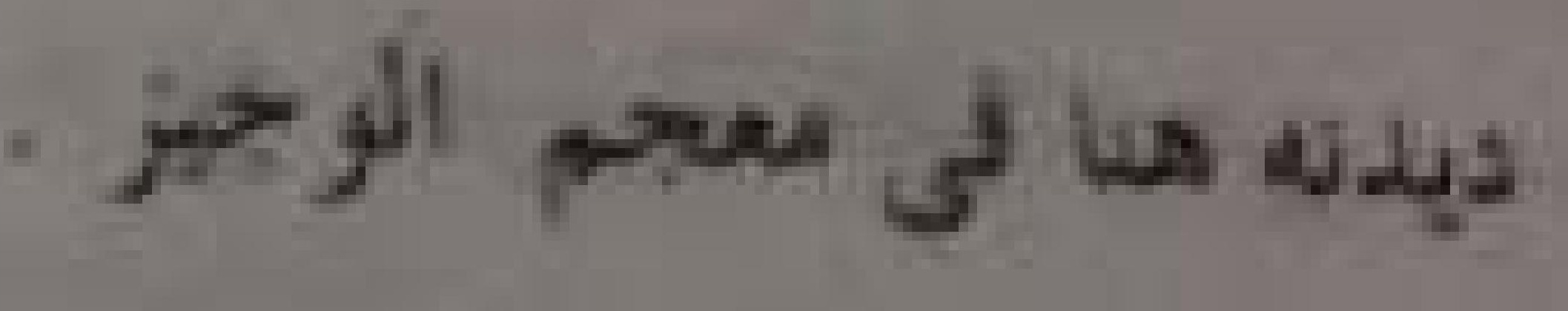

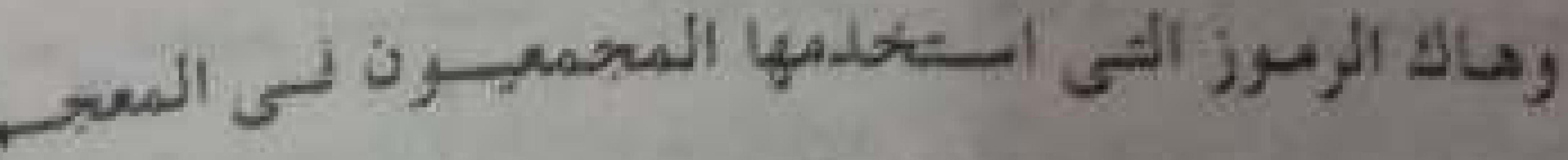

$$
-: j p
$$

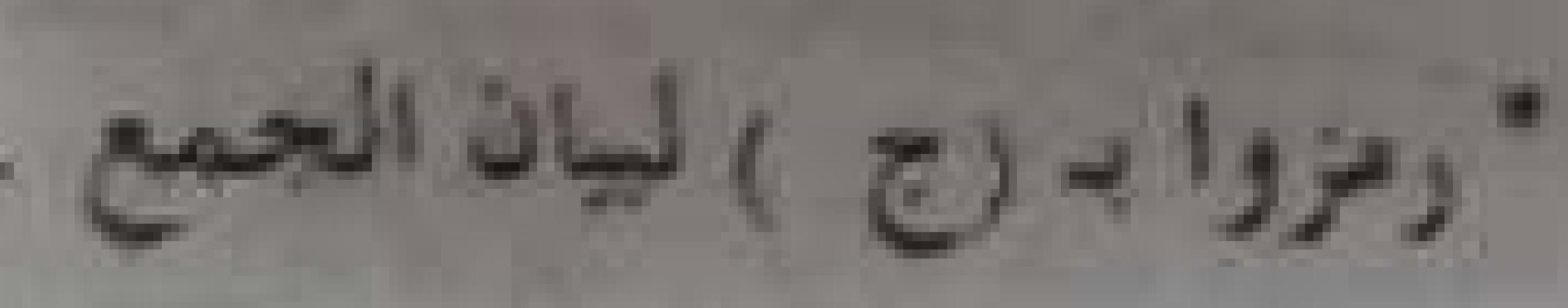

"2

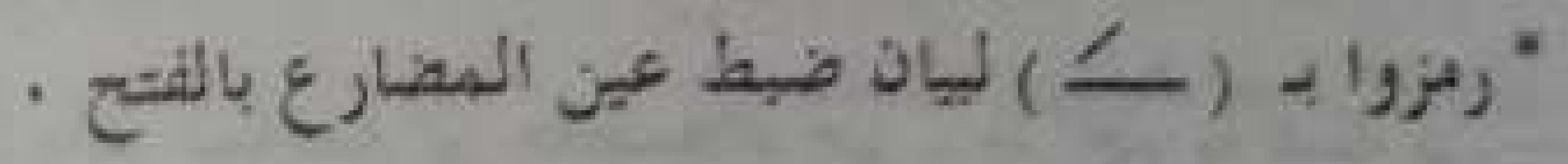

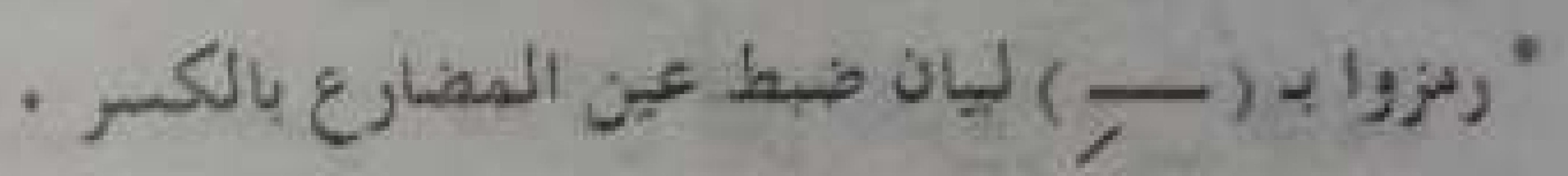

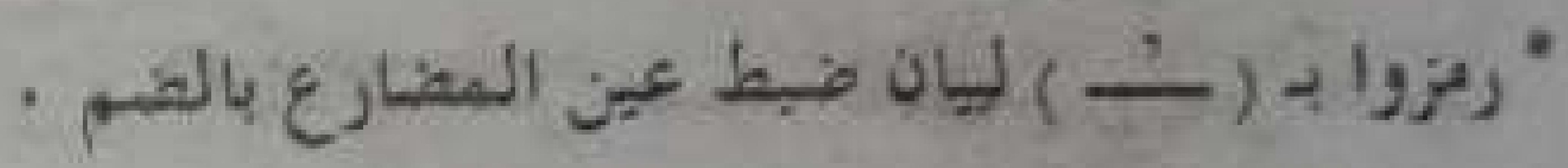

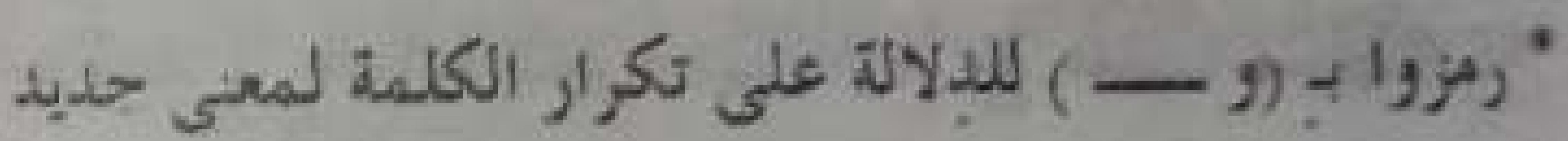

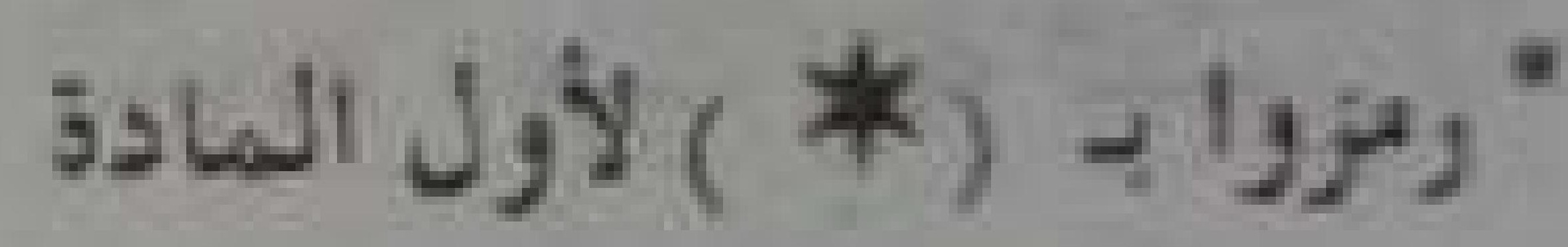

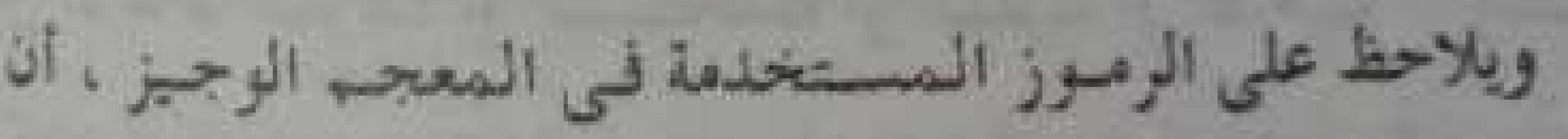

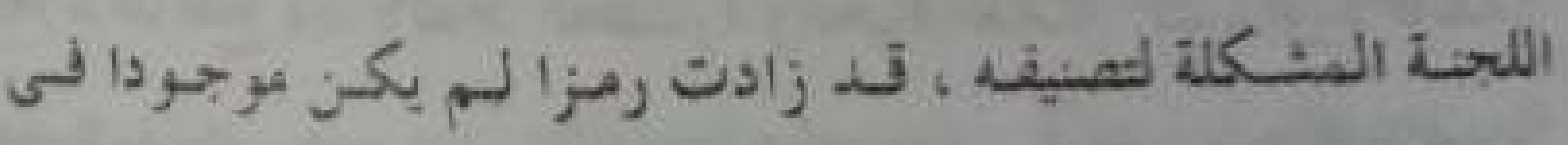

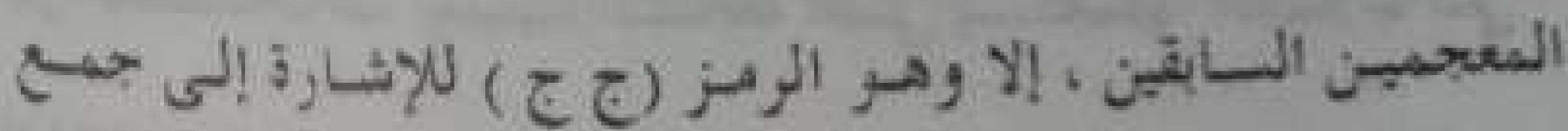

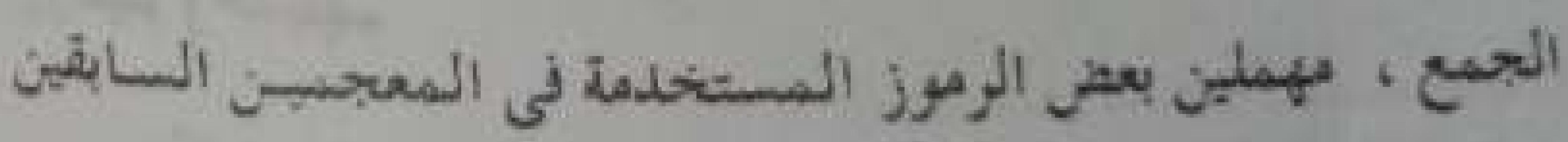

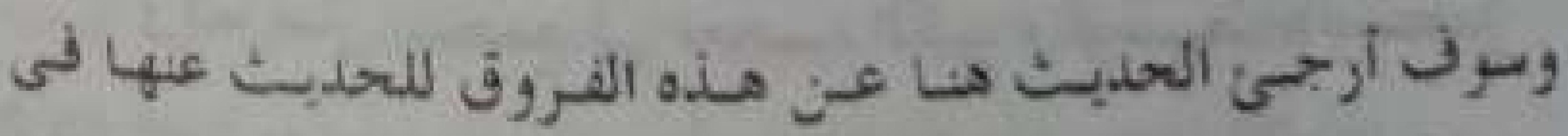

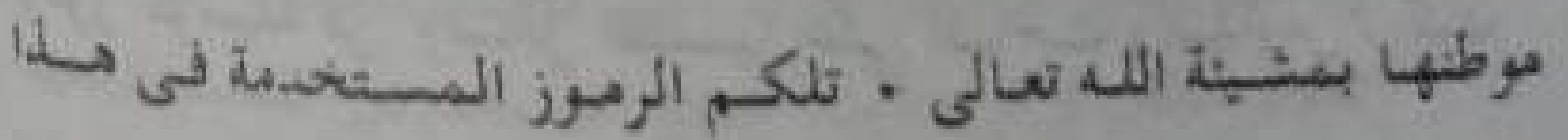

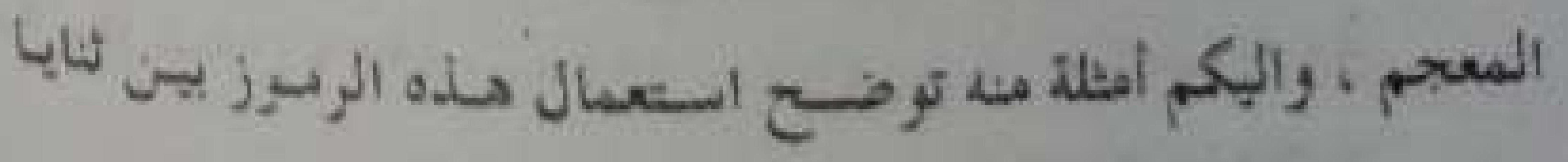




\section{(1) (1)

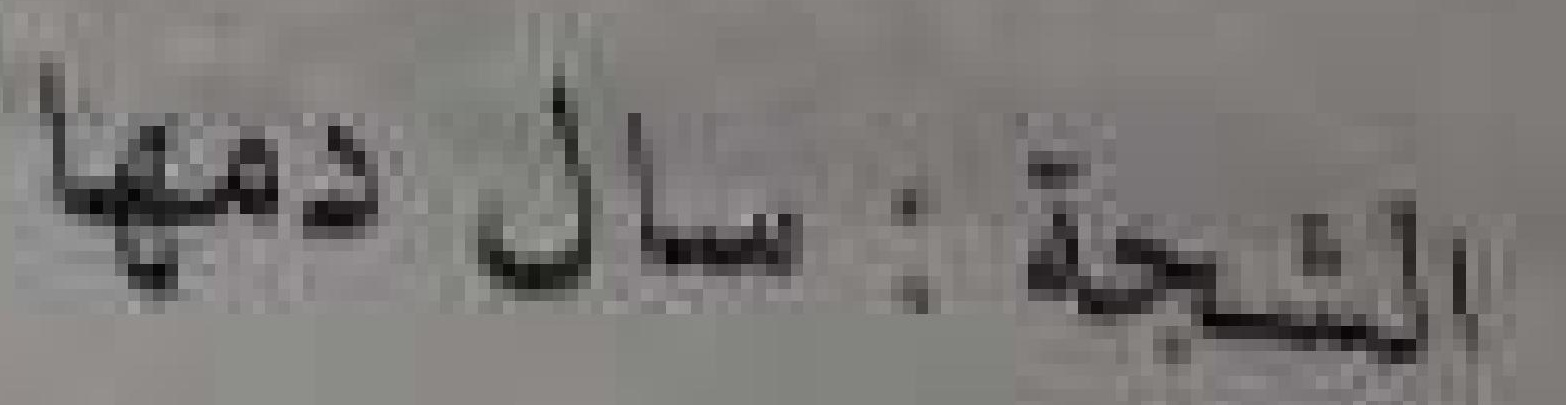

بعد الفراغ من الأمثلة على الرموز اللغوية المستحملة في هذا

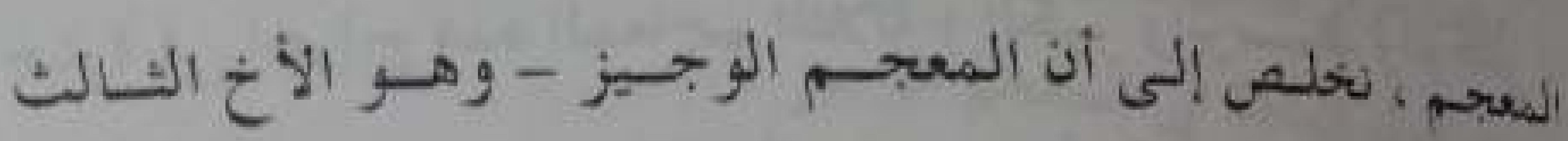

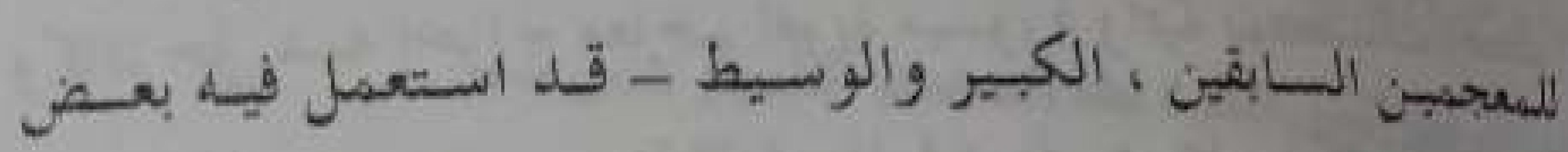

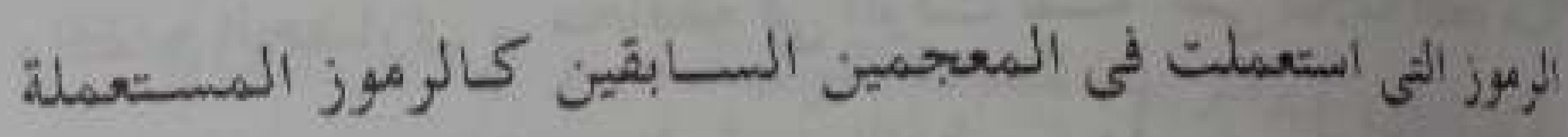

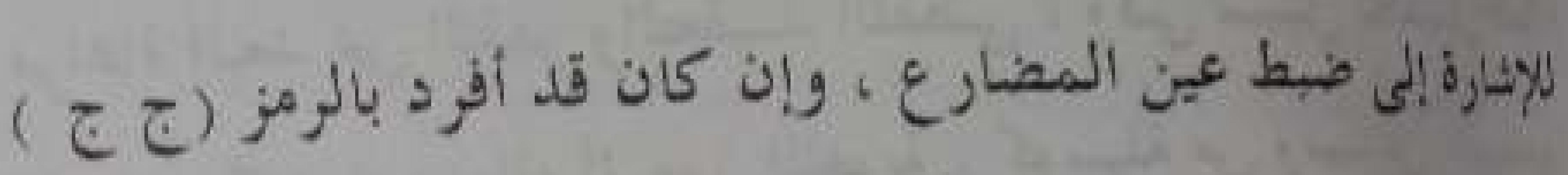
الاثلازة إلى حمع الجمع دون أقر ائه.

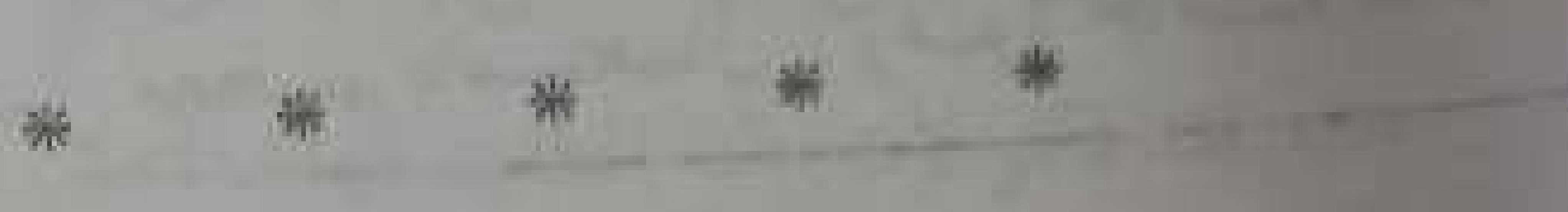

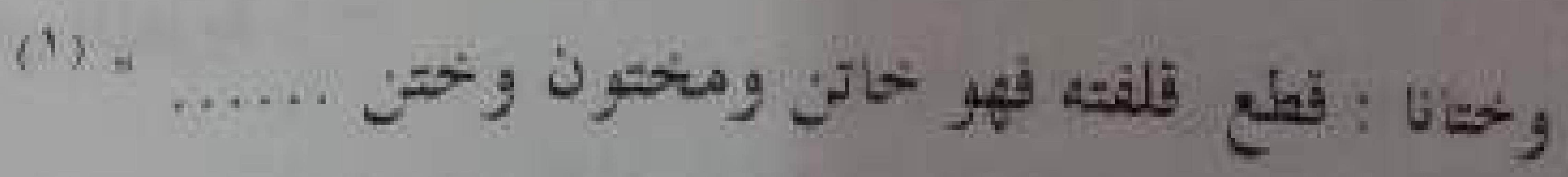

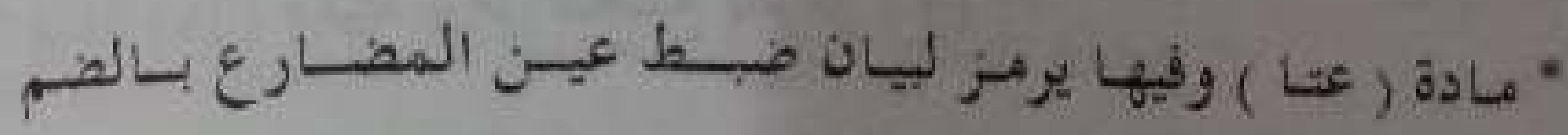
$-i\left(\frac{1}{)}\right)$

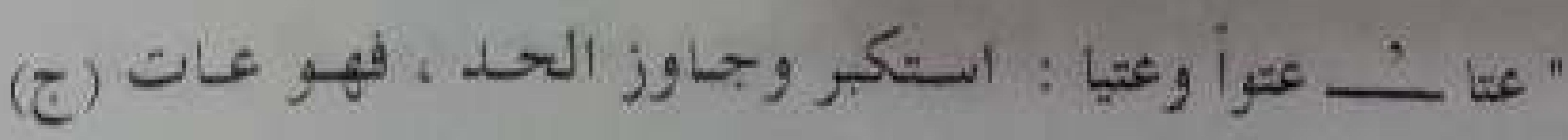

$$
\text { (T) " उLE }
$$

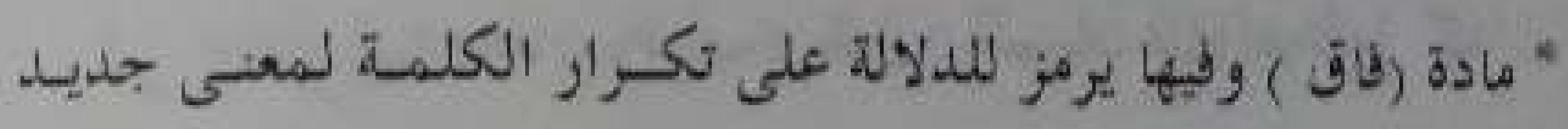

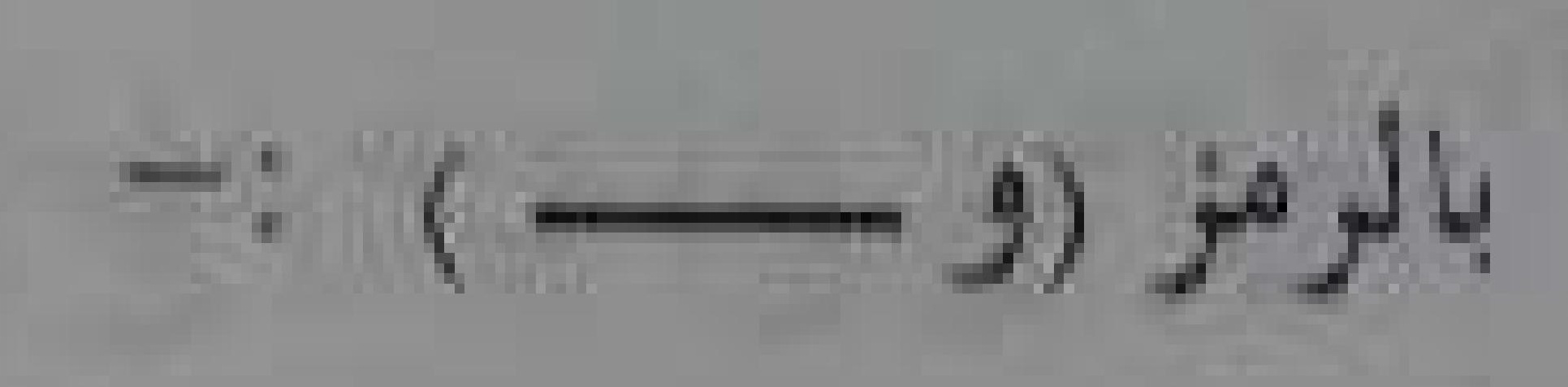

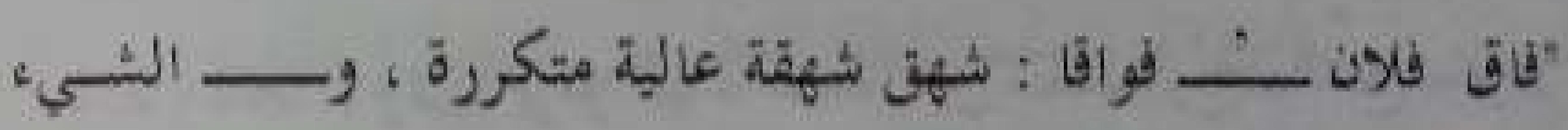

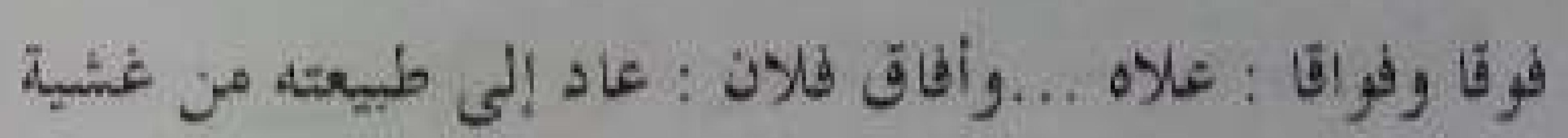

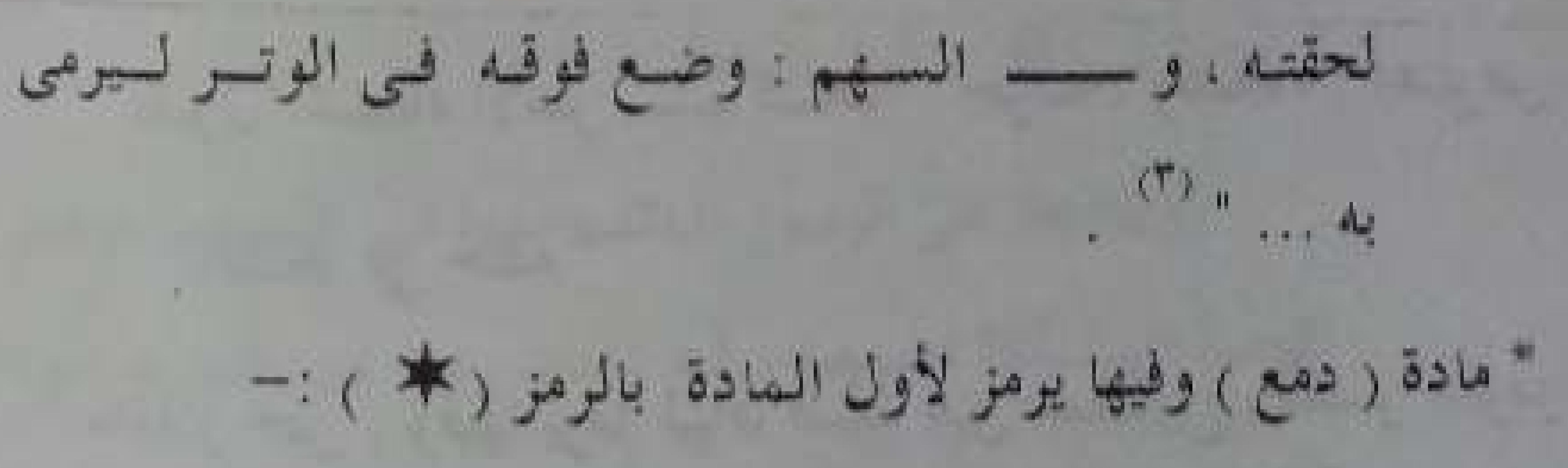

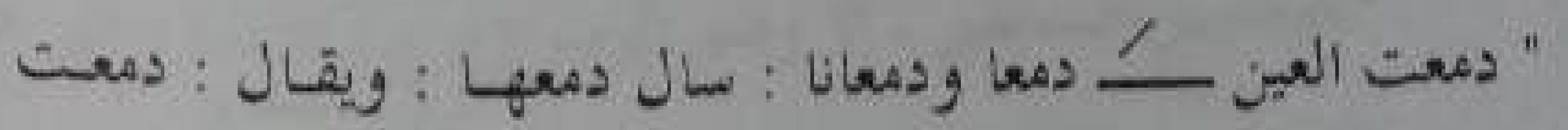


(الكبير

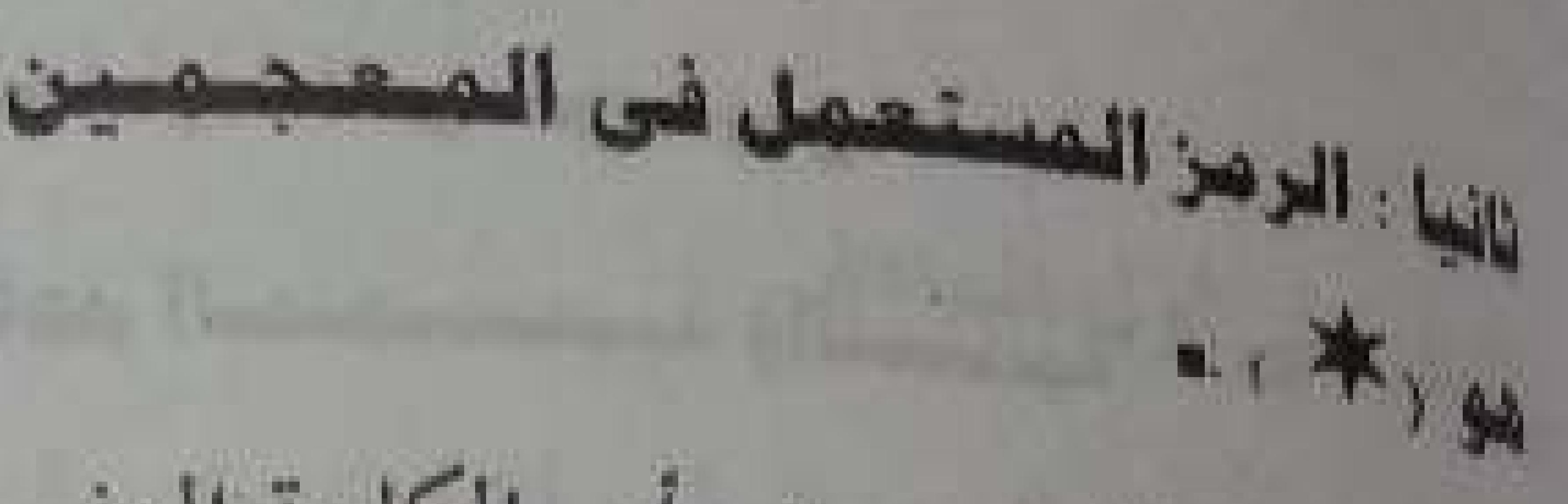

وهدا الرمز يسيق رأس الكلمة المفسرة في المعجم الكبـير .

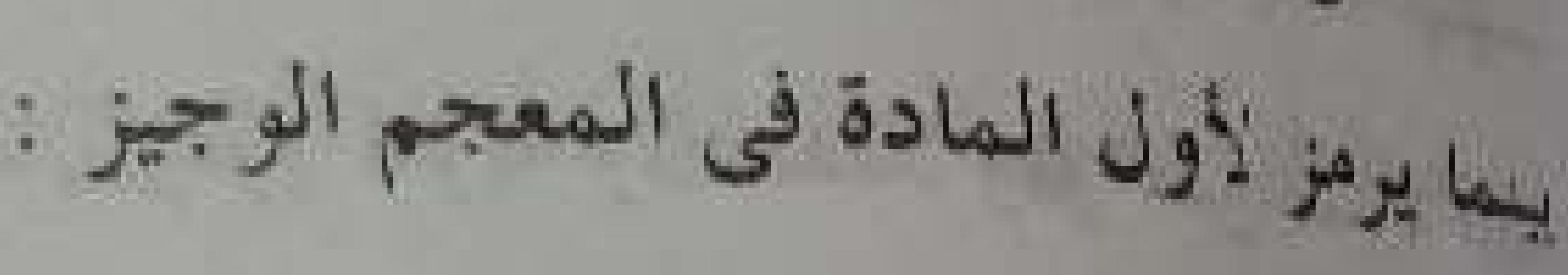
: :

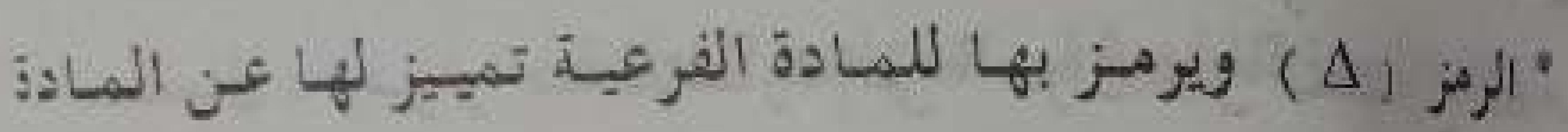
الأسلية.

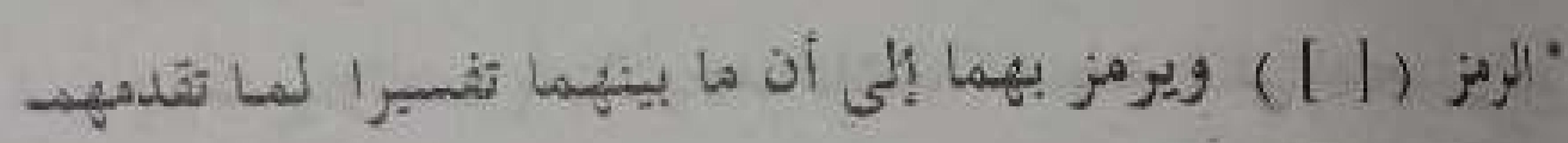

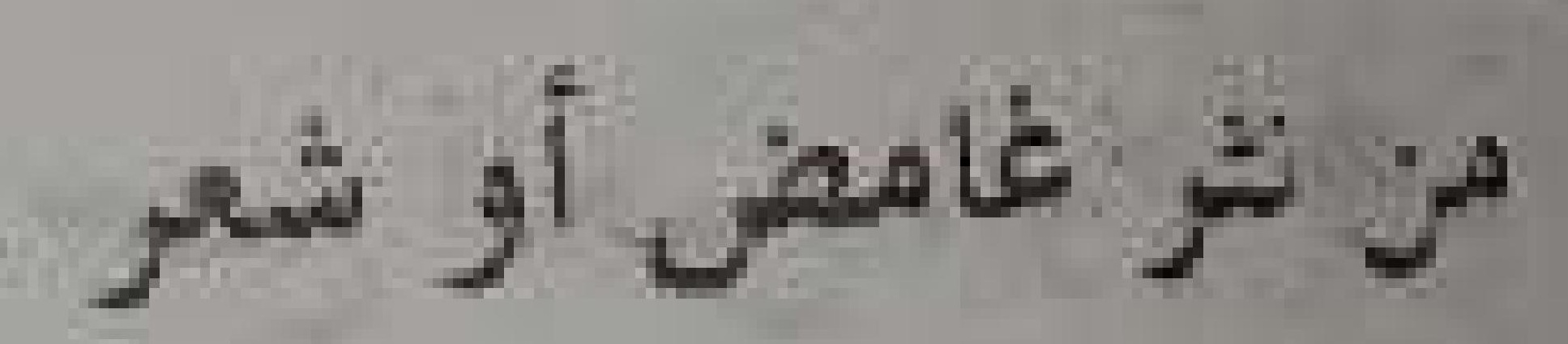

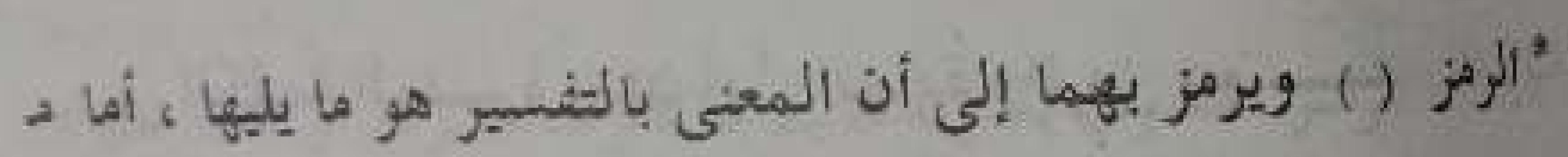

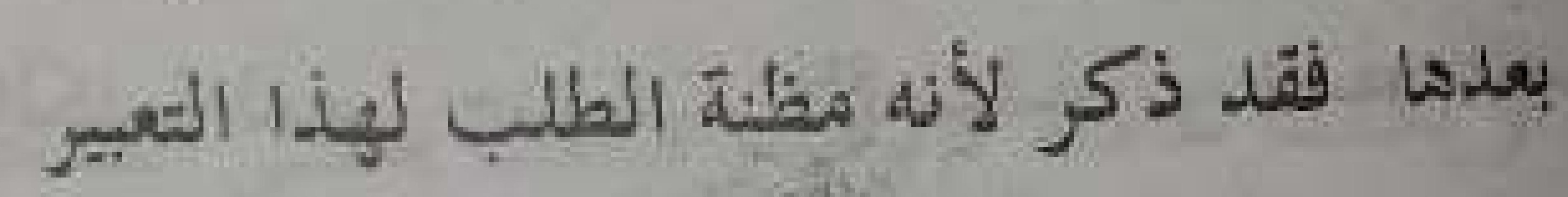

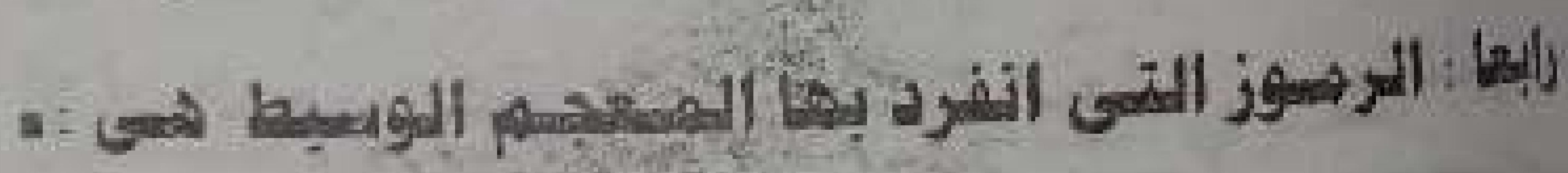

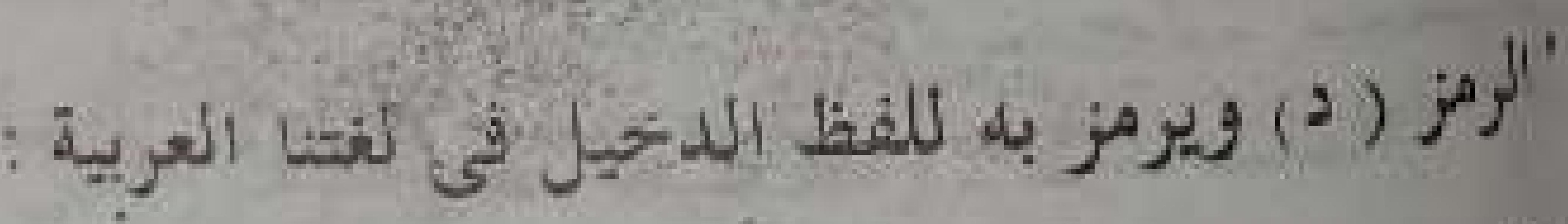

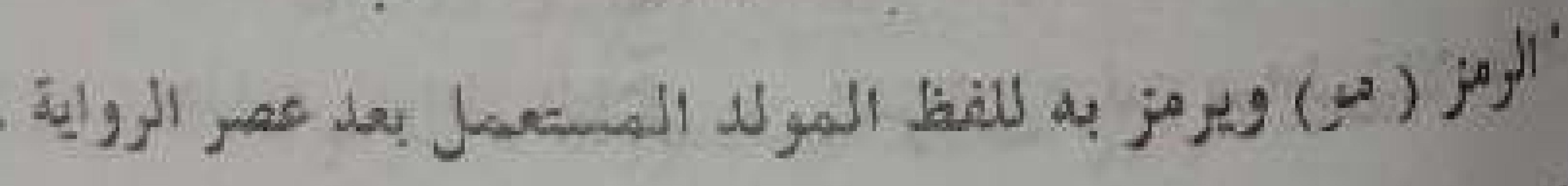

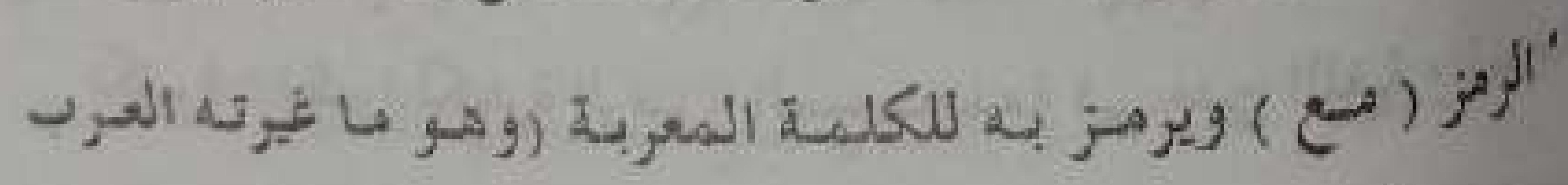

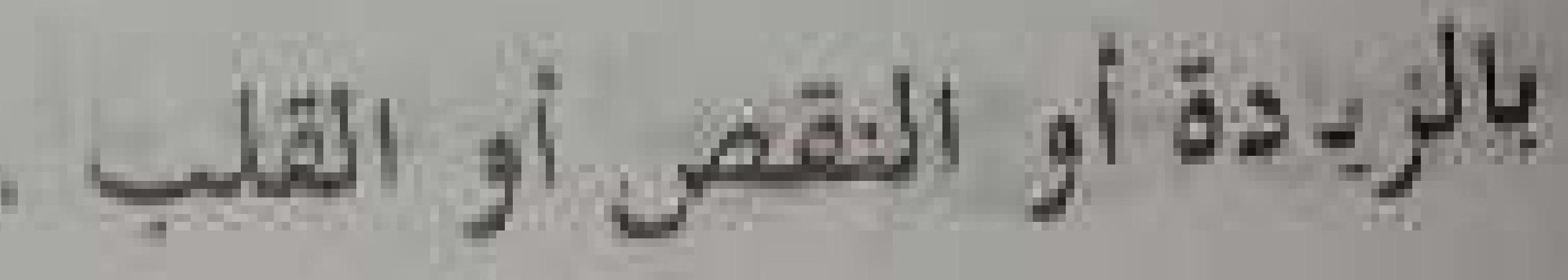

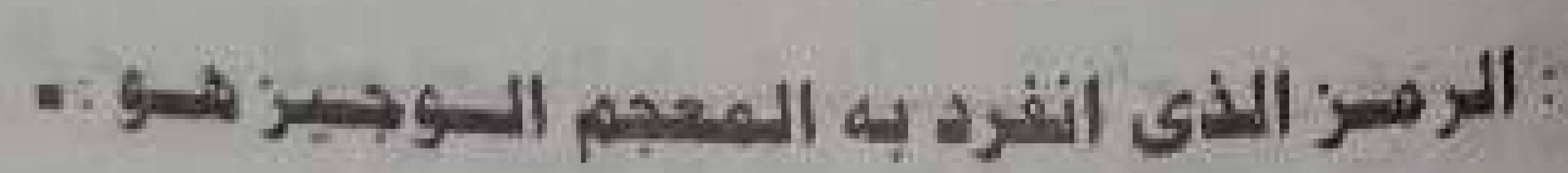

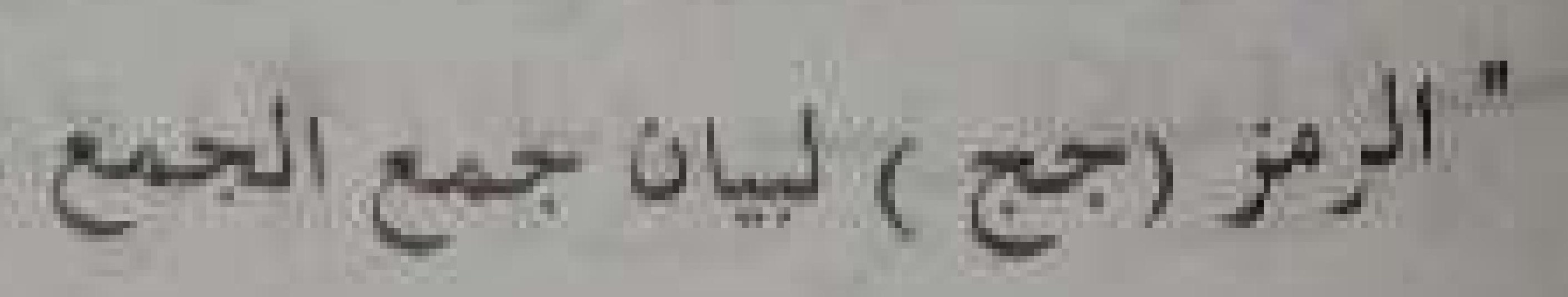

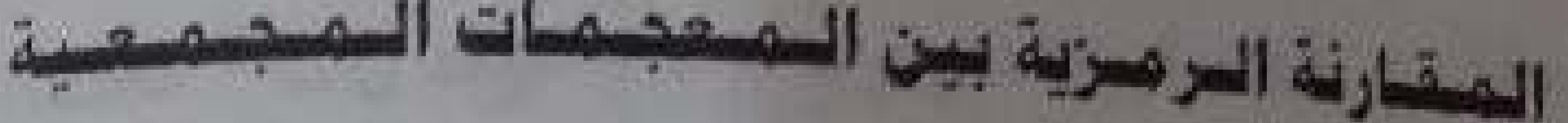

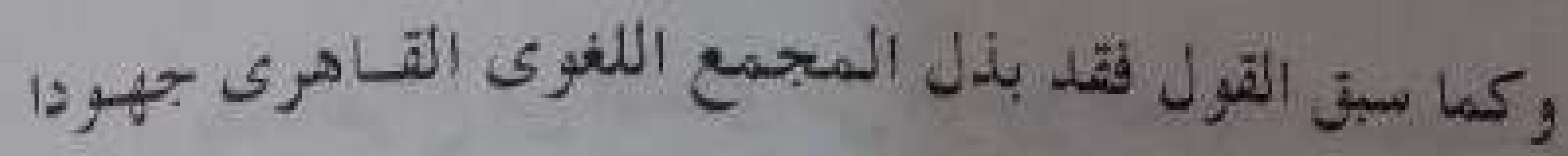

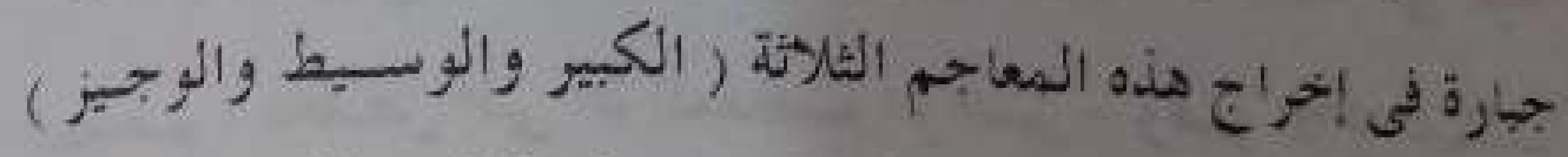

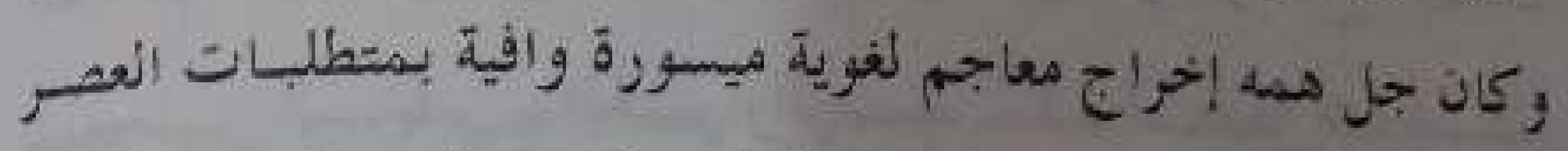

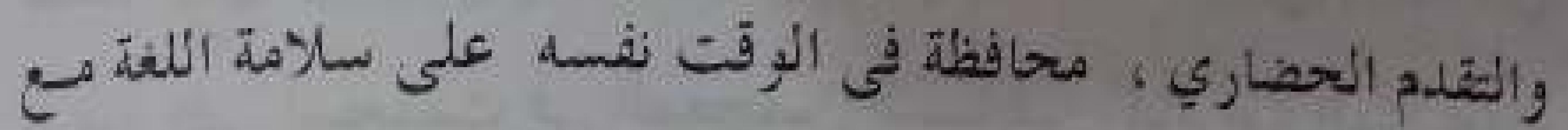

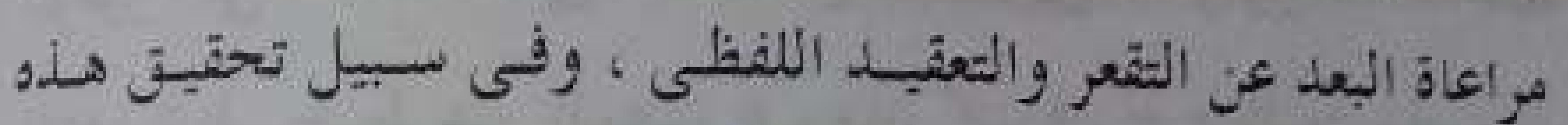

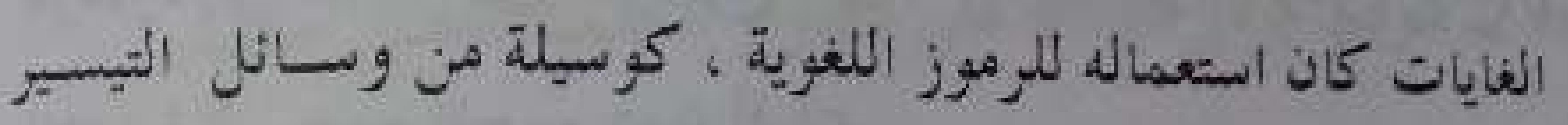

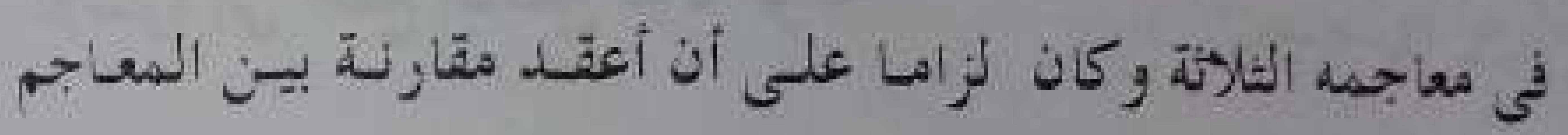

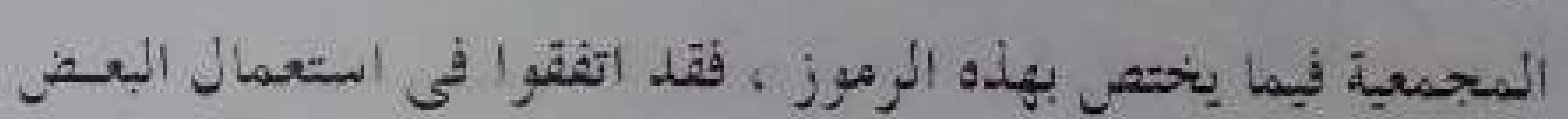

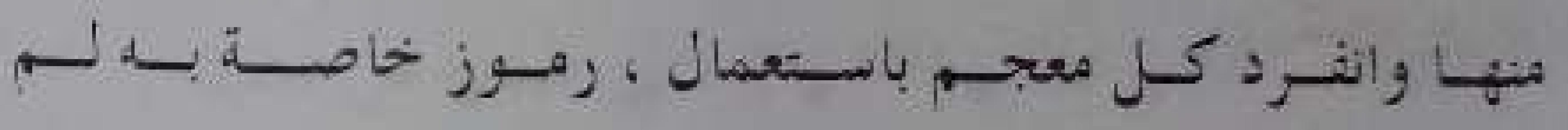
يستحدمها أقرانه

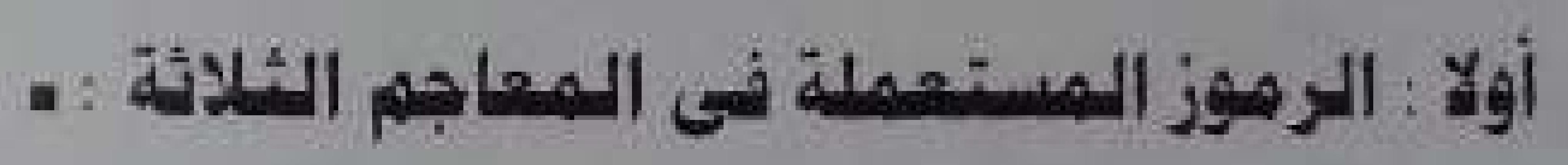

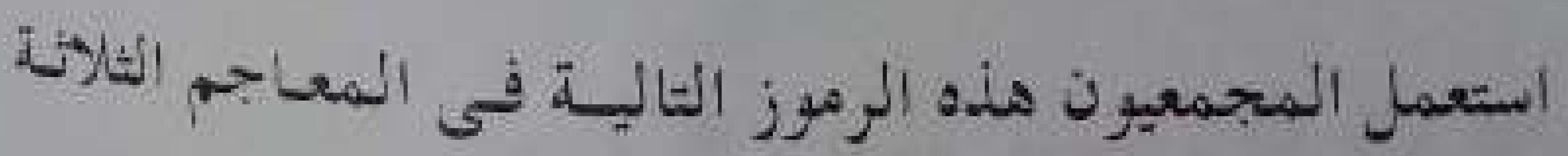

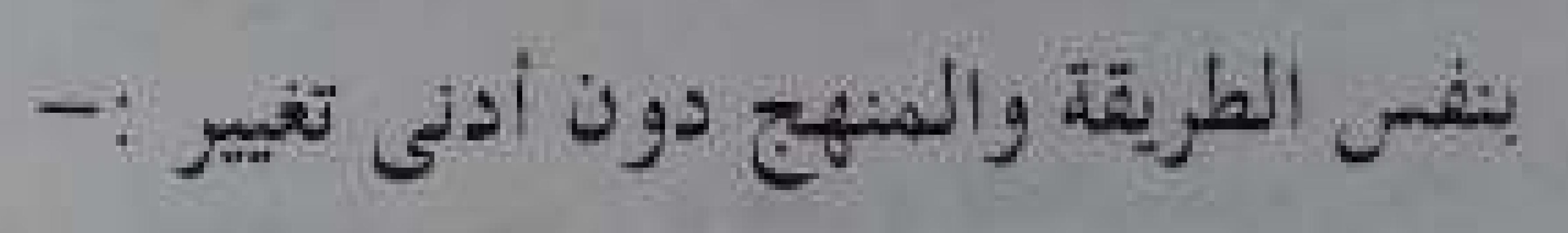

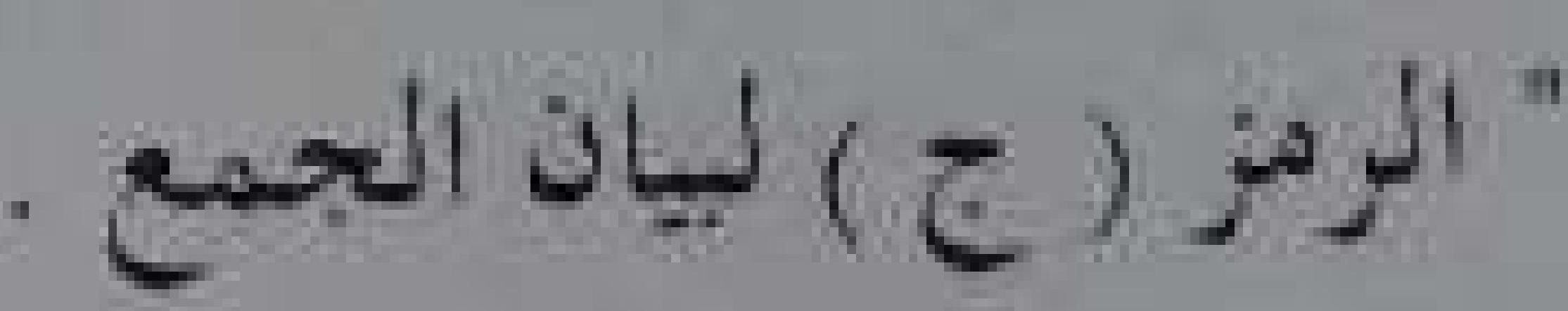

" الرمز ( ) لبيان ضبط عين المضارع بالنتح.

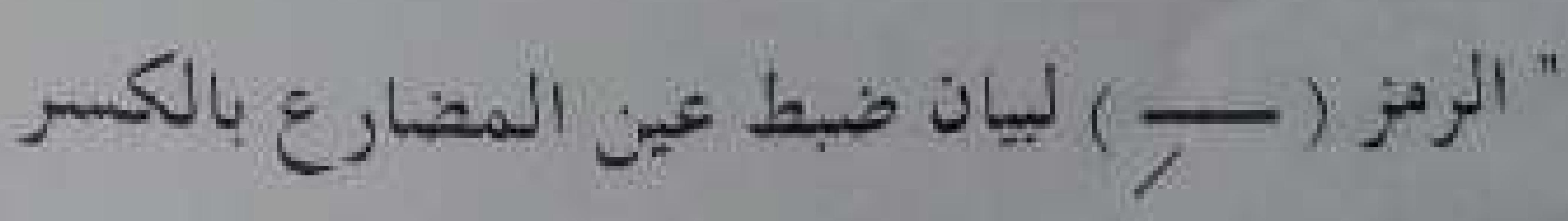

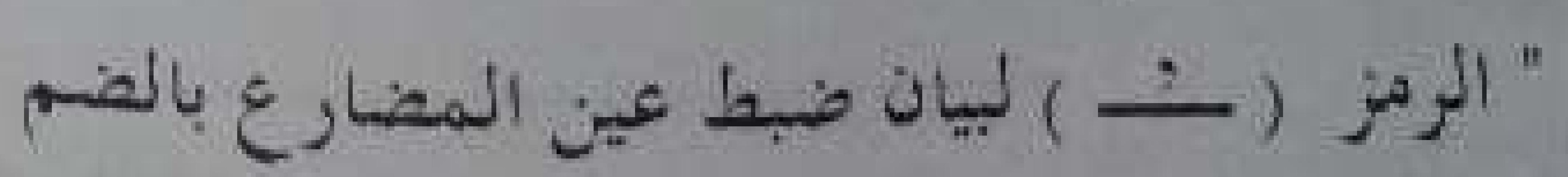


النال على أول ألمادة.

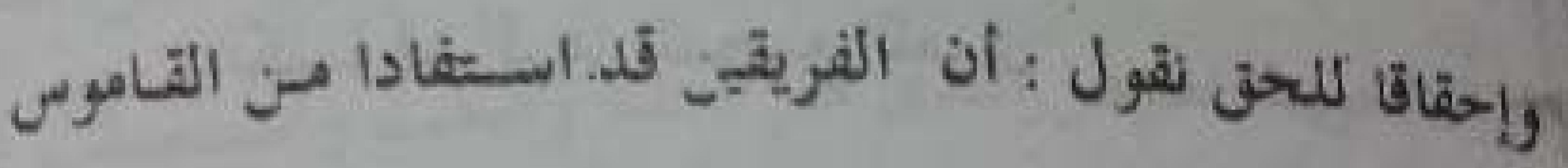

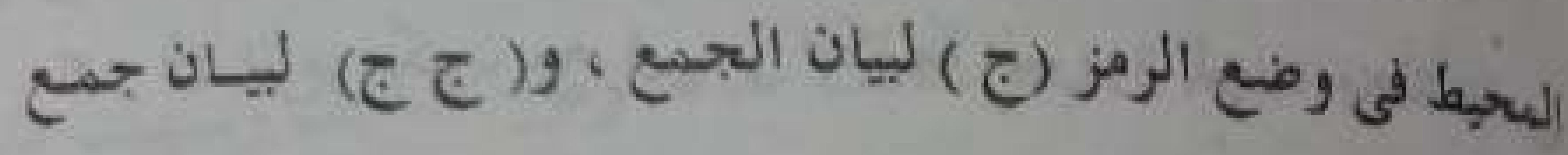

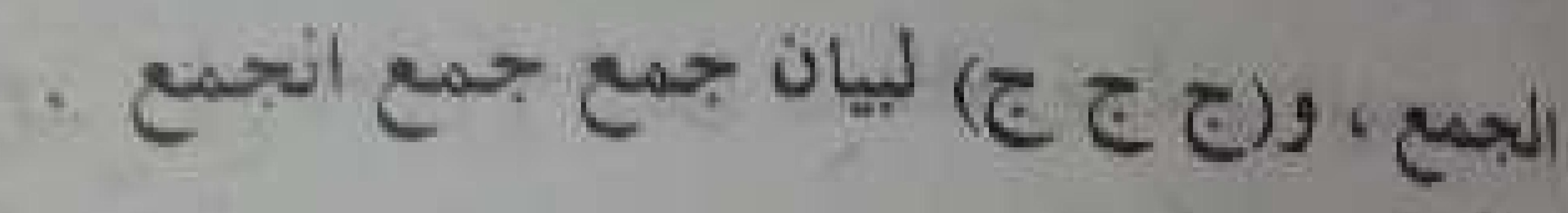

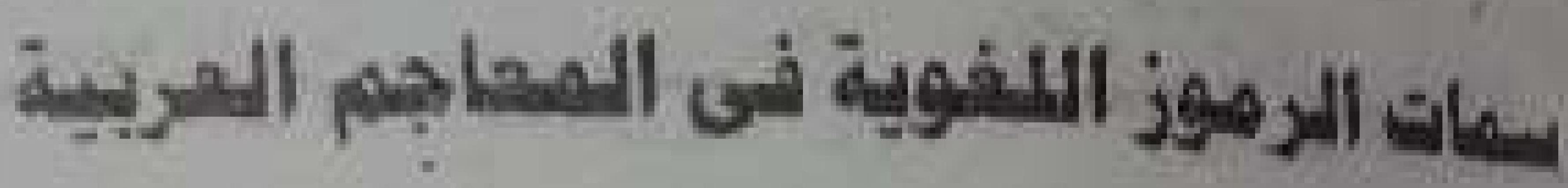

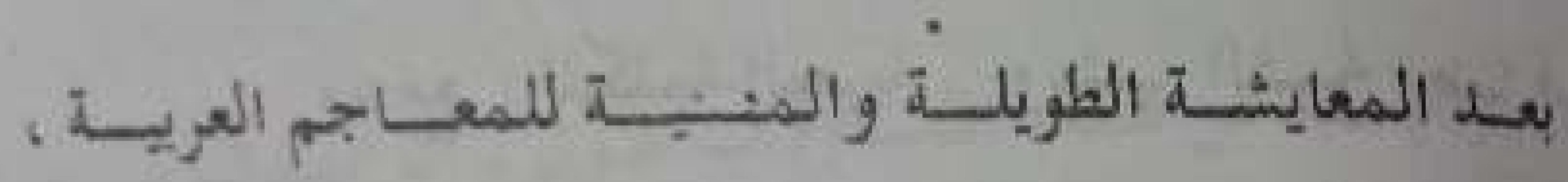

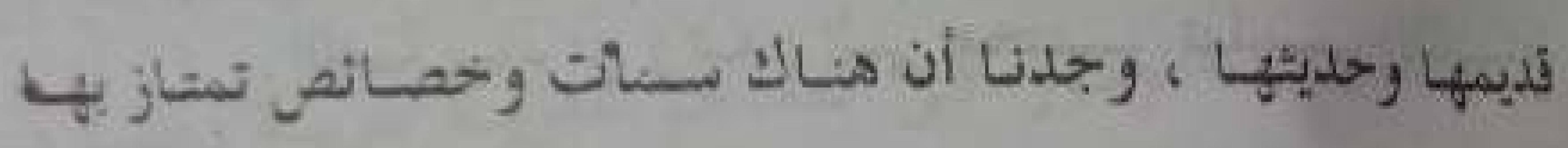

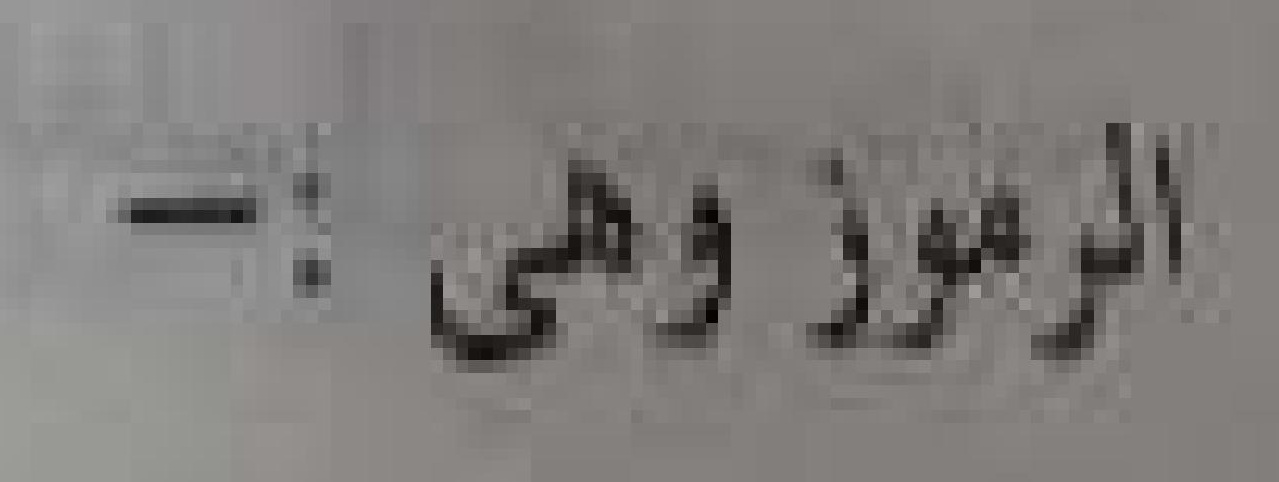

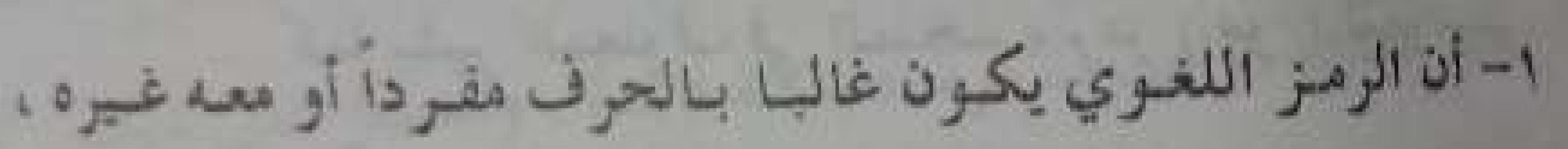

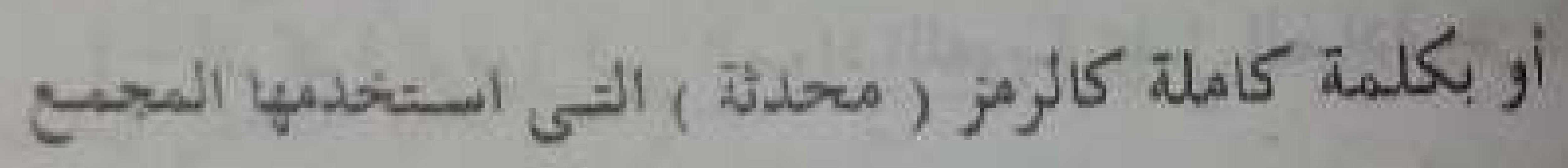

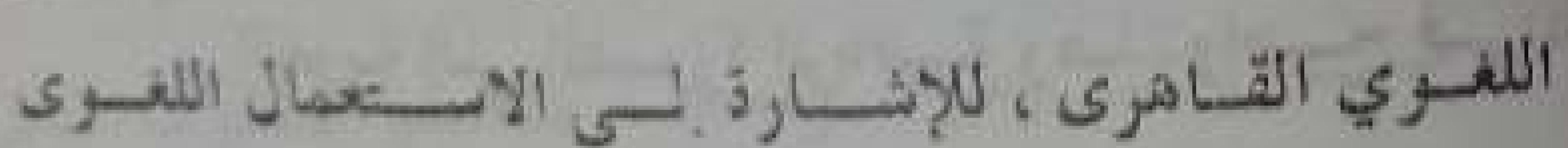

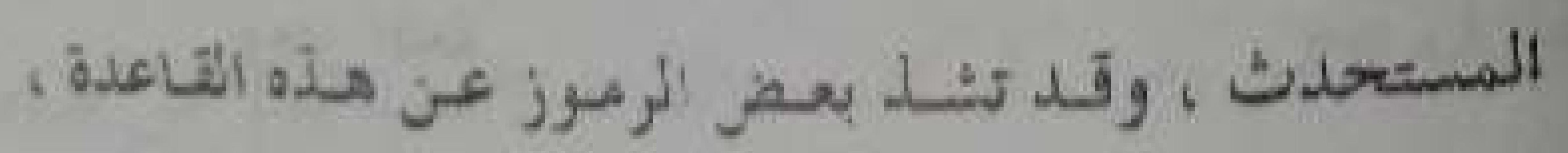

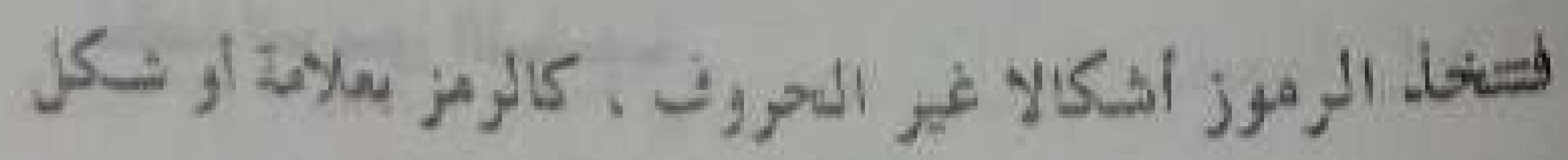

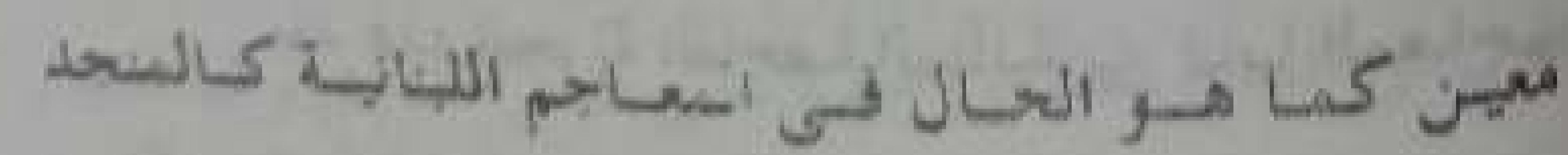

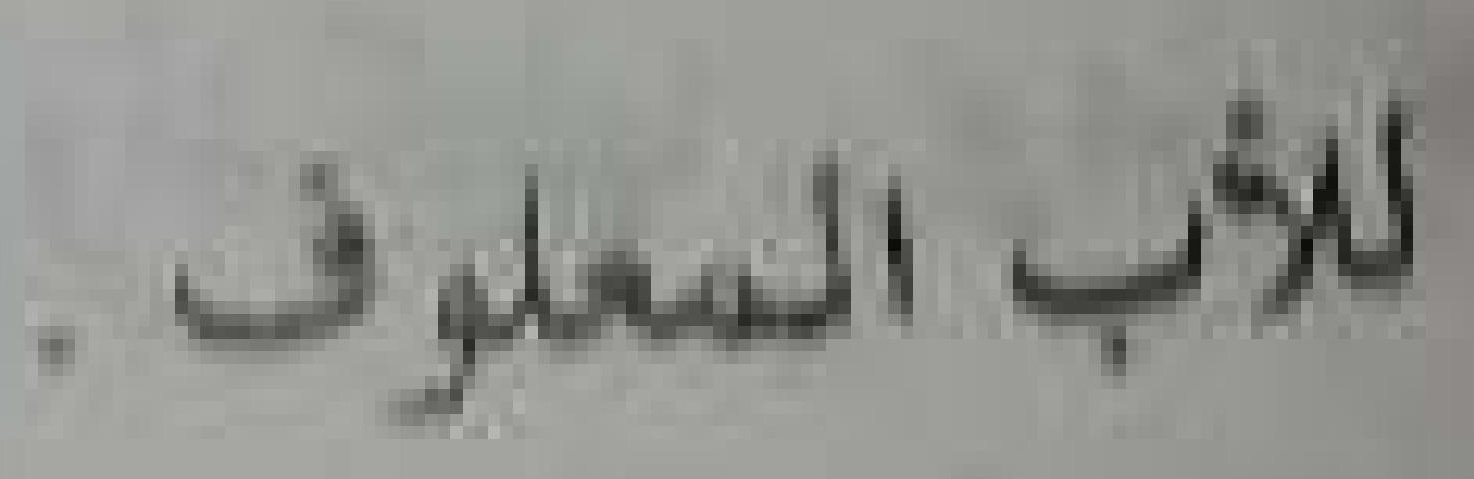

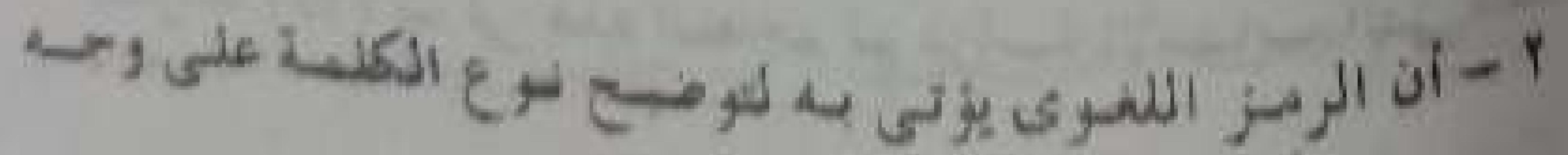

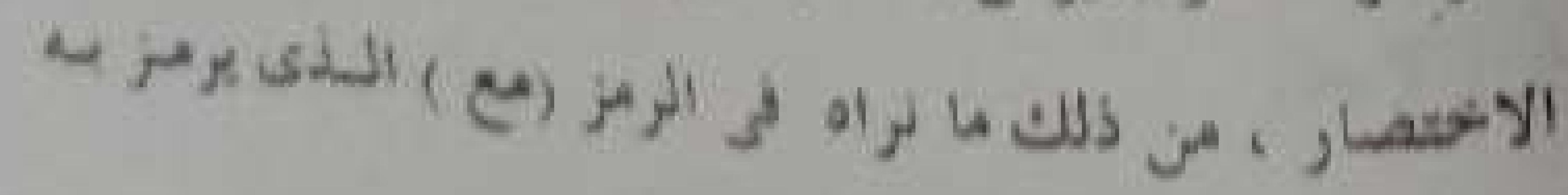

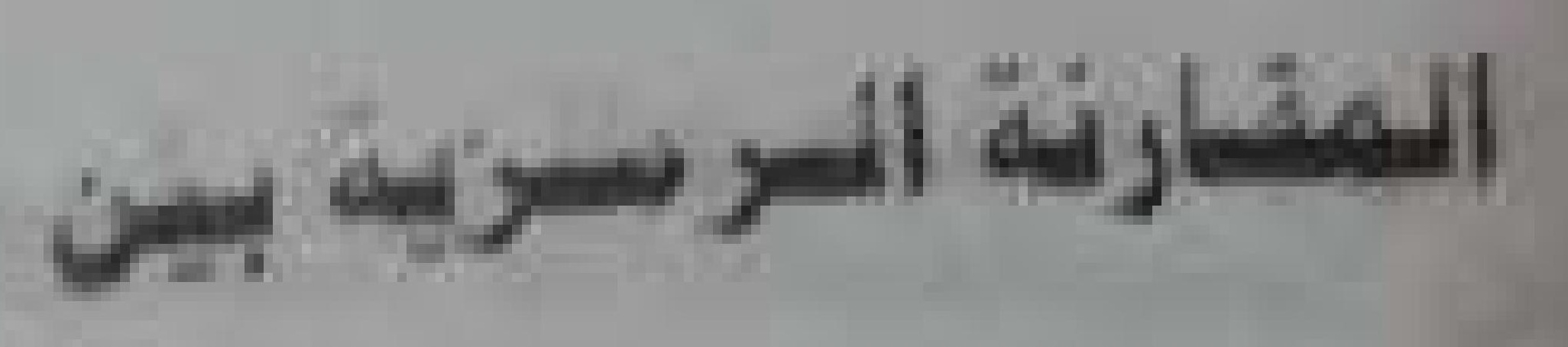

atidg

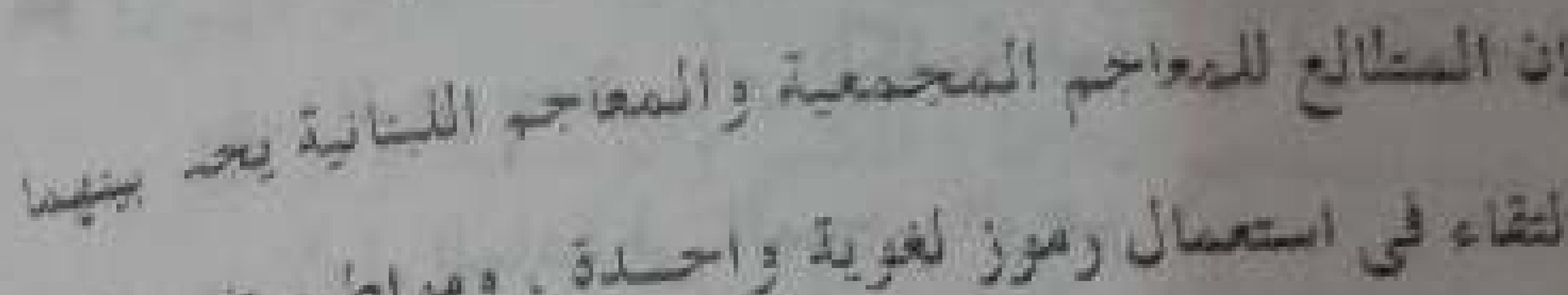

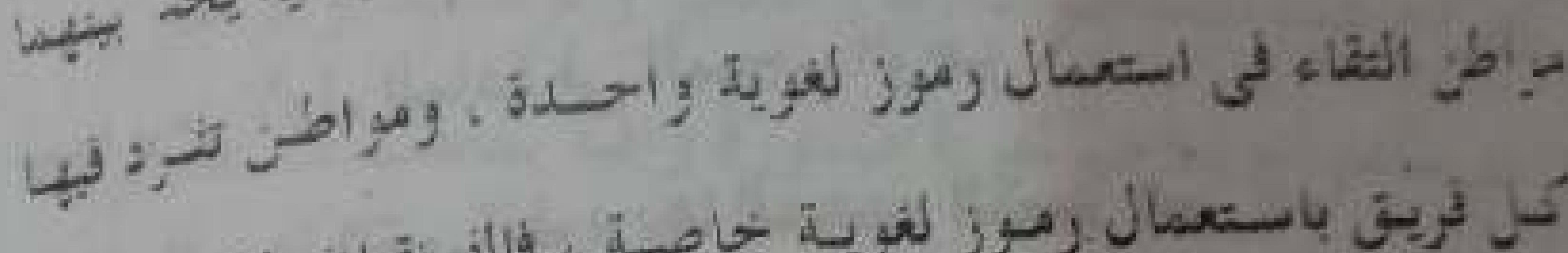

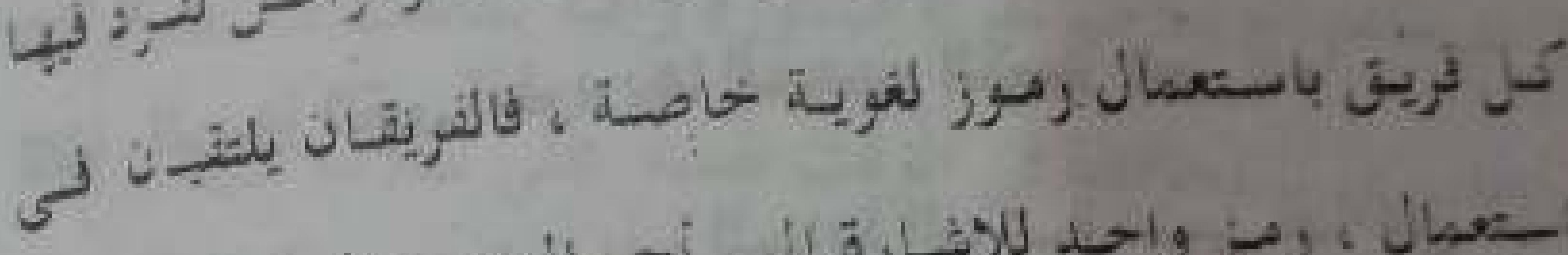

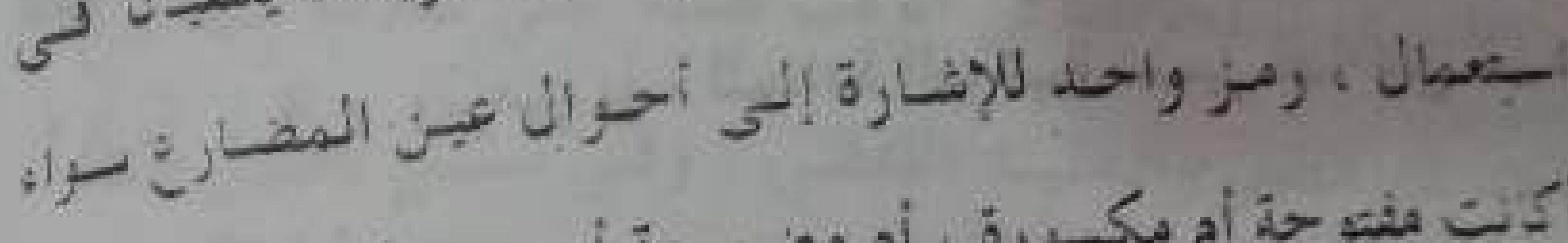

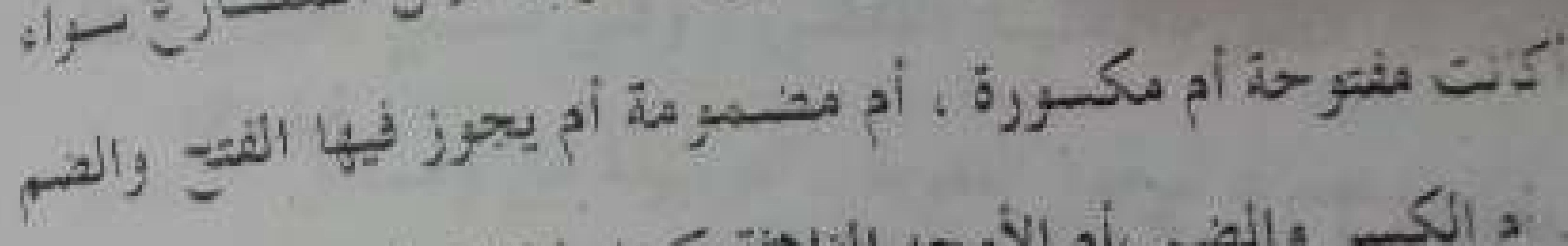

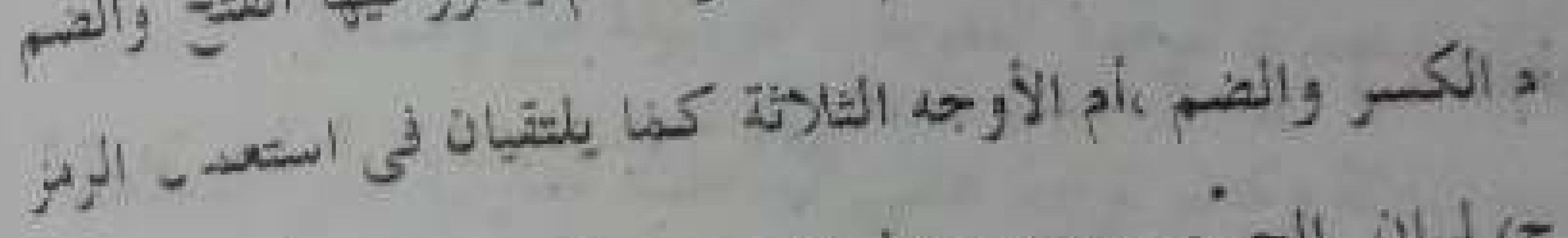

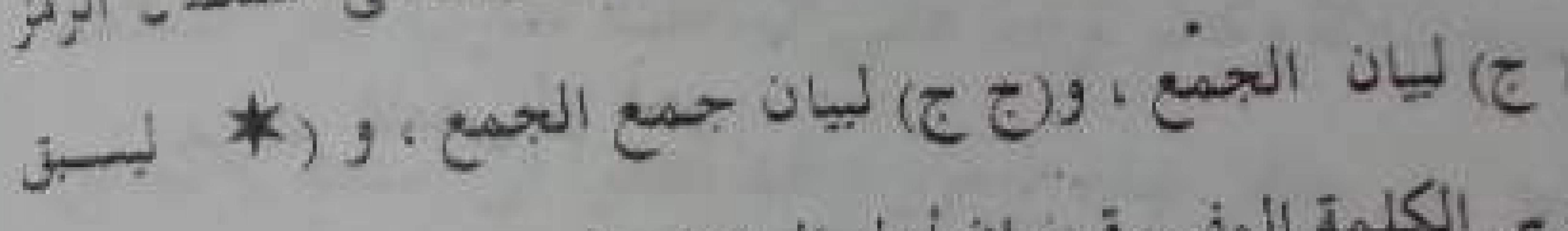

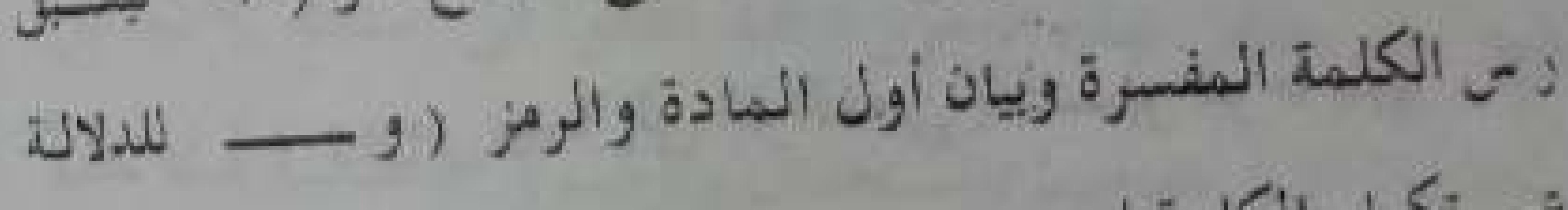

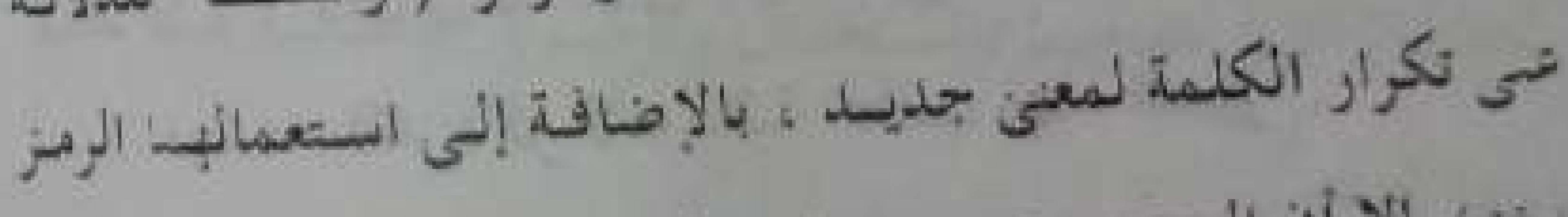

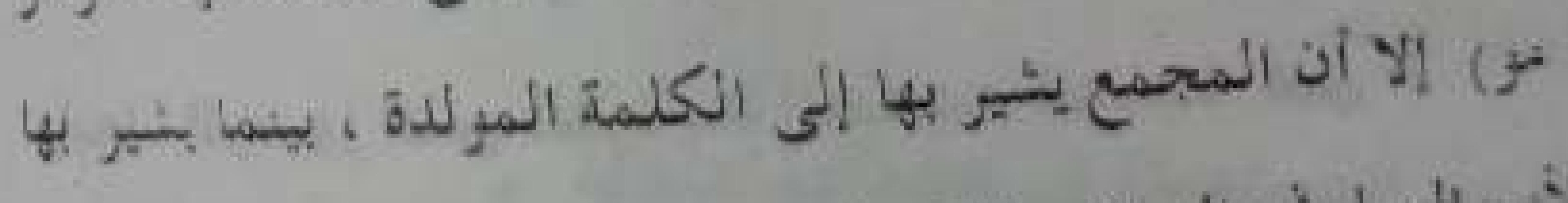
其

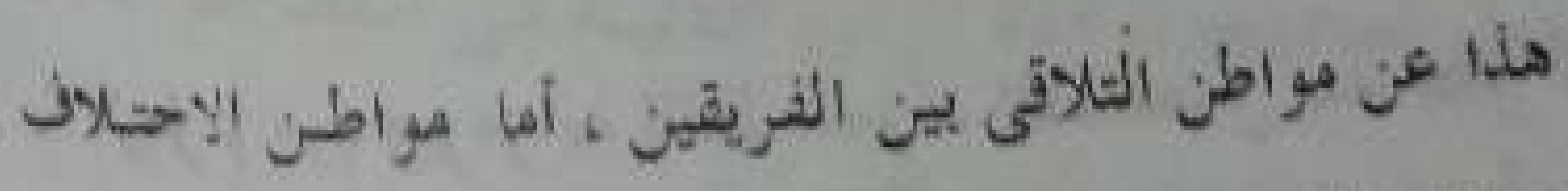

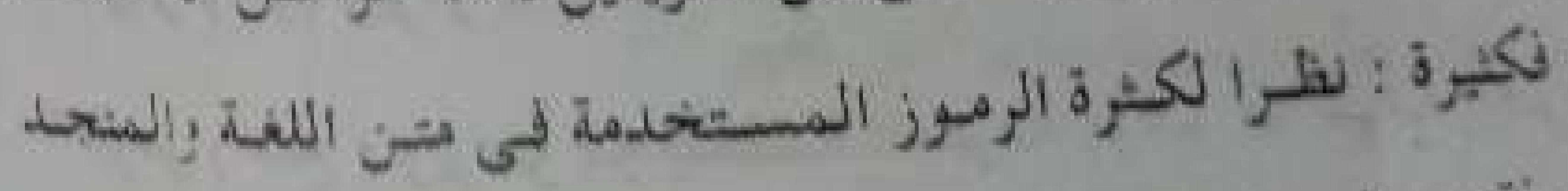

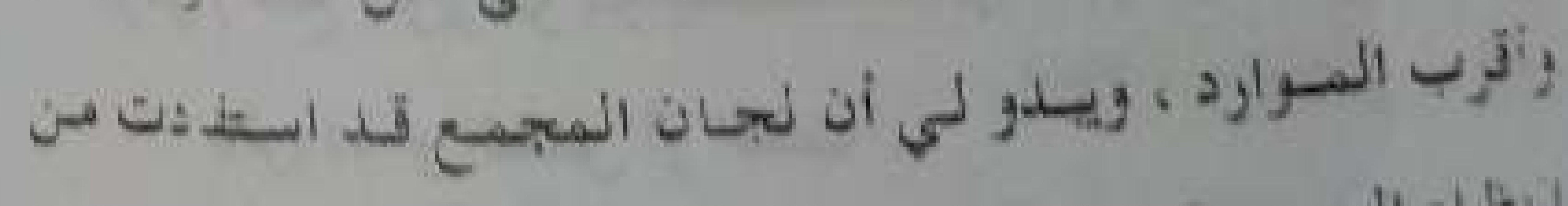

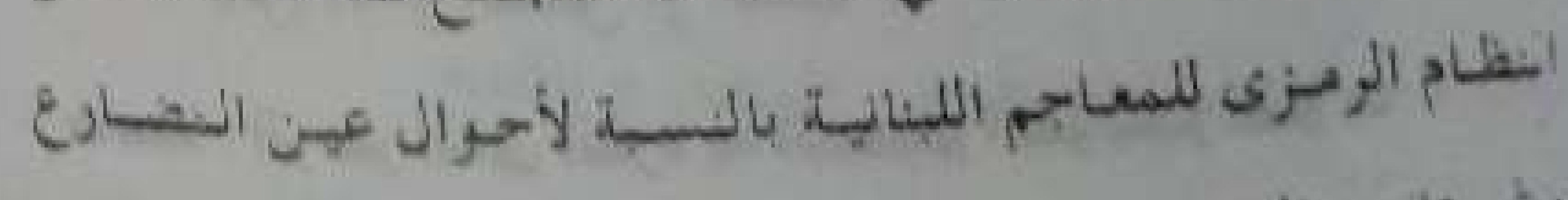

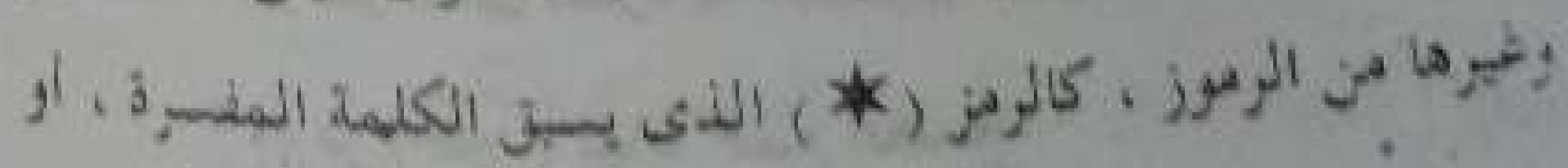




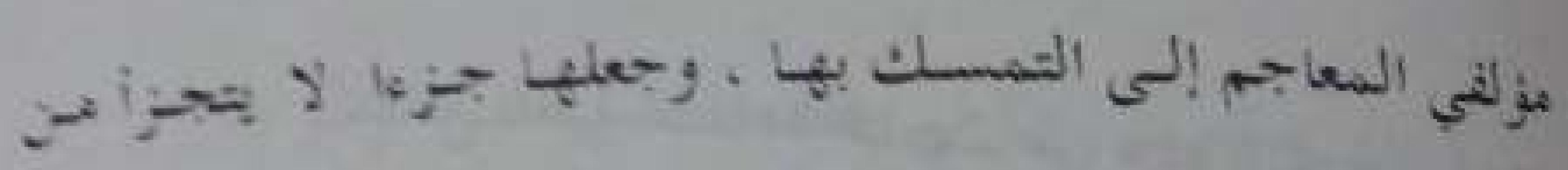

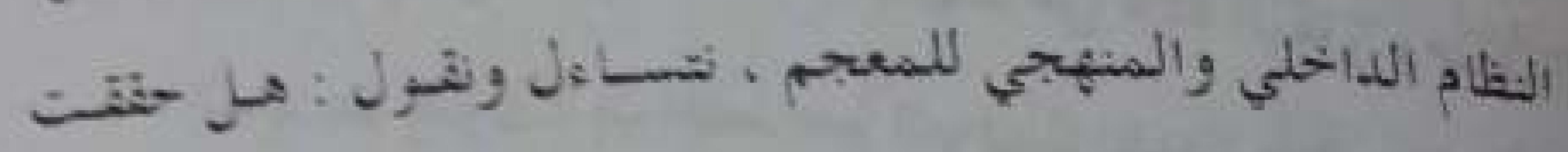

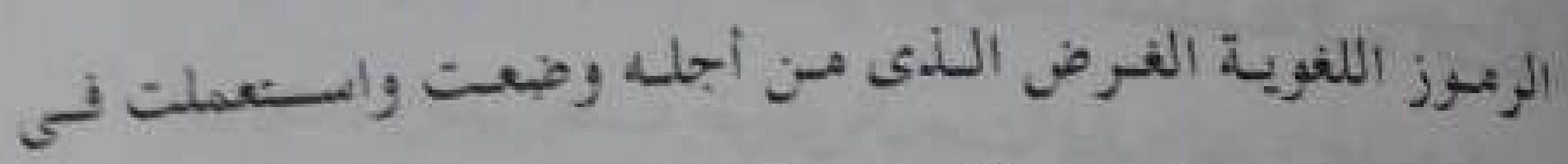

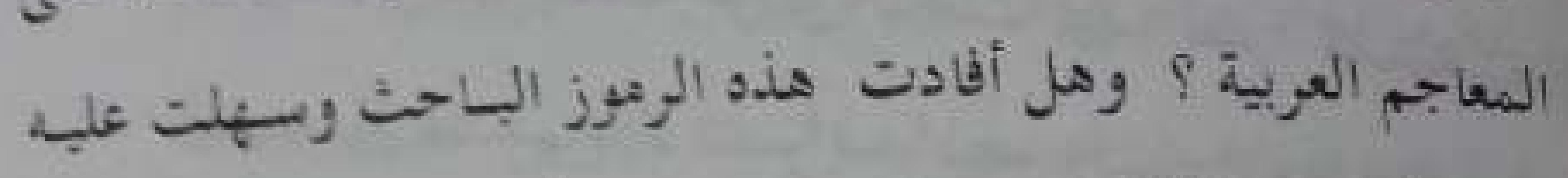

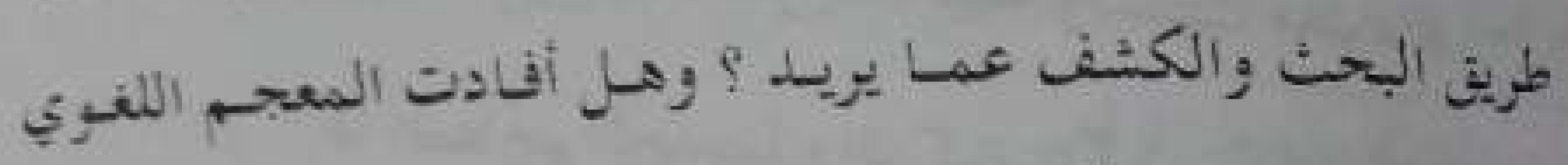
العربي تسيقا ونهبرلة وإيجازا ؟

ولاججابة عن هـذه التسـاولات تقول : أن الهيدف مي وراء

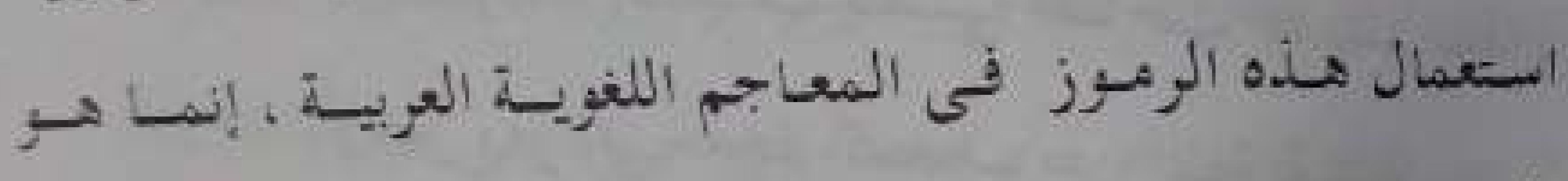

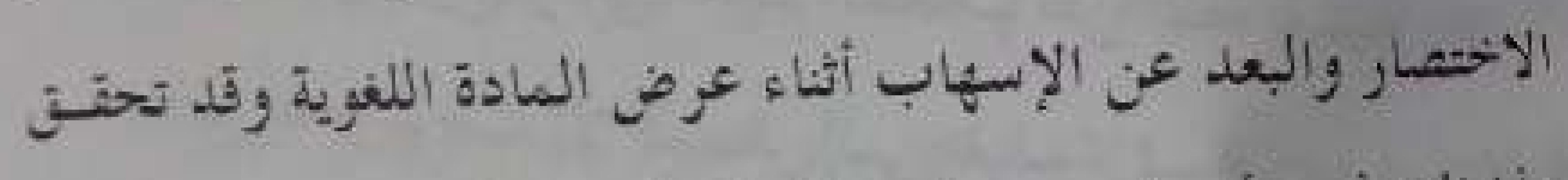

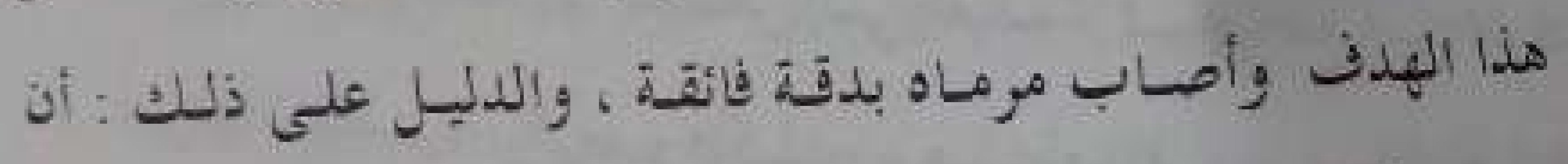

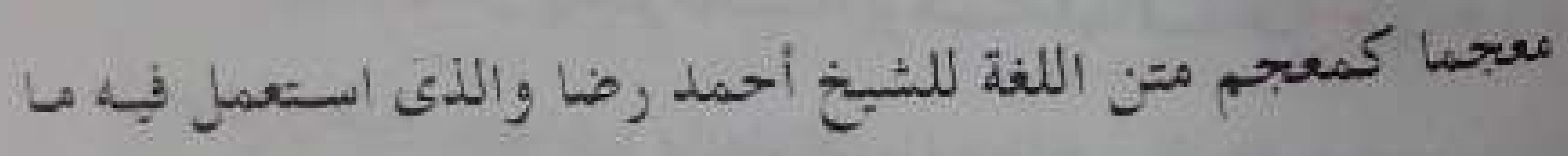

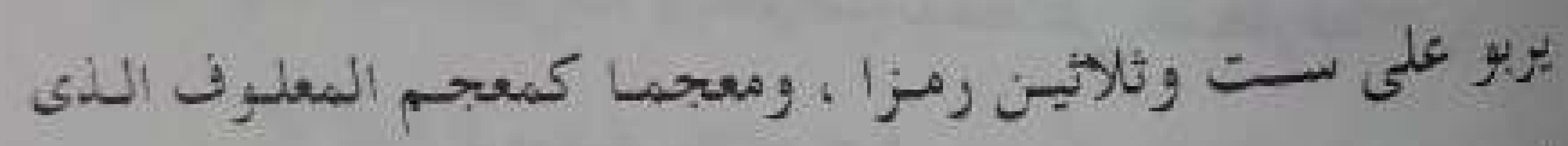

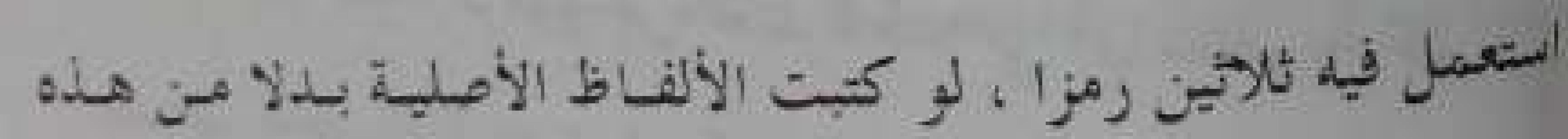

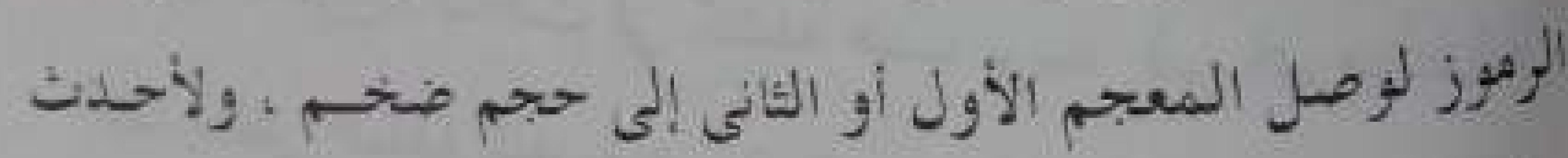

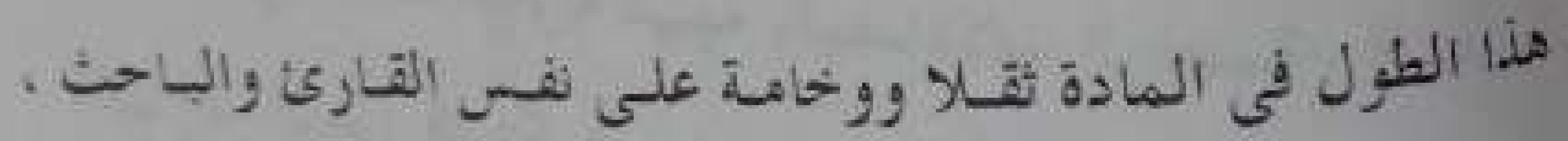

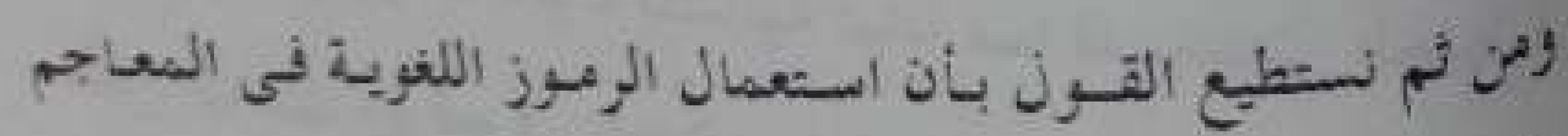

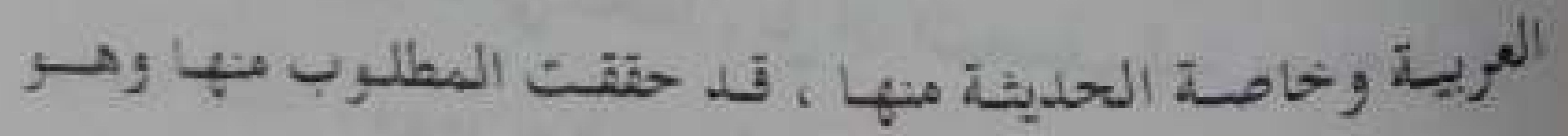

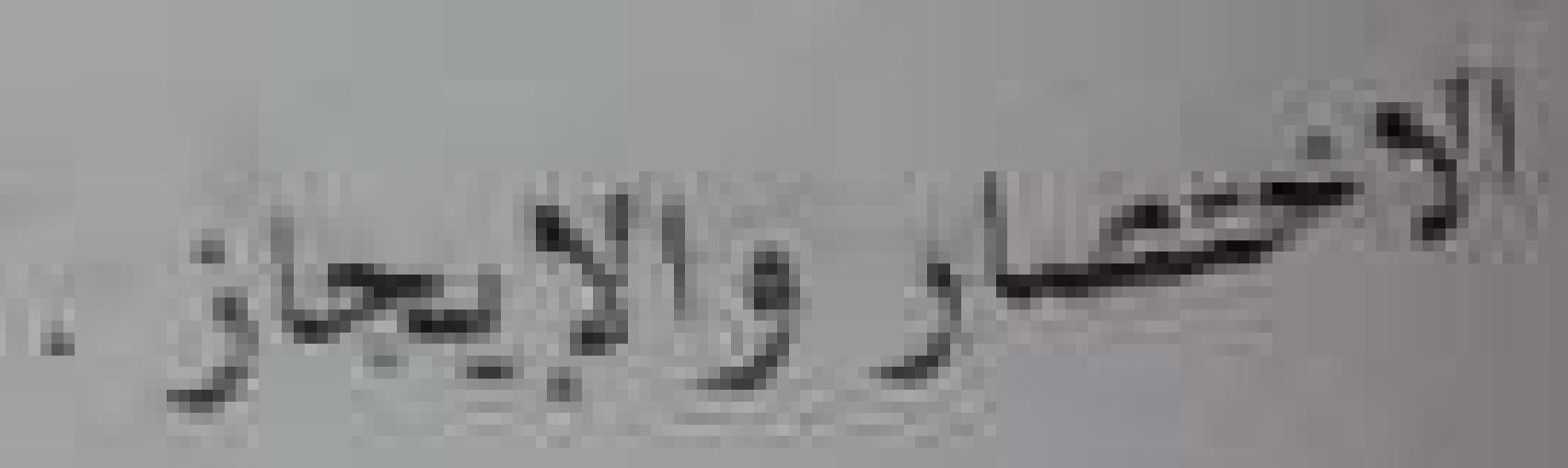

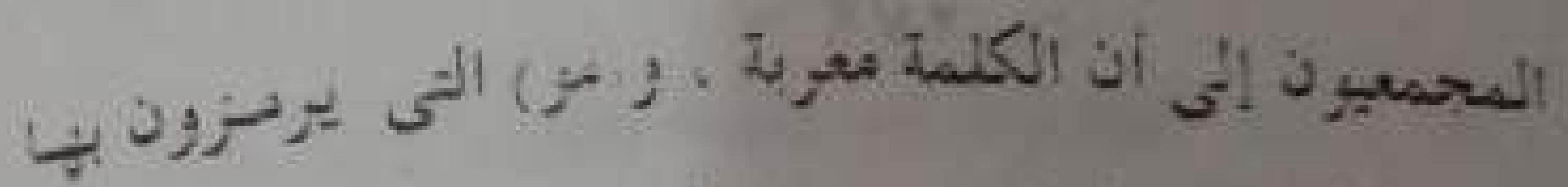

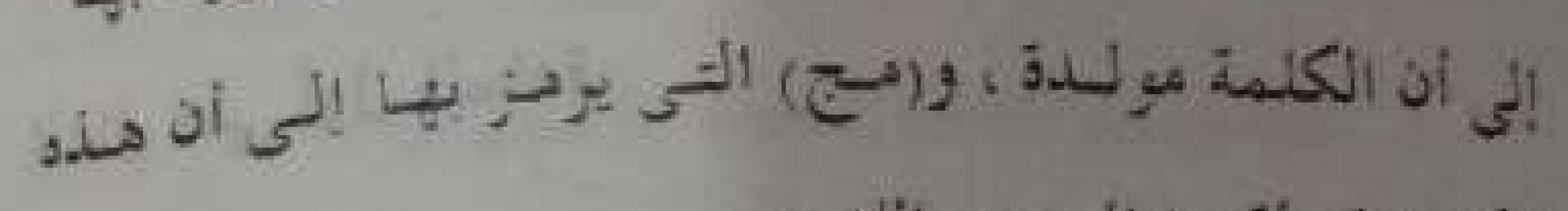

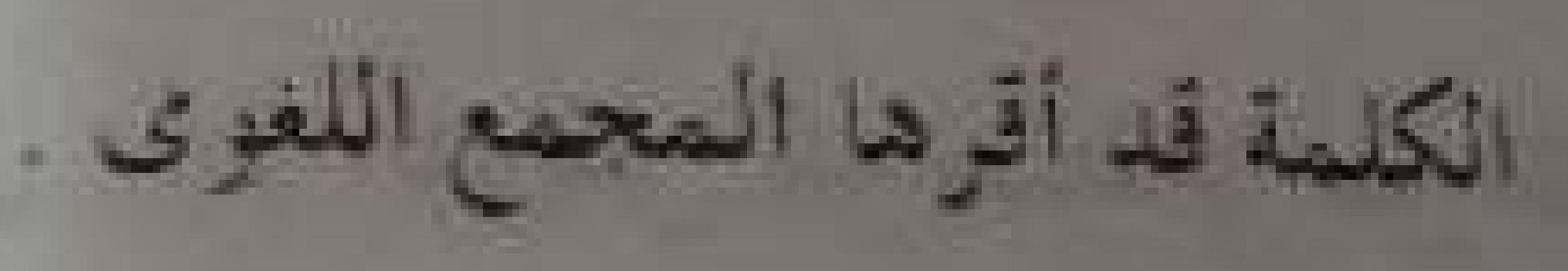

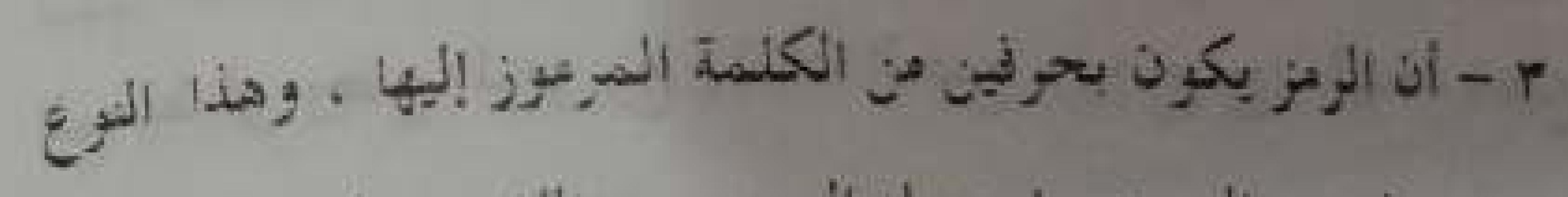

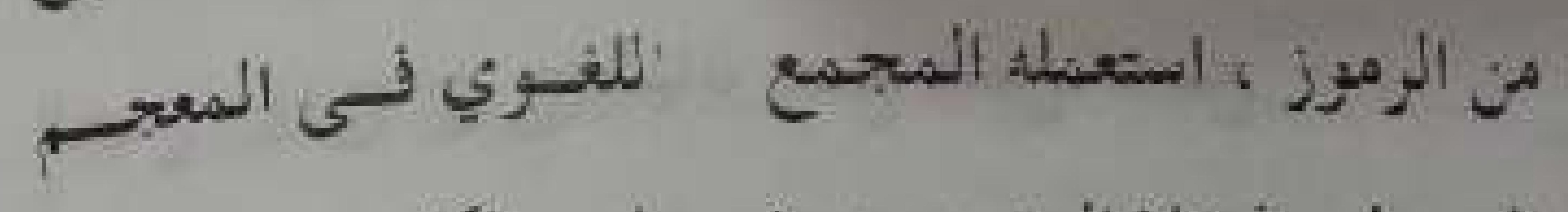

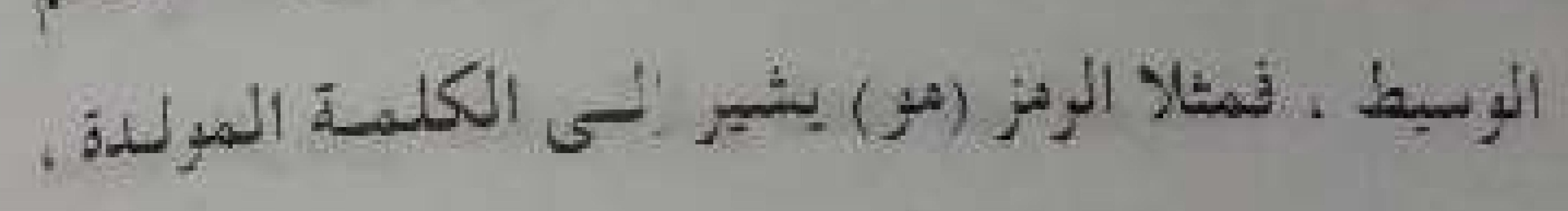

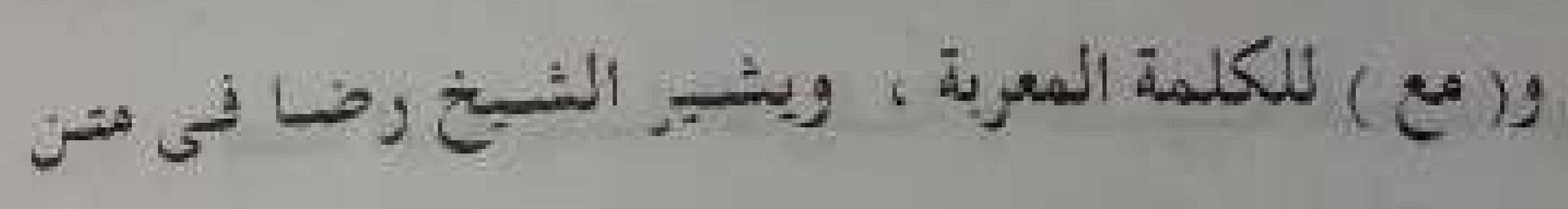

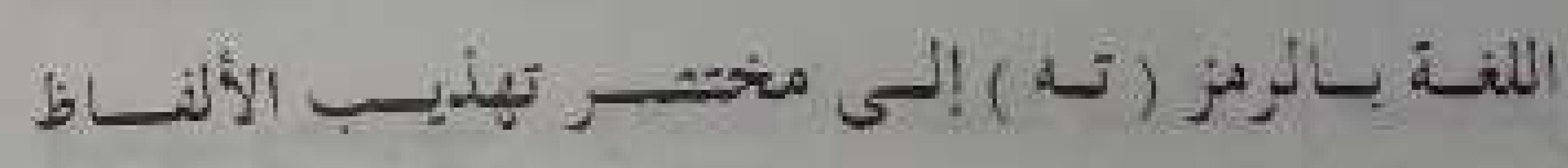

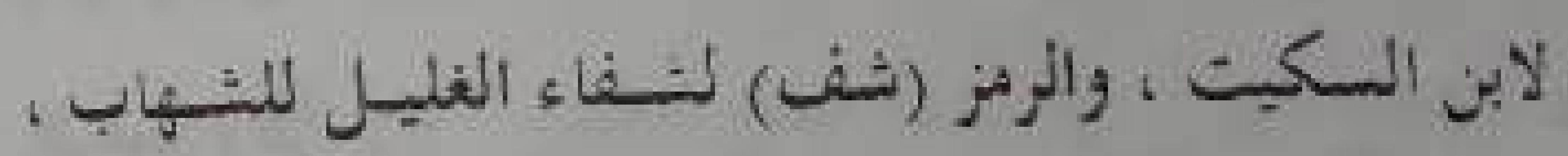

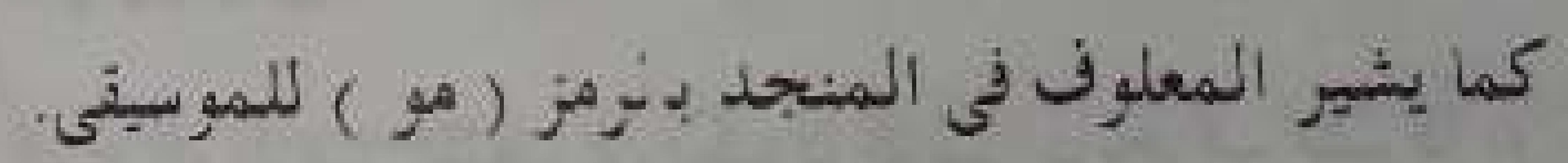

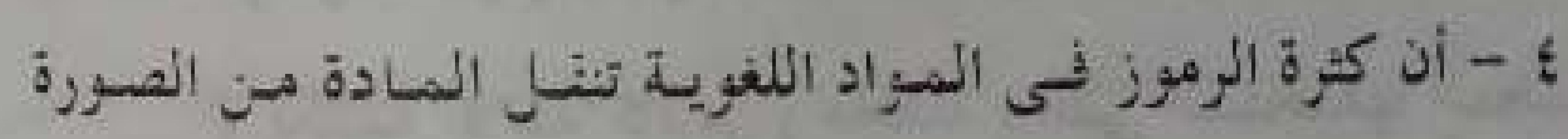

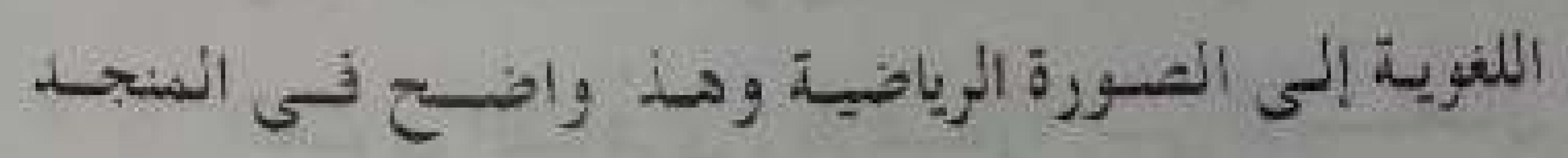
وبت اللفة

\section{لمائدة المرهميز اللـفتية}

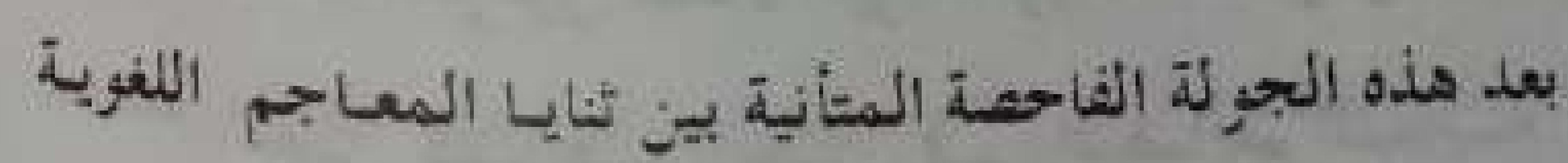

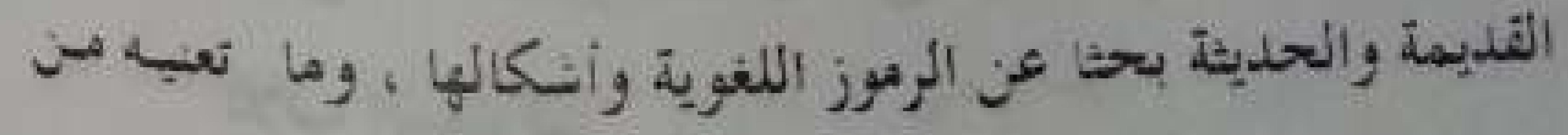

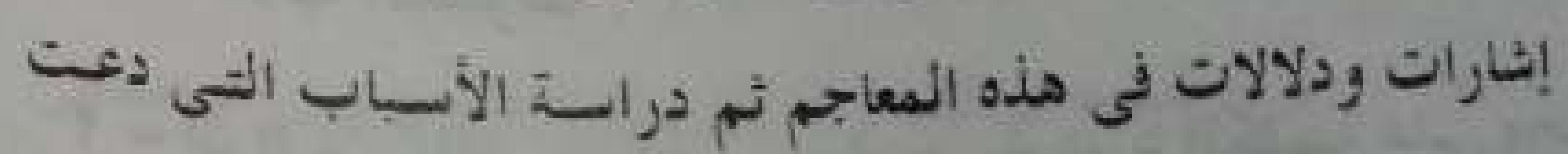




\section{- TAR -}

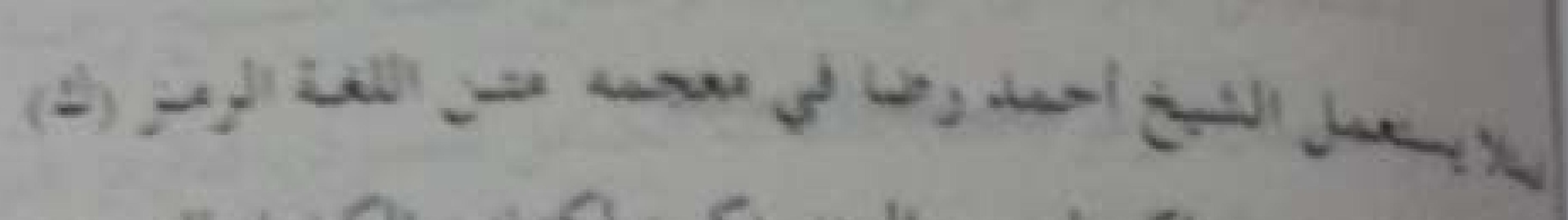
: ن

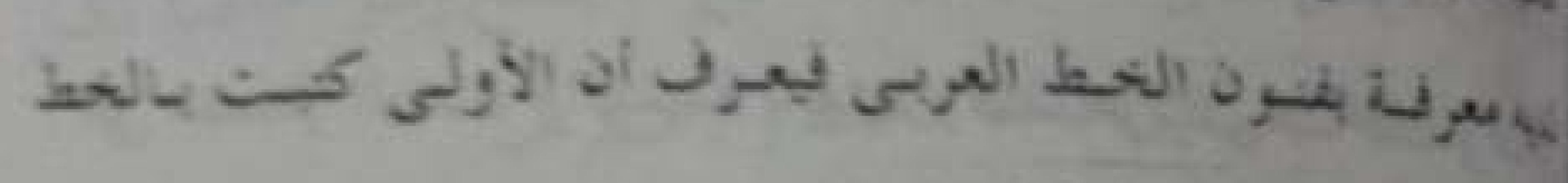

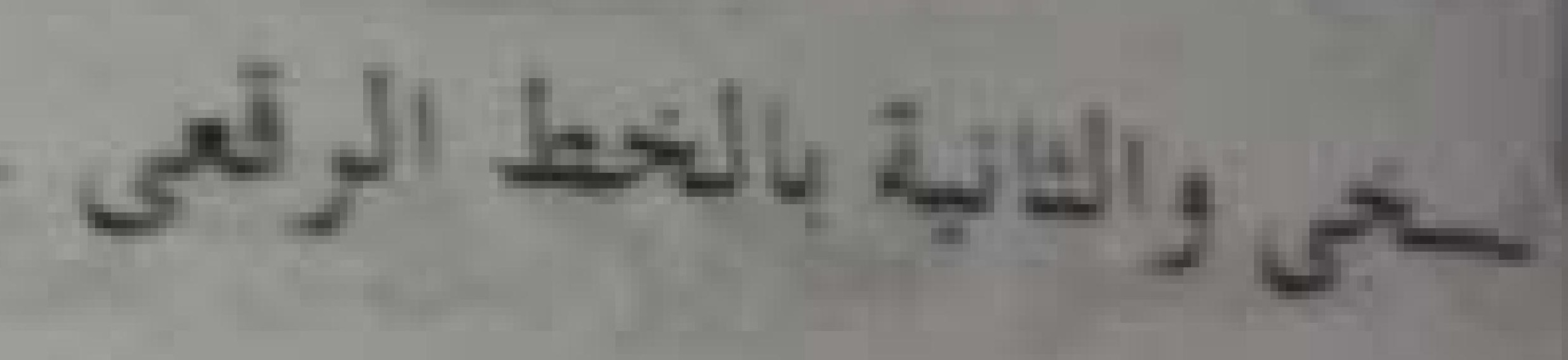

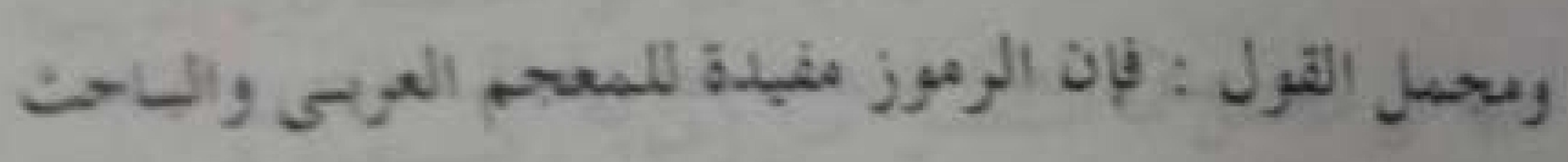

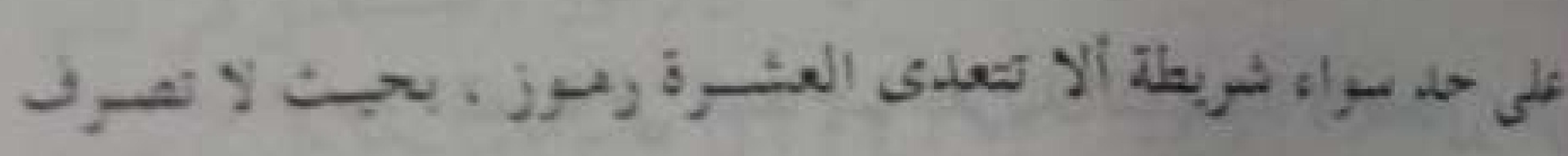

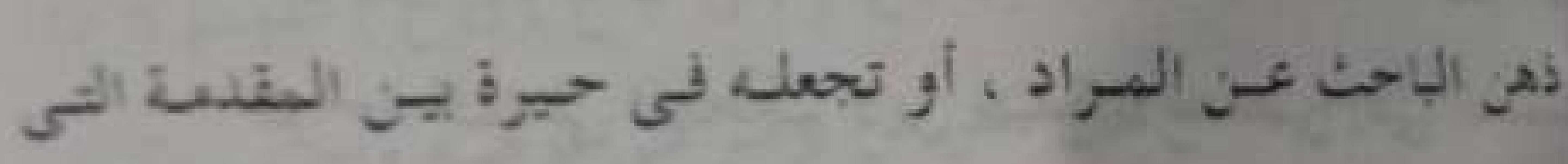

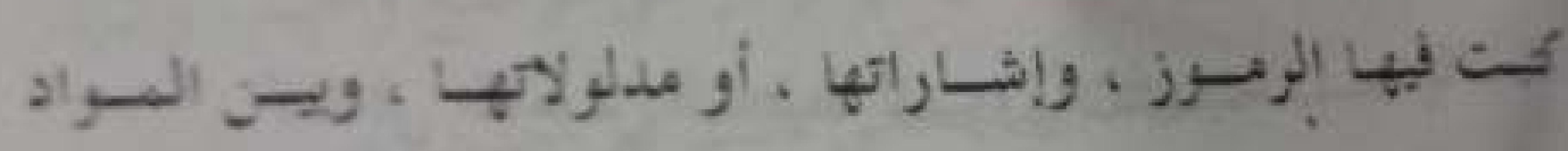

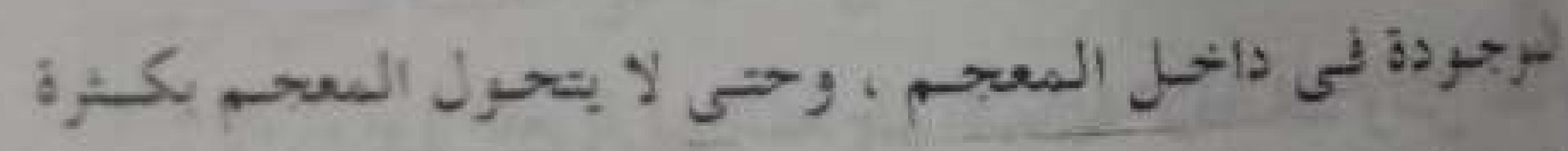

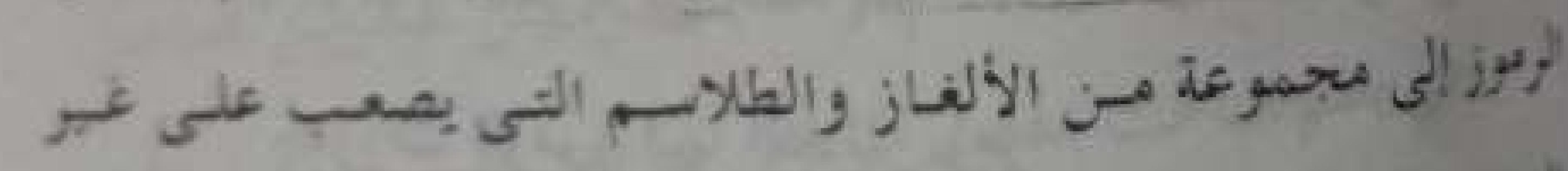

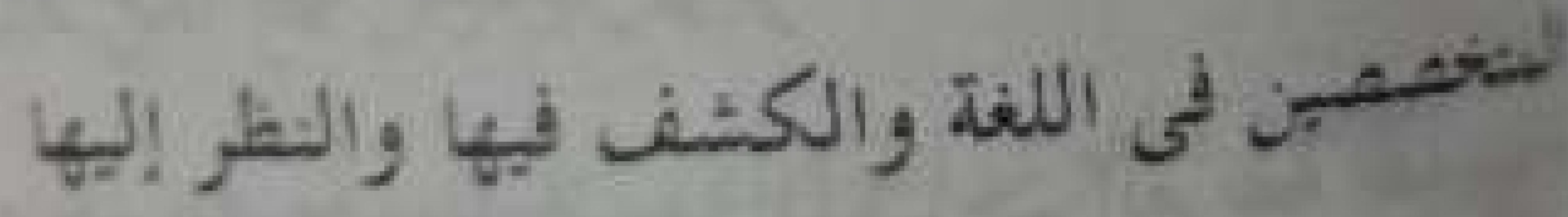

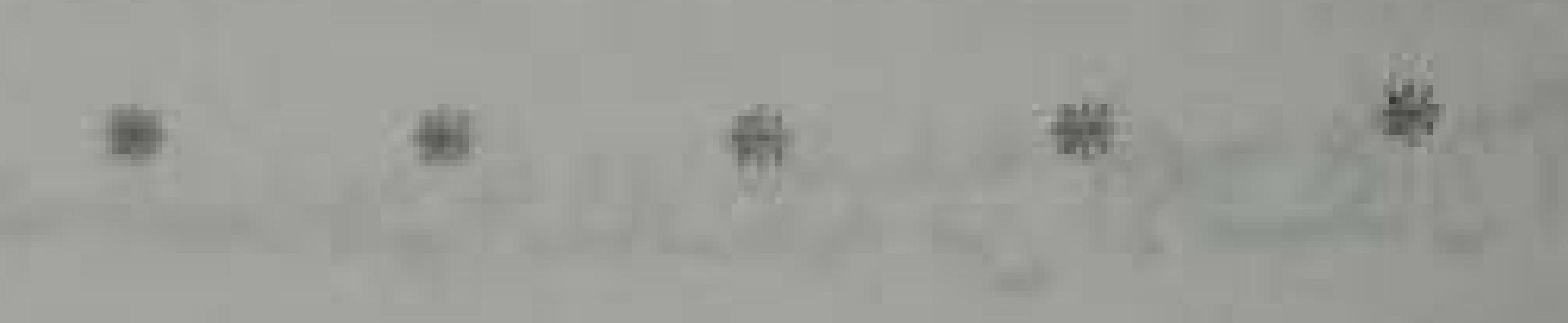

\section{- TAT}

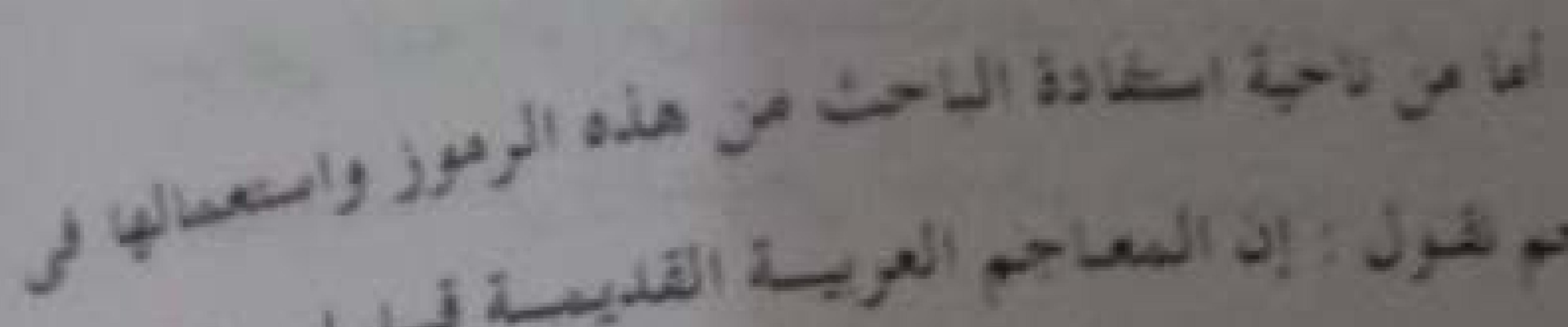

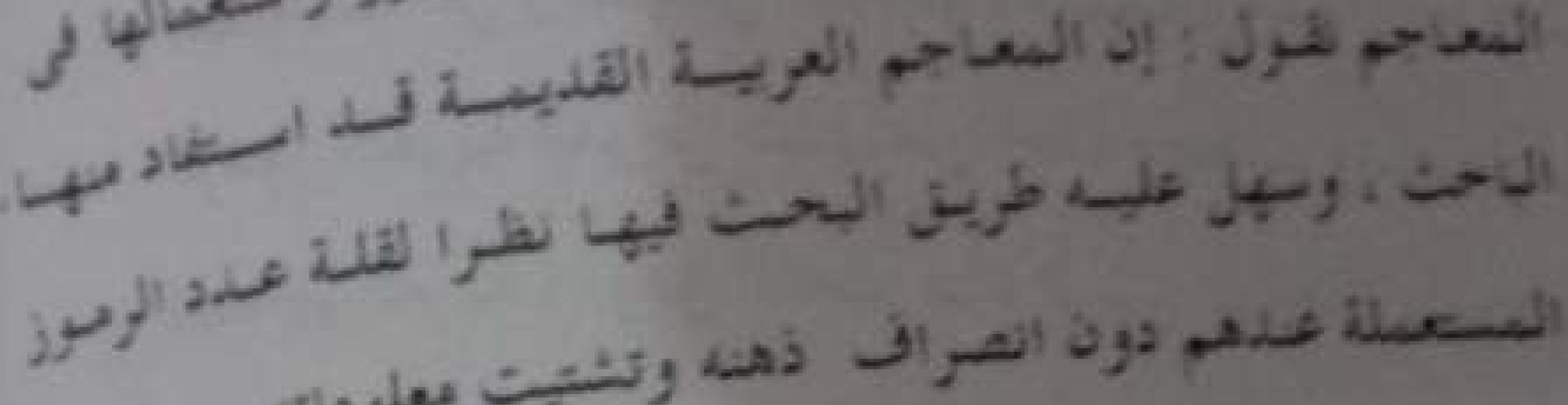

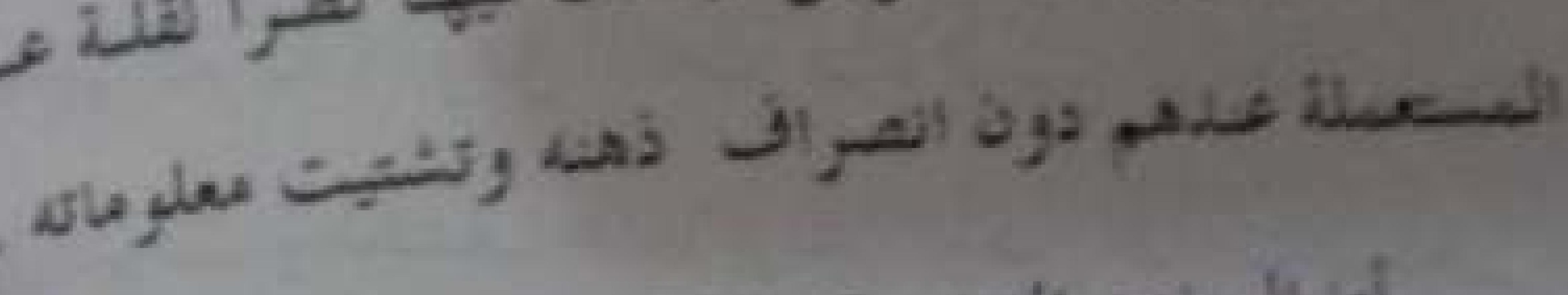
أنسا

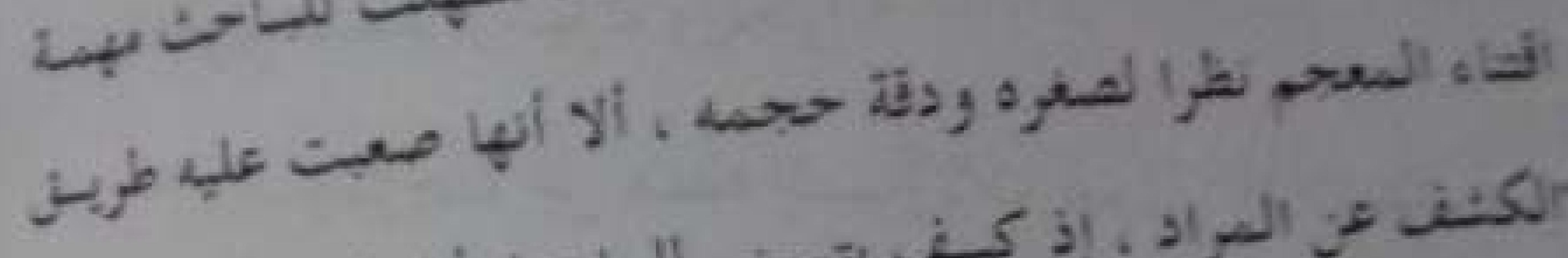

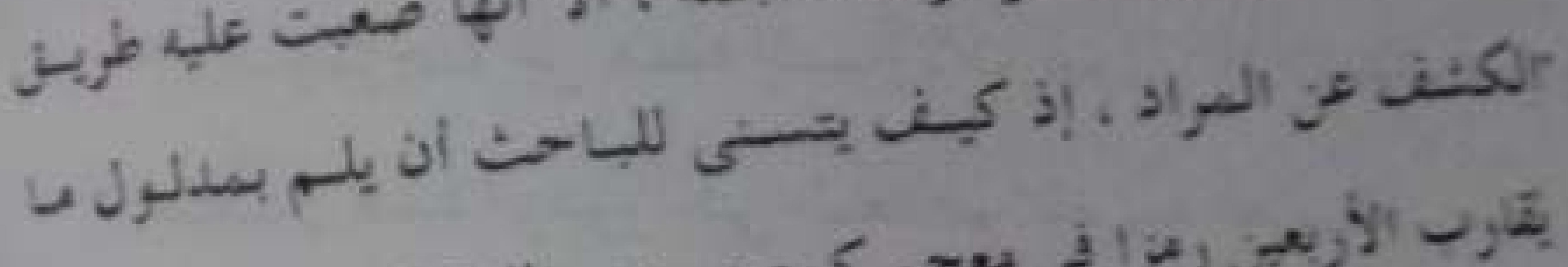

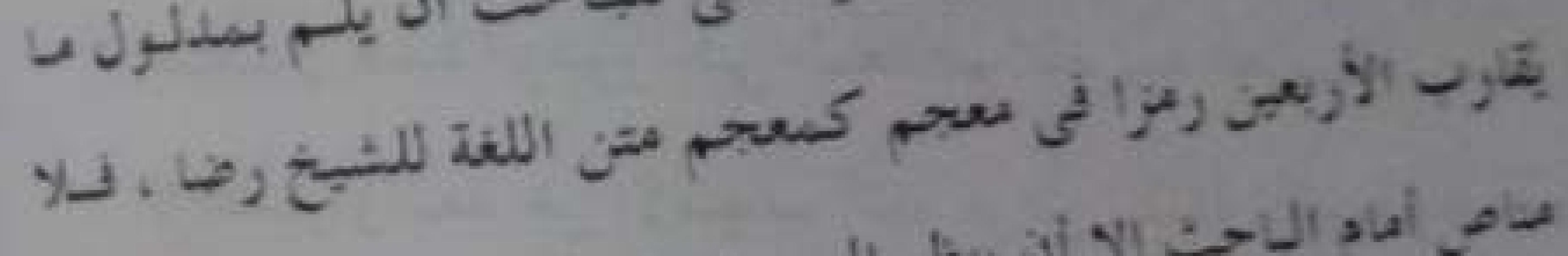

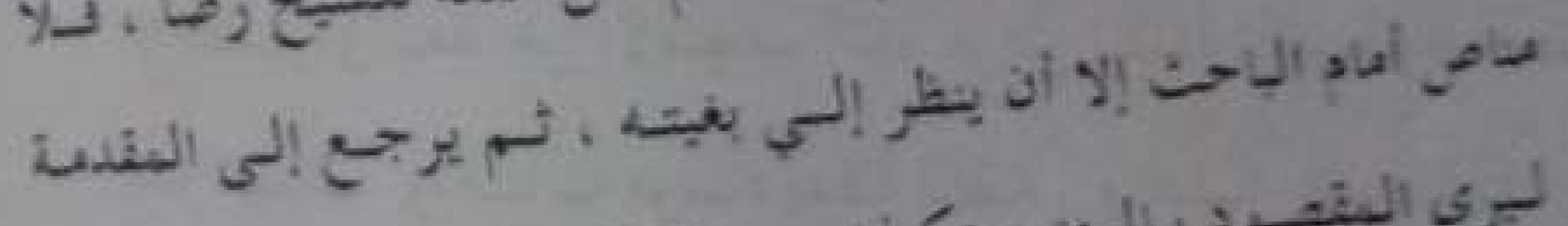

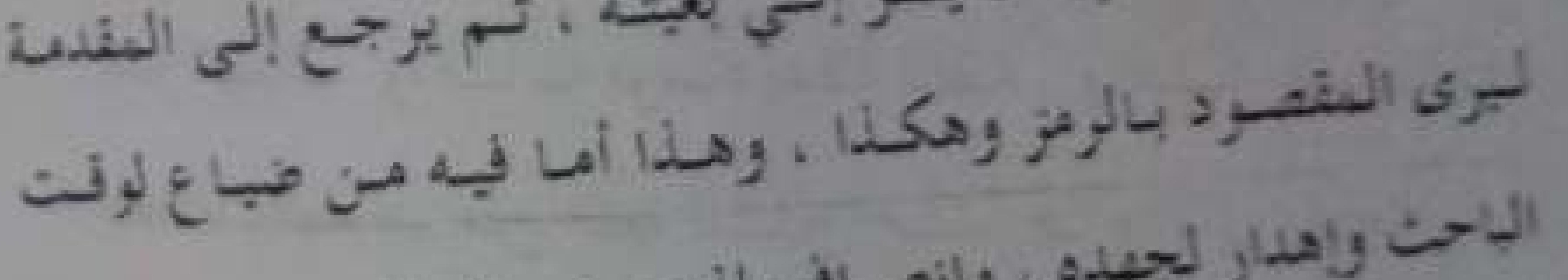

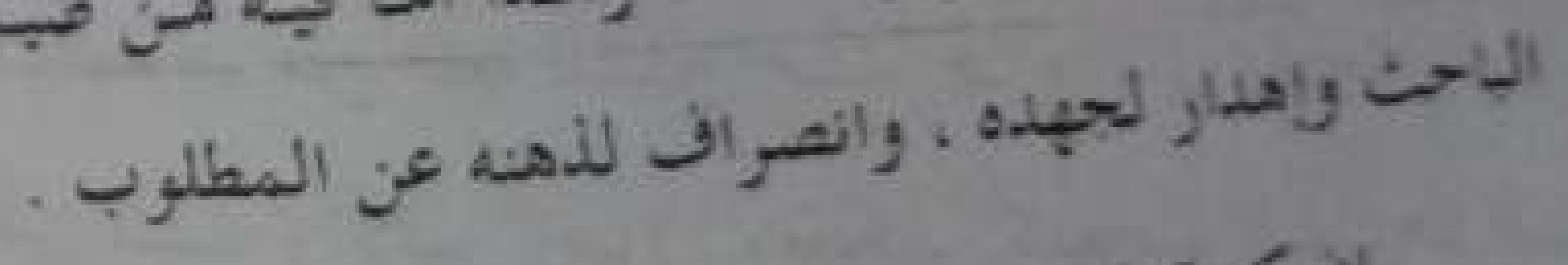

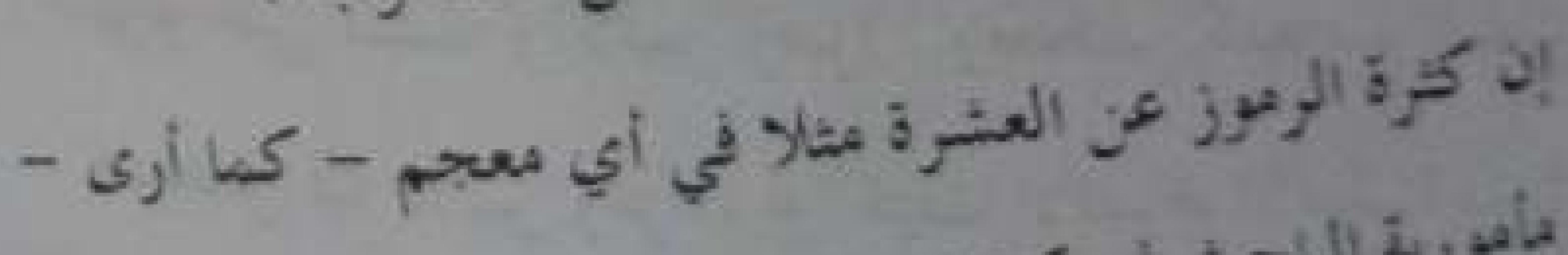

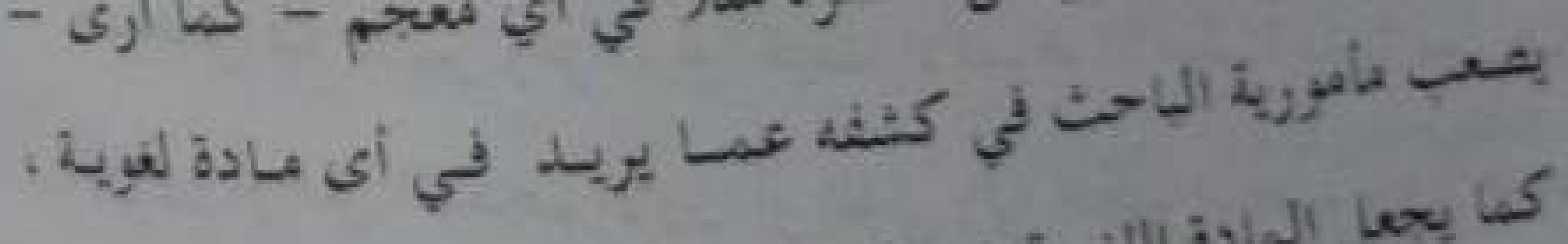

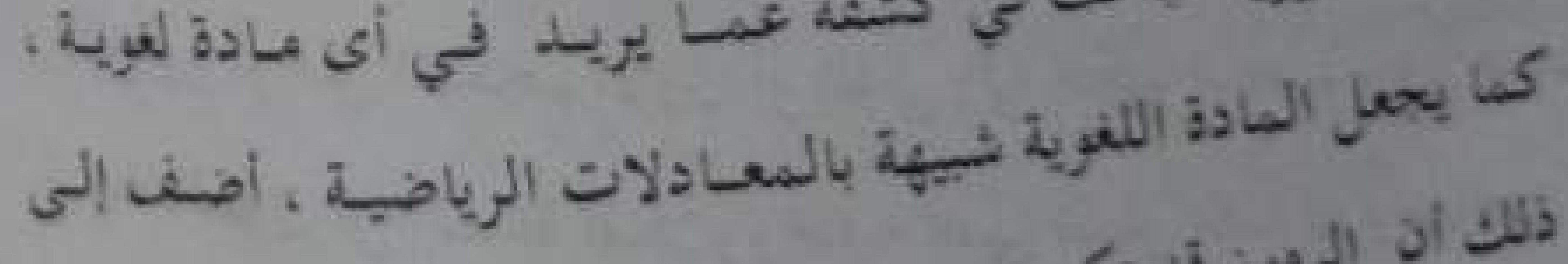

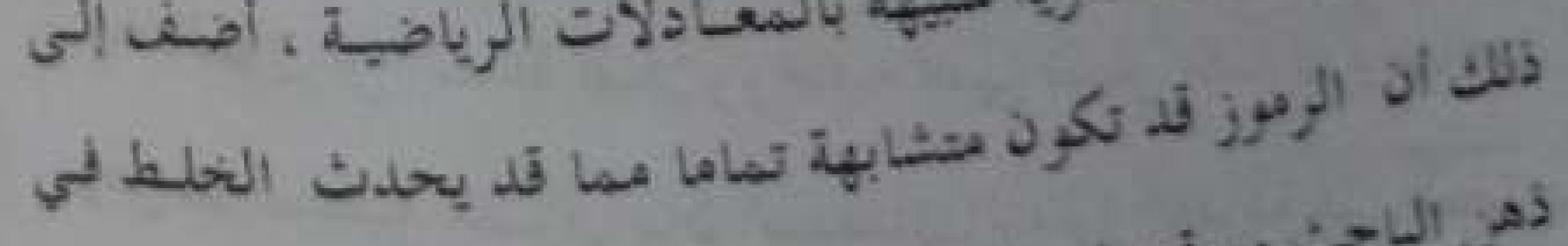

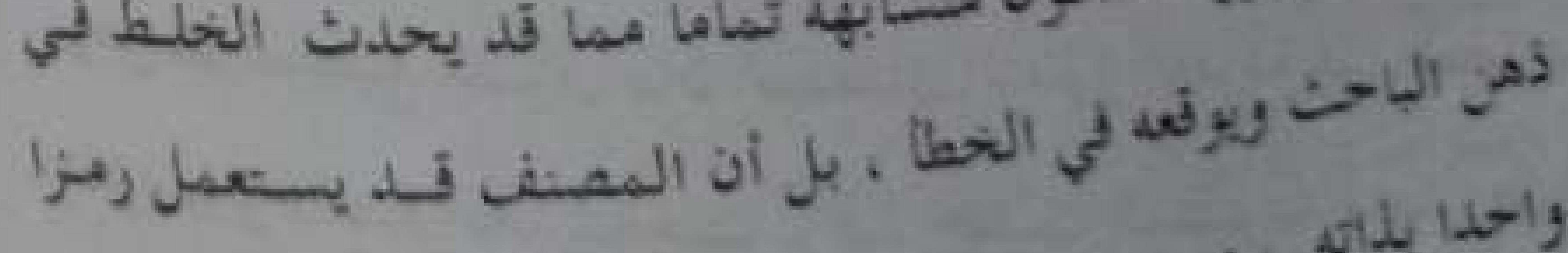

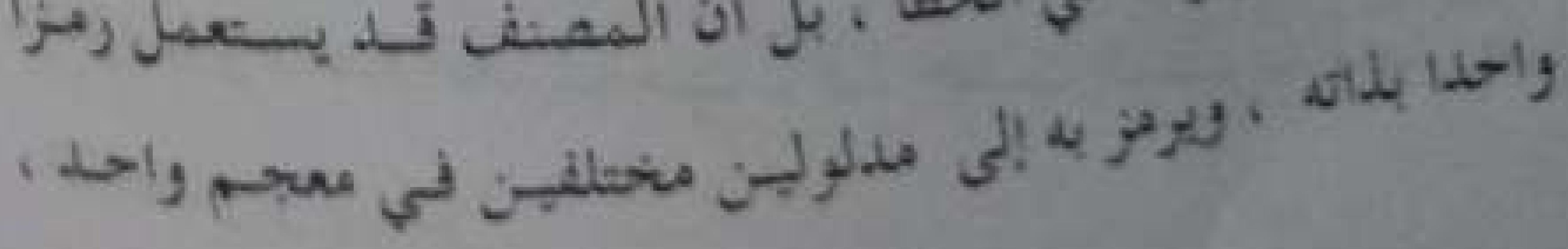




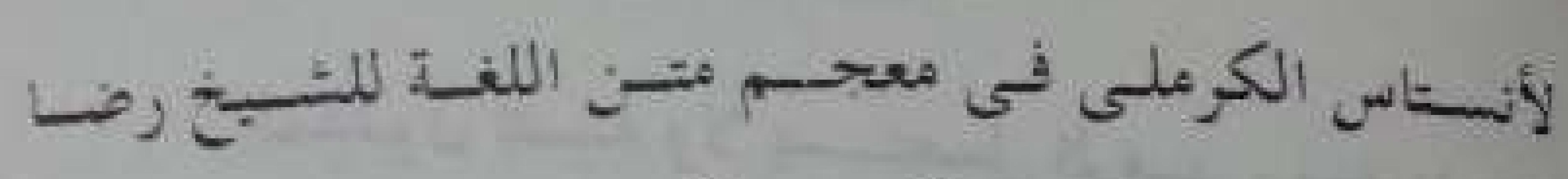

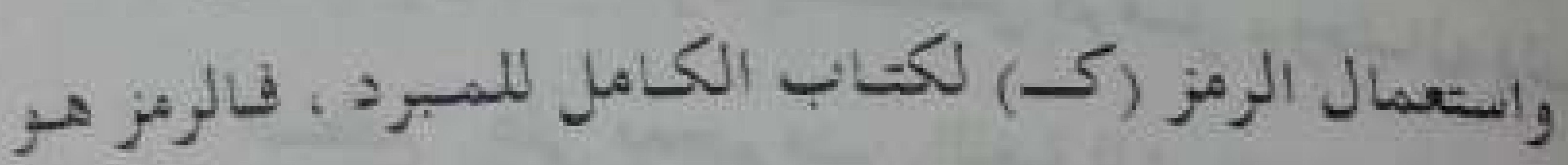

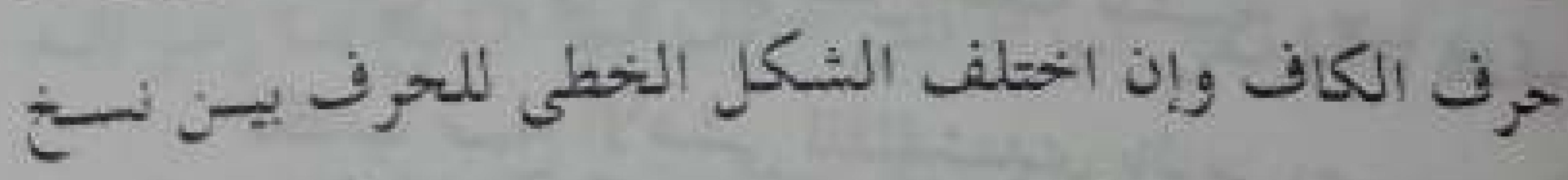

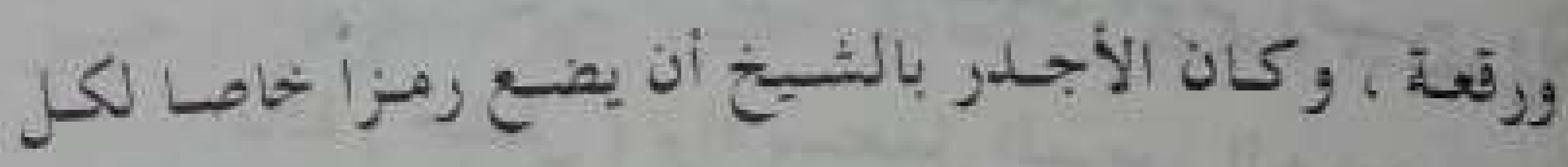
إنارة حتى لا يحدث الخلط والاهبر ابب.

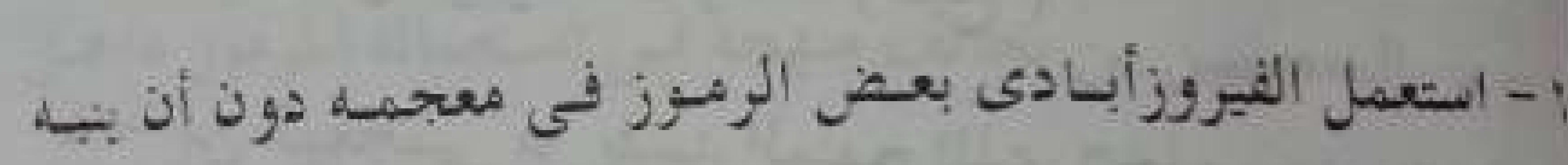

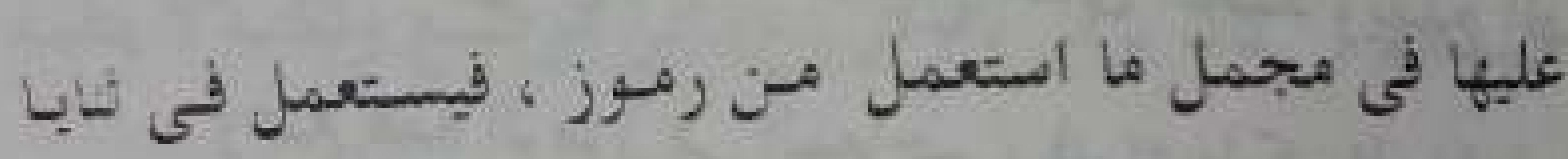

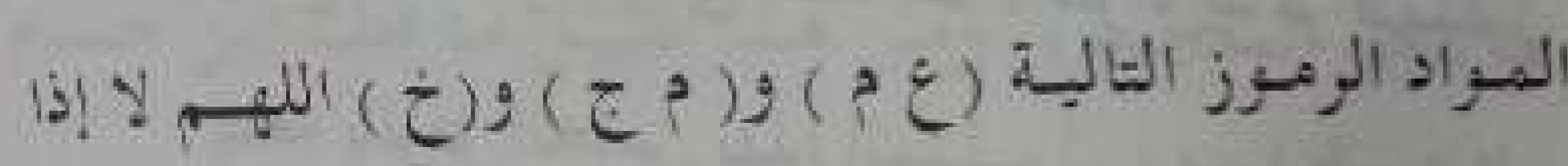

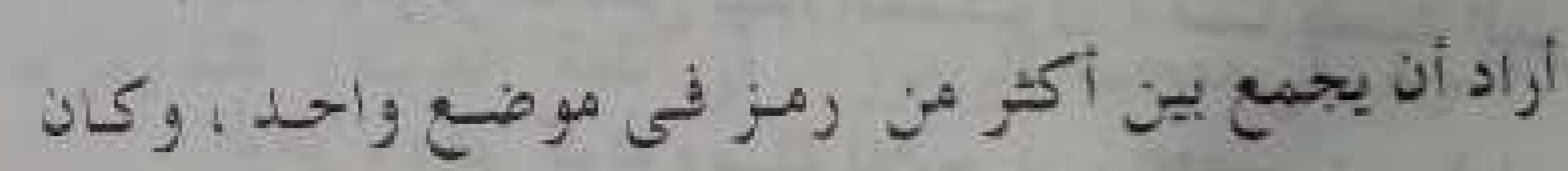

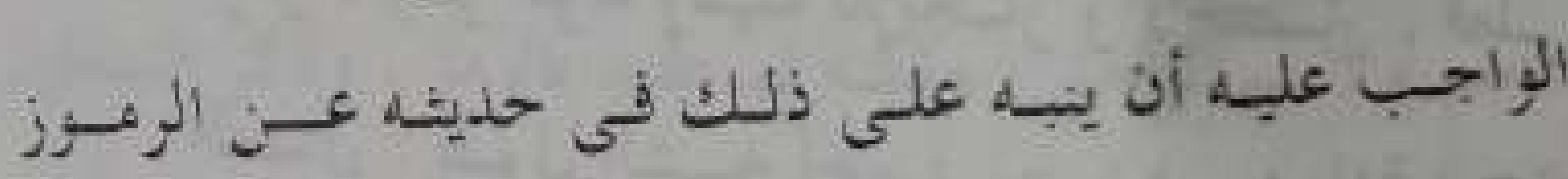

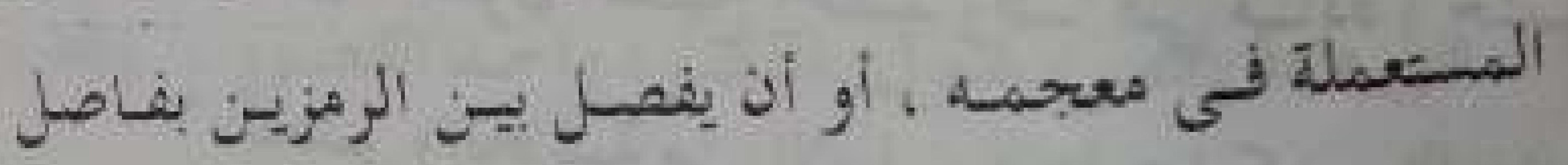

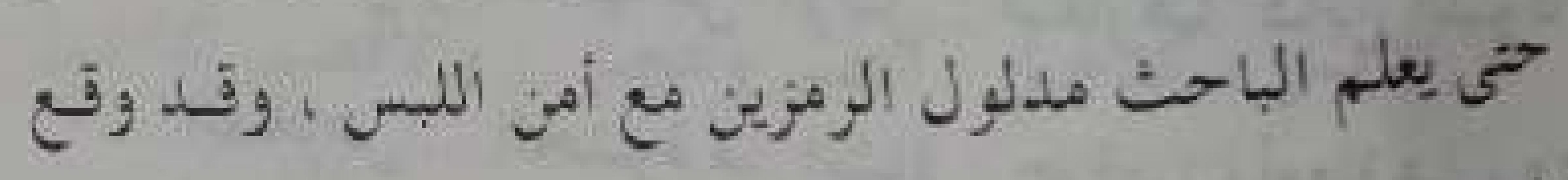

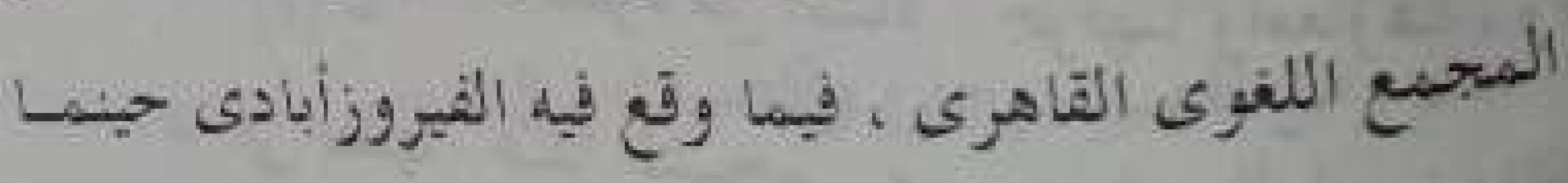

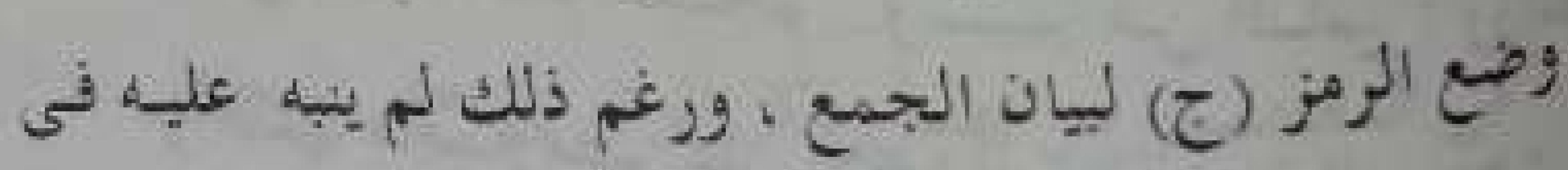

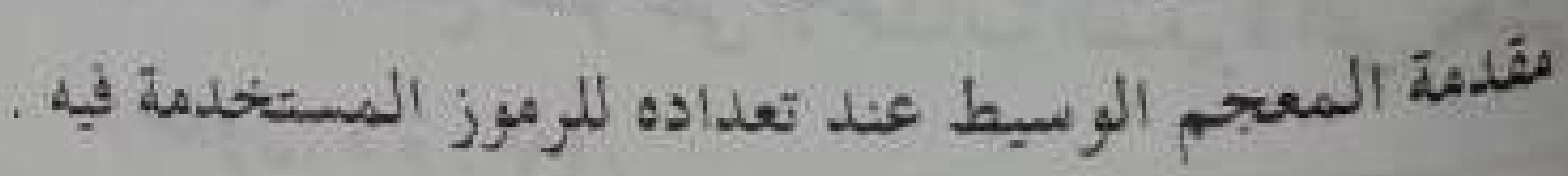

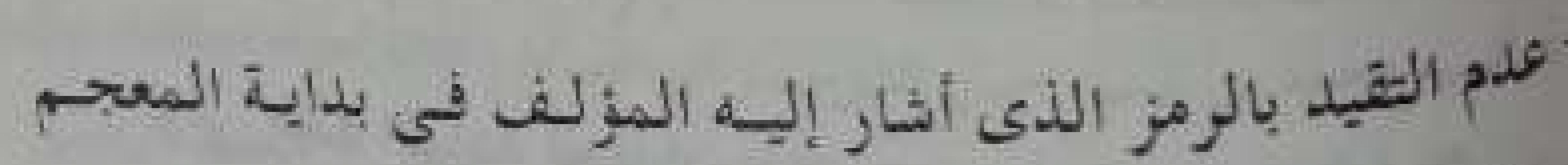

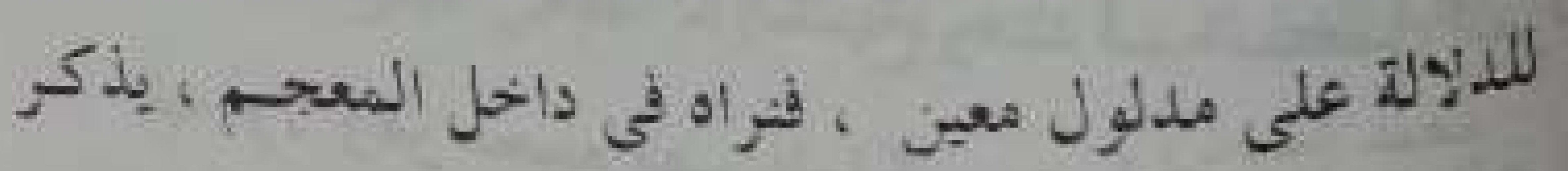

\section{$\longleftrightarrow$ g- g-}

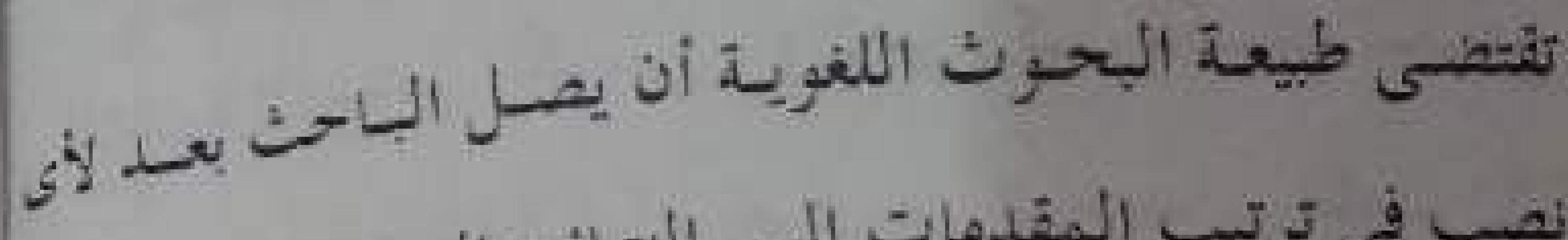

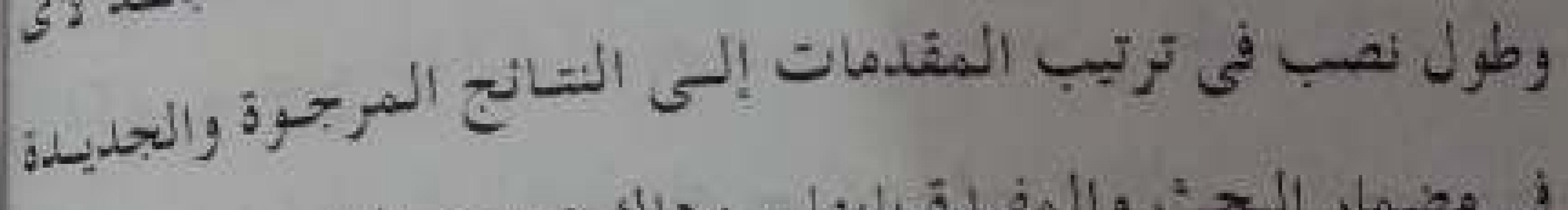

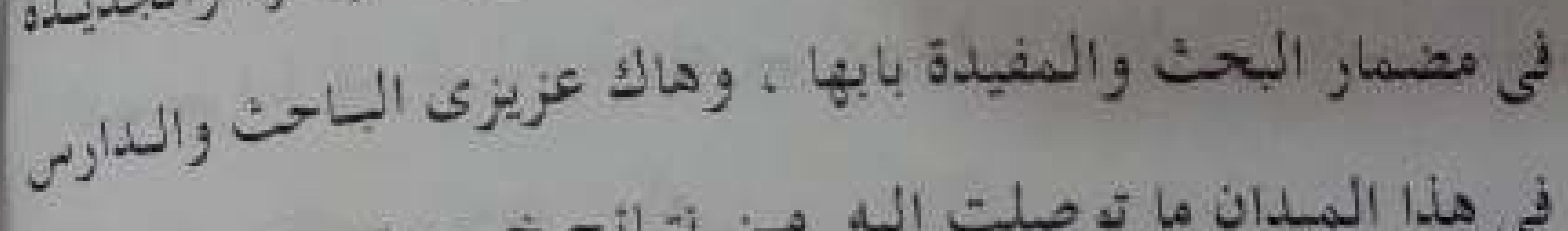

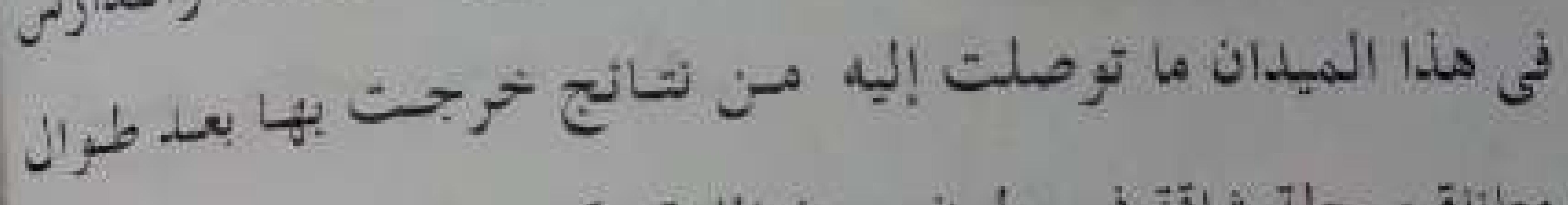

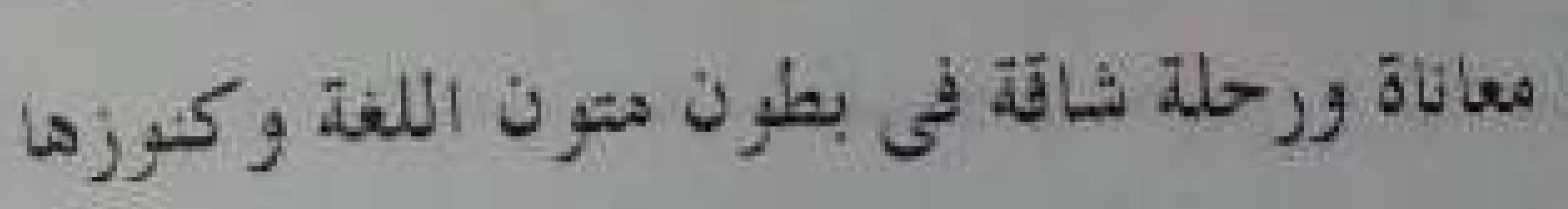

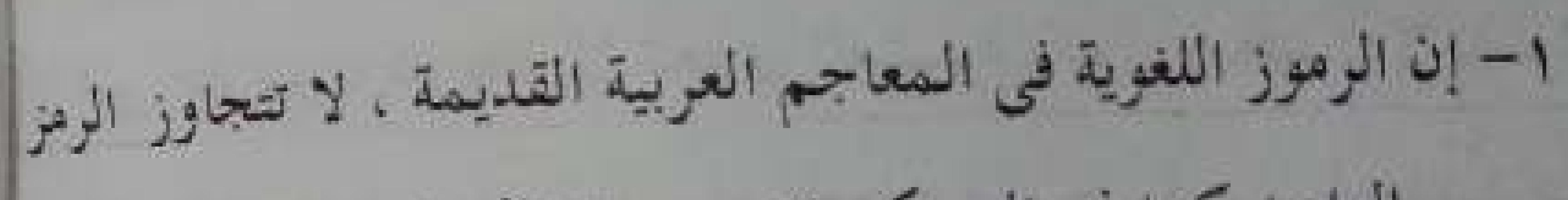

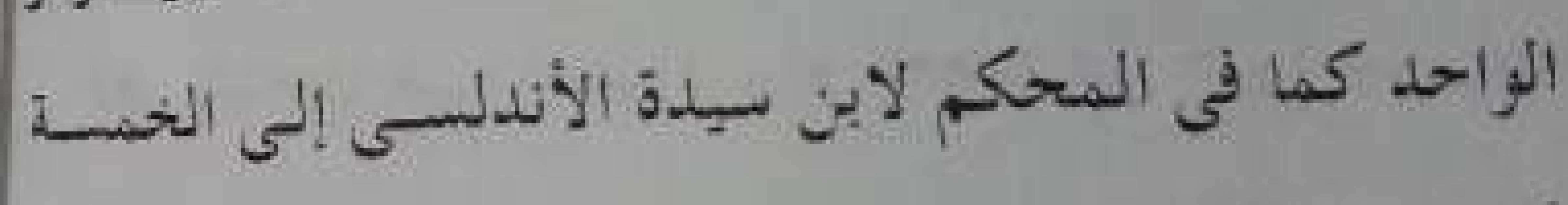
كما في القاموس المتحيط للفيروزأبادى .

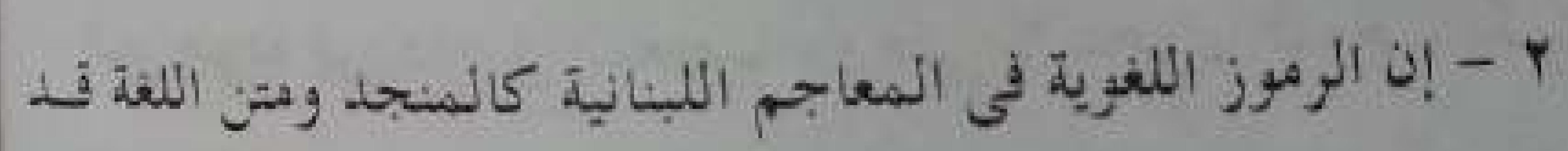

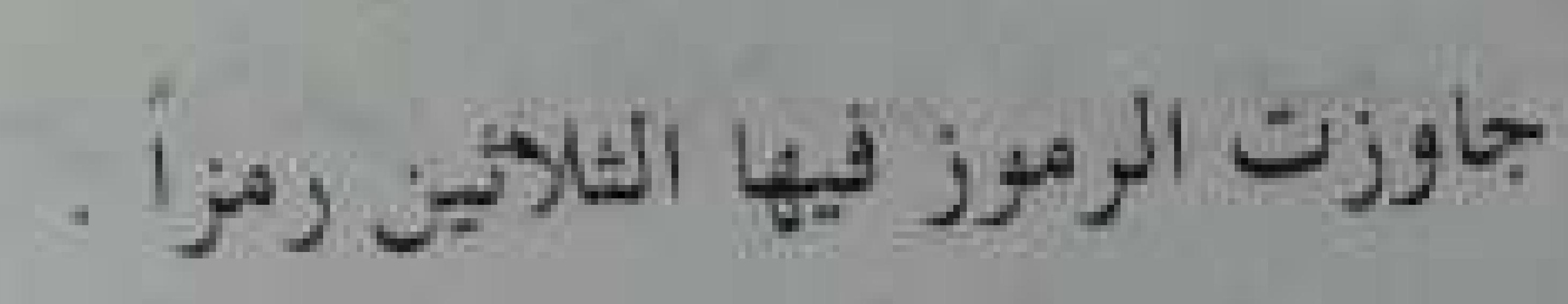

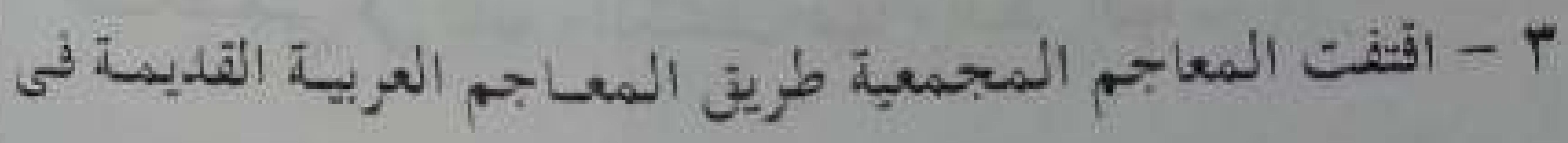

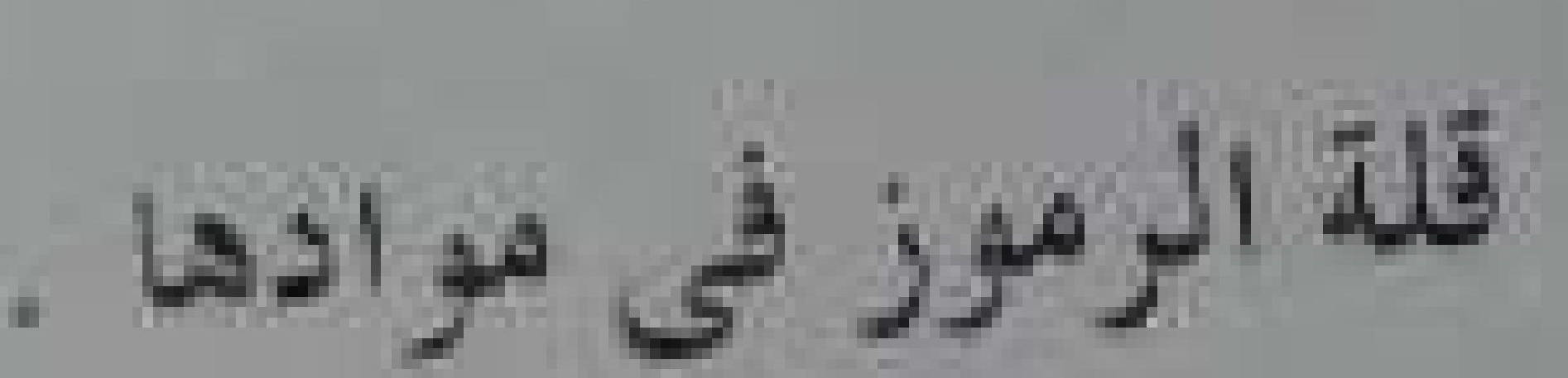

\& - استفادت المعاجم المجمعية من الأثكال الرمزية المهنعلة فى المعاحم اللبنانية واستعمال بعضبا فى مواد معاجمبه

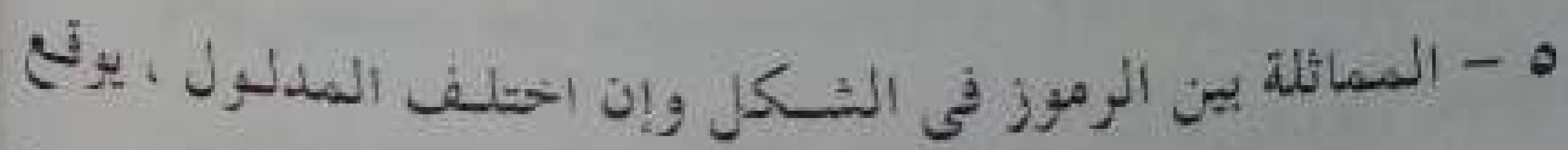

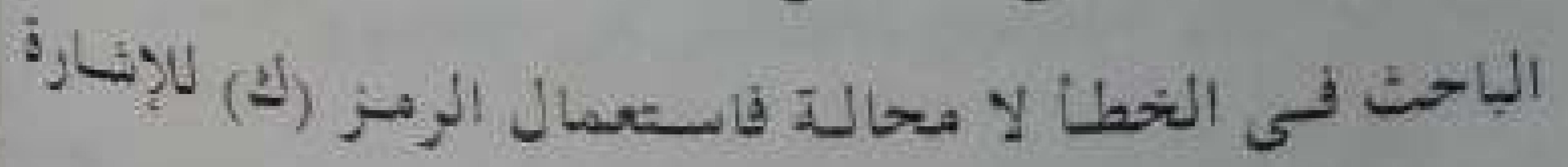


$($ a.p) ong 4

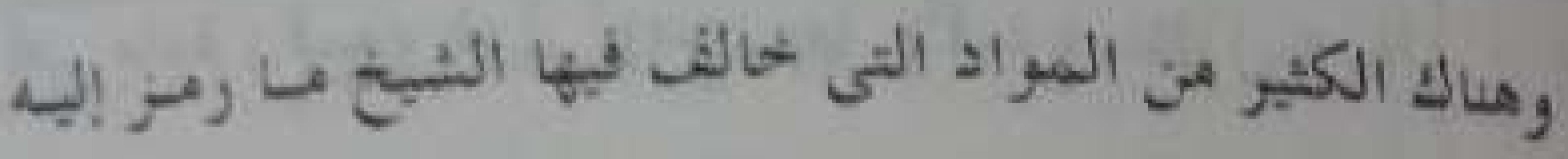

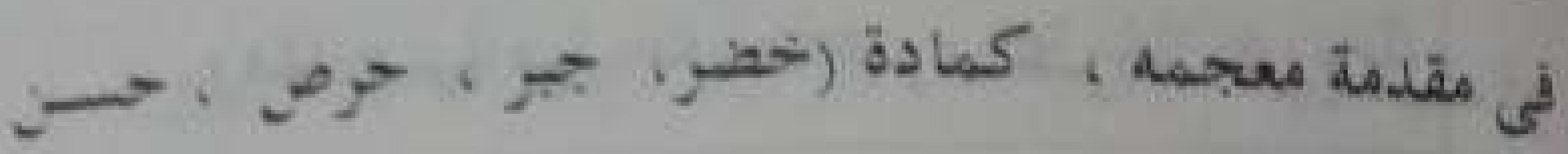
.

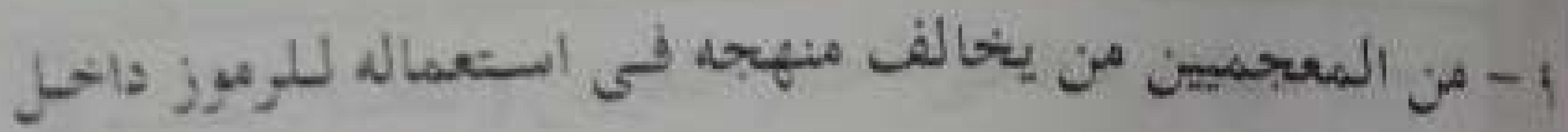

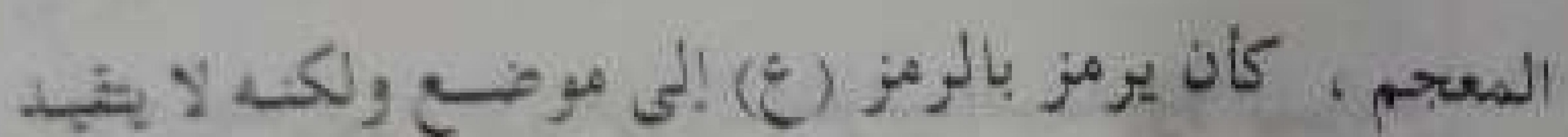

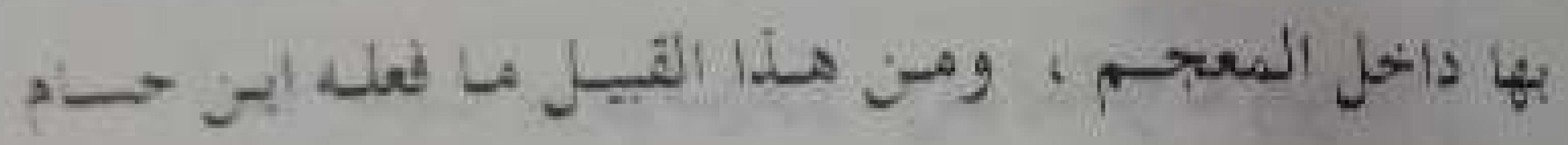

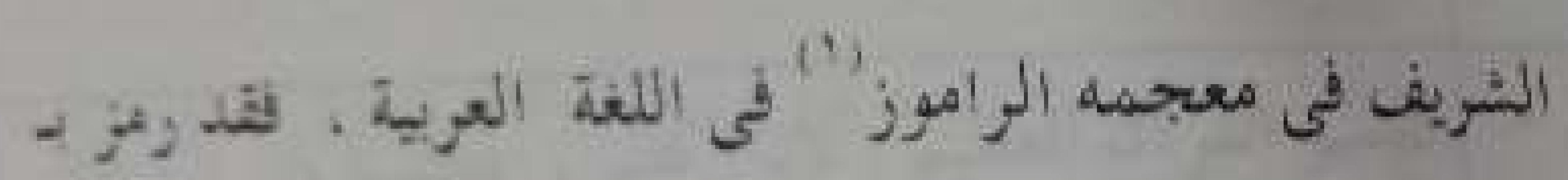

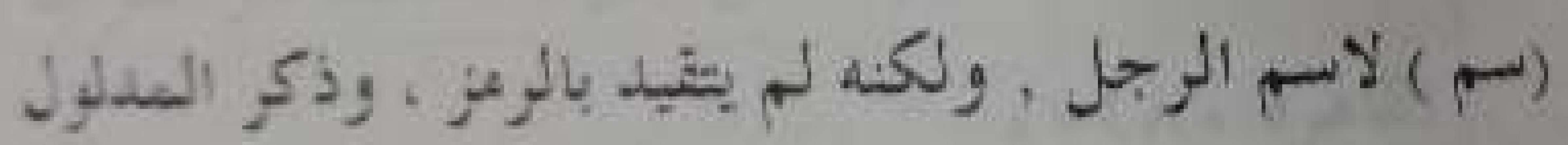

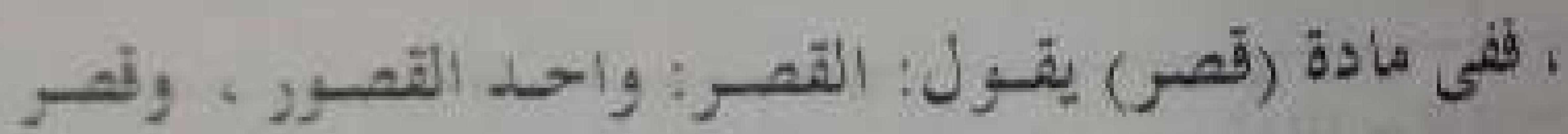

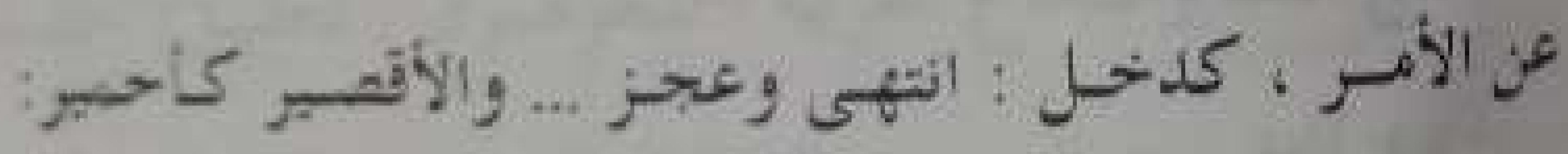

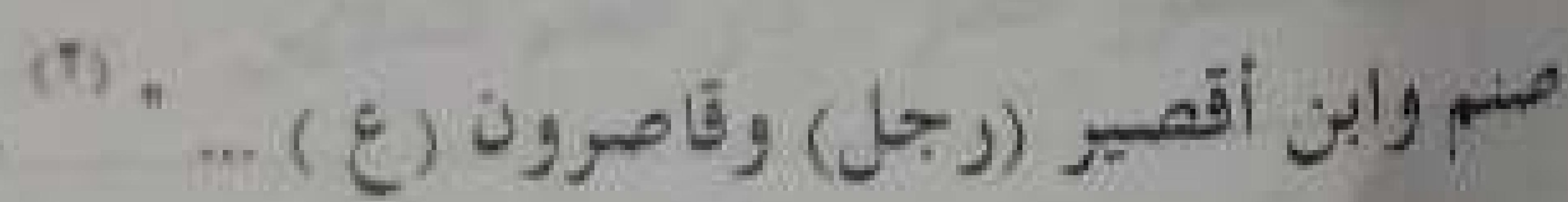

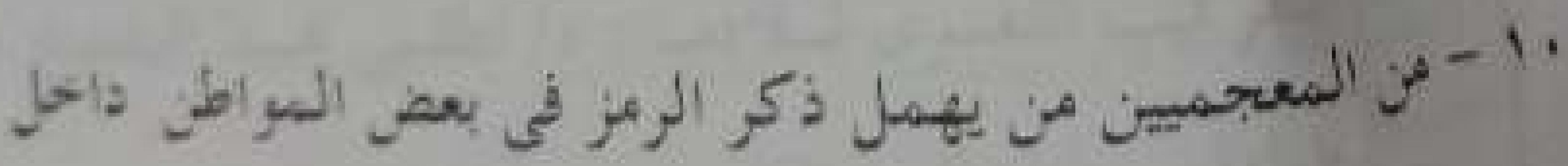

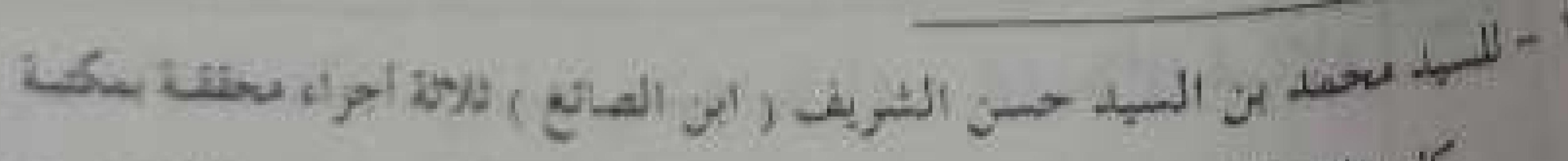

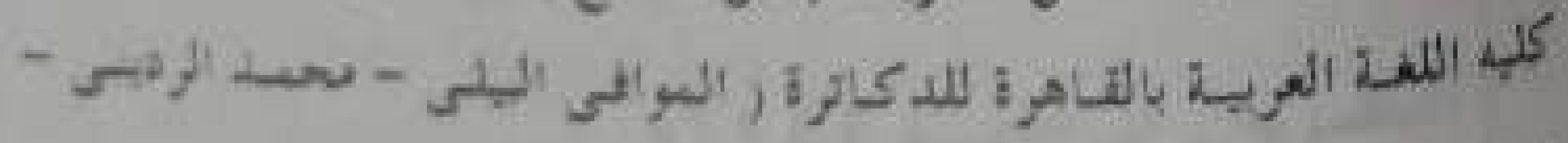

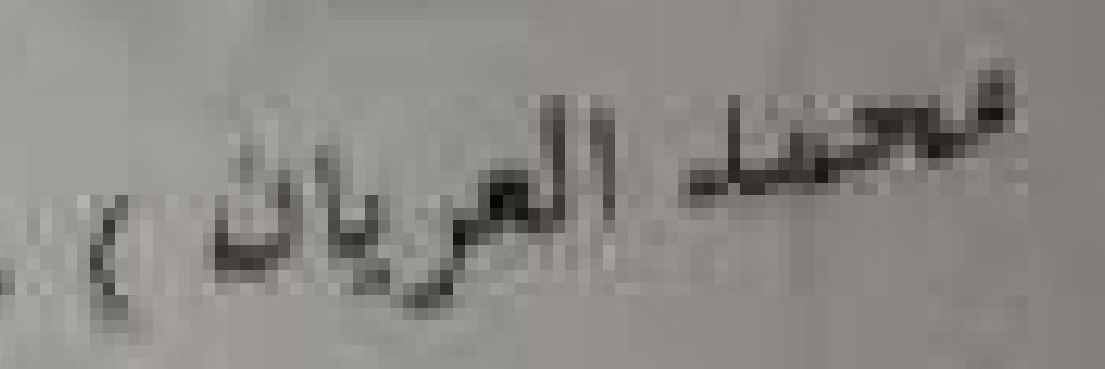

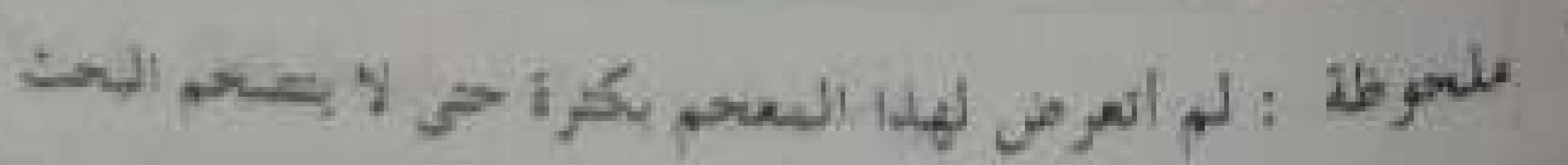

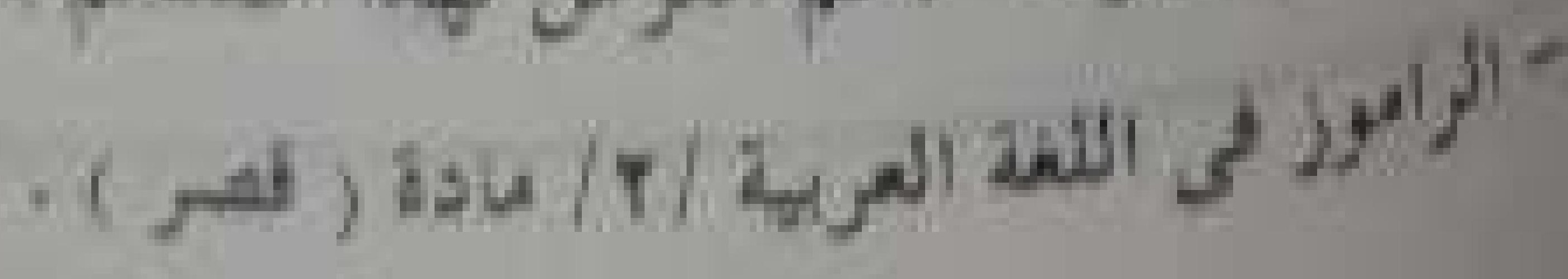

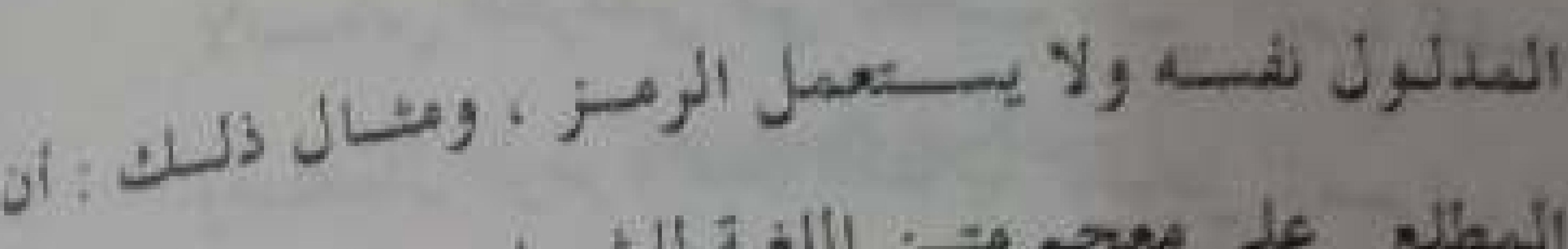

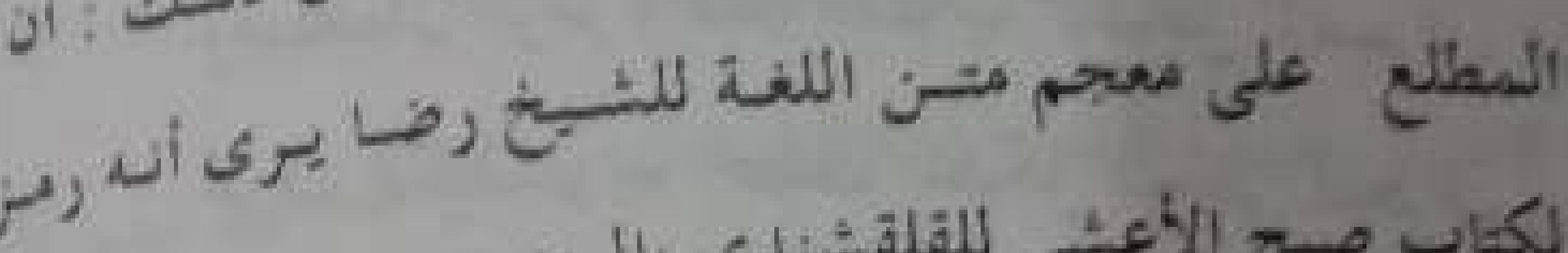

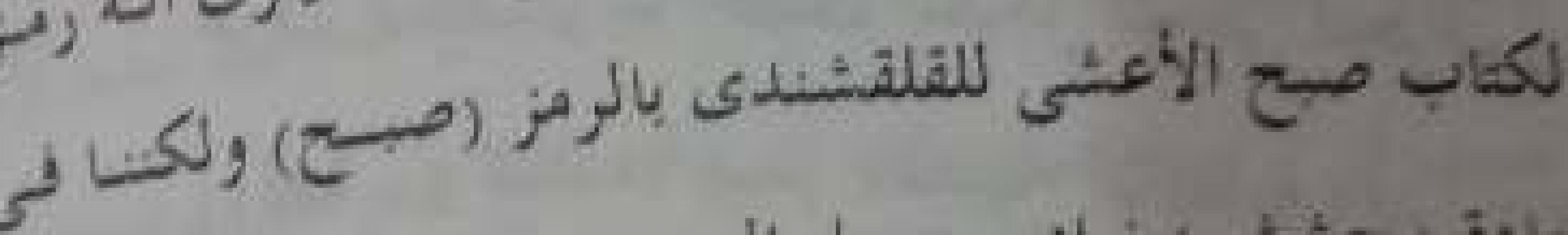

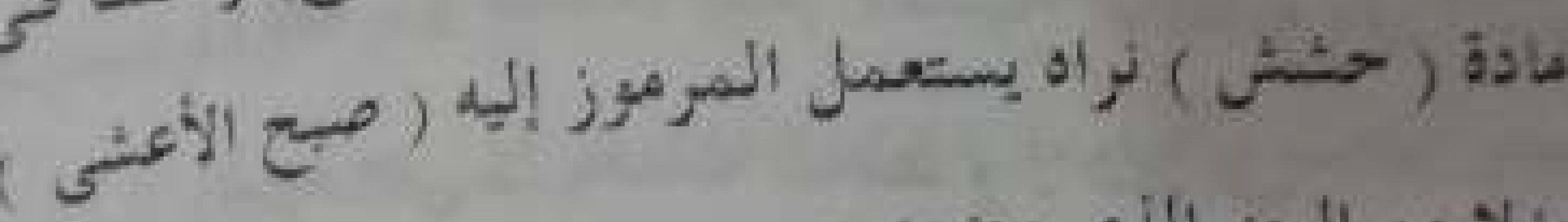
بدلا مز الرمز اللذى وضعة (صبح )

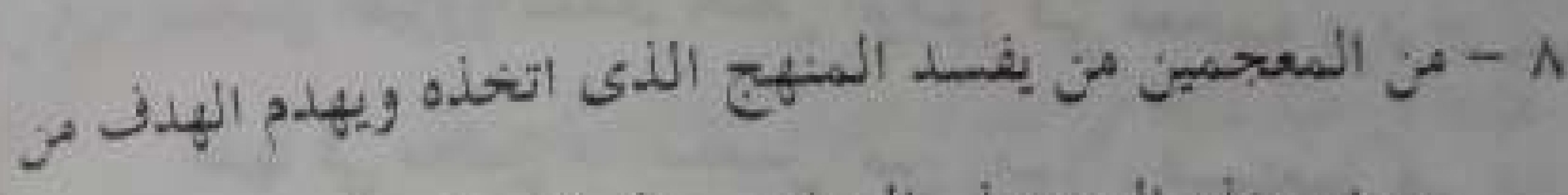

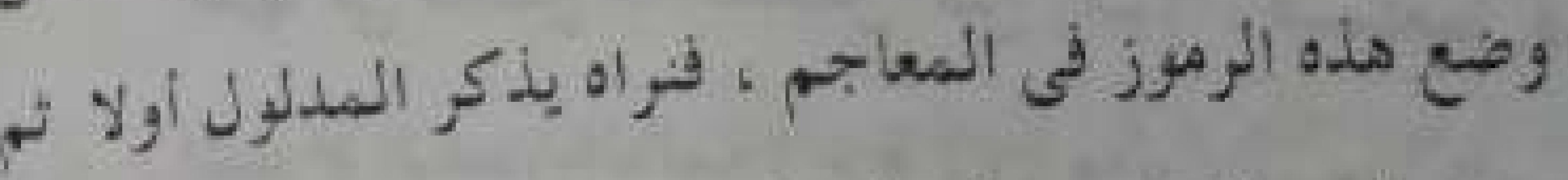

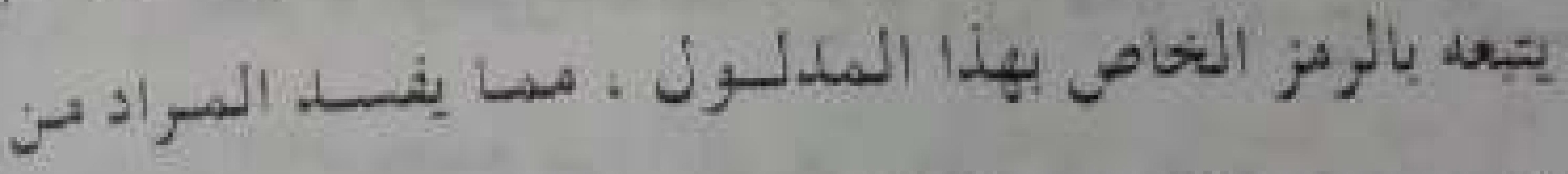

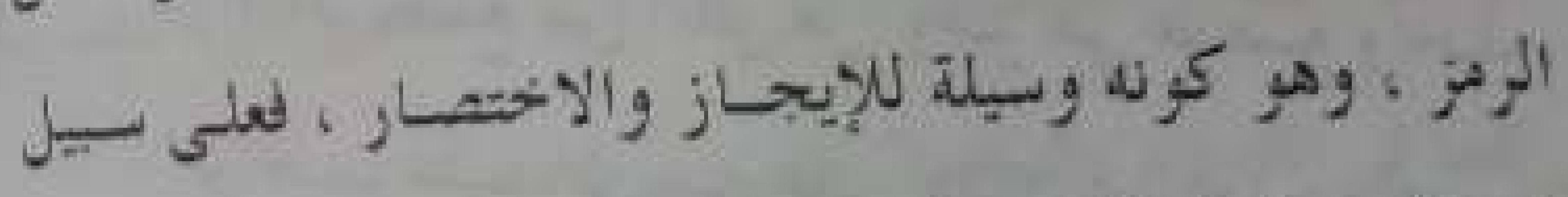

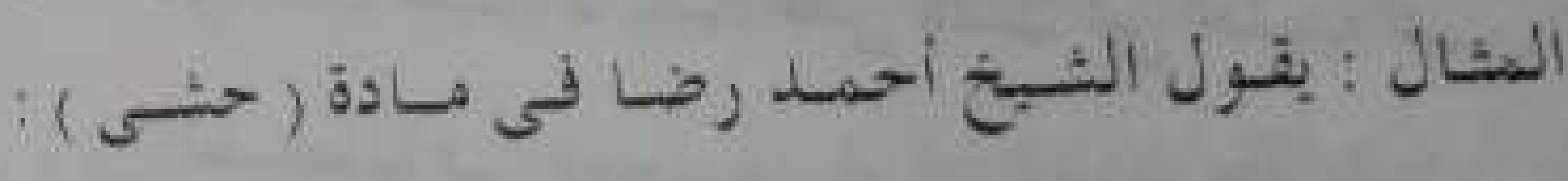

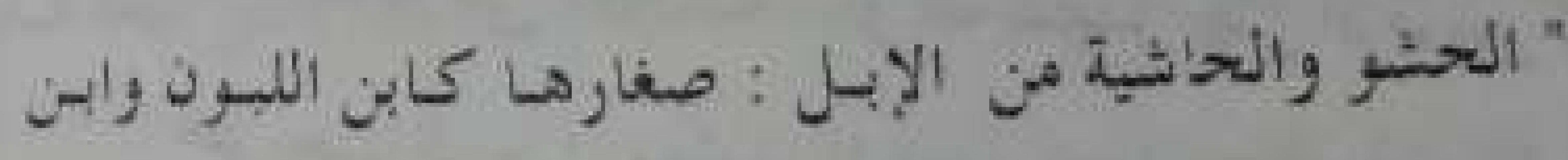

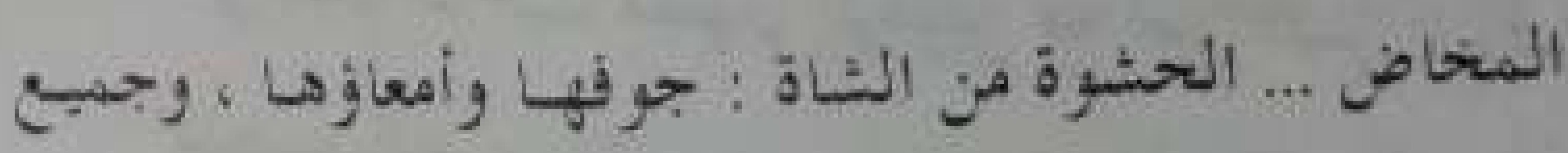

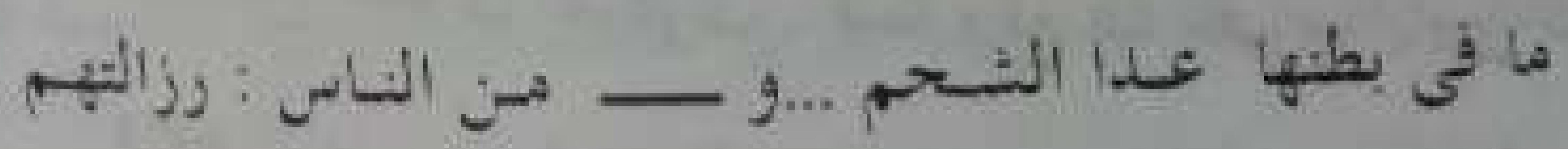
وأطلقها مجسع مصر على الأخشاب الصغيرة ألثى يحثى باب ( جدول: (

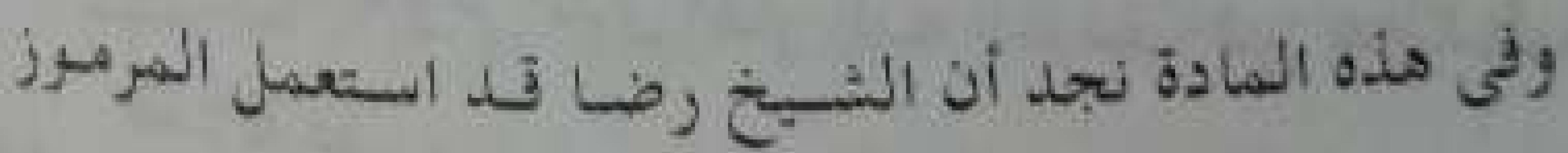

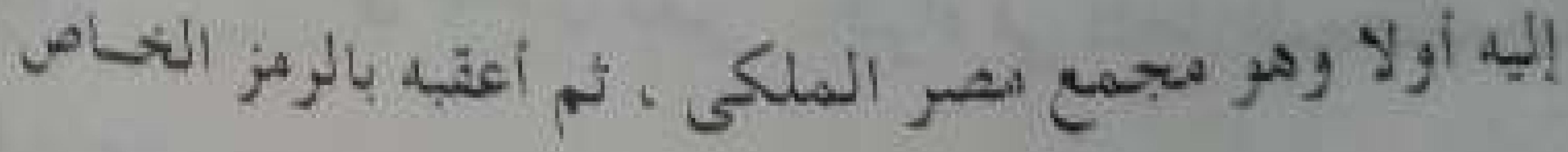




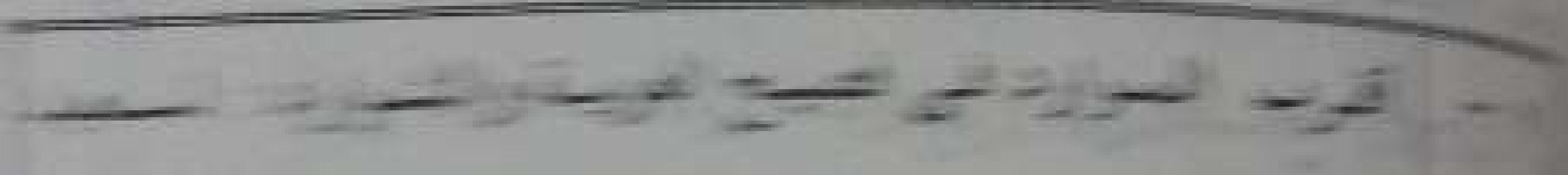

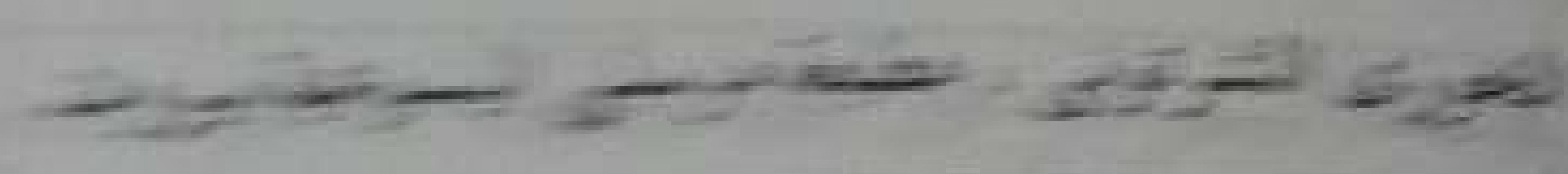

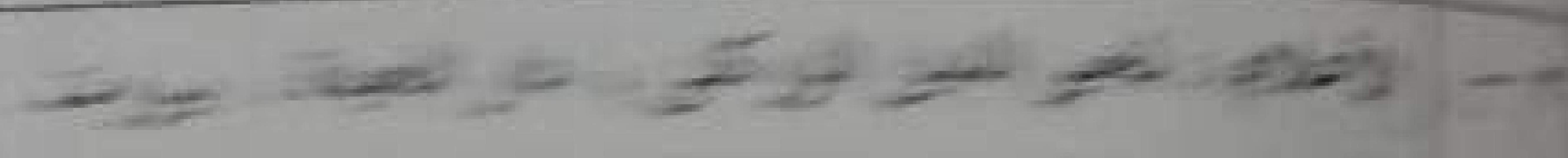

20,

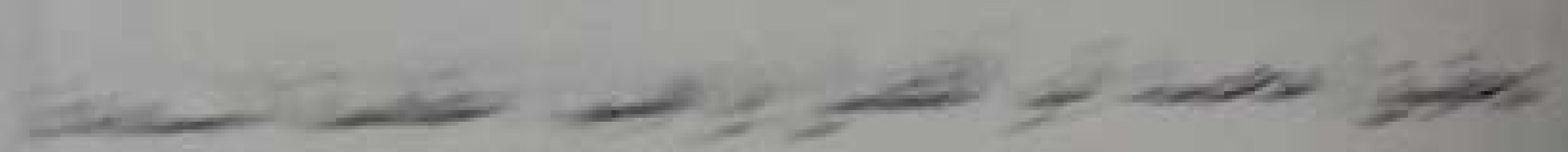
gute plas ing

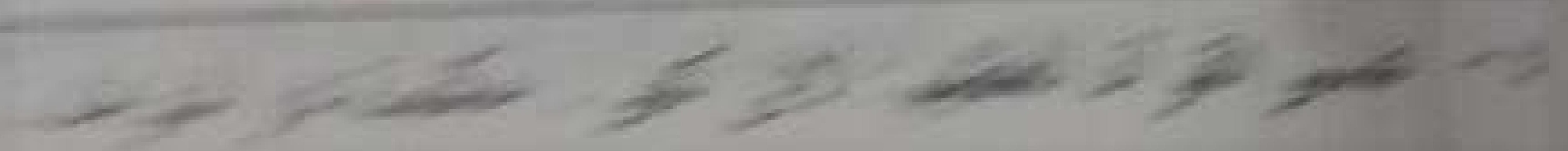

aisions

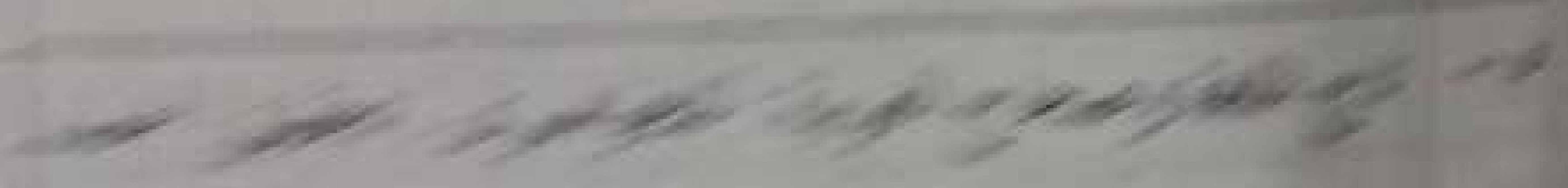

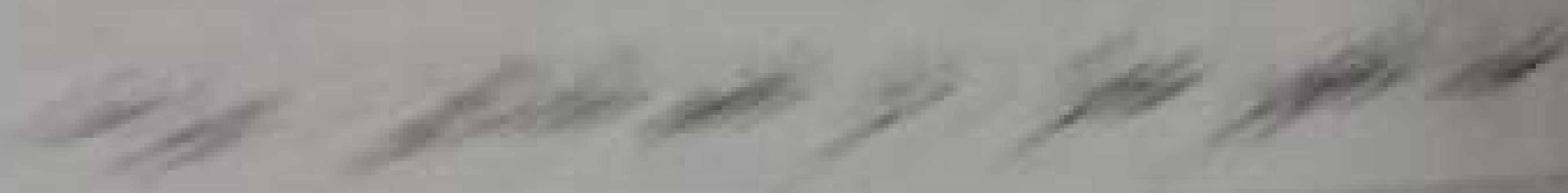

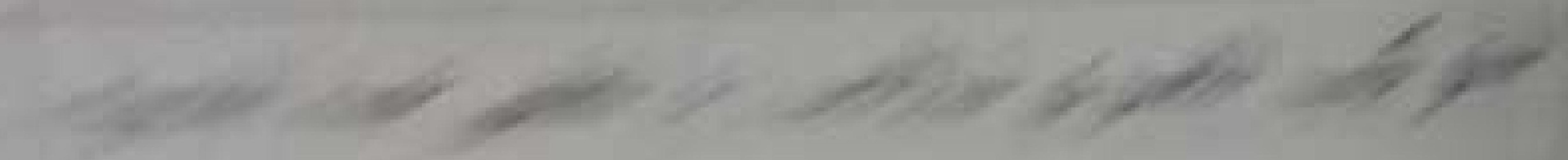
nasu nes

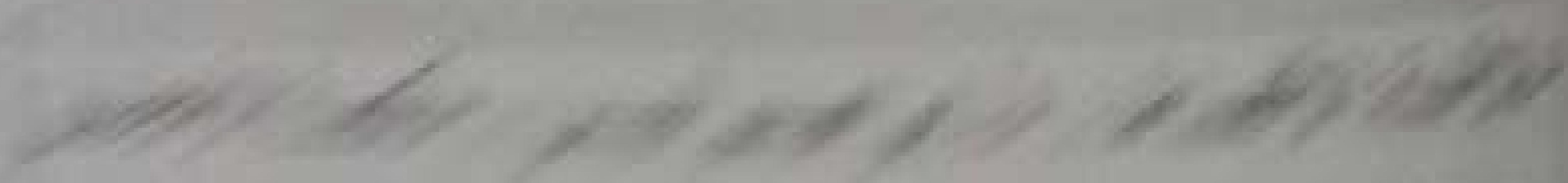

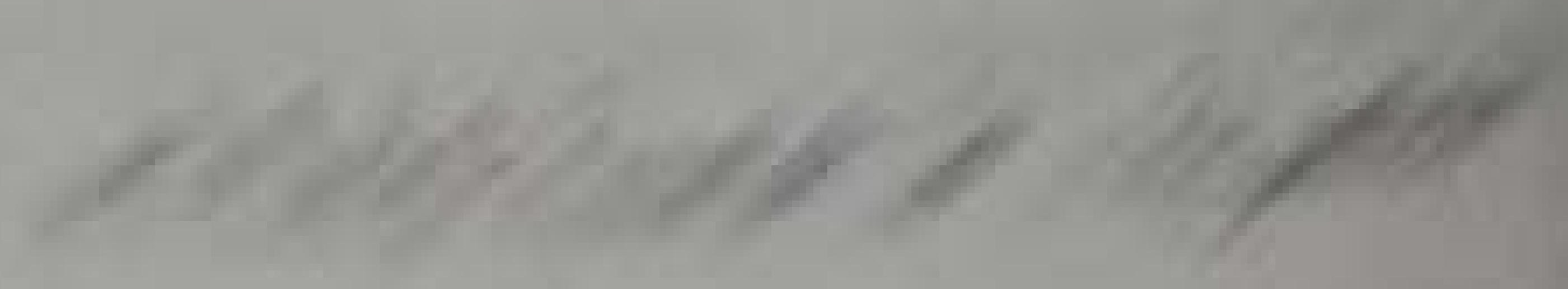

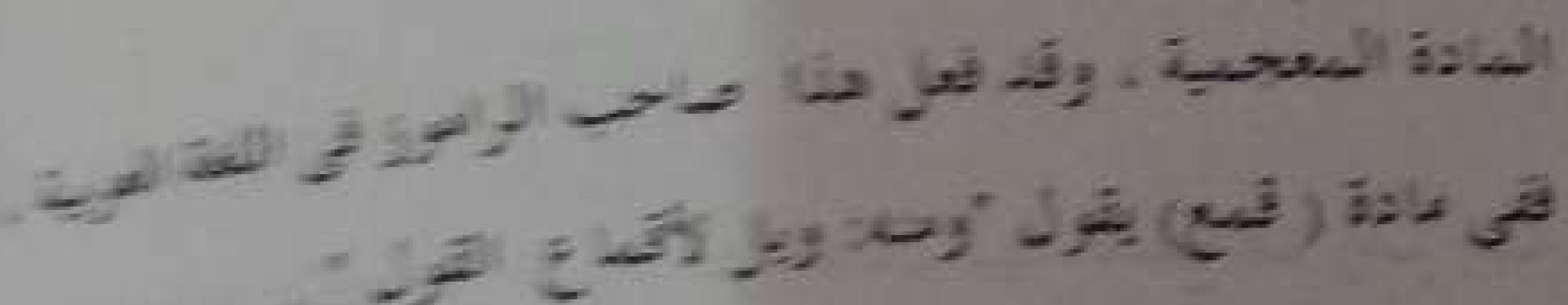

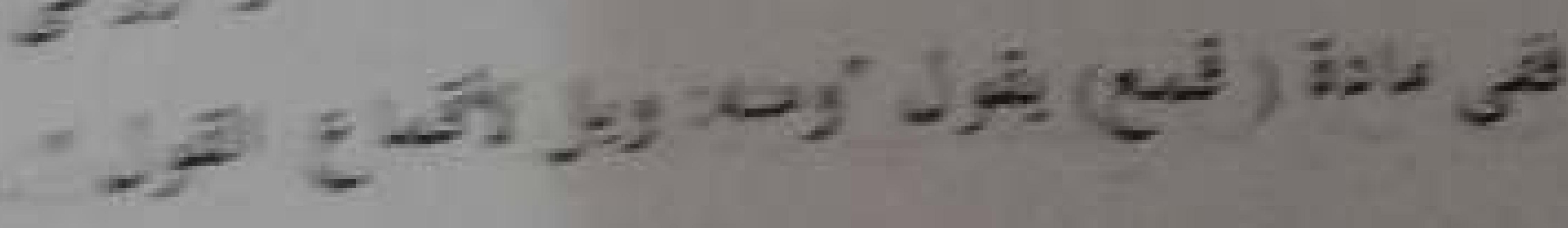

at:

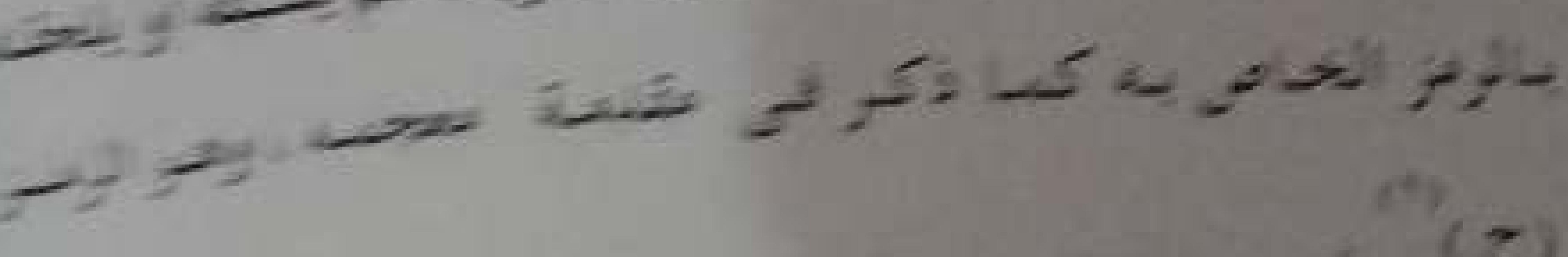

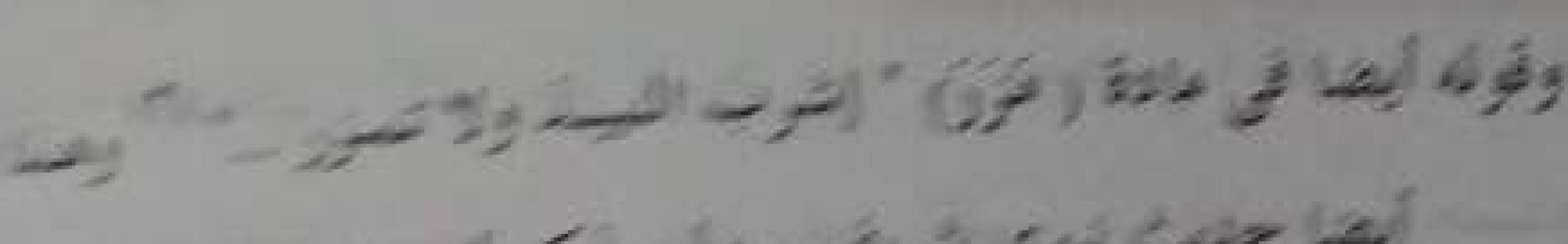

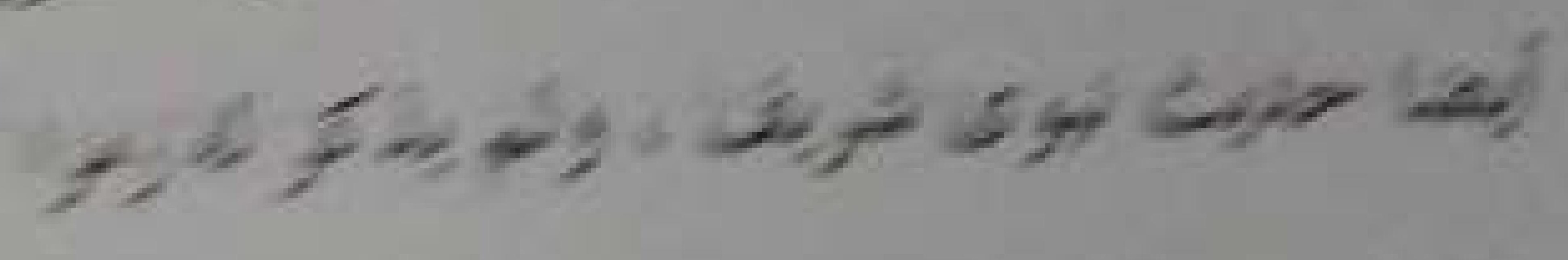
$(2)$ 


\begin{tabular}{|c|c|}
\hline 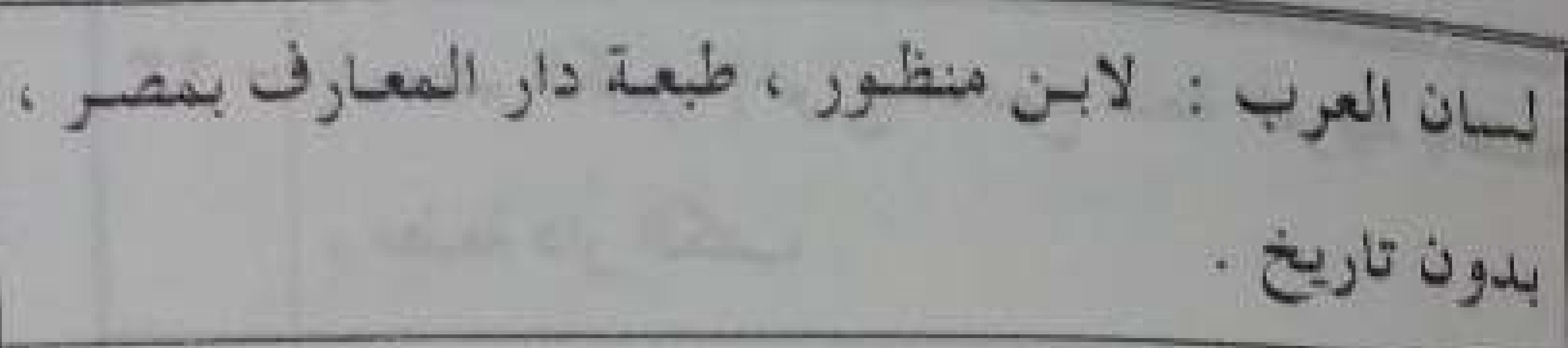 & -10 \\
\hline 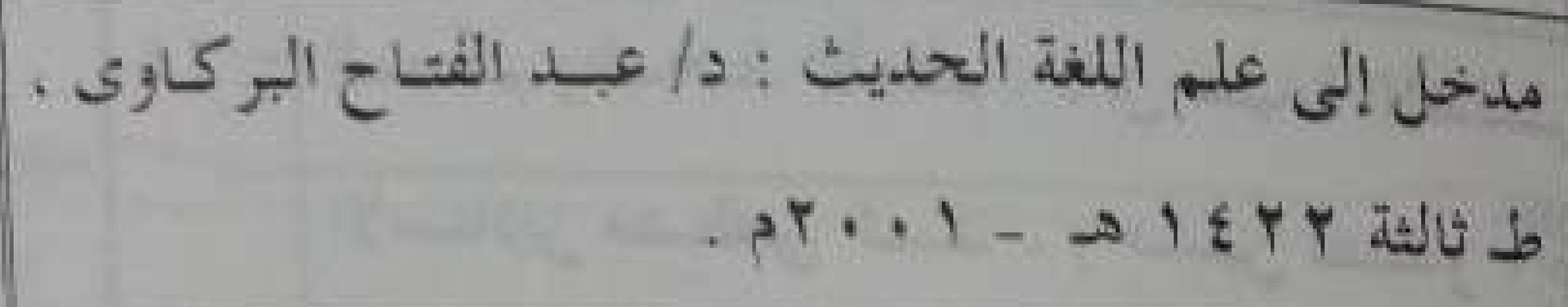 & -17 \\
\hline 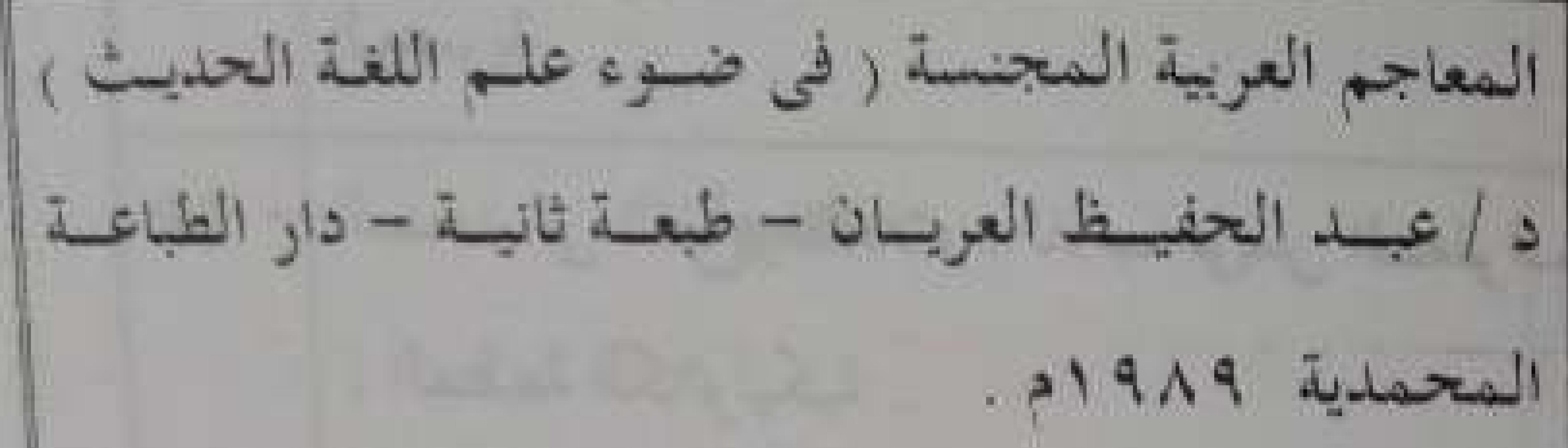 & $-1 \mathrm{~V}$ \\
\hline 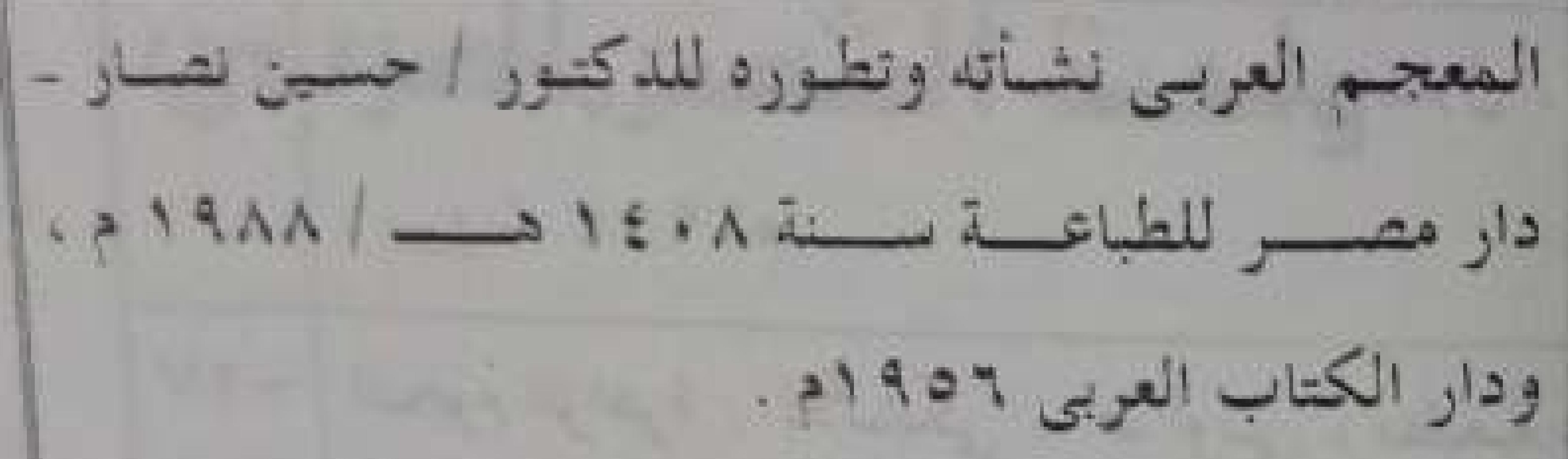 & $-1 \mathrm{~A}$ \\
\hline 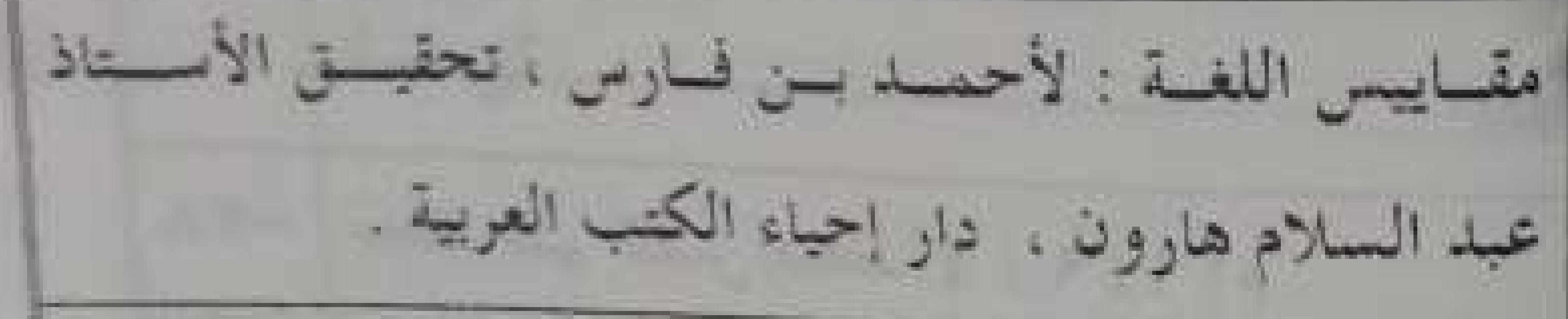 & -18 \\
\hline 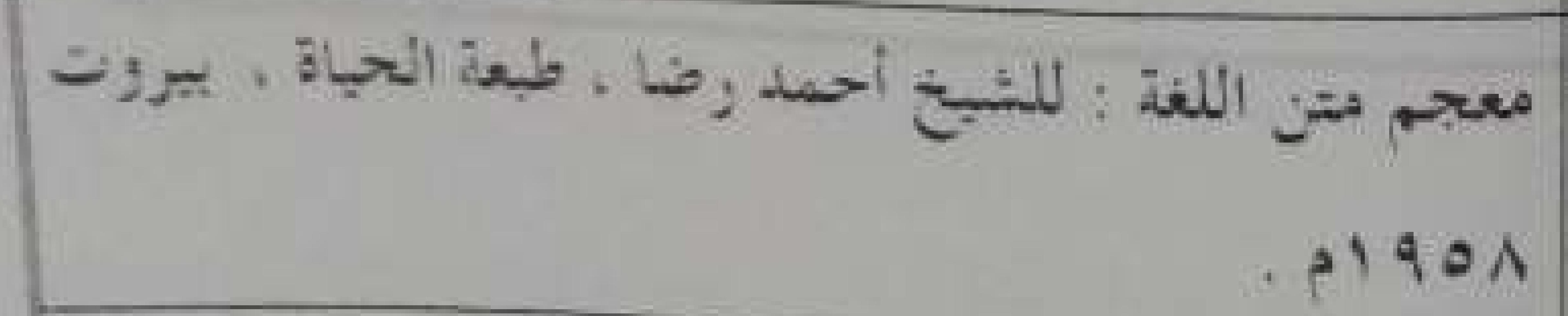 & $-r$. \\
\hline 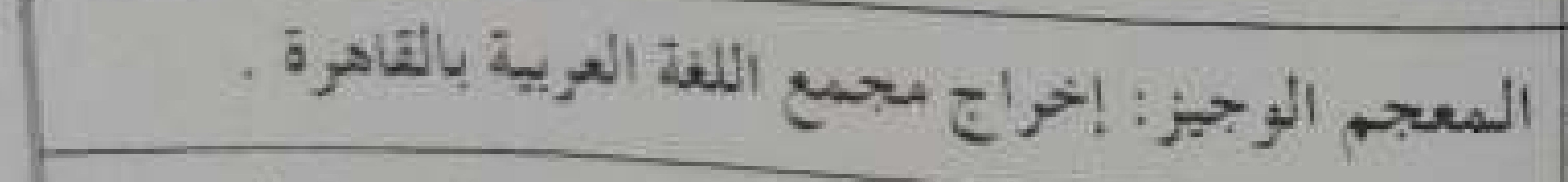 & $-r_{1}$ \\
\hline 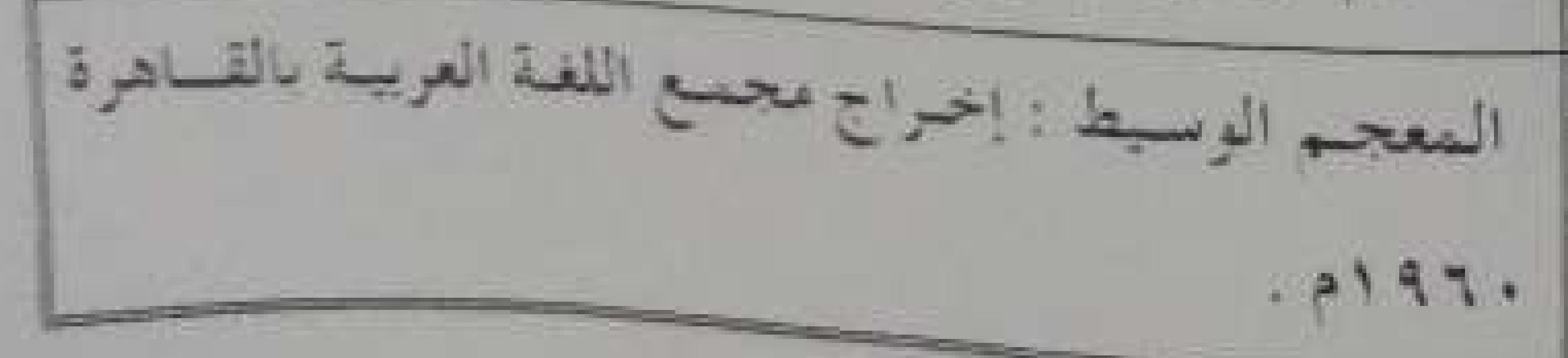 & $-T_{T}$ \\
\hline
\end{tabular}

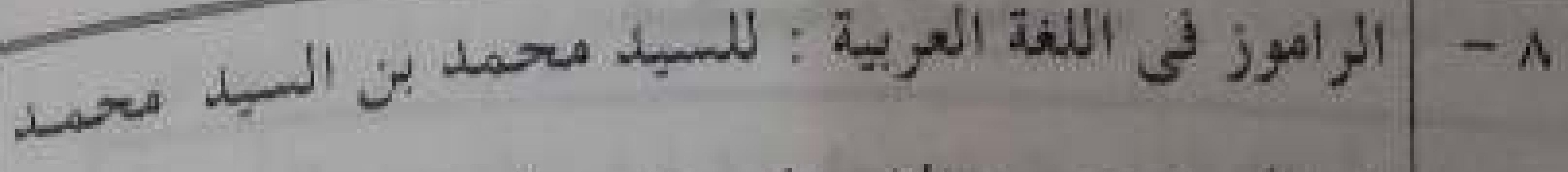

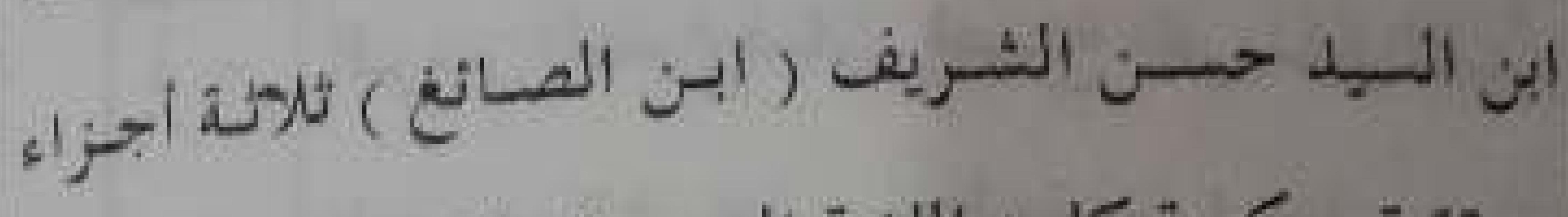

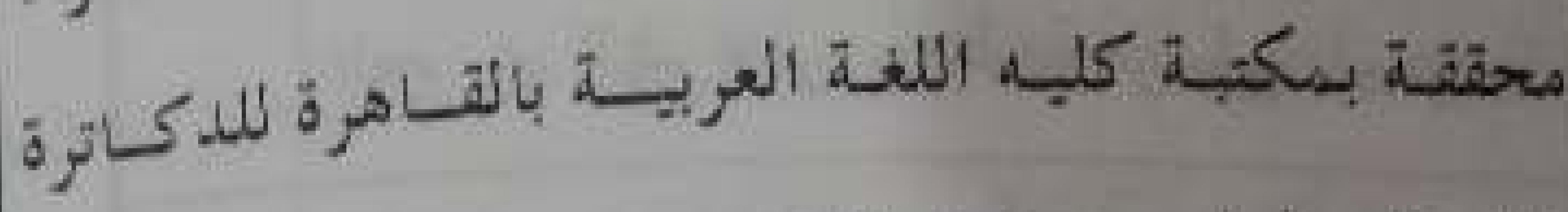

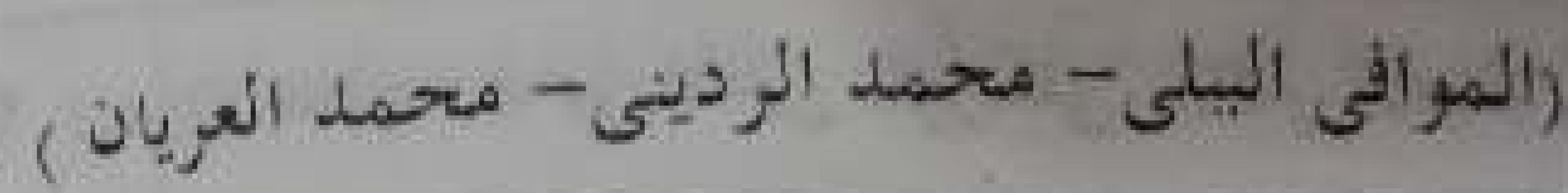

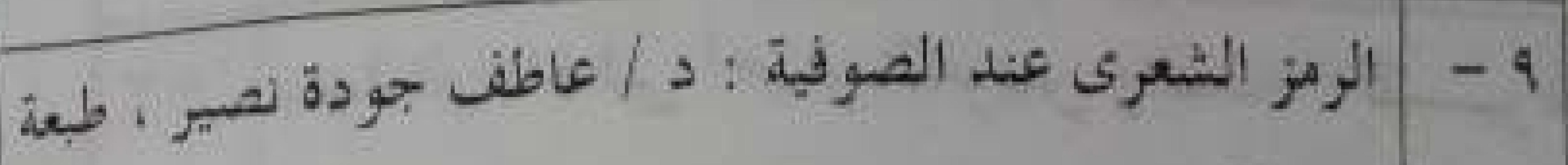

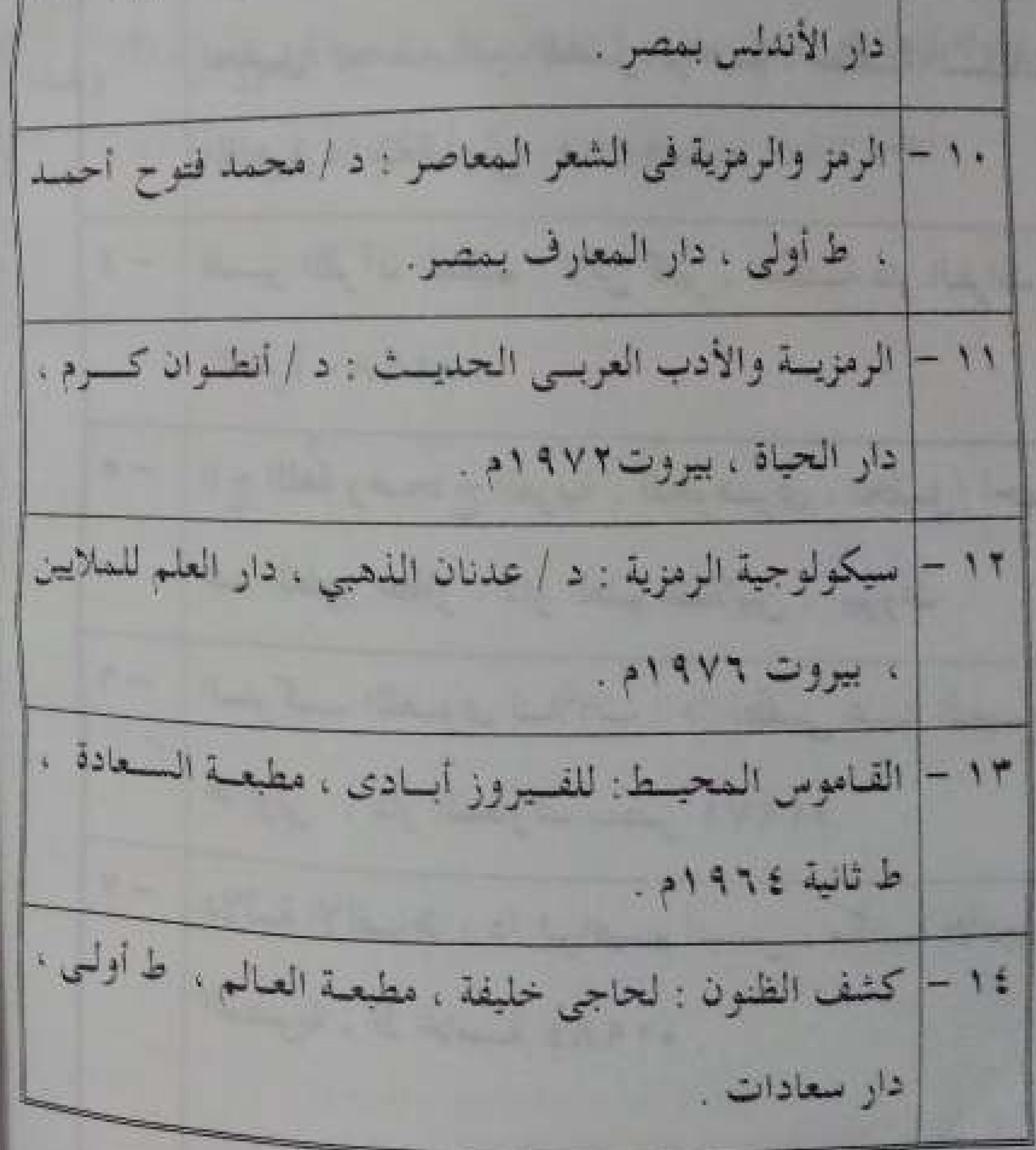


ب - المعجم الكبير : إخراج مجمع اللغة العربية بالقـاهرة مج 197

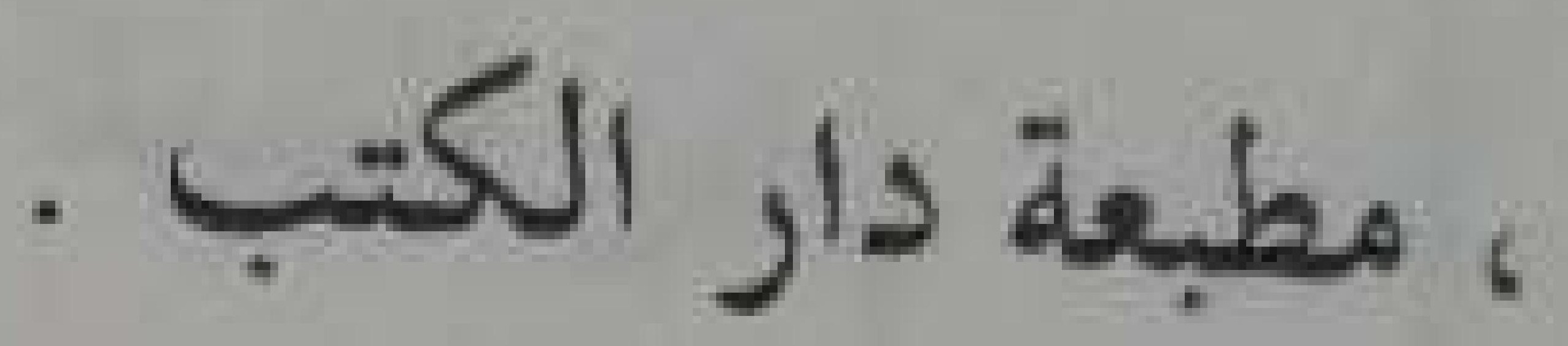

؛ ب - المحكم والمحيط الأعظم : لابن سسيدة الأندلسي ، تحقيتّ الأستاذين مصطفى السقا ، وحسسين نصسـار ، دار الكتسب المصرية .

هب - المنجد فى اللغة والأعلام : للأب لويس المعلوف اليسـوعى ، المطبعة الكاتوليكية .

با - النقد الأدبي الحديث : 2 / محمد غنيمى هلال ، دار العودة

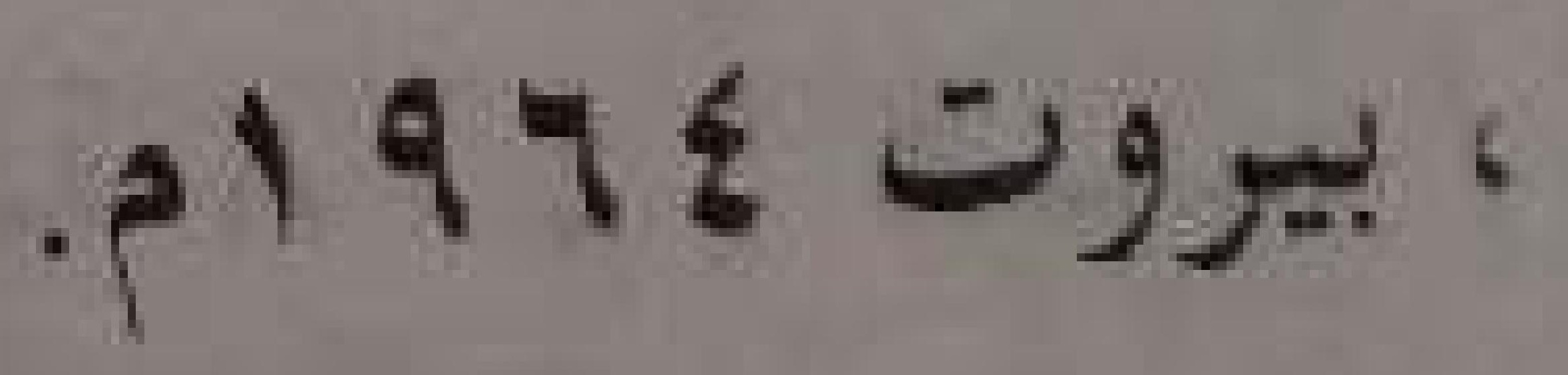

VY النجوم الزاهوة : للأتسبكى ، ط أولى ، مطبعة دار الكتب المصرية.

ر 


\section{$-r+s-\quad=t h$}

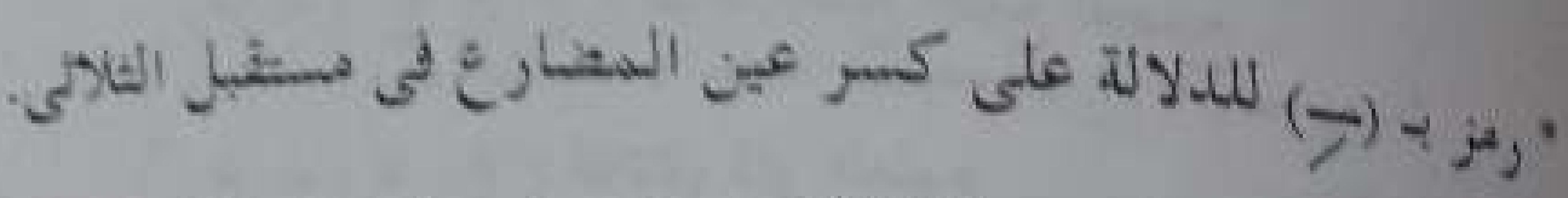

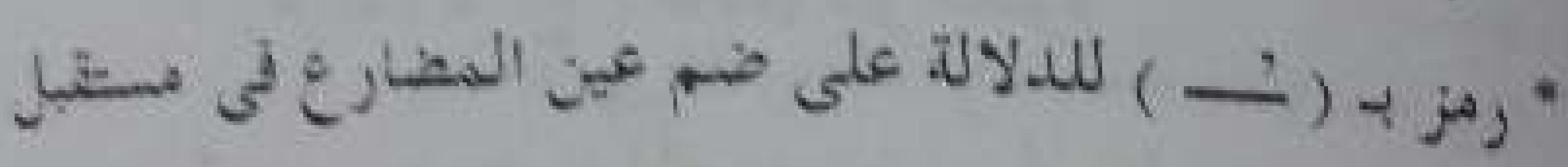
- ज)

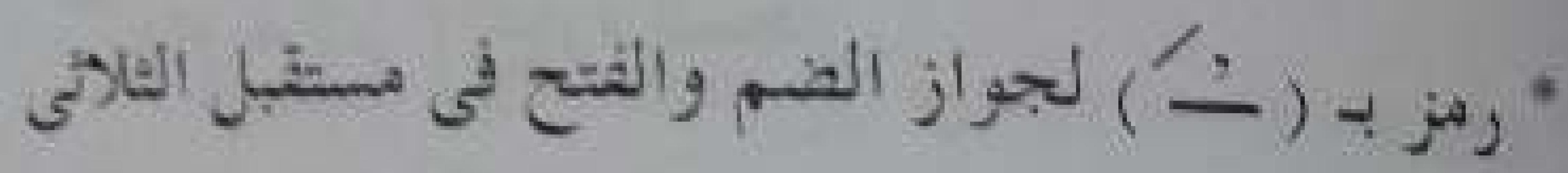

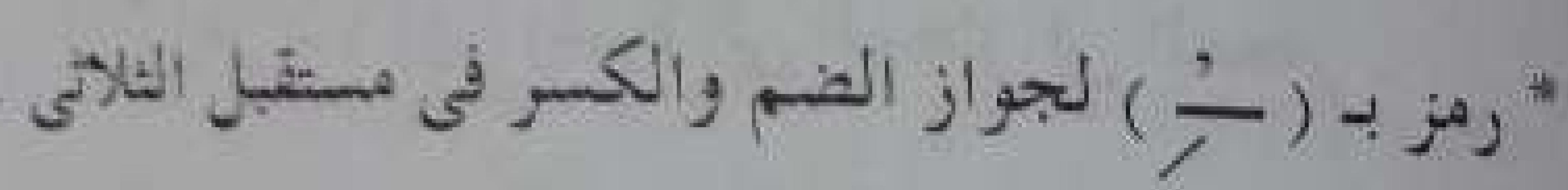

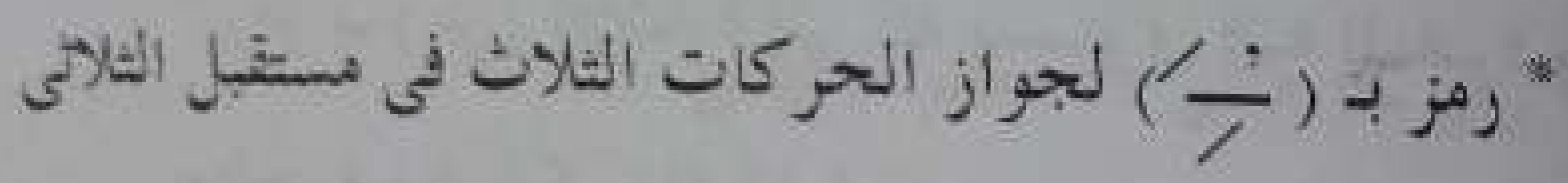
" رمز بـ (: ) لإتيان الكلمة الدفسرة في عثبها.

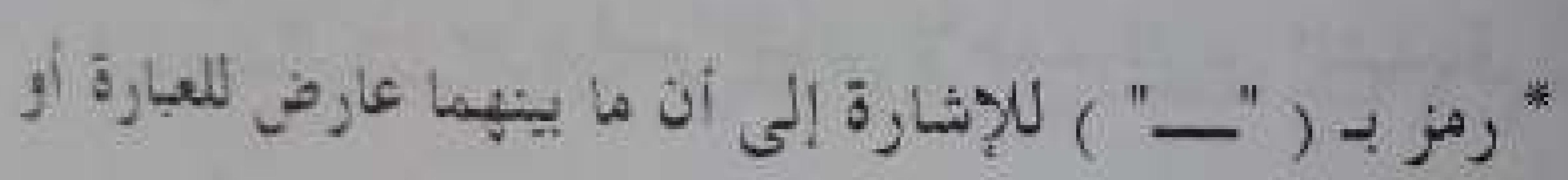

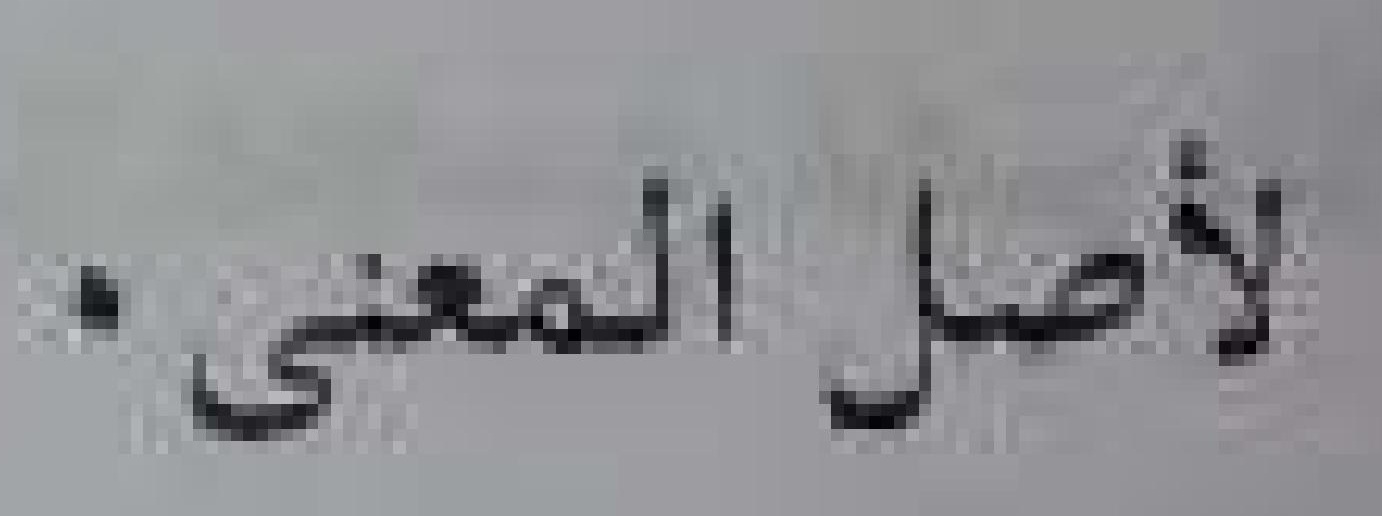

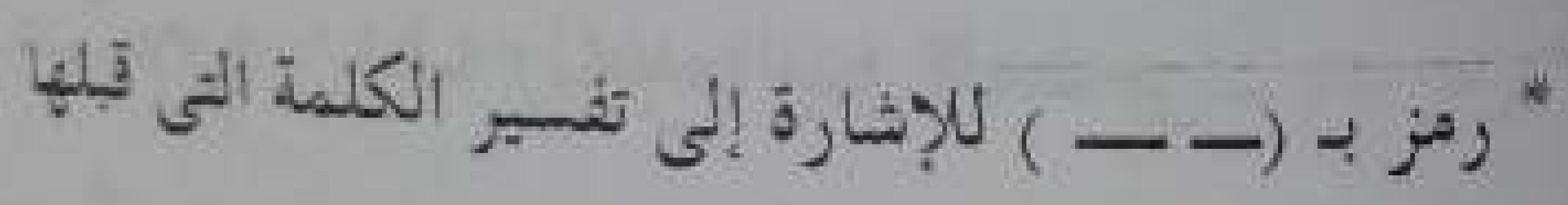

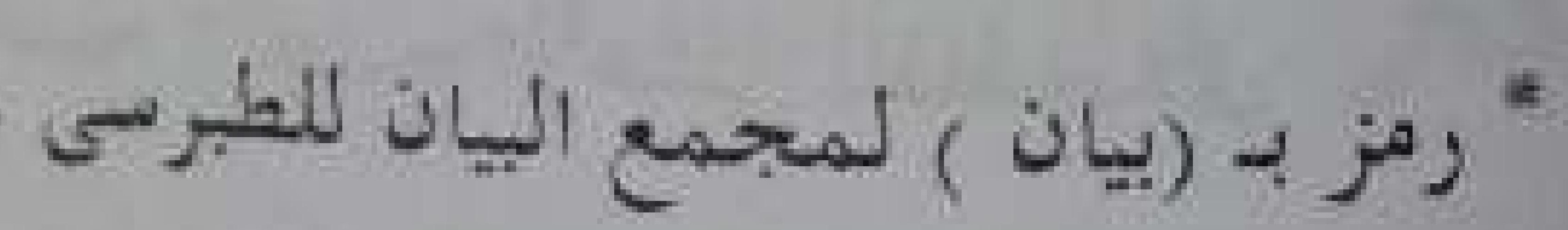

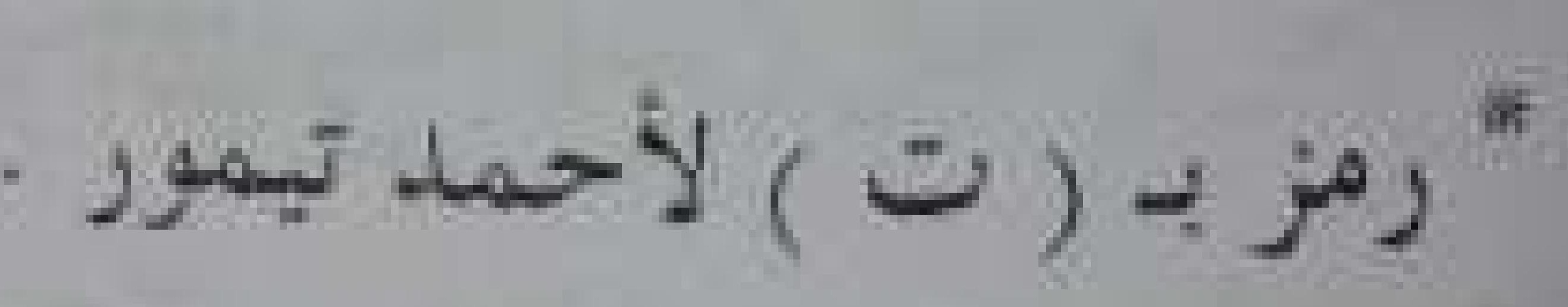

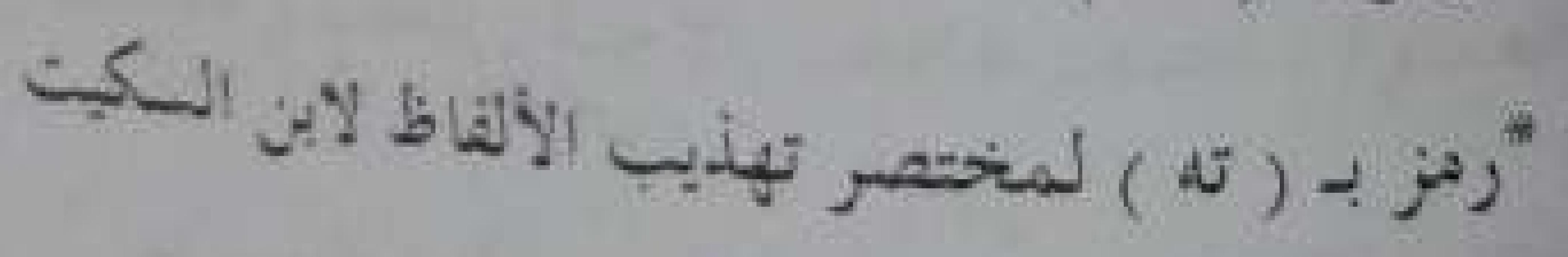

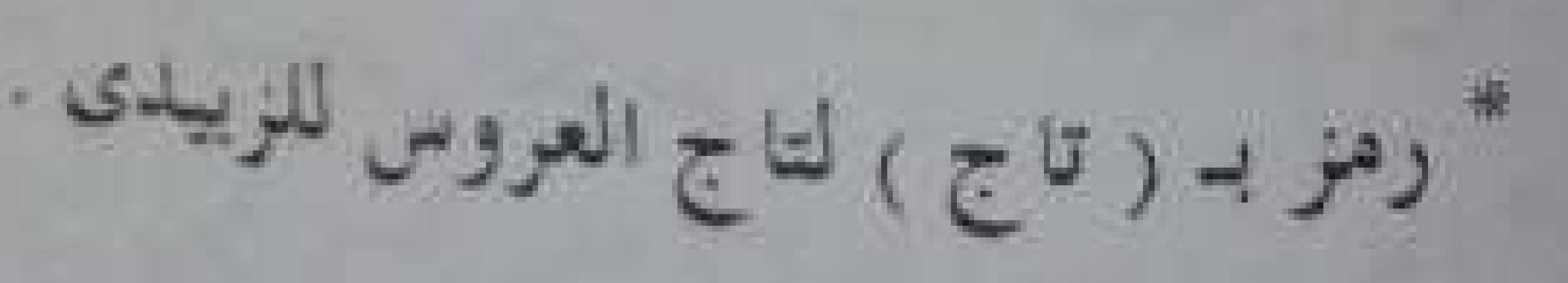

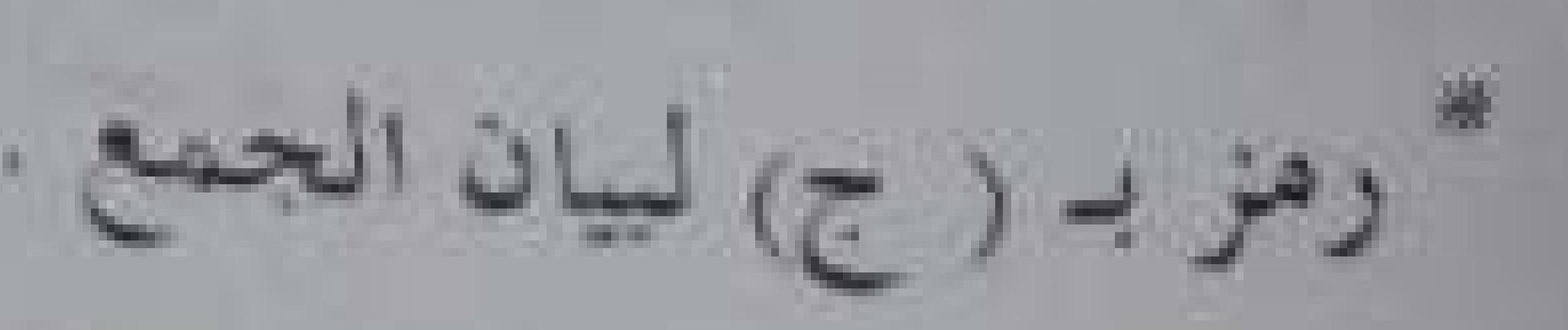

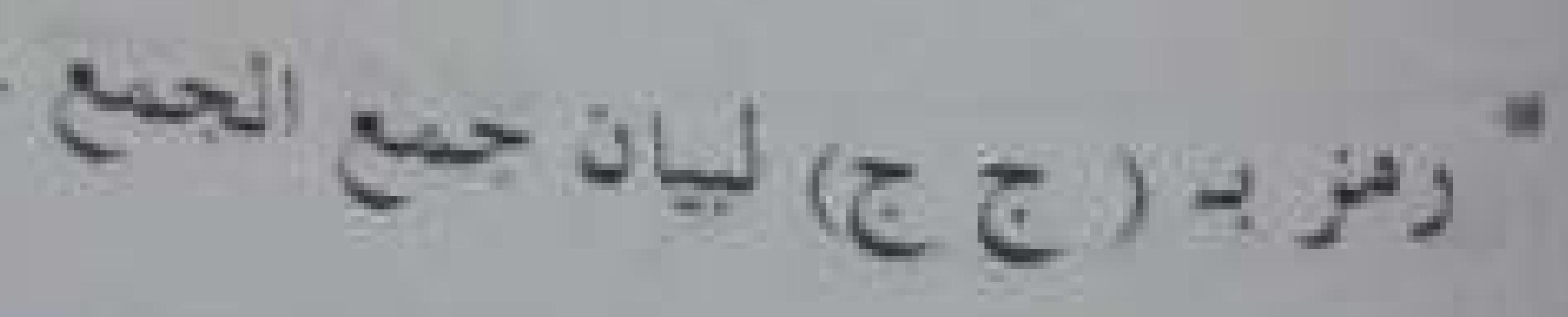

$$
-r+4-
$$

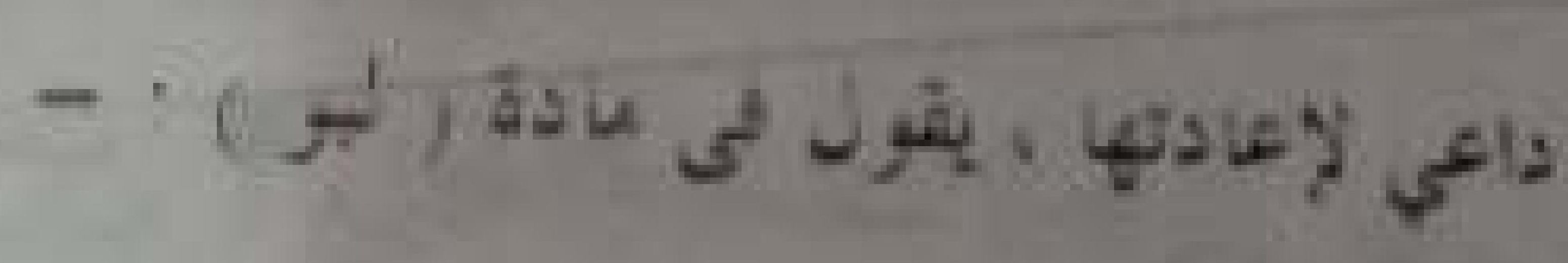

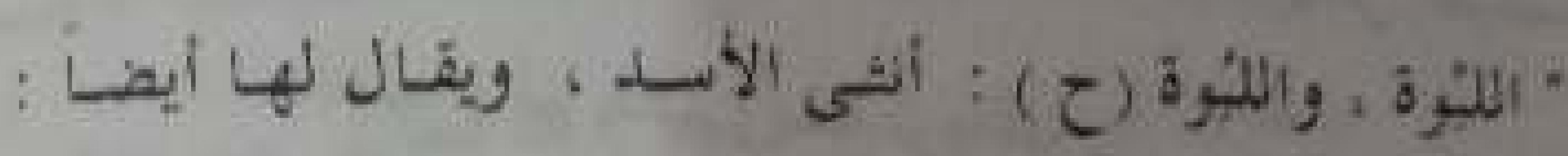

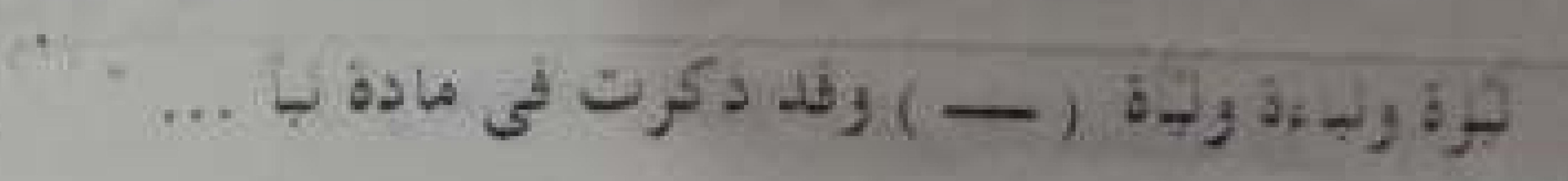

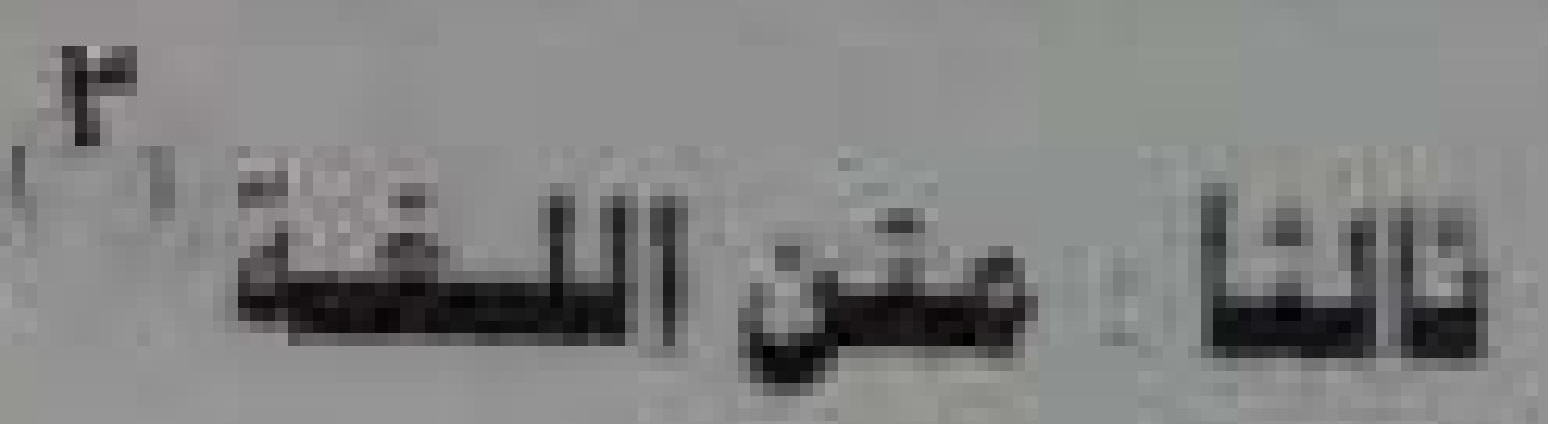

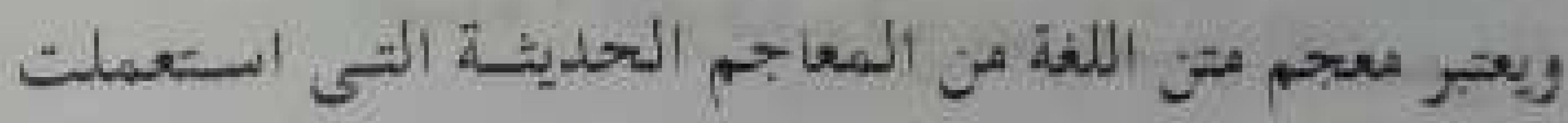

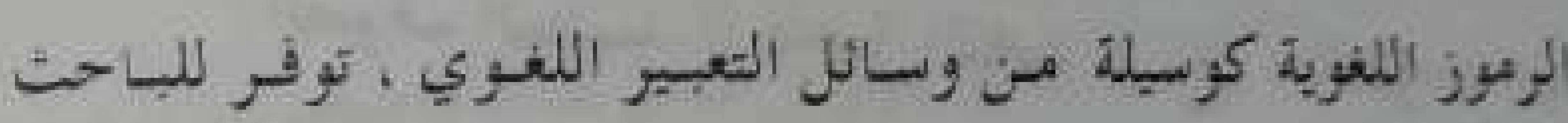

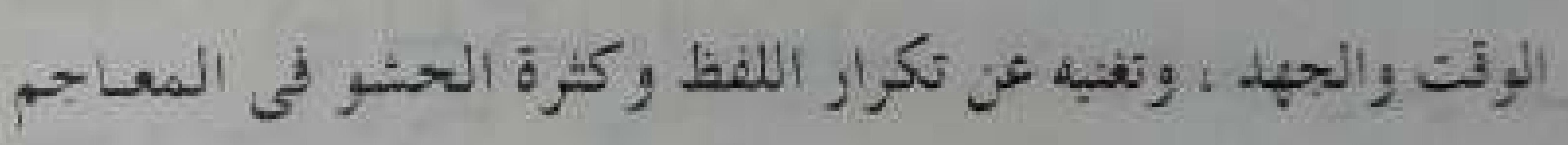

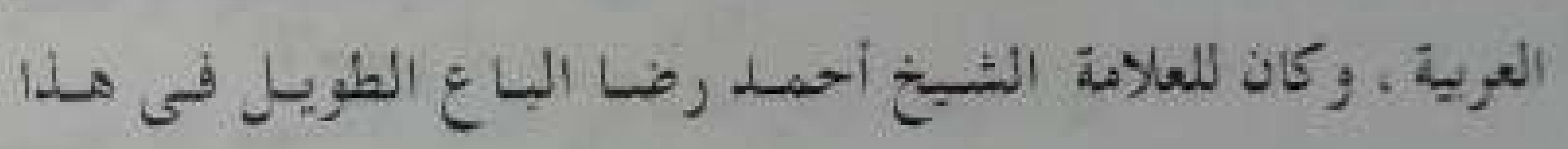

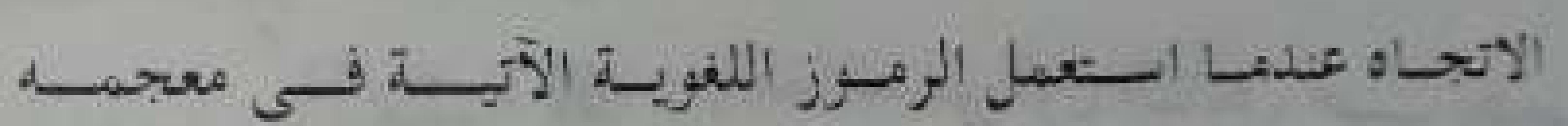

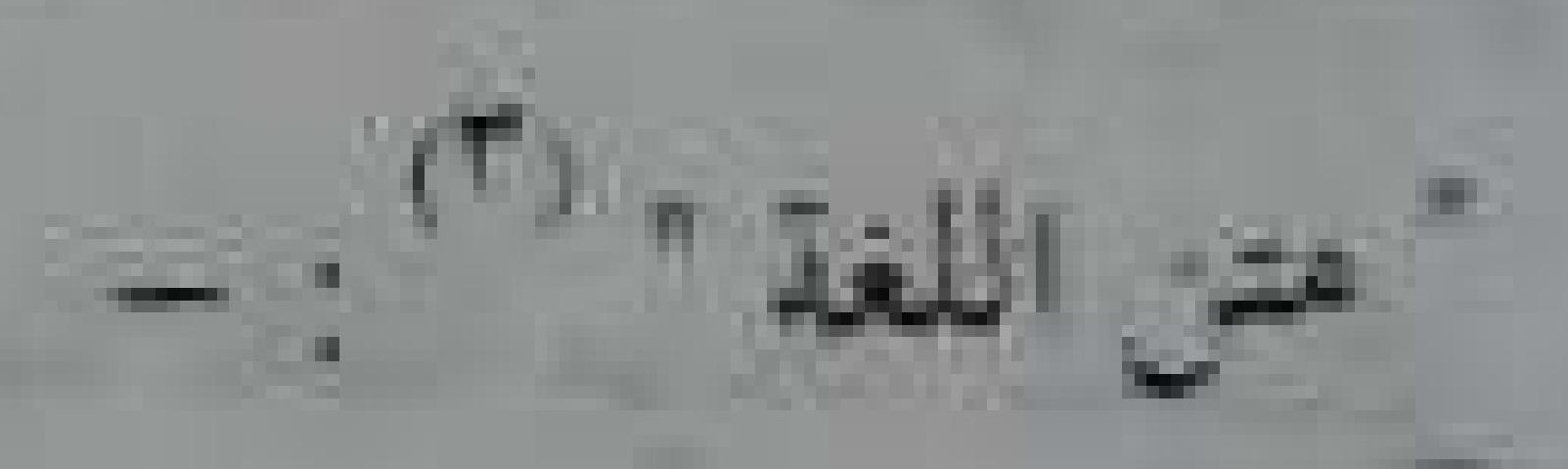

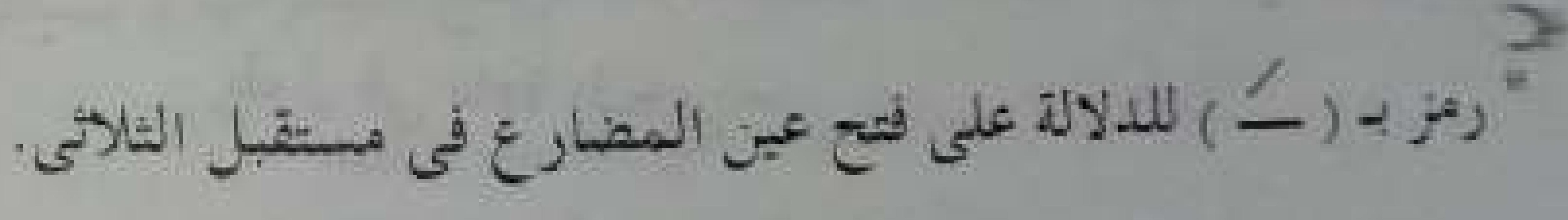

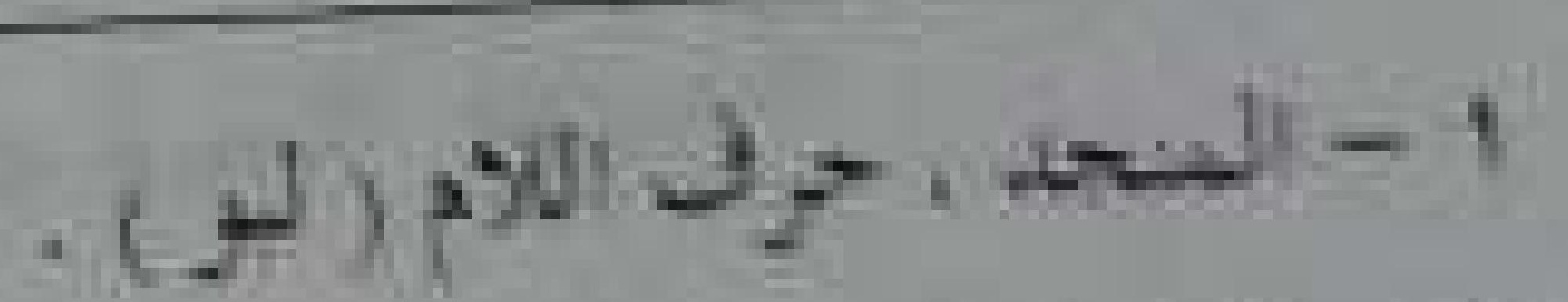

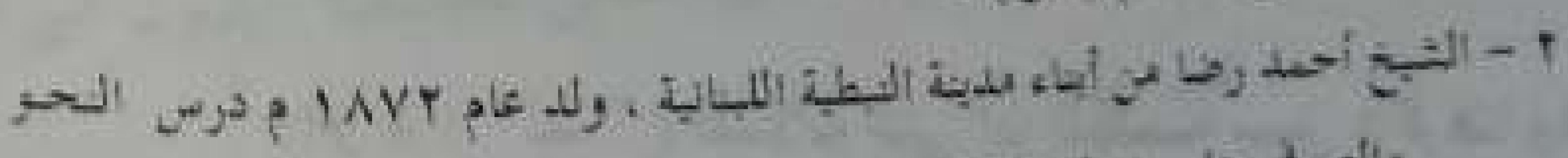

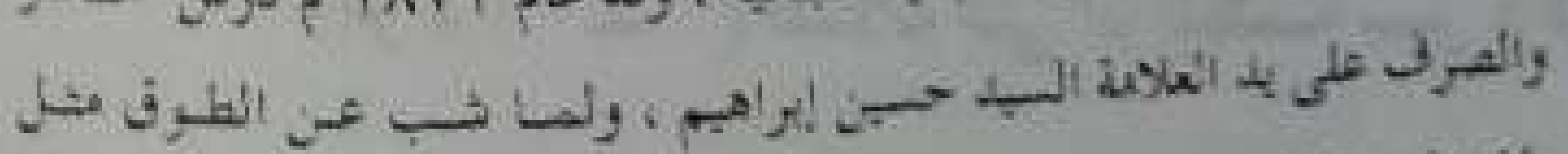

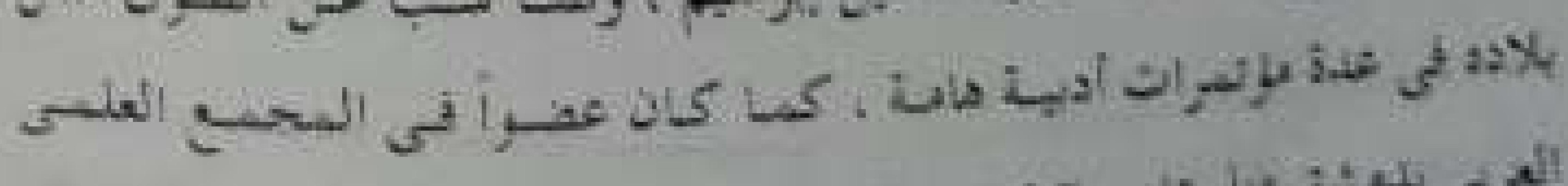

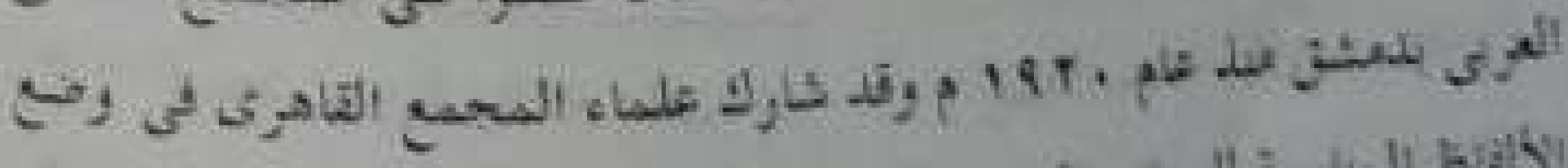

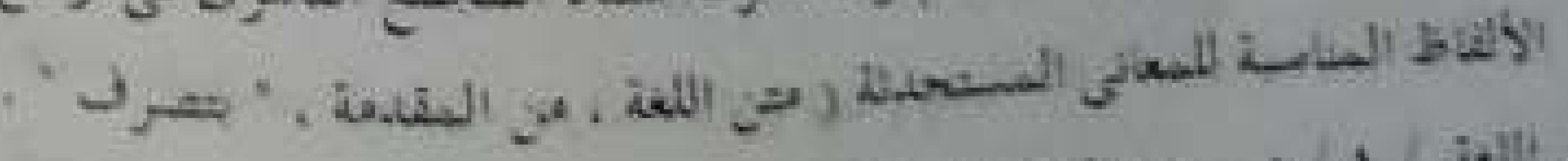

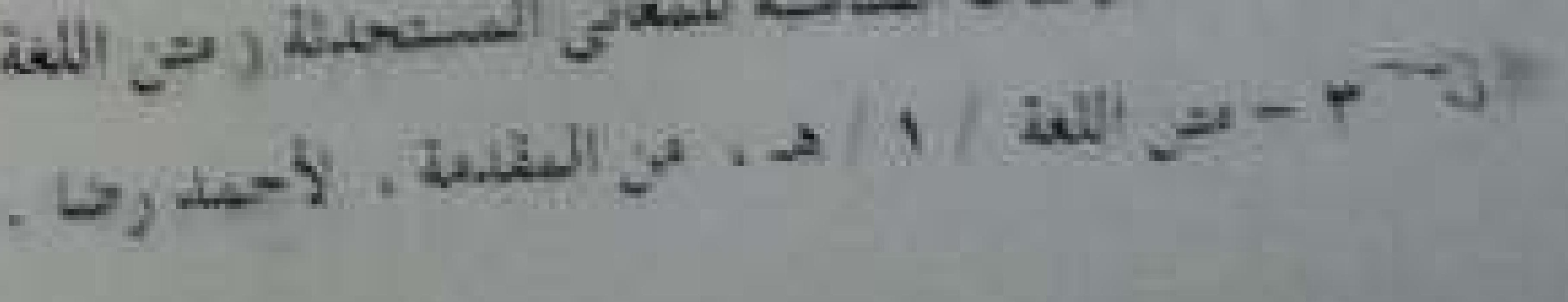


رمز بـ (

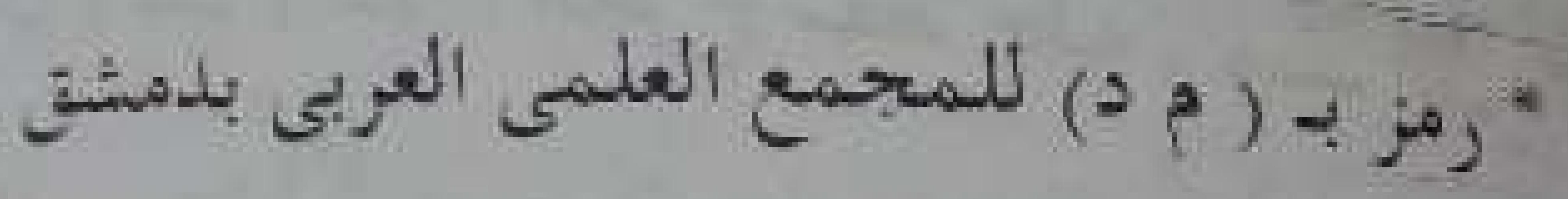

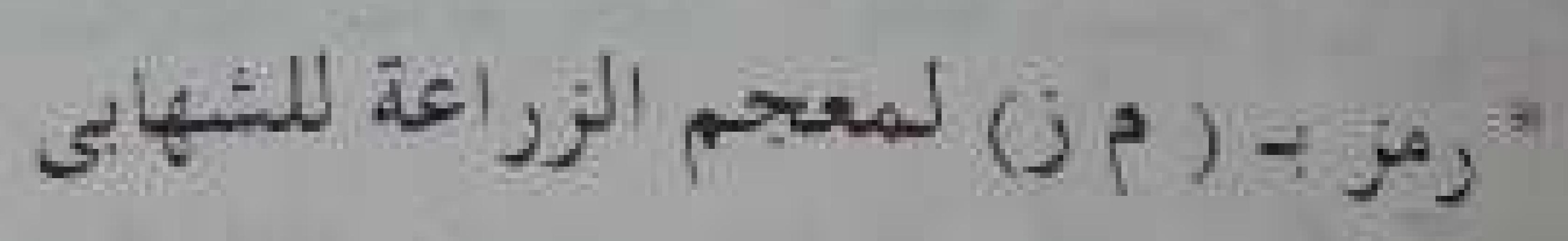

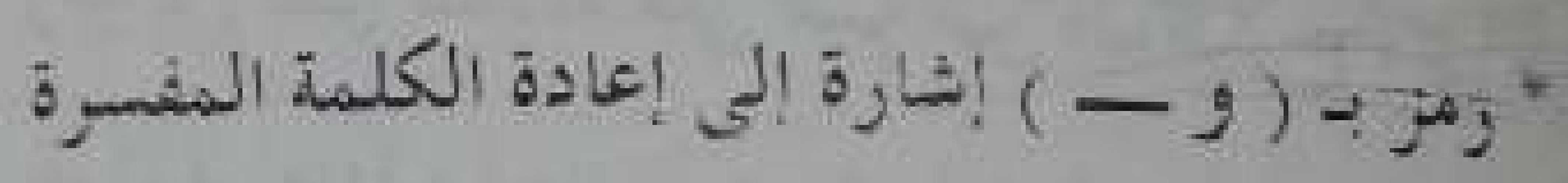

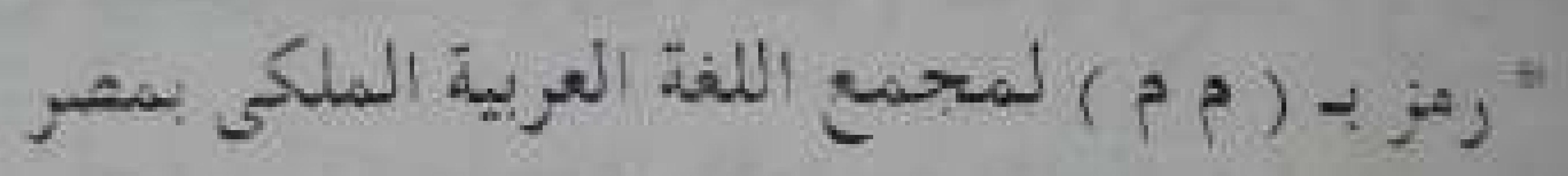

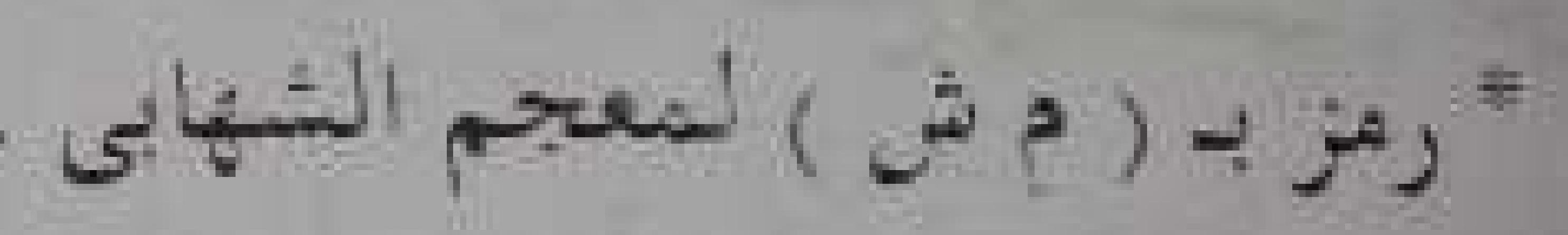

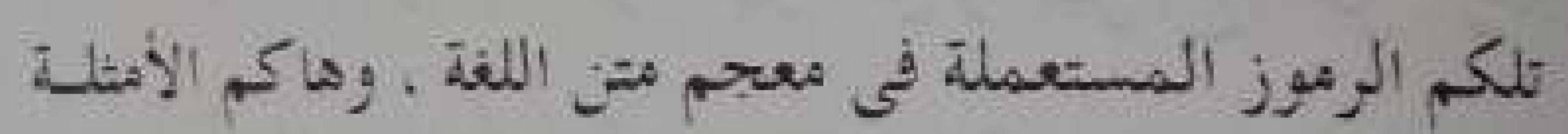

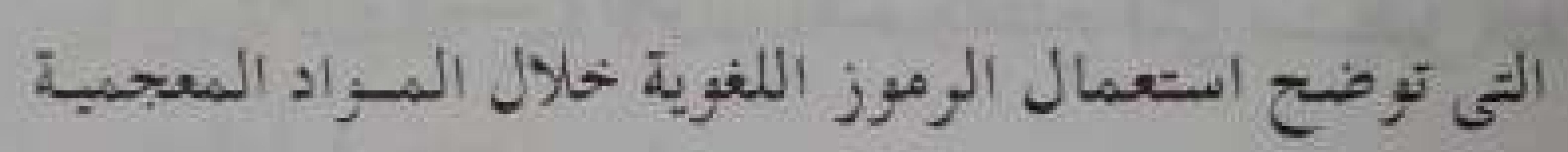
كريلة يد وبسائل التعير اللفوى : -

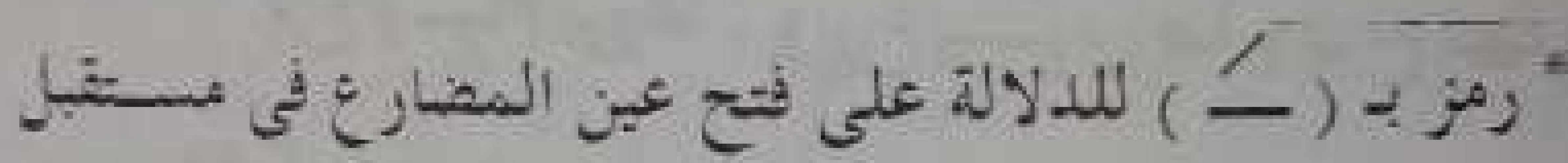

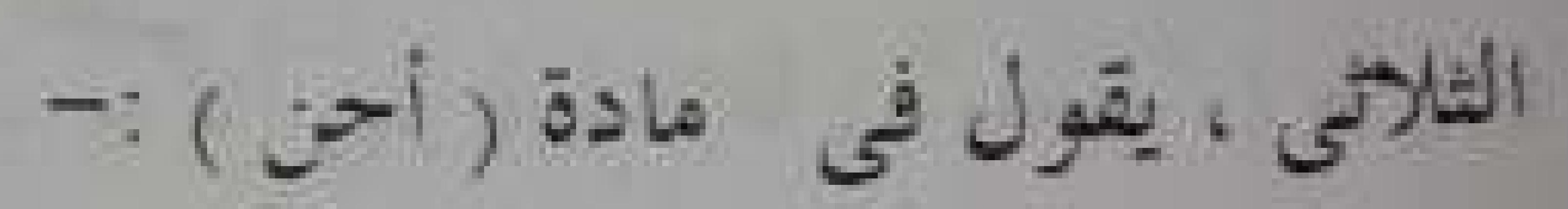

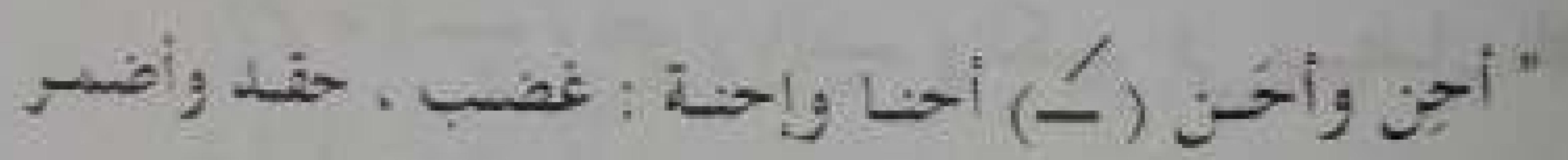

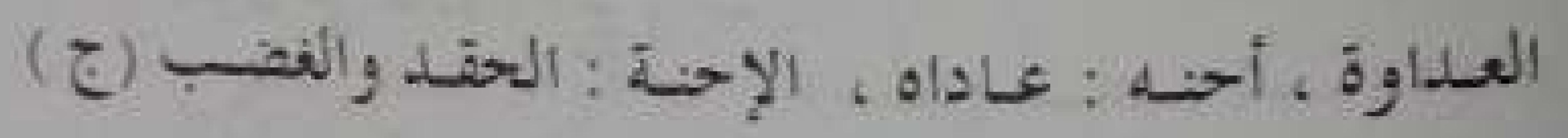

(1) . ...

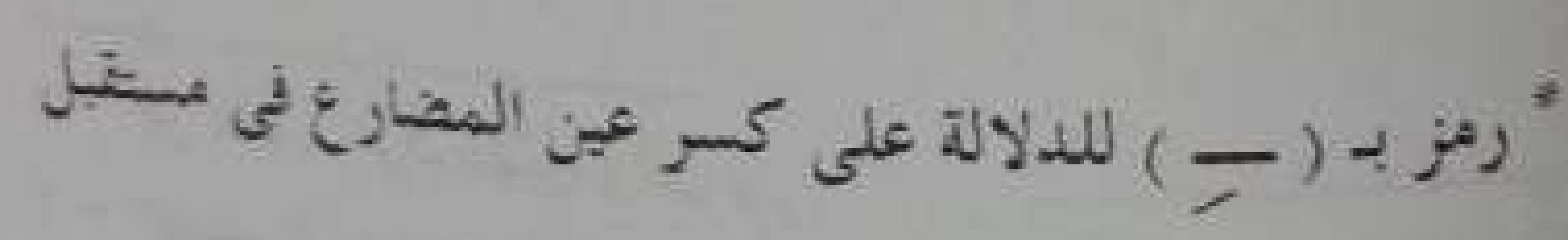

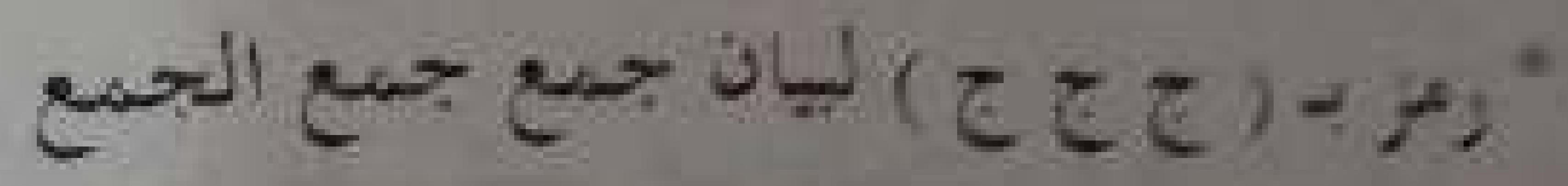

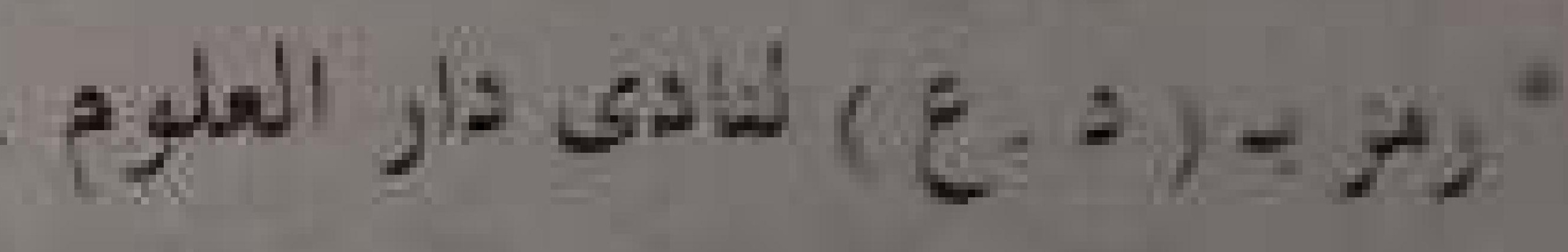

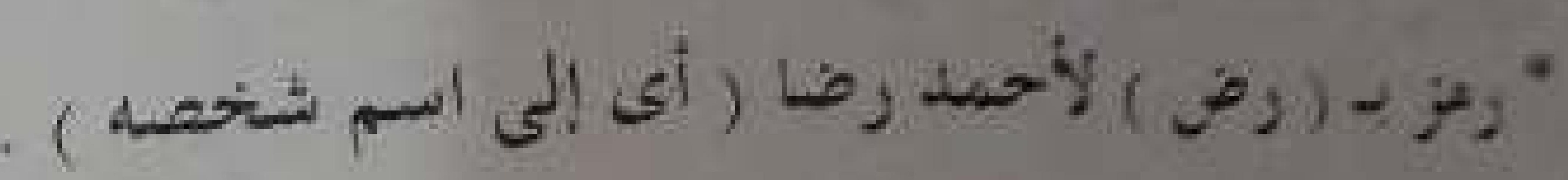
. jacilo

.

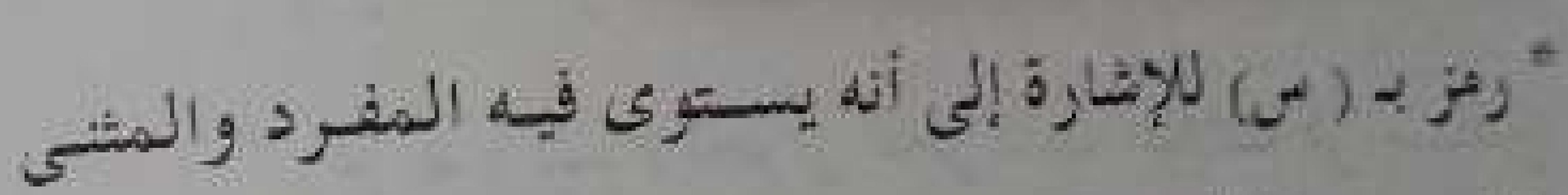

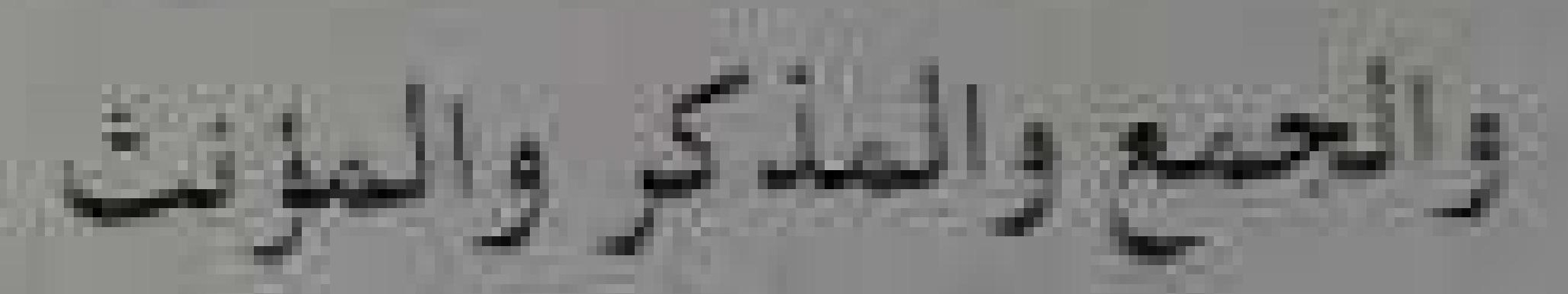

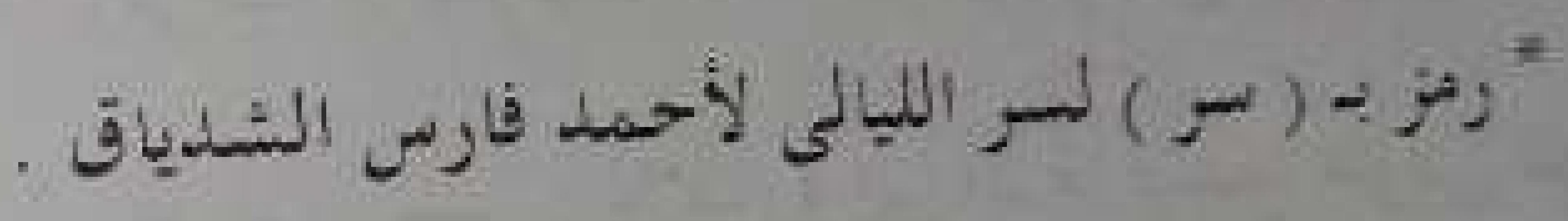

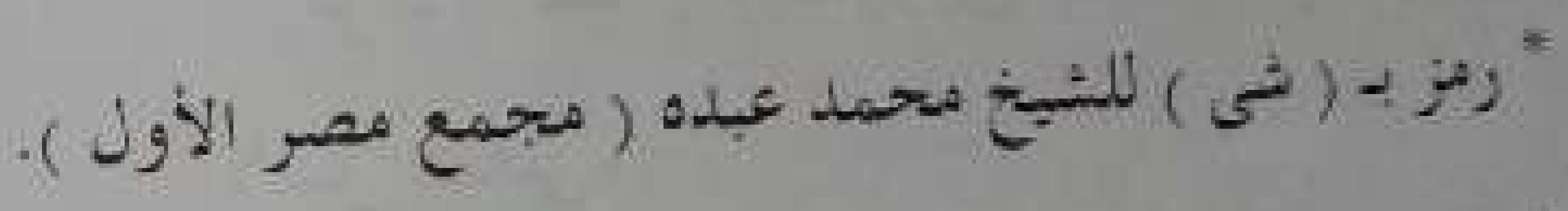
(

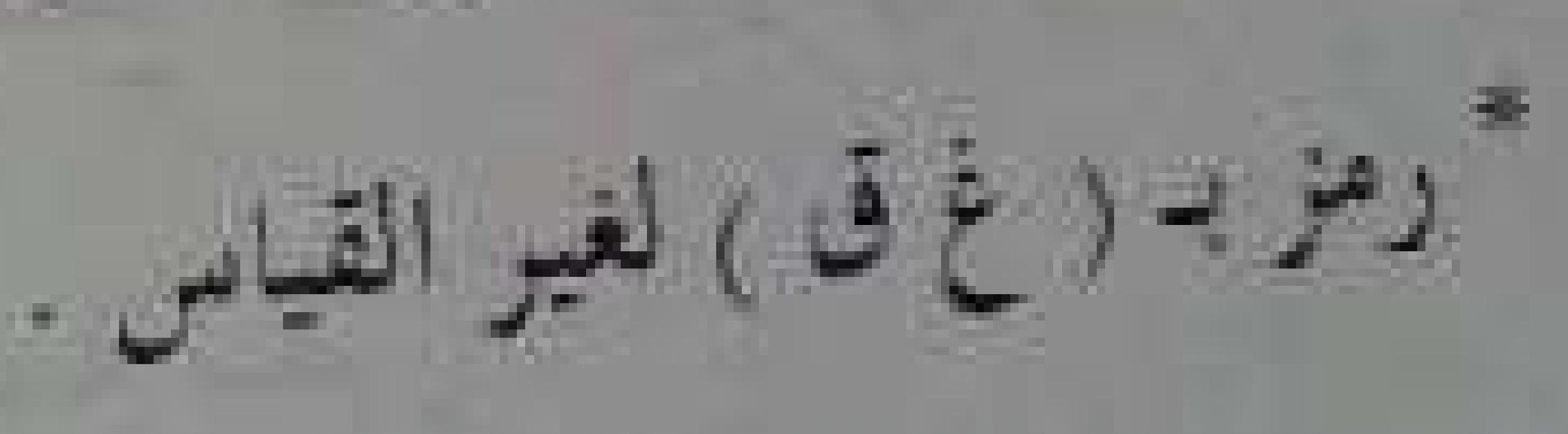

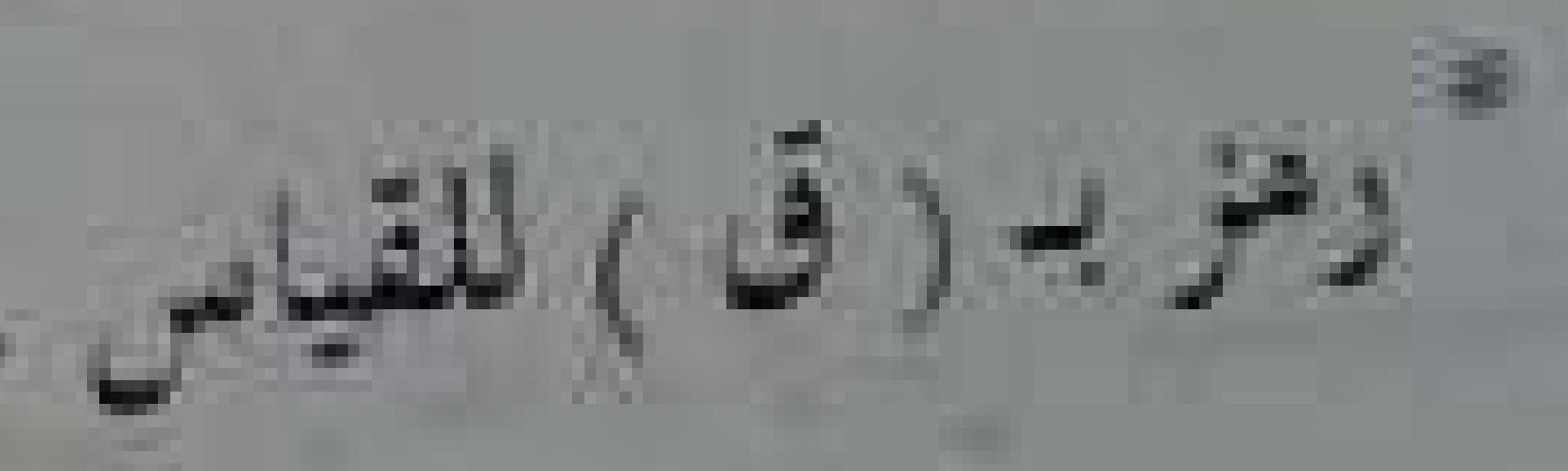

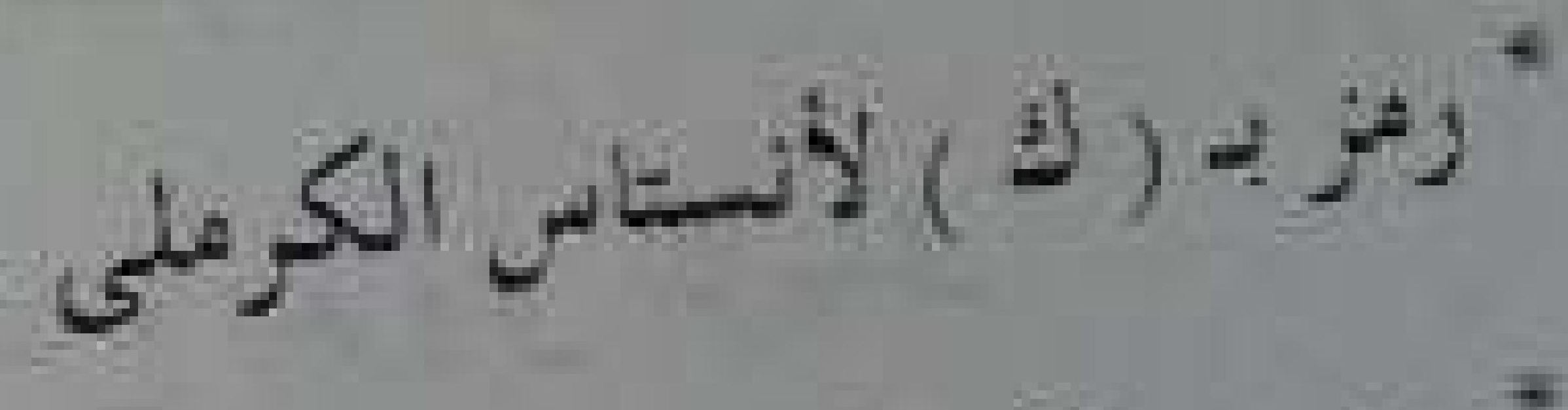
.

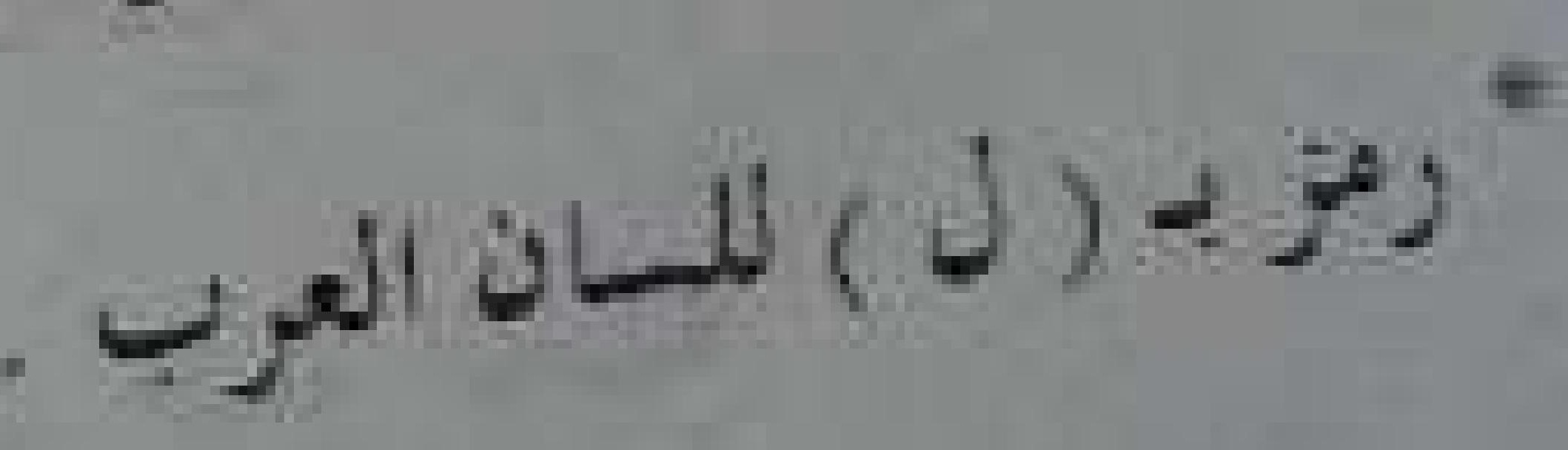




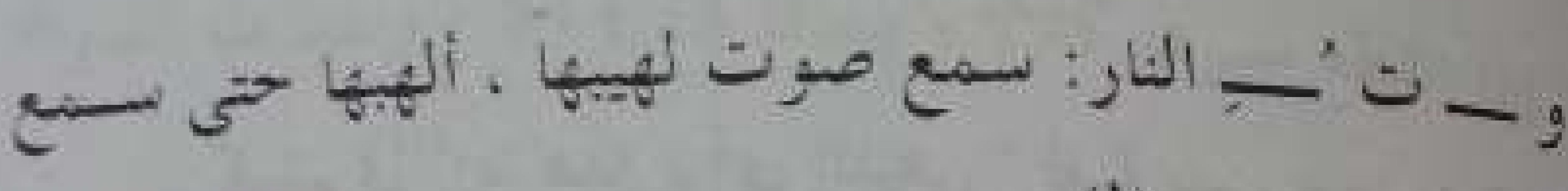
(1) "... .

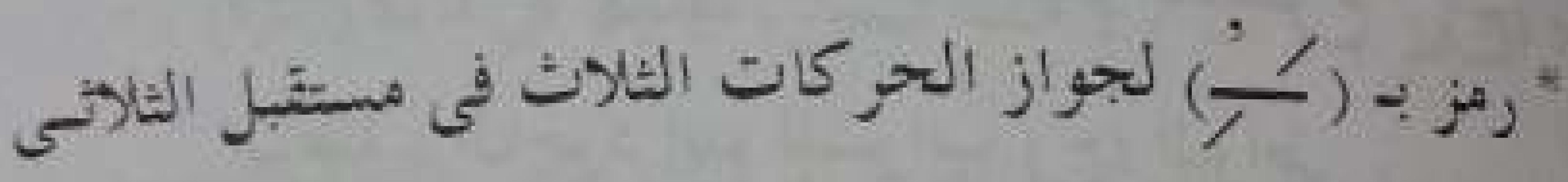

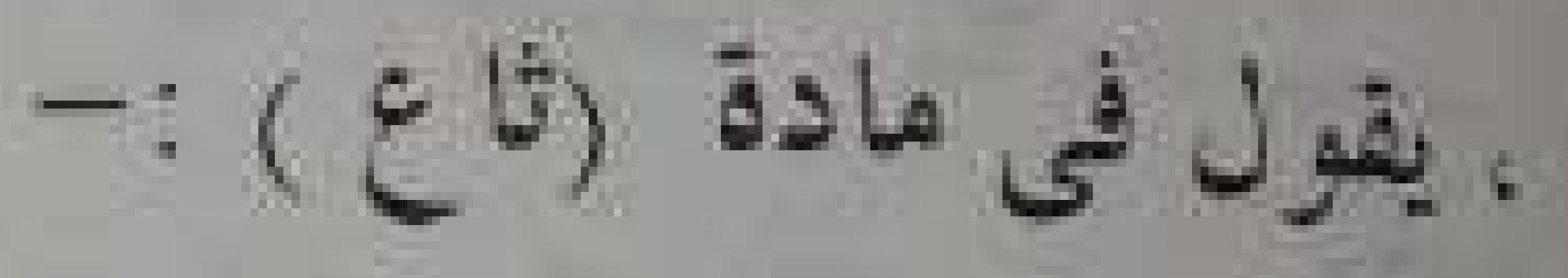

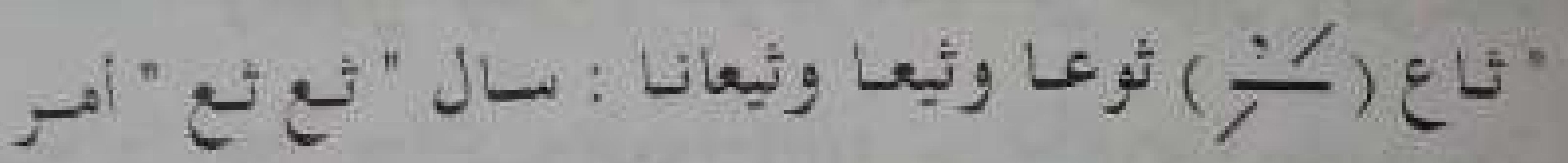

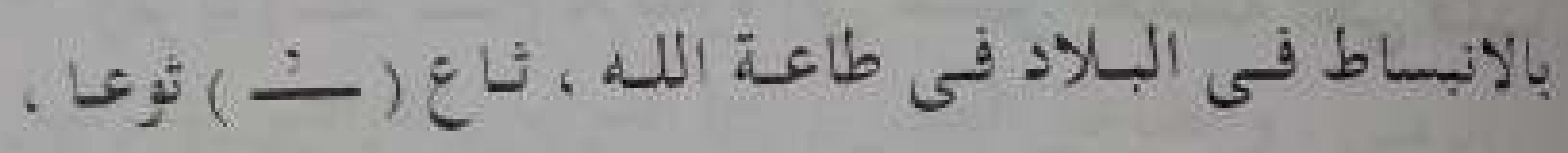

$$
\text { (r) }=\ldots \times \text { ق }: \text { : }
$$

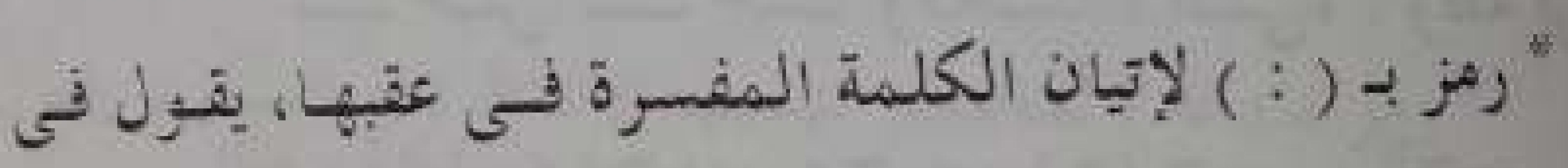

$$
\text { - : ثادور) }
$$

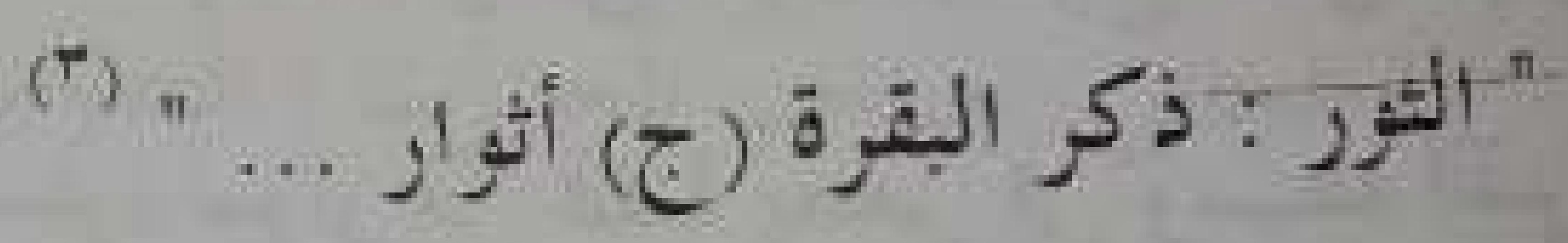

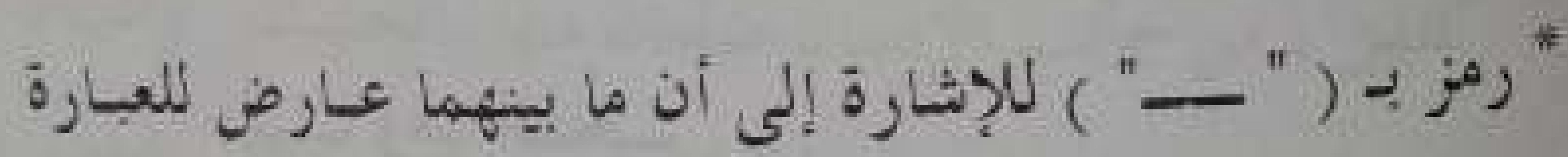

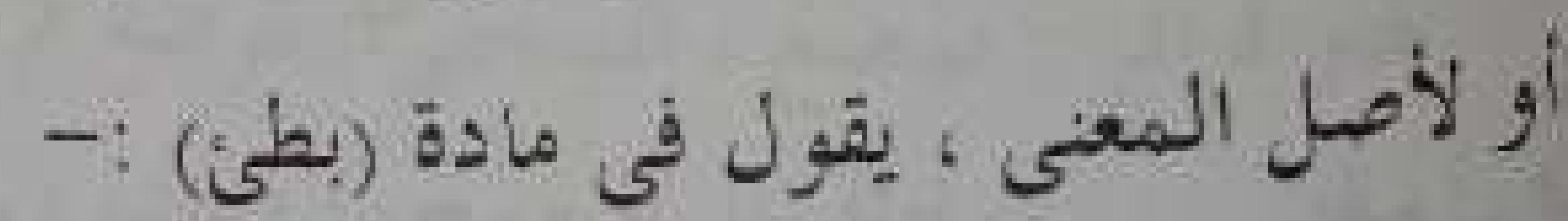

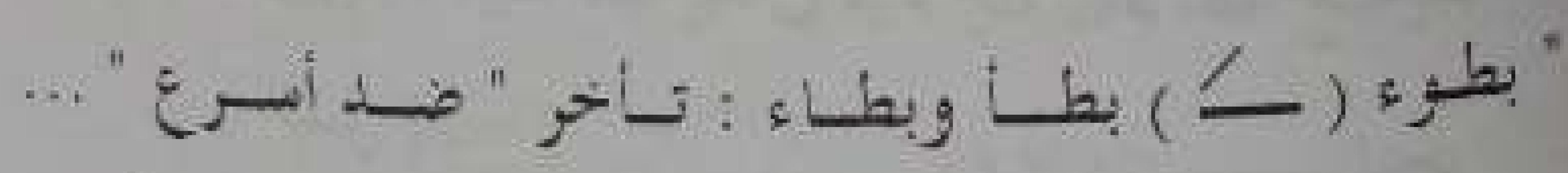

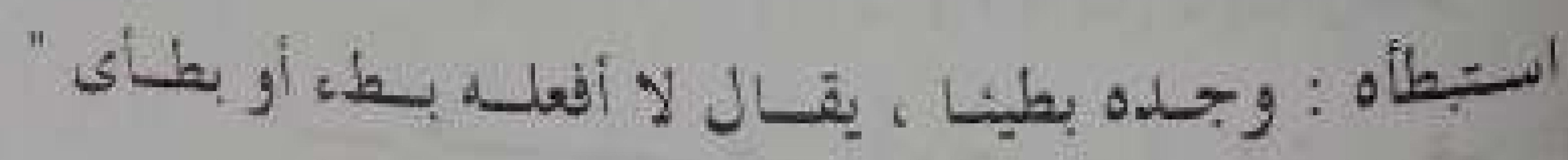

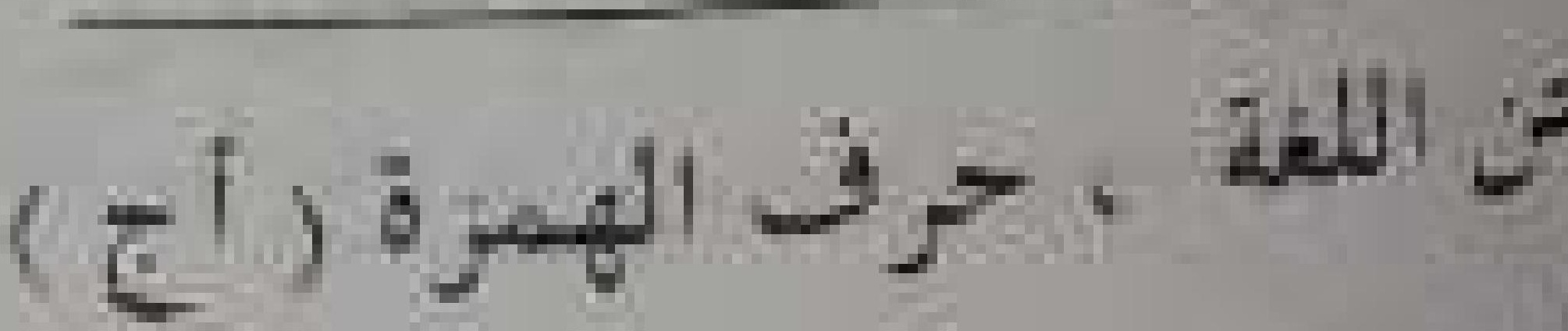

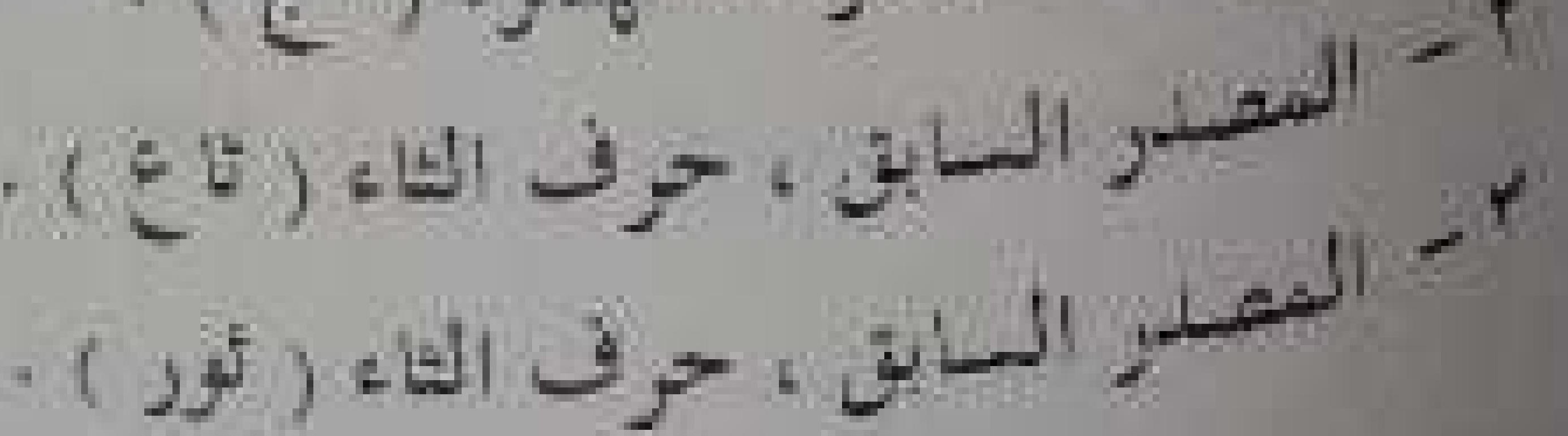

Sen $-4 R-$

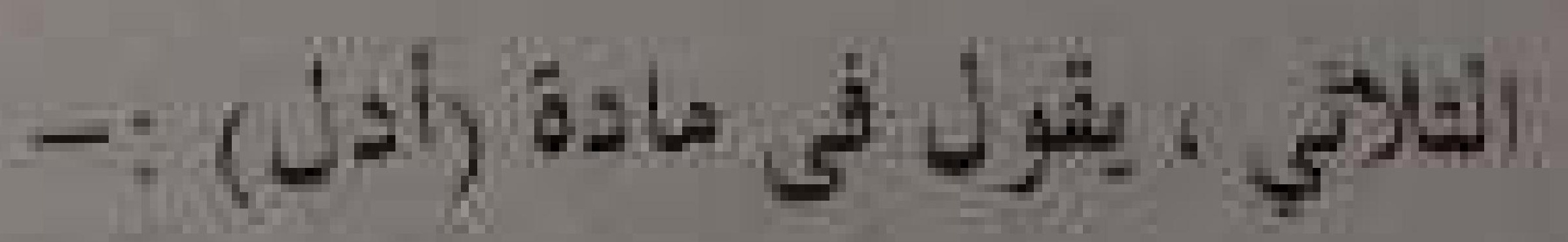

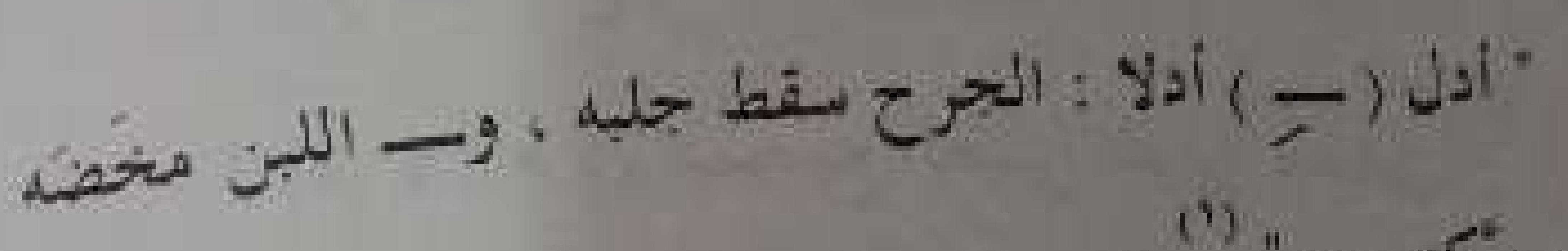
(1) $1 . . .5 \% 3$ "

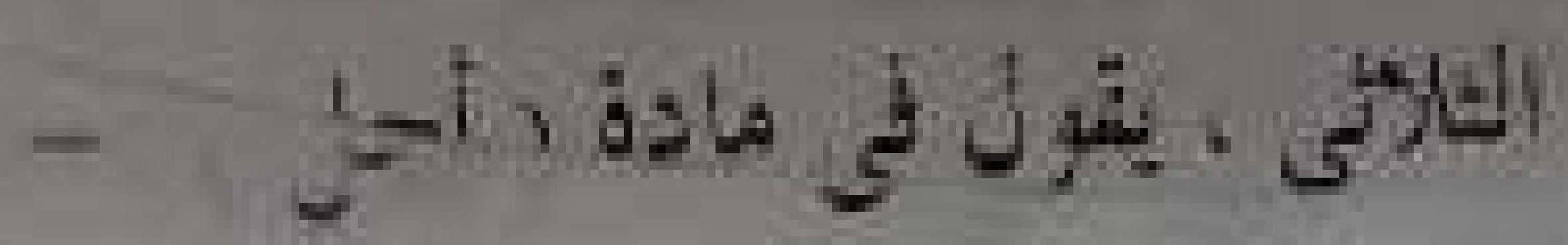

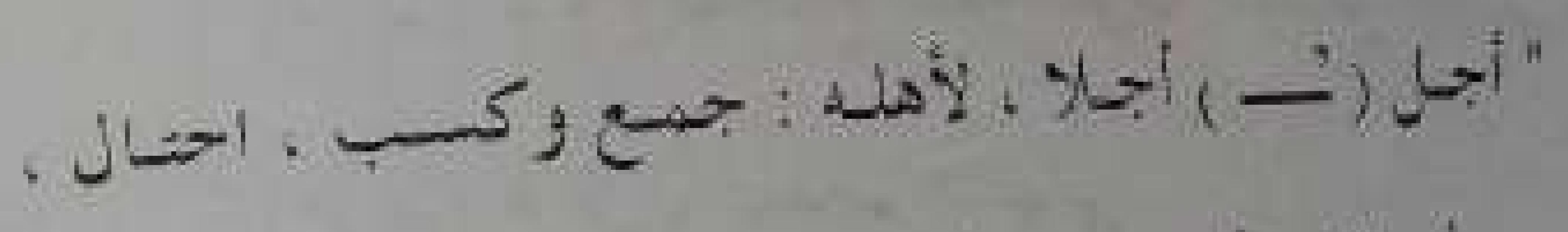

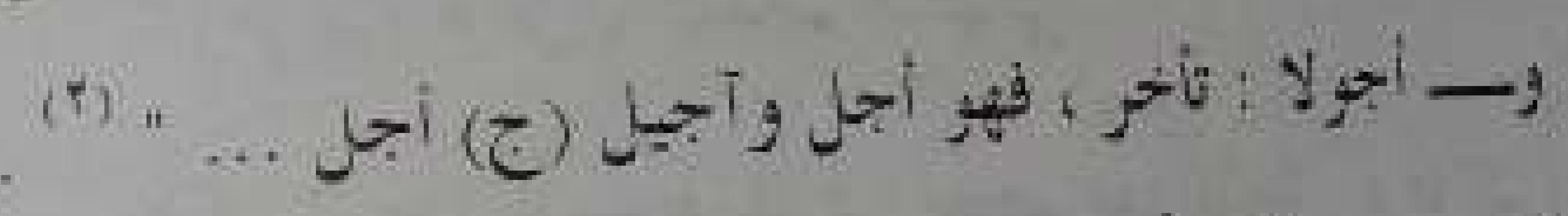

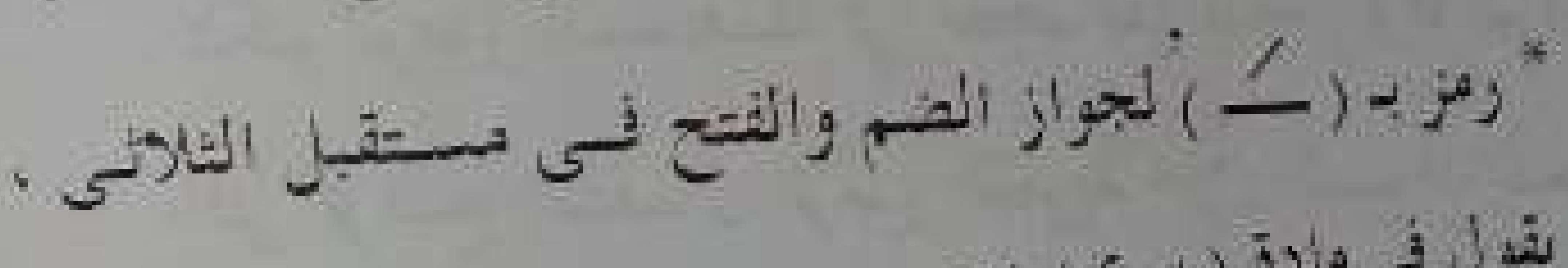

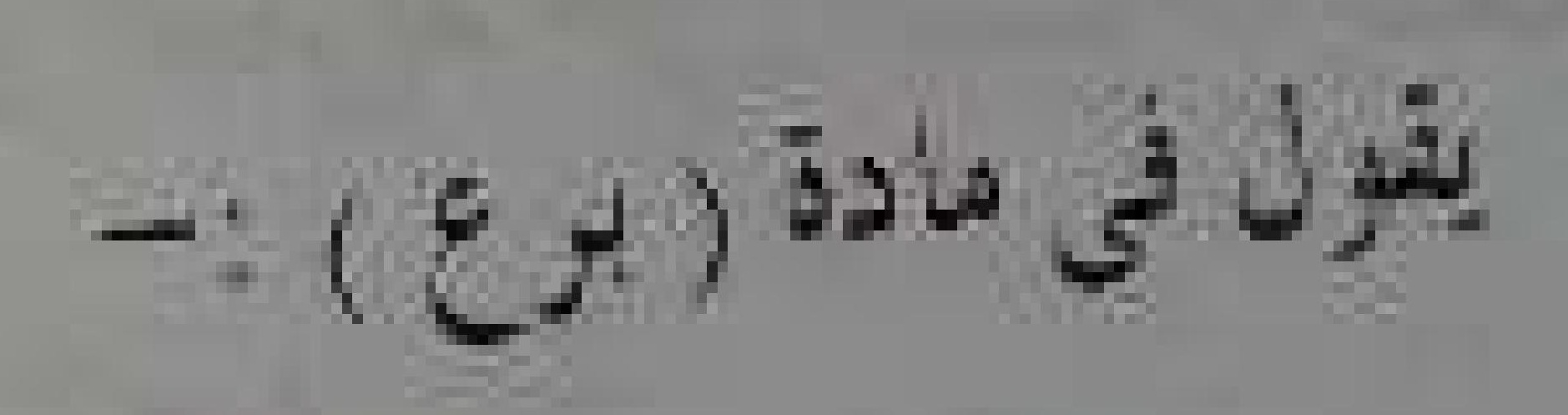

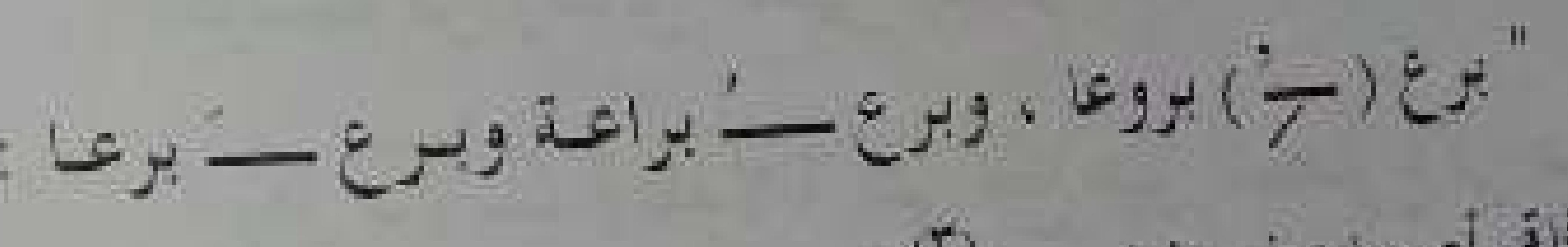

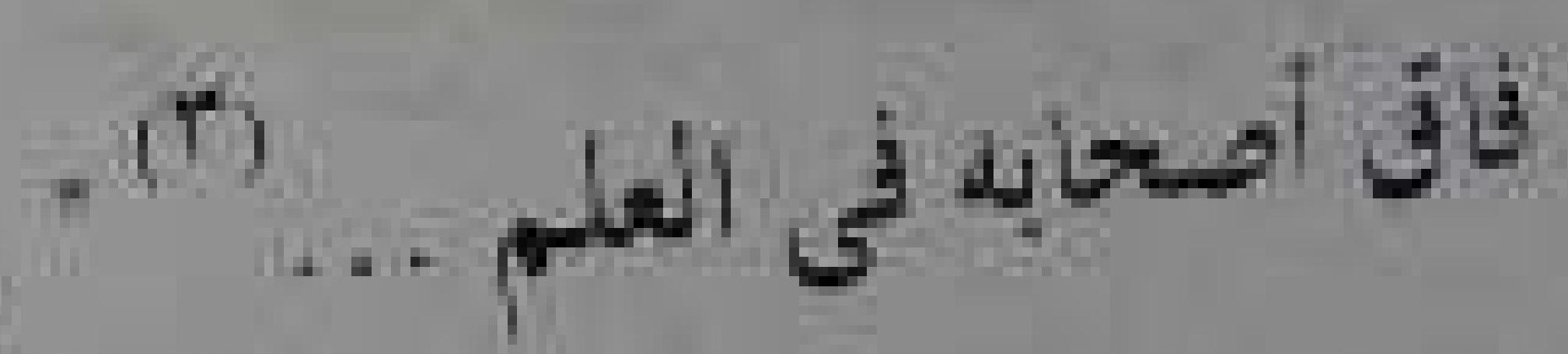

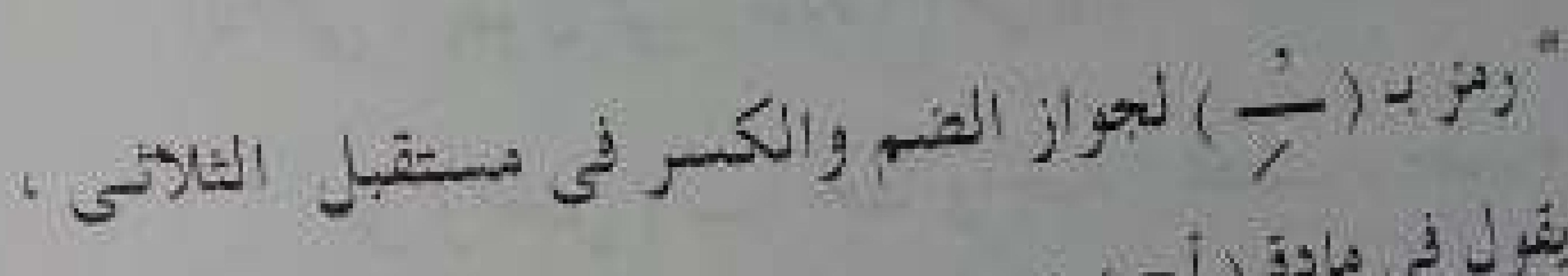
$-:\left(\tau^{i}\right)^{320} \mathrm{~s}^{3} \mathrm{~d}+\mathrm{j}^{3}$ .

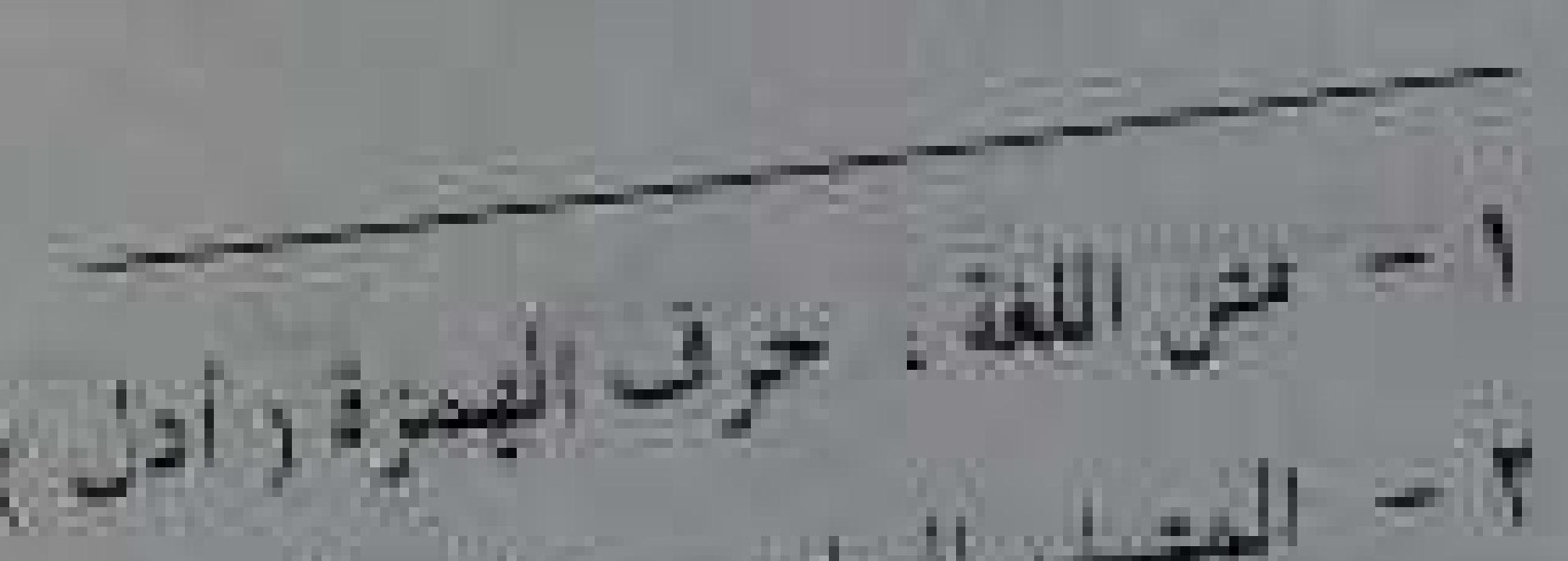
(j)

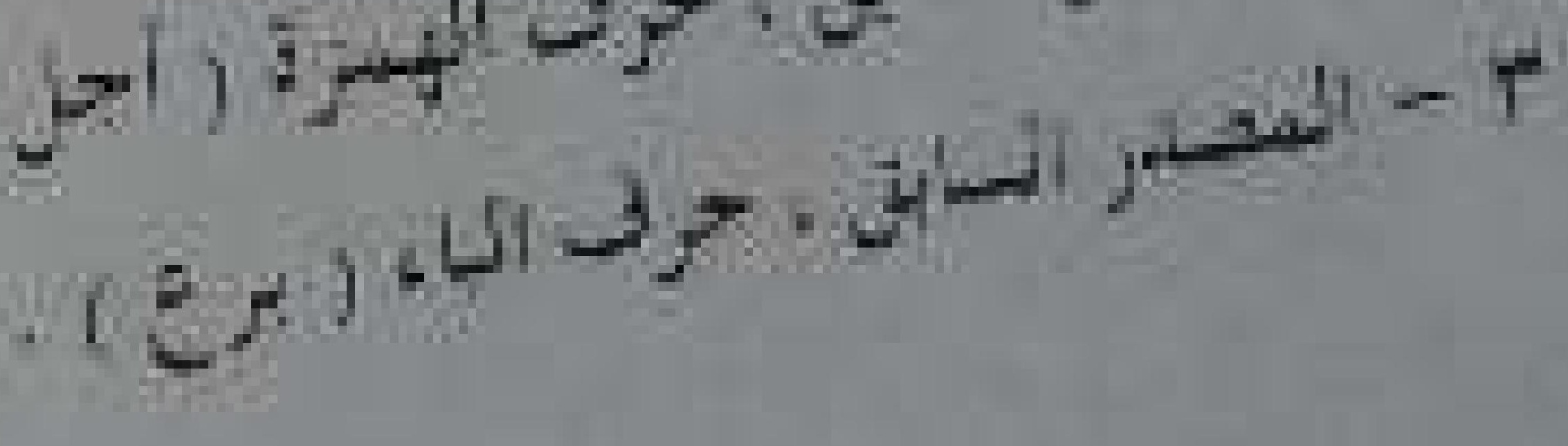




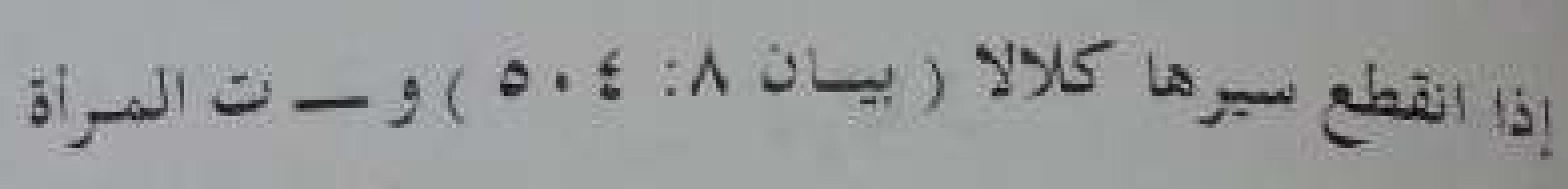

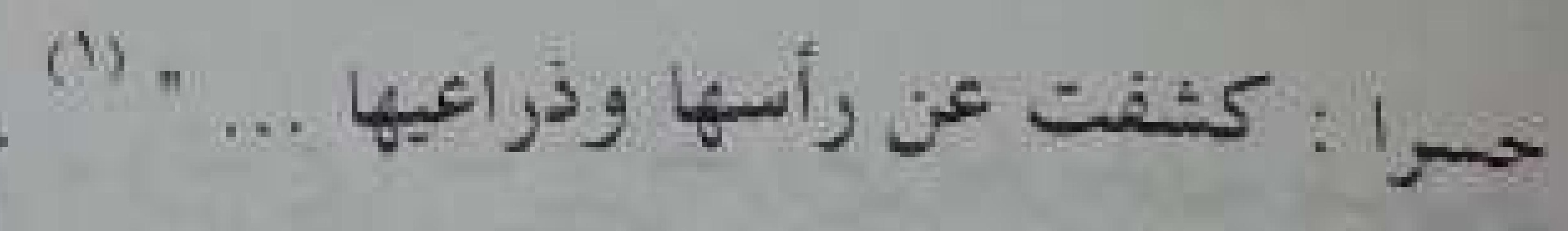

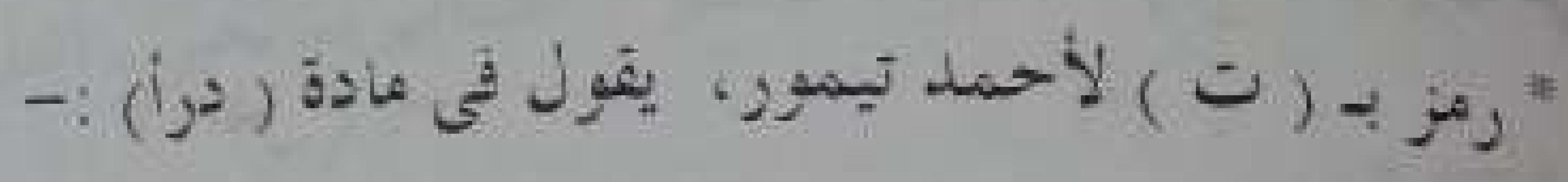
" اللدرئ : الميل والعوج أو ذلك خاص بالقناة وائعـا...

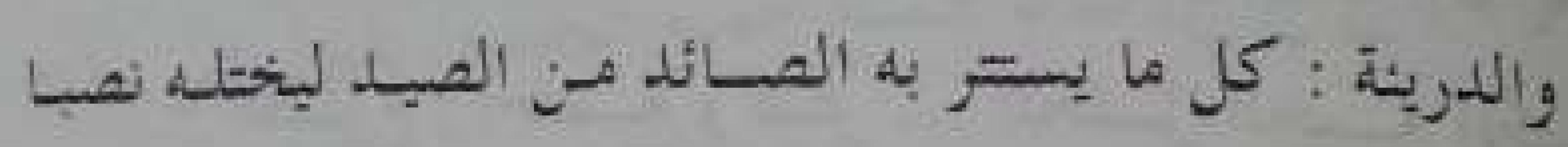

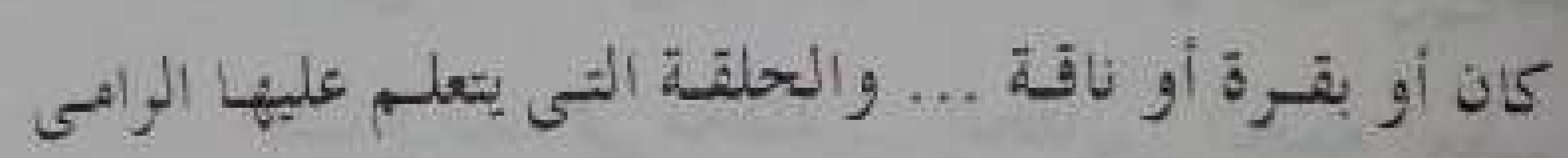

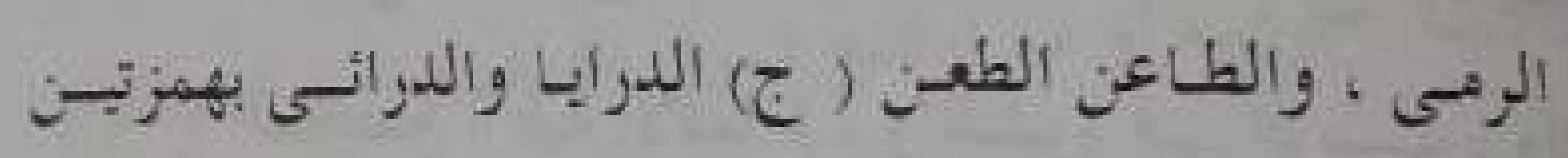

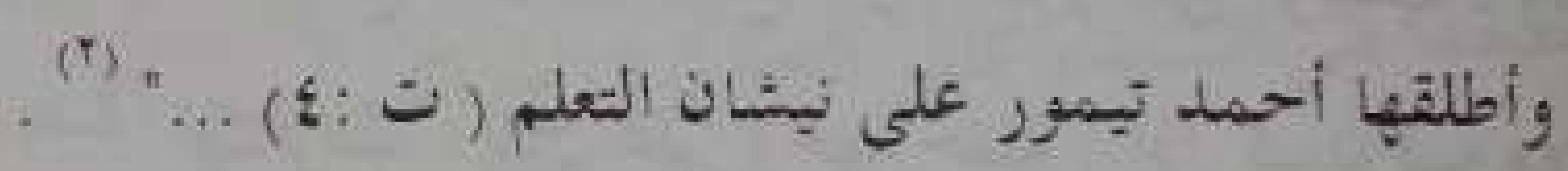
" رمز ب- (ته ) لمبختصر تهذيب الألفاط لابن السكيت بقترل

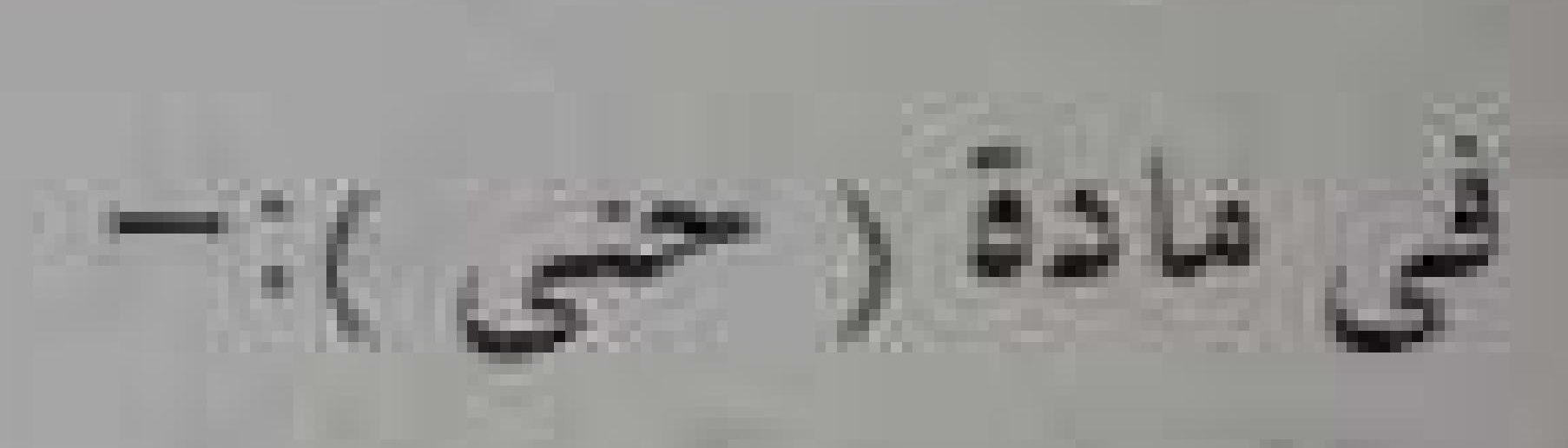

" الحانى : صاحب الحانوت : الحلواني ، أطول الأضـلاع كلهن ، هي حانب الانسان فلعان منها، الحبيان : واديبن ،

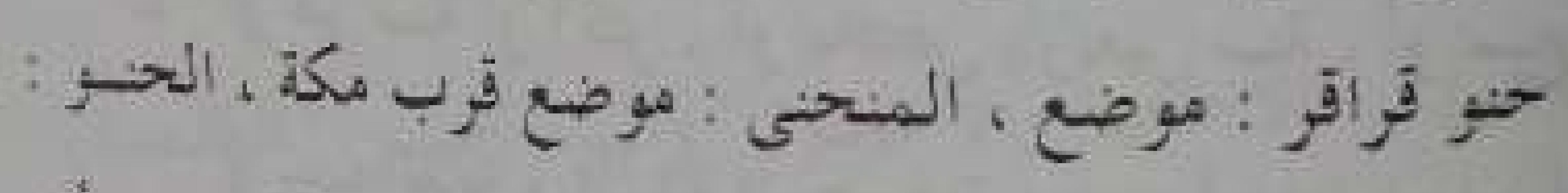

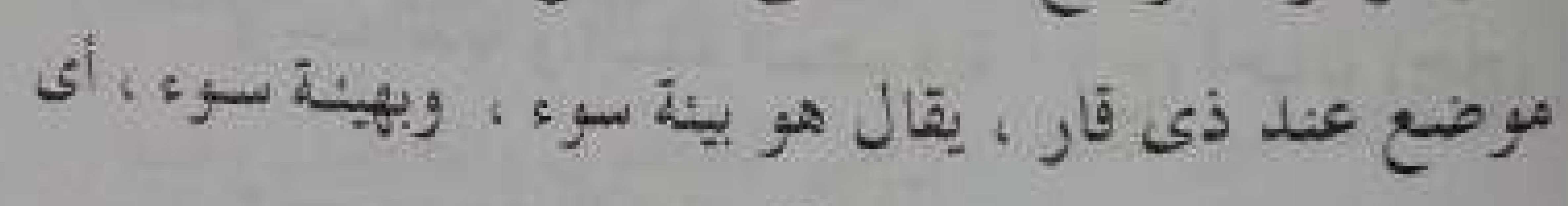
(T) " ... (1V d (J)

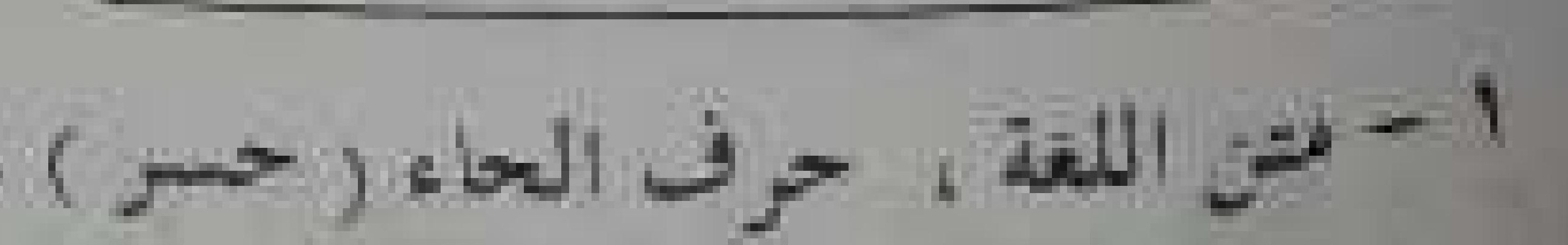

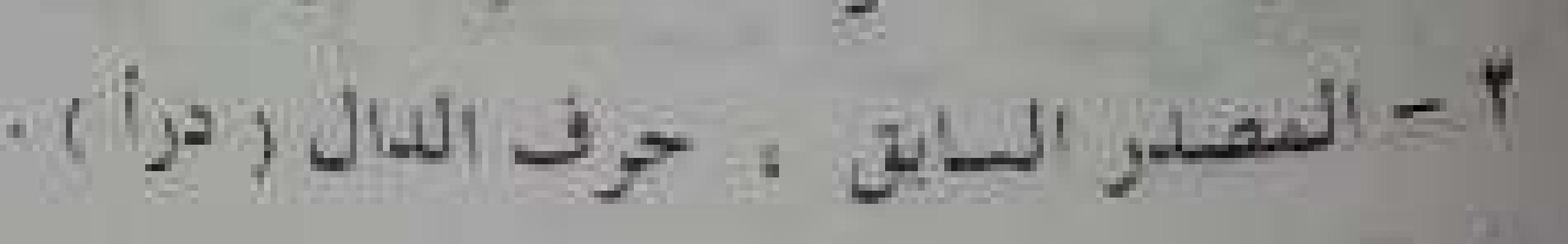

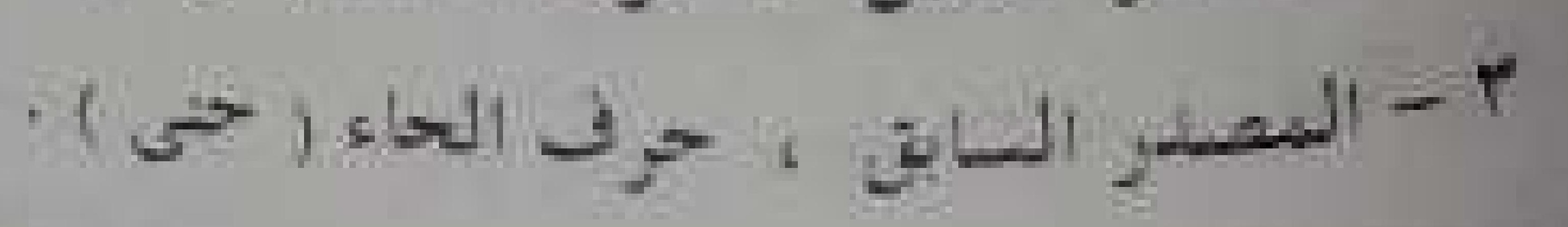

- $q_{t},-$

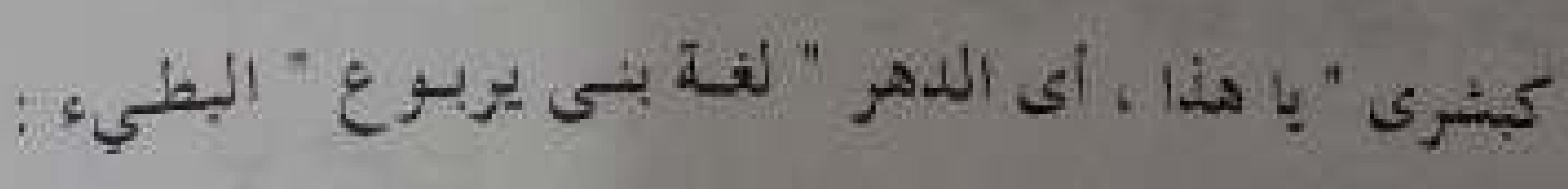

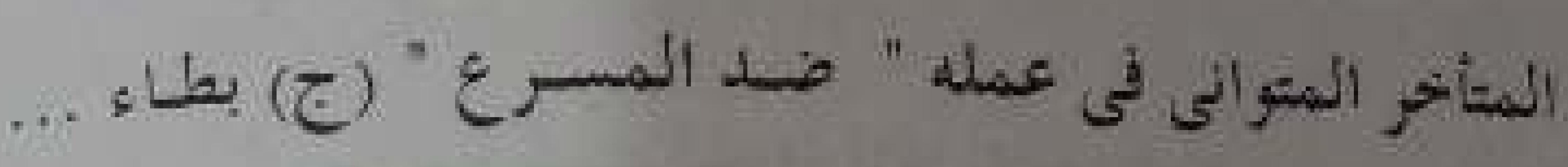

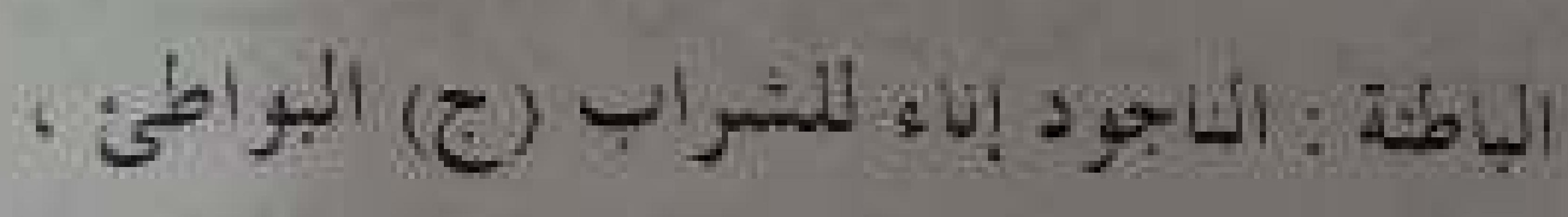

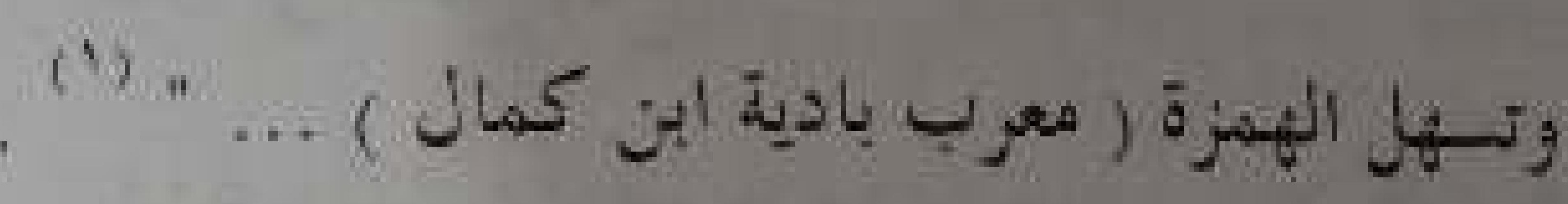

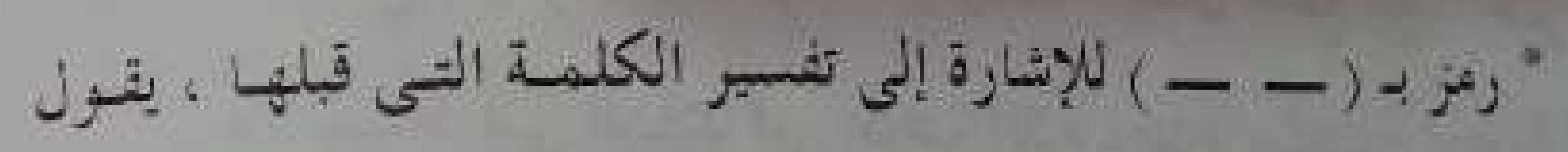

$$
-:(u \rightarrow) \text { 3isi }
$$

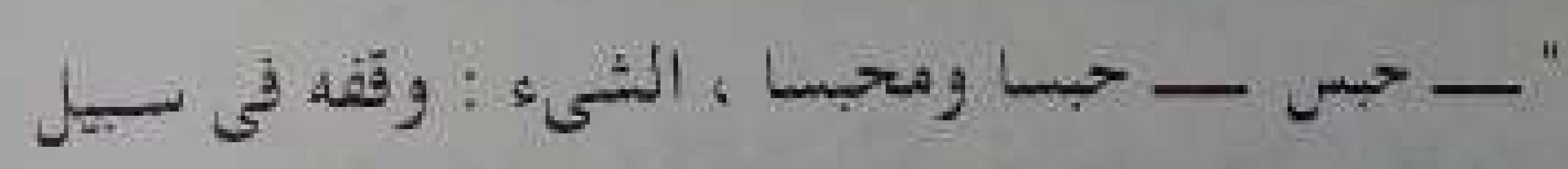

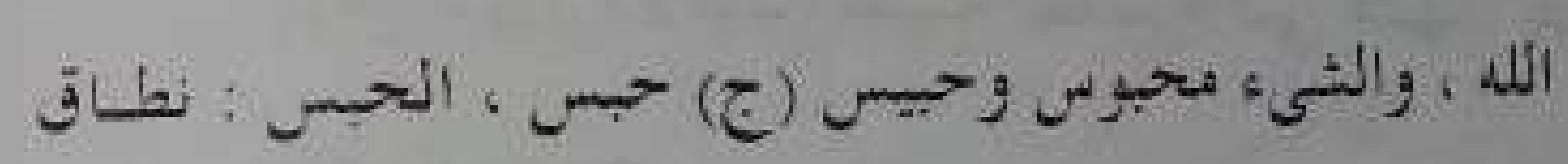

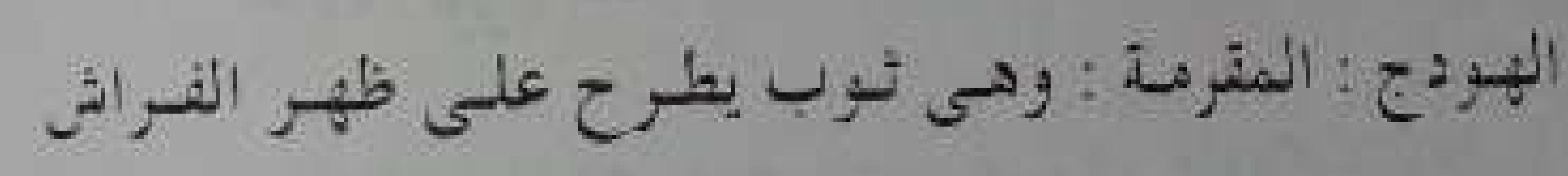

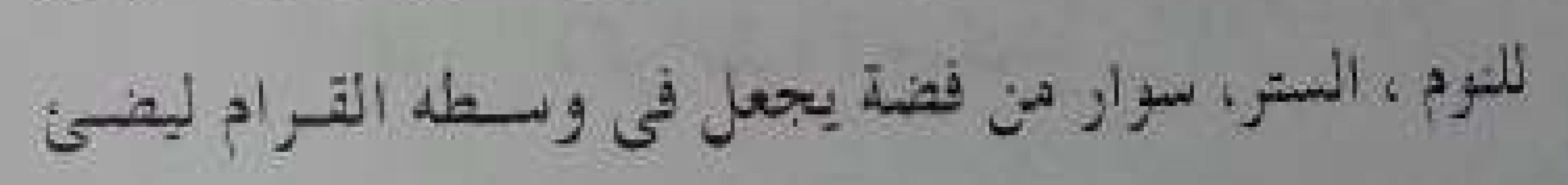

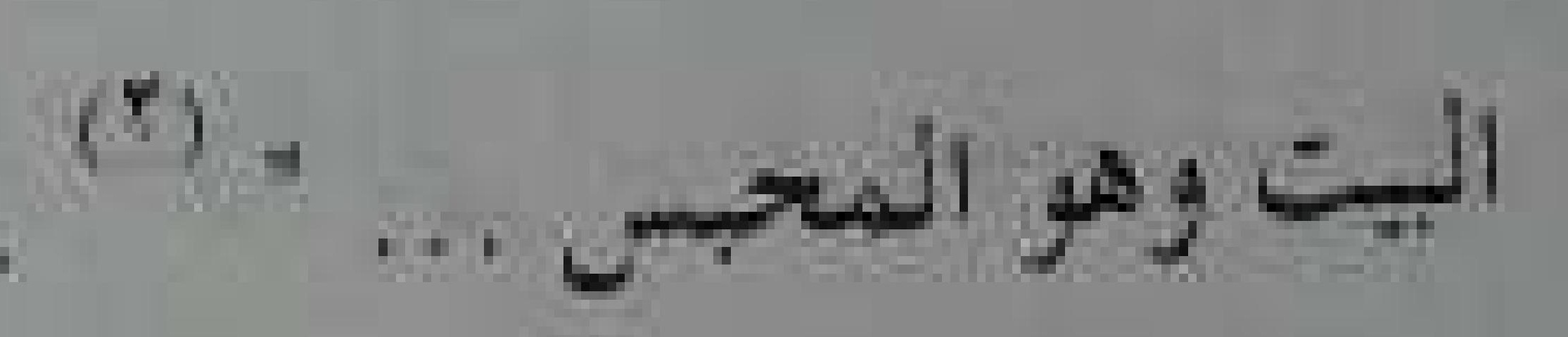

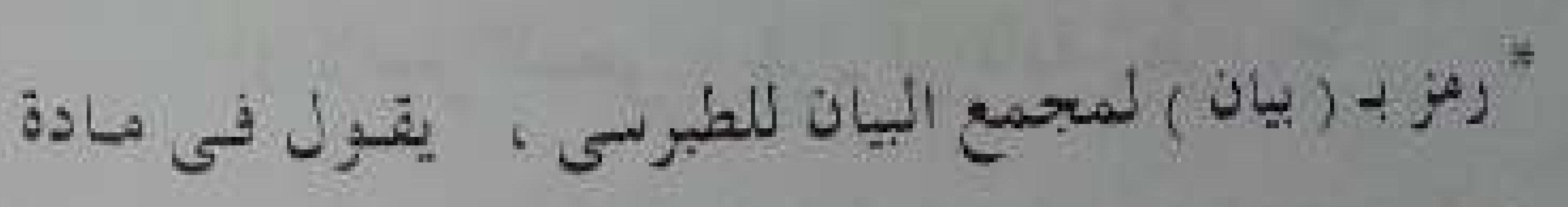
$-:(r)$

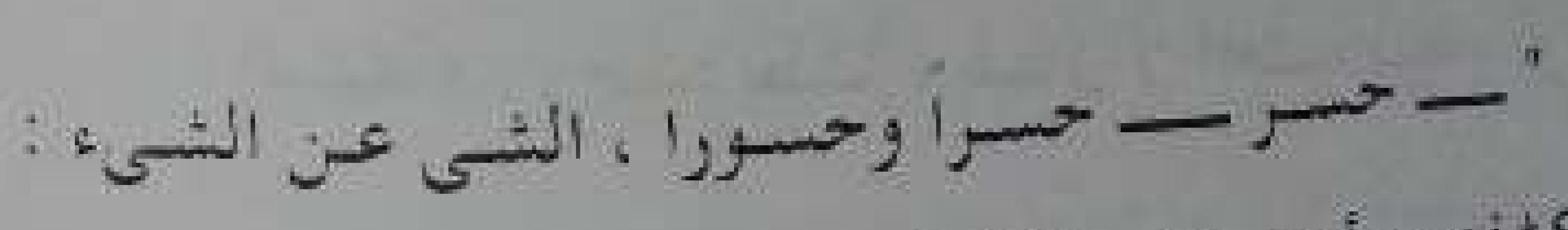
كثفه ، وأصل الباب الانقط ع ويقال : انحسروت وحسر الدابة :

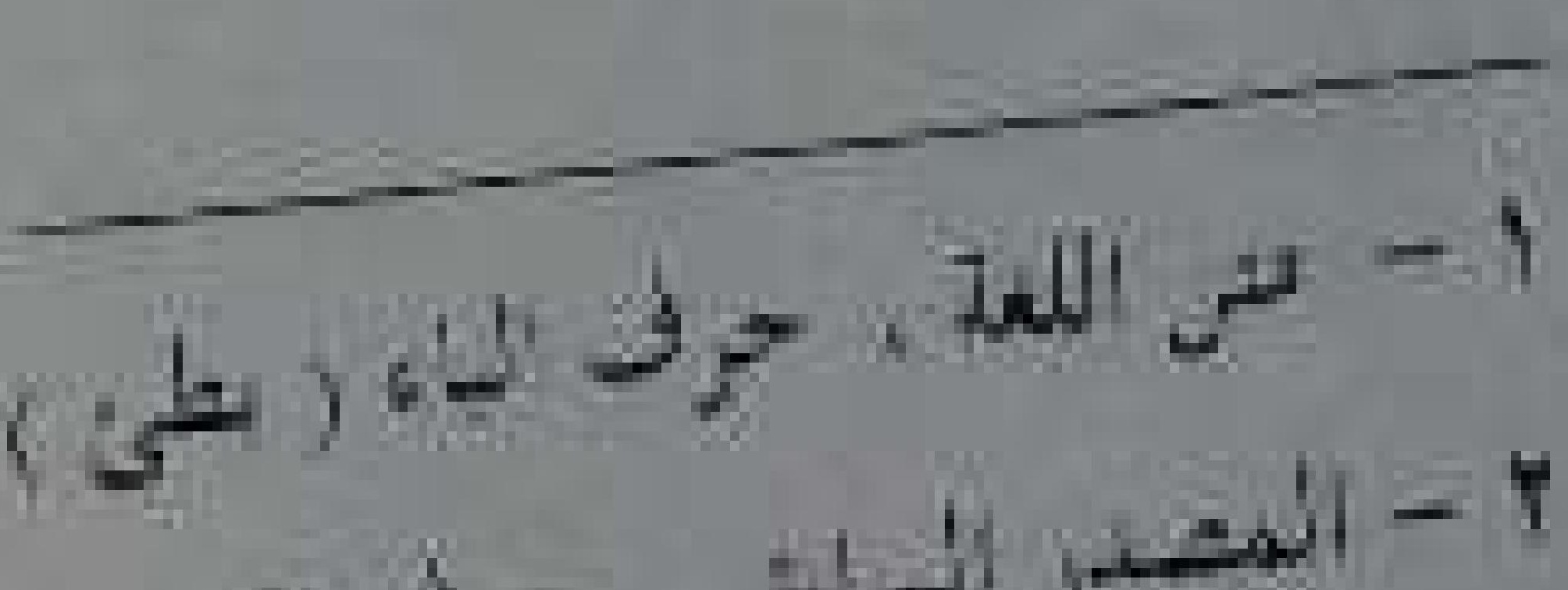

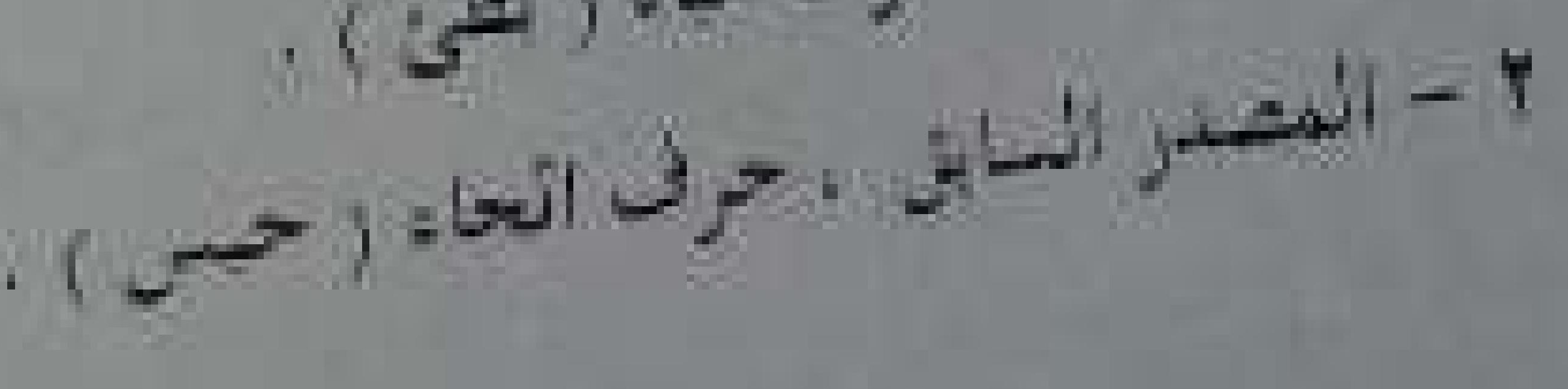




\section{- r $\leqslant r-$}

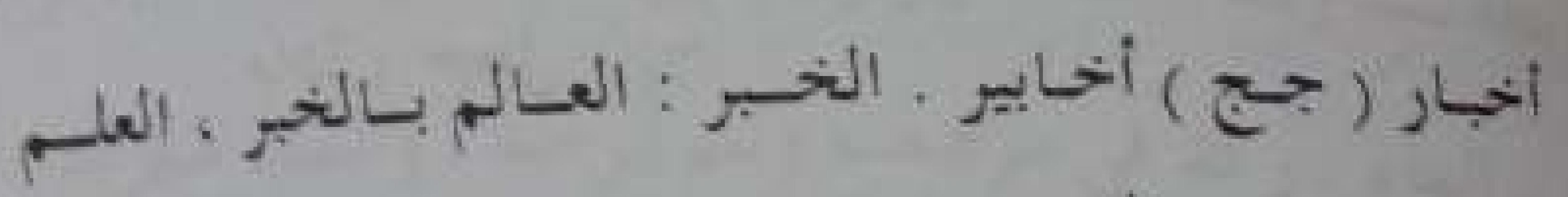

$$
\text { (1) ".... بالثي }
$$

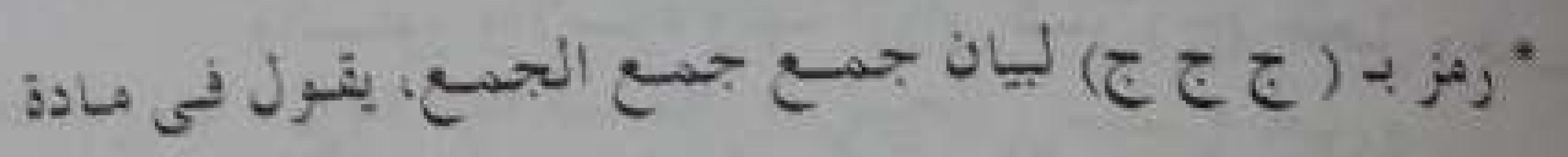

$$
-:(\text { (أ) }
$$

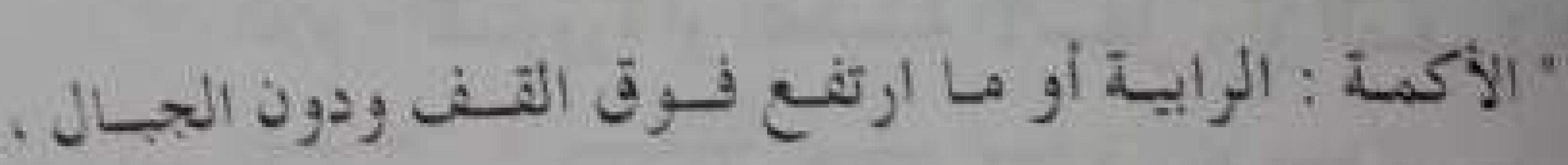

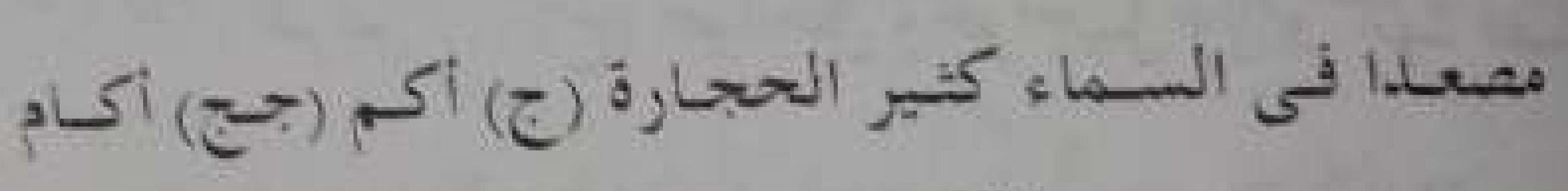

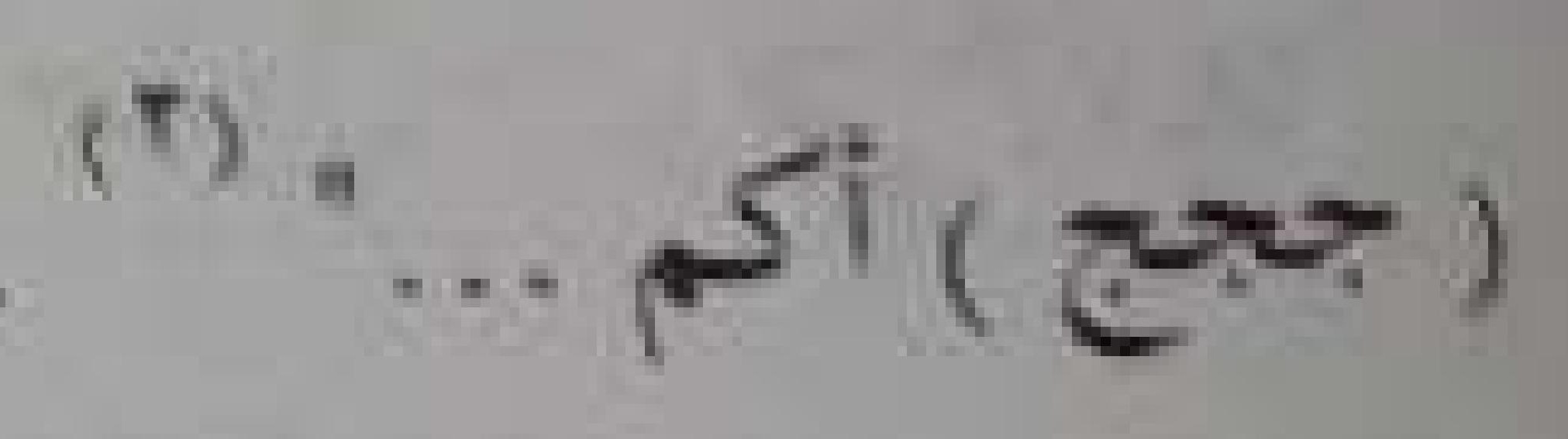

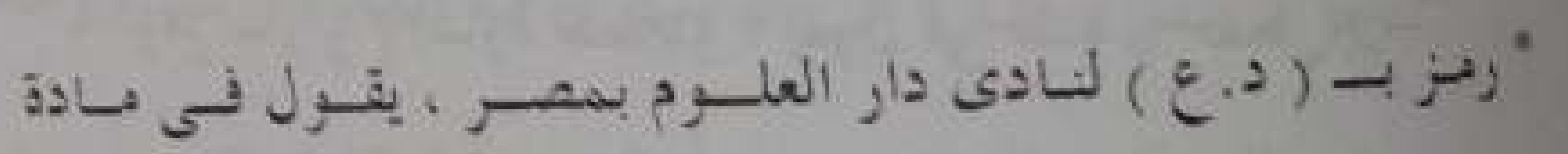

$$
-:(\omega)
$$

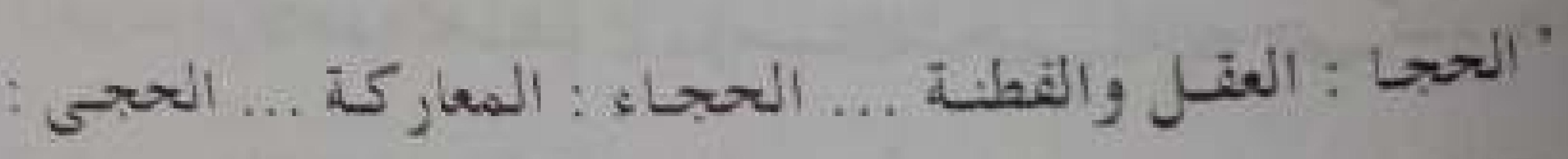

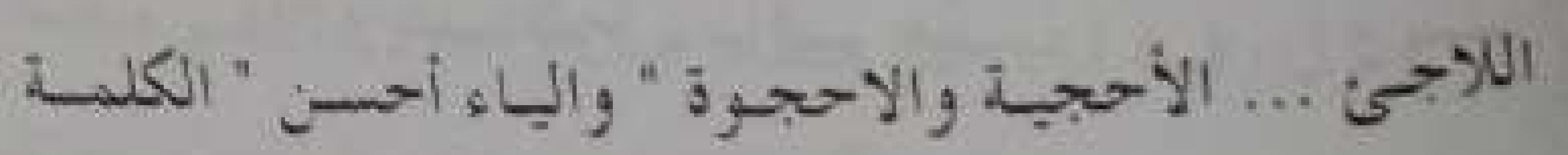

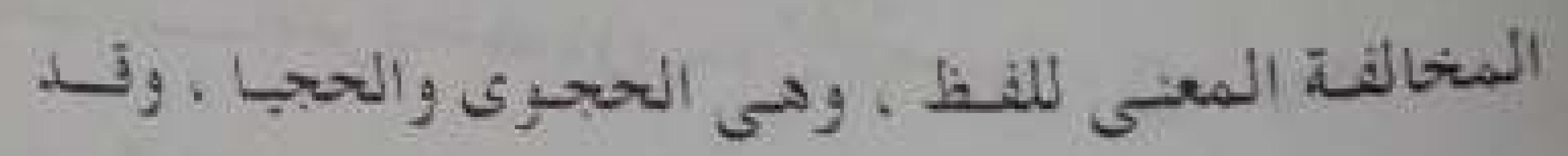

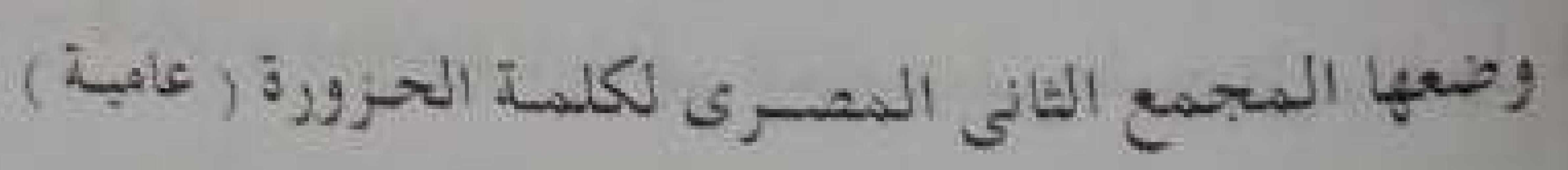

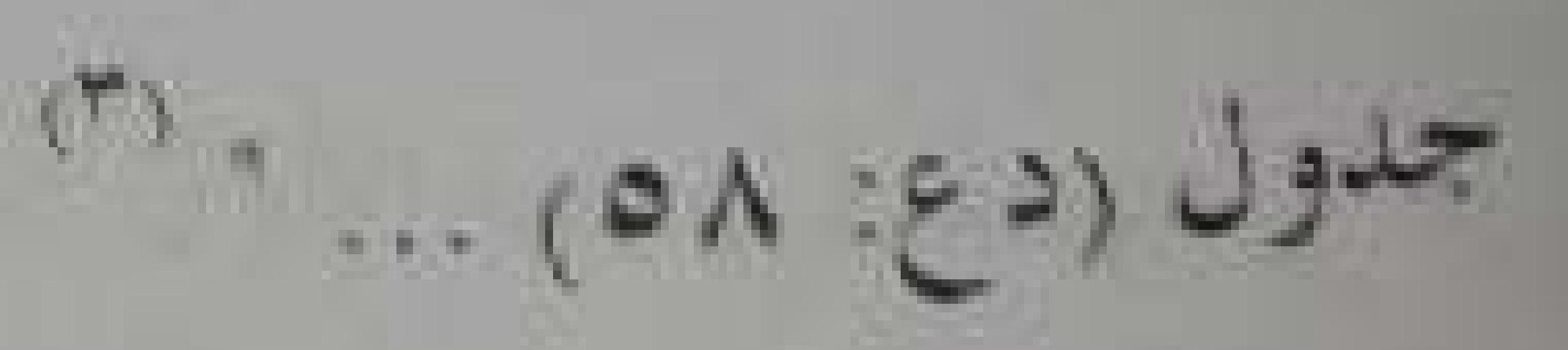

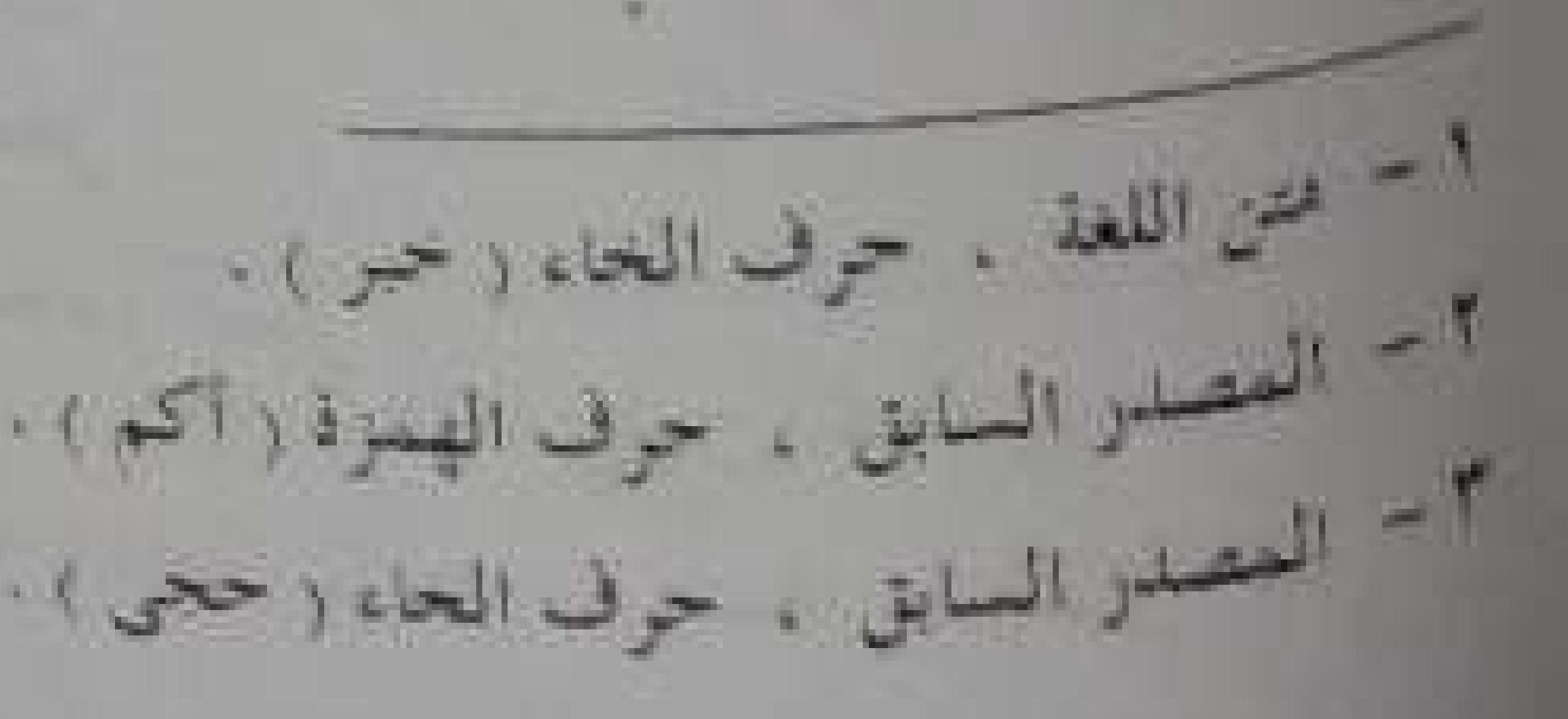

\section{- rir -}

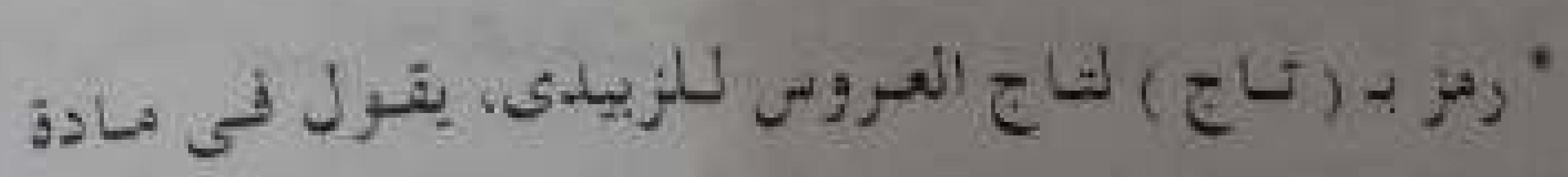

$$
-:(j)
$$

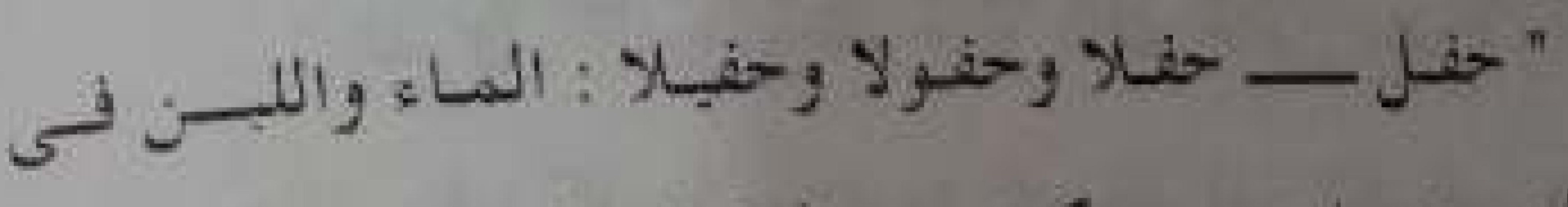

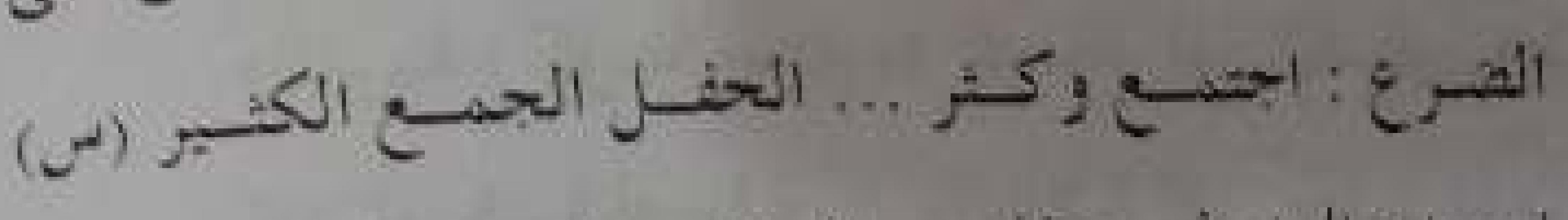

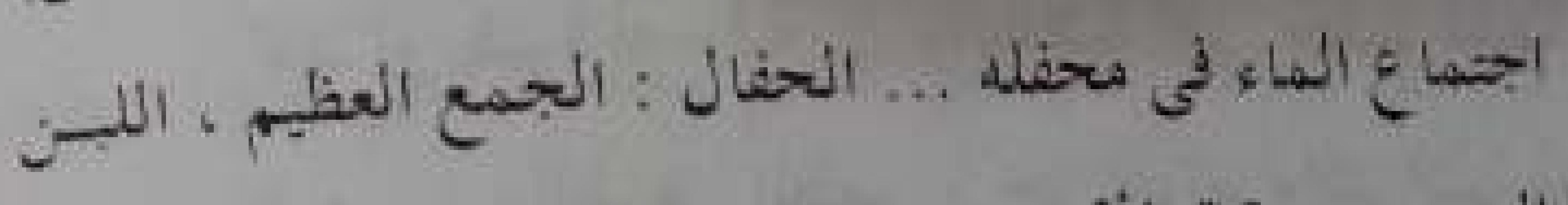

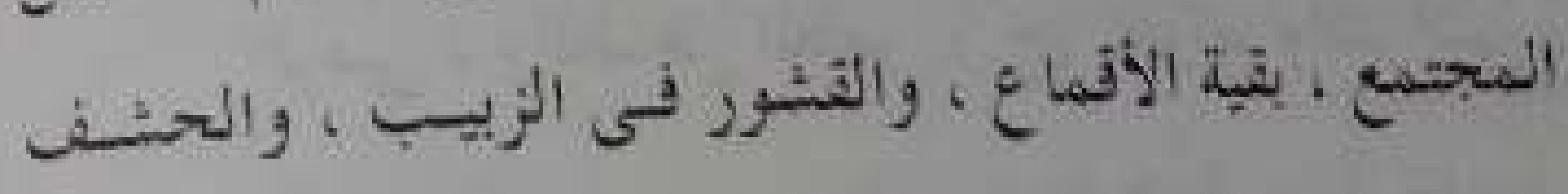

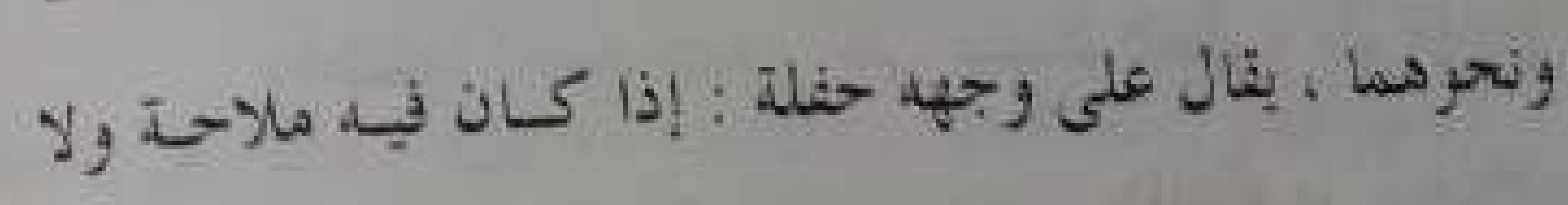

$$
\text { (1) ".... (נ) }
$$

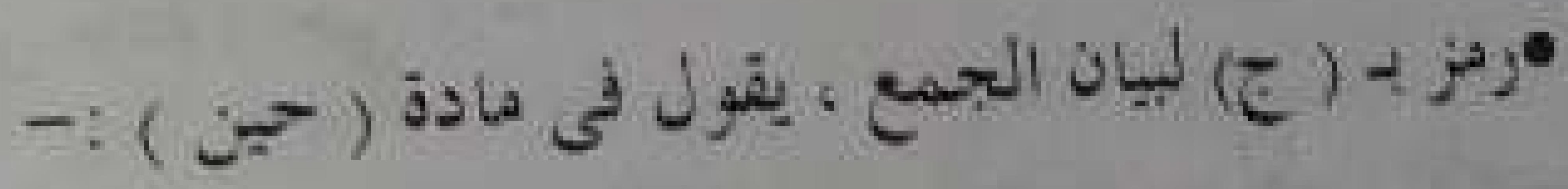

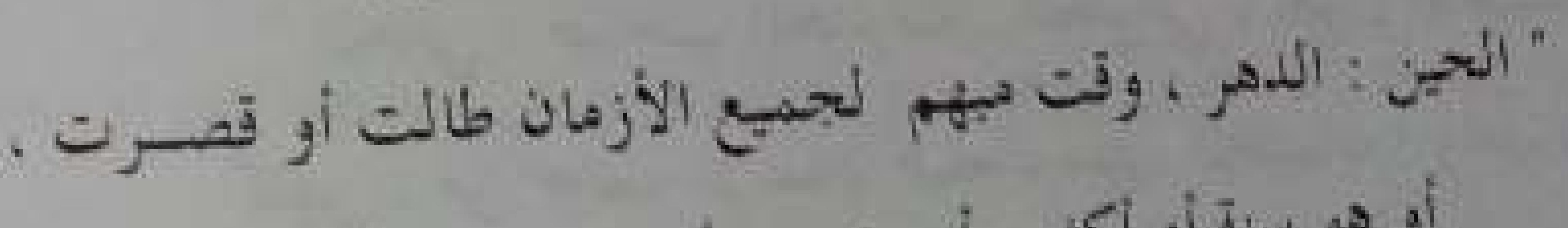

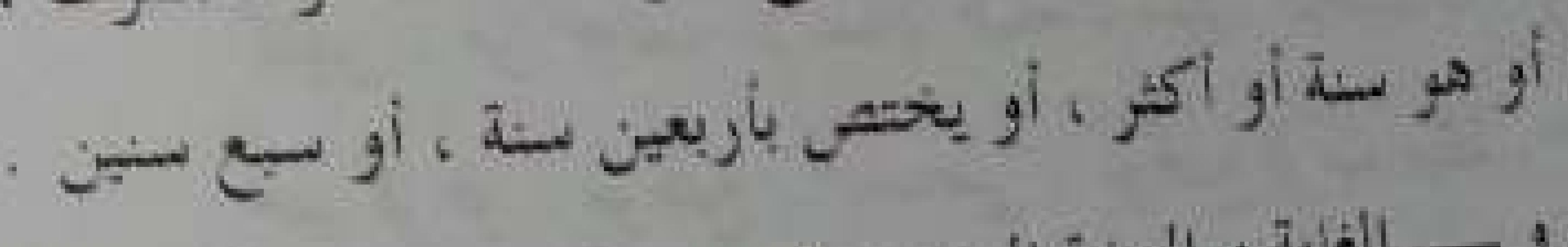

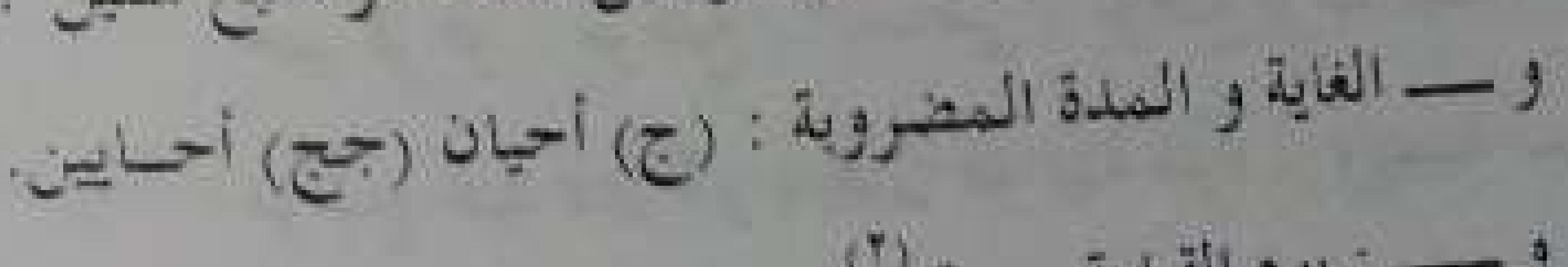

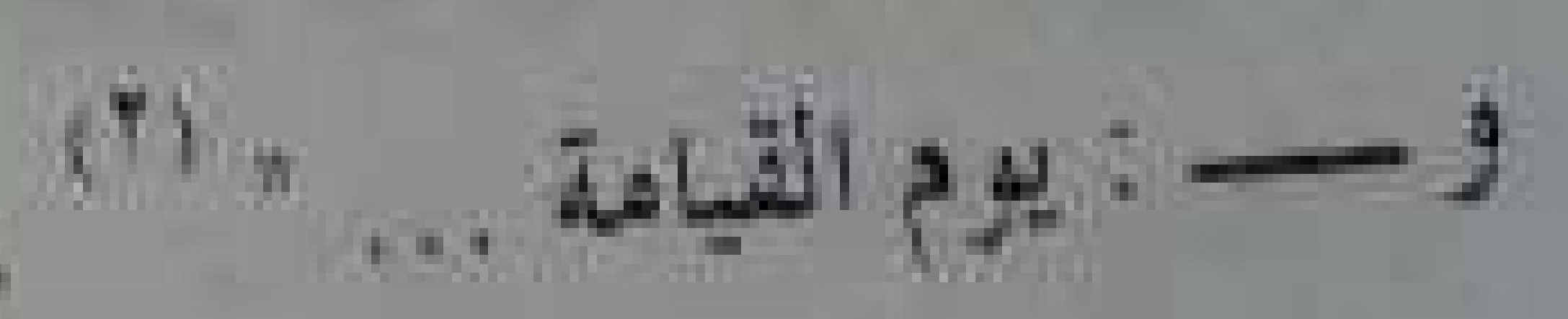

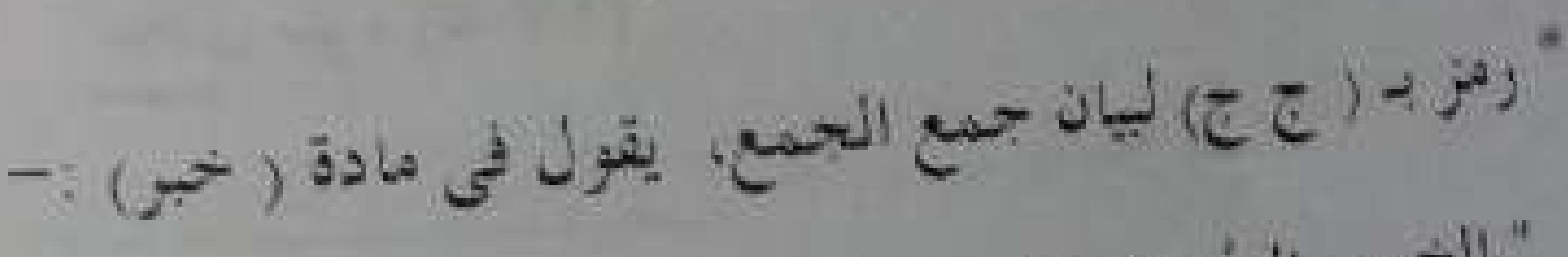

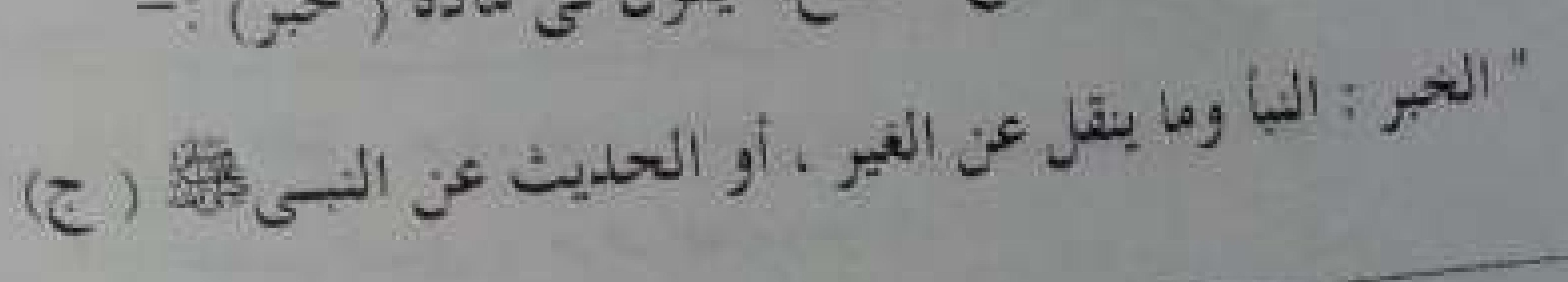




\section{- r $\leqslant 0-$}

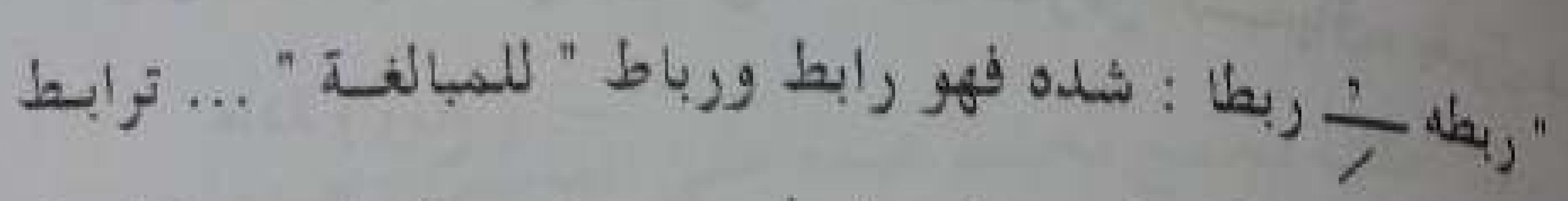

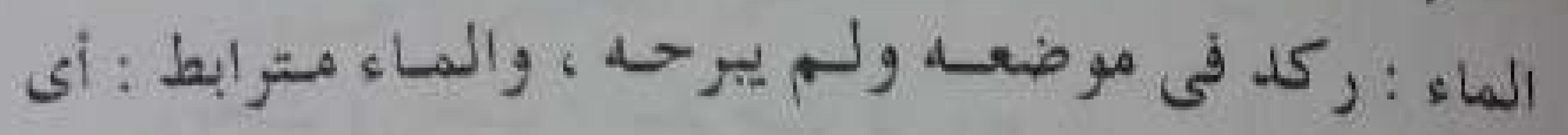

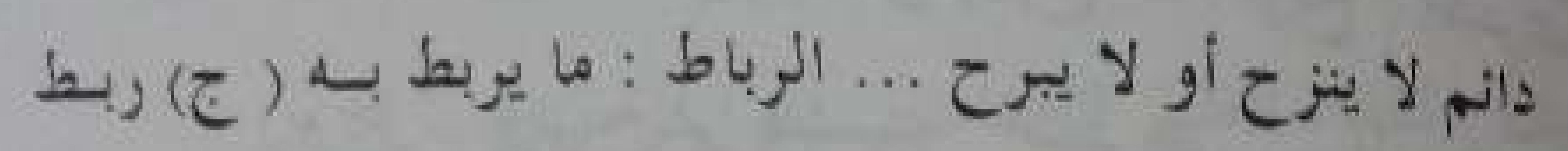

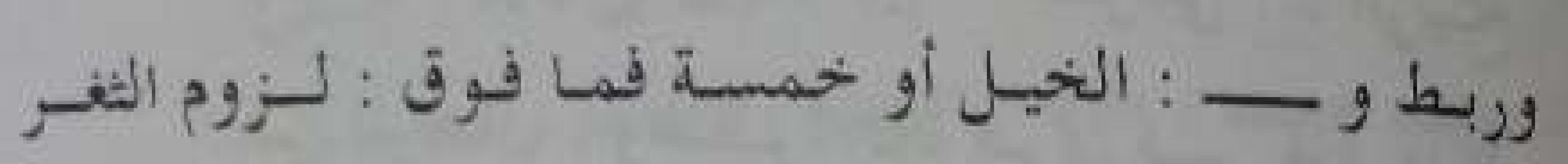

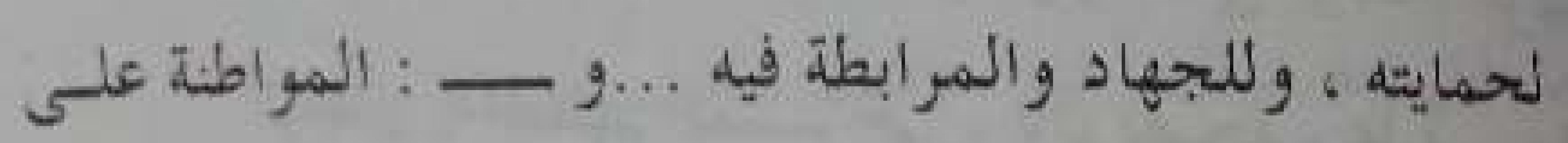

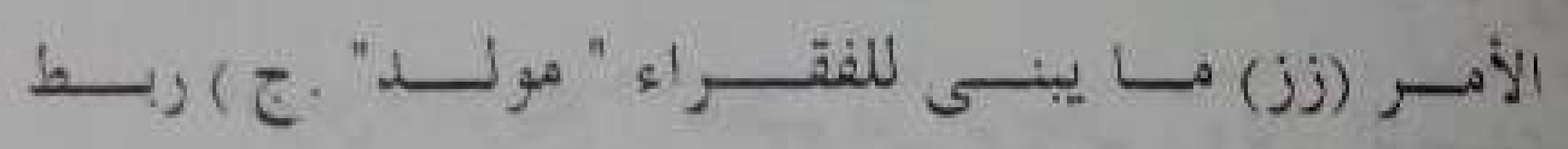

(1) " ... . (1)

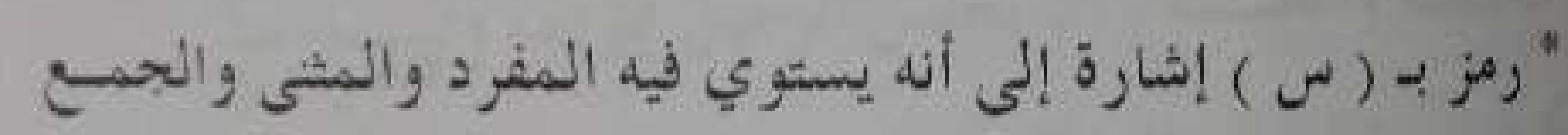
والمذكر والمونث ، يقول في مادة (حل) : "

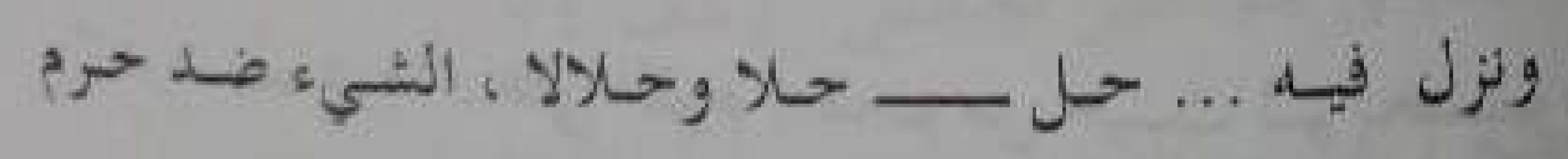

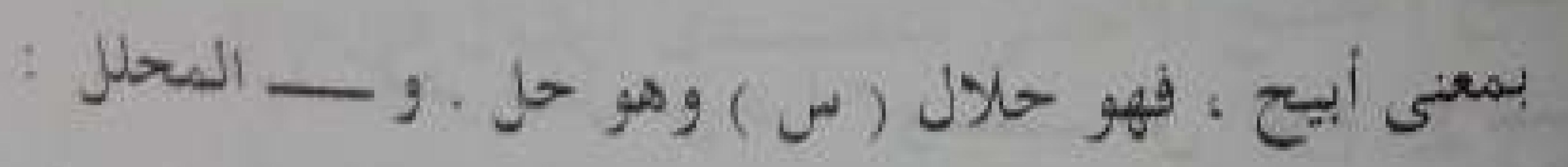

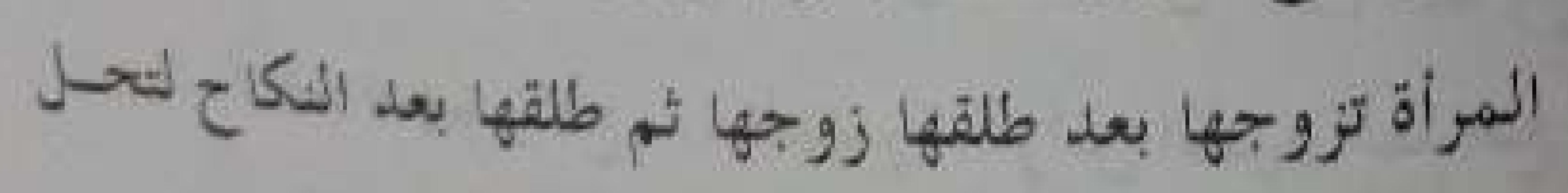

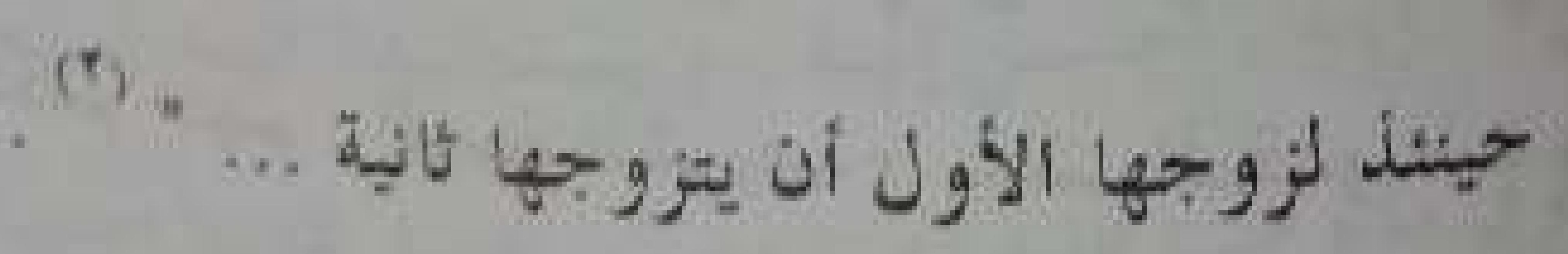

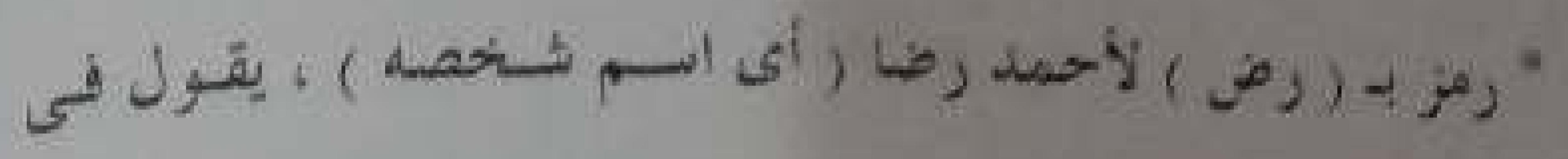
$-:$ ( )

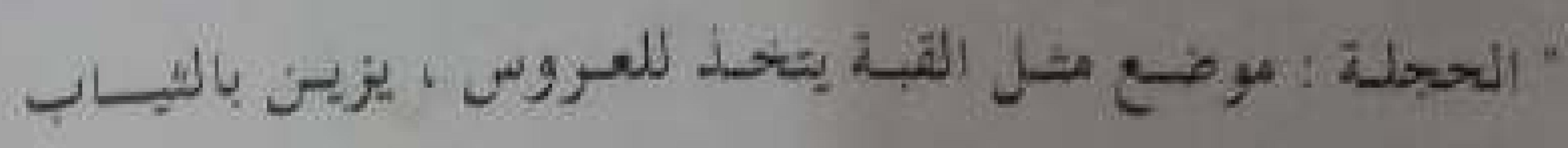

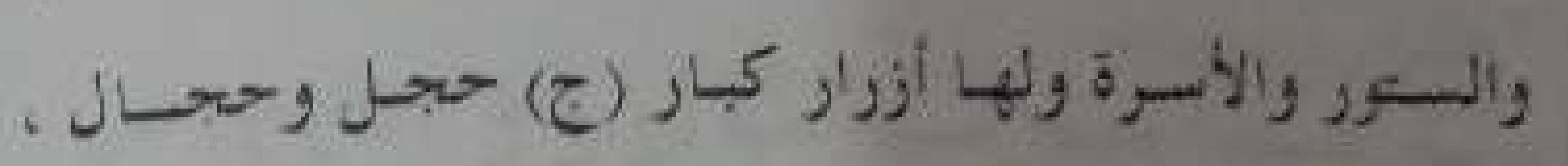

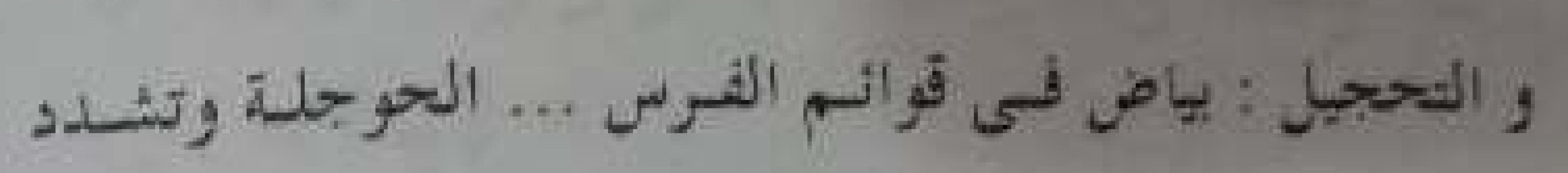

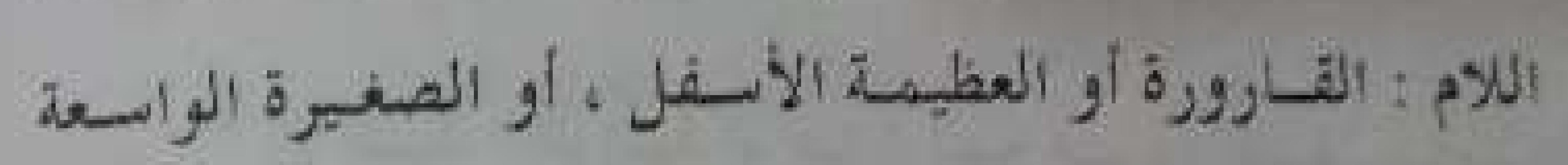

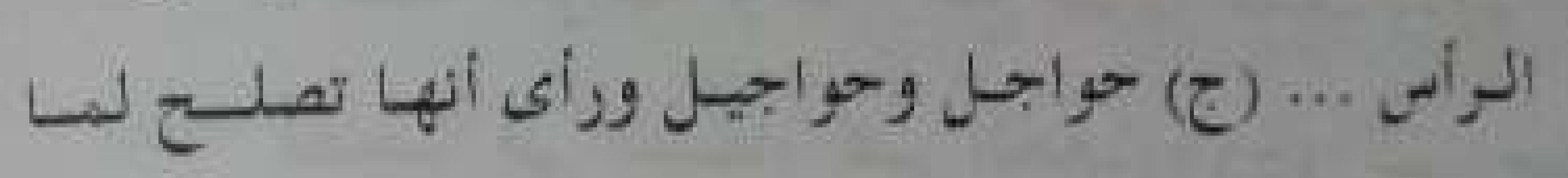

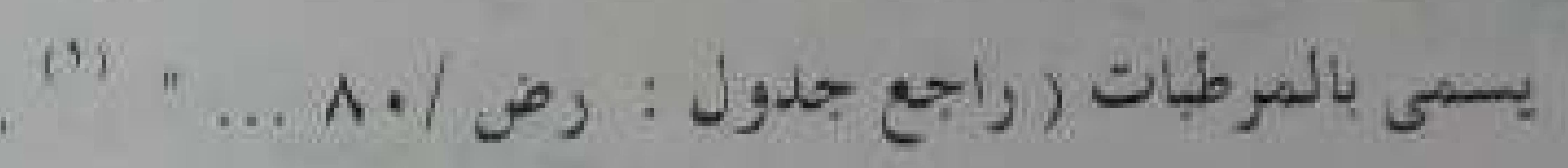

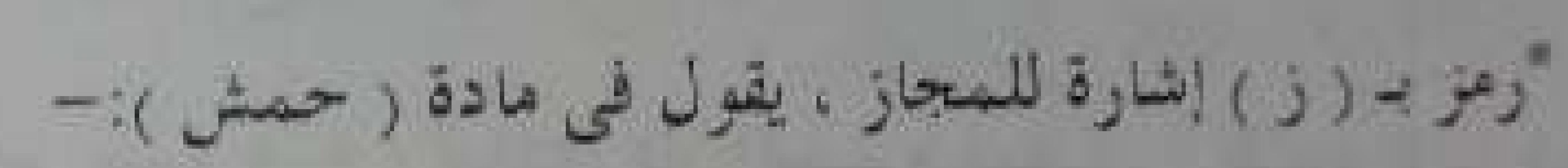

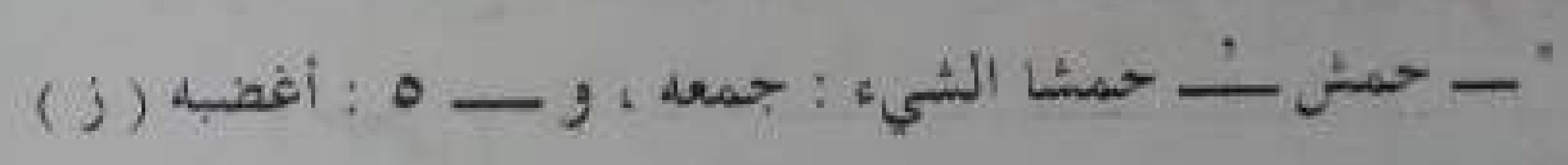

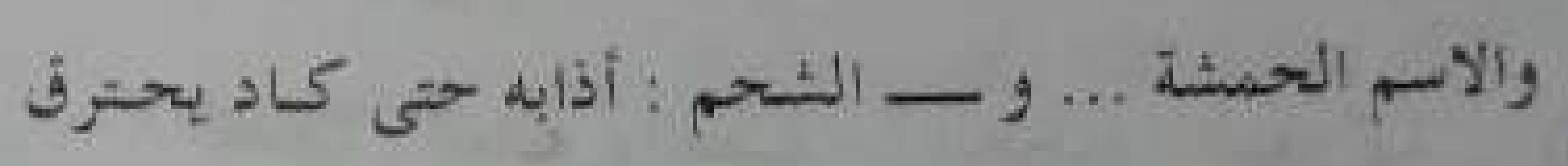

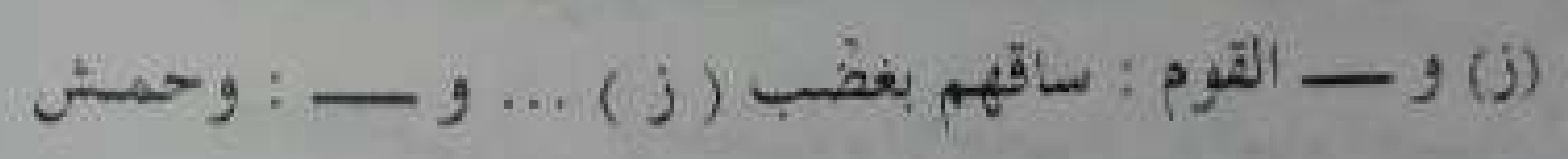

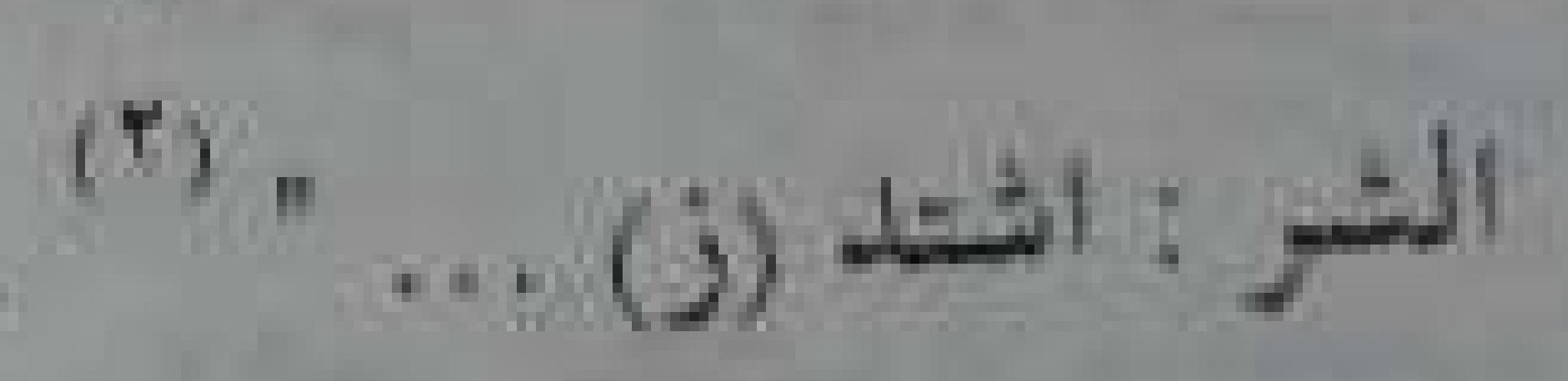

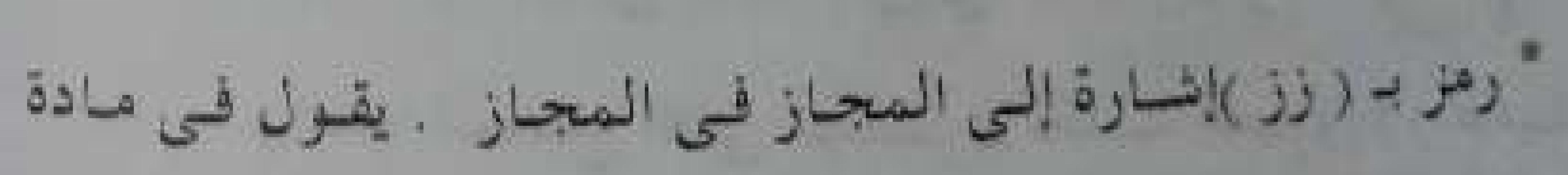
$-:(b y)$ 


$$
-T \leqslant Y-
$$

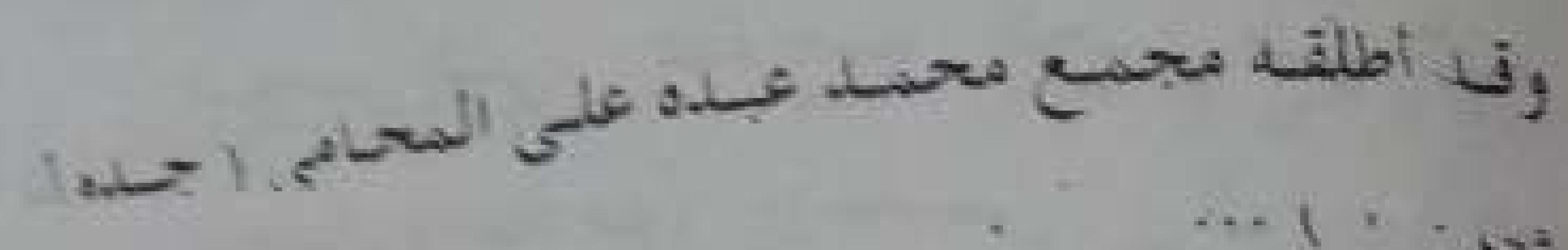

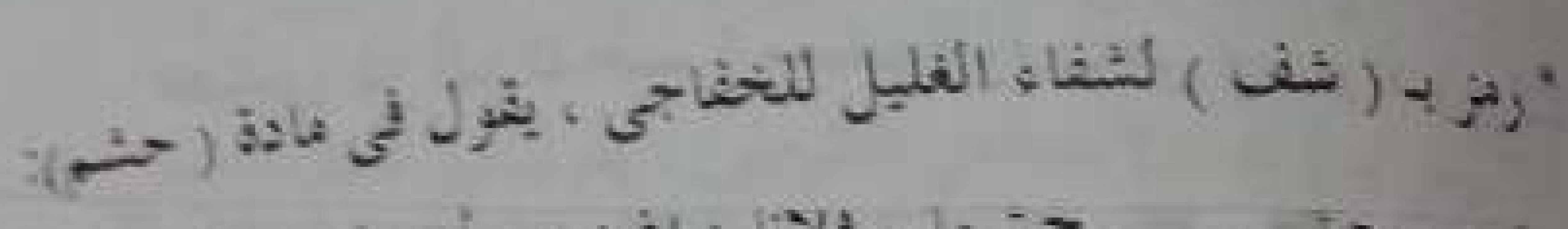
$\longrightarrow+$ :

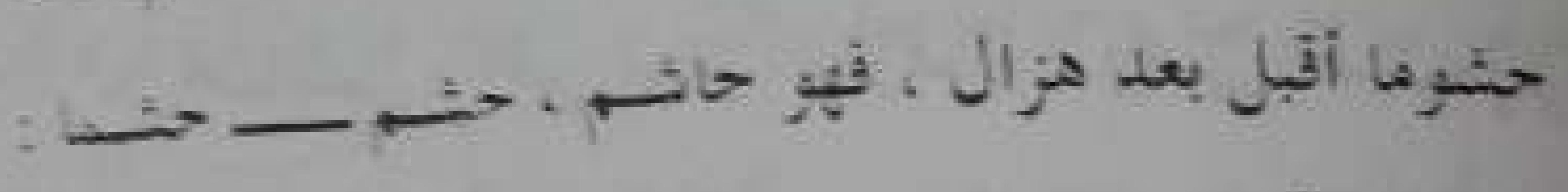

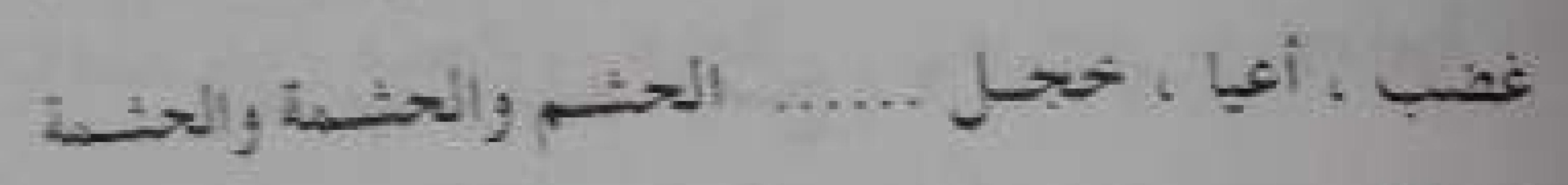
....

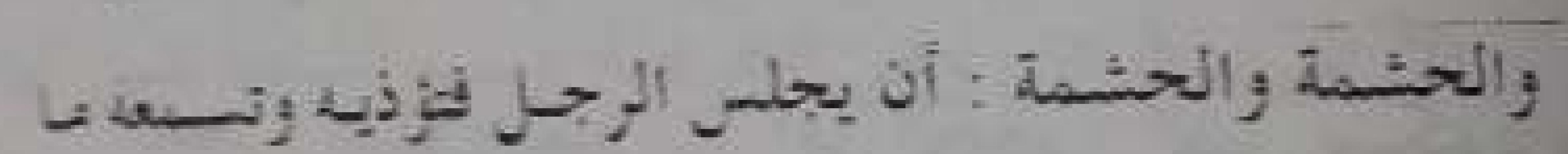

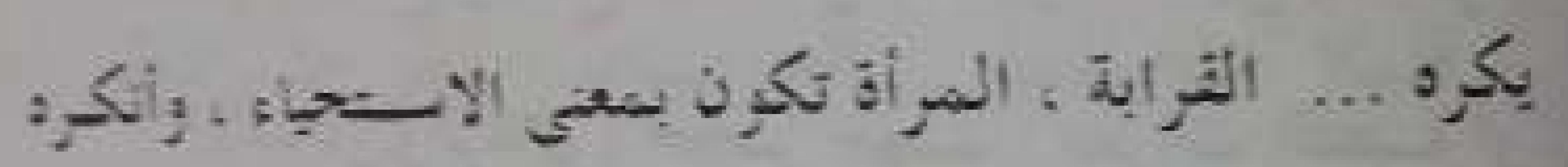

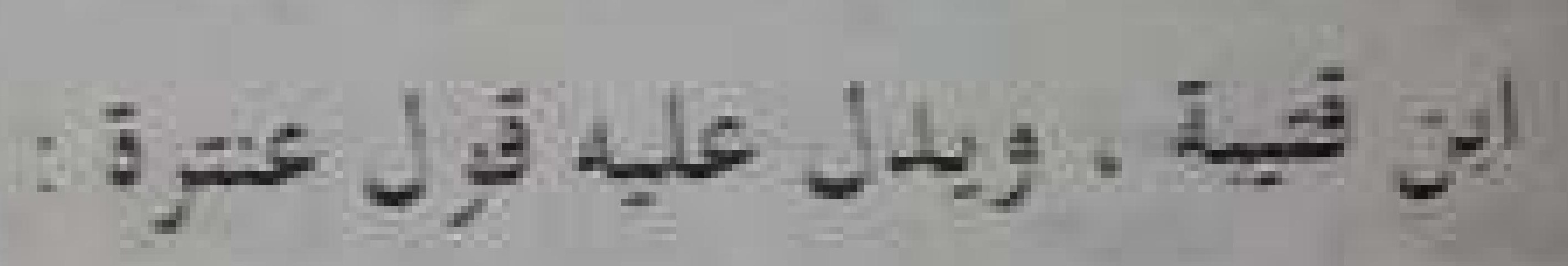

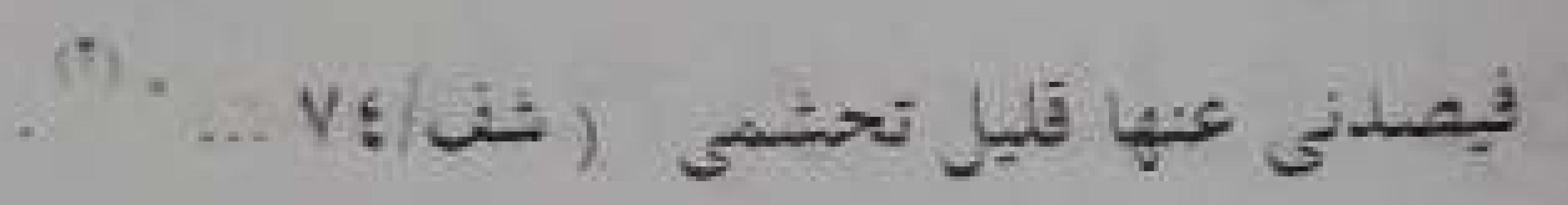
ill $-(a)$

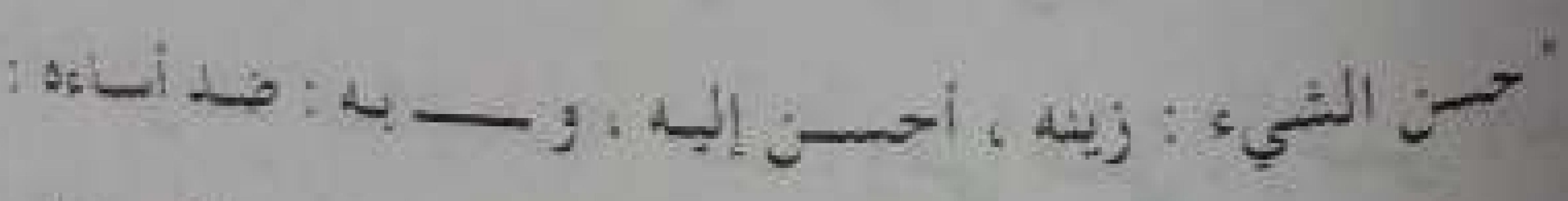

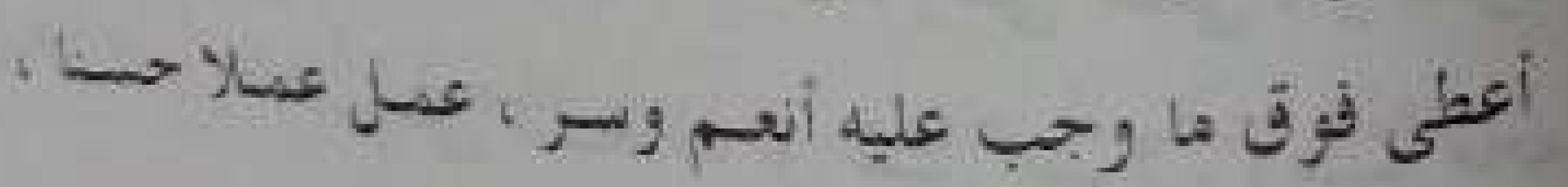

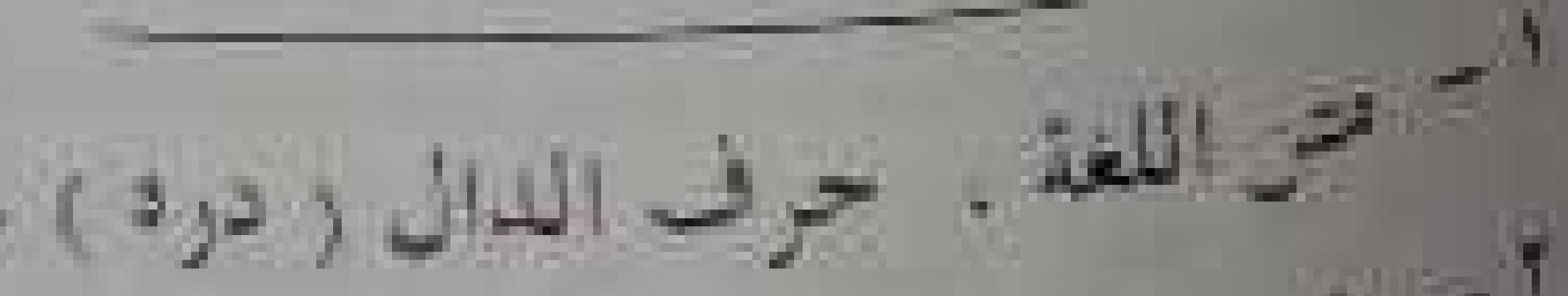

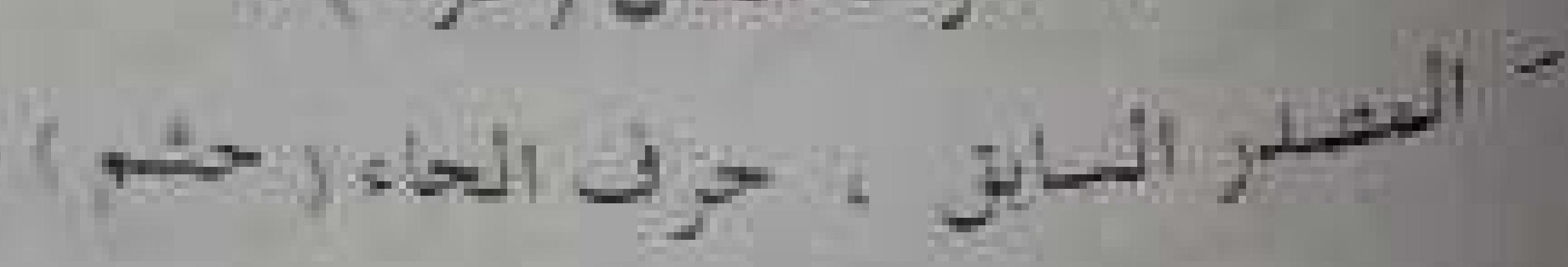

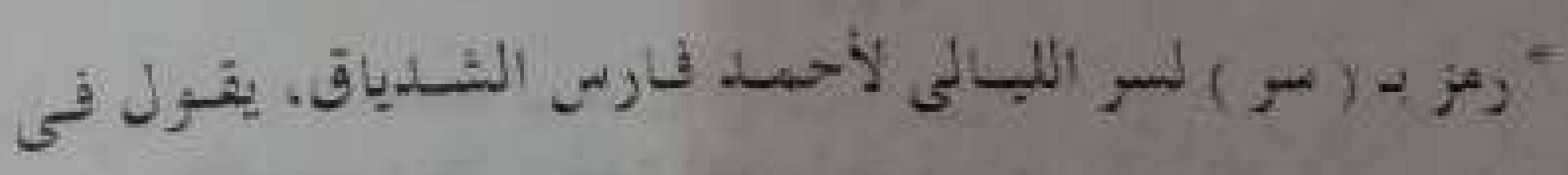

$$
-:(t, y) j s u
$$

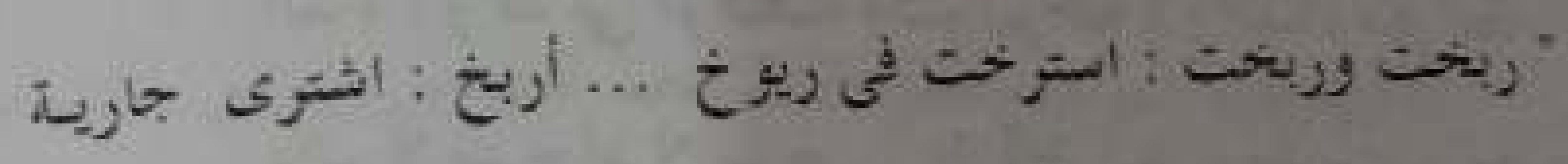

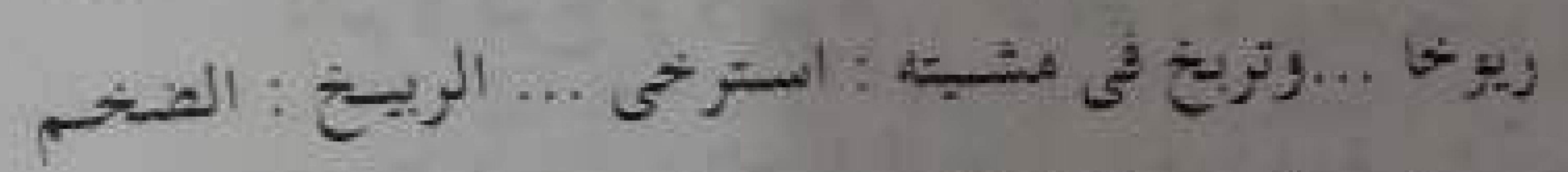

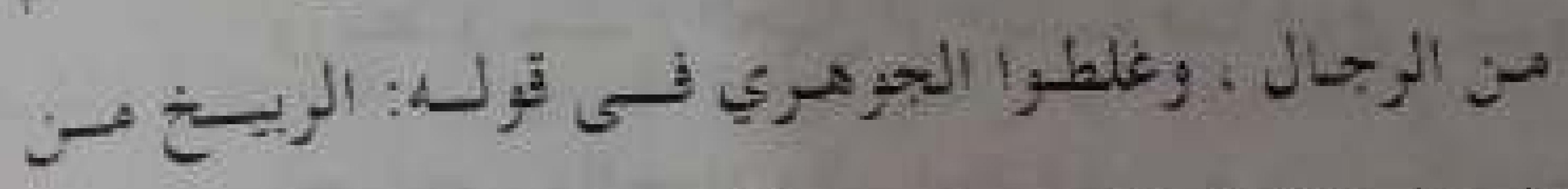

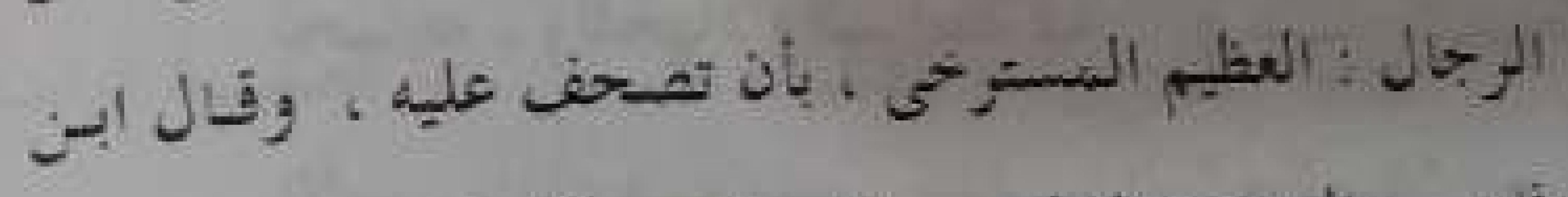

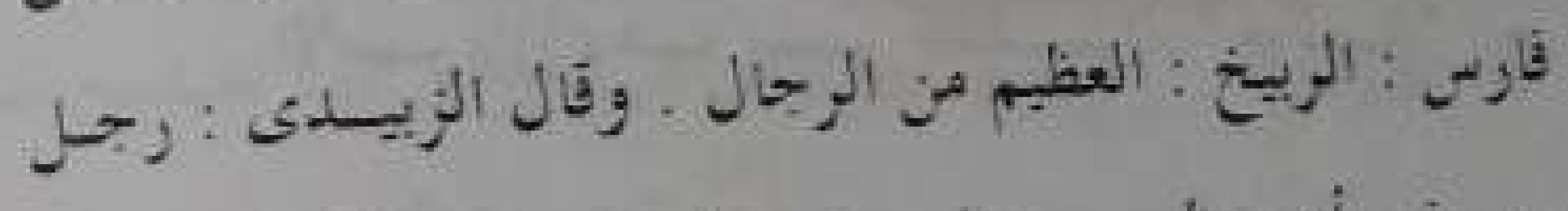

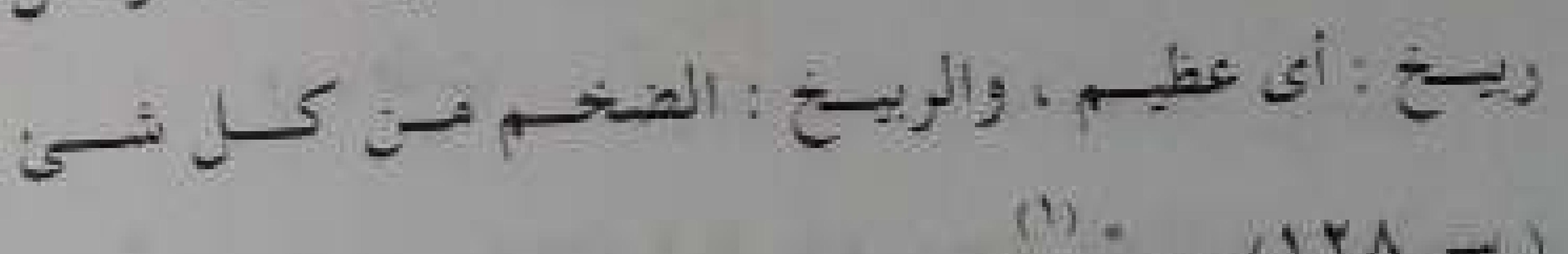
(1). ...( (1) $\times,-)$

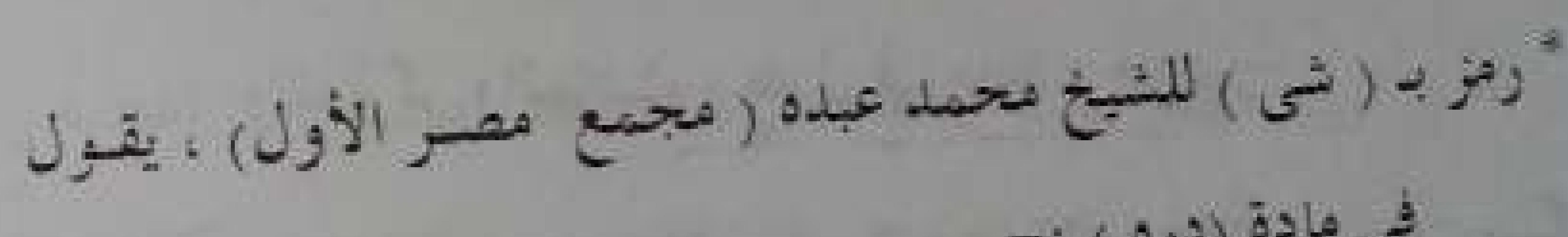

$$
-:(0,2) \text { a } 26 g^{3}
$$

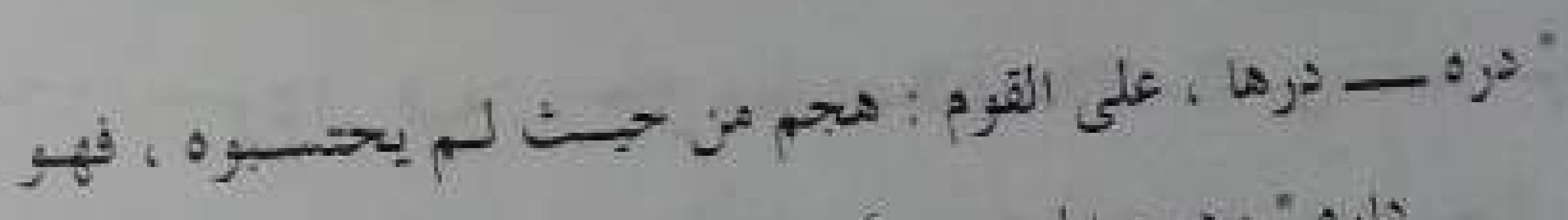

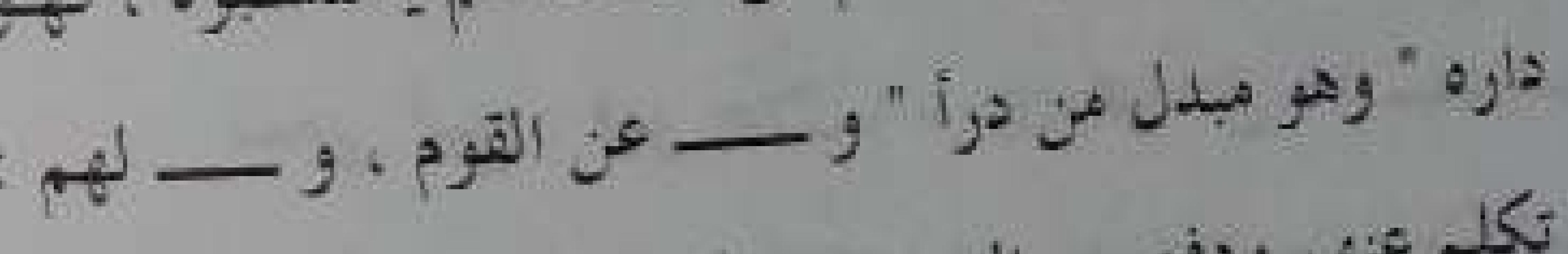

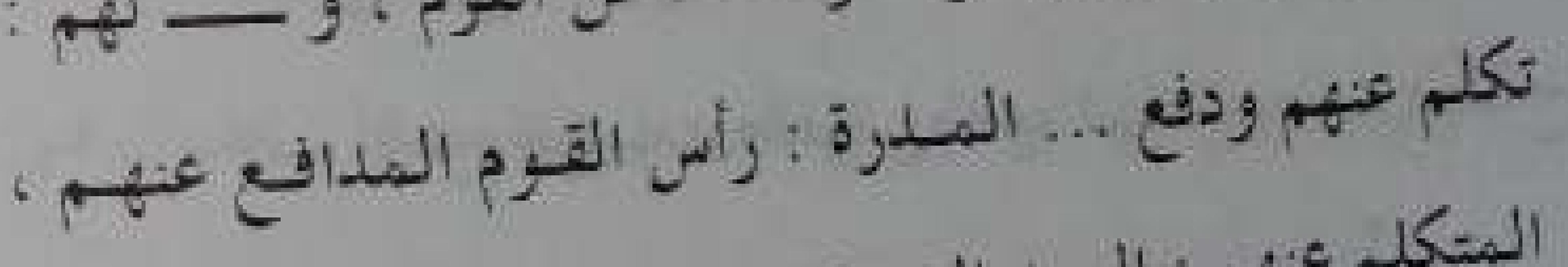

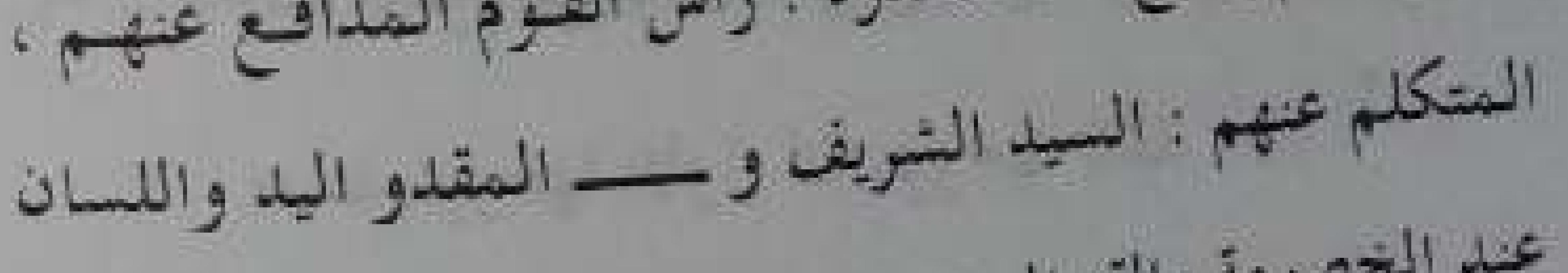

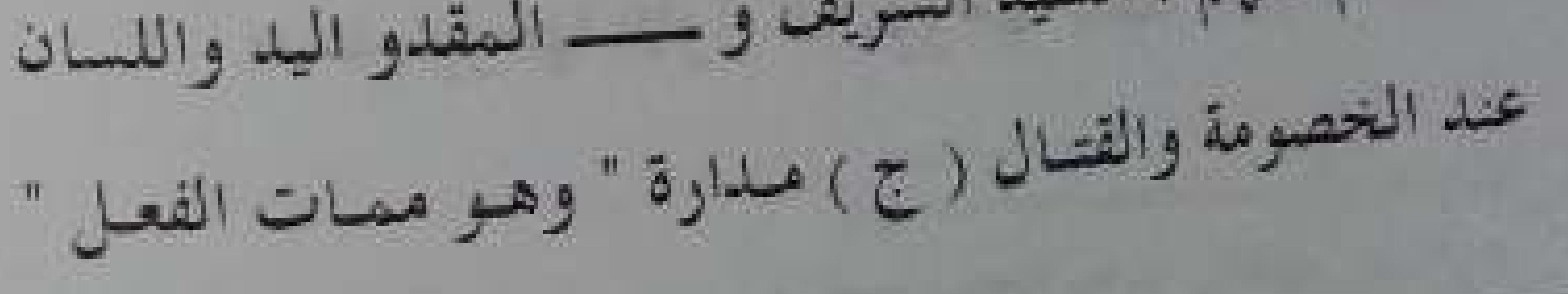

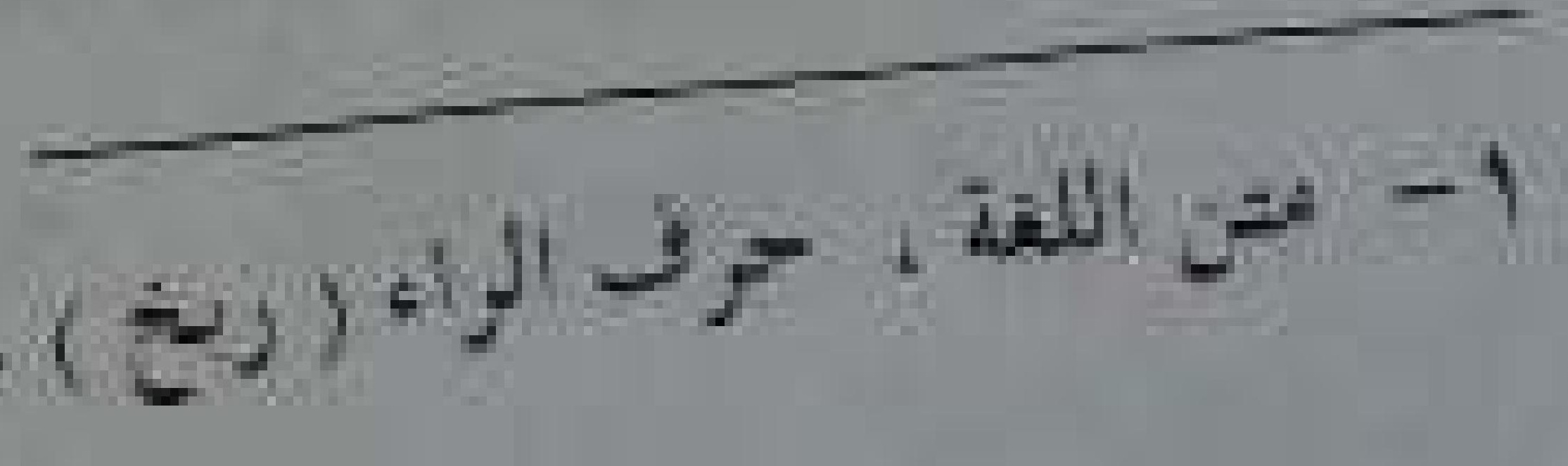




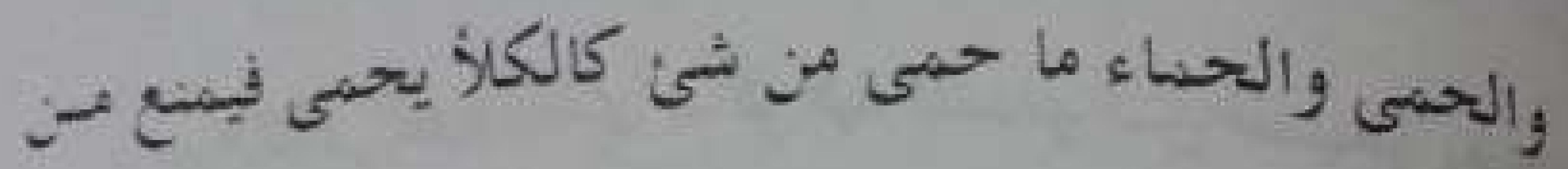

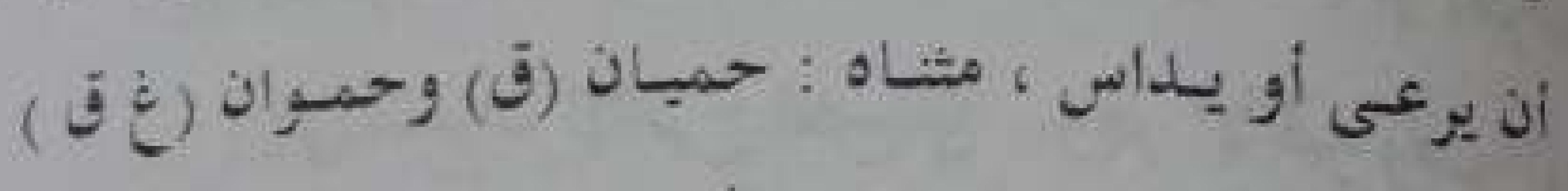

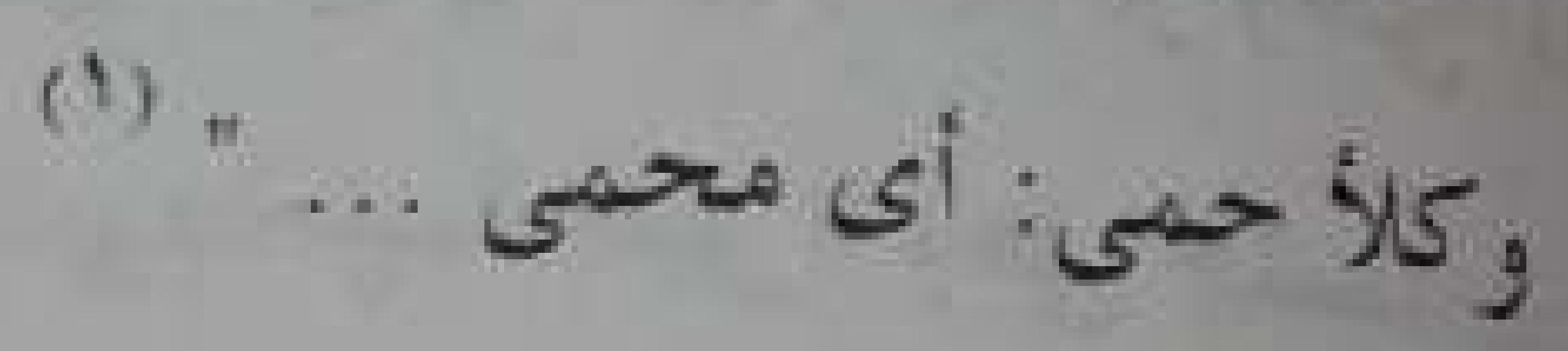

"رمز بـ (ك) ) لأنستاس الكرملى ، يقول فى مادة ( حرص) : "حرص - حرصا وحرصا على الشيء : صار ذا إدارة وشره إليسه . فهو حارص وحريص ... الحرص : الجشع ، وهو شلدة إزادة

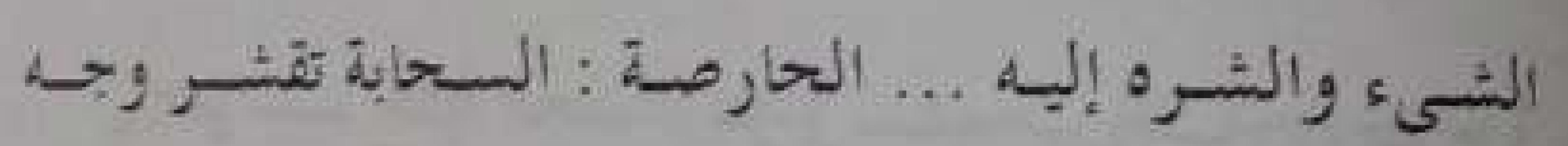

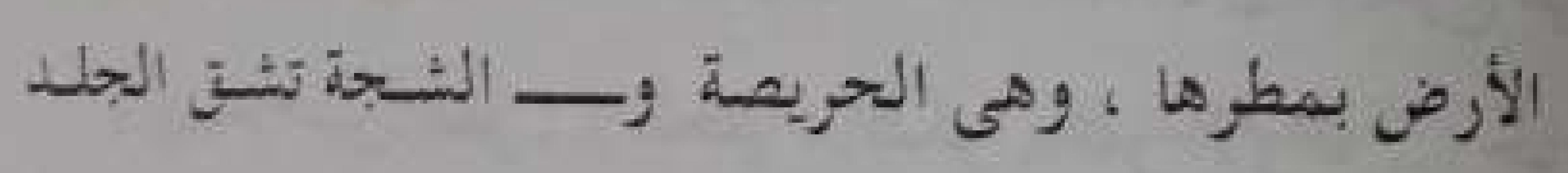

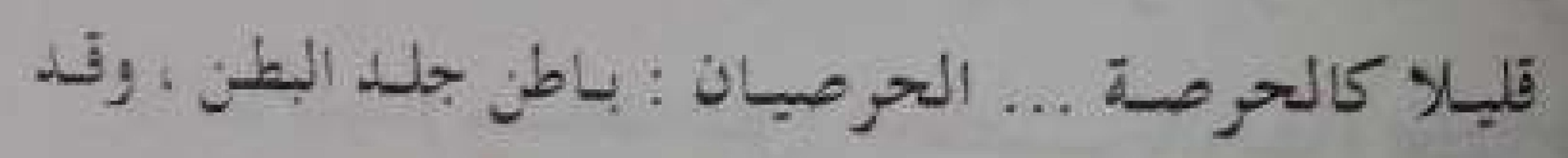

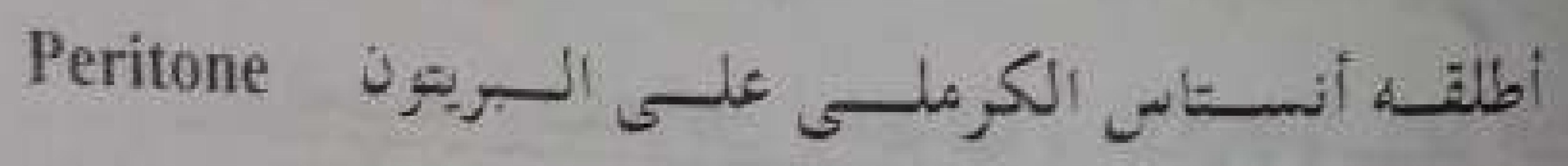

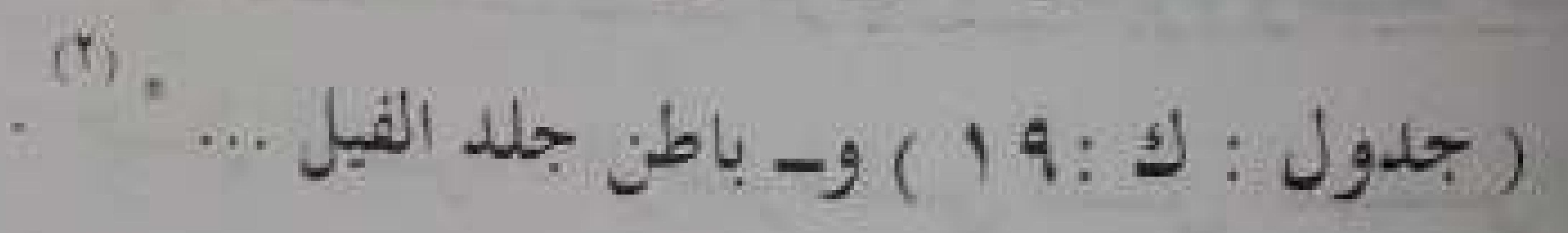

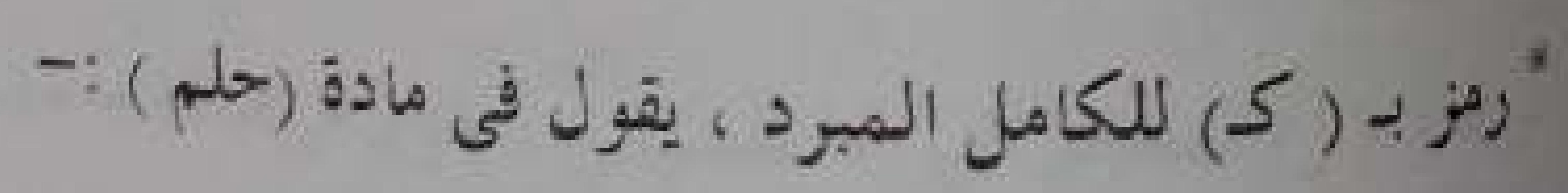

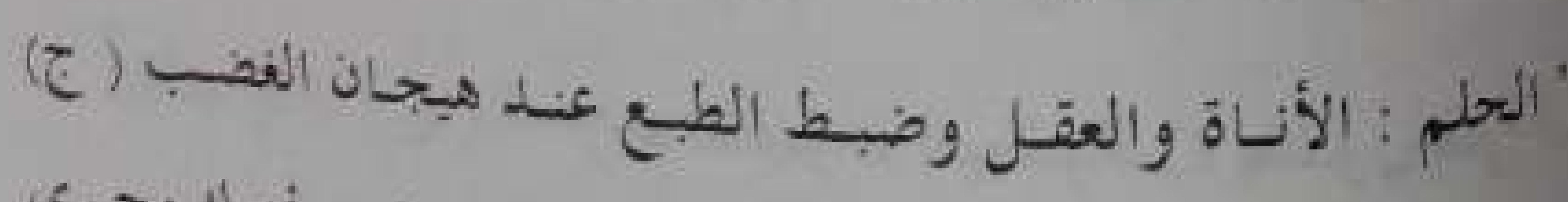

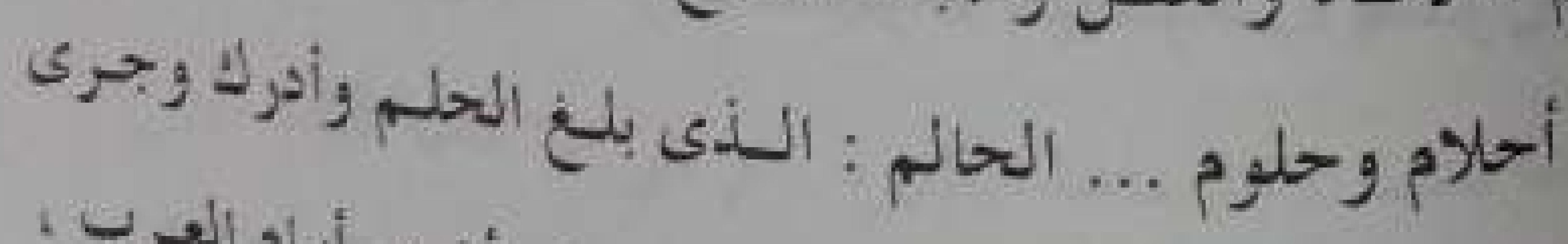

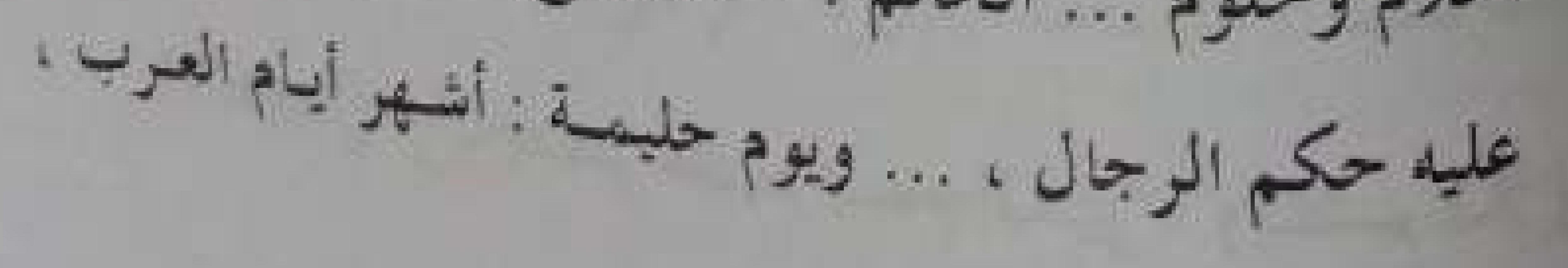

( 3 (

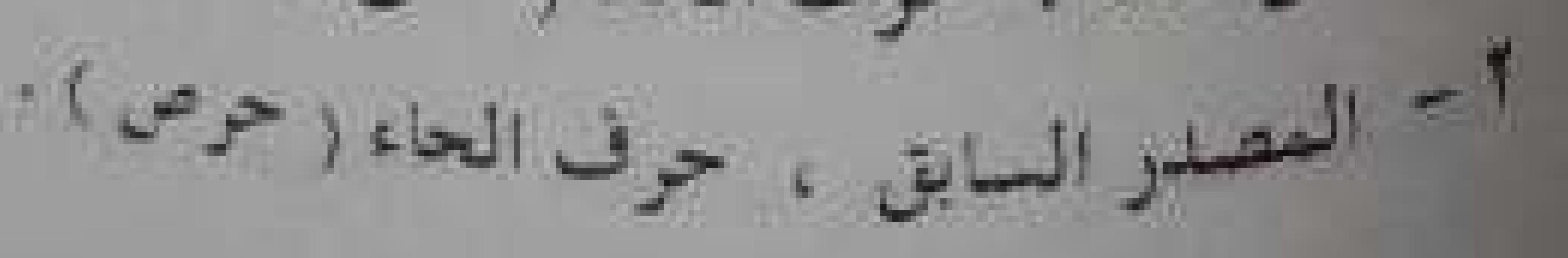

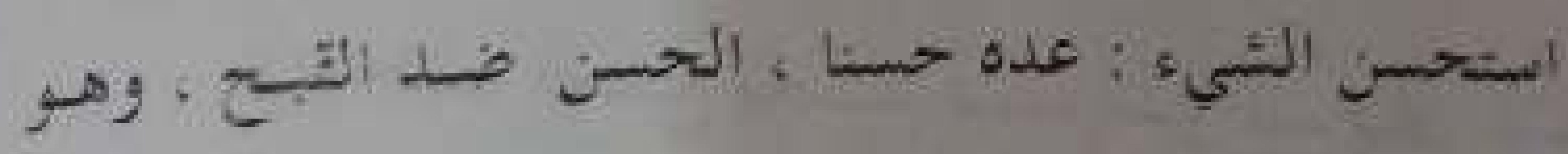

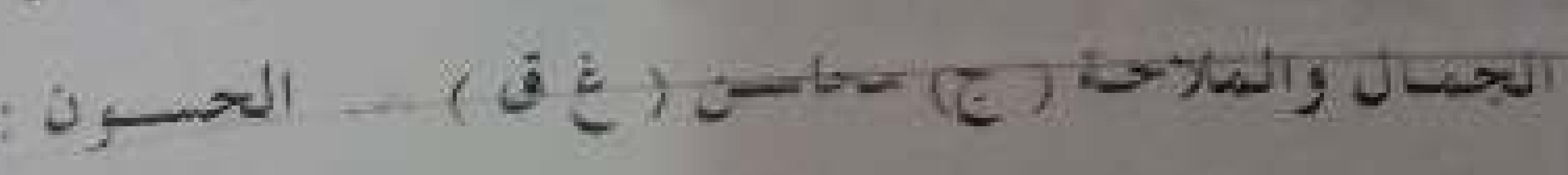

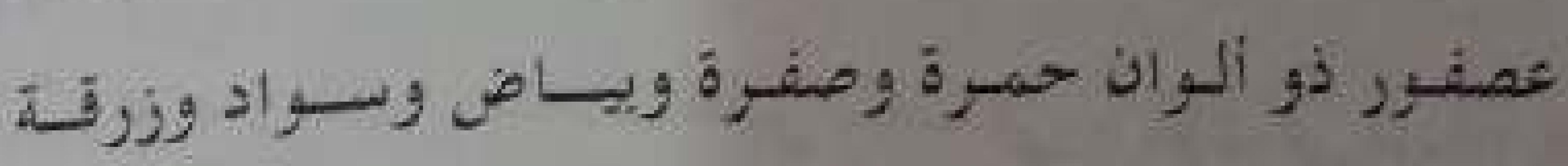

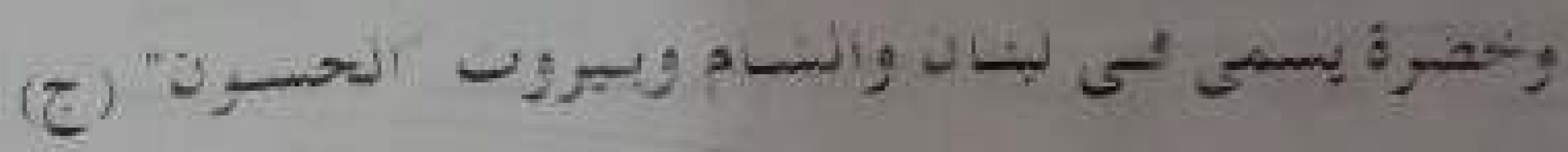

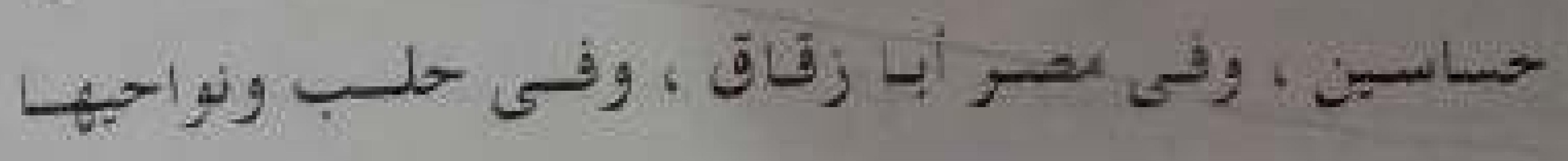

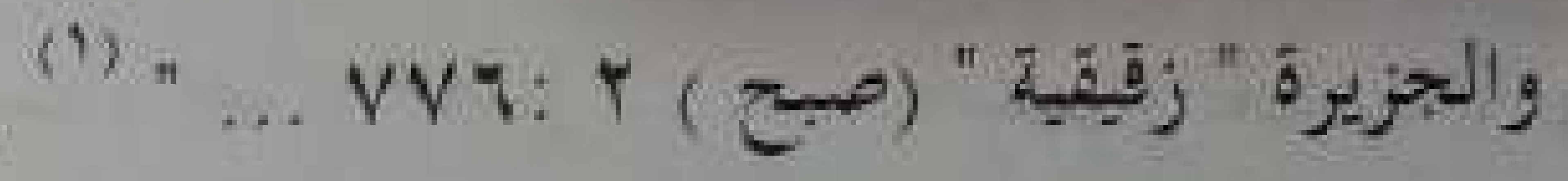

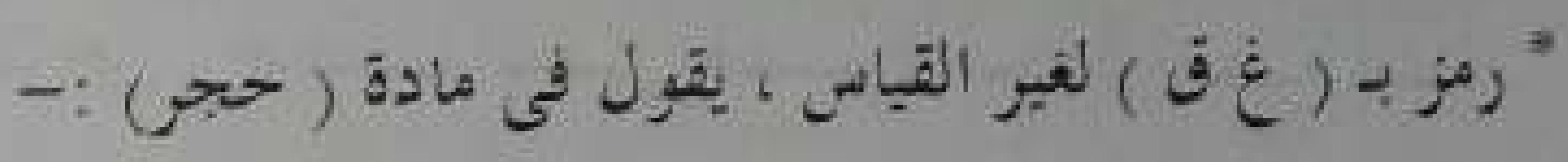

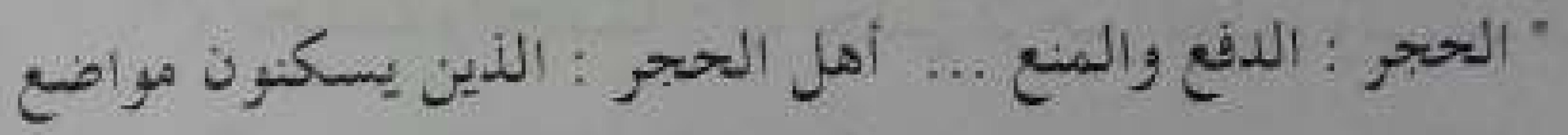

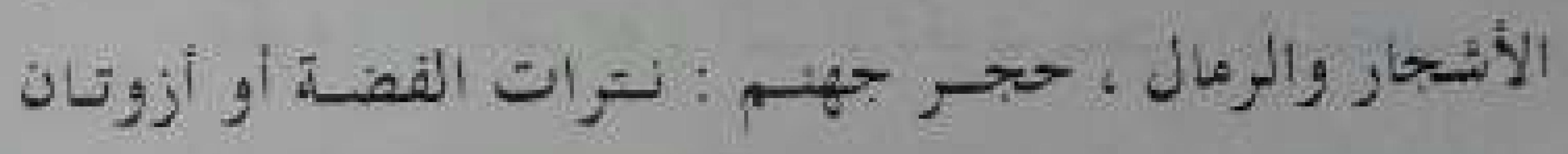

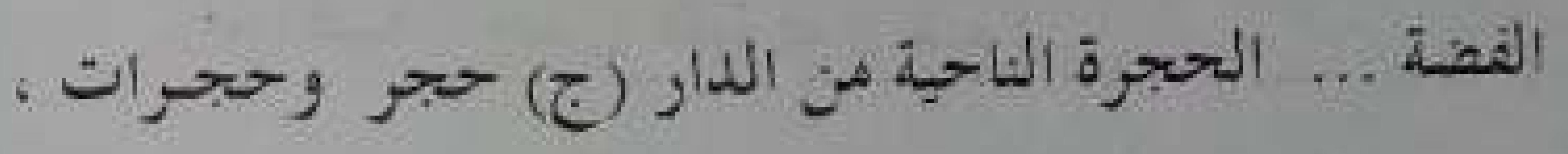

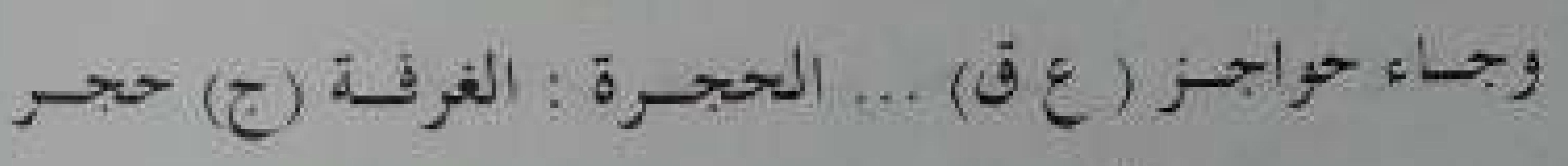
(i) $+. ., 01,0$

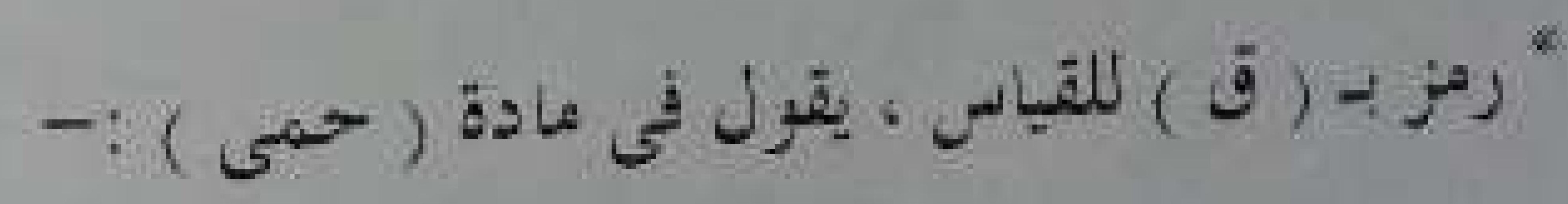
"

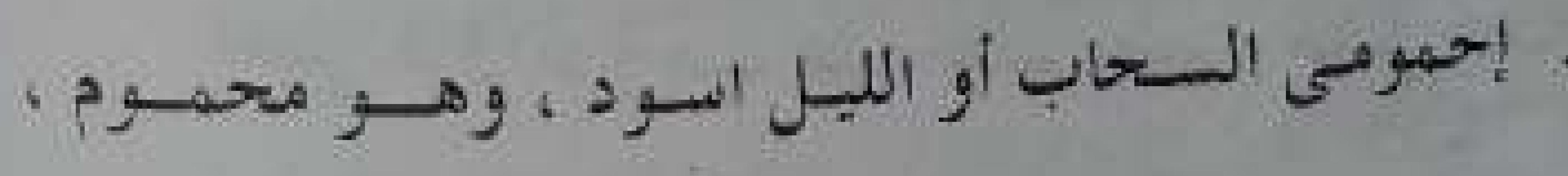

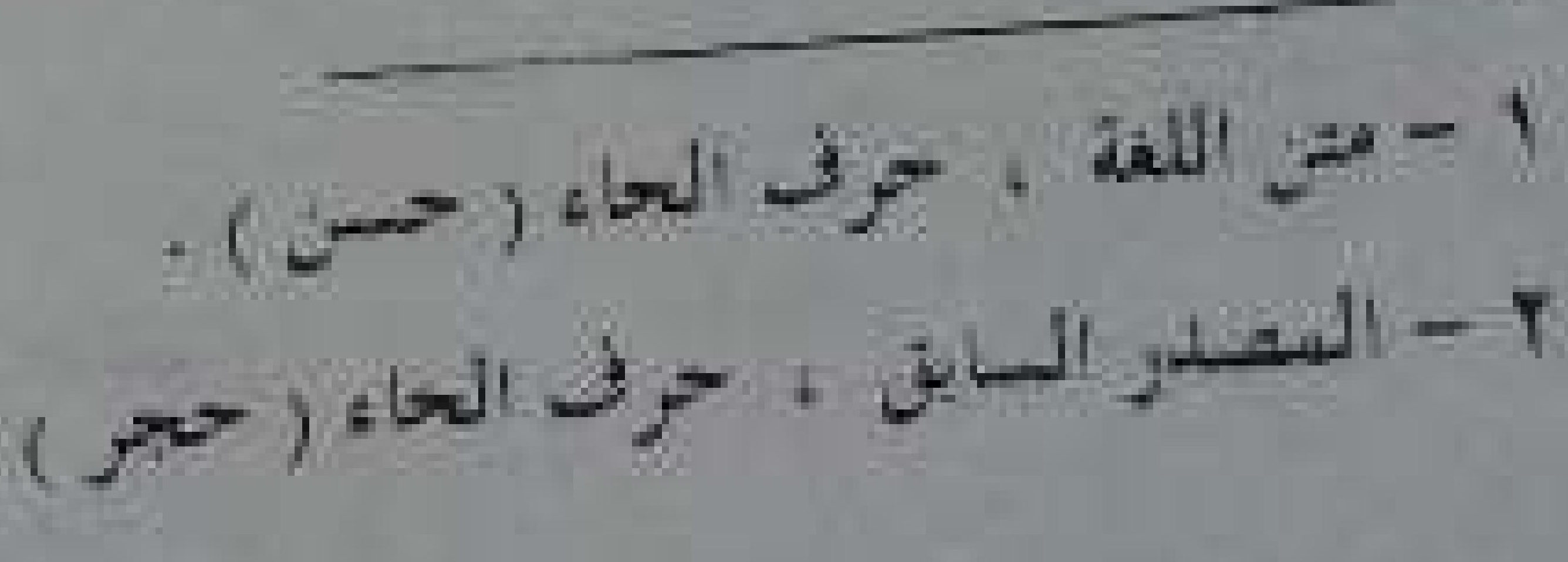




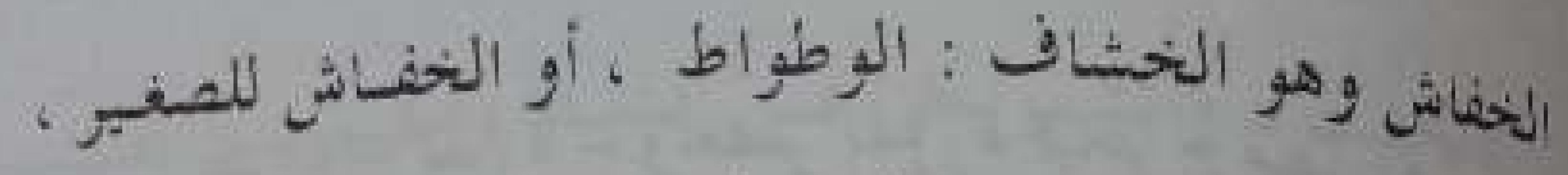
والوطو اط للكير ، وهو طائر يطير بـالليل (ج) خفافيش ....

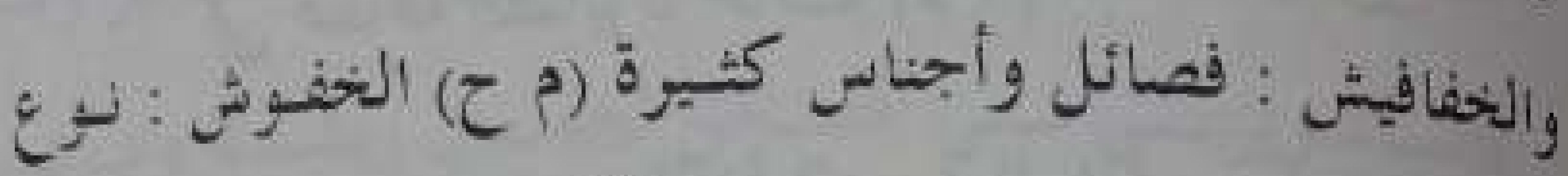

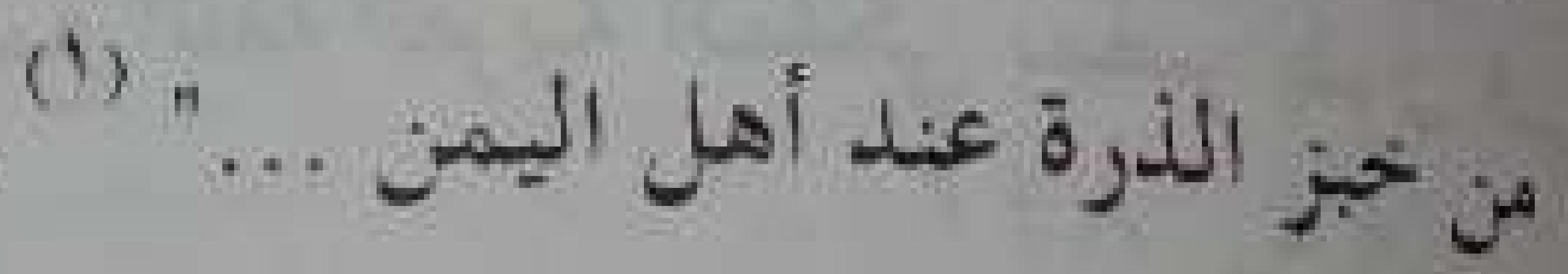

اريز بـ (م د) للمجسع العلمى العربى بدمشتق ، يقول فى مـادة $-:$ : (ح)

"لاهنى : شجر ينبت على ساق ، الحذية : مـا قطع مي اللحم.

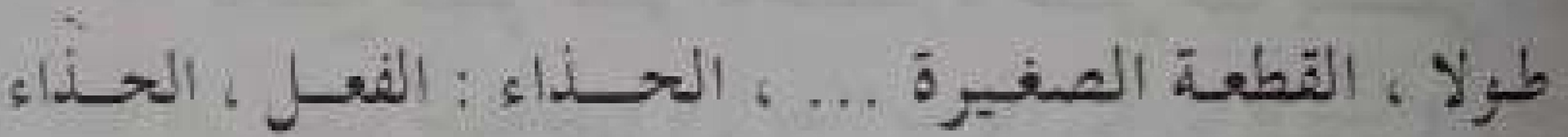

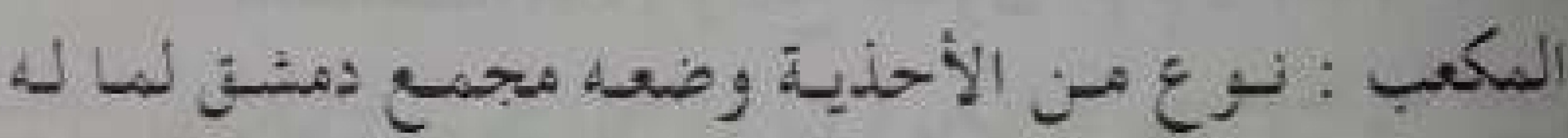

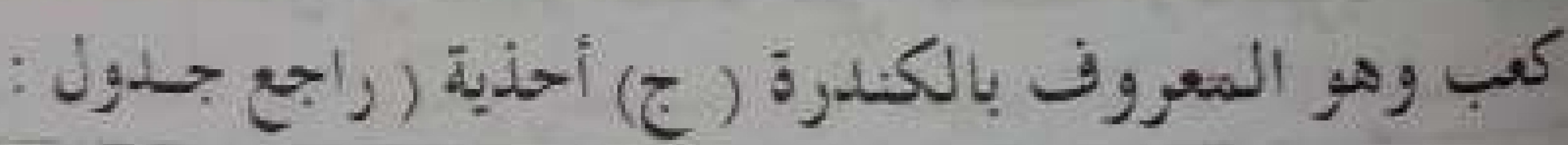
(4) " ... (9):2p

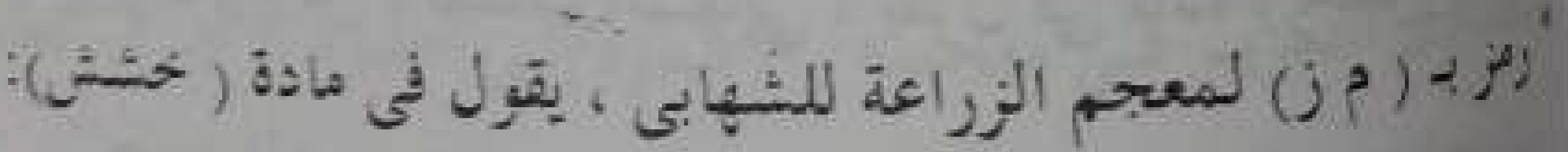

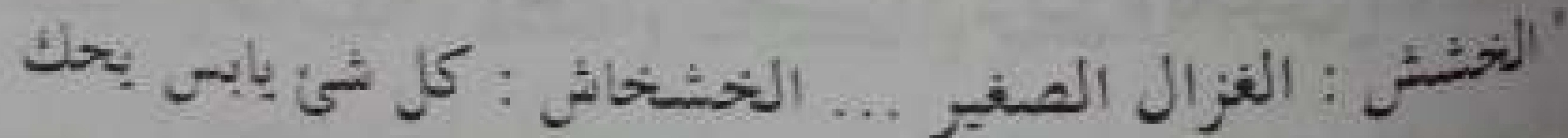

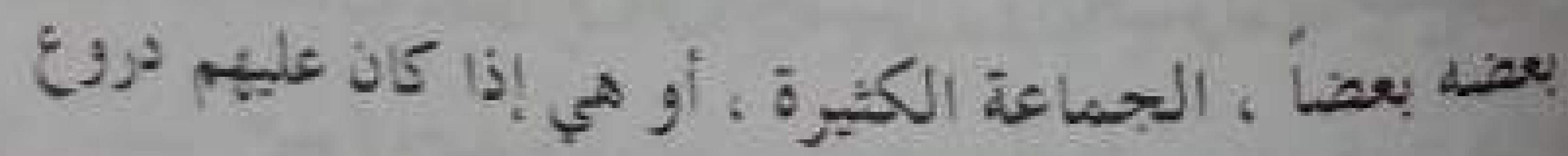

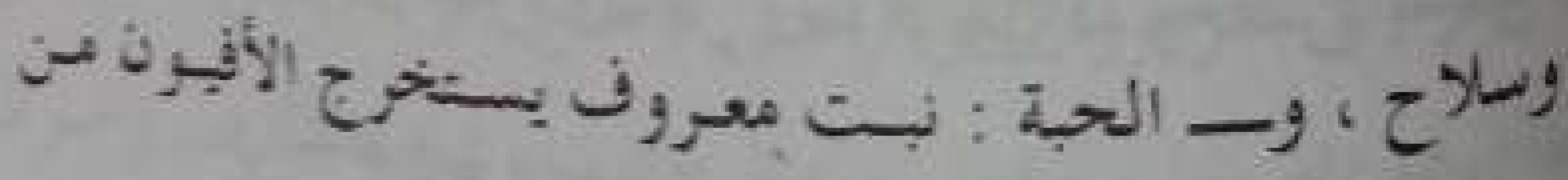

- ro. -

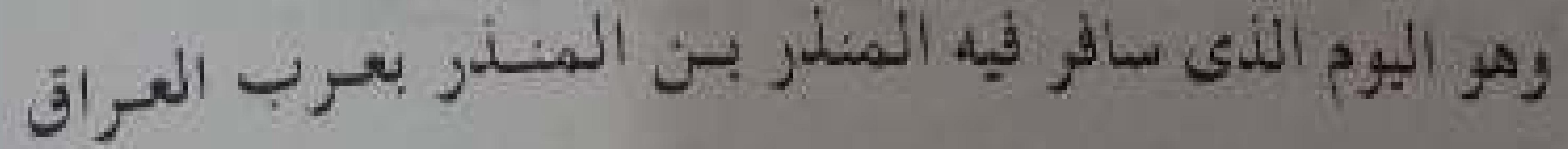

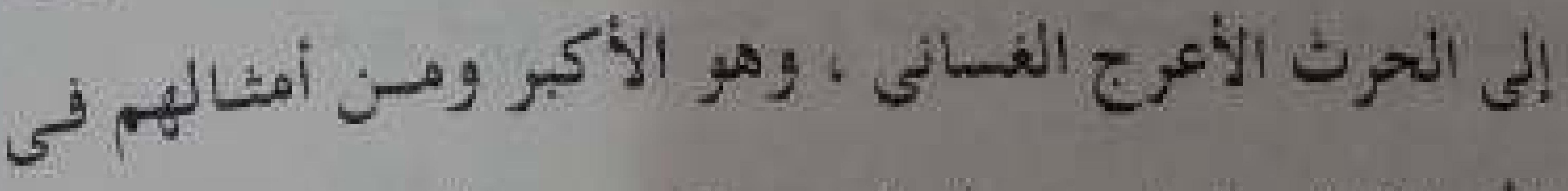

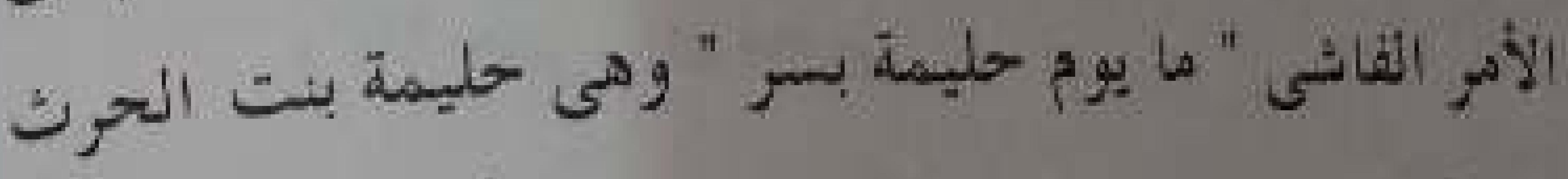

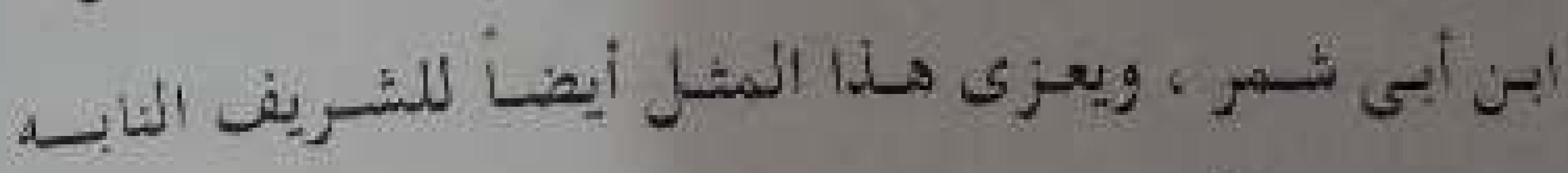

(4)

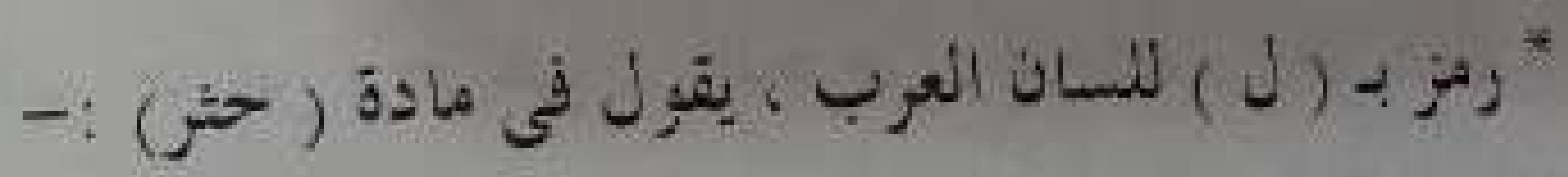

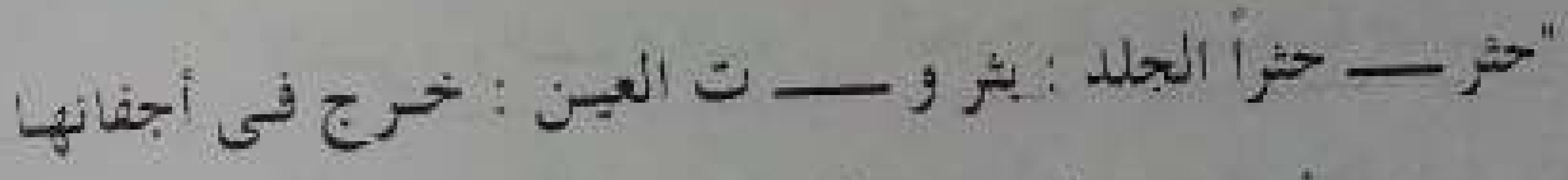

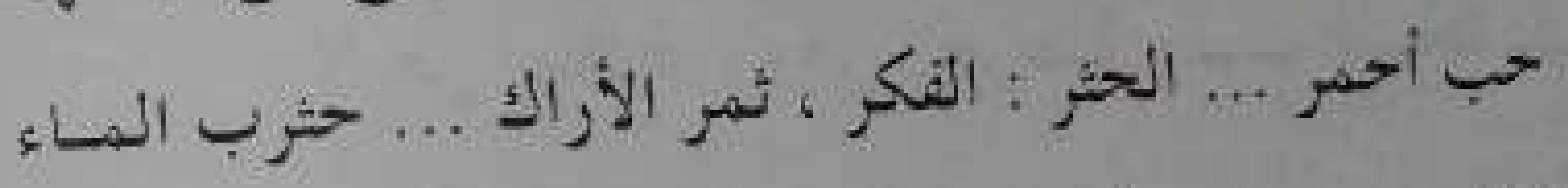

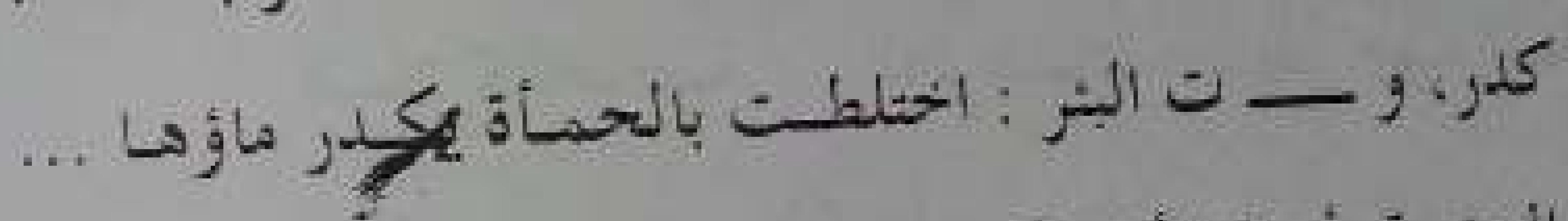

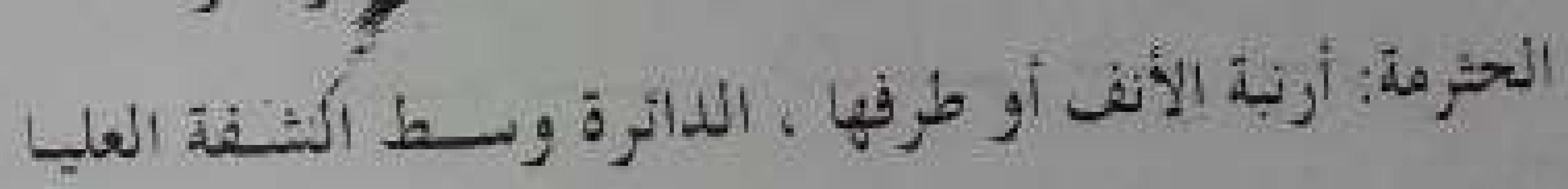

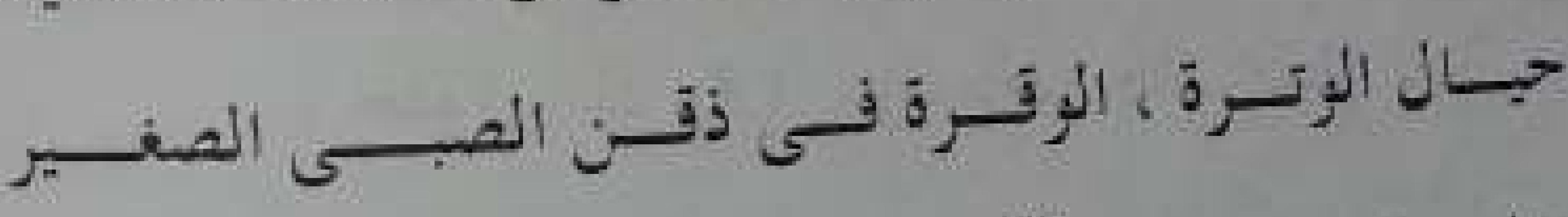

$$
\text { (i) }+\ldots(0, j, j)
$$

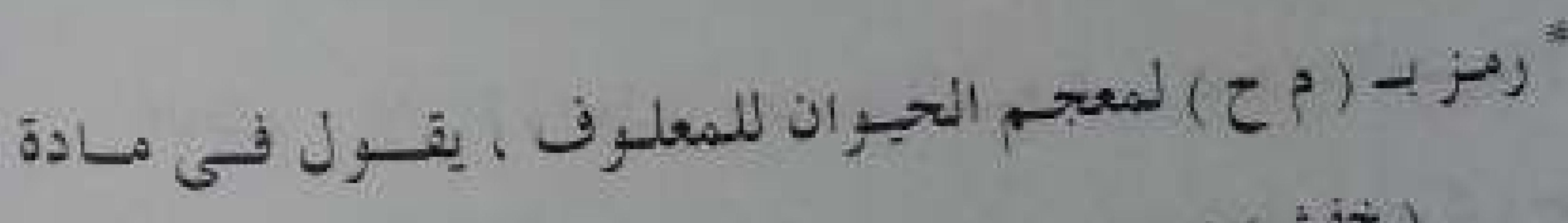
$-:(خ)$

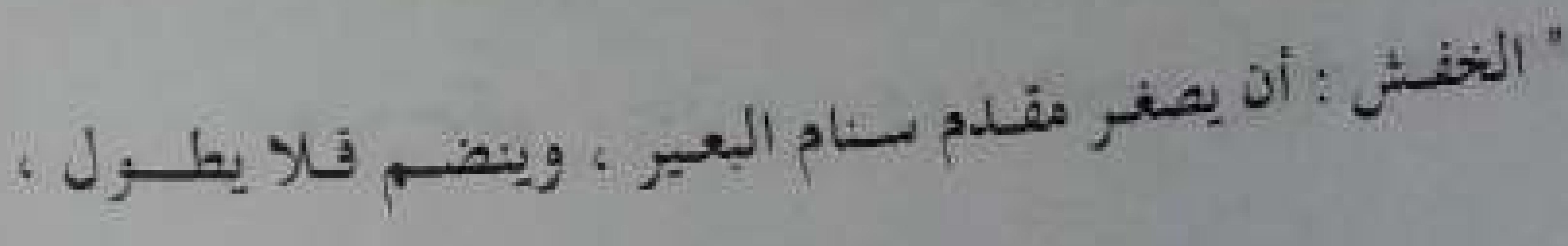

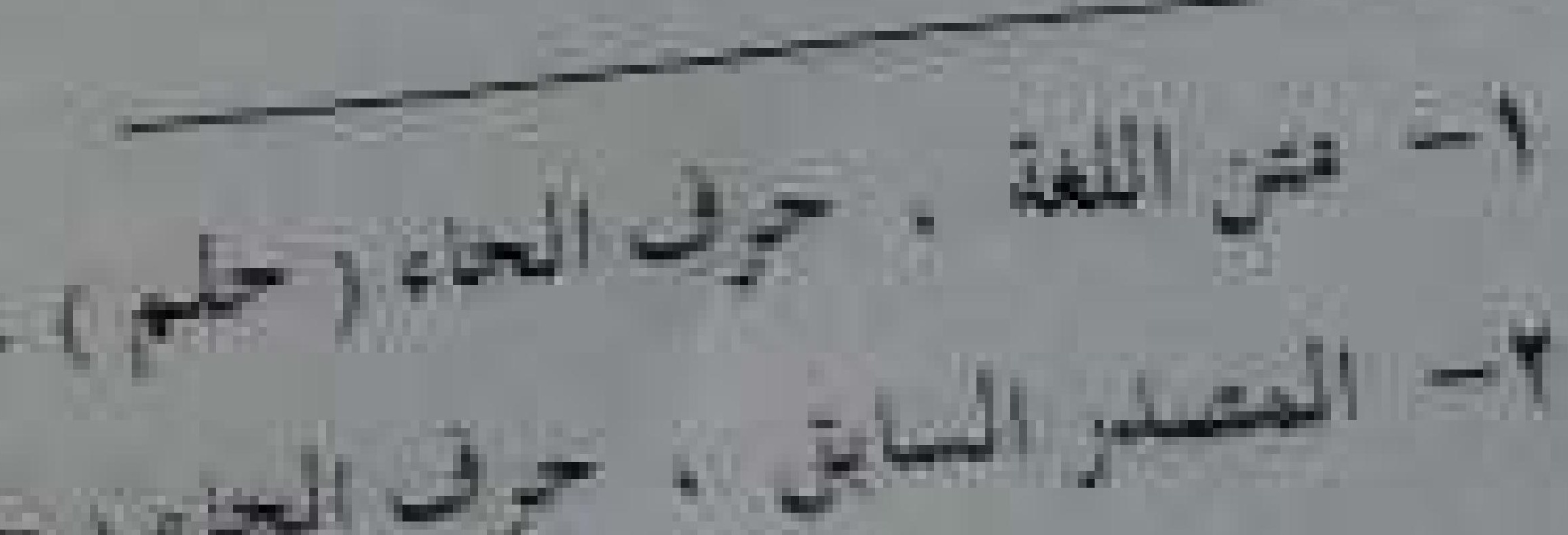
1- 


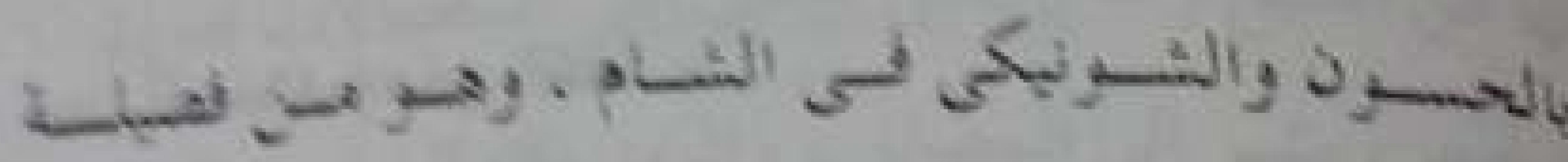

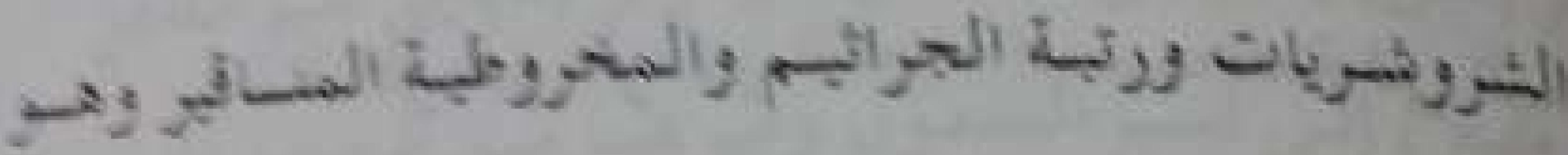

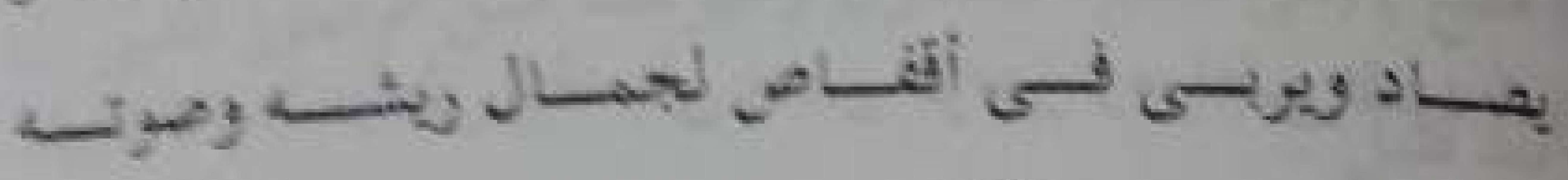
(1) $, \ldots, \pm \Lambda: j \beta)$

المقارنة الريزية بين المعاجيم اللبنانية

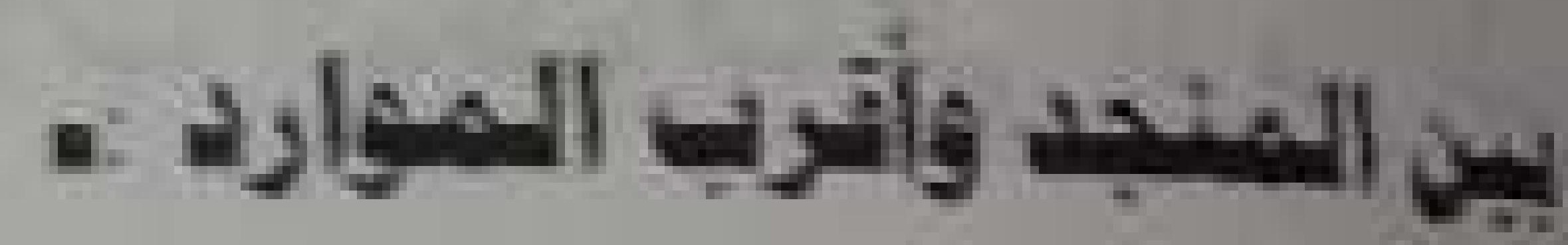

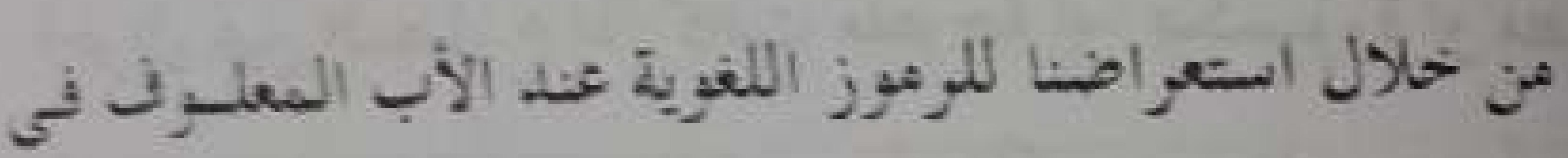

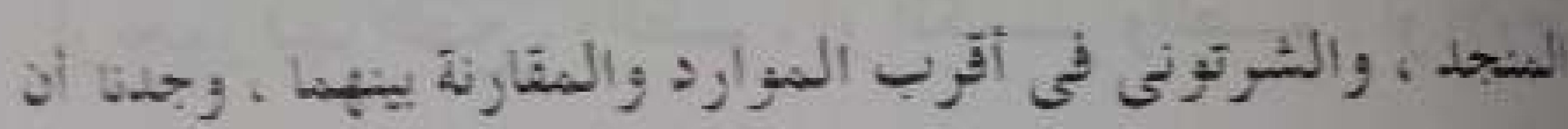

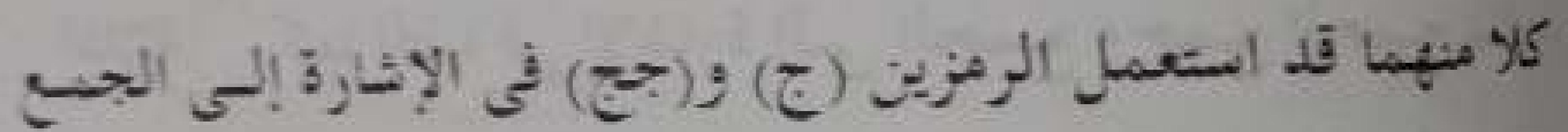

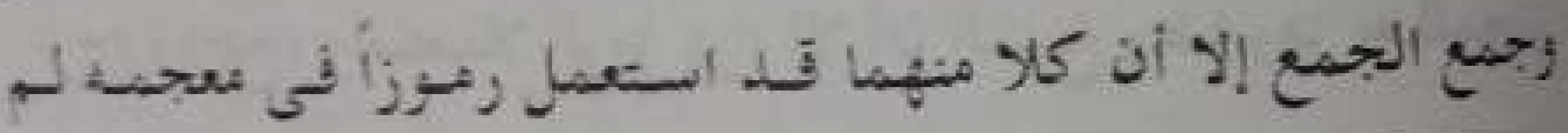

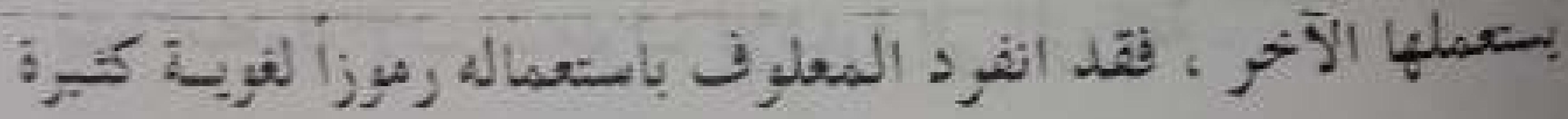

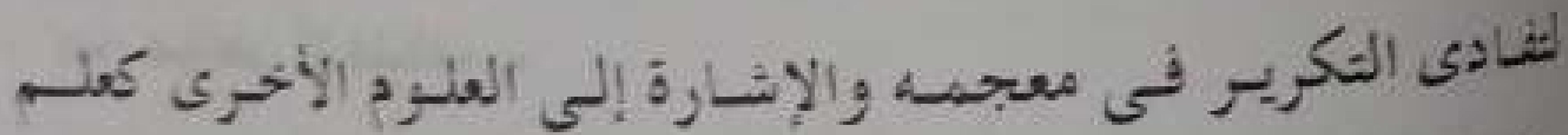

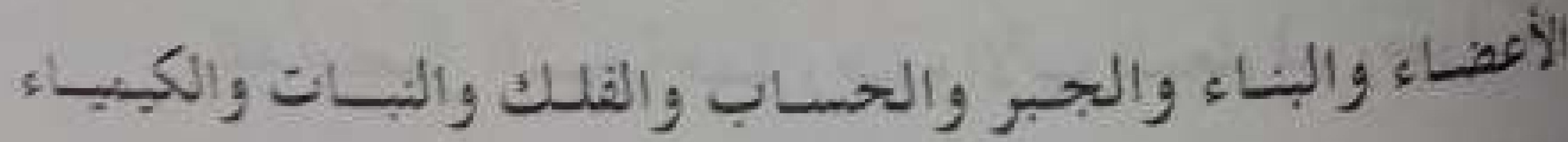

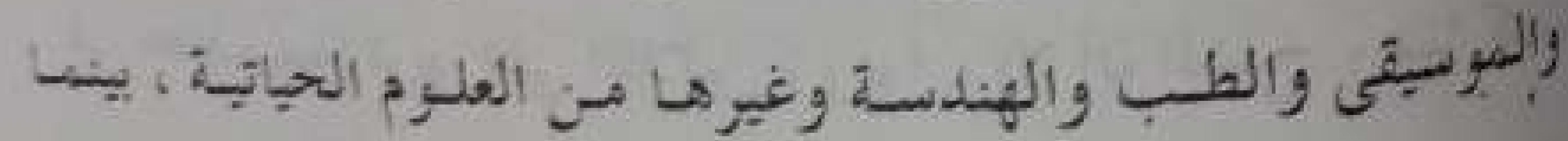

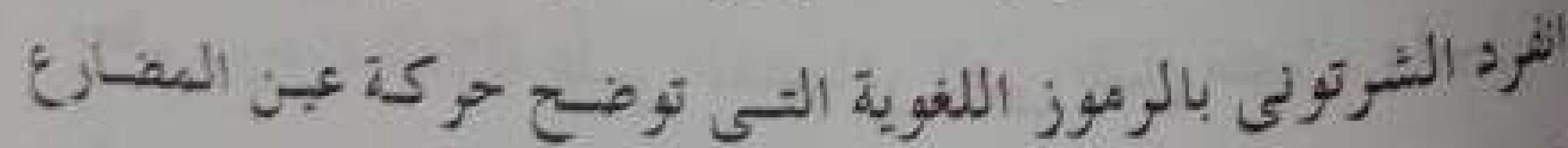

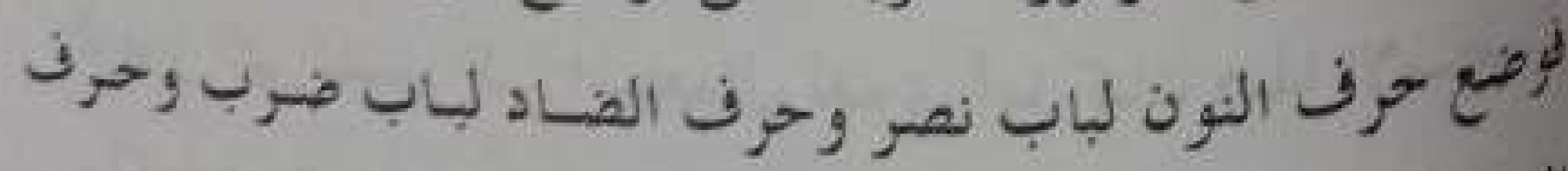

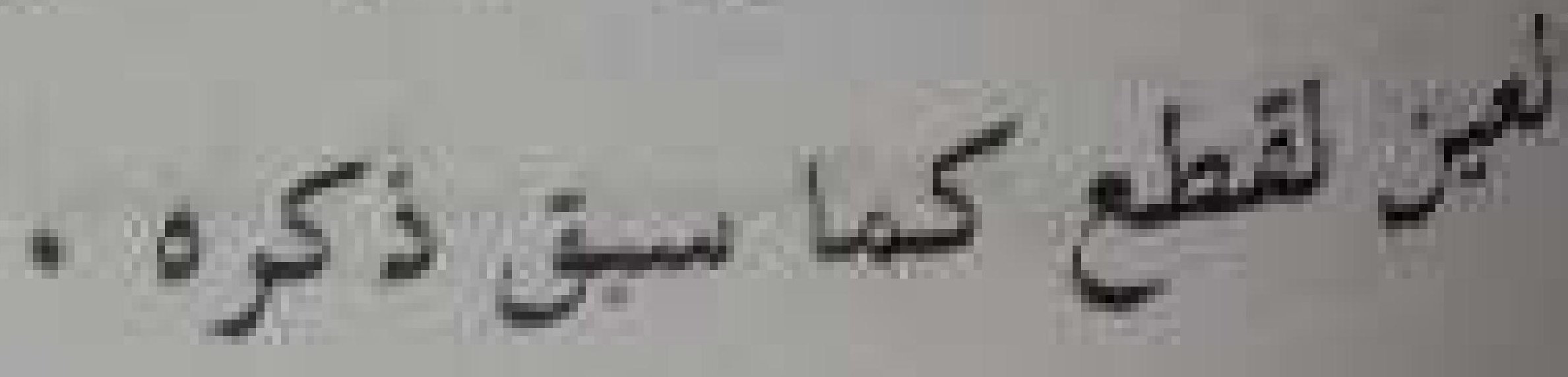

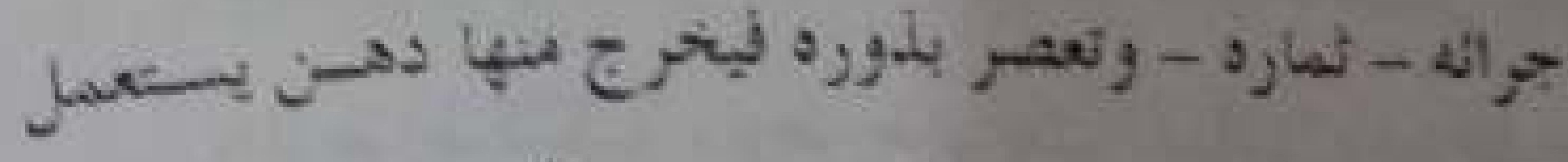

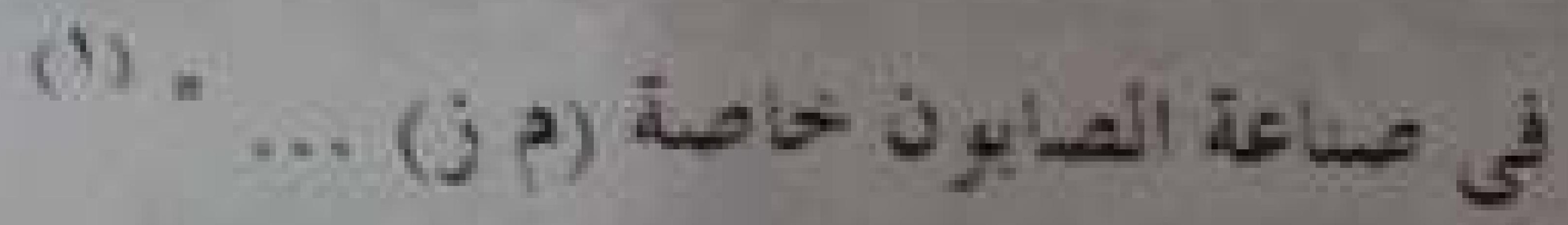

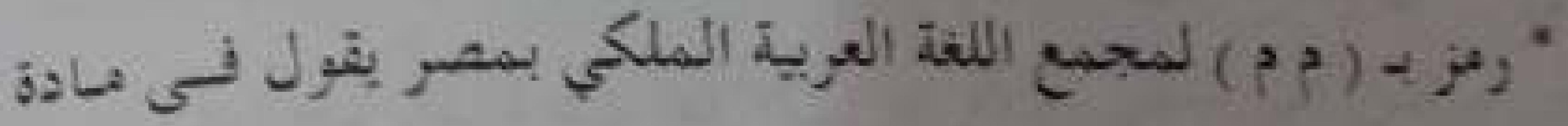
$-:(\mu)$

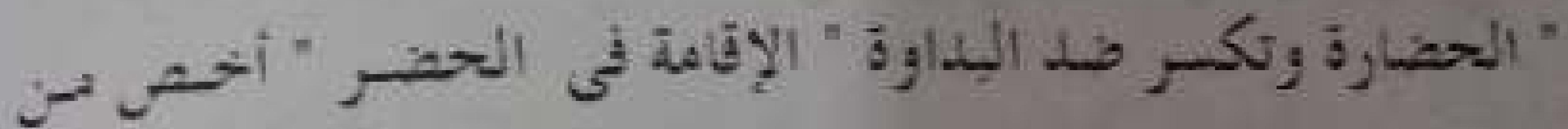

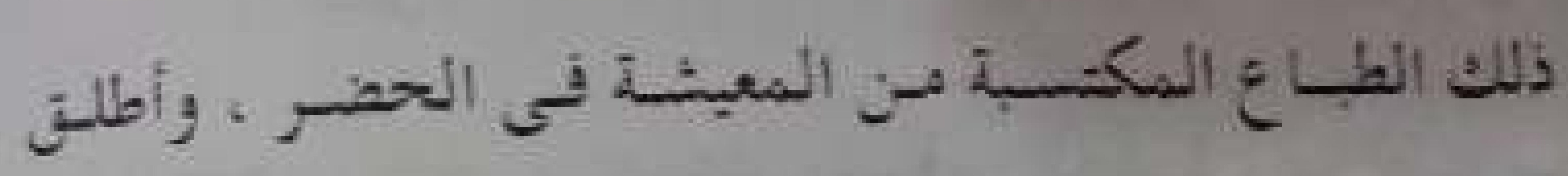

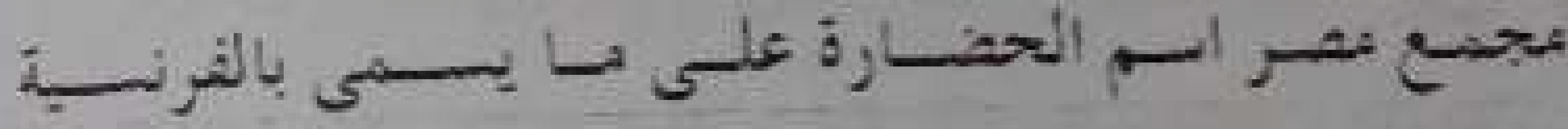

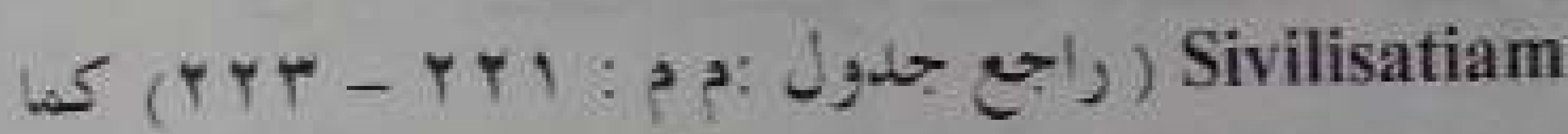

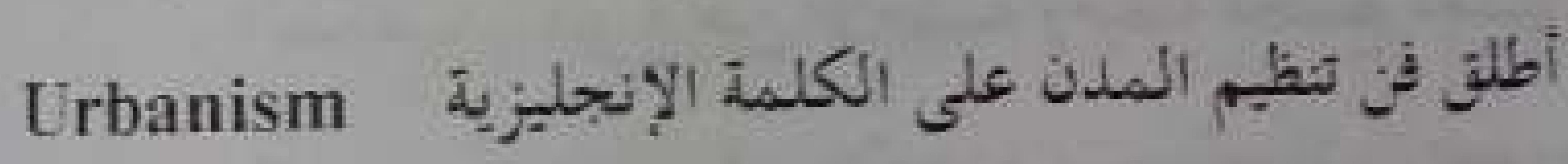

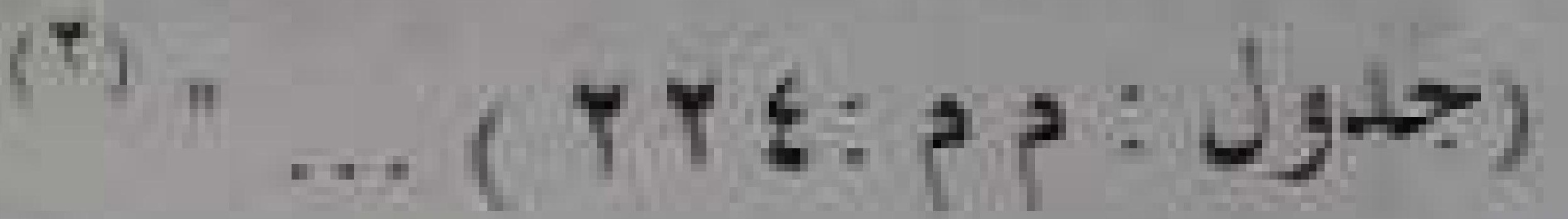

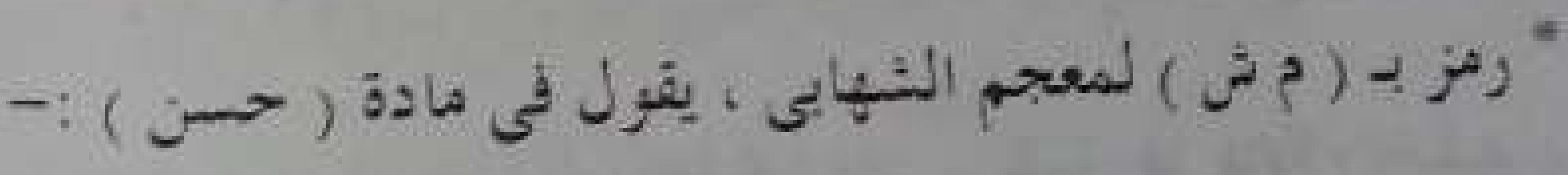

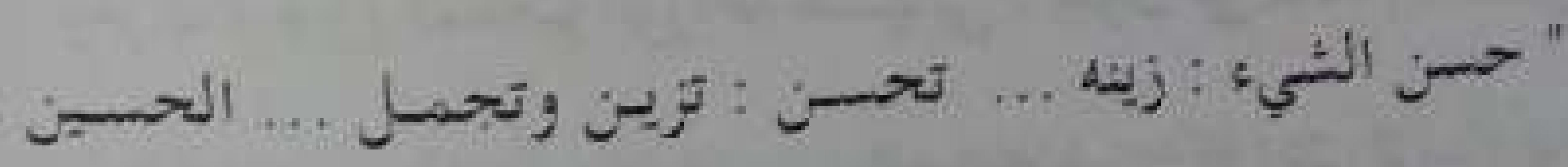

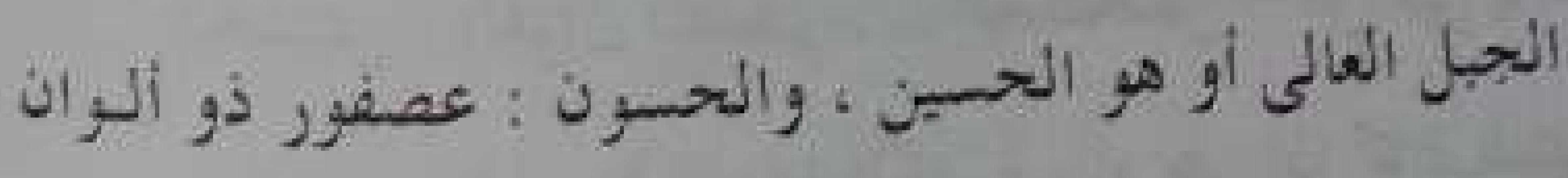

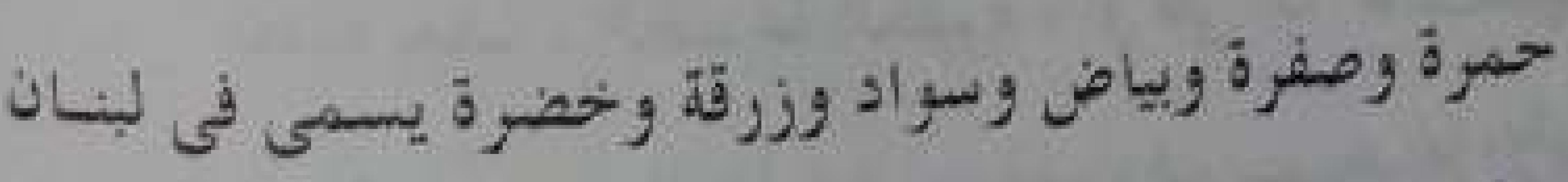

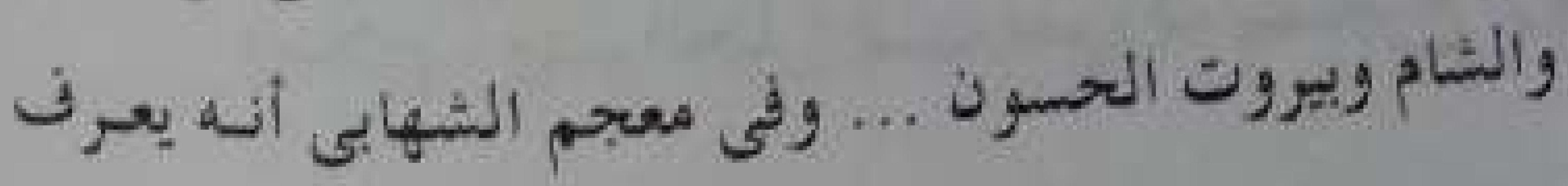




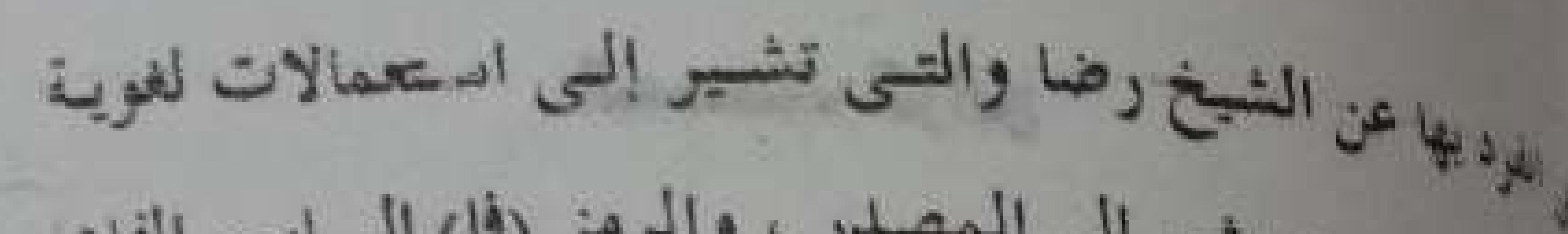

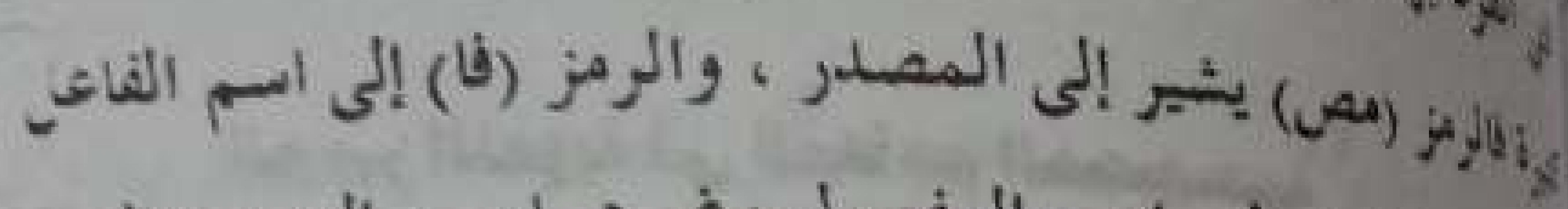

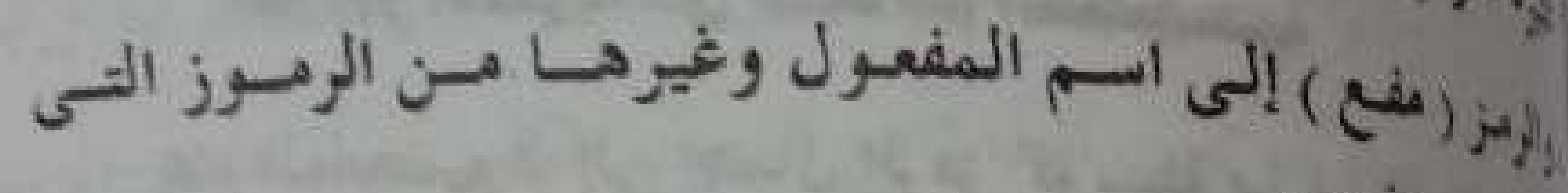

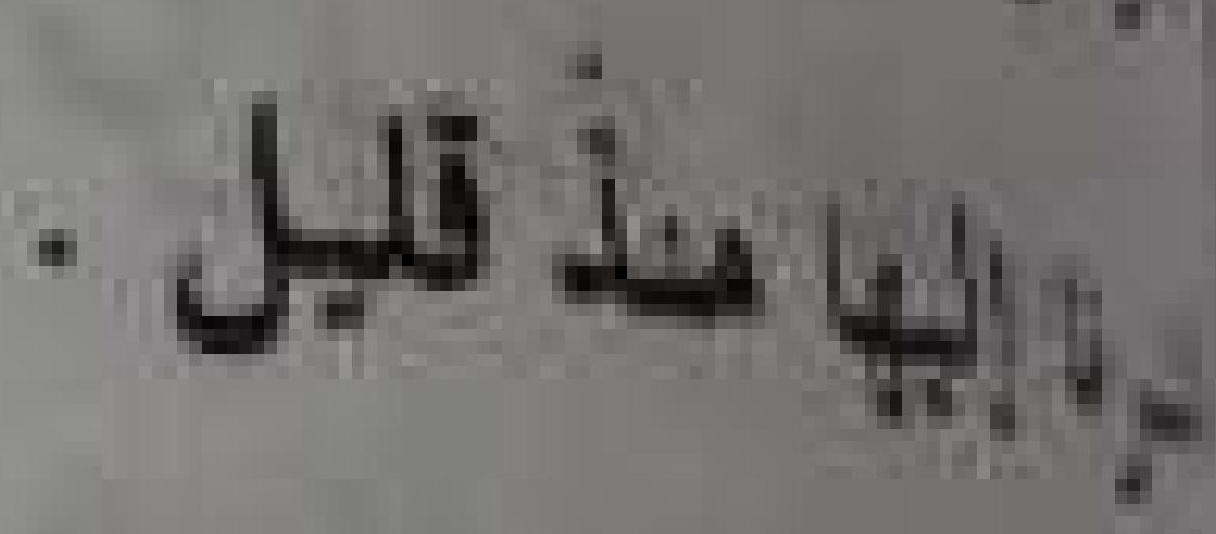

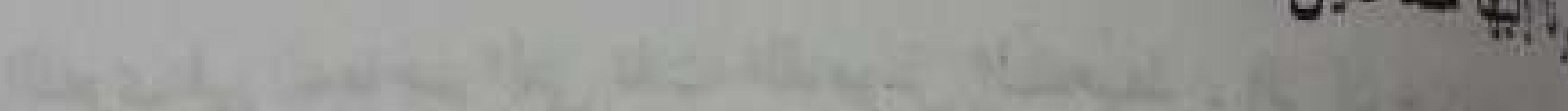

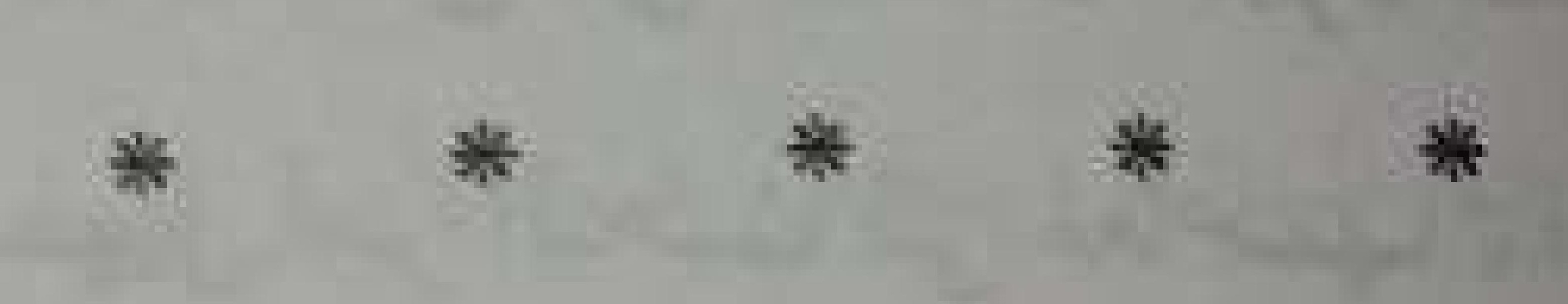

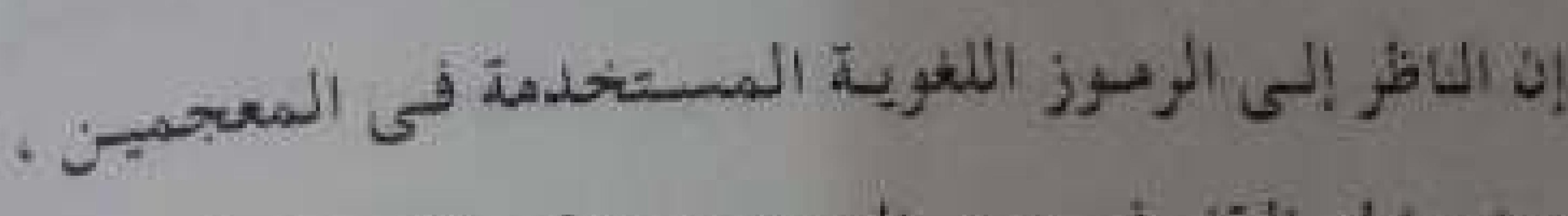

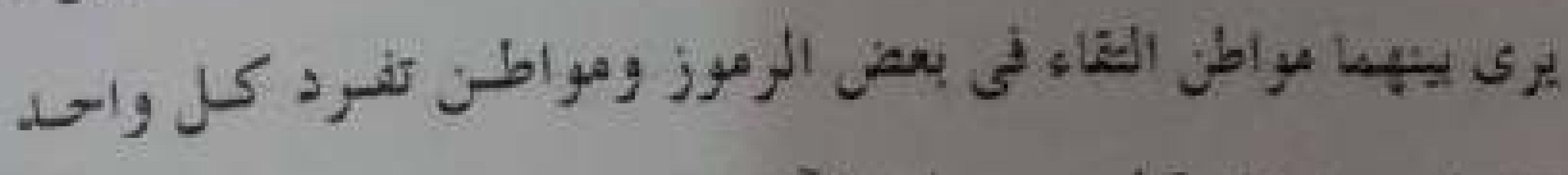

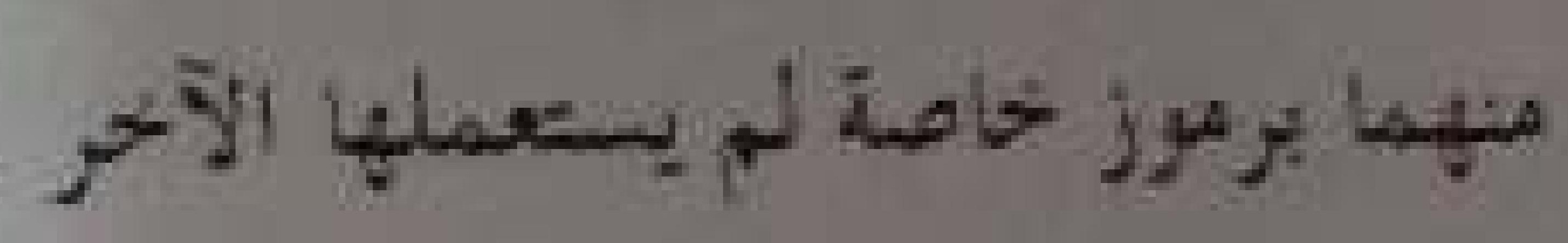

-

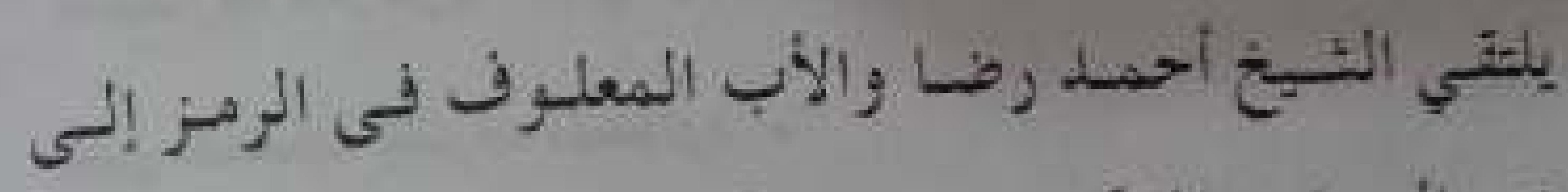

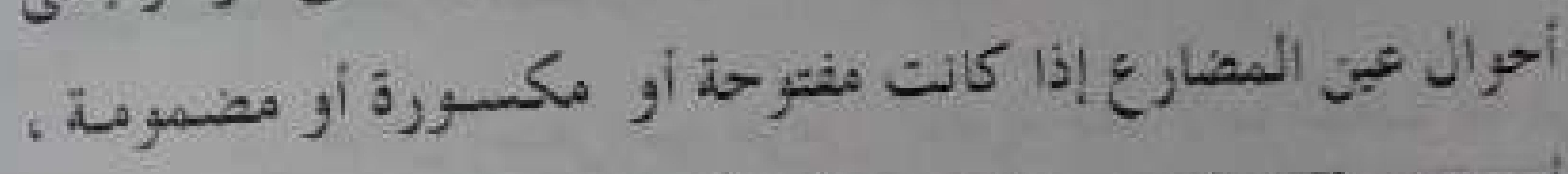

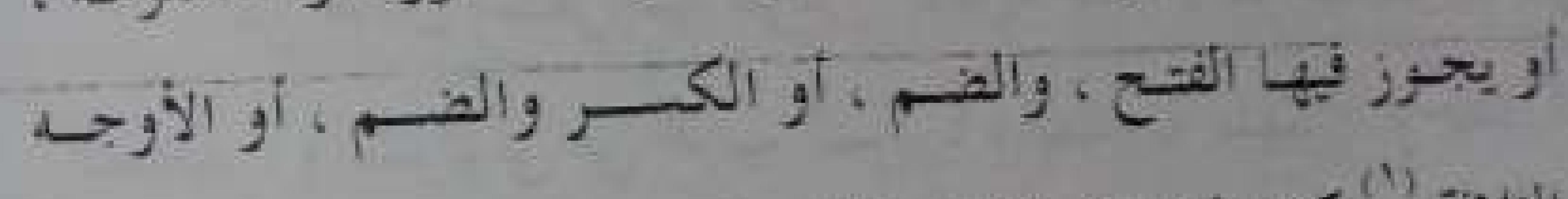

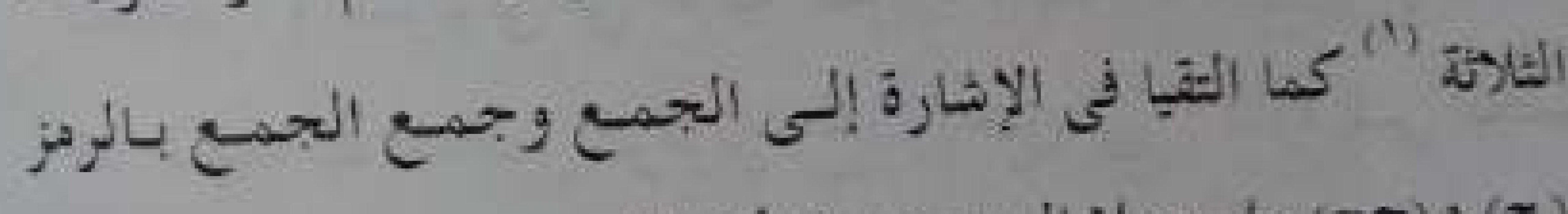

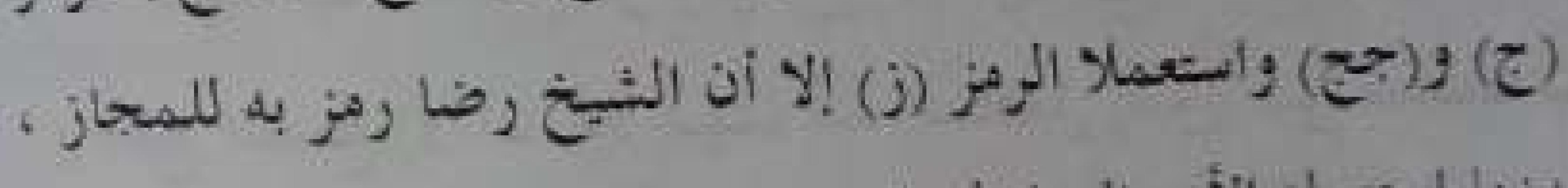

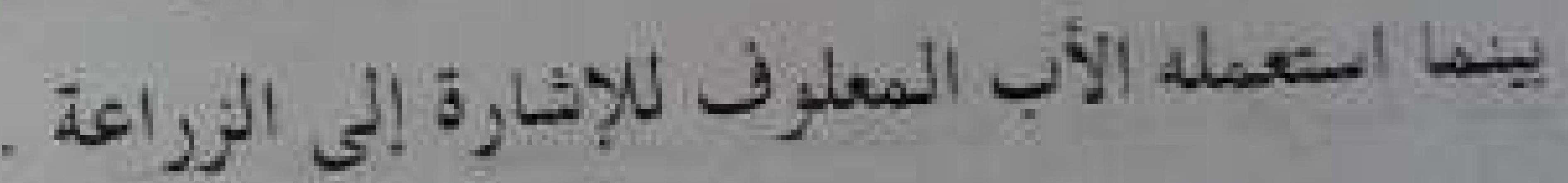

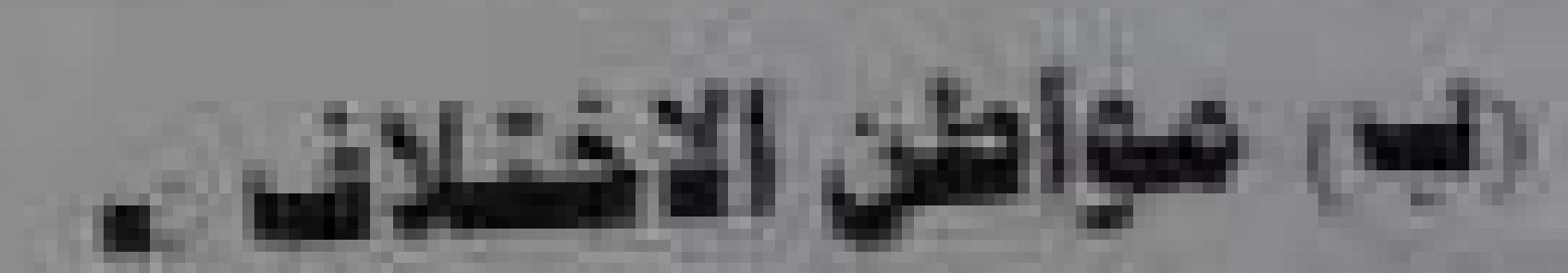

لقد اسعمل الثيخ أحسل رضا والأب المعلون رموزاً كيرة

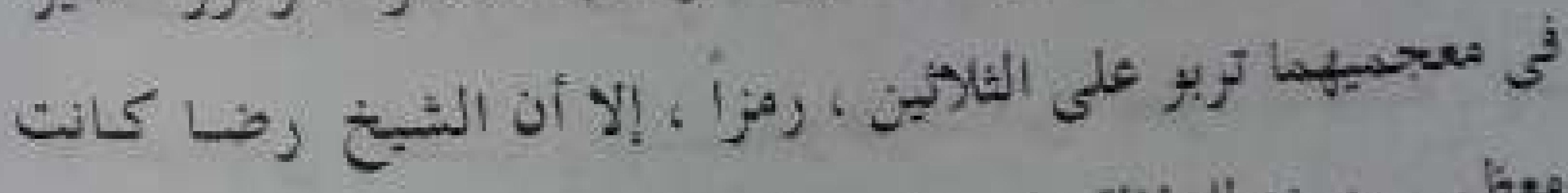

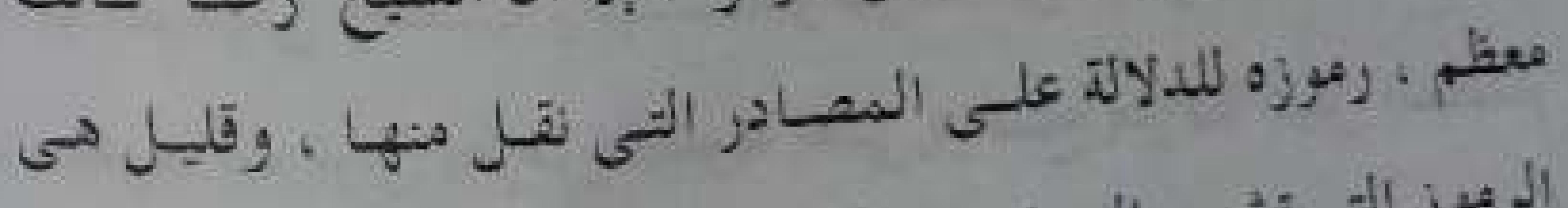

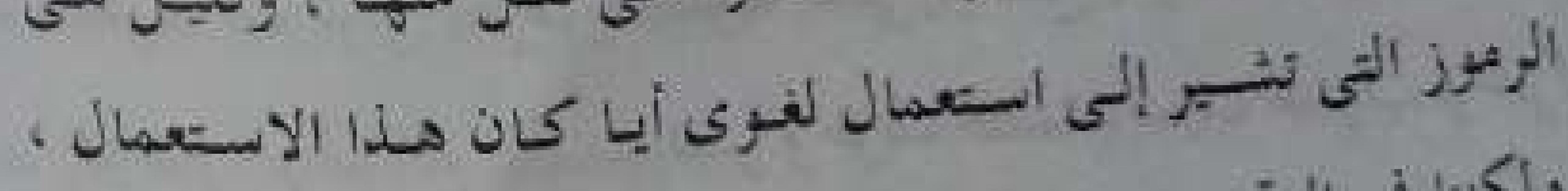

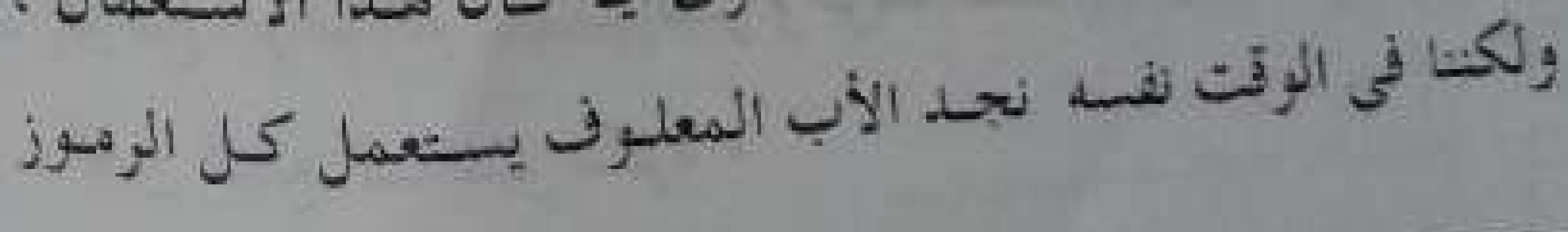

